UNIVERSIDADE DE SÃO PAULO

FACULDADE DE FILOSOFIA, LETRAS E CIÊNCIAS HUMANAS

FERNANDO SELIPRANDY

Documentário e memória intergeracional das ditaduras do Cone Sul

Versão corrigida

São Paulo

2018 
FERNANDO SELIPRANDY

\section{Documentário e memória intergeracional das ditaduras do Cone Sul}

\section{Versão corrigida}

(Versão original encontra-se na unidade que aloja o Programa de Pós-Graduação)

Tese apresentada ao Programa de PósGraduação em História Social da Faculdade de Filosofia, Letras e Ciências Humanas da Universidade de São Paulo para a obtenção de título de Doutor em História Social.

Área de concentração: História Social

Orientador: Prof. Dr. Marcos Francisco Napolitano de Eugênio 
Autorizo a reprodução e divulgação total ou parcial deste trabalho, por qualquer meio convencional ou eletrônico, para fins de estudo e pesquisa, desde que citada a fonte.

Catalogação na Publicação

Serviço de Biblioteca e Documentação

Faculdade de Filosofia, Letras e Ciências Humanas da Universidade de São Paulo

SS $465 d$

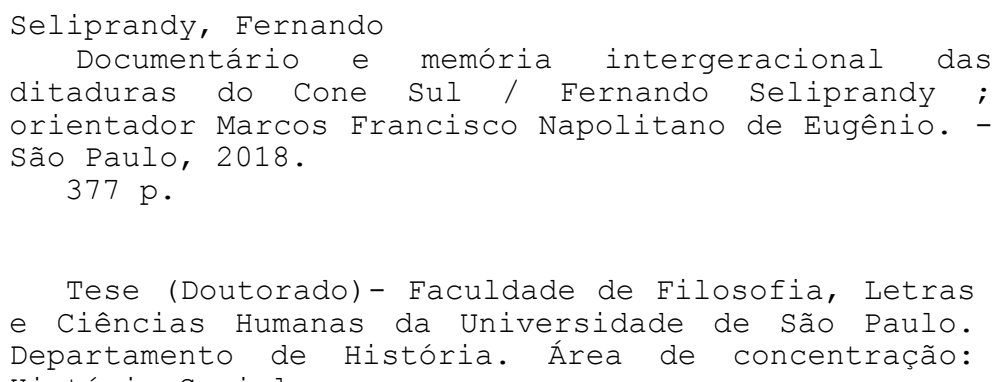

1. Documentário cinematográfico. 2. Memória Social. 3. Filhos. 4. Ditadura. 5. História da América do Sul. I. Eugênio, Marcos Francisco Napolitano de, orient. II. Título. 
SELIPRANDY, Fernando. Documentário e memória intergeracional das ditaduras do Cone Sul. 2018. 377 p. Tese (Doutorado em História Social) - Faculdade de Filosofia, Letras e Ciências Humanas, Universidade de São Paulo, São Paulo, 2018.

Aprovado em:

Banca examinadora

$\operatorname{Prof}(\mathrm{a}) . \operatorname{Dr}(\mathrm{a}) .:$

Instituição:

Julgamento:

$\operatorname{Prof}(\mathrm{a}) . \operatorname{Dr}(\mathrm{a})$ :

Instituição:

Julgamento:

Prof(a). Dr(a).:

Instituição:

Julgamento:

Prof(a). Dr(a).:

Instituição:

Julgamento: 


\section{AGRADECIMENTOS}

Ao professor Marcos Napolitano, pelos indeléveis e aprazíveis anos de formação sob sua orientação. Aos professores Eduardo Morettin e Ignacio Del Valle Dávila, cujos apontamentos seminais no exame de qualificação se somaram às tantas outras contribuições feitas desde o início desta pesquisa. Aos componentes da banca final que avaliou esta tese, professores Ana Laura Lusnich, Ignacio Del Valle Dávila, Eduardo Morettin e Maria Helena Capelato, que fizeram ponderações essenciais para o aprimoramento desta versão corrigida.

Aos professores e colegas do grupo "História e audiovisual: circularidades e formas de comunicação", pelas leituras e debates em conjunto que ecoaram decisivamente nas páginas a seguir, especialmente a Carolina Amaral de Aguiar, Mônica Kornis, Reinaldo Cardenuto, Mariana Martins Villaça, Alexsandro de Souza e Silva, Lúcia Ramos Monteiro e Danielle Crepaldi Carvalho. Aos colegas orientandos do professor Napolitano, pela estimulante interlocução acerca da temática da memória e das ditaduras, além das generosas leituras dos resultados parciais desta investigação, essenciais para o resultado final aqui apresentado. Às professoras Gabriela Pellegrino Soares e Ana Claudia Mei Alves de Oliveira, pelas portas que me abriram ao longo deste caminho.

À professora Ana Laura Lusnich, da Universidade de Buenos Aires (UBA), que gentilmente me recebeu no Centro de Investigación y Nuevos Estudios sobre Cine (CIyNE) durante a temporada argentina da pesquisa. Sou grato ainda aos investigadores que ali conheci, pela disposição para o diálogo e pelas dicas práticas fundamentais, nomeadamente a Pablo Piedras. Também aos funcionários da biblioteca da Escuela Nacional de Experimentación y Realización Cinematográfica (Enerc).

À professora Patrizia Violi, da Universidade de Bolonha (Unibo), pela acolhida no Centro di Studi Interdisciplinare su Memorie e Traumi Culturali (TraMe), espaço que me abriu o horizonte de outros processos de rememoração ao redor do globo. Aos demais pesquisadores daquele grupo, igualmente agradeço pela troca acadêmica e pela franca hospitalidade em Bolonha, especialmente a Cristina Demaria, Francesco Mazzucchelli, Daniele Salerno e Mario Panico. Aos funcionários da Unibo e da biblioteca da Cineteca di Bologna, também agradeço por facilitarem o cotidiano das pesquisas.

Aos amigos que participaram mais diretamente da elaboração deste trabalho, seja por meio de discussões em grupo, de indicações bibliográficas, da revisão dos resumos em língua estrangeira ou, momento fundamental, da leitura que fizeram deste texto quando ele ainda 
estava em processo: Julián Fuks, Renato Prelorentzou, Tárcio Vancim de Azevedo, Guilherme de Paula Costa Santos, Fábio Silva de Souza, Rodolfo Mói de Oliveira, Paolo Demuru, Eduardo Socha, Alexandre Socha e Daniel Lago Monteiro. Na mesma medida, sou grato às amigas e aos amigos de todas as horas pelas trocas de ideias sempre inspiradoras e animadas.

Às famílias, pelo suporte desde sempre. À Graziela, por mais esta aventura que vivemos literalmente lado a lado, desbravando novos ares ou focados intensivamente em nossos respectivos temas. 
$\grave{E}$ un godimento intenso, fisico, inesprimibile, essere nella mia casa, fra persone amiche, e avere tante cose da raccontare: ma non posso non accorgermi che $i$ miei ascoltatori non mi seguono. Anzi, essi sono del tutto indifferenti: parlano confusamente d'altro fra di loro, come se io non ci fossi.

Primo Levi, Se questo è un uomo (2014, p. 54). 


\section{RESUMO}

SELIPRANDY, Fernando. Documentário e memória intergeracional das ditaduras do Cone Sul. 2018. 377 p. Tese (Doutorado em História Social) - Faculdade de Filosofia, Letras e Ciências Humanas, Universidade de São Paulo, São Paulo, 2018.

O objeto da pesquisa é o cinema documental contemporâneo ligado aos descendentes de militantes de esquerda vítimas das ditaduras do Cone Sul. Desde fins dos anos 1990, ganha relevo na região a produção de documentários dirigidos ou protagonizados por filho(a)s, sobrinho(a)s ou neto(a)s daqueles que se opuseram aos regimes autoritários vigentes entre as décadas de 1960 e 1980. Nessa filmografia, as histórias de resistência e repressão vividas pela geração anterior são revistas pelas gerações mais jovens pelo enfoque familiar e íntimo. A tendência se manifesta na Argentina, no Chile, no Brasil, no Uruguai e no Paraguai, no âmbito de um fenômeno de memória intergeracional mais vasto, que abrange outras expressões artísticas - além de outras conjunturas traumáticas. Quatro títulos compõem o corpus principal do trabalho: Diário de uma busca (Flavia Castro, Brasil / França, 2010); Los rubios (Albertina Carri, Argentina, 2003); Mi vida con Carlos (Germán Berger-Hertz, Chile / Espanha, 2009); Os dias com ele (Maria Clara Escobar, Brasil / Portugal, 2013). Metodologicamente, a argumentação confronta a análise dessas obras específicas com um corpus fílmico expandido e outros materiais externos, construindo uma abordagem global e nuançada sobre as expressões da memória intergeracional nesse documentarismo. Quatro objetivos centrais guiam as reflexões, desdobrando aspectos salientes nos títulos do corpus principal. Respectivamente: descrever a formação dessa filmografia ao longo dos anos, examinando as dinâmicas transnacionais e temporais em jogo, bem como os influxos exercidos pelos festivais de cinema e pela escrita acadêmica nesse processo; ampliar o debate sobre o circuito de interações entre as gerações, destacando o papel ativo dos descendentes e abarcando vetores de memória que extrapolam a transmissão de um legado traumático; delinear o repertório de formas cinematográficas e narrativas dessa produção, rastreando paralelismos, matizes, contradições estéticas e lugares de enunciação da primeira pessoa; interpretar aquilo que a representação audiovisual testemunha sobre o peso do passado e sua ancoragem em um presente ainda marcado pelo autoritarismo. A investigação indaga as balizas conceituais desse campo de estudos para descortinar um fenômeno denso em sua historicidade, com imagens carregadas de conexões transnacionais, transferências culturais, tensões formais e nexos referenciais. O resultado final é um quadro multifacetado do documentarismo intergeracional do Cone Sul, com perspectivas renovadas pelo prisma da subjetividade e dos afetos, mas no qual também se plasmam novas fórmulas da memória.

Palavras-chave: Documentário. Cinema. Memória. Pós-memória. Filhos. Ditadura. Cone Sul. 


\begin{abstract}
SELIPRANDY, Fernando. Documentary and intergenerational memory of the Southern Cone dictatorships. 2018. 377 p. Doctoral Dissertation (PhD in Social History) - Faculdade de Filosofia, Letras e Ciências Humanas, Universidade de São Paulo, São Paulo, 2018.

The subject of this research is the documentary filmmaking related to descendants of leftist militants who were victims of Southern Cone dictatorships. Since the late 1990s, there has been a significant production of documentaries directed by or focused on children, nephews, nieces or grandchildren of those who opposed authoritarian regimes in the region from the 1960 s to the 1980s. In this filmography, histories of repression and resistance experienced by the previous generation are revisited by the younger generations from a familiar and intimate point of view. Nonfiction works of this type have been released in Argentina, Chile, Brazil, Uruguay, and Paraguay, inside a broader cultural framework of intergenerational remembrances that reaches out other forms of artistic expressions - besides other traumatic historical contexts. The main corpus of this investigation includes four documentaries: Diary, letters, revolutions (Flavia Castro, Brazil / France, 2010); The blonds (Albertina Carri, Argentina, 2003); My life with Carlos (Germán Berger-Hertz, Chile / Spain, 2009); The days with him (Maria Clara Escobar, Brazil / Portugal, 2013). Methodologically, the argumentation contrasts the analysis of these specific works with an expanded filmic corpus and other external materials, constructing a global and nuanced overview of the intergenerational memory expressions in this documentary production. Four key objectives are pursued, developing central aspects identified in each title of the main corpus. Respectively: to describe the formation of this filmography over the years, considering the transnational and temporal dynamics at stake, as well as the role of both film festivals and academic writing in this process; to broaden discussions about the interactions circuit between the generations, emphasizing the descendant's agency and embracing memory vectors far beyond the transmission of a traumatic burden; to outline the range of cinematographic and narrative forms used in the films, scrutinizing aesthetics parallels, variations and contradictions, along with the locus of enunciation of the first person; to decipher what audiovisual representation testifies about the weight of the past and its concrete links with a present still marked by authoritarian legacies. The research inquires the conceptual assumptions of this field of studies in order to bring to light the historicity of a dense phenomenon, whose images are full of transnational connections, cultural transfers, formal tensions, and referential grounds. The outcome is a multiform portrait of the intergenerational documentary made in the Southern Cone, with renewed perspectives derived from the subjective and affective viewpoint, but in which new memory patterns also start to get shaped.
\end{abstract}

Keywords: Documentary. Cinema. Memory. Postmemory. Children. Dictatorship. Southern Cone. 


\section{RESUMEN}

SELIPRANDY, Fernando. Documental y memoria intergeneracional de las dictaduras del Cono Sur. 2018. 377 p. Tesis (Doctorado en Historia Social) - Faculdade de Filosofia, Letras e Ciências Humanas, Universidade de São Paulo, São Paulo, 2018.

El objeto de esta investigación es el cine documental contemporáneo vinculado a los descendientes de militantes de izquierda víctimas de las dictaduras del Cono Sur. Desde fines de los años 1990 gana importancia en la región la producción de documentales dirigidos o protagonizados por hijos/as, sobrinos/as y nietos/as de aquellos que se opusieron a los regímenes autoritarios vigentes entre las décadas de 1960 y 1980. En esta filmografía, las historias de resistencia y represión vividas por la generación anterior son revisadas por las generaciones más jóvenes desde un enfoque familiar e íntimo. La tendencia se hace presente en Argentina, Chile, Brasil, Uruguay y Paraguay, en el marco de un fenómeno más amplio de rememoración intergeneracional, lo cual comprende otras expresiones artísticas - más allá de otros contextos históricos traumáticos. Cuatro películas componen el corpus principal del trabajo: Diario de una búsqueda (Flavia Castro, Brasil / Francia, 2010); Los rubios (Albertina Carri, Argentina, 2003); Mi vida con Carlos (Germán Berger-Hertz, Chile / España, 2009); Los días con él (Maria Clara Escobar, Brasil / Portugal, 2013). Metodológicamente, la argumentación contrasta el análisis de estas obras específicas con un corpus fílmico extendido y otros materiales externos, construyendo un acercamiento global y matizado a las expresiones de la memoria intergeneracional en este cine documental. Cuatro objetivos centrales guían las reflexiones, desplegando aspectos sobresalientes de las películas del corpus principal. Respectivamente: describir la formación de esta filmografía a lo largo de los años, examinando las dinámicas transnacionales y temporales en juego, así como los influjos ejercidos por los festivales de cine y la escritura académica en este proceso; profundizar la discusión sobre el circuito de interacciones entre las generaciones, destacando el rol activo de los descendientes y abarcando vectores de la memoria que sobrepasan la transmisión de un legado traumático; delinear el repertorio de formas cinematográficas y narrativas de esta producción, rastreando paralelismos, variaciones, contradicciones estéticas y las posturas enunciativas de la primera persona; interpretar aquello que la representación audiovisual puede testimoniar acerca del peso del pasado y su anclaje en un presente todavía marcado por el autoritarismo. La investigación indaga en el andamiaje conceptual de este campo de estudios para desvelar un fenómeno denso en su historicidad, cuyas imágenes están cargadas de conexiones transnacionales, transferencias culturales, tensiones formales y nexos referenciales. El resultado final es un retrato polifacético del cine documental intergeneracional del Cono Sur, de lo cual emergen perspectivas renovadas por el prisma subjetivo y afectivo, pero que también plasma nuevas fórmulas de la memoria.

Palabras clave: Documental. Cine. Memoria. Posmemoria. Hijos. Dictadura. Cono Sur. 


\section{SUMÁRIO}

\section{INTRODUÇÃO, 12}

\section{CAPÍTULO I: DINÂMICAS DA FORMAÇÃO DE UMA MEMÓRIA TRANSNACIONAL, 24}

- O diagnóstico da "guinada subjetiva" do documentário e seus problemas, 24

- Diário de uma busca transnacional, 31

- Pré-fílmico: do exílio às coproduções internacionais, 35

- Fílmico: travellings, planos fixos e a geografia da memória, 52

- Pós-fílmico: circulações nos festivais de cinema, 65

- A formação transnacional de um fenômeno cinematográfico e de memória, 99

\section{CAPÍTULO II: A MEMÓRIA INTERGERACIONAL E SEUS MÚLTIPLOS VETORES, 103}

- Os usos da noção de "pós-memória", 107

- A "pós-memória” e os elos palpáveis da transmissão, 121

- A memória tateante em Los rubios, 129

- As transferências conceituais da "pós-memória", 138

- Transmissão, distanciamento e transferências culturais, 149

- Um circuito de laços intergeracionais, 161

\section{CAPÍTULO III: FORMAS E TENSÕES ESTÉTICAS DO DOCUMENTÁRIO INTERGERACIONAL,} 164

- Leituras da indeterminação formal, 164

- Mi vida con Carlos e o repertório estético-narrativo do documentário intergeracional, 176

- Banda sonora, 177

- Voz over em primeira pessoa, 177

- Trilha musical, 179

- Sonoplastia, 181

- Linguagem cinematográfica, 183

- Travelling itinerante, 184

- Entrevistas, 185

- Inserções, 195

- Intertítulos e legendas informativas, 198 
- Cores e suportes alternativos, 203

- Reflexividade, 207

- O visível, 217

- A presença do documentarista diante da câmera, 217

- Os entrevistados, 222

- Os lugares, 228

- Intertextualidades, 231

- Materiais de arquivo, 233

- O baú da família, 233

- Os arquivos públicos, 241

- Tópicos da memória intergeracional, 244

- Vivências de época, 244

- Questões identitárias, 246

- Estruturas narrativas, 251

- Conformações da memória: matizes e contradições da primeira pessoa no documentário intergeracional, 257

\section{CAPÍTULO IV: APORIAS E APOSTAS DO REPRESENTÁVEL, 269}

- O abismo do irrepresentável: variações em torno de uma cadeira vazia, 269

- Reconhecendo a potencialidade da representação, 300

- Uma aposta no representável: a cadeira, o documento e a imaginação historiográfica, 304

- Dialética entre aporias e apostas: o vazio, o vestígio, a performance, o testemunho, 319

CONSIDERAÇÕES FINAIS: MEMÓRIA INTERGERACIONAL, HISTORICIDADE DAS IMAGENS, 321

\section{REFERÊNCIAS, 324}

FICHAS TÉCNICAS DOS FILMES DO CORPUS PRINCIPAL, 354

LISTA DOS FILMES DO CORPUS EXPANDIDO, 355

APÊNDICE A - Prêmios E CIRCulações dos títulos do Corpus nos Festivais de CINEMA POR PAÍS (1996-2017), 358 


\section{INTRODUÇÃO}

As vozes dos descendentes de militantes de esquerda conquistaram um lugar de destaque na arena das reelaborações dos anos autoritários no Cone Sul. Desde a segunda metade dos anos 1990, multiplicam-se as produções artísticas ligadas a filho(a)s, sobrinho(a)s ou neto(a)s daqueles que se opuseram às ditaduras vigentes na região entre as décadas de 1960 e 1980. Episódios de resistência, repressão, assassinatos, desaparecimentos e exílios são revistos pelo foco da intimidade. As derrotas políticas se revestem com a carga das perdas familiares. O prisma dos afetos revela outras facetas da grande história. Uma memória intergeracional se adensa no campo cultural.

O papel central dos familiares das vítimas nos processos de rememoração das ditaduras não é, em si, uma novidade. Logo na primeira hora, mães, pais, avós, esposas, maridos, entre outros parentes coetâneos aos fatos, já se arriscavam em angustiantes buscas sobre o paradeiro dos entes sequestrados e desaparecidos. Eram os passos iniciais de uma ação ainda impulsionada pelo trauma privado, mas que ultrapassaria a esfera familiar no contexto das aberturas políticas, assumindo formas coletivas de organização. Grupos de mães, avós e familiares viriam a ser constituídos, dando uma dimensão pública para o luto e para as reivindicações por verdade e justiça. Essas agrupações assumiram a linha de frente dos processos de rememoração nos países vizinhos, com a Argentina na dianteira (CATELA, 2001; JELIN, 2010b). No Brasil, ao contrário, as demandas dos familiares rapidamente seriam preteridas no tabuleiro das transações políticas da redemocratização (TELES, J. A., 2005). As consequências de tal diferença são substantivas, indo de uma maior assimilação social dos esforços para que os perpetradores fossem julgados até a construção de um forjado “consenso" em torno da anistia. De um modo ou de outro, porém, as matrizes dominantes da memória que iam se esboçando nesse cenário convergiam em grandes sínteses que aparavam as arestas do passado: de um lado, a universalização da condição de vítima, releitura fundamental para a agenda dos direitos humanos, mas que acabava despolitizando a violência que marcara o período, além de tecer um manto de inocência grande o bastante para ocultar colaboracionismos e cumplicidades no seio social; de outro, a épica da resistência, que convenientemente abarcava os mais diversos atores e iniciativas, com destaque para o sacrifício heroico daqueles que ousaram pegar em armas contra a tirania, operando-se um deslocamento do caráter revolucionário daquela luta em nome do imperativo moral de resistir (LVOVICH; BISQUERT, 2008; NAPOLITANO, 2015, 2017; REIS FILHO, 2005; 
ROLLEMBERG, 2006). Tanto o viés humanitário quanto o da monumentalização devem ser interpretados à luz das circunstâncias em que se delinearam, quando atendiam a anseios indubitavelmente legítimos: a luta pelos direitos humanos, a valorização dos atos de oposição aos regimes. Ainda assim, ambas as linhas deixavam margem para uma ideia geral de “conciliação" social (a sociedade em bloco foi vítima, a sociedade em bloco resistiu), com maior ou menor grau de tolerância à impunidade dos perpetradores.

Os descendentes eram então muito novos, às vezes sequer nascidos. Somente anos depois, quando chegaram à juventude, eles se fariam ouvir. A questão não é simplesmente etária, a emergência desses novos atores ampliava o diapasão do debate sobre as ditaduras, com suas vozes reverberando em um ambiente cultural propenso às vicissitudes do íntimo e do subjetivo. Nos países vizinhos, as organizações de hijos iam surgindo na segunda metade dos anos 1990, revigorando as cobranças sociais por verdade e justiça com formas inéditas de protesto, como o "escracho" (BONALDI, 2006; LEVEY, 2014; RÚA, 2010; VEZZETTI, 1998). Nas produções culturais das novas gerações, descortinavam-se aspectos por muito tempo deixados em segundo plano pelas versões da vitimização e do heroísmo: a infância clandestina e exilada; as tensões entre engajamento político e abandono afetivo; a imagem fugidia dos pais desaparecidos e a presença sufocante do fantasma heroico; a orfandade e os curtos-circuitos identitários. As releituras do passado autoritário ligadas aos filhos de militantes chegavam atravessadas pelos meandros dos laços familiares, reivindicando verdade e justiça, mas também titubeando quanto aos sentidos da experiência. Juntos, o grito público e o tom menor introspectivo viriam a compor um contraponto frente às matrizes consagradas da memória coletiva. No entanto, como se verá ao longo destas páginas, o curso dessa inflexão é complexo e não pode ser reduzido a um "antes" e um "depois". ${ }^{1}$ Se, por um lado, é verdade que as perspectivas abertas pelos descendentes oxigenaram as discussões, por outro, é fato que muitas continuidades se mantêm em suspensão nessa atmosfera. Mais ainda, a memória intergeracional tampouco está isenta da sedimentação de suas novas pautas e fórmulas.

O fenômeno é amplo e se manifesta em tantas outras conjunturas históricas, em latitudes diversas. $\mathrm{O}$ recorte desta tese é o cinema documentário realizado ou protagonizado

\footnotetext{
${ }^{1}$ Apenas a título de exemplo, e antes de desenvolver as ponderações que complicam o terreno, Cazadores de utopías (David Blaustein, Argentina, 1995) e Hércules 56 (Silvio Da-Rin, Brasil, 2006) são dois casos de documentários de "primeira geração" que já foram contrapostos à produção intergeracional aqui estudada (AGUILAR, 2007b; SELIPRANDY, 2013). Porém, como a tese se dedicará a demonstrar, essas delimitações sumárias precisam ser tratadas com cautela. Os próprios limiares geracionais são movediços, havendo contraexemplos significativos de cineastas de "primeira geração" que passaram a fazer documentários de viés subjetivo e introspectivo, tais como: Chile: la memoria obstinada (Patricio Guzmán, Chile / Canadá / França, 1997); Calle Santa Fe (Carmen Castillo, Chile / França / Bélgica, 2007); Decile a Mario que no vuelva (Mario Handler, Uruguai, 2007).
} 
por descendentes no Cone Sul. Nesse âmbito, os títulos do que se pode chamar de um documentarismo intergeracional vêm sendo produzidos desde pelo menos 1996 até o presente. Em 2017, os lançamentos ligados a essa tendência mantêm a vitalidade, com passagens exitosas pelo circuito de festivais internacionais de cinema. A pesquisa levantou um corpus de 67 títulos nessa chave, entre curtas, médias e longas-metragens - elencados na abertura do primeiro capítulo. A Argentina se destaca nesse conjunto, sendo a origem de aproximadamente metade das produções identificadas. O Chile vem em seguida, com 17 títulos, cerca de um quarto dessa filmografia. Brasil (8 títulos) e Uruguai (7 títulos) têm uma participação equilibradamente mais moderada e, por último, com um título localizado, está o Paraguai. Esses números, por si só, já indicam certas tendências dessa produção no interior do espaço regional - as quais serão esquadrinhadas no Capítulo I -, mas não dizem tudo, claro. Notadamente porque as dinâmicas das coproduções internacionais muitas vezes complicam a atribuição da proveniência nacional dos filmes. Em todo caso, neste momento introdutório, basta sugerir que a profusão de documentários intergeracionais dá uma dimensão do alcance de tal cinematografia como canal de difusão e formatação dessa vertente de rememoração no Cone Sul.

De modo a não se perder nesse universo, a análise de quatro títulos em particular será o fio condutor das reflexões: Diário de uma busca (Flavia Castro, Brasil / França, 2010), Los rubios (Albertina Carri, Argentina, 2003), Mi vida con Carlos (Germán Berger-Hertz, Chile / Espanha, 2009) e Os dias com ele (Maria Clara Escobar, Brasil / Portugal, 2013). Os quatro têm direção de filha(o)s ${ }^{2}$ de militantes vítimas das ditaduras de seus respectivos países, lidando com problemáticas que passam pela ausência dos pais causada pelo desaparecimento forçado, pelas sequelas traumáticas da tortura e pelo desenraizamento do exílio. Os quatro tiveram uma carreira consistente no circuito de festivais internacionais, tendo ademais suscitado leituras acadêmicas que compõem uma fortuna crítica considerável. São filmes que conquistaram uma relevância no campo, para dizer de algum modo, mas a justificativa determinante para a seleção desses quatro documentários que compõem o corpus principal da investigação remonta a um critério temático. Em cada uma dessas obras, a matéria audiovisual põe em relevo questões centrais desse campo de estudos a serem debatidas nos quatro capítulos da tese. Respectivamente: o caráter transnacional desse fenômeno; as complexas relações entre as gerações da memória; o repertório formal e narrativo dessa cinematografia;

\footnotetext{
2 Para abordagens dessa produção a partir da perspectiva de gênero, cf. AMADO, 2004, 2005b; BETTENDORFF; RIAL, 2014; FELDMAN, 2017; HOLANDA, 2015; PARADA, 2015.
} 
as dificuldades e possibilidades de representação do passado traumático. Eis, em poucas palavras, as pautas que se desdobrarão desde a imanência dessas quatro obras.

Evidentemente, tais aspectos são observáveis também em outros títulos do documentarismo intergeracional do Cone Sul. É por isso que este trabalho fez questão de mobilizar nas reflexões um corpus expandido, constituído pelo conjunto dos documentários nesse viés identificados ao longo das investigações. Aqui cabe mais uma explicitação quanto à lógica de seleção filmográfica: o recorte para a inclusão dos demais títulos no escopo desta pesquisa orientou-se pela centralidade da perspectiva dos descendentes nas histórias narradas. O critério básico era que a obra colocasse em primeiro plano a elaboração de uma memória intergeracional. Estão aí incluídos os títulos dirigidos por filhas e filhos, e também aqueles realizados por descendentes com outros laços de parentesco, nomeadamente, sobrinho(a)s e neto(a)s. Ao lado desses, entram os documentários que não são dirigidos por descendentes, mas que contam com seu protagonismo, no papel de testemunhas, novos militantes, vítimas ou condutores das buscas fílmicas. Tampouco houve qualquer restrição quanto à modalidade estilística das obras. Nesse campo de estudos, costuma-se privilegiar os documentários em primeira pessoa, subjetivos, performativos, autobiográficos, entre outros termos empregados para caracterizar a produção contemporânea, dependendo da entrada conceitual adotada (cf. BOSSY; VERGARA, 2010; FRANÇA; MACHADO, 2014b; MOLFETTA, 2011a, 2011b; PIEDRAS, 2014; ROS, 2012). A esses casos foi dedicada uma atenção especial nas análises, e os títulos do corpus principal estão todos na órbita dessas poéticas. Contudo, não foram ignorados os documentários vinculados a outras tradições, mesmo que fossem obras esteticamente bem convencionais. Também não houve condicionantes no que diz respeito aos recursos de produção ou à metragem fílmica. Foram considerados, sem hierarquizações prévias, tanto os filmes "extraordinários", que se destacam pela originalidade formal e narrativa, quanto os contraexemplos mais triviais, menos incensados pela crítica, alguns inclusive de fatura precária - uma das lições da micro-história é, justamente, o reconhecimento da potência cognitiva daquilo que é aparentemente irrelevante (GINZBURG, 2007c). Em suma, a pesquisa foi ao material audiovisual existente e trouxe para as reflexões os títulos mais diversos no que toca à pessoa da enunciação, às filiações estilísticas e aos resultados alcançados. Afinal, é preciso salientar, o objeto último das indagações é o fenômeno da memória intergeracional em seu alcance e suas variadas manifestações no documentarismo realizado nos últimos anos no Cone Sul - e não uma qualidade específica do cinema documental contemporâneo, no que seria um recorte demasiadamente tributário dos valores estéticos em voga. "Documentário intergeracional" é a denominação abrangente que 
será usada nestas páginas para designar essa filmografia, e o segundo capítulo detalhará a pertinência do termo "intergeracional" ao enfatizar as interações atuantes nos gestos de rememoração.

Vale esclarecer também que foi desse levantamento que surgiram as primeiras balizas temporais da pesquisa: os anos de 1996 a 2017, período em que foram produzidos os títulos do corpus expandido - e tudo indica que essa tendência seguirá tendo vigor nos próximos anos. É claro que, uma vez que se trata de obras memorialísticas, esse recorte cronológico será extrapolado retrospectivamente rumo ao passado evocado nas narrativas.

Diante de tal amplitude, as entradas dos títulos do corpus expandido nas análises serão inevitavelmente sumárias, na forma de comentários pontuais dedicados a expandir as considerações, indicando tendências gerais, nuances e contracorrentes no interior dessa cinematografia. A ideia é contrastar outros exemplos com os quatro títulos examinados minuciosamente em cada capítulo. A articulação entre corpus principal e corpus estendido, no fim das contas, mostrou-se fértil para o delineamento de um cenário mais complexo nesse espaço entre os casos específicos e o conjunto filmográfico.

Tal ponderação conduz às questões de método que guiaram as indagações. Em primeiro lugar, como já ficou implícito, está o jogo de escalas. O leitor perceberá que, em termos metodológicos, a obra do historiador italiano Carlo Ginzburg é uma fonte de inspiração que atravessa toda a tese. A argumentação aqui promoverá uma alternância constante entre as perspectivas micro e macro: entre o mergulho em um filme e o panorama da filmografia; entre as vivências íntimas narradas e os processos de rememoração das ditaduras no Cone Sul; entre as minúcias dos textos analíticos e as correntes teóricas que pautam esses debates. Enfim, “um contínuo vaivém entre micro e macro-história, entre closeups e planos gerais ou grandes planos gerais [extreme long shots], a pôr continuamente em discussão a visão conjunta do processo histórico por meio de exceções aparentes e causas de breve período." (GINZBURG, 2011b, p. 269).

A perspectiva transnacional é o horizonte macro-histórico mais evidente neste trabalho. Não custa explicitar que o olhar para além das fronteiras nacionais está na base desta investigação sobre o documentário e a memória intergeracional das ditaduras do Cone Sul. A tentativa de compreender esse fenômeno em escala regional se filia a esse viés de abordagem cada vez mais difundido nas ciências humanas. O objetivo é ir além da comparação em paralelo entre exemplos de cada país, rastreando fluxos, atritos e deslocamentos nesse espaço comum de rememoração pela via do cinema (a bibliografia nesse campo é vasta e será oportunamente introduzida no primeiro capítulo, o qual lida mais diretamente com as 
dinâmicas transnacionais do corpus estudado). Isso não quer dizer, porém, que as especificidades locais serão anuladas. Não se trata aqui de uma adesão irrefletida à corrente acadêmica em voga. As escalas sempre estão em jogo, o espaço transnacional não é homogêneo.

O principal antídoto metodológico contra as generalizações redutoras será o "paradigma indiciário" de Carlo Ginzburg (2007c), outra linha de força das reflexões desenvolvidas adiante. Uma atenção toda especial será dada aos "pormenores aparentemente negligenciáveis" (GINZBURG, 2007c, p. 178) inscritos nas imagens dos documentários. Cada detalhe da linguagem cinematográfica foi levado em conta: enquadramentos, movimentos de câmera, justaposições, fusões, inserções, legendas, intertítulos, suportes, texturas, colorações etc. Eis as formas de expressão indissociáveis do teor daquilo que é visível (pessoas, lugares, objetos, intertextualidades, planos de fundo etc.) e audível (entrevistas, vozes off e over, temas musicais, trilhas incidentais, sonoplastia, ruídos, silêncios etc.). Com tal foco, esta pesquisa se filia abertamente à vertente dos estudos historiográficos que eleva a matéria audiovisual à condição de fonte primordial, colocando em primeiro plano o específico fílmico e seus modos próprios de estruturação narrativa. No decorrer das análises, as imagens jamais serão convocadas para "ilustrar" um conceito ou uma conjuntura social. Pois isso seria cair no equívoco de relegar os filmes a uma função acessória, de exemplificação "figurativa" de algo já sabido de antemão (MORETTIN, 2007, 2013; NAPOLITANO, 2006).

Pelo contrário: a ida aos conceitos e outros materiais externos efetuada em vários momentos ao longo destas páginas sempre toma como ponto de partida um indício inscrito nas obras cinematográficas. A direção metodológica adotada, portanto, é diametralmente oposta ao uso do filme como "ilustração" de um dado exterior preconcebido. Trata-se de olhar para as imagens antes de assumir certas premissas, de seguir o fio dos signos audiovisuais ao trazer para o debate outras fontes que iluminem seus possíveis sentidos históricos. Em suma, nesta investigação, os pormenores intrínsecos às imagens é que sinalizarão os veios extrafílmicos, conceituais ou intertextuais, a serem explorados pela abordagem historiográfica. É nesse sentido que o mesmo Ginzburg (2010, p. 26) professa “a impossibilidade de falar de fenômenos artísticos numa perspectiva histórica sem entrelaçar dados estilísticos e dados extraestilísticos". Tal é a ideia que orientou o constante cruzamento da soleira entre o fílmico e o extrafílmico nesta tese: lançar um atento olhar historiográfico "que parte da concretude da obra e a ela retorna, sem se perder em generalidades vazias" (GINZBURG, 2010, p. 285). A primazia dada ao específico cinematográfico só tem a ganhar 
quando trata de compreender os acenos feitos desde a imanência das imagens em direção ao universo dos materiais externos: outras obras artísticas citadas, documentos da repressão, registros ligados à produção dos filmes, bancos de dados cinematográficos, catálogos de festivais, bibliografia etc.

Todos esses elementos serão convocados pelas análises no bojo da consideração sobre as circulações culturais que gravitam em torno dos documentários do corpus. Esse é outro viés metodológico que se mostrou frutífero para as reflexões, com destaque para a noção de "transferência cultural”, proposta por Michel Espagne (2013). A ideia básica é que toda circulação de bens culturais implica uma reinterpretação, uma transformação dos significados que é rica em si mesma. Segundo tal prisma, há que se romper com a visão hierárquica das trocas culturais, o raciocínio nos termos do "modelo" ou da "influência" de uma cultura sobre a outra, postura que se inclina a um olhar míope que vê apropriações "deturpadas" frente a uma formulação "original”. De acordo com Espagne, o mais interessante é, justamente, compreender a vivacidade dessas passagens. As interpretações desenvolvidas nesta tese acerca do emaranhado de referências e metamorfoses na órbita do documentarismo intergeracional devem muito a tal abordagem.

Também nesse terreno, Carlo Ginzburg (2006a) oferece fundamentos seminais, principalmente no que diz respeito ao exame dos eloquentes deslocamentos de sentido que surgem na ciranda de leituras e releituras de um texto. Nas palavras do historiador italiano: "[...] o modo como um ser humano reelabora os livros que lê é muitas vezes imprevisível" (GINZBURG, 2004, p. 14). Ao longo destas páginas, o leitor se defrontará em vários momentos com leituras das leituras feitas por outros autores, em uma espécie de mise en abyme intertextual. Isso é decorrência da maneira como a fortuna crítica acadêmica acerca da produção intergeracional foi incorporada neste trabalho: não só como referência bibliográfica, mas sobretudo como objeto da investigação. Pois é de se registrar que o adensamento dessa cinematografia no decorrer dos últimos anos foi acompanhado de um crescimento do campo de estudos a ela dedicado. Quanto a isso, a hipótese de saída é que a profusão de textos analíticos voltados a esse documentarismo é parte do fenômeno da memória intergeracional, exercendo um papel substantivo em seus desdobramentos. A bibliografia não examina os filmes desde fora dos processos de rememoração: ao destacar algumas obras, ao ignorar outras, ao aplicar determinadas chaves de interpretação, ao celebrar certos traços estéticos, as análises acadêmicas estão tomando parte nas dinâmicas de conformação da memória intergeracional. Eis a premissa que justifica o constante confronto aqui promovido entre a matéria audiovisual e outras análises escritas, em uma indagação entrelaçada dessas duas 
esferas discursivas. Com tal gesto, esta tese entra com ânimo franco no debate, dialogando abertamente com os pares, acreditando sinceramente na discussão como caminho para se conhecer melhor o tema em pauta - sem qualquer pendor para o polemismo estéril, vale esclarecer, e defendendo que silenciar o dissenso seria, esta sim, uma postura autoritária. Trata-se de propor uma releitura historiográfica das leituras fílmicas acadêmicas já existentes, incluindo-as entre os vetores da constituição do fenômeno, cotejando-as com aquilo que é visível nas imagens.

Isso explica um movimento que estrutura todos os capítulos: as problematizações conceituais são o motor das proposições historiográficas. Esses dois impulsos são indissociáveis na argumentação, as ressalvas em série são já a reivindicação de um novo ponto de vista. A opção por organizar as reflexões partindo de uma interrogação conceitual foi se esboçando desde as primeiras aproximações com a bibliografia dedicada à produção intergeracional em particular e ao documentário contemporâneo em geral. Salta aos olhos nesse campo de estudos a recorrência com que certas premissas são evocadas para descrever as mais variadas obras. Nomeadamente, as noções de "guinada subjetiva", "pós-memória", “indeterminação formal” e "irrepresentável”, derivações teóricas que remetem às matrizes do pós-estruturalismo e dos estudos da Shoah. A suspeita de base é que uma grade analítica assim sedimentada acarreta em duas limitações fundamentais. Em primeiro lugar, o risco de que a matéria audiovisual termine ofuscada pelo espesso anteparo teórico que se interpõe entre o olhar analítico e os filmes. Em segundo lugar, uma tendência ao engessamento das dinâmicas históricas e culturais que orbitam essa cinematografia dentro de um arcabouço de ideias preconcebidas. Tais foram as inquietações primordiais que levaram a uma estrutura argumentativa que desestabiliza os apriorismos analíticos para construir, simultaneamente, um retrato mais complexo desse fenômeno de memória. No fim das contas, no avesso das ponderações conceituais surge uma paisagem carregada de circulações, conexões, transferências, formas e densidades históricas. Um quadro, enfim, no qual se delineiam as proposições essenciais da tese: as elaborações dos descendentes sem dúvida estão afinadas com certa sensibilidade estética e teórica contemporânea, porém, seus traços escapam aos determinismos conceituais sumários; a emergência da memória intergeracional abre novos canais de revisão do passado, isso é inegável, mas também traz consigo um magma composto por camadas prévias da memória social, velhas tradições do cinema documentário e cristalizações de novidades já não tão candentes.

Esta última ponderação faz um aceno para outra ideia que se revelou fundamental ao longo das reflexões: a da dialética básica entre forma e indeterminação operando no cerne das 
obras de arte que tendem à abertura dos significados. Umberto Eco (2016) foi uma referência teórica frutífera nesse campo, não apenas para o Capítulo III, centrado em uma discussão propriamente estética, como também, de modo mais difuso, para toda a tese. As análises avançam lidando com a fricção entre, de um lado, a oscilação da margem de novidade e imprevisibilidade nessas reelaborações da memória e, de outro, os impulsos extrínsecos (festivais de cinema, crítica acadêmica) e estilísticos que vão formatando o documentarismo intergeracional. De fato, os termos dos enunciados de Eco sobre a problemática da forma e da indeterminação mantêm-se subjacentes na passagem de um capítulo a outro, conectando as questões enfocadas em cada um deles em um conjunto sempre tenso, feito de horizontes abertos e codificações.

As inquietações acima apontadas estão evidentemente ligadas ao lugar disciplinar desde onde esta tese é elaborada. Este é um trabalho historiográfico, algo que por si só já direciona as perguntas feitas aos filmes e à bibliografia. $\mathrm{O}$ que não quer dizer, não custa reiterar, que as imagens serão colocadas em segundo plano, como se a história estivesse fadada a se ocupar tão somente da crônica factual externa às obras cinematográficas. Já faz tempo, pelo menos desde Marc Ferro (2010), que as relações da disciplina histórica com o cinema são mais ricas do que isso, pautadas pela consideração atenta da imanência fílmica, com suas formas próprias de estruturação das releituras do passado (MORETTIN, 2007, 2013; NAPOLITANO, 2006). Porém, esta atenção à matéria audiovisual não abre mão de levar as interpretações para o terreno da concretude histórica. A premissa é que imagens e conjuntura se iluminam reciprocamente, dando a ver os complicados meandros dos processos de rememoração. É em função desse nexo referencial que as análises farão um constante movimento de ida e volta entre o fílmico e o extrafílmico, como já ficou indicado mais acima. A “descrição densa" (NAPOLITANO, 2006, p. 274) das imagens e dos circuitos em seu entorno é parte fundamental desse esforço. As passagens expositivas do texto são decisivas para a historicização dos filmes e das vicissitudes da memória neles manifestas. Ao enfrentar estas páginas, o leitor deve ter em mente que descrever obstinadamente é um dos recursos da operação historiográfica contra a redução das obras e do "contexto" às abstrações genéricas (a etiqueta do documentário subjetivo e suas variantes, a "era da subjetividade", a pós-ditadura, a pós-modernidade etc.). Porque, como já escreveu Carlo Ginzburg (2010, p. 18-19), “muitas vezes, as conexões entre obra de arte e contexto são colocadas em termos brutalmente simplificados". O autor prossegue: "Muito mais difícil de rejeitar preliminarmente (mas também muito mais trabalhosa e árdua de empreender) é a reconstrução analítica da intrincada rede de relações microscópicas que todo produto artístico, mesmo o mais elementar, 
pressupõe." (GINZBURG, 2010, p. 19). A paciência historiográfica é um antídoto contra a pressa em definir conceitualmente. E o leitor fica desde já convidado a acompanhar o texto nessa paciência, em particular nos momentos em que se faz necessário repassar a miríade de elementos que tornam o quadro mais complexo. Nesse mesmo impulso referencial, e longe de qualquer ingenuidade epistemológica, reivindica-se a possibilidade de se conhecer algo sobre o passado autoritário e o presente das representações a partir dos filmes. Eis, em termos sumários, a fundamentação teórica da abordagem historiográfica empreendida neste trabalho, inspirada sobretudo pelas leituras de Paul Ricœur (2007), Georges Didi-Huberman (2012) e, mais uma vez, Carlo Ginzburg (2014).

Junto com o lugar disciplinar, existe outro "lugar" em questão que deve ser explicitado: o lugar geográfico da pesquisa. $\mathrm{O}$ olhar aqui é transnacional, mas o ponto de vista é localizado (RADSTONE, 2011). Escreve-se desde o Brasil, onde, como se verá, os familiares das vítimas da ditadura nunca chegaram a assumir um protagonismo na memória social análogo àquele conquistado pelos familiares nos países vizinhos (TELES, J. A., 2005). Redige-se em português, e isso também tem suas implicações. Há que se dizer que o Brasil poucas vezes entra no escopo dos estudos em língua espanhola ou inglesa sobre a produção memorialística intergeracional do Cone Sul. No fundo, ao incluir dois títulos de origem brasileira no corpus principal, a investigação está ao mesmo tempo assumindo conscientemente e reivindicando essa localização da própria perspectiva.

Chega enfim o momento de sintetizar o passo a passo da tese a cada capítulo. $O$ Capítulo I apresenta um panorama do fenômeno do documentarismo intergeracional no Cone Sul. Indo além da mera contextualização, a análise de Diário de uma busca serve ali como porta de entrada para a identificação das diversas facetas do transnacionalismo nesse cenário: desde a dimensão transnacional das histórias de resistência e repressão nos anos autoritários; passando pela experiência do exílio; pela militância dos hijos nos países vizinhos na década de 1990; pela carreira transnacional da cineasta Flavia Castro; pelas lógicas da coprodução cinematográfica internacional; pela topografia da memória inscrita na itinerância das imagens fílmicas; desembocando nas dinâmicas das circulações e premiações dos títulos do corpus expandido em festivais de cinema ao redor do globo. O exame desse multifacetado transnacionalismo, com suas cadências temporais e nuances espaciais, coloca-se no lugar do diagnóstico sumário que descreve o documentarismo intergeracional como resultado de uma "guinada subjetiva" da cultura contemporânea.

Feita a cartografia mais concreta do fenômeno, o Capítulo II promove um debate conceitual sobre a definição dessa vertente de revisão das ditaduras. A análise de Los rubios 
amplia o leque dos vetores da memória e destaca o papel ativo de filhas, filhos e outros descendentes. Com isso, a reflexão se afasta da ênfase na transmissão do trauma dos pais que dá o tom da fórmula mais empregada para nomear essa filmografia: a noção de "pósmemória", tal qual cunhada por Marianne Hirsch (1993, 1997, 2008, 2012). De fato, o capítulo se debruça sobre as ressignificações e metamorfoses pelas quais essa noção passa ao ser confrontada com as imagens do documentário de Albertina Carri. Afinal, nelas a filha manuseia uma imprevisível miríade de referências intertextuais, mostrando que os laços entre as gerações da memória assumem sentidos que não se restringem à transmissão passiva de um fardo traumático. A ideia de "circuito intergeracional" fica então sugerida como uma saída heurística mais apta a abarcar o emaranhado de interações que preenche os gestos de rememoração dos descendentes.

Debatidos os termos que procuram conceituar essa memória, o Capítulo III se volta para o universo das formas cinematográficas identificáveis nessa filmografia. A abordagem retoma o olhar macroscópico, agora em função de uma comparação em paralelo dos recursos estético-narrativos mobilizados nos títulos do corpus expandido. Mi vida con Carlos é o eixo desse levantamento, sobretudo por ser um exemplo marcado demais pelos artifícios que costumam ser tidos como característicos do documentário realizado pelos descendentes. A decupagem analítica realizada monta um vasto elenco das formas empregadas no documentarismo intergeracional do Cone Sul, repassando os componentes da banda sonora, as configurações das tomadas, os elementos visíveis, até chegar aos tópicos de memória que se destacam nas narrativas. Entre as novidades, as permanências e as repetições desse repertório, a análise segue o rastro de uma contradição latente entre forma e indeterminação no conjunto desses filmes. Na encruzilhada entre obras abertas e a consolidação de determinadas fórmulas, fica matizado o pressuposto de que a "indeterminação formal" seria um traço inerente a esse cinema. É a partir daí que se propõe uma distinção dos lugares de enunciação assumidos pela primeira pessoa nessa produção, desde os quais o "eu" organiza a constelação de recursos estéticos e vai conformando novos "lugares de memória" (NORA, 1984).

Após a revisão do espectro das formas cinematográficas do corpus ampliado, o Capítulo IV opera um último reenquadramento da argumentação para se concentrar no núcleo referencial das imagens. Os embates visíveis em Os dias com ele são examinados em prol de uma intervenção na discussão sobre o tema da irrepresentabilidade do trauma. As reflexões levam em conta as aporias e as lacunas da rememoração, mas não se eximem de fazer suas apostas interpretativas. Trata-se do capítulo mais teórico da tese e, ao mesmo tempo, aquele que reivindica mais abertamente uma prática analítica que parte das imagens, vai aos arquivos 
e retorna às imagens para restituir sua densidade histórica. Junto com os vazios da representação, esse movimento busca vislumbrar o impacto da dor no pai torturado e a ancoragem da obra na viva disputa pelas versões sobre a ditadura no Brasil. Não por acaso, esse capítulo conclusivo será o mais "brasileiro" do trabalho, justamente porque nele se faz a crítica urgente das relações do presente com o autoritarismo passado.

A trajetória global da tese fica assim esboçada: partindo da cartografia transnacional, a argumentação repassa o circuito de laços intergeracionais e a gama de formas cinematográficas para culminar na questão-chave da carga referencial das imagens, a qual atravessa todo o debate. Há um crescendo aí, cada passo dado busca uma aproximação com os filmes em sua historicidade, indo além da grade conceitual dominante que tende a “enquadrar” essas manifestações da memória (POLLAK, 1989, p. 9-12). Oscilando do macro ao micro, no vaivém entre a matéria audiovisual e os materiais extrafílmicos, entre problematizações e proposições, seguindo o rastro da dialética entre forma e indeterminação, o texto constrói um panorama dinâmico do fenômeno da memória intergeracional no documentarismo do Cone Sul. Ao revolver o terreno da concretude das imagens, a abordagem historiográfica tenta dar conta dessa complexidade. Sem ingenuidades, sem qualquer ilusão objetivista de captar a realidade imediata. Pelo contrário, trata-se de nunca baixar a guarda autocrítica, de jamais se contentar com as balizas teóricas predefinidas. De assumir uma postura, afinal, epistemologicamente coerente com a reflexividade estética celebrada nas obras cinematográficas. E, nesse impulso, não ser indiferente às imagens, como se elas ali não estivessem. Tal era o pesadelo de Primo Levi (2014, p. 54), incluído como epígrafe deste trabalho: testemunhar e não ser escutado, porque as pessoas ao seu redor insistiam em ficar falando de outras coisas. 


\section{CAPÍTULO I}

\section{DINÂMICAS DA FORMAÇÃO DE UMA MEMÓRIA TRANSNACIONAL}

Este primeiro capítulo, como era de se esperar, encarrega-se de apresentar ao leitor o corpus fílmico e as linhas básicas da memória intergeracional. Trata-se de oferecer uma visão panorâmica do objeto da investigação, esquivando-se, porém, de duas tendências que costumam pautar esse tipo de esforço descritivo introdutório. Por um lado, estas páginas problematizam o diagnóstico genérico que atribui essa produção de viés íntimo e familiar a uma "guinada subjetiva" da cultura contemporânea. Por outro, evita-se o clássico capítulo de contextualização, no qual, em tantos casos, uma série de episódios conjunturais vem elencada antes, e de forma dissociada, da análise efetiva das obras. Uma abordagem historiográfica transnacional é assumida aqui como meio de superar ao mesmo tempo a definição abstrata e a mera crônica factual. O objeto vai sendo apresentado à medida que a argumentação repassa, atravessando o campo fílmico e extrafílmico, os meandros interconectados da formação do documentarismo intergeracional do Cone Sul ao longo dos anos. A proposta central é construir um quadro descritivo que restitua a profundidade espaçotemporal desse fenômeno de memória, questionando os determinismos sumários pela identificação das instâncias de legitimação (os festivais de cinema, a escrita acadêmica) de uma linha estética em particular nesse universo.

\section{O diagnóstico da "guinada subjetiva" do documentário e seus problemas}

Para o leitor minimamente familiarizado com a bibliografia sobre as manifestações culturais contemporâneas, não pareceria estranho se este capítulo se iniciasse com um diagnóstico de época. Se, logo de saída, surgisse a afirmação de que o documentário intergeracional sobre as ditaduras do Cone Sul é uma expressão da “"crise dos metarrelatos' [...] - uma crise que é intrínseca à mudança epistemológica que o pós-modernismo supôs e que, no caso que nos concerne, fez explodir a historiografia tradicional em uma multiplicidade de vozes originais e heterogêneas" (ESTEVE, 2009, p. 483, tradução nossa). Esse mesmo leitor não se surpreenderia caso ficasse dito que "é precisamente desse lugar - isto é, desde o novo, o diverso e também desde o emotivamente pessoal - que as criações desta [segunda] geração se enfrentam - às vezes timidamente, outras vezes de maneira frontal - com as 
grandes narrativas" que dominaram a opinião pública desde o fim das ditaduras (ESTEVE, 2009, p. 483, tradução nossa).

Também não pareceria incomum a avaliação de que, frente aos "grandes relatos" e as "grandes verdades" do cinema latino-americano dos anos 1960 e 1970, o cinema contemporâneo "dirigiu o olhar para a incerteza, para a descrença e para o sentimento emergente de que as grandes respostas já não eram válidas" (RIERA, 2009, p. 33, grifo da autora, tradução nossa). Que “dos relatos fundacionais que narravam a 'grande história' nacional recente $[\ldots]$ foi-se dando lugar progressivamente a uma perspectiva cinematográfica mais subjetiva" (BELLO, 2011, p. 77, tradução nossa). Ou, ainda, caso se dissesse que o "ponto de ancoragem" do documentário contemporâneo se encontra "na própria figura do cineasta e, sobretudo, em seu próprio corpo" (BERNINI, 2004, p. 43, tradução nossa). E que, “com isso, estaríamos assistindo a um último deslocamento do lugar da verdade documental em sua história, na medida em que esta já não reside no mundo representado nem na enunciação com que se dá conta dele, mas, em contrapartida, no eu do autor [...]" (BERNINI, 2004, p. 43, tradução nossa).

Tampouco soaria impróprio dizer que "o documentário pessoal ou subjetivo alcançou uma contemporaneidade surpreendente nos anos noventa e em começos deste século" (RUFFINELLI, 2005, p. 324, tradução nossa). Que “a dimensão subjetiva que o documentário tem desenvolvido desde a década de 1990, embora não seja dominante em termos quantitativos, traz consigo um reposicionamento significativo em relação à linguagem, em que as relações autor - representação do real - espectador se modificam" (GÁLVEZ, 2008, p. 78, grifo da autora). Ou que os documentários recentes "têm a particularidade de colocar em tensão os pressupostos epistemológicos do gênero. São os chamados documentários subjetivos, que registram a realidade desde o 'eu", renunciando à "imposição de certezas para dedicar-se a registrar o processo complexo através do qual se constrói um relato acerca da realidade" (KRIGER, 2007, p. 34, tradução nossa). E também que a irrupção do documentário em primeira pessoa ocorre em um contexto no qual "se reconfigura o campo artístico a partir da emergência da experiência e da subjetividade como eixos necessários para sustentar um discurso sobre o mundo, quando parecem se encontrar em transe os grandes relatos ideológicos, sociais, econômicos e políticos" (PIEDRAS, 2014, p. 29, tradução nossa).

Igualmente, não causaria surpresa a constatação de que, nos últimos anos, observa-se uma "guinada rumo à memória (rumo ao privado, ao individual e ao subjetivo)" (LAZZARA, 2009, p. 148, tradução nossa). Que "a emergência desse verdadeiro boom de um 'cinema em primeira pessoa' se explica, pois, em parte, pela preeminência que se atribuiu desde as artes e 
as humanidades às expressões subjetivas que reivindicam a memória" (LABBÉ, 2012b, p. 1415, tradução nossa). Sendo de se esperar que tais diagnósticos fossem completados com a afirmação de que:

Esta tendência [...] é parte de um fenômeno mais amplo, que envolve não só o cinema, mas o conjunto das artes visuais, a literatura, os meios de comunicação, a política e até a pesquisa acadêmica: uma insistência na expressão da própria subjetividade, da vivência, do biográfico - e, por certo, do autobiográfico -, do "verdadeiramente" vivido e experimentado [...]. (ARFUCH, 2014, p. 132, tradução nossa).

Chegando-se, afinal, à conclusão de que esse fenômeno delineia:

[...] os contornos preliminares de um "espaço biográfico" [...]. Um espaço sempre em expansão, de notável primazia sobre outros registros da discursividade social, que aparec[e] como um horizonte de inteligibilidade para dar conta, em uma leitura sintomática, do que se poderia definir como uma verdadeira reconfiguração da subjetividade contemporânea. (ARFUCH, 2014, p. 132, tradução nossa).

O que, sim, intriga é que tais avaliações, em si mesmas pertinentes, não costumam levar em consideração um problema que lhes é subjacente. As reflexões de Renato Prelorentzou (2015), já desde a forma de sua escrita, descortinam esse ponto em outro contexto de análise. Pensando sobre os cruzamentos entre historiografia e literatura, Prelorentzou (2015, p. 94) escreve:

Era curioso notar como a crítica em geral sempre reduzia o passado a algum esquematismo, dentro de determinações estanques, como se "hoje" e "ontem", "pré-moderno" e "contemporâneo" fossem homogêneos. Nessas formas de construção do anterior, a crítica produzia narrativas totais sobre o passado, ainda que falasse exatamente sobre o fim das narrativas totalizantes - e talvez valesse refletir sobre as implicações que tudo isso trazia à escrita acadêmica. Afinal, [...] dizer que toda a história do moderno talvez pudesse ser contada como um longo deslocamento da perspectiva totalizante para a particular, da grande narrativa para o relato íntimo, da certeza da onisciência para a dúvida mediada, era também escrever uma grande narrativa sobre o fim da grande narrativa.

Nos diagnósticos da "guinada subjetiva" do documentário, chama atenção que a descrição dessa passagem do geral ao particular acabe construindo exatamente essa "grande narrativa sobre o fim da grande narrativa". Outros dois problemas derivam desse primeiro: que a análise da virada rumo à incerteza epistemológica termine afirmando o esgotamento dos discursos assertivos; que a constatação da fragmentação dos relatos nos últimos anos se projete em uma ampla leitura da contemporaneidade. Na bibliografia dedicada ao 
documentário recente, muitas vezes a forma assumida pelos diagnósticos vai na contramão do teor diagnosticado. Generaliza-se o fim das generalizações; afirma-se o fim das afirmações; amplia-se a fragmentação para uma condição de época.

Esses três pontos levam à suspeita, levantada por Prelorentzou, de que os discursos crítico e acadêmico não têm voltado suas constatações contra si mesmos. Hábeis para perceber as dinâmicas discursivas em voga, é como se tal habilidade não se aplicasse a seus próprios gestos discursivos. Como se os enunciados dessas instâncias fossem isentos do diagnóstico que elaboram. Como se a dúvida e a fragmentação não lhe tocassem. Como se fossem vozes que pairassem sobre as outras.

Não é que se negue a pertinência de tais avaliações. Pois é fato que o fenômeno de uma memória íntima e subjetiva no documentário intergeracional é observável em seus contornos ampliados. Há uma inflexão em jogo aí, um certo deslocamento em relação às matrizes de memória consolidadas das ditaduras (a vitimização universal, a épica da resistência). Nesse sentido, é eloquente a profusão de títulos dirigidos por filhas e filhos, ou ainda sobrinho(a)s e neto(a)s de militantes de esquerda vítimas das ditaduras do Cone Sul. Além das obras que, embora não sejam dirigidas, contam com uma participação central desses descendentes, ora testemunhando, ora conduzindo as buscas do documentário. No recorte temático da memória intergeracional das ditaduras, o corpus ampliado desta pesquisa alcança 67 documentários, entre curtas, médias e longas-metragens, ${ }^{3}$ em estilos que vão das convencionais "cabeças falantes" até a reflexividade radical em primeira pessoa.

Da Argentina, há: Los Argenmex 20 años después: la historia ésta (Jorge Denti, México, 1996); Pasaportes (Inés Ulanovsky, Argentina, 1997); Hasta la memoria, siempre (Rodrigo Vázquez, Argentina, 1997); H.I.J.O.S. de la historia (Roberto Leonardo, Argentina, 1998); Papá Iván (María Inés Roqué, México / Argentina, 2000); En memoria de los pájaros (Gabriela Golder, França / Argentina, 2000); (h) Historias cotidianas (Andrés Habegger, Argentina, 2000); Panzas (Laura Bondarevsky, Argentina, 2000); H.I.J.O.S. (Francisco Zinzer, Argentina, 2000); Generación golpe (Fabián Agosta e Lisandro Costa, Argentina, 2001); Che vo cachai (Laura Bondarevsky, Argentina, 2002); H.I.J.O.S.: El alma en dos (Carmen Guarini e Marcelo Céspedes, Argentina, 2002); Organizaciones horizontales (Fausta Quattrini, Argentina, 2002); Los rubios (Albertina Carri, Argentina, 2003); El tiempo y la sangre (Alejandra Almirón, Argentina, 2004); Encontrando a Víctor (Natalia Bruschtein, México / Argentina, 2004); Nietos (identidad y memoria) (Benjamín Ávila, Argentina, 2004);

\footnotetext{
${ }^{3}$ A lista incluída no fim da tese especifica a metragem de cada título do corpus expandido.
} 
Hermanos de sangre (Fabián Vittola, Argentina, 2005); Diario argentino (Lupe Pérez García, Argentina / Espanha, 2006); Nacimos en su lucha, viven en la nuestra: 10 años de H.I.J.O.S. La Plata (Camilo Cagni, Pablo Balut, Pablo Roesler e Juan Aíub, Argentina, 2006); Mansión Seré (Jorge Bianchini, Argentina, 2006); Semillas de utopía (Rodolfo Colombara e Emanuela Peyretti, Itália, 2006); Argenmex: exiliados hijos (Violeta Burkart Noë e Analía Miller, Argentina, 2007); ¿Quién soy yo? Los niños encontrados de Argentina (Estela Bravo, Argentina / EUA / Reino Unido, 2007); $M$ (Nicolás Prividera, Argentina, 2007); Victoria (Adrián Jaime, Argentina, 2008); Tiempo suspendido (Natalia Bruschtein, México / Argentina, 2015); La parte por el todo (Roberto Persano, Santiago Nacif Cabrera e Andrés Martínez Cantó, Argentina, 2015); 70 y Pico (Mariano Corbacho, Argentina, 2016); La guardería (Virginia Croatto, Argentina, 2016); Retour: volver (Martin Bourgault, Canadá / Argentina, 2016); El padre (Mariana Arruti, Argentina, 2016); El (im)posible olvido (Andrés Habegger, Argentina / Brasil / México, 2016); Cuatreros (Albertina Carri, Argentina, 2016).

Do Chile: En algún lugar del cielo (Alejandra Carmona, Chile, 2003); Reinalda del Carmen, mi mamá y yo (Lorena Giachino Torréns, Chile, 2006); El telón de azúcar (Camila Guzmán Urzúa, França / Cuba / Espanha, 2006); ${ }^{4}$ Héroes frágiles (Emilio Pacull, Chile / França, 2007); La promesa de mi madre (Marianne Hougen-Moraga, Dinamarca / Chile / Reino Unido, 2007); Mi vida con Carlos (Germán Berger-Hertz, Chile / Espanha, 2009); La quemadura (René Ballesteros, Chile / França, 2009); El memorial (Andrés Brignardello Valdivia, Chile, 2009); El edificio de los chilenos (Macarena Aguiló e Susana Foxley, Chile / Cuba / França / Bélgica, 2010); El eco de las canciones (Antonia Rossi, Chile, 2010); Abuelos (Carla Valencia Dávila, Equador / Chile, 2010); Allende mi abuelo Allende (Marcia Tambutti, Chile / México, 2015); Venían a buscarme (Álvaro de la Barra, Chile, 2016); Guerrero (Sebastián Moreno, Chile, 2017); El color del camaleón (Andrés Lübbert, Chile / Bélgica, 2017); Mute (Claudia Aguilera, Chile, 2017); El pacto de Adriana (Lissette Orozco, Chile, 2017).

Do Brasil, existem: 15 filhos (Maria Oliveira e Marta Nehring, Brasil, 1996); Diário de uma busca (Flavia Castro, Brasil / França, 2010); Marighella (Isa Grinspum Ferraz, Brasil, 2011); Repare bem (Maria de Medeiros, Brasil / Portugal / Espanha, 2012); Os dias com ele (Maria Clara Escobar, Brasil / Portugal, 2013); Em busca de Iara (Flavio Frederico, Brasil, 2013); Orestes (Rodrigo Siqueira, Brasil, 2015); e, em alguma medida, Elena (Petra Costa, Brasil, 2012), embora neste último a temática da ditadura seja apenas tangencial.

\footnotetext{
${ }^{4}$ No caso de El telón de azúcar, a produção não é chilena, mas a diretora é filha do realizador Patricio Guzmán e seu filme conta a história de um exílio motivado pela ditadura chilena.
} 
Do Uruguai: Los huérfanos del Cóndor (Emilio Pacull, França / Uruguai, 2003); HIJOS Uruguay (Lucas Silva e Víctor Burgos Barreiro, Uruguai, 2006); Secretos de lucha (Maiana Bidegain, Uruguai / França, 2007); D.F. (destino final) (Mateo Gutiérrez, Uruguai, 2008); A contrarreloj (Pablo Sobrino, Uruguai, 2011); Tus padres volverán (Pablo Martínez Pessi, Uruguai, 2015); Todos somos hijos (Esteban Barja e Carlos Conti, Uruguai, 2015); do Paraguai: Cuchillo de palo (Renate Costa, Paraguai / Espanha, 2010).

Enfim, trata-se de um conjunto significativo de documentários, e isso para ficar apenas nesse recorte de gênero. Porque o fenômeno da memória intergeracional das ditaduras do Cone Sul é ainda mais amplo, manifestando-se, em prismas diversos, também no cinema de ficção, ${ }^{5}$ bem como na literatura, ${ }^{6}$ na fotografia ${ }^{7}$ e em outros campos artísticos. Ademais, o olhar de segunda geração no cinema volta-se para outros conflitos na América Latina ${ }^{8}$ e, para além do continente, filhos, sobrinhos e netos abordam o passado nas conjunturas históricas as mais variadas.

A lista acima demonstra que são numerosos os documentários ligados à segunda ou à terceira geração da memória das ditaduras. E que é possível seguir expandindo a escala dos campos artísticos e dos contextos históricos nos quais essa tendência ganha corpo. Jordana Blejmar e Natalia Fortuny (2013, p. 3, tradução nossa) apontam, para além das diferenças e especificidades, quatro características básicas compartilhadas pelas expressões ligadas à cultura da memória das novas gerações na América Latina. Em primeiro lugar, essas obras trariam "à luz novas reconfigurações da dicotomia público-privado", pensando em termos

\footnotetext{
${ }^{5}$ Por exemplo, em: La cara del ángel (Pablo Torre, Argentina, 1998); El despertar de L. (Poli Nardi, Argentina, 1999); Figli/Hijos (Marco Bechis, Argentina / Itália / Espanha, 2001); Ciudad del sol (Carlos Galettini, Argentina, 2001); Los pasos perdidos (Manane Rodríguez, Argentina / Espanha, 2001); Kamchatka (Marcelo Piñeyro, Argentina / Espanha, 2002); Valentín (Alejandro Agresti, Argentina / Espanha / França / Países Baixos / Itália, 2002); Cautiva (Gastón Biraben. Argentina, 2003); Machuca (Andrés Wood, Chile / Espanha / Argentina / Reino Unido / França, 2004); O ano em que meus pais saíram de férias (Cao Hamburger, Brasil, 2006); Ma fille (Mi hija) (Enrique Stavron, Argentina, 2007); Veo veo (Benjanín Ávila, Argentina, 2007); Cordero de Dios (Lucía Cedrón, Argentina, 2008); El nombre de las flores (Juan Alecsovich e Romina Haurie, Argentina, 2008); O dia em que eu não nasci (Florian Cossen, Alemanha / Argentina, 2010); Eva \& Lola (Sabrina Farji, 2010); La última mirada (Víctor Jorge Ruiz, Argentina / Espanha, 2010); El premio (Paula Markovitch, México / França / Polônia / Alemanha, 2011); Infancia clandestina (Benjamín Ávila, Argentina / Espanha / Brasil, 2011); Avanti popolo (Michael Wahrmann, Brasil, 2012); Manuel (Joel e Natanael Navas, Argentina, 2016). No cinema de animação, Historia de un oso (Gabriel Osorio, Chile, 2014) foi vencedor do Oscar de melhor curta-metragem da categoria em 2016.

${ }^{6}$ Alguns dos livros mais conhecidos são La casa de los conejos, de Laura Alcoba (2014); Formas de volver a casa, de Alejandro Zambra (2014); e A resistência, de Julián Fuks (2015).

${ }^{7}$ Por exemplo, a série Arqueología de la ausencia, de Lucila Quieto (1999-2001), ou o ensaio fotográfico Nietas/os, de Alejandro Reynoso (2016).

${ }^{8}$ Tais como a insurreição do Sendero Luminoso no Peru, em Tempestad en los Andes (Mikael Wiström, Peru / Suécia, 2014); a guerrilha na Guatemala, em Las colmenas (Alejandro Ramírez Anderson, Cuba, 2007); a violência política na Colômbia, em Pizarro (Simón Hernández, Colômbia, 2014) e Carta a una sombra (Daniela Abad Lombana e Miguel Salazar, Colômbia, 2015); a Revolução Sandinista, na ficção Princesas rojas (Laura Astorga, Costa Rica / Venezuela, 2012).
} 
políticos a relação entre essas duas esferas. Em segundo lugar, Blejmar e Fortuny (2013, p. 3, tradução nossa) destacam "a mescla entre autobiografia e ficção", em geral "ocultando tanto quanto expondo a identidade e as vidas de seus autores”. A terceira caraterística comum a essas obras seria "a natureza interdisciplinar dos textos culturais produzidos pelas gerações da pós-ditadura" (BLEJMAR; FORTUNY, 2013, p. 4, tradução nossa). No caso específico do documentarismo, as autoras mencionam a inserção de "animação e ficção para retratar o trabalho de memória". O quarto traço comum dessa produção cultural identificado por Blejmar e Fortuny (2013, p. 4, tradução nossa) é o exercício de "formas de rememoração dessacralizadas e não solenes", criando "condições para uma potencial discussão de questões tabu".

Seja pela presença de um conjunto consistente de obras, seja pela identificação de certos traços básicos, fica claro que existe algo que se pode chamar de memória intergeracional das ditaduras do Cone Sul. Frente à constatação de tal inflexão, o que se busca aqui, no recorte do cinema documental, é compreender suas manifestações como um fenômeno histórico, em escala macro. Ao mesmo tempo, contudo, essa abordagem macroscópica não abre mão de lançar um olhar reflexivo sobre o grande diagnóstico da "guinada subjetiva" do documentário e da memória, de modo a perceber suas complicações epistemológicas. Já ficou esboçado o paradoxo da "grande narrativa sobre o fim da grande narrativa". Sobre a faceta "subjetiva" da guinada e seus excessos, Beatriz Sarlo (2007) já polemizou longamente. Resta apontar o problema trazido pela própria ideia de "guinada", tão comum nos estudos do documentário contemporâneo (e em tantos outros campos de pesquisa). Já este "contemporâneo" conduz à pergunta: o que seria aquele "anterior" que se contrapõe ao "atual"? Pois a palavra "guinada" (em geral, uma tradução do termo em inglês turn ou do espanhol giro) traz consigo essa conotação de passagem de um antes a um depois. Mais ainda, em português "guinada" remete a uma mudança súbita, abrupta. É verdade que esse emprego da palavra não costuma ser assim literal. Entretanto, fica o risco subjacente de que, no limite, a reflexão nesses termos se incline a uma lógica dicotômica: antes, o documentário e a memória eram objetivos e assertivos; hoje, ambos são subjetivos e hesitantes.

Outro problema que ronda esse diagnóstico é a tautologia. Afinal, não se está muito longe disso quando se diz que o documentário contemporâneo sobre as ditaduras é subjetivo porque hoje se vive uma "era" da subjetividade. Roger Chartier (2002, p. 35) já escreveu que “esse 'espírito do tempo', esse 'Zeitgeist' [...], mais do que aquilo que explica, é justamente aquilo que é necessário explicar." Falar em "guinada subjetiva" significa, no fundo, usar uma 
ideia desencarnada para descrever um processo cultural que é histórico. O que se quer salientar aqui é que uma ampla síntese teórica da contemporaneidade, tanto mais quando pautada pela lógica da guinada, acaba esvaziando de sua historicidade um fenômeno de memória específico e pleno de vaivéns: aquele que se manifesta no documentarismo de filhos, sobrinhos e netos de militantes vítimas das ditaduras do Cone Sul.

Mas não se trata de voltar ao bom e velho capítulo de contextualização, vale dizer. Inverter a mão da análise não resolveria a questão. Pois seria igualmente problemático partir do "contexto" histórico para projetar uma homologia sobre as obras estéticas por ele supostamente "determinadas". Se o "espírito do tempo" não explica essa filmografia, tampouco o faria um elenco de fatos de seu "contexto". A historicidade aqui é compreendida em outros termos, em sua profundidade temporal e espacial. Ela se manifesta nos fluxos e refluxos dessa filmografia ao longo dos anos, nas circulações das obras além das fronteiras. Em suma, propõe-se neste capítulo um deslocamento do olhar da "guinada" para a diacronia, do diagnóstico geral para o alcance geográfico. Enfim, uma leitura que relativize o grande corte conceitual (o antes/depois do documentário e da memória) por meio da análise das dinâmicas históricas da constituição dessa filmografia.

\section{Diário de uma busca transnacional}

A abordagem transnacional desponta, então, como uma solução possível para os problemas acima elencados. Um viés, enfim, apto a guiar a reflexão sobre as dinâmicas históricas do fenômeno aqui estudado, com algumas vantagens. Por um lado, o prisma do transnacionalismo mantém o olhar em escala macro, sem, contudo, ficar preso a um diagnóstico abstrato sobre a época contemporânea. Por outro, ele evita a redução da historicidade do documentarismo intergeracional do Cone Sul à sua mera "contextualização" factual.

As pesquisas em escala transnacional têm ganhado cada vez mais fôlego nos estudos do cinema e da memória (para não falar de outros campos das ciências humanas). É óbvio que as dinâmicas transnacionais não são uma novidade nessas práticas de representação. O que vem ocorrendo nos últimos anos é a ascensão do interesse acadêmico pelo transnacionalismo (LEFERE; LIE, 2016, p. 4), uma tendência que costuma ser vinculada a matrizes diversas: a globalização (neoliberal, diga-se) dos anos 1990, que teria alimentado essa crescente atenção às trocas culturais entre os países (ASSMANN; CONRAD; 2010; LIE, 2016, p. 18); os estudos pós-coloniais, na contracorrente, concentrados nas cargas de dominação, resistência e 
hibridismo desses fluxos (HIGBEE; LIM, 2010; ROTHBERG, 2009; SEIGEL, 2005, p. 62). No fundo, mais do que diferentes, essas matrizes podem ser tidas como divergentes (SEIGEL, 2005, p. 63), e as implicações ideológicas da filiação a uma ou outra não são irrelevantes. Há vozes que acusam a falta de perspectiva crítica ou autorreflexiva nos estudos transnacionais (HUYSSEN, 2014, p. 16; LIE, 2016, p. 21-22; RADSTONE, 2011). Muitos seriam os trabalhos que, segundo tais ponderações, acabam tomando o transnacionalismo como um dado ou banalizam o uso do termo a ponto de torná-lo um "significante potencialmente vazio, flutuante" (HIGBEE; LIM, 2010, p. 10, tradução nossa). Mais ainda, aponta-se o risco de que a palavra “"transnacional' acabe exercendo um papel estranhamente homogeneizante" (HJORT, 2010, p. 13), anulando, ao invés de sublinhar, as especificidades e tensões dos processos que quer descrever. Como afirma Nadia Lie (2016, p. 17): "Nos últimos anos, o conceito de transnacional se converteu em um dos termos mais presentes, mas também mais imprecisos, na área das ciências humanas. Essa vagueza terminológica se deve, em primeiro lugar, a sua genealogia interdisciplinar."

Seja qual for a matriz desde onde se fale, mesmo dentro dessa profusão e vagueza, existe um consenso de base sobre o transnacionalismo: a superação das abordagens limitadas às fronteiras da nação. O que não significa, de forma alguma, negar o papel da escala nacional, tampouco de outras escalas menores, nas dinâmicas estudadas (HUYSSEN, 2014, p. 14; LEFERE; LIE, 2016, p. 6; MIDDENTS, 2013, p. 149). Quanto a isso, vale citar neste ponto a definição proposta por Nataša Ďurovičová (2010a, p. ix-x, grifo da autora, tradução nossa):

Em contraposição a "global", um conceito ligado à categoria filosófica de totalidade, e em contraste com "internacional", que supõe sistemas políticos em uma relação latente de paridade, como indicado pelo prefixo "inter-", "transnacional", palavra intermediária e mais aberta, reconhece a persistente agência (agency) do Estado, em uma relação variável, mas fundamentalmente legitimadora, na escala da "nação". Ao mesmo tempo, o prefixo "trans-" implica relações de desigualdade e mobilidade. É essa relativa abertura a modalidades de formas geopolíticas, a relações sociais e, especialmente, à escala variável em que as relações se deram na história do cinema que confere a esse termo-chave sua força dinâmica e sua utilidade como um quadro para hipóteses sobre as formas emergentes.

Mesmo diante da ascensão desse paradigma nos estudos do cinema e da memória, há que se dizer que as leituras propriamente transnacionais não são tão comuns quanto se poderia supor quando o tema é a produção memorialística intergeracional dos países do Cone Sul. Existem os artigos acadêmicos isolados, que em geral se concentram na análise de um título, 
ou de um número pequeno de filmes, quase sempre do mesmo país. ${ }^{9}$ Nos dossiês especialmente dedicados a essas manifestações culturais na região, os artigos tendem a abordar de modo estanque exemplos dos distintos países (BLEJMAR; FORTUNY, 2013). Nos trabalhos monográficos de maior fôlego, ou o recorte é a filmografia de um país (BARRIL, 2013; ESTEVE, 2009; PIEDRAS, 2014); ou, quando abrangem mais de um país, a perspectiva é sobretudo comparativa (FRIED, 1999; ROS, 2012; SERPENTE, 2013; SOUZA, 2007); podendo ocorrer também que o foco seja a figuração dos espaços de memória nas imagens, e não tanto uma espacialidade em chave transnacional (GRAY, 2015). Mesmo nos casos em que as pesquisas reivindicam uma perspectiva transnacional ou "transatlântica", a análise, no fundo, realiza uma comparação entre representações de segunda geração de dois países (NÚÑEZ, 2014; SEYDEL, 2015).

Os limites do comparatismo já foram muito discutidos. De fato, os debates em torno do paradigma transnacional são, em grande medida, uma resposta aos problemas derivados do cotejamento de casos nacionais "congelados", em geral em busca de semelhanças e diferenças (WEINSTEIN, 2013, p. 18-19). Em poucas palavras: a análise comparativa se dá em paralelo, de modo sincrônico, pautada por fronteiras bem demarcadas; o viés transnacional, por sua vez, enfatiza as circulações, as mediações, os cruzamentos, as zonas de contato (ESPAGNE, 1994; LUSNICH, 2014; PRADO, 2005; SEIGEL, 2005, p. 65; WERNER; ZIMMERMANN, 2003).

De todo modo, a ideia aqui não é realizar um balanço demorado das discussões acerca do paradigma transnacional. ${ }^{10}$ No lugar da glosa da bibliografia, algo que adiaria o enfrentamento do objeto específico desta pesquisa, a ideia é incorporar esses debates conceituais na análise de um documentário em particular: Diário de uma busca (Flavia Castro, Brasil / França, 2010). Nesse filme, a diretora parte da suspeita acerca da morte do pai, Celso Castro, militante do Partido Operário Comunista (POC) e exilado político que retornou com a família para o Brasil após a Lei de Anistia de 1979. Em 1984, em circunstâncias nebulosas, ele e um amigo, Nestor Herédia, foram mortos a tiros após invadirem o apartamento do alemão Rudolf Goldbeck, suposto oficial nazista radicado em Porto Alegre. As dúvidas sobre o episódio fatal levam Flavia Castro a percorrer novamente os lugares de sua infância, seguindo os rumos da militância dos pais e do exílio familiar. A

\footnotetext{
${ }^{9}$ A lista destes casos é demasiado extensa para ser incluída neste ponto. Esses artigos serão mobilizados ao longo das análises.

${ }^{10}$ Para um histórico do conceito de "transnacional" com foco nos estudos do cinema, cf. LIE, 2016. Além dos textos já citados, vale mencionar as seguintes coletâneas dedicadas à produção audiovisual e/ou à memória latino-americanas em chave transnacional: BARROW; FALICOV, 2013; DENNISON, 2013a; LEFERE; LIE, 2016; LIE; MAHLKE, 2014; PERRIAM; SANTAOLALLA; EVANS, 2007.
} 
diretora ouve ainda os parentes próximos, com destaque para a mãe, Sandra Macedo, cuja avaliação retrospectiva dos descompassos entre a militância e a vida familiar é de uma franqueza desconcertante; e o irmão João Paulo Castro, o "Joca", com quem discute o próprio processo de realização do filme. Antigos companheiros dos pais são também entrevistados, e a diretora localiza inclusive os policiais envolvidos na operação que resultou na morte de Celso Castro. Todo esse roteiro é alinhavado pelas cartas enviadas pelo pai naqueles anos, lidas no filme em voz over pelo irmão da diretora. ${ }^{11}$

Esse título é aqui encarado não como um "caso exemplar", mas, antes, como uma porta de entrada para a reflexão sobre as variadas facetas do transnacionalismo no documentário intergeracional do Cone Sul. Trata-se de olhar para um filme determinado para pensar o fenômeno em escala ampliada. Enfim, ir do micro ao macro e vice-versa (GINZBURG, 2011b), fazendo com que Diário de uma busca e a dimensão transnacional do documentarismo intergeracional se iluminem reciprocamente. Esse jogo de escalas evita que a solução transnacional caia na substituição de uma generalização por outra, a troca da abstração da "guinada subjetiva" por uma noção vaga de transnacionalismo. A matéria fílmica é o ponto de partida para se compreender os contornos e as dinâmicas do fenômeno.

$\mathrm{Ou}$ melhor, a matéria fílmica e aquilo que a precede e sucede. Pois o transnacionalismo não é uma chave metodológica que a análise imponha aos documentários aqui estudados. Muitos aspectos transnacionais estão presentes já nas próprias imagens desses filmes. E, antes disso, nas trajetórias de seus realizadores e nas dinâmicas de produção. E, depois disso, nas circulações desses títulos em festivais pelo mundo. No fundo, o viés transnacional é uma escolha metodológica condizente com certos traços salientes dessa cinematografia, seja no campo fílmico ou extrafílmico.

Seguindo essa trilha, a análise em chave transnacional de Diário de uma busca se desdobrará em três momentos básicos. O primeiro gira em torno do que aqui ficará denominado pré-fílmico, incluindo facetas da trajetória da diretora Flavia Castro e da produção deste que é seu primeiro longa-metragem. Em segundo lugar, o foco vai para aquilo que é propriamente fílmico, ou seja, as marcas estéticas do transnacionalismo nas imagens do documentário. Em terceiro lugar, vem o pós-fílmico, levando adiante as considerações

\footnotetext{
${ }^{11} \mathrm{O}$ termo over designa os sons cuja fonte está isolada do espaço diegético (a locução sobreposta às imagens é o exemplo clássico), ao passo que off refere-se às vozes e sons emitidos dentro do espaço diegético, mas fora do enquadramento (AUMONT; MARIE, 2009, p. 214-215 e 300). Sobre Diário de uma busca, cf. também: AVELLAR, 2016, p. 103-110; BARTOLOMEU; VEIGA, 2015; COQUET, 2014; FRANÇA; MACHADO, 2014a; GUERRA, 2016; MAIA, 2015b; ROVAI, 2015; SELIPRANDY, 2013; SILVA, M. D. J., 2015.
} 
desencadeadas pela circulação de Diário de uma busca nos festivais internacionais. ${ }^{12}$ Tal percurso analítico busca cobrir três das principais "formas de transnacionalismo" no cinema: os "diretores transnacionais"; os "modos transnacionais de produção, distribuição e exibição"; e os “modos transnacionais de narração" (LEFERE; LIE, 2016, p. 7, tradução nossa).

\section{Pré-fílmico: do exílio às coproduções internacionais}

Introduzindo a sequência do retorno dos exilados após a anistia de 1979, Diário de uma busca traz uma inserção de arquivo carregada de significados: trata-se de uma entrevista concedida pela adolescente Flavia Castro, então com quatorze anos, a Roberto D'Ávila. Ambos estão sentados no banco de uma praça em Paris. A legenda informa: "Paris, setembro de 1979 / Programa de TV Abertura". Logo de saída, um detalhe chama a atenção: Flavia Castro fala português com sotaque francês, ela confunde certas palavras, comete deslizes de pronúncia. Perguntada por D’Ávila, ela informa que saiu do Brasil há quase oito anos, que morou "primeiro no Chile, depois na Argentina, um pouquinho na Bélgica e aqui." A adolescente faz um balanço do exílio, diz que foi uma experiência difícil, com os constantes processos de readaptação, mas que, ao mesmo tempo, isso trouxe um amadurecimento. $\mathrm{O}$ entrevistador indaga se ela está com vontade de voltar para o Brasil. Flavia Castro responde:

Não. Eu acho muito bom que tenha tido a anistia e tudo, mas eu não estou com vontade porque, primeiro, não tem nada garantido para nós de que lá seja bom, quer dizer, que a minha mãe consiga um emprego que ela goste, que a gente fique mais contente do que aqui. E, segundo, porque eu estou acostumada aqui, gosto daqui. Bom, e a minha vida está aqui, eu vivi quase a metade dela aqui.

A conversa envereda para a temática do machismo da sociedade brasileira, um tema candente entre as mulheres exiladas que se aproximaram do feminismo na França (PEDRO, 2008; ROLLEMBERG, 1999, p. 208). Roberto D’Ávila pergunta, então, se Flavia Castro tem lembranças do Brasil. Ela responde que é tudo muito vago, que se lembra de cenas, mas que, no fundo, não conhece o Brasil.

O sotaque da Flavia Castro adolescente nessa passagem ecoa a noção de "accented cinema", cunhada por Hamid Naficy (2001) para descrever uma cinematografia do exílio e da diáspora. Desdobrando essa ideia, o autor lembra que "os cineastas com sotaque (accented filmmakers) [...] são também sujeitos empíricos, situados nos interstícios de culturas e

\footnotetext{
${ }^{12}$ Guardadas as devidas proporções, a inspiração para esta organização da análise de Diário de uma busca vem de LINDEPERG, 2007.
} 
práticas cinematográficas que existem fora e antes de seus filmes" (NAFICY, 2001, p. 4, tradução nossa). A narrativa de Diário de uma busca coloca em primeiro plano a história de vida Celso Castro, pai de Flavia. No entanto, no fluxo do relato, a subjetividade da diretora não fica restrita ao lugar de enunciação, à voz que diz "meu pai" ou "minha família". Junto com a história de Celso, o espectador fica conhecendo também algo da trajetória pessoal de Flavia Castro. De seu exílio ainda criança, de sua errância de país em país, a reboque da militância política dos pais, ao sabor dos ventos autoritários que sopravam no Cone Sul. O exílio, neste como em tantos outros casos, não foi apenas uma história herdada, mas uma experiência vivida em primeira pessoa pela diretora. Naquela entrevista de 1979, quando o desterro poderia enfim terminar, a pronúncia afrancesada da adolescente Flavia era uma forma de expressão eloquente de seu próprio deslocamento. De um não querer abandonar a França onde havia morado boa parte de sua vida, de um não desejar voltar para um país que seria seu, mas que não conhecia. ${ }^{13}$

Nesse ponto, o prisma do transnacionalismo se reveste com a carga do desenraizamento do exílio. A enigmática morte de Celso Castro no apartamento de um suposto ex-oficial nazista em Porto Alegre parece ter sido o desfecho extremo de uma sensação ubíqua de não pertencimento. É esse inexplicável da morte do pai que dá o primeiro impulso ao documentário da filha. E que, já na esteira da repercussão de Diário de uma busca, leva o antropólogo João Paulo Macedo e Castro (que no documentário de Flavia Castro é "Joca", seu irmão, com quem ela trava diálogos sobre o próprio projeto fílmico) a escrever um artigo acadêmico sobre a trajetória do pai. O antropólogo não abre mão de ser filho. Sua análise inicia-se em primeira pessoa, a frase de abertura do texto é quase idêntica às palavras introdutórias de Diário de uma busca. "Meu pai faleceu no dia 4 de outubro de 1984", escreve João Paulo Macedo e Castro (2014, p. 7). "Meu pai morreu em Porto Alegre, no dia 4 de outubro de 1984, em circunstâncias misteriosas", é a primeira frase dita em voz over por Flavia Castro no longa-metragem. Em seu texto acadêmico, João Paulo Macedo e Castro examina as reações ao filme da irmã, as cartas do pai e a repercussão na imprensa à época do fato, buscando compreender as tentativas de se encaixar a biografia dos indivíduos, ou melhor, de seu pai, em esquemas mais gerais da memória coletiva.

Era como se para os outros houvesse uma sucessão de eventos encadeados de forma linear e quase autoexplicativos. Com início, meio e fim. Como se

\footnotetext{
${ }^{13}$ Em 2014, Flavia Castro e seu irmão, João Paulo Macedo e Castro, foram declarados anistiados políticos pela Comissão de Anistia do Ministério da Justiça, em um reconhecimento oficial dos danos transgeracionais causados pela perseguição política a seus pais durante a ditadura (BRASIL, 2014).
} 
sua história obedecesse a um roteiro previamente instituído, e o sentido de ações, escolhas e emoções produzidas ao longo de sua vida pudessem ser ressignificados de forma clara e contínua dentro de um determinado campo de possibilidades. (CASTRO, J. P. M., 2014, p. 7).

Segundo o filho-antropólogo, o ato final de Celso Castro, que o levou à morte, escaparia às linhas mestras da reelaboração social da memória da ditadura, explicitando:

[...] uma incompatibilidade não apenas com a nova realidade política conjuntural, mas também uma rejeição a estabelecer um elo de continuidade entre o conjunto de experiências e vivências anteriores e as que se colocavam no seu presente. O que foi derrotado então não foi apenas um "projeto político" ou uma "visão de mundo", mas uma possibilidade existencial de estar no mundo. (CASTRO, J. P. M., 2014, p. 27-28).

O derradeiro gesto de Celso Castro traria a marca da irredutibilidade, no duplo sentido da palavra: o pai não transigiu com a abertura política tutelada pelos militares; sua morte não pode ser subsumida às versões dominantes da memória da resistência. O desfecho trágico do percurso de Celso Castro eclode como uma ruptura idiossincrática com a dimensão coletiva daquela experiência. As condições enigmáticas de sua morte são uma "anomalia" (GINZBURG, 2011b, p. 262-263 e 277) no contexto social de reinserção dos ex-exilados: um corte extremo entre o passado revolucionário (derrotado) e o presente da redemocratização (transigida). Contudo, antes do ato fatal, é patente que a biografia de Celso Castro tem um forte vínculo com as vivências compartilhadas pelos militantes de esquerda naquele período. O próprio João Paulo Macedo e Castro (2014, p. 8, grifo nosso) o reconhece:

Celso foi militante do Partido Operário Comunista (POC) nos anos 1970 e, como muitos militantes da época, exilou-se no Chile, na Argentina, em Paris e na Venezuela, retornando ao Brasil em 1979 com a Lei de Anistia. Seu percurso poderia confundir-se com outras tantas trajetórias de ex-militantes e ex-exilados que tiveram que reordenar suas vidas após a experiência do exílio político, se não fosse a sua morte em 1984 em circunstâncias misteriosas.

A morte de Celso Castro é uma exceção difícil de explicar. Os filhos buscam, cada um com sua forma de expressão (o cinema, a escrita acadêmica), elaborar a seu modo essa perda. Mas a vida de Celso Castro, a militância de Sandra Macedo (a mãe) e as errâncias do exílio familiar se integram a uma história maior. $\mathrm{O}$ ato irredutível que põe fim à trajetória de Celso não apaga os nexos dessa vida, da vida de sua família, com a experiência coletiva do exílio.

Um indício concreto desse vínculo é o destaque que tem a voz de Flavia Castro no livro que se tornou referência historiográfica sobre o tema: Exílio: entre raízes e radares, de Denise Rollemberg, publicado em 1999. Para pensar o exílio brasileiro durante a ditadura, a 
historiadora Rollemberg inclui no seu universo de fontes: um depoimento de Sandra Macedo publicado em Anistia em abril de 1978 (ROLLEMBERG, 1999, p. 348); o diário de Flavia Castro de 1979, o mesmo que depois seria mobilizado em seu documentário (ROLLEMBERG, 1999, p. 283 e 350); um “texto autobiográfico de Flavia Castro, escrito como roteiro de filme, relatando o exílio sob a ótica da criança, onde o desespero da volta aparece com intensidade. Flavia Castro, Quase um filme, Rio de Janeiro, 1984, mimeo" (ROLLEMBERG, 1999, p. 348 e 180); e uma entrevista feita por Denise Rollemberg com Flavia Castro em Paris, no dia 23 de fevereiro de 1995, na chave da história oral (ROLLEMBERG, 1999, p. 222, 329, 344, 348-350 e 357).

Essas fontes dos Castro coletadas pela historiadora na década de 1990 revelam que, bem antes de Diário de uma busca, Flavia já vinha elaborando sua trajetória de exílio familiar, seja no diário redigido no calor das vivências, seja no roteiro de cinema, Quase um filme, que escreveu bem jovem, no início dos anos $1980 .{ }^{14}$ Em 1995, ela o faz mais uma vez, quando concede a entrevista para Denise Rollemberg. E a historiadora, por sua vez, inclui tudo isso no corpus documental de sua pesquisa sobre o fenômeno do exílio brasileiro. A trajetória dos Castro surge com destaque em alguns momentos específicos de Exílio: entre raízes e radares. Primeiro, na descrição das condições dos brasileiros refugiados na embaixada argentina em Santiago, logo após o golpe que derrubou Allende, em 1973 (ROLLEMBERG, 1999, p. 180). Depois, nos capítulos dedicados ao retorno dos exilados para o Brasil. O mal-estar da véspera do regresso, manifestado por Flavia Castro na entrevista concedida a Roberto D’Ávila em 1979, reaparece nas páginas de Rollemberg (1999, p. 274275) vinte anos depois, com um dado novo:

Na preparação para a volta, aos 14 anos, sentiu e de certa forma previu o que muitos outros exilados, envolvidos na empolgação do momento, viveram um pouco mais tarde. Em 1979, integrada à sociedade francesa, não queria deixar o país [...]. Ficou no Brasil até os 25 anos, quando foi (voltou a) viver em Paris.

A morte do pai como símbolo de uma inadaptação radical no novo Brasil também é discutida por Denise Rollemberg (1999, p. 283):

Celso Castro morreu em outubro de 1984. A história do militante gaúcho, exilado no Chile, na Argentina, na Bélgica, na França e na Venezuela, é hoje contada pela filha Flavia. A dificuldade de readaptação frustrou as

\footnotetext{
${ }^{14}$ Denise Rollemberg (1999, p. 180 e 348) informa o ano de 1984 para o roteiro Quase um filme. Os direitos autorais do roteiro foram registrados no Diário Oficial da União de 3 set. 1986 (BRASIL, 1986, p. 80).
} 
expectativas dos anos de exílio. Um final trágico aguardava Celso no Brasil. A experiência talvez tenha extremado o que muitos sentiram e viveram.

Essas são elaborações do percurso de Flavia Castro e de sua família que já vinham circulando bem antes da existência de Diário de uma busca. ${ }^{15} \mathrm{O}$ exílio dos Castro passou por Chile, Argentina, Bélgica e França. Celso, a certa altura, formou uma nova família na Venezuela. A adolescente Flavia não queria retornar do exílio para o Brasil. Os quatro voltaram, mas aqui se depararam com os dilemas da readaptação, em termos extremos. Aos 25 anos, Flavia Castro foi viver novamente na França. Os desenraizamentos em série deixaram marcas indeléveis naquela família específica, isso é algo que jamais pode ser minorado. Porém, sem desconsiderar toda a dramaticidade desse caso em particular, eis aí uma trajetória que está conectada com uma escala mais ampla, a da experiência coletiva do exílio. ${ }^{16}$

E também com outra escala ainda maior. Pois é preciso dizer que essa experiência foi ao mesmo tempo coletiva e transnacional. E não só porque o exílio obrigava à saída do país de origem e, muitas vezes, a uma deriva angustiante de país em país em busca de asilo. $\mathrm{O}$ exílio familiar dos Castro fez parte do exílio brasileiro, o qual, por sua vez, está inserido na conjuntura mais ampla do exílio latino-americano. Depois do Brasil, a série de golpes de Estado no Cone Sul nos anos 1970 foi expulsando gerações de militantes de esquerda da região. É claro que a história dessa diáspora tem dinâmicas próprias em cada país, principalmente no que toca à sua cronologia. Os oposicionistas brasileiros já vinham sendo forçados ao exílio ao longo dos anos 1960, em duas ondas principais: a de 1964, logo após o golpe; e a de 1968, depois do endurecimento do regime no marco do Ato Institucional $\mathrm{n}^{\circ} 5$ (AI-5) (ROLLEMBERG, 1999, p. 49-52). No ano de 1973, inicia-se a diáspora de uruguaios (SCHELOTTO, 2015) e chilenos (GAILLARD, 1997, p. 11-15). Em 1976, é a vez dos argentinos, cujo exílio teve ainda outro pico em 1981 (FRANCO, 2008, p. 50). Os momentos de retorno dos exilados também variam de acordo com os processos de redemocratização de cada país, indo desde as leis de anistia do Brasil, de 1979 (ROLLEMBERG, 1999, p. 263), e do Uruguai, de 1985 (SCHELOTTO, 2015); passando pelo fim da ditadura argentina após a

\footnotetext{
${ }^{15}$ Algo da experiência de Flavia Castro aparece também na matéria "Filhos do exílio", publicada na edição de 14 jun. 1999 da revista Época (FERNANDES, M. C., 1999), em parte repercutindo o lançamento do livro de Denise Rollemberg (1999). Para um relato autobiográfico de Flavia Castro escrito depois do lançamento de Diário de uma busca, cf. CASTRO, F., 2014. O projeto do filme seguinte da diretora, uma ficção chamada A memória é um músculo da imaginação, carrega certo teor autobiográfico. A sinopse diz: "Joana é uma adolescente que se alimenta de literatura e rock. Lê, para viver ou para sobreviver. No início dos anos 1980, ela chega ao Rio de Janeiro com seus pais e seus irmãos, depois de uma vida inteira morando no exílio. O choque com a nova realidade faz emergir o seu passado.” (AGÊNCIA NACIONAL DO CINEMA, 2012).

${ }^{16}$ Para uma análise das memórias dos filhos de exilados e militantes brasileiros, cf. PAIVA, 2006, 2011.
} 
derrota na Guerra das Malvinas, em 1982 (FRANCO, 2008, p. 261); até a gradualíssima transição chilena, que se arrastou até 1990 (GAILLARD, 1997, p. 15). O lugar dos exilados nos processos sociais de memória também possui suas peculiaridades, desde o protagonismo assumido pelos retornados na "moda do verão da chegada" no Brasil (ROLLEMBERG, 1999, p. 289) - uma euforia que incomodava Celso Castro e que teve seus desdobramentos na ressignificação da luta revolucionária (derrotada) como resistência democrática (cujos frutos finalmente estariam sendo colhidos) - até o "estigma do exílio" que por muitos anos gerou um silêncio sobre o tema na Argentina, pairando sobre os retornados a pecha do abandono da causa pela qual tantos foram vitimados (FRANCO, 2008, p. 17, 26 e 288).

Ainda assim, junto às dinâmicas próprias, também é verdade que essas histórias de exílio são análogas em muitos aspectos. Em primeiro lugar, no que toca aos modos como os exilados de cada nacionalidade vivenciaram as distintas fases do desenraizamento. Começando pela sensação de que o afastamento seria temporário, apenas um recuo tático, uma retirada, em geral para países vizinhos, que precederia o regresso para a continuidade da luta revolucionária no país de origem. Depois, na distância da Europa, vem o reconhecimento de que o exílio seria mais longo do que se pensava. Com isso, tem lugar a revisão da militância política que opera uma substituição da retórica revolucionária pelo discurso dos direitos humanos. Já no momento de retorno, a dificuldade de reinserção foi uma experiência igualmente compartilhada, plasmando o sentimento de que se vivia um novo exílio no próprio país de origem (BRITO, A. X.; VASQUEZ, 2008, p. 210-211 e 217-220; FRANCO, 2008, p. 54-55, 74-75 e 273-274, ROLLEMBERG, 1999, p. 53-58 e 263-297). ${ }^{17}$

Tudo isso ainda diz respeito à comparação entre os exílios causados pelas ditaduras do Cone Sul, uma espécie de busca por diferenças e semelhanças entre as experiências de desterro dos oposicionistas de cada nacionalidade. Os limites da abordagem comparativa já foram esboçados mais acima. O que se quer salientar aqui, a partir de Diário de uma busca, é a dimensão transnacional dessa experiência, ultrapassando os cotejamentos em paralelo. Nesse sentido, Elizabeth Jelin (2010a, p. 63, tradução nossa) elenca quatro aspectos das histórias de ditaduras do Cone Sul nos quais as circulações e os cruzamentos se destacam. Em primeiro lugar:

[...] havia um contínuo movimento de exilados políticos através das fronteiras. Os exilados participavam ativamente na organização de movimentos oposicionistas em prol de transformações políticas em seus

\footnotetext{
17 Para uma análise da "memória diaspórica" da segunda geração de exilados chilenos e argentinos, cf. SERPENTE, 2011, 2013.
} 
países de origem, ao mesmo tempo que mantinham contatos próximos e duradouros de aliança e solidariedade com forças políticas nos seus países de acolhida.

Em segundo lugar, prossegue Jelin (2010a, p. 63, tradução nossa), “a repressão transcendia as fronteiras nacionais. $\mathrm{O}$ exemplo mais marcante da coordenação da repressão em nível regional é a chamada Operação Condor, que envolveu os governos de Argentina, Chile, Uruguai, Brasil, Paraguai e Bolívia”. A autora continua elencando os termos do transnacionalismo naquele contexto histórico: "Em terceiro lugar, como contrapartida, existia uma rede de solidariedade altamente interconectada e integrada denunciando violações de direitos humanos, a qual continuou seu trabalho após as transições políticas" (JELIN, 2010a, p. 64, tradução nossa). "Por fim”, Jelin (2010a, p. 64, tradução nossa) destaca, "nos anos 1980 e 1990, os processos de transição nos diferentes países também foram interconectados; havia constantes diálogos e intercâmbios entre estrategistas, analistas e ativistas políticos, e foi possível aprender muito com as experiências 'além-fronteiras'.” Ou seja, o que Elizabeth Jelin aponta é que, dos golpes às transições democráticas, passando pela repressão, pela militância política, pelas denúncias das atrocidades cometidas pelos regimes e, aquilo que neste tópico interessa mais de perto, pelo exílio, essa foi uma história plena de cruzamentos e interconexões.

A entrada de filhas e filhos das vítimas das ditaduras na arena pública da memória segue essa mesma dinâmica transnacional. De fato, no corpus de documentários aqui considerado, existe uma vertente de títulos que dá visibilidade à atuação das organizações de filhos que surgiram no Cone Sul na segunda metade dos anos 1990: Hasta la memoria, siempre (Rodrigo Vázquez, Argentina, 1997); H.I.J.O.S. de la historia (Roberto Leonardo, Argentina, 1998); (h) Historias cotidianas (Andrés Habegger, Argentina, 2000); Panzas (Laura Bondarevsky, Argentina, 2000); H.I.J.O.S. (Francisco Zinzer, Argentina, 2000); Generación golpe (Fabián Agosta e Lisandro Costa, Argentina, 2001); Che vo cachai (Laura Bondarevsky, Argentina, 2002); H.I.J.O.S.: El alma en dos (Carmen Guarini e Marcelo Céspedes, Argentina, 2002); Organizaciones horizontales (Fausta Quattrini, Argentina, 2002); Nacimos en su lucha, viven en la nuestra: 10 años de H.I.J.O.S. La Plata (Camilo Cagni, Pablo Balut, Pablo Roesler e Juan Aíub, Argentina, 2006); Semillas de utopía (Rodolfo Colombara e Emanuela Peyretti, Itália, 2006); HIJOS Uruguay (Lucas Silva e Víctor Burgos Barreiro, Uruguai, 2006); A contrarreloj (Pablo Sobrino, Uruguai, 2011); Todos somos hijos (Esteban Barja e Carlos Conti, Uruguai, 2015). São filmes, em linhas gerais, inclinados à estilística do documentário convencional de entrevista e que trazem 
testemunhos de filhas e filhos que militam nas agrupações HIJOS de Argentina, Chile e Uruguai. ${ }^{18}$ Frente à conjuntura regional de indultos e anistias da década de 1990, tais organizações deram novo impulso aos debates sobre a memória das ditaduras nos países vizinhos. Com práticas públicas inventivas e incisivas de reivindicação por verdade e justiça, os hijos entravam em cena resgatando a faceta militante da geração dos pais. Com isso, repolitizavam a memória das vítimas, buscando um deslocamento em relação ao viés humanitário universalizante que até então dava o tom dos discursos públicos sobre os anos autoritários, com destaque para vozes das madres e das abuelas da Praça de Maio (BONALDI, 2006; FRIED, 1999; LEVEY, 2011, 2014; RÚA, 2010).

Dentre os documentários que retratam essa militância de segunda geração, Che vo cachai é aquele que coloca em primeiro plano sua dimensão transnacional. Mesclando termos do jargão coloquial de Argentina, Uruguai e Chile, desde seu título Che vo cachai conecta a experiência de militância de filhos de desaparecidos desses três países. Entre conversas, churrascos, entrevistas, reuniões, protestos e "escrachos", a segunda geração vai afirmando a unidade de sua luta, o caráter transnacional do terror de Estado de ontem e das pautas dos hijos de hoje. O filme vai passando de país a país, com uma montagem cinematográfica que apaga fronteiras. Revela, assim, uma condição geracional comum que se projeta na solidariedade em prol da luta por verdade e justiça em torno do desaparecimento dos pais. Isso ocorre no documentário não apenas por meio de um olhar em paralelo. Nesse sentido, destaca-se a história de Lena Fontella, jovem uruguaia cujo pai foi desaparecido em Santiago do Chile. Elaborando esse passado, ela atravessa os Andes em uma viagem na qual conhece as experiências análogas de membros da organização HIJOS de lá. ${ }^{19}$

Essa viagem é pró-fílmica, a diretora Laura Bondarevsky - ela mesma argentina nascida em Genebra por causa do exílio dos pais montoneros - acompanha a uruguaia Lena Fontella em sua travessia da cordilheira para se encontrar com os filhos chilenos. Mas outro cruzamento similar já havia ocorrido antes, na conjuntura de formação dos movimentos de hijos. A gênese dessas agrupações ocorreu em La Plata, Argentina, quando, a partir de 1994, filhos de desaparecidos daquela cidade começaram a se organizar em torno das bandeiras da identidade, da memória e da justiça. Logo essa experiência foi se disseminando por outras cidades argentinas, com mais filhos se mobilizando em uma rede de organizações horizontais

\footnotetext{
${ }^{18}$ No caso argentino, a palavra "hijos" foi transformada em acrônimo: Hijos e Hijas por la Identidad y la Justicia contra el Olvido y el Silencio (H.I.J.O.S.). Sobre as relações entre o surgimento das agrupações de filhos e o cinema, cf.: AMADO, 2004, 2009; BERGER, 2008; ESTEVE, 2009, p. 342-386; LAZZARA, 2009, p. 153-154; ROS, 2012, p. 25-36.

${ }^{19}$ Sobre Che vo cachai, cf. ESTEVE, 2009, p. 365-373; HADOUCHI, 2010, p. 72-74.
} 
pelo país (BONALDI, 2006; RÚA, 2010). Em julho de 1996, uma delegação de integrantes de H.I.J.O.S. da Argentina fez uma viagem ao Uruguai, em um intercâmbio que acabou dando origem à agrupação HIJOS neste último país (FRIED, 1999, p. 9; LEVEY, 2014, p. 14). Trata-se, portanto, de uma história cruzada, cujos "pontos de intersecção" (WERNER; ZIMMERMANN, 2003, p. 15) são identificáveis em escala transnacional, no bojo da difusão de uma nova forma de protesto pela região, o "escracho" (escrache, na Argentina e no Uruguai, funa no Chile) (LEVEY, 2011, p. 317). ${ }^{20}$

Mas isso não quer dizer que a militância dos filhos fosse homogênea no Cone Sul. Pois havia divergências já no interior das próprias agrupações (BONALDI, 2006, p. 169-179; RÚA, 2010), bem como diferenças entre os movimentos de cada país que não podem ser ignoradas (FRIED, 1999). Nesse sentido, é significativo o fato de que uma organização desse tipo não tenha surgido no Brasil. Aqui entra em jogo, mais uma vez, a questão das especificidades locais dentro da escala transnacional. Segundo a análise da historiadora Janaína de Almeida Teles (2005) - ela mesma sequestrada no DOI-CODI quanto tinha cinco anos de idade, junto com os pais militantes (TELES, J. A., 2014, p. 261-266) -, no processo de abertura brasileiro, as demandas por verdade e justiça dos familiares de mortos e desaparecidos foram perdendo espaço dentro da própria esquerda, à medida que se iam delineando os caminhos da "conciliação" democrática. Os termos dessa "conciliação", como se sabe, foram marcados pela impunidade de assassinos e torturadores garantida pela Lei de Anistia de 1979. Entre acomodações e transigências, as pautas mais incisivas dos familiares foram preteridas, em uma espécie de saldo negativo das transações pela redemocratização no Brasil. O luto pela morte política dos entes queridos terminou, assim, relegado à esfera privada, distanciado da justiça, isolado em uma sociedade que se ia reorganizando em torno do consenso da impunidade (TELES, J. A., 2005). Na Argentina, o processo se deu em um sentido inverso e, por lá, as organizações de avós, de mães e, desde fins dos anos 1990, de filhos sempre estiveram no centro da agenda dos direitos humanos (JELIN, 2010b).

Vê-se, portanto, que essa história transnacional possui conexões palpáveis, mas também abriga descompassos ligados às vicissitudes da redemocratização em cada país. De todo modo, é interessante notar que, no mesmo momento em que se formavam as

\footnotetext{
${ }^{20}$ Em linhas gerais, os "escrachos" são protestos realizados nas proximidades da residência ou do local de trabalho de um perpetrador de violações dos direitos humanos durante as ditaduras, com atos performáticos que sinalizam essa presença à vizinhança ou aos colegas de profissão, chamando a atenção para a impunidade. Pablo Daniel Bonaldi (2006, p. 166, tradução nossa, grifo do autor) define essa forma de protesto nos seguintes termos: "Escrachar significa denunciar, pôr em evidência. É uma ação voltada a romper com o anonimato (ou a aparente normalidade) de um responsável pela violação dos direitos humanos, tornando públicos os seus crimes do passado para provocar uma condenação moral no presente." Cf. também KAISER, 2002; LEVEY, 2011; TAYLOR, 2002; VEZZETTI, 1998. Sobre o “escracho" no contexto brasileiro, cf. BRITO, A. P., 2017.
} 
organizações de hijos nos países vizinhos, no Brasil surgia um documentário pioneiro em dar voz a essa geração por aqui: o curta-metragem 15 filhos (Maria Oliveira e Marta Nehring, Brasil, 1996). O vídeo traz relatos pungentes de jovens (incluindo Janaína de Almeida Teles) que foram vítimas em primeira mão da ditadura, que foram presos junto com os pais, que os viram desfigurados pela tortura, crianças privadas de sua identidade, forçadas ao desenraizamento, submetidas à angústia da espera pelos desaparecidos, à imaterialidade da morte, quando não obrigadas a assistir ao assassinato a sangue frio do próprio pai. Todos esses são tópicos que emergem ali com muita força, nos poucos minutos do curta, trazendo à tona uma memória da ditadura brasileira de segunda geração, a qual destoava da narrativa enquadrada na matriz de exaltação do sacrifício guerrilheiro como passo para a redemocratização. $^{21}$

O que chama a atenção no caso da filmografia local é que exista um hiato de quatorze anos entre o pioneiro 15 filhos, de 1996, e Diário de uma busca, de 2010, o segundo documentário que viria a abordar a ditadura brasileira a partir do prisma intergeracional. Nos demais países do Cone Sul, no mesmo intervalo, essa tendência do documentário ganhava fôlego na viva atmosfera de militâncias e produções culturais de segunda geração que marcou a década de 2000. Em escala macro, a hipótese de Janaína de Almeida Teles (2005) sobre o isolamento social da memória dos familiares no Brasil é pertinente para explicar essa lacuna na filmografia nacional e o descompasso com relação à produção dos países vizinhos. Mas a gestação de Diário de uma busca também deve ser compreendida nas raias da trajetória individual de Flavia Castro: de sua biografia marcada pelo exílio e pelo deslocamento, dos desdobramentos dessa experiência em sua carreira cinematográfica. A argumentação neste ponto retoma o fio do olhar micro, após fazer uma série de ampliações de escala: da vivência familiar dos Castro à experiência coletiva do exílio brasileiro; daí à dimensão transnacional do exílio latino-americano e das ditaduras do Cone Sul, chegando à militância dos filhos, com suas conexões e disparidades.

Tudo isso joga uma nova luz sobre o detalhe do sotaque da adolescente Flavia Castro, ajudando a compreender melhor a cineasta Flavia Castro, em um movimento que leva os contornos do espaço transnacional aqui descrito para além do continente. Já ficou mencionado que ela escrevera um roteiro autobiográfico ainda bem jovem, no início dos anos 1980, e que, aos 25 anos de idade, retornara para a França (ROLLEMBERG, 1999, p. 180, 275, 284 e 348). O minicurrículo da diretora que consta na página dedicada a Diário de uma busca no

\footnotetext{
${ }^{21}$ Para uma análise mais detida de 15 filhos, cf. ARANTES, 2008.
} 
catálogo do Buenos Aires Festival Internacional de Cine Independiente (Bafici) de 2011 agrega:

Formada no mestrado em cinema da Sorbonne, em Paris, foi assistente de direção de Richard Dindo em Ernesto Che Guevara: o diário da Bolívia (1993) e de Philippe Grandrieux em Jogo do bicho (1994). Escreveu roteiros de documentários e ficções, entre eles Les Kadiwéus (2003) e Os golpes do Estado Novo (2007). Diário de uma busca é sua estreia como diretora. (BUENOS AIRES FESTIVAL INTERNACIONAL DE CINE INDEPENDIENTE, 2011, p. 217, tradução nossa).

Sucinto, esse texto apresenta as referências básicas para se compreender a carreira transnacional de Flavia Castro. Em primeiro lugar, sua formação em cinema na Sorbonne, onde defendeu uma dissertação sobre John Cassavetes (BEZERRA, 2012). Depois, o trabalho como assistente de direção junto a realizadores atuantes na França, além da atividade como roteirista na televisão daquele país. Jogo do bicho (Philippe Grandrieux, França, 1994) é um documentário sobre o jogo de apostas brasileiro homônimo. ${ }^{22}$ Les Kadiwéus (Jean-Marie Cornuel, França, 2004) é o episódio sobre os "índios cavaleiros" do Mato Grosso do Sul em uma série da televisão francesa sobre comunidades cavaleiras ao redor do mundo. Nesses dois casos, ocorre um olhar desde a França para o Brasil.

Porém, é no olhar cruzado entre Ernesto Che Guevara: le journal de Bolivie (Richard Dindo, França / Suíça, 1994) e Diário de uma busca que as "transferências culturais" (ESPAGNE, 2013) ligadas à experiência francesa de Flavia Castro se manifestam com mais força. A diretora costuma assinalar em entrevistas e debates a importância do trabalho com Richard Dindo para a formação de sua própria visão do fazer documental. Em entrevista concedida a Pablo Russo ([2011], tradução nossa), por exemplo, ela declara: “O primeiro diretor de documentário com quem trabalhei foi Richard Dindo, em um filme que se chama Ernesto Che Guevara: o diário da Bolívia. Foi muito importante para mim. Eu era assistente, fizemos mais ou menos o mesmo trajeto do Che na Bolívia. Foi uma viagem transformadora."

Vale a pena ir além das palavras da própria diretora e deter-se por um instante nas analogias observáveis entre as duas obras. A começar pelos títulos, ambos remetendo o cinema à forma diário. No terreno propriamente fílmico, entre imagens de arquivo, entrevistas com moradores locais e inserções de jornais da época, a narrativa do documentário de Dindo é conduzida pela leitura cronológica, em voz over, do diário de Che Guevara, com inserções do texto original manuscrito na tela. Essa leitura é acompanhada por tomadas deambulantes pelas florestas e montanhas bolivianas, como que refazendo o trajeto percorrido pelo Che em seus

\footnotetext{
${ }^{22}$ Para uma análise de Jogo do bicho, cf. HAINGE, 2017, p. 61-64.
} 
últimos dias. Diário de uma busca lança mão de um dispositivo formal similar, em que o relato vai sendo alinhavado pela leitura das cartas do pai em over pela voz do irmão, João Paulo Macedo e Castro. O que se vê nos momentos dessas leituras são imagens que figuram a itinerância do exílio familiar, tomadas desde um automóvel em movimento, cruzando fronteiras ou percorrendo cidades longínquas, tal como os Castro uma vez o fizeram. Nos dois casos, essa sobreposição entre a voz dos documentos privados e as imagens dos vaivéns do passado dá forma cinematográfica às viagens de retorno aos palcos das experiências. Em ambos os filmes-diários, do Che e "de uma busca", a memória traz a marca da derrota do projeto revolucionário. De um lado, tem-se a imagem do herói acossado e assassinado. De outro, um retrato do pai desiludido e morto em circunstâncias estranhas. Em cada um dos filmes, o desfecho se dá em tom menor. Os diários e as cartas; as imagens errantes; o olhar sereno para a frustração da utopia: as analogias possíveis entre Ernesto Che Guevara: le journal de Bolivie e Diário de uma busca vão além do paralelismo. Elas ecoam uma experiência de trabalho, uma conexão efetiva. Colocados lado a lado, esses dois filmes remetem à assimilação e à ressignificação na França de um modo de fazer documental. $\mathrm{O}$ exílio de Flavia Castro está na origem dessas transferências. ${ }^{23}$

Regressando novamente para o Brasil em 2000 (DUARTE-PLON, 2011), Flavia Castro segue sua carreira por aqui. A informação do catálogo do Bafici de que "Diário de uma busca é sua estreia como diretora" não é exata. Isso porque ela havia dirigido antes um curta-metragem intitulado Cada um com seu cada qual (Flavia Castro, Brasil, 2006), ficção que gira em torno dos primeiros passos de uma menina de oito anos com uma câmera de filmar. Flavia Castro trabalhou ainda como roteirista junto com Eduardo Escorel, no documentário que viria a se intitular Imagens do Estado Novo 1937-45 (Eduardo Escorel, Brasil, 2016).

Mesmo com essa atuação no Brasil, é na França que se dão os primeiros encaminhamentos mais efetivos para a concretização do longa-metragem Diário de uma busca. Como informado no próprio documentário, o ponto de partida da obra foram as filmagens realizadas em 2002 na ocasião da visita ao Brasil da meia-irmã de Flavia Castro, Maria Cavalli. Essa rodagem, contudo, ocorreu de modo independente, ainda com recursos próprios (TOMAZZONI, 2011). Foi em 2005 que Flavia Castro, agora respaldada pela empresa produtora francesa Les Films du Poisson, ganhou um prêmio de desenvolvimento de

\footnotetext{
${ }^{23}$ Analisando o exílio de intelectuais brasileiros e chilenos na França durante as ditaduras, Helenice Rodrigues da Silva (2007, p. 5) escreve: "Pensar o exílio dos intelectuais pressupõe, então, levar em conta as noções de circulação dos indivíduos (entre o país de origem e a terra de acolhida), de transculturação (uma segunda fase do exílio) e de transferências culturais (assimilação e transformações do pensamento e das ideias)."
} 
roteiro concedido pelo Centre National de la Cinématographie (CNC) daquele país. O projeto originalmente se chamava Où sont les documents?, segundo os registros ligados a essa gênese do filme (CENTRE NATIONAL DE LA CINÉMATOGRAPHIE, 2005, p. 3). Em março de 2007, ainda com esse título, o projeto ganhou outro auxílio de uma instituição de fomento francesa, desta vez do Conseil Régional d'Île de France (2010, p. 14). Do lado brasileiro, é de outubro de 2007 a aprovação inicial para captação de recursos junto à Agência Nacional do Cinema (Ancine), para a fase de finalização do documentário, sob os auspícios da companhia produtora Tambellini Filmes (AGÊNCIA NACIONAL DO CINEMA, 2007). Ou seja, no processo de produção e financiamento de Diário de uma busca, o Brasil chegou depois da França.

Isso se repete no momento da estreia comercial do documentário. Pois Diário de uma busca foi lançado em salas primeiro em Paris, em 22 de junho de 2011, e apenas em agosto do mesmo ano estreou no circuito brasileiro. Aquele título francês da origem do projeto havia sido deixado para trás. Depois de se cogitar Journal d'une recherche, equivalente literal do nome brasileiro, optou-se afinal por Lettres et révolutions. ${ }^{24}$ A alteração semântica gerada por esse abandono da tradução direta merece atenção. É verdade que tanto o título brasileiro quanto o francês têm como ponto de partida as formas da escrita privada: o diário, em um caso; as cartas, no outro. Mas, no complemento, o foco do nome brasileiro está na busca íntima, enquanto que, na construção em francês, prevalece a ideia de revoluções, no plural.

Esse deslocamento de ênfase identificável nos títulos reverbera nos distintos projetos gráficos dos cartazes brasileiro e francês. No primeiro, Diário de uma busca vem escrito em letras minúsculas de cor fúcsia, as palavras se organizam de cima para baixo, sobrepondo-se ao fundo de uma fotografia de Flavia Castro e do irmão quando crianças. O tratamento cromático da imagem em tom próximo do sépia faz pensar em um olhar nostálgico para a infância, para o passado buscado (fig. 1). O cartaz francês, por seu turno, traz sobre o fundo branco uma impressão digital que compõe os contornos da América do Sul. Aquilo que há de único em um indivíduo, sua digital, projeta-se em uma região geográfica. E esta, por sua vez, vem marcada pelo título que traz a carga política das cartas e das revoluções. Uma gota de sangue em um dos cantos brancos do cartaz é o sinal do espectro trágico que rondou essa história ao mesmo tempo privada e continental (fig. 2).

\footnotetext{
${ }^{24}$ Informação dada pela diretora em debate ocorrido no contexto da mostra "Silêncios históricos e pessoais", em São Paulo/SP, dia 29 mar. 2014. Para o catálogo da mostra, cf. BARRENHA; PIEDRAS, 2014.
} 


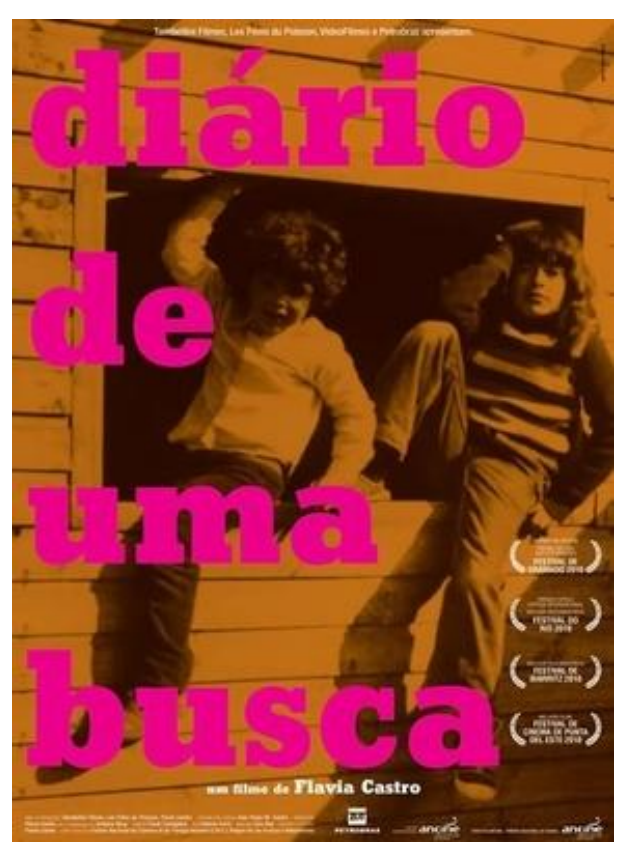

Figura 1 - Cartaz brasileiro de Diário de uma busca (Flavia Castro, 2010). Fonte: Tambellini Filmes.

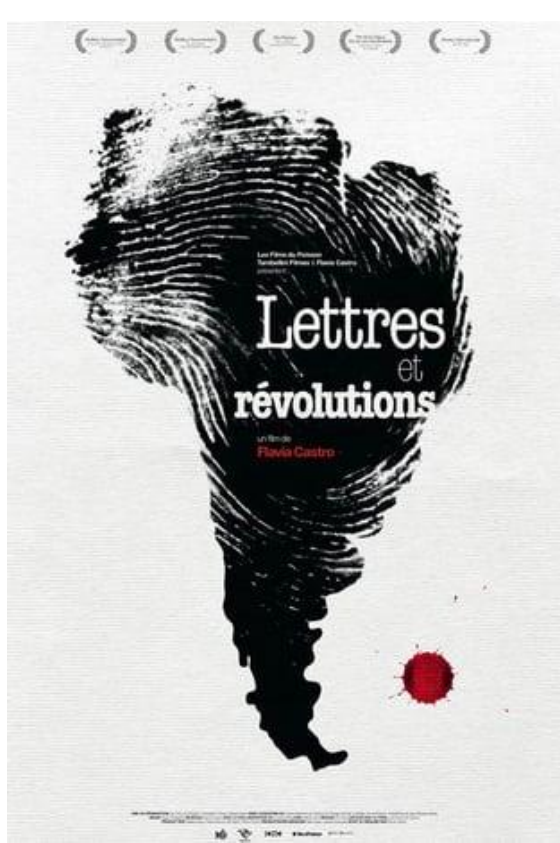

Figura 2 - Cartaz francês de Lettres et révolutions (Flavia Castro, 2010). Fonte: Les Films du Poisson.

As traduções não se limitaram ao título ou ao material de divulgação do documentário. Além desses elementos paratextuais, a coprodução resultou em duas versões do filme, cada uma com locução em over e intertítulos próprios, em francês e português. A tradução das legendas informativas ao longo da obra é simples, literal, funcionando para identificar pessoas, momentos e lugares. O que chama mais atenção na versão internacional é a voz over de Flavia Castro em francês, recitando nesta língua o teor da locução que o espectador brasileiro escuta em português. O texto em over em francês e português é fundamentalmente o mesmo, na medida em que isso é possível em uma tradução, repetindo os passos da narrativa e o sincronismo da montagem. Salta aos ouvidos, porém, a desenvoltura com que Flavia Castro fala um e outro idioma, a dicção fluente em francês e português, como se o sotaque da adolescente tivesse sido substituído pelo bilinguismo da adulta como indício do deslocamento.

As questões em torno da "tradução" de um filme vão muito além da mera compreensibilidade de um idioma. Elas indicam vetores e fluxos das dinâmicas transnacionais (ĎUROVIČOVÁ, 2010b). Para além das duas versões de Diário de uma busca, há no interior do documentário um percurso que é poliglota: refazendo os passos do exílio, Flavia Castro interage com outras pessoas em espanhol e francês, além do português; ela lê para Maria Cavalli a carta do pai relatando o dia de seu nascimento, traduzindo os termos em português que a meia-irmã mais nova não compreende; na inserção de um áudio de arquivo, ouve-se 
Celso Castro falando em espanhol, ainda com esperanças na construção de um partido de massas em São Paulo; as canções que acompanham a narrativa remetem ao universo sonoro dos lugares de passagem da família (Salta, pequeña langosta, de 1969, interpretada pelo argentino Rubén Mattos; L'internationale, cantada pelo francês Jacques Tritsch; Métro (c'est trop), de 1977, da banda de rock francesa Téléphone; Canción de las simples cosas, interpretada por Mercedes Sosa).

Não se trata de um caso isolado. Na filmografia aqui estudada, encontram-se outros exemplos em que as questões linguísticas trazem uma carga de sentidos que merece consideração. Secretos de lucha (Maiana Bidegain, Uruguai / França, 2007) foi lançado em três versões (em espanhol, francês e inglês) e suas imagens estão marcadas por um bilinguismo imanente: nas entrevistas concedidas à filha - nascida no exílio em Bayonne, França -, o pai ora fala em francês, ora em espanhol, dependendo de que lado do Atlântico está. Em Papá Iván (María Inés Roqué, México / Argentina, 2000) e Encontrando a Víctor (Natalia Bruschtein, México / Argentina, 2004), o sotaque mexicano das filhas-diretoras de origem argentina reveste com o hibridismo do exílio a narrativa do desaparecimento dos respectivos pais (AMADO, 2003, p. 148). Che vo cachai (Laura Bondarevsky, Argentina, 2002) joga com os regionalismos do espanhol, como se as variantes da língua franca da região fossem um eco das particularidades no interior da luta comum dos filhos. Na contramão, observa-se a ausência de legendas em português (ou, em certas ocasiões, em qualquer outro idioma) em DVDs dos títulos do corpus lançados comercialmente, algo que faz lembrar a barreira linguística operante nas relações entre os países vizinhos e o Brasil. Em suma, nesses exemplos, a variedade de idiomas, as sutilezas de sotaques e regionalismos ou até a ausência de traduções fazem pensar sobre os deslocamentos e cruzamentos culturais em jogo, entrelaçando os meandros da memória com as dinâmicas da produção cinematográfica.

Tudo isso se insere em uma lógica mais ampla das coproduções internacionais. Uma lógica que, nessa filmografia, refaz os caminhos de exílios passados, mas que também é movida pelas desigualdades regionais da atividade cinematográfica. Do corpus de 67 documentários intergeracionais considerados neste trabalho, 23 títulos são coproduções internacionais. Mais de um terço do universo estudado, portanto, traz esse aspecto do transnacionalismo já na fase de construção da obra. Contudo, é importante estar atento aos desequilíbrios nesse circuito. Das 23 coproduções, treze são entre países do Cone Sul e da Europa: En memoria de los pájaros (Gabriela Golder, França / Argentina, 2000), curtametragem experimental sobre a memória dos desaparecidos que faz uma colagem com imagens de arquivo públicas e privadas; Los huérfanos del Cóndor (Emilio Pacull, França / 
Uruguai, 2003), sobre a recuperação da identidade de crianças sequestradas pela ditadura argentina; Diario argentino (Lupe Pérez García, Argentina / Espanha, 2006), no qual a diretora, emigrante econômica após a crise argentina de 2001, regressa para questionar a geração anterior sobre as escolhas políticas que levaram o país àquela condição; Héroes frágiles (Emilio Pacull, Chile / França, 2007), o qual traz a memória do padrasto do realizador, colaborador de Allende que se suicidou no dia do golpe chileno; La promesa de mi madre (Marianne Hougen-Moraga, Dinamarca / Chile / Reino Unido, 2007), sobre as buscas da mãe da realizadora para recuperar os restos mortais da irmã exilada; Secretos de lucha (Maiana Bidegain, Uruguai / França, 2007), em que a filha acompanha o pai em sua viagem de regresso ao Uruguai, após anos no exílio francês; Mi vida con Carlos (Germán BergerHertz, Chile / Espanha, 2009), no qual o filho conta a história do desaparecimento do pai no norte chileno, forçando a família ao exílio; La quemadura (René Ballesteros, Chile / França, 2009), em que o diretor e sua irmã buscam descobrir o paradeiro da mãe, que os abandonou no Chile, seguindo o rastro da coleção de livros proibidos da editora Quimantú, ligada à Unidade Popular, deixada por ela; Diário de uma busca (Flavia Castro, Brasil / França, 2010); Cuchillo de palo (Renate Costa, Paraguai / Espanha, 2010), no qual a diretora conta a história de seu tio, vítima da perseguição aos homossexuais na ditadura Stroessner; Repare bem (Maria de Medeiros, Brasil / Portugal / Espanha, 2012), dirigido pela atriz e cineasta portuguesa, contando a história de dispersão da família de Eduardo Collen Leite, o "Bacuri”, assassinado pela ditadura brasileira; Os dias com ele (Maria Clara Escobar, Brasil / Portugal, 2013), no qual a filha vai até Portugal, onde o pai vive recluso, querendo saber mais sobre os traumas de seu passado; El color del camaleón (Andrés Lübbert, Chile / Bélgica, 2017), em que o filho acompanha o pai em uma viagem de retorno ao Chile, revolvendo um passado de violações sofridas. Ou seja, mais da metade das coproduções segue o vetor Sul-Norte, com as relações concentradas em alguns países europeus: a França, com seis coproduções; a Espanha, com quatro; Portugal, com duas (sendo uma junto com a Espanha); além dos casos de coprodução com Bélgica, Dinamarca e Reino Unido.

Enquanto isso, são apenas seis as coproduções entre países latino-americanos, em uma relação Sul-Sul: Papá Iván (María Inés Roqué, México / Argentina, 2000), em que a filha, radicada no México após ali crescer no exílio, vai à Argentina em busca de compreender a entrega heroica do pai montonero; Encontrando a Víctor (Natalia Bruschtein, México / Argentina, 2004), o retorno da filha exilada ainda criança no México à procura de traços do pai desaparecido na Argentina; Abuelos (Carla Valencia Dávila, Equador / Chile, 2010), no qual a diretora contrasta as utopias e os destinos trágicos de seus dois avôs, um chileno e o 
outro equatoriano; Tiempo suspendido (Natalia Bruschtein, México / Argentina, 2015), nova incursão de Bruschtein na memória de sua família, desta vez retratando a avó, uma das madres de primeira hora na Argentina; Allende mi abuelo Allende (Marcia Tambutti, Chile / México, 2015), dirigido pela neta de Salvador Allende, em uma coprodução que ecoa o exílio da família no México após do golpe; El (im)posible olvido (Andrés Habegger, Argentina / Brasil / México, 2016), que refaz o mapa do exílio da família no México e do desaparecimento do pai do cineasta no Rio de Janeiro. Nesse conjunto, ocorre uma concentração ainda maior quanto aos países coprodutores, com o México presente em cinco das seis coproduções continentais.

No corpus estendido, as coproduções que envolvem ao mesmo tempo países latinoamericanos e europeus são minoria, somente duas, ambas com a presença de Cuba: El telón de azúcar (Camila Guzmán Urzúa, França / Cuba / Espanha, 2006), em que a filha de Patricio Guzmán retorna à Cuba de seu exílio infantil; El edificio de los chilenos (Macarena Aguiló e Susana Foxley, Chile / Cuba / França / Bélgica, 2010), que narra a experiência da diretora no exílio infantil coletivo em Cuba, em um projeto que abrigava os filhos dos militantes engajados na contraofensiva armada no Chile. Do lado europeu, França e Espanha se destacam também nesse recorte.

Por fim, nota-se que as coproduções que envolvem a América do Norte são rarefeitas: Retour: volver (Martin Bourgault, Canadá / Argentina, 2016), que segue a viagem do cantor Tomás Jensen do Canadá para a Argentina, país do qual teve que se exilar aos seis anos de idade; ¿ ¿Quién soy yo? Los niños encontrados de Argentina (Estela Bravo, Argentina / EUA / Reino Unido, 2007), que agrupa relatos de filhos que tiveram suas identidades recuperadas, estando também presente na coprodução um país europeu.

$\mathrm{Na}$ maioria dos casos, os países de coprodução foram lugares de passagem ou de acolhida nas histórias de militâncias e exílios narradas, o que demonstra que os vínculos estabelecidos ao longo dessas experiências se atualizam no momento de concretização dos documentários. Porém, o vetor oriundo do passado não opera sozinho, há que se adicionar nessa equação as condições vigentes da produção cinematográfica nas diferentes regiões e nos distintos países. Isso inclui o maior ou menor dinamismo do setor audiovisual, o peso das relações Sul-Norte (DENNISON, 2013b; MIDDENTS, 2013; NEWMAN, 2010), a origem dos fundos de financiamento (FALICOV, 2010, 2013; RABADÁN, 2016), bem como os percalços da integração cinematográfica no continente (SILVA, D. M., 2007; MOGUILLANSKY, 2016). 
Em síntese, o transnacionalismo precede sob variadas formas a cinematografia de descendentes aqui estudada, desde muito antes da existência dos próprios filmes: nas histórias de ditaduras e exílios dos anos 1960 a 1980; na militância dos filhos nos anos 1990; nas carreiras cinematográficas diaspóricas; nos processos de tradução; nas lógicas de coprodução e seus desequilíbrios regionais. Tudo isso compõe uma intrincada malha transnacional préfílmica, com diferentes escalas, conexões palpáveis e particularidades incontornáveis. Enfim, um circuito, carregado de tensões, no qual se cruzam veredas além-fronteiras que desembocam no documentarismo intergeracional sobre as ditaduras do Cone Sul.

\section{Fílmico: travellings, planos fixos e a geografia da memória}

Depois de percorrer os meandros pré-fílmicos do transnacionalismo, chega o momento de desviar a trajetória da análise para dentro das obras. Ou melhor, desdobrar as idas e vindas da argumentação em uma sondagem cujo ponto de partida são os modos de figuração da itinerância, um traço estético pregnante nessa filmografia. Diário de uma busca continua sendo o fio condutor das considerações, começando pelos segmentos que trazem essa marca da mobilidade.

O documentário de Flavia Castro é pontuado do início ao fim por inserções que retratam as andanças da diretora no presente e da família no passado. O travelling é o recurso cinematográfico que dá forma a essas idas e vindas, com seu "movimento de translação do eixo da câmera" (AUMONT; MARIE, 2009, p. 201), ou seja, quando o aparelho de filmagem como um todo se desloca no espaço sobre algum tipo de veículo, em direções que podem variar, em geral se mantendo o mesmo eixo óptico. ${ }^{25}$ Para além da descrição técnica, vale lembrar que existe um longo debate crítico acumulado a respeito do travelling, com o caso Kapò (Gillo Pontecorvo, Itália / França / Iugoslávia, 1960) sendo talvez seu episódio mais polêmico (DE BAECQUE, 2011; RIVETTE, 1961). Contudo, o que interessa mais de perto aqui é a mobilização específica desse recurso em Diário de uma busca, nos trechos em que a câmera está em um automóvel ou avião em movimento, a tomada é feita através da janela, a paisagem vai passando enquanto as vozes, em over, vão situando a narrativa.

Esses planos itinerantes se repetem ao longo do documentário, mas os significados que assumem mudam dentro da lógica fílmica. De saída, ao menos três sentidos podem ser

\footnotetext{
${ }^{25} \mathrm{O}$ travelling costuma ser contraposto à panorâmica, movimento em que a câmera realiza uma rotação sobre seu próprio eixo, sem que este último saia do lugar. Para uma descrição dos principais movimentos de câmera e seus possíveis sentidos, cf. AUMONT; MARIE, 2009, p. 201-202; BORDWELL; THOMPSON, 1997, p. 243258; GIANNETTI; LEACH, 2001, p. 167-180; KONIGSBERG, 2004; MARTIN, 2002, p. 51-62.
} 
identificados nesses segmentos em travelling. Em primeiro lugar, há aquelas imagens que mostram a busca da diretora pelas estradas do Brasil, pelas ruas de São Paulo e de Porto Alegre (fig. 3-6). Nesses casos, a busca está mais diretamente ligada à trama investigativa do documentário, com tomadas feitas desde um carro em movimento precedendo as entrevistas de Flavia Castro com jornalistas e policiais, pessoas que antes dela se debruçaram sobre o caso que levou à morte de seu pai. Ela vai ao encontro desses testemunhos para descobrir que, por razões muito distintas, eles não levarão a uma resposta conclusiva.

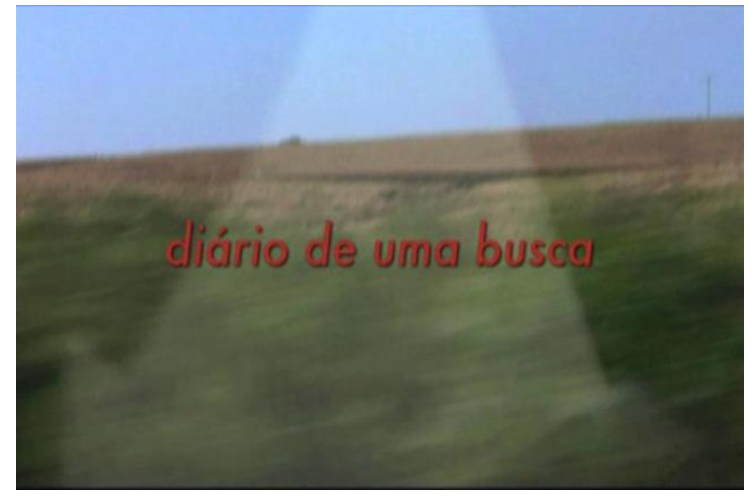

Figura 3 - Travelling da busca, pelas estradas. Fonte: Diário de uma busca (Flavia Castro, 2010).

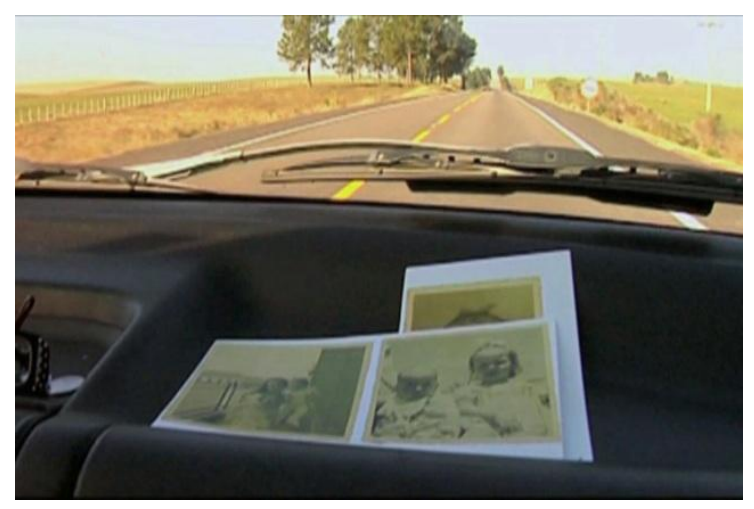

Figura 5 - Travelling da busca, as fotografias e o caminho. Fonte: Diário de uma busca (Flavia Castro, 2010).

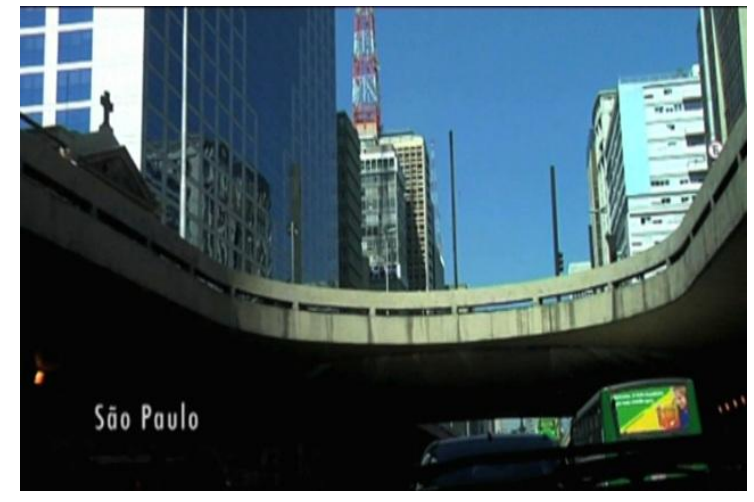

Figura 4 - Travelling da busca, em São Paulo. Fonte: Diário de uma busca (Flavia Castro, 2010).

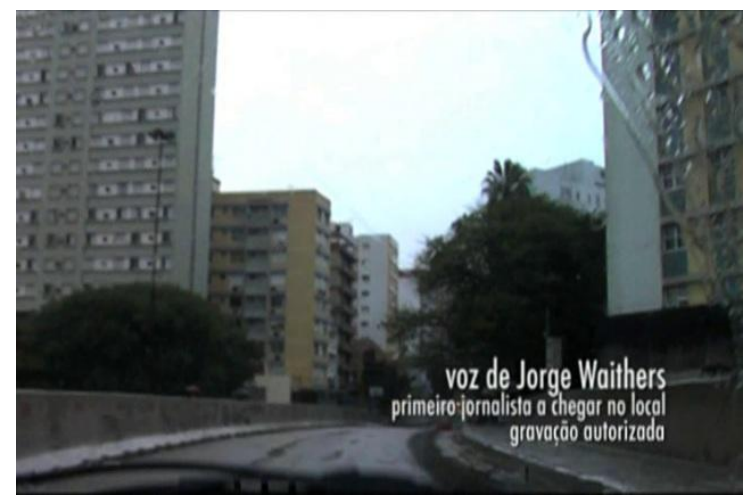

Figura 6 - Travelling da busca, em Porto Alegre. Fonte: Diário de uma busca (Flavia Castro, 2010).

Um segundo grupo dessas tomadas em travelling representa os vaivéns da vida no exílio, as viagens aéreas e o cruzamento de fronteiras terrestres, quase sempre com legendas informando o país e o ano da chegada à nova paragem do deslocamento forçado, até o retorno para o Brasil em 1979 (fig. 7-14). 


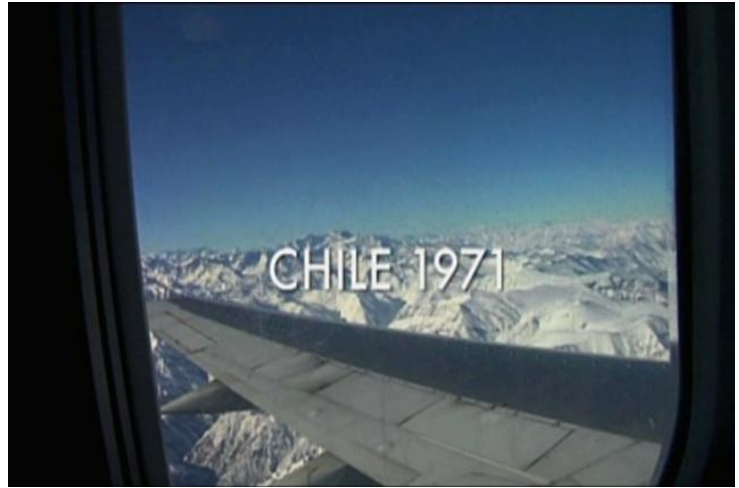

Figura 7 - Travelling da ida para o Chile, 1971. Fonte: Diário de uma busca (Flavia Castro, 2010).

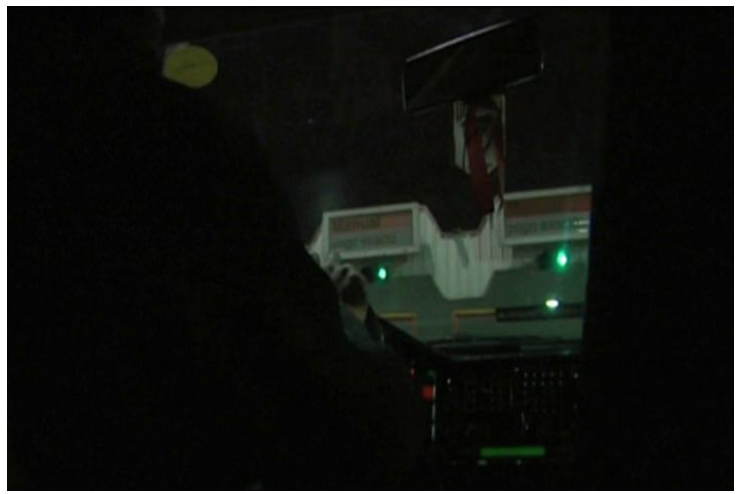

Figura 9 - Travelling ilustra saída clandestina da Argentina. Fonte: Diário de uma busca (Flavia Castro, 2010).

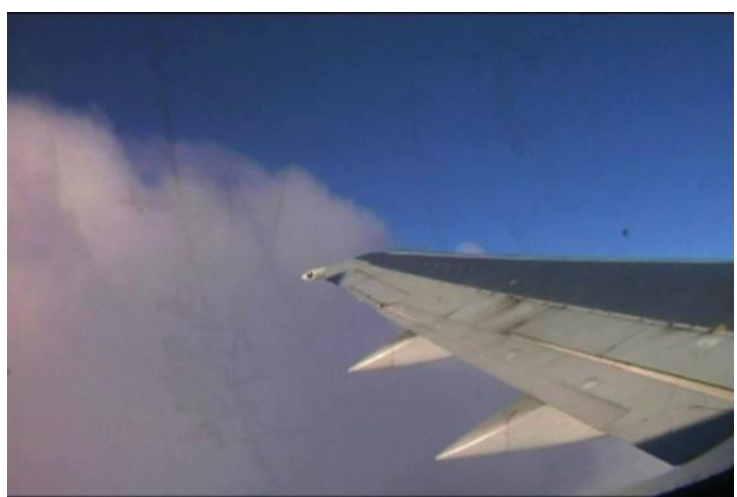

Figura 11 - Travelling ilustra voo para a Europa. Fonte: Diário de uma busca (Flavia Castro, 2010).

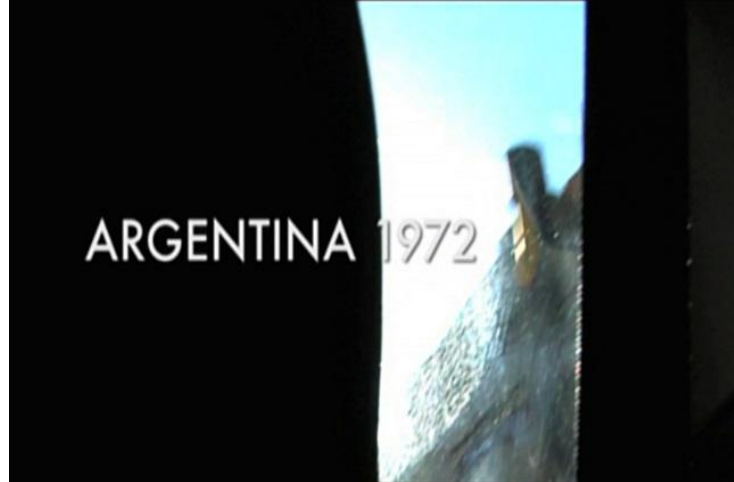

Figura 8 - Travelling Argentina, 1972. Fonte: Diário de uma busca (Flavia Castro, 2010).

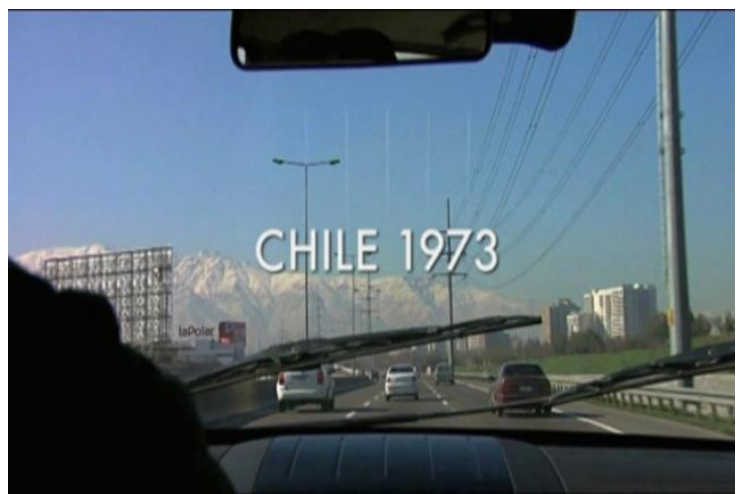

Figura 10 - Travelling do regresso ao Chile, a Cordilheira dos Andes ao fundo. Fonte: Diário de uma busca (Flavia Castro, 2010).

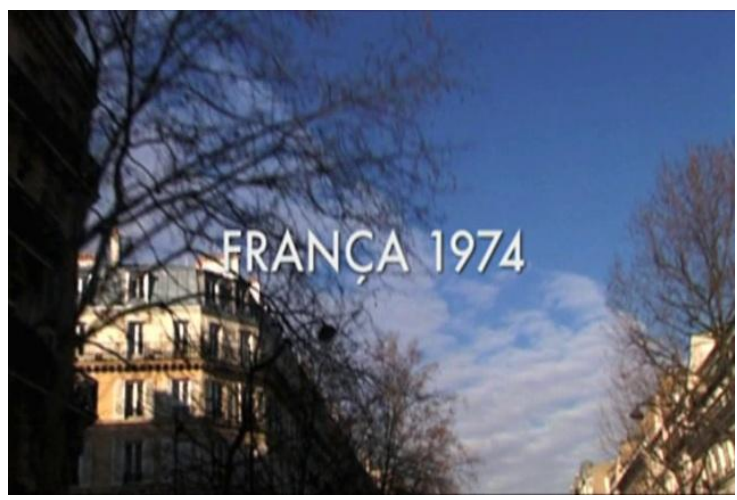

Figura 12 - Travelling da chegada na França, 1974 Fonte: Diário de uma busca (Flavia Castro, 2010). 


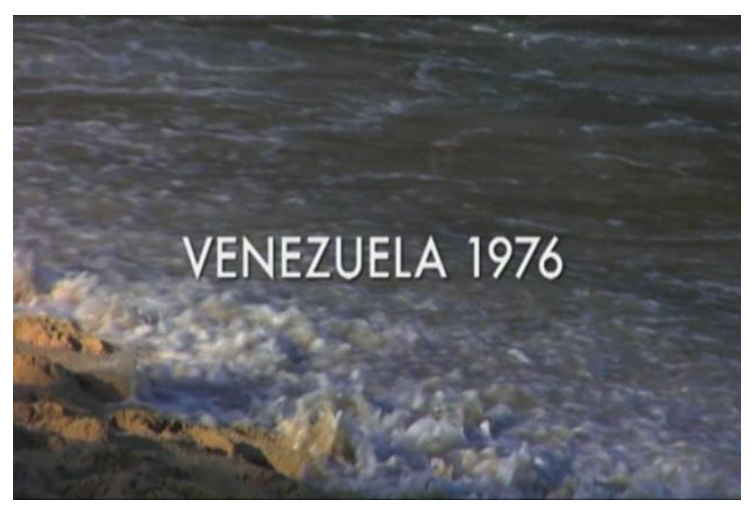

Figura 13 - Venezuela, 1976, as ondas é que se movem. Fonte: Diário de uma busca (Flavia Castro, 2010).

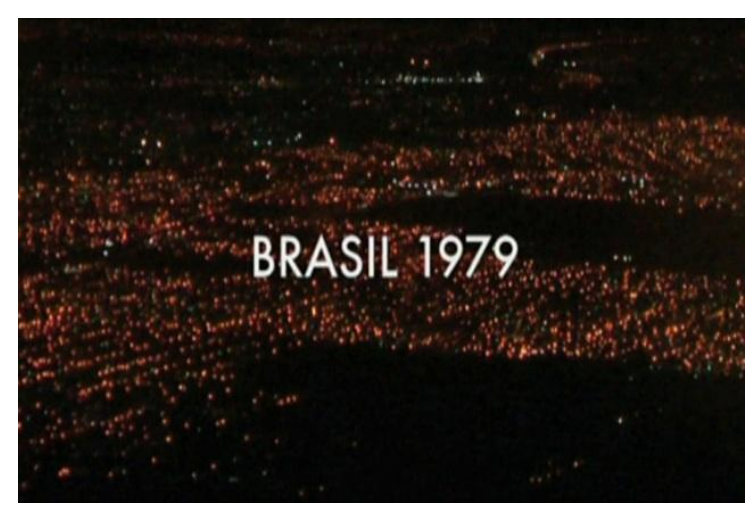

Figura 14 - Travelling do retorno para o Brasil, 1979. Fonte: Diário de uma busca (Flavia Castro, 2010).

Para além do movimento em si, vale ressaltar alguns detalhes dessas tomadas em travelling que refazem o percurso do exílio. Vista do avião ou do carro na estrada, a Cordilheira dos Andes serve como uma espécie de marco topográfico que identifica as passagens para o Chile (fig. 7 e 10). A chegada e a saída da Argentina são retratadas através de frestas, em contra-plongée (angulação em que a câmera se encontra em um ponto mais baixo que o objeto filmado), como se a câmera estivesse sendo operada de modo oculto no interior do carro, algo que, de certa forma, emula a condição de clandestinidade da família enfatizada nesses trechos (fig. 8-9). A montagem da chegada a Paris em 1974, por sua vez, com a tomada em travelling desde a janela do avião (fig. 11) e, em seguida, do carro, pelas ruas da cidade, captando em contra-plongée edifícios e árvores (fig. 12), parece fazer uma citação da sequência dos créditos de abertura de Les quatre cents coups (Os incompreendidos, François Truffaut, França, 1959), evocando a ideia da infância vivida na capital francesa. O plano que introduz a transferência do pai para a Venezuela é o único dessa série que é fixo. $\mathrm{O}$ movimento, nesse caso, fica por conta das ondas que chegam à praia (fig. 13). Logo em seguida, na leitura em over da carta que Celso Castro enviou de lá à irmã, voltam as imagens em travelling. A tomada aérea noturna da volta para o Brasil (fig. 14) é acompanhada pela interpretação de Mercedes Sosa da Canción de las simples cosas, cuja letra aborda em tom nostálgico a temática do regresso. Esses detalhes revestem com símbolos e sentimentos a figuração cinematográfica das idas e vindas do exílio. A dimensão transnacional da experiência ganha relevo nessas imagens de fluxos (ASSMANN; CONRAD, 2010, p. 2; LIE, 2016, p. 19-20), os travellings figuram a história daqueles que "cruzam muitas fronteiras e se envolvem em muitas jornadas de desterritorialização e reterritorialização" (NAFICY, 2001, p. 5, tradução nossa). 
Existe ainda uma terceira modalidade de tomadas em travelling que merece atenção em Diário de uma busca. Trata-se daquelas imagens vistas durante a leitura em over das cartas mais melancólicas de Celso Castro. Na carta que ele enviou aos pais de Paris, em 1975, ele informa sobre os amigos caídos na Argentina. E conclui: "Bem, é isso, estou muito deprimido para escrever mais. Quando a repressão se abate sobre gente chegada, é muito duro." No começo da leitura, vê-se um plano fechado tomado desde o que, pela sugestão dos ruídos escutados ao fundo, parece ser um trem de metrô em movimento. Parece, porque o plano é tão fechado que é quase impossível distinguir algo além do puro movimento (fig. 15). Depois de algumas fusões com close-ups do manuscrito da missiva e inserções de jornais noticiando as prisões mencionadas, as últimas palavras sobre o estado depressivo de Celso Castro são ouvidas enquanto se vê mais uma tomada em travelling desde um automóvel. Contudo, desta vez, a progressiva retirada do foco da imagem noturna transforma a paisagem além da janela em manchas luminosas sobre um fundo negro.

Tal recurso se reitera nos travellings vistos logo adiante, quando da leitura da carta de Celso Castro para Ana Cavalli. Ele escreve: “Às vezes, a convivência consigo mesmo se torna difícil. São aquelas horas perdidas na noite em que uma vaga tristeza, um cansaço sem sono, uma grande saudade e alguns tragos a mais ajudam a aprofundar uma depressão que já é quase estrutural.” E conclui dizendo que está buscando uma alternativa, uma mudança de vida, uma maneira de se "inserir em um projeto político realmente sério e viável”. Na tela, de início o que surge são close-ups do manuscrito lido em over. Logo o texto da carta é substituído em fusão por tomadas noturnas feitas a partir de um carro pelas ruas de Paris. A princípio, é possível distinguir letreiros, postes, sinais de trânsito, placas, árvores, pontes, enfim, a cidade à noite. Mas a câmera opera uma oscilação de desfocamentos, reenquadramentos e mudanças de angulação, criando uma sequência de fusões na qual a paisagem noturna é distorcida a ponto de se tornar uma espécie de quadro cinético abstrato (fig. 16-17). São imagens as quais, em sua desfigurada inquietude, servem de espelho para a deriva existencial do pai, agravada pelos tropeços do projeto político.

O travelling que segue a leitura da carta escrita por Celso Castro dois meses antes de sua morte retoma a figurativismo da paisagem. O carro segue veloz, vê-se o crepúsculo no horizonte, é o ocaso da vida do pai: "Não vou conseguir. Para mim, não foi possível." No filme, este é o último travelling tomado desde um veículo (fig. 18). 


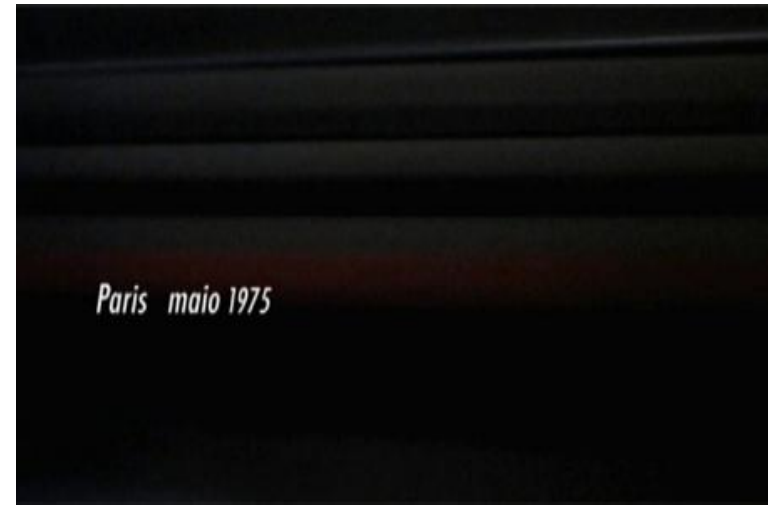

Figura 15 - Travelling abstrato, puro movimento. Fonte: Diário de uma busca (Flavia Castro, 2010).

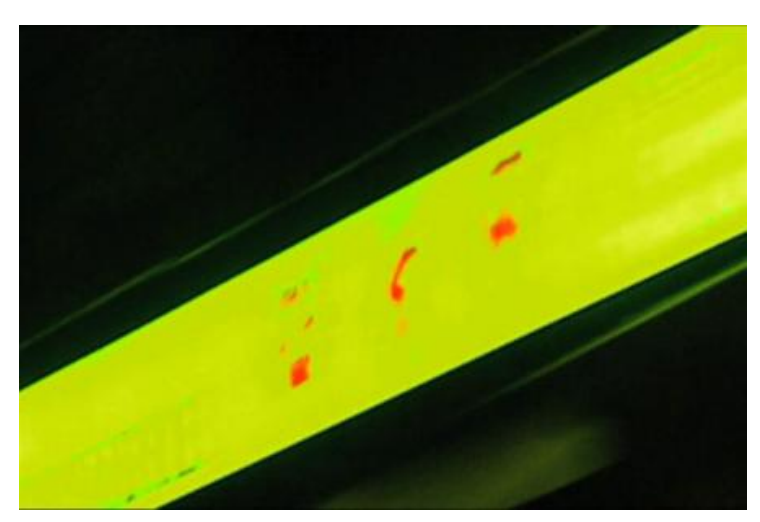

Figura 17 - Travelling e a errância existencial. Fonte: Diário de uma busca (Flavia Castro, 2010).

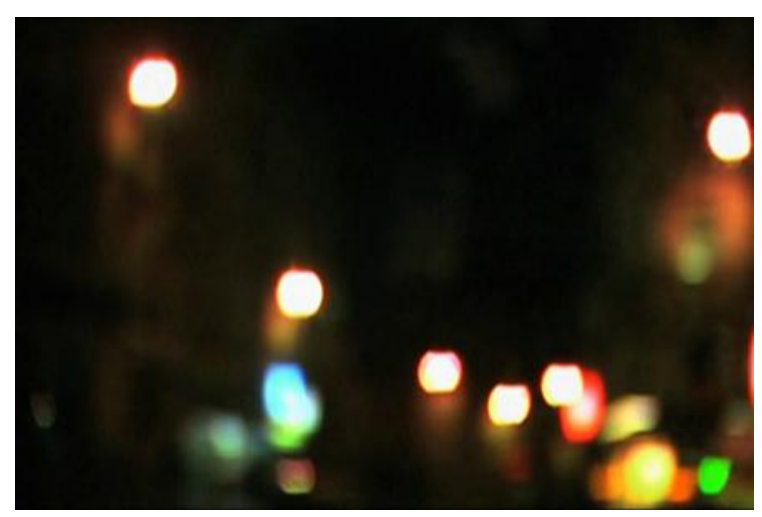

Figura 16 - Travelling de uma deriva desfocada. Fonte: Diário de uma busca (Flavia Castro, 2010).

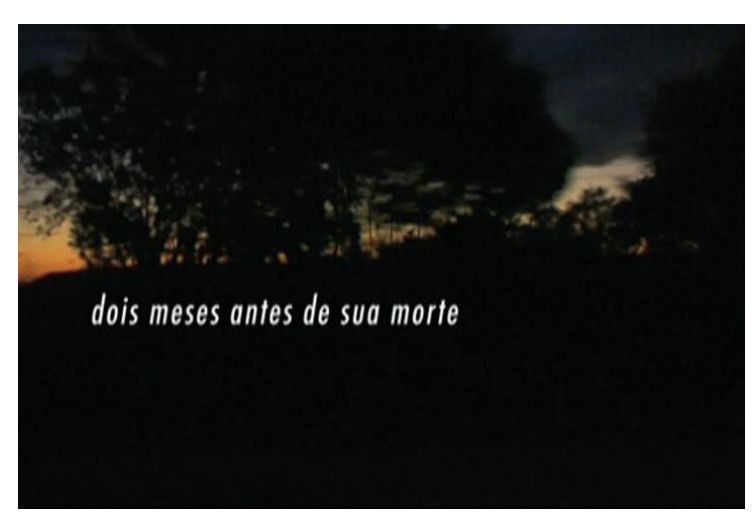

Figura 18 - Travelling do ocaso. Fonte: Diário de uma busca (Flavia Castro, 2010).

As andanças de uma busca pessoal. Os vaivéns do exílio. A deriva existencial. O travelling em veículos é o recurso de linguagem usado para expressar esses sentidos da itinerância em Diário de uma busca e em tantos outros documentários subjetivos contemporâneos. Laia Quílez Esteve (2009, p. 373, tradução nossa) já havia identificado uma recorrência de tomadas desse tipo no documentário de segunda geração argentino, interpretando os percursos em carros, trens e ônibus vistos nos filmes como uma materialização da "viagem emocional, anamnésica e identitária" empreendida pelos filhos de desaparecidos. Na mesma linha, Jens Andermann (2015, p. 190-191, tradução nossa) escrevera: "A este movimento através do espaço - que representa um sujeito de enunciação desarraigado e à deriva, ainda que também ativo e combativo - corresponde uma divisão ou crise da instância narrativa". María José Bello (2011, p. 79, tradução nossa) propõe uma leitura análoga ao considerar essas idas e vindas nas obras dos filhos chilenos como "uma viagem desde o presente até o passado; desde a maturidade e a estabilidade da idade adulta até a insegurança, as angústias e os medos de uma infância [...] sobressaltada pelos acontecimentos políticos de um país dispersado e fragmentado". María Teresa Johansson e 
Constanza Vergara (2014) também sugerem que os deslocamentos e travellings nos documentários de filhos chilenos são parte do processo de elaboração da memória traumática. $^{26}$

Nadia Lie e Pablo Piedras (2014) desdobram a questão, lendo essa recorrência como o indício de uma inflexão no campo do cinema documental:

Frente a certo sedentarismo presente nas obras testemunhais dos anos $1980 \mathrm{e}$ 1990, que organizavam seus discursos mediante a montagem de entrevistas e materiais de arquivo, os documentários contemporâneos expressam em seus dispositivos visuais diversas formas da mobilidade: percursos com câmera na mão por lugares significativos para a memória, longos travellings tomados desde câmeras localizadas em automóveis, ônibus, trens e até aviões, planos-sequência sobre álbuns fotográficos etc. (LIE; PIEDRAS, 2014, p. 73, tradução nossa).

Nesse mesmo impulso, os autores identificam um diálogo do documentário latinoamericano com os códigos de gênero road movie, com casos em que "[...] a narrativa da viagem toma a forma de uma busca - uma das duas variantes sob as quais se apresenta o deslocamento no road movie (a outra é a fuga)" (LIE; PIEDRAS, 2014, p. 79). ${ }^{27}$ E essa busca, segundo escrevem, cada vez mais se volta para "a família como núcleo de exploração sobre a identidade dos realizadores" (LIE; PIEDRAS, 2014, p. 73).

No que toca mais diretamente a Diário de uma busca, Flavia Castro já chegou a declarar em entrevista (MIRANDA, 2011) e debates ${ }^{28}$ que ficou impressionada ao descobrir No sex last night (Sophie Calle e Greg Shepard, EUA, 1992). Híbrido de road movie, videoarte e documentário subjetivo, a obra acompanha o casal de realizadores em seus desencontros amorosos durante uma viagem através dos Estados Unidos. O filme avança com um jogo constante entre imagens em movimento e fixas: os travellings tomados desde o carro e as fotografias still de cenas da jornada - o título está dedicado a Chris Marker e seu La jetée (França, 1962). Junto com as imagens, as vozes em over do casal, ela passando do inglês para o francês, ele sempre em inglês, vão se alternando na expressão de seus pensamentos sobre aquela rotina de estradas, oficinas mecânicas, hotéis baratos e discussões da relação.

A citação da obra de Sophie Calle e Greg Shepard não é apenas externa, há ecos de No sex last night na estrutura fílmica de Diário de uma busca. Essa referência lança luz sobre o

\footnotetext{
${ }^{26}$ Para mais uma abordagem com foco nos deslocamentos, cf. COELHO, 2016.

27 Bem antes, Ana Amado (2003, p. 148-149) já havia aproximado a itinerância de Papá Iván (María Inés Roqué, México / Argentina, 2000) ao road movie. Sobre o road movie em geral, cf. LADERMAN, 2002; MOSER, 2008; ORGERON, 2008. Para uma análise desse gênero no cinema latino-americano, cf. CHANAN, 2016; BERGER, 2016; e nos cinemas contemporâneos de Argentina e Brasil, cf. PINAZZA, 2014.

${ }^{28}$ Em debates ocorridos na Cinemateca Brasileira, em 24 mar. 2012, e na programação da mostra "Silêncios históricos e pessoais", dia 29 mar. 2014, ambos em São Paulo/SP.
} 
jogo entre tomadas em travelling e planos fixos existente na representação das viagens de Flavia Castro. ${ }^{29}$ Porque, sim, é verdade, os travellings de Diário de uma busca dão a ver as investigações da filha-diretora, a diáspora do exílio e as oscilações de humor do pai militante. Tudo isso se insere, de fato, na tendência à mobilidade que vem marcando o documentário subjetivo realizado nos últimos anos, em seus cruzamentos com as temáticas da família e da identidade. No entanto, a itinerância de Diário de uma busca não é pura errância identitária. Ela traz consigo uma concretude geográfica, o retorno efetivo aos locais daquela experiência. E, no filme, esses lugares de memória específicos são quase sempre pontuados com tomadas fixas.

Em seu clássico texto, Pierre Nora (1984, p. XL, tradução nossa), descrevendo as variantes do "aspecto material dos lugares" de memória, menciona os lugares "topográficos, que devem tudo a sua localização precisa e seu enraizamento no solo". Diário de uma busca tem uma série de planos estáticos que dão visualidade aos lugares de memória topográficos da história familiar. São imagens que, em sua fixidez, remetem a essa ideia de uma memória enraizada no solo, ou melhor, nos endereços exatos das experiências passadas.

O primeiro lugar de memória topográfico visitado no filme é o edifício no bairro Moinhos de Ventos, em Porto Alegre, onde faleceu Celso Castro. Aqui as tomadas ainda são dinâmicas, a câmera perscruta através do portão do condomínio, passa pela sua fachada em contra-plongée, revelando o número do imóvel em uma rua da qual o espectador desconhece o nome. Há movimento nessas tomadas, mas não a velocidade do travelling feito do automóvel ou do avião. O deslocamento se dá a pé, com a câmera na mão, uma visita de passagem a um lugar de memória dolorosa.

Já outros lugares de memória são exibidos de forma mais estável, com imagens fixas, em um dispositivo que se repete ao longo do filme, como que indicando os pontos de apoio de uma recordação afetiva. A começar pela casa da infância na rua Silva Paes, 1767, Porto Alegre, o endereço completo informado, agora sim, pela legenda sobreposta à inserção da antiga fotografia que mostra o radiante flamboyant no quintal (fig. 19). Depois, vem a casa da rua Apolo 5, em Santiago do Chile, lugar em que a família viveu a primeira temporada do exílio naquele país. Nesse caso, após a recepção pelos atuais moradores, entra uma sequência de tomadas fixas: no quintal, vê-se um lençol no varal, as árvores, um balanço de criança; até que em certo momento a câmera enquadra imóvel a placa da rua na esquina, com a cordilheira

\footnotetext{
${ }^{29} \mathrm{Na}$ faixa comentada incluída entre os extras do DVD brasileiro de Diário de uma busca, Flavia Castro explicita esse jogo, o qual seria pautado pela fonte da enunciação: a voz over das memórias de infância dela seria acompanhada por imagens fixas; a voz over da leitura das cartas do pai, por imagens em movimento.
} 
ao fundo, inscrevendo o endereço e o marco topográfico do país na própria imagem captada, e não mais pela inclusão de legendas informativas (fig. 20). A parada seguinte é o apartamento na rua Humberto Primo, em Buenos Aires, onde a família ficou encerrada em uma clandestinidade profunda. Esse enclausuramento ganha expressão fílmica nas tomadas estáticas dentro do cômodo escuro, um quadro que se duplica na janela através da qual não se vê sequer uma faixa de céu, apenas os soldadinhos de chumbo no parapeito e, mais além, a parede com outras janelas igualmente desoladoras (fig. 21). De volta ao Chile, a vida retoma certa "normalidade". A diretora retorna com a mãe à Escuela Básica Esperanza Joven, em La Cisterna, comuna de Santiago, onde estudara quando criança. O nome da escola e sua localização na cidade são visíveis na placa da entrada e no estandarte posto na sala daquele que parece ser o diretor da instituição. Após o encontro e as apresentações iniciais, as tomadas esquadrinham pátio e salas de aula, primeiro em câmera na mão, depois em planos fixos. Adiante, mãe e filha tentam visitar mais uma casa dessa história, aquela da segunda temporada chilena, situada na rua Zurich Norte, 802, Santiago do Chile, como informa a legenda. A câmera, na mão, mantém-se do outro lado da esquina, como que pressentindo a má acolhida. Ao contrário do que vinha ocorrendo, Flavia Castro e Sandra Macedo não são recebidas ali com simpatia, elas não conseguem entrar neste lugar de memória. Mesmo com o malogro da visita, a câmera na mão, tendo se aproximado, detém-se e enquadra o muro com a placa que exibe o endereço exato do local (fig. 22).

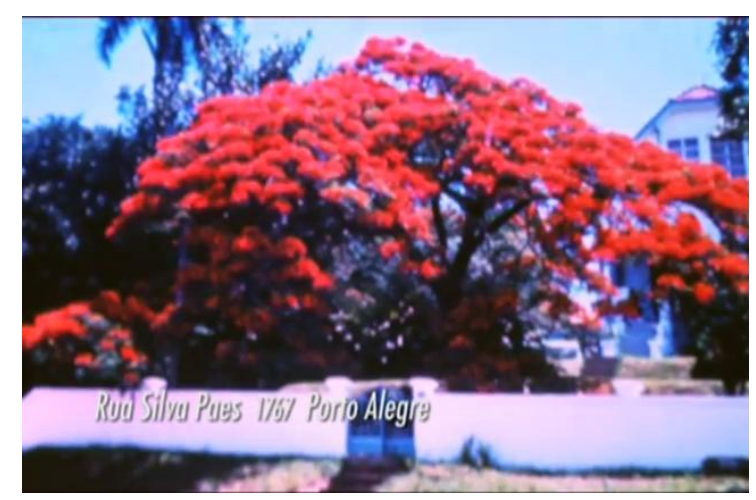

Figura 19 - Rua Silva Paes, 1767, Porto Alegre, a primeira casa da família. Fonte: Diário de uma busca (Flavia Castro, 2010).

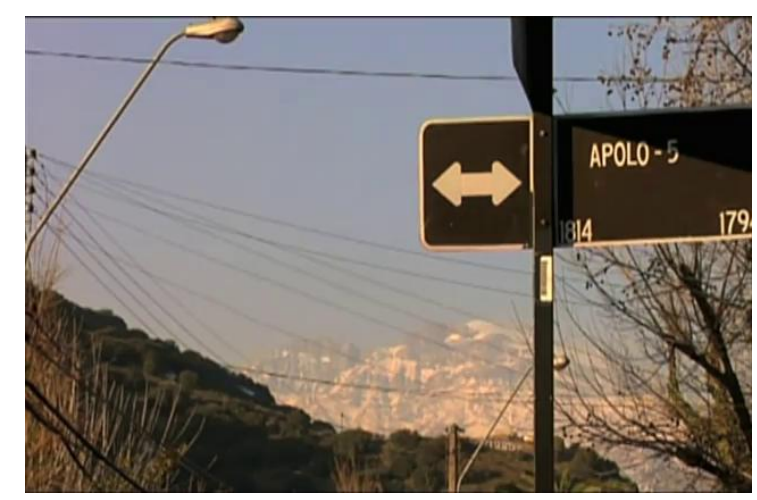

Figura 20 - Rua Apolo 5, Santiago do Chile, endereço de um dos lares-aparelhos do exílio. Fonte: Diário de uma busca (Flavia Castro, 2010). 


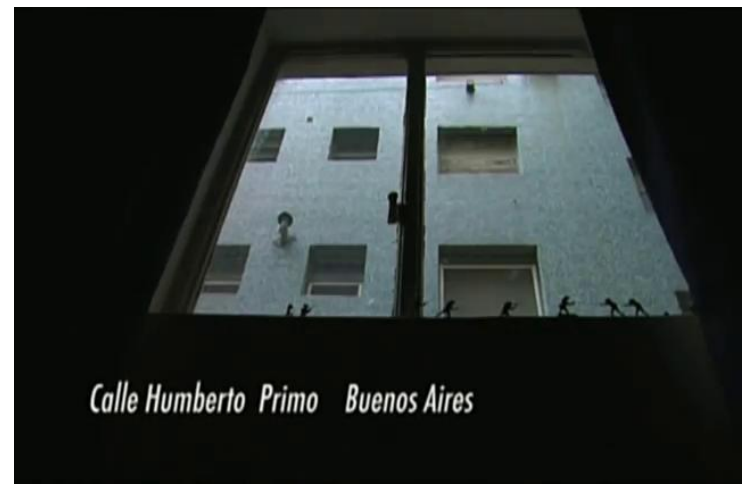

Figura 21 - Rua Humberto Primo, Buenos Aires, Argentina. Fonte: Diário de uma busca (Flavia Castro, 2010).

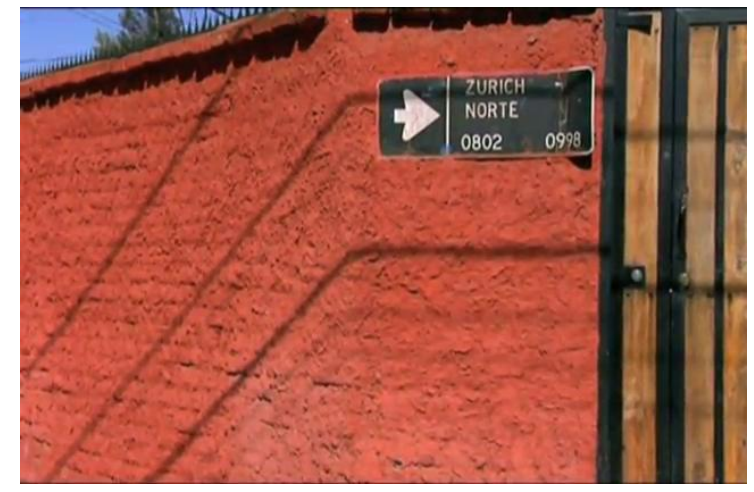

Figura 22 - Rua Zurich Norte, 802, Santiago do Chile. Fonte: Diário de uma busca (Flavia Castro, 2010).

Esse último plano é sucedido imediatamente por uma sequência de tomadas fixas de um quintal com laranjas caídas no solo onde se projeta a sombra de uma pérgola vazia, é um jardim malcuidado com muro descascado. Em over, escuta-se o áudio de arquivo com o anúncio do golpe chileno, acompanhado por uma sonoplastia com ruídos de helicópteros. Um novo segmento mostra Flavia Castro e Sandra Macedo caminhando até o bar de uma esquina próxima, desde onde a mãe telefonara para Celso logo após a invasão da casa da rua Zurich Norte pelos militares, quando Nelson de Souza Khol foi sequestrado. É outro lugar de memória, filmado com câmera na mão: as duas é que estão paradas diante do bar, a mãe relata para a filha os acontecimentos. Em corte seco, entra uma sequência de tomadas fixas do interior do Estádio Nacional do Chile (fig. 23). Em over, Flavia Castro narra em detalhes as circunstâncias da detenção de Nelson, a impressão causada pelo "seu último olhar antes de desaparecer". Aqui entra em cena um dos lugares de memória centrais do golpe chileno. Um espaço público, o Estádio Nacional, emblema dos sequestros e desaparecimentos em massa perpetrados pelos militares logo após a tomada do poder. Até esse momento da narrativa de Diário de uma busca, os lugares revisitados carregavam uma ambiguidade entre as lembranças privadas e coletivas. Os endereços das residências dos Castro eram, ao mesmo tempo, espaços da intimidade familiar e da militância política. Eram lares-aparelhos que abrigavam crianças e escondiam armas. Brinquedos armados, os soldadinhos de chumbo vistos na janela do apartamento portenho são um signo dessa confusão entre família e organização clandestina, infância e luta revolucionária (fig. 21).

A embaixada argentina em Santiago é o próximo lugar de memória de caráter mais coletivo que surge no documentário. Flavia Castro, agora sozinha, visita o espaço onde ela e tantos outros exilados brasileiros no Chile tiveram que se refugiar imediatamente após o golpe (ROLLEMBERG, 1999, p. 179-180). Intercalada ao registro desse retorno, entra a inserção de um plano fixo do palacete, tomado desde o gramado do jardim (fig. 24). Em seguida, uma 
tomada com câmera na mão vai passando pela fachada do edifício. Em over, a diretora narra a tentativa frustrada do pai de também entrar ali. O "Nosocômio" da rua Combate de los Pozos, 2113, em Buenos Aires, é a próxima parada da fuga do Chile. O espaço é apresentado com uma série de planos fixos, com legenda localizando-o e trilha sonora incidental ao violão (fig. 25). E segue no restante da narrativa a lógica das tomadas imóveis pontuando os lugares de memória topográficos, situados com precisão: a sede do semanário comunista Rouge, na "2 Rue Richard Lenoir, Montreuil”, onde os pais foram trabalhar no exílio francês (fig. 26); o apartamento em Paris, na "82 Boulevard Masséna" (fig. 27); de volta a Porto Alegre, o endereço do pai na rua Hilário Ribeiro, 208, filmado em um movimento de câmera ascendente e lento, um plano fechado noturno que vai revelando aos poucos a fachada do prédio, do chão em frente até o teto (fig. 28); por último, o Cemitério da Santa Casa de Porto Alegre, cuja estrutura é apresentada em dois planos fixos, um geral e outro fechado, e uma terceira tomada que se move mas logo se estabiliza, enquadrando os detalhes arquitetônicos do conjunto (fig. 29).

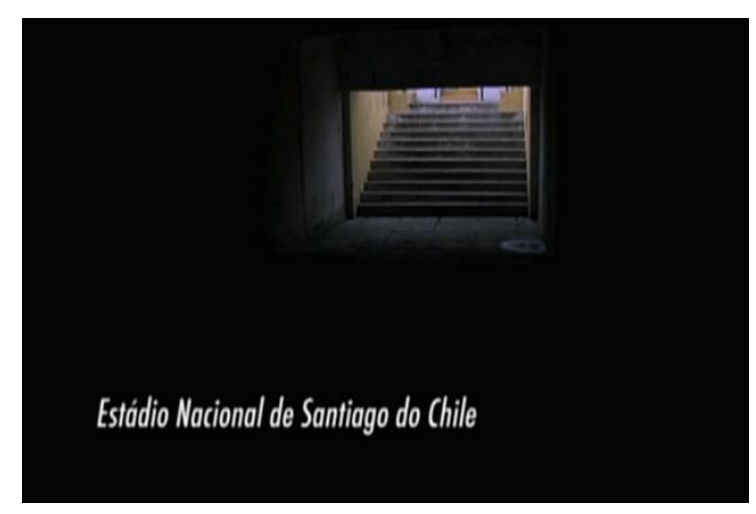

Figura 23 - Estádio Nacional do Chile. Fonte: Diário de uma busca (Flavia Castro, 2010).

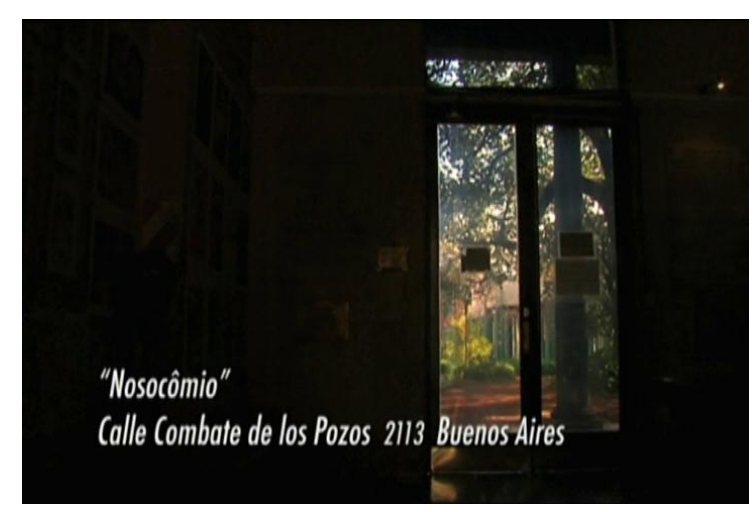

Figura 25 - "Nosocômio", rua Combate de los Pozos, 2113, Buenos Aires, Argentina. Fonte: Diário de uma busca (Flavia Castro, 2010).

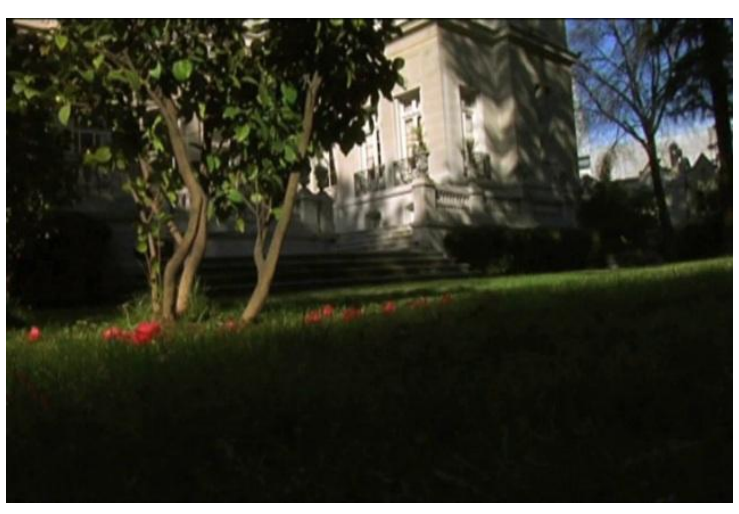

Figura 24 - Embaixada da Argentina em Santiago do Chile. Fonte: Diário de uma busca (Flavia Castro, 2010).

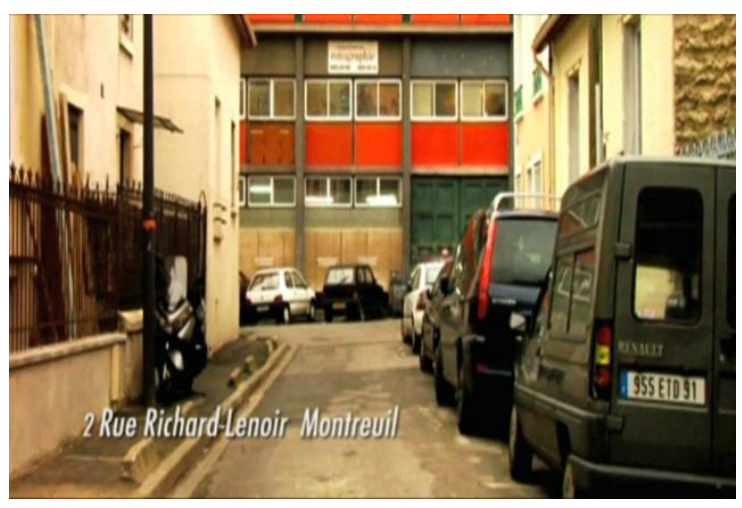

Figura 26 - Sede do Rouge, 2 Rue Richard Lenoir, Montreuil, França. Fonte: Diário de uma busca (Flavia Castro, 2010). 


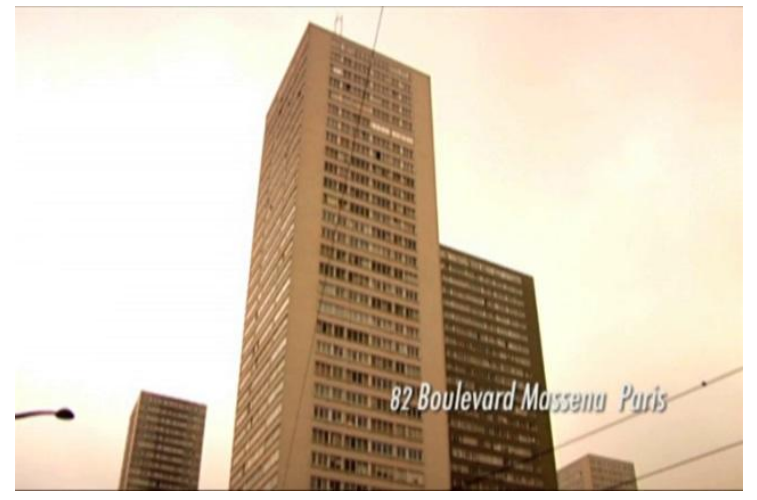

Figura 27 - 82 Boulevard Masséna, Paris, França. Fonte: Diário de uma busca (Flavia Castro, 2010).

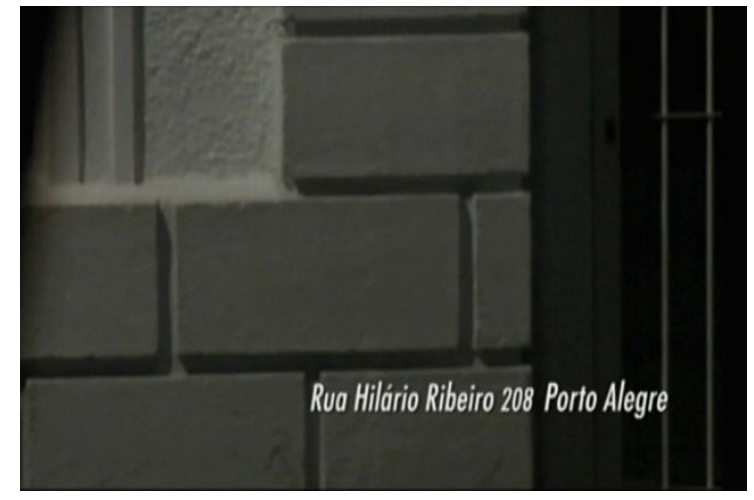

Figura 28 - Rua Hilário Ribeiro, 208, Porto Alegre. Fonte: Diário de uma busca (Flavia Castro, 2010).

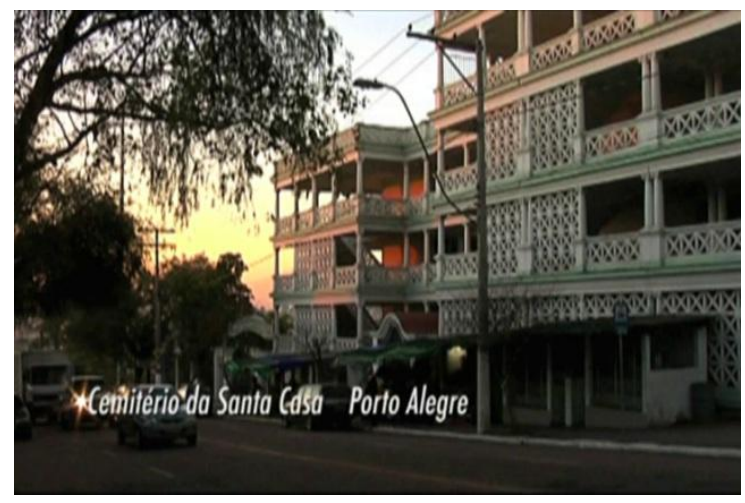

Figura 29 - Cemitério da Santa Casa, Porto Alegre. Fonte: Diário de uma busca (Flavia Castro, 2010).

Há que se dizer que em algumas dessas tomadas não há um efetivo nexo indicial entre a imagem e o lugar de memória topográfico. Ou seja, que existem casos nos quais a locação da filmagem não corresponde ao exato espaço referencial em que os eventos ocorreram no passado. ${ }^{30} \mathrm{Na}$ faixa comentada que consta nos extras da versão brasileira do DVD do filme, perguntada por João Moreira Salles, Flavia Castro revela que a tomada da janela do apartamento em Buenos Aires foi feita, na verdade, no quarto do hotel onde ela ficara hospedada durante a rodagem na cidade. Ela diz, entretanto, que o apartamento original era "parecido com isso". O mesmo acontece quando os comentários se dedicam à sequência de travellings em praias vista enquanto se ouve a carta de Celso Castro enviada da Venezuela para a irmã. Pelo que é dito, fica claro que as imagens não foram feitas nas praias daquele país. Nesses dois casos, os planos são mais alusivos do que propriamente referenciais. Sem que a captação tenha sido realizada nos mesmos lugares do passado, essas tomadas evocam

\footnotetext{
${ }^{30}$ Sobre a relação indicial entre espaço e memória, cf. MAZZUCCHELLI; DER LAARSE; REIJNEN, 2014; VIOLI, 2014. Para análises do documentarismo recente sobre as ditaduras de Argentina e Chile a partir da figuração da paisagem e do espaço, cf. ANDERMANN, 2012, 2015, p. 190-191; GRAY, 2015.
} 
sensações espaciais daquela história: a vivência do enclausuramento em Buenos Aires; a luminosidade tropical da nova vida do pai na Venezuela. Mas a maioria das imagens dos lugares específicos de memória foi feita no próprio local das vivências. As legendas informam os endereços precisos. Em certas ocasiões, a câmera enquadra as placas das ruas, tornando inequívoca a presença no lugar. Seja como for, parece infrutífero encaminhar a análise para um debate sobre a autenticidade ou a "ilusão" dessas tomadas. Nem sempre isso é indiferente, vale esclarecer. Contudo, ao menos nesse caso, mais importante é considerar o espaço diegético construído pela obra, a forma como imagens e palavras delineiam um universo fílmico que é, ao mesmo tempo, um espaço de memória.

Pierre Nora (1984, p. XLI) pensava os lugares de memória dentro dos limites da história nacional. A itinerância das imagens de Diário de uma busca dá a ver um constante cruzar de fronteiras, uma história transnacional. A mobilidade sem dúvida é uma linha de força do documentário subjetivo contemporâneo, e os títulos do corpus desta pesquisa seguem de perto essa tendência estética. No entanto, um mapa da memória elaborado a partir dessa cinematografia não estaria completo sem a inclusão dos lugares que se fixam. A chance de que o percurso não leve a uma conclusão definitiva é parte dessas buscas pessoais. Porém, essas mesmas buscas significam algo mais do que uma errância indefinida, uma deriva identitária. Elas refazem caminhos outrora transitados e, nessas andanças, fincam os pés em determinados pontos. De mãos dadas com a face mais subjetiva dos deslocamentos, surge em Diário de uma busca uma espacialidade concreta. Um mapa de escalas distintas, composto por imagens móveis e estáticas, uma cartografia das recordações que indica longos percursos e lugares precisos.

De acordo com Susannah Radstone (2011, p. 115, tradução nossa), o apagamento do específico é um risco que ronda os estudos transnacionais da memória:

Sem prestar atenção à localização da memória, bem como aos seus movimentos, as teorias da memória transnacional e transcultural, com seu foco na viagem $[\ldots]$ da memória ao redor do globo, arriscam-se a eliminar tais memórias de vista, precisamente por causa de sua localização e imobilidade.

A atenção aos travellings e aos planos fixos torna-se uma espécie de antídoto contra esse perigo, sendo a linha condutora de um mapeamento que integra o macro e o micro. Surge daí uma geografia transnacional da memória que não ignora os traços localizados. Que abrange um voo transandino para o Chile, a ida para a Argentina, de carro de volta ao Chile, um voo transatlântico para a França e, daí, para a Venezuela, até o retorno para o Brasil. E 
também os endereços exatos de uma história simultaneamente familiar e coletiva: casas e lares-aparelhos; o centro do horror no qual se tornara o Estádio Nacional de Santiago; a gráfica do semanário comunista francês; novos domicílios; e o cemitério da cidade de origem, triste ponto final da jornada. Eis a cartografia de uma "memória multidirecional" (ROTHBERG, 2009), híbrida, que carrega o peso dos golpes no Brasil, no Chile e na Argentina, do exílio na América Latina e na Europa. Uma memória feita de rotas e marcos, representados por imagens que acompanham formalmente essa dinâmica: planos itinerantes e estáticos que dão a ver, em suma, os fluxos e as paragens de um espaço além-fronteiras da memória intergeracional das ditaduras.

\section{Pós-fílmico: circulações nos festivais de cinema}

Pouco a pouco, esse fenômeno de memória vai se delineando em sua profundidade temporal e abrangência geográfica. Como se viu, as facetas do transnacionalismo se manifestam já desde a repressão e a resistência durante as ditaduras, passando pela experiência do exílio, pela militância dos filhos, pelas transferências culturais e coproduções internacionais. Um mapa da memória ganha forma cinematográfica nas imagens de Diário de uma busca e de tantos outros títulos do corpus. Nesse espaço-tempo, vislumbra-se a historicidade dessa tendência do cinema documentário, o que engloba também aquilo que vem depois dos filmes: as circulações que reverberam em variadas latitudes a produção intergeracional aqui estudada.

Ficou mencionado que o documentário de Flavia Castro estreou comercialmente em Paris e no Brasil em meados de 2011. A recepção crítica foi em geral positiva nos dois países, mas o público alcançado na ocasião do lançamento foi limitado. Por aqui, segundo os números oficiais, o filme teve 3.658 espectadores em seis salas de cinema (AGÊNCIA NACIONAL DO CINEMA, 2016, p. 5). Entretanto, é preciso considerar que, antes disso, o título teve um exitoso percurso no circuito de festivais.

No bojo da ascensão do prisma transnacional, os festivais passaram a atrair cada vez mais o interesse de pesquisas no campo historiográfico (FLÉCHET et al., 2013) e dos estudos do cinema (DE VALCK, 2007; PAPADIMITRIOU; RUOFF, 2016, p. 1). Frente à proliferação desses eventos pelo mundo desde fins do século $\mathrm{XX}$, já houve mesmo quem acusasse certa "festivalização" da cultura (GOETSCHEL; HIDIROGLOU, 2013, p. 11). Os eventuais excessos, contudo, não anulam o fato de que os festivais podem ser analisados "como vetores de transferências culturais e lugares de emergência de novas formas [...] 
híbridas" (FLÉCHET, 2011, p. 262, grifo da autora). No caso específico do cinema, os festivais favorecem os contatos entre filmografias de diferentes partes, operando como “pontos nodais" (DE VALCK, 2007, p. 15, tradução nossa) das circulações de títulos; como "centros cruciais para o desenvolvimento de conhecimento cinematográfico e práticas fílmicas" (WONG, 2011, p. 1, tradução nossa); como "pontos de encontro vitais para cineastas e profissionais do cinema locais e internacionais" (GUTIÉRREZ, C. A.; WAGENBERG, 2013, p. 296, tradução nossa).

Tais fluxos, porém, não são isentos de tensões. Principalmente pelas variadas funções assumidas pelos festivais, "seu papel de lançamento, de fabricação, de promoção, de consagração e, por que não, de canonização de artistas, de obras, de movimentos e de formas artísticas" (GOETSCHEL; HIDIROGLOU, 2013, p. 13, tradução nossa). Contatos, descobertas, difusão, legitimação, sedimentação, tudo isso entra em jogo nas dinâmicas de circulação dos documentários intergeracionais pelos festivais. ${ }^{31}$

A passagem de Diário de uma busca por esse circuito já dá uma ideia do panorama. $\mathrm{O}$ título de Flavia Castro foi laureado em sete festivais pelo mundo. Em 2010, no Festival de Cinema de Gramado, ele ganhou os prêmios da crítica e do júri de estudantes de cinema. No Festival de Biarritz: cinémas et cultures d'Amérique Latine, na França, conquistou no mesmo ano o prêmio Documental Unión Latina de melhor documentário. Ainda em 2010, no Festival do Rio, levou o prêmio de melhor longa-metragem documental e o prêmio da Federação Internacional de Críticos de Cinema (Fipresci). Já em 2011, Diário de uma busca ganhou o prêmio da crítica de melhor filme no Festival Internacional de Cine de Punta del Este, Uruguai; de melhor documentário de investigação e melhor filme internacional em língua portuguesa no Doclisboa, em Portugal; de melhor longa-metragem na competição nacional do Festival do Filme Documentário e Etnográfico de Belo Horizonte (forumdoc.bh); e o prêmio especial do júri na categoria documentário no Festival Internacional del Nuevo Cine Latinoamericano de Havana, Cuba.

Há também aqueles festivais pelos quais Diário de uma busca circulou sem ser premiado. Em 2011, o título passou pelo Buenos Aires Festival Internacional de Cine Independiente (Bafici), na Argentina; pelo $13^{\mathrm{e}}$ Festival du Cinéma Brésilien de Paris, na França; pelo Festival Internacional de Documentales de Madrid (DocumentaMadrid), Espanha; e pelo Festival Internacional de Documentales de Santiago (Fidocs), no Chile. Em

\footnotetext{
${ }^{31}$ As considerações a seguir enfatizam os planos da exibição e da premiação, embora não se ignore o influxo exercido nesse universo pelas plataformas de produção e financiamento incluídas nos festivais, isto é, os laboratórios, as seções de work in progress e os fundos de fomento (FALICOV, 2010, 2013; RABADÁN, 2016).
} 
2012, Diário de uma busca estava na programação do International Human Rights Documentary Film Festival em Kiev (Docudays UA), na Ucrânia. E, em 2013, o filme ainda teve fôlego para circular no Festival Visages, em Vevey, na Suíça. ${ }^{32}$

Nota-se que Diário de uma busca foi selecionado e premiado em relevantes festivais no Brasil (Gramado, Rio, Forumdoc.bh), na América Latina (Punta del Este, Havana, Bafici, Fidocs) e na Europa (Biarritz, Doclisboa, Cinéma Brésilien de Paris, DocumentaMadrid, Docudays UA, Vevey). Essas circulações cruzam as escalas nacional, regional e transatlântica, revelando outra camada da espacialidade da memória ligada a essa filmografia.

Pois o documentário de Flavia Castro não estava sozinho nesse circuito. De fato, o ano de seu lançamento, 2010, foi um momento-chave para o documentarismo intergeracional sobre as ditaduras do Cone Sul. Além de Diário de uma busca, outros quatro títulos dessa filmografia surgiram em 2010, expandindo o leque de países coprodutores em relação aos anos anteriores: El edificio de los chilenos (Macarena Aguiló e Susana Foxley, Chile / Cuba / França / Bélgica, 2010), que narra em primeira pessoa a história dos filhos dos militantes do Movimiento de Izquierda Revolucionaria (MIR) enviados a uma comunidade de crianças em Cuba para que os pais retornassem do exílio em contraofensiva ao regime de Pinochet; El eco de las canciones (Antonia Rossi, Chile, 2010), no qual a diretora, nascida no exílio em Roma, com uma espécie de colagem de imagens díspares, reflete em voz over sobre a condição do desenraizamento; ${ }^{33}$ Abuelos (Carla Valencia Dávila, Equador / Chile, 2010), que traça um paralelo entre o assassinato do avô chileno da diretora pela ditadura de Pinochet e o sonho de imortalidade de seu outro avô, equatoriano; Cuchillo de palo (Renate Costa, Paraguai / Espanha, 2010), sobre a perseguição aos homossexuais pela ditadura paraguaia que vitimou o tio da diretora. ${ }^{34}$ No recorte temporal do corpus expandido (1996-2017, com um total de 67 títulos), a marca de cinco produções no ano está acima da média, sendo observada em 2000 e

\footnotetext{
${ }^{32}$ Realizou-se um levantamento das premiações e circulações em festivais dos 67 títulos do corpus. As reflexões das páginas seguintes têm como base a compilação e o cruzamento dessas informações, consolidadas no APÊNDICE A. Este último oferece uma visão complementar pormenorizada das ramificações geográficas e segmentações temáticas dos festivais, bem como dos tipos de prêmios conquistados. Bancos de dados filmográficos on-line, listas de vencedores, catálogos e notícias de imprensa foram as principais fontes. Entre as bases de dados, destacam-se: Portal del Cine y el Audiovisual Latinoamericano y Caribeño (http://cinelatinoamericano.org); Cinechile: Enciclopedia del Cine Chileno (http://cinechile.cl); Cinenacional.com (http://www.cinenacional.com); Filmografia Brasileira (http://www.cinemateca.gov.br); UruguayTotal.com: Cinestrenos (http://www.uruguaytotal.com/estrenos/); Centro de Capacitación Cinematográfica: Producción Fílmica (http://www.elccc.com.mx/sitio/index.php/produccion-filmica); Filmoteca Unam: Filmografía Mexicana (http://www.filmografiamexicana.unam.mx/busqueda.html); Internet Movie Database (IMDb) (http://www.imdb.com); FilmAffinity (http://www.filmaffinity.com); British Council: Festivals Directory (http://film.britishcouncil.org/); Guia Kinoforum: Festivais Audiovisuais (http://www.kinoforum.org.br/guia/).

${ }^{33}$ Sobre El edificio de los chilenos e El eco de las canciones, cf. ARÁNGUIZ, 2012; BARRENHA, 2013a; BELLO, 2011; BOSSY; VERGARA, 2010; LLANOS, 2014; PINTO, 2012.

${ }^{34}$ Sobre Cuchillo de palo, cf. TAVARES, D., 2018.
} 
2010, só superada pelos seis lançamentos observados em 2007 e 2015, além dos sete de 2006 e $2016 . .^{35}$

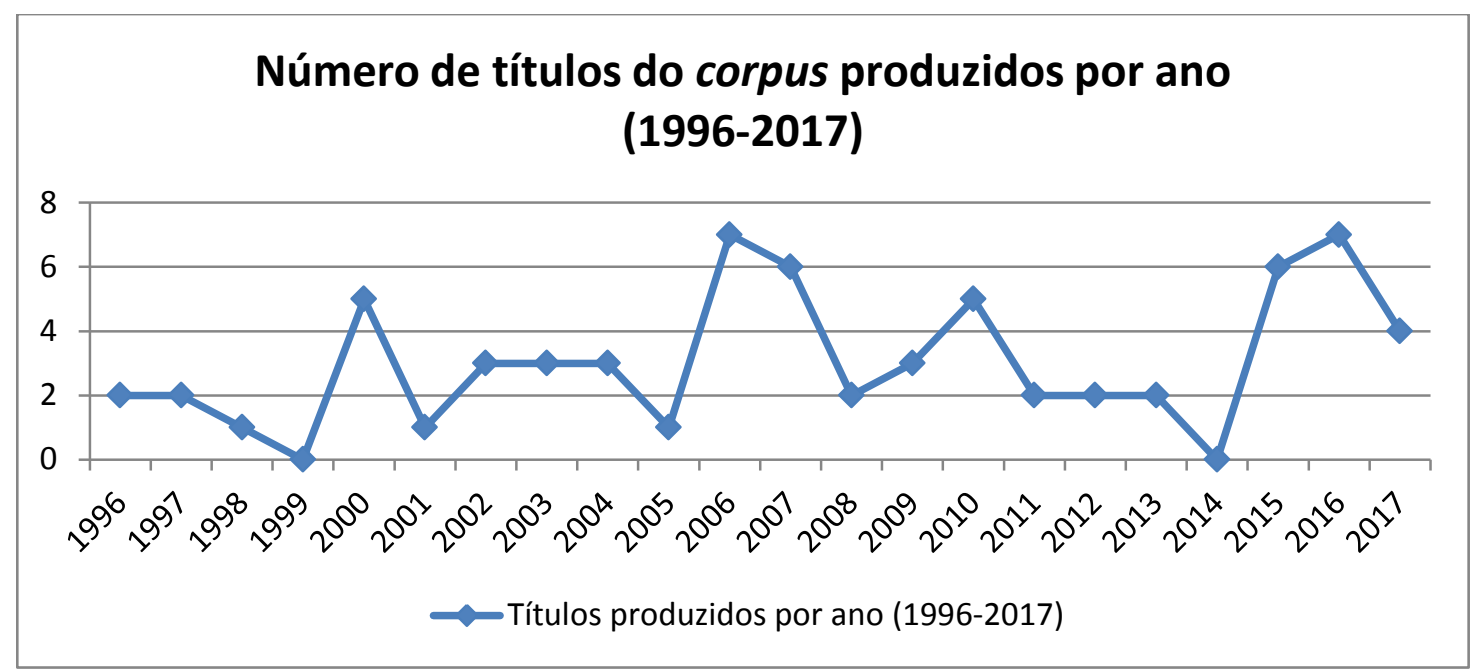

Gráfico 1 - Número de títulos do corpus (total de 67) produzidos por ano (1996-2017). Fonte: Elaboração do próprio autor.

Mas não é exatamente na quantidade de títulos que 2010 se destaca. Este foi também um ano pródigo em premiações em festivais para o documentarismo intergeracional do Cone Sul. Na mesma edição de 2010 do Festival de Gramado, quando Diário de uma busca recebeu os prêmios da crítica e do júri de estudantes de cinema, Mi vida con Carlos (Germán BergerHertz, Chile / Espanha, 2009) acumulava outros três prêmios: de melhor longa-metragem estrangeiro, de melhor fotografia e prêmio do público de melhor filme. Ainda em 2010, o filme de Germán Berger-Hertz conquistaria prêmios no Rencontres du Cinéma SudAméricaine de Marseille, na França; na Mostra de Cinema Llatinoamericà de Catalunya e no Festival de Málaga, ambos na Espanha; no Ischia Film Festival, na Itália; no San Diego Latino Film Festival, nos Estados Unidos; e no Hot Docs Canadian International Documentary Festival, em Toronto.

Outro documentário produzido no ano anterior, La quemadura (René Ballesteros, Chile / França, 2009), também colhia prêmios em 2010: no Festival Internacional de Cine de Santiago (Sanfic) e no Festival Internacional Cine//B, ambos no Chile; no DocumentaMadrid, na Espanha (por onde também passaria, no ano seguinte, Diário de uma busca); e no Cinéma du Réel, em Paris.

Os títulos produzidos em 2010 não ficariam para trás. El edificio de los chilenos (Macarena Aguiló e Susana Foxley, Chile / Cuba / França / Bélgica, 2010) conquistou no

\footnotetext{
${ }^{35}$ Para os detalhes dos títulos, ver listagem na abertura deste capítulo. Sobre a datação dos filmes do corpus, optou-se aqui pelo ano de produção, nem sempre coincidente com o ano de estreia.
} 
Chile o grande prêmio da competição nacional no Fidocs, em Santiago, além dos prêmios de melhor documentário no Festival de Cine Documental de Chillán (ChileReality) e no Festival de Documentales de La Pintana (Pintacanes). Obteve ainda menção honrosa na competição de jovens talentos no DOK Leipzig, na Alemanha. E, no Festival de Havana, o filme de Macarena Aguiló e Susana Foxley conquistou o Segundo Prêmio Coral para documentários, enquanto Cuchillo de palo (Renate Costa, Paraguai / Espanha, 2010), também nesta edição do festival cubano, recebeu uma menção especial na mesma categoria.

Este é outro título que se destacou nos festivais de 2010. Além da menção em Havana, Cuchillo de palo ganhou prêmios no Bafici, em Buenos Aires; no Festival Internacional de Cine en Guadalajara, no México; no Festival de Málaga (na mesma edição que premiou também Mi vida con Carlos) e no Festival de Cine Documental de Cádiz (Alcances), ambos na Espanha; no Doclisboa, em Portugal; no Festival dei Popoli, em Florença, na Itália; no One World International Human Rights Documentary Film Festival, em Praga, na República Checa; e no Rencontres Internationales du Documentaire de Montréal (RIDM), no Canadá.

Entre os títulos de 2010, foram ainda premiados neste mesmo ano: El eco de las canciones (Antonia Rossi, Chile, 2010), laureado no Festival International de Cinéma de Marseille (FIDMarseille), na França; e Abuelos (Carla Valencia Dávila, Equador / Chile, 2010), vencedor do prêmio do público no Encuentros del Otro Cine: Festival Internacional de Cine Documental (Edoc), no Equador.

O ano de 2010 é, de longe, aquele em que o circuito de festivais concedeu mais prêmios ao documentarismo intergeracional sobre as ditaduras do Cone Sul. E é preciso considerar que este é também um ano em que seguem circulando os documentários "acumulados" no tempo, muito por conta da retomada de títulos anteriores em mostras específicas inseridas em festivais. Por exemplo, Los Argenmex 20 años después: la historia ésta (Jorge Denti, México, 1996), originalmente uma série para a televisão que, nos vinte anos do golpe argentino, reunia testemunhos de filhos de exilados no México, estreia no circuito de festivais em 2010, quatorze anos depois de sua produção, com um formato de 56 minutos, no Festival de la Memoria: Documental Iberoamericano en Tepoztlán (FMDI), no México. Los rubios (Albertina Carri, Argentina, 2003) - um radical experimento reflexivo sobre as dificuldades de reconstrução da memória dos pais desaparecidos da diretora ${ }^{36}$ - foi exibido em uma retrospectiva temática (“.doc: los nuevos caminos de la no ficción”) na edição de 2010 do Festival Internacional de Cine de San Sebastián, na Espanha. M (Nicolás Prividera,

\footnotetext{
${ }^{36}$ A vasta bibliografia sobre Los rubios será mobilizada no próximo capítulo.
} 
Argentina, 2007) - outro dos títulos centrais da filmografia argentina nessa chave, no qual o filho-diretor faz uma investigação exasperada em busca de rastros da mãe desaparecida ${ }^{37}$ - foi exibido como estudo de caso em um workshop no DocMontevideo de 2010, no Uruguai. E, claro, como se viu, ainda circulavam os então recentíssimos Mi vida con Carlos e La quemadura, ambos de 2009.

A produção acima da média, abrangendo mais países, incluindo o Brasil de Diário de uma busca. O recorde de prêmios, em prestigiosos festivais pelo mundo. A continuidade da circulação de títulos produzidos em anos anteriores. Tal panorama leva à conclusão de que 2010 foi um ano de adensamento do fenômeno do documentarismo intergeracional sobre as ditaduras do Cone Sul. Note-se, porém, que a noção de adensamento se contrapõe aqui a uma ideia desencarnada de guinada. ${ }^{38}$ Pois se o ano de 2010 merece uma atenção especial, não é para a afirmação de um corte claro, embora definido em termos genéricos, entre um antes e um depois. Ao contrário, no lugar de cravar um marco fixo em um terreno abstrato, esta seção empreende um levantamento minucioso das circulações concretas dos títulos do corpus nos festivais. A árdua "reconstrução analítica da intrincada rede de relações microscópicas" (GINZBURG, 2010, p. 19) em torno dos filmes é um caminho que vale a pena ser percorrido. Tal esforço permite que se desdobre a densidade desse momento específico, descortinando as várias dimensões da temporalidade do fenômeno: os picos e os prêmios (o pontual, o excepcional), mas também as circulações que se mantêm (a continuidade). A conjunção singular de 2010 serve aqui como porta de entrada para o mergulho na formação paulatina dessa filmografia. As cadências condensadas naquele ano em particular sinalizam os imbricados vetores daquilo que ocorreu antes e depois, à montante e à jusante desse ponto da história (WERNER; ZIMMERMANN, 2003, p. 31). Abre-se o horizonte de um processo que, sendo histórico, é diacrônico. Mais do que a "guinada", a ideia de adensamento traz consigo essa carga de uma temporalidade complexa.

Muita coisa aconteceu entre 1996, quando surgiram os primeiros títulos do corpus, e 2010, ano de adensamento desse documentarismo intergeracional. O próprio gráfico acima inserido com o número de produções ano a ano já revela a faceta processual da constituição dessa filmografia. O surgimento dos documentários foi se dando ao longo do tempo, com altos e baixos, fluxos e refluxos. E não de uma vez, em uma inflexão bem demarcada, como

\footnotetext{
${ }^{37}$ Sobre $M$, cf. AGUILAR, 2007a; ESTEVE, 2009, p. 456-477.

38 Sobre as ideias desencarnadas e universalizantes, Roger Chartier (2002, p. 26-27) já escreveu: "Conceder deste modo atenção às condições e aos processos que, muito concretamente, determinam as operações de construção do sentido [...] é reconhecer, contra a antiga história intelectual, que as inteligências não são desencarnadas, e, contra as correntes de pensamento que postulam o universal, que as categorias aparentemente mais invariáveis devem ser construídas na descontinuidade das trajetórias históricas."
} 
poderia sugerir a ideia de "guinada". Tampouco essa formação segue uma progressão crescente e continuada.

Os lançamentos, as premiações e as circulações nos festivais entre 1996 e 2009 ajudam a compreender os vaivéns dessa cinematografia rumo ao adensamento de 2010. A começar pelos dois títulos precursores do corpus, produzidos em 1996: Los Argenmex 20 años después: la historia ésta (Jorge Denti, México, 1996) e 15 filhos (Maria Oliveira e Marta Nehring, Brasil, 1996). O primeiro é uma produção mexicana dirigida por Jorge Denti, cineasta argentino integrante do Grupo Cine de la Base em meados dos anos 1970 e que, forçado ao exílio após o golpe de 1976, radicou-se no México (MASMUN, 2011). Trata-se, para dizer de algum modo, de um cineasta da "primeira geração" que volta sua câmera para os jovens "argenmex", ouvindo o que estes têm a dizer sobre a ditadura e o exílio (GUTTER, 2009). O formato original desse título era a série televisiva, sem que tenha passado pelo circuito de festivais no momento de seu surgimento.

O curta-metragem 15 filhos chama mais atenção nesse início do recorte temporal. Nesse caso, as duas diretoras, Maria Oliveira e Marta Nehring, são filhas de militantes vítimas da ditadura brasileira. No vídeo de cerca de dezoito minutos, as duas estão diante e atrás da câmera, testemunhando e escutando os demais filhos com experiências de vida similares. Originalmente, 15 filhos surgiu para ser exibido em um evento realizado em 1996 na Unicamp, “A revolução possível: homenagem às vítimas do regime militar”, organizado pela mãe de Marta Nehring, a professora Maria Lygia Quartim de Moraes (ARANTES, 2008, p. 79; NEHRING, 2014, p. 46-47). O curta acabou ganhando fôlego em um circuito mais amplo, tendo sido premiado em festivais em Bogotá, no Rio de Janeiro, em Curitiba e no Ceará. Em 1997 e 1998, 15 filhos circulou mundo afora com o projeto Itinerância Videobrasil, passando por Alemanha, Países Baixos, Inglaterra, Japão, Chile, França e Burkina Faso (OLIVA, 1997). Não basta, portanto, dizer que 15 filhos teria sido um "antecedente" daquilo que estava por vir no documentarismo da região. O curta teve seu momento próprio, mereceu prêmios e circulou por países da América Latina, da Europa e até da África. O fato é intrigante quando se pensa que, ao mesmo tempo, ele demarca o longo hiato do olhar intergeracional do documentarismo brasileiro para a ditadura. Um intervalo que vai de 1996 a 2010, ano de Diário de uma busca, justamente o período em que o fenômeno foi se desenvolvendo nas cinematografias vizinhas.

Mais acima, ficou apontada a concomitância entre o surgimento de 15 filhos no Brasil e a formação das agrupações de hijos nos demais países do Cone Sul. Àquela altura da argumentação, o foco eram os aspectos mais propriamente históricos, os descompassos e as 
vicissitudes dos processos de redemocratização dos países da região, com destaque para a proposição de Janaína de Almeida Teles (2005) - ela que também havia sido uma das testemunhas entre os quinze filhos do curta de 1996 - sobre o isolamento social da memória dos familiares no Brasil, preterida em um contexto no qual a matriz abrangente da resistência vinha a calhar em meio às dinâmicas de acomodação política. Agora vale a pena retomar em termos estéticos a discussão sobre o descompasso brasileiro.

Essa lacuna entre 15 filhos e Diário de uma busca poderia passar a impressão de que de fato existe um antes assertivo (testemunhal e coletivo) e um depois subjetivo (titubeante e privado) no interior do próprio documentarismo intergeracional sobre as ditaduras. Afinal, em 15 filhos as falas compõem uma voz geracional, as duas diretoras dão seus depoimentos tal qual os outros treze filhos, na chave estética do documentário de entrevista convencional: plano fechados nas "cabeças falantes", vozes fragmentadas e rearranjadas coerentemente pela edição, inserções de imagens ilustrativas (cf. BERNARDET, 2003; NICHOLS, 1991, p. 54). Ou seja, o teor claramente original e renovado das lembranças daqueles filhos ganhava expressão dentro de uma forma tradicional do cinema documentário. Ali, a primeira pessoa é, antes de tudo, a testemunha que narra uma experiência vivida, e não exatamente a matriz problemática de uma enunciação hesitante. Esse raciocínio da guinada pareceria se confirmar com o surgimento de Diário de uma busca, título que, a se seguir essa lógica, enfim marcaria a entrada do documentarismo intergeracional brasileiro em uma "etapa" efetivamente subjetiva, na qual estariam alinhados o conteúdo novo da memória e o modo contemporâneo de expressão cinematográfica. Porque, é verdade, depois do filme de Flavia Castro, surge $O s$ dias com ele (Maria Clara Escobar, Brasil / Portugal, 2013), outro documentário pleno de hesitações realizado por uma filha de militante que parte da história familiar, nesse caso os desencontros de sua relação com o pai, para tentar iluminar aspectos do passado autoritário. Além desses dois títulos dirigidos por filhas, é a partir de 2010 que também são lançados no Brasil outros documentários nos quais as vozes dos descendentes de militantes estão no centro da rememoração da ditadura: Marighella (Isa Grinspum Ferraz, Brasil, 2011), realizado pela sobrinha do líder guerrilheiro; Repare bem (Maria de Medeiros, Brasil / Portugal / Espanha, 2012), trazendo o depoimento de Eduarda Ditta Crispim Leite, filha de Denise Crispim, detida grávida em 1970 e também entrevistada no filme, com Eduardo Collen Leite, o "Bacuri”, militante assassinado pela ditadura naquele mesmo ano; Em busca de Iara (Flavio Frederico, Brasil, 2013), no qual as indagações e entrevistas são conduzidas por Mariana Pamplona, sobrinha de Iara Iavelberg, assassinada pela ditadura em 1971; Orestes (Rodrigo Siqueira, Brasil, 2015), em que o trauma de Nasaindy Barrett de Araújo, filha de Soledad Barrett 
Viedma, assassinada pela ditadura em 1973, é o eixo de um experimento radical que entrelaça documentário, psicodrama, história, teatro e a violência de Estado de ontem e de hoje; além de Elena (Petra Costa, Brasil, 2012), caso em que a militância e a clandestinidade dos pais da diretora são aludidas de passagem na narrativa, centrada no trauma familiar do suicídio da irmã. ${ }^{39}$

Em um primeiro olhar, esse conjunto de documentários intergeracionais brasileiros posteriores a 2010 pode ser visto como portador de algo novo: enfim, também por aqui, as marcas estilísticas e narrativas da primeira pessoa passam a conduzir de ponta a ponta a rememoração da ditadura através da lente da família. Mas as coisas não são assim tão simples. De saída, porque esse olhar para um período em particular (o pós-2010) e um recorte temático específico (a memória intergeracional da ditadura) tende a superdimensionar o teor de novidade desses títulos. Ora, não é incomum a avaliação de que o cinema brasileiro estaria "atrasado" frente ao de alguns países vizinhos, principalmente em comparação com a produção argentina dedicada aos anos autoritários. Pensar 2010 como um marco do documentário intergeracional subjetivo no Brasil poderia passar a impressão de que este suposto "atraso" se confirmaria. Entretanto, isso significaria ignorar o pujante documentarismo que vinha sendo realizado no país antes de 2010, dedicado a outras temáticas. Para ficar no terreno intergeracional, basta lembrar dos títulos ligados àquilo que Jean-Claude Bernardet (2005) chamou de "documentário de busca": 33 (Kiko Goifman, Brasil, 2003) e Um passaporte húngaro (Sandra Kogut, Brasil / França / Hungria / Bélgica, 2001). Ou, ainda, os documentários de filhos de cineastas realizados ao longo da década de 2000: Rocha que voa (Eryk Rocha, Brasil / Cuba, 2002); Person (Marina Person, Brasil, 2006); e Histórias cruzadas (Alice de Andrade, Brasil, 2008) (cf. MACHADO, P., 2009). Sem esquecer, obviamente, do fenômeno Santiago (João Moreira Salles, Brasil, 2006). Tratase de obras marcadas por uma intimidade reflexiva, em prisma familiar, seguindo uma trilha que oxigenou o panorama do documentário brasileiro no primeiro decênio do novo século.

Ou seja, não é que o documentarismo brasileiro em geral tenha tardado para absorver a poética da subjetividade. Foi o tema da ditadura, stricto sensu, que veio a ser abordado pelo cinema documentário local em chave subjetiva e familiar somente após 2010. Valeria a pena discutir as possíveis razões disso: a já referida hipótese da perda do protagonismo dos familiares de mortos e desaparecidos nas transações da abertura política (TELES, J. A., 2005);

\footnotetext{
${ }^{39}$ Vale dizer que o documentário Uma longa viagem (Lúcia Murat, Brasil, 2011), embora aborde o período ditatorial a partir do prisma familiar, não entrou no corpus da pesquisa por não se inserir no recorte da memória intergeracional. $\mathrm{O}$ foco, nesse filme, são as experiências do irmão da diretora.
} 
a força da memória que monumentaliza a resistência no Brasil, desde a redemocratização, relegando outras versões a um segundo plano (NAPOLITANO, 2015); o fato de por aqui não ter surgido uma organização de filhos análoga às que se formaram nos países vizinhos em meados dos anos 1990. São questões complexas em jogo, as quais ditam uma temporalidade particular ao fenômeno do documentário intergeracional brasileiro sobre a ditadura. E isso não diz respeito propriamente a um "atraso", mas às dinâmicas de memória próprias a cada sociedade.

Em segundo lugar, cabe problematizar a ideia das "fases" por uma questão estilística interna à própria filmografia intergeracional: as marcas da subjetividade convivem nesses títulos com o peso das convenções do documentário de entrevista. Pois vale lembrar que a entrevista nunca desapareceu do documentarismo aqui analisado. $\mathrm{Na}$ verdade, na maioria dos casos, ainda que haja uma forte presença da primeira pessoa em chave reflexiva, os depoimentos (de familiares ou companheiros de militância dos pais) estruturam a narrativa de forma decisiva, com um maior ou menor grau de convencionalismo - o terceiro capítulo se dedicará com mais vagar a essa questão. Mesmo em Los rubios, o gesto de desconstrução estética da fórmula entrevista - ao não se dar muito ouvido às falas dos companheiros dos pais; ao tratar essas vozes reflexivamente no interior do filme, rebobinando e avançando as fitas com seu registro; ao se encenar explicitamente o testemunho pessoal - não passou em branco e suscitou acaloradas polêmicas (KOHAN, 2004a; SARLO, 2007).

Surge aqui outra faceta das cadências temporais da formação desse documentarismo: as simultaneidades estéticas. Mais do que uma "evolução" dividida em "etapas" ou uma passagem do documentário testemunhal (que afirmaria uma grande síntese da memória) para o documentário subjetivo (às voltas com as fugidias lembranças privadas), o que se observa é a convivência nessa cinematografia de traços estilísticos muitas vezes tidos como excludentes: o mosaico de vozes de terceiros e o cineasta enunciando em primeira pessoa; as fórmulas básicas da entrevista e as marcas reflexivas da subjetividade. Diante disso, talvez seja melhor pensar em termos de concomitância ou, em muitos casos, de entrelaçamento de modos documentais e matrizes de rememoração díspares. As reflexões de Raymond Williams (2005) sobre a cultura podem ser operacionais nesse sentido, desdobradas neste debate específico a fim de jogar luz sobre a dinâmica entre aquelas que podem ser consideradas formas dominantes (as convenções do documentário de entrevista, cada vez mais travestidas com os signos da indagação subjetiva; as matrizes da memória da vitimização e da heroicização); formas residuais (o documentário clássico em suas roupagens contemporâneas, atualizando as grandes sínteses assertivas da memória) (RAMOS, 2008, p. 24 e 41); e formas emergentes (o 
“documentário de busca" subjetivo e reflexivo; a memória pelo viés familiar) (BERNARDET, 2005).

O caso de Marighella, de Isa Grinspum Ferraz, é eloquente quanto a essa convivência nem sempre harmônica entre estilos de documentário e matrizes de rememoração. Nesse filme, o mosaico de entrevistas (de ex-companheiros, do filho, de historiadores, antropólogos etc.) estrutura a construção de uma memória épica do líder guerrilheiro, com as falas devidamente ilustradas por uma profusão de imagens de arquivo e do cinema fíccional. Porém, mesmo com essa organização geral da biografia do herói na chave do documentário convencional de entrevista, a narrativa é pontuada por vinhetas nas quais a diretora, com voz over em primeira pessoa, vasculha suas próprias reminiscências infantis à procura de algo que a ajude a compreender a figura do "tio Carlos". Fotografias de família e tomadas que emulam a textura do super-8, além de uma trilha melodiosa, acompanham essas falas de tom íntimo. Nesse exemplo, é patente que o relato está estruturado do início ao fim pelos depoimentos de terceiros, sejam eles testemunhas ou especialistas, reiterando de modo concatenado as linhas mestras da monumentalização da resistência. Mas o filme busca uma roupagem contemporânea, um toque afinado com a forma emergente do documentário subjetivo que entrecruza recordações familiares e eventos históricos (SELIPRANDY, 2016). ${ }^{40}$

Tais descompassos e concomitâncias levam à conclusão de que o documentário intergeracional sobre as ditaduras do Cone Sul não pode ser considerado como “inerentemente" subjetivo e reflexivo. ${ }^{41}$ Tampouco haveria uma "evolução" progressiva dessa

\footnotetext{
${ }^{40}$ Sobre Marighella, cf. também FEITOSA, 2013; MAIA, $2015 \mathrm{~b}$.

${ }^{41}$ Nesse sentido, $O$ dia que durou 21 anos (Camilo Tavares, Brasil, 2012) é um contraexemplo que vale a menção. Seu diretor é filho de Flávio Tavares, um dos militantes de esquerda libertados em troca do embaixador estadunidense Charles Elbrick em 1969. No entanto, formalmente, esse título apaga qualquer traço visível da subjetividade do filho, a narrativa passa ao largo dos dilemas da intimidade, sua abordagem da história prescinde da família como ponto de partida. O filme tem outra proposta, situada no extremo oposto daquela que em geral se atribui ao documentarismo intergeracional. Trata-se ali muito mais de atestar, pela revelação de documentos e a palavra de especialistas, a ação conspiratória dos EUA em prol do golpe de 1964 no Brasil. O tom do documentário é o do jornalismo investigativo, apresentando os resultados de um trabalho feito a quatro mãos: na produção, estiveram lado a lado pai e filho, o jornalista experiente, autor de crônicas e testemunhos sobre o período (TAVARES, F., 1999), e o documentarista estreante em longas-metragens. Outro exemplo análogo, embora menos radical, é La ciudad de los fotógrafos (Sebastián Moreno, Chile, 2006). Nesse caso, o pai do realizador foi integrante da agremiação retratada no filme, a Asociación de Fotógrafos Independientes (AFI). Contudo, as alusões a essa implicação familiar do diretor na história contada, feitas por meio da voz over em primeira pessoa, da presença de José Moreno (seu pai) na tela e das inserções de fotografias de infância, concentram-se na abertura e no desfecho do documentário, compondo uma moldura subjetiva muito tênue ainda mais frágil do que as digressões introspectivas da sobrinha que pontuam Marighella. No correr do relato de La ciudad de los fotógrafos, as entradas esparsas da voz over de Sebastián Moreno vão assumindo uma função informativa acessória, subordinada ao fluxo do coral de entrevistas com os protagonistas e das inserções de imagens de época. O foco narrativo não é sequer a trajetória do parente do cineasta, mas sim a atuação coletiva dos membros da AFI na resistência à ditadura Pinochet (cf. BARROSO, 2015, p. 28-30). Nos exemplos citados nesta nota, mesmo que ambos sejam documentários dirigidos por filhos de opositores, os nexos
} 
filmografia nesse sentido, levando a uma "inevitável" superação das grandes matrizes da memória das ditaduras. Variações desse tipo de determinismo não são incomuns na bibliografia específica, ainda que com expressões mais amenas. Uma visão essencialista sobre o que seja o documentário contemporâneo não ajuda em nada na compreensão das dinâmicas estéticas e mnemônicas em ação nesse campo. Se é fato que muitos dos títulos do início do recorte temporal pendem mais para a forma da entrevista convencional calcada no testemunho assertivo, desde 15 filhos, no Brasil, até o conjunto de títulos ligados à agenda militante das organizações de hijos dos países vizinhos (ROS, 2012, p. 30), isso não significa, em primeiro lugar, que essas obras reiterem, em bloco, os velhos padrões de rememoração. Em segundo lugar, pressupor a "superação" dos modos assertivos pela poética titubeante significaria ignorar a continuidade do peso dos esquemas consagrados do documentário (a entrevista) e da memória social (o heroísmo, a vitimização) mesmo em obras de verniz subjetivo e hesitante lançadas nos últimos anos. Emergentes ou dominantes, as formas cinematográficas e as versões do passado seguem convivendo e se cruzando em ritmos e equilíbrios variados ao longo do tempo, em uma correlação que depende simultaneamente das dinâmicas coletivas de rememoração e das escolhas estilísticas individuais de cada realizador.

O inverso também é verdadeiro. Se ainda hoje a forma do documentário de entrevista possui certa dominância, o documentário em que o "eu" é um lugar de enunciação problemática já emerge nos primórdios dessa filmografia. A ideia das "etapas" do documentário intergeracional se fragiliza ainda outra vez quando se retorna no tempo e se olha com atenção para os títulos lançados no início do recorte temporal do corpus. Depois de 1996, ano de produção dos pioneiros 15 filhos e Los Argenmex 20 años después: la historia ésta, em 1997 surge Pasaportes (Inés Ulanovsky, Argentina, 1997), outro curta-metragem que traz testemunhos de jovens que passaram a infância no exílio; e Hasta la memoria siempre (Rodrigo Vázquez, Argentina, 1997), também um curta-metragem, o qual segue a militância de Lucía García na agrupação H.I.J.O.S. Em 1998, H.I.J.O.S. de la historia (Roberto Leonardo, Argentina, 1998), mais um curta-metragem, também aborda a militância na organização de filhos. Nesses primeiros anos, o fenômeno do documentário intergeracional era incipiente, composto por alguns poucos curtas-metragens, com predominância das produções da Argentina, além de uma série de televisão que somente depois ganharia uma versão em média-metragem. Outros títulos surgiriam apenas em 2000, todos com origem argentina, confirmando essa concentração inicial da produção naquele país. O longa- 
metragem (h) Historias cotidianas (Andrés Habegger, Argentina, 2000) reúne as vozes de seis filhos de desaparecidos argentinos. Das seis testemunhas, nenhuma é o próprio Habegger, também ele filho de pai desaparecido, tendo passado a infância no exílio. No lugar de um relato em primeira pessoa, a montagem do filme constrói um panorama coletivo das experiências compartilhadas dos filhos. Uma memória da nova geração, veiculada em uma linguagem marcada pelas convenções do documentário de entrevista. Panzas (Laura Bondarevsky, Argentina, 2000) é um média-metragem igualmente calcado em entrevistas com filhos, nesse caso todos militantes de H.I.J.O.S., assim como a diretora Laura Bondarevsky, nascida no exílio. De modo análogo ao que se vê (h) Historias cotidianas, mesmo que a cineasta compartilhe uma história com seus entrevistados, também em Panzas prevalece uma voz testemunhal coletiva. Naquele ano surgia ainda o curta-metragem H.I.J.O.S. (Francisco Zinzer, Argentina, 2000). Todos esses títulos podem ser lidos na chave do documentário de entrevista, em que o sujeito que diz "eu" é o outro do testemunho, com os diretores preferindo montar um mosaico de vozes em terceira pessoa, inclusive quando tiveram suas próprias vidas diretamente afetadas pela violência de Estado (AMADO, 2003, p. 145; ESTEVE, 2009, p. 342-373).

Mas no ano de 2000 observa-se também a produção de títulos nos quais a primeira pessoa das diretoras está no centro da rememoração intergeracional, sendo o lugar desde onde emanam as indagações. Na verdade, o curta-metragem En memoria de los pájaros (Gabriela Golder, França / Argentina, 2000) tende mais para o vídeo experimental, com um dispositivo em que a tela está sempre dividida em duas janelas, exibindo paralelamente imagens públicas e privadas de distintas bitolas e origens. Não há ali uma linearidade narrativa, mas planos paralelos, textos e vozes que evocam a memória dos desaparecidos. ${ }^{42} \mathrm{O}$ média-metragem Papá Iván (María Inés Roqué, México / Argentina, 2000), por seu turno, naquele momento já continha os traços mais característicos do documentário subjetivo: as hesitações de uma busca em primeira pessoa; a leitura da carta deixada pelo pai; a revisão de álbuns de família; planos de viagens em travelling; além das entrevistas com familiares e ex-companheiros de militância de Juan Julio Roqué, codinome "Iván”. A diretora, que ainda criança partiu com a família para o exílio no México após o assassinato do pai, dirigente montonero, realiza o filme como trabalho de conclusão de curso no Centro de Capacitación Cinematográfica (CCC) daquele país, onde se radicou. Logo em 2000, o título foi exibido em festivais em Buenos Aires (no Festival Internacional de Escuelas de Cine, no final de julho; e no III Festival

\footnotetext{
${ }^{42}$ Para uma análise de En memoria de los pájaros, cf. ESTEVE, 2009, p. 311-317.
} 
Internacional de Cine y Video sobre Desarrollo Humano, entre novembro e dezembro). Papá Iván não tardou a chamar a atenção da crítica acadêmica e, desde cedo, artigos se debruçaram sobre este documentário no contexto do debate sobre a emergência das vozes dos filhos de desaparecidos na Argentina (AMADO, 2003). Ao longo dos anos, o filme de María Inés Roqué se tornaria uma espécie de referência básica na abordagem desse documentarismo de segunda geração, em geral ao lado de Los rubios (Albertina Carri, Argentina, 2003) e $M$ (Nicolás Prividera, Argentina, 2007) (AMADO, 2009; AON, 2011; ESTEVE, 2009; ORTEGA, 2010; ROS, 2012; VERZERO, 2009). Quanto a isso, vale registrar que Papá Iván só teve estreia comercial em Buenos Aires no fim de julho de 2004, após toda a repercussão em torno de Los rubios, algo que suscitou uma intertextualidade que já se manifesta em algumas das matérias de imprensa que apresentam o documentário de Roqué (BERNADES, 2004; LERER, 2004). De fato, esse olhar cruzado não deixou de ter reverberações ao longo do tempo. Nesse sentido, é curioso como em algumas análises acadêmicas, em uma releitura $a$ posteriori feita à luz da radicalidade reflexiva de Los rubios, Papá Iván acaba sendo enquadrado em uma modalidade mais convencional do documentário, lado a lado com $(h)$ Historias cotidianas (BERGER, 2008; LAZZARA, 2009, p. 157; ROS, 2012, p. 45).

De todo modo, antes dessa "interferência" dos títulos lançados posteriormente, em um dos primeiros artigos acadêmicos dedicados ao documentarismo intergeracional na Argentina, Ana Amado (2003, p. 145-146, tradução nossa) distinguia o modo como, em (h) Historias cotidianas, Andrés Habegger "elude a primeira pessoa e legitima sua própria perspectiva através de outras vozes, como se houvesse uma dificuldade em falar em nome próprio acerca do desaparecimento", de um lado, e, de outro, em Papá Iván, a forma como María Inés Roqué lança mão de "estratégias com as quais organiza uma narrativa pessoal sobre a história, ou sobre aquela porção da história que a envolve em suas consequências pessoais". Os dois títulos, produzidos no mesmo ano de 2000, vinculam-se a modalidades estilísticas diferentes do documentário: o coral de vozes que serve para que o filho-diretor construa uma narrativa geracional em terceira pessoa; a subjetividade explicitada pela filha-diretora, que ouve as testemunhas da geração anterior, mas coloca sua própria voz em primeiro plano em um relato francamente pessoal.

Essa simultaneidade formal, identificada em uma análise em paralelo dos títulos surgidos em 2000, desnuda os limites da leitura evolutiva da formação do documentário intergeracional. Torna-se problemático concluir, como o faz Verena Berger (2008, p. 34, tradução nossa), levando em conta os títulos surgidos até o momento da escrita do artigo, que se registra "um desenvolvimento contínuo do gênero, que abarca desde documentários 
convencionais até filmes docuficcionalizados, bem como um constante aprofundamento do enfoque do tema da memória"; ou que "está se formando um corpus de cinema de filhos de desaparecidos que vai evoluindo do mero intento documental autobiográfico, testemunhal e político (Roqué, Habegger) para formas mais sutis e menos classificáveis no que diz respeito a gênero (Carri) ou conteúdo (Prividera)."

Ana Ros (2012, p. 36, tradução nossa) segue uma lógica semelhante ao considerar que os "documentários pioneiros" ligados à agrupação H.I.J.O.S., entre eles (h) Historias cotidianas, "autorizaram uma nova voz geracional", tornando "possível para outros filhos e filhas consolidarem sua presença no subgênero do cinema sobre a ditadura". Esse conjunto de filmes "pioneiros", talvez por conta de sua forma mais convencional, são vistos pela autora como um primeiro passo, algo que abre caminho para uma nova fase do documentarismo intergeracional, na qual se destacariam Los rubios, Papá Iván e $M$. Estes três filmes, segundo Ros (2012, p. 36, tradução nossa), "podem ser vistos como o próximo passo no lento desdobramento de práticas de memória mais inclusivas", desafiando narrativas consolidadas, abordando silêncios e tabus. Acontece que essa leitura evolutiva tropeça em uma confusão cronológica, uma vez que Ana Ros só leva em conta o ano da estreia comercial de Papá Iván, 2004, ignorando seu ano de produção, 2000. Tal diferença de datas induz a autora a incluir o documentário de María Inés Roqué no que considera o passo seguinte das práticas de memória intergeracional, entre Los rubios, de 2003, e M, de 2007.

$\mathrm{Na}$ contracorrente, Lorena Verzero (2009, p. 214-215, tradução nossa) enxerga a diversidade no documentarismo contemporâneo argentino sobre a ditadura por outro prisma, não o progressivo, mas o da "abertura de um espaço de diálogo com o passado e com as distintas perspectivas políticas do presente". A autora prossegue: "Em alguns casos, a primeira pessoa assume a narração colocando-se em primeiro plano (Los rubios, Papá Iván ou $M)$; em outros, se oculta, mas se deixa ver ((h) Historias cotidianas) [...]." E conclui afirmando que as "diferentes manifestações do sujeito da narração refletem a problemática das relações entre o privado e o público", compondo uma "ampla gama de modos de representação do tecido social".

A identificação das modalidades estilísticas variadas que já se manifestavam no documentarismo intergeracional lá em 2000 está aqui a serviço de uma abordagem menos esquemática das cadências da constituição dessa filmografia. Trata-se de enxergar, na diacronia e na sincronia, as formas cinematográficas em jogo: a primazia da entrevista com as convencionais "cabeças falantes"; o vídeo experimental com um dispositivo disjuntivo; o documentário em primeira pessoa em seus traços mais salientes. Porém, a ressalva à leitura 
evolutiva não se dá em nome de uma "complexidade indiferente" (WILLIAMS, 2005, p. 218). Ainda é fundamental qualificar essa temporalidade, refletir sobre as tensões e, ponto nevrálgico na formação dessa cinematografia, os processos de legitimação que se desdobram ao longo dos anos. Porque, isto sim, a consagração de uma dessas vertentes do documentarismo intergeracional no circuito de festivais é uma tendência consistente desde as origens dessa filmografia.

A carreira de Papá Iván nos festivais já sinalizava esse processo. Em setembro de 2000, o média-metragem de María Inés Roqué recebia uma menção honrosa no festival Contra el Silencio, Todas las Voces, no México. No mês de dezembro do mesmo ano, a consagração viria com o Primeiro Prêmio Coral na categoria documentário no Festival Internacional del Nuevo Cine Latinoamericano em Havana, Cuba. É curioso que o documentário de Andrés Habegger, (h) Historias cotidianas, tenha sido exibido nesta mesma edição do festival cubano que laureou Papá Iván, mas em uma mostra paralela. Papá Iván seria ainda premiado em 2001, recebendo uma menção especial na Muestra Internacional de Cortometraje de Monterrey; o prêmio de melhor documentário no Festival Expresión en Corto, em Guanajuato, ambos no México; e uma menção na categoria documentário de média-metragem no Festival Cinematográfico Internacional del Uruguay. Em 2002, o filme ainda teve fôlego para conquistar o segundo prêmio na competição internacional de documentários do Festival Internazionale di Cinema delle Donne di Torino, na Itália.

Nenhum dos outros títulos produzidos em 2000 teve êxito nessa medida nos festivais. O vídeo experimental En memoria de los pájaros, naquele mesmo ano, conquistaria o grande prêmio do Festival Vidéoformes, em Clermont-Ferrand; o prêmio Euroregião no Festival du Film Transfrontalier Estavar-Llivia, ambos na França; além de um prêmio no Tokyo Video Festival, já em 2002. Panzas, por sua vez, receberia uma menção especial no Festival Internacional de Cine de Derechos Humanos (DerHumALC), em Buenos Aires, ainda em 2000 .

Essa tendência de os festivais privilegiarem os documentários intergeracionais de corte mais subjetivo foi se confirmando ao longo dos anos. É verdade que, em 2002, o mesmo Festival Internacional del Nuevo Cine Latinoamericano em Havana que premiara Papá Iván concedeu uma menção especial na categoria documentário a H.I.J.O.S.: El alma en dos (Carmen Guarini e Marcelo Céspedes, Argentina, 2002), cujo formato se enquadra nas convenções básicas do coral de entrevistas, dando voz aos filhos militantes da organização que intitula o filme. Mas o sucesso de Los rubios no Buenos Aires Festival Internacional de Cine Independiente (Bafici) de 2003 parece ter feito a balança da chancela dos festivais 
pender de modo decisivo para o lado da subjetividade reflexiva. Ali, em um dos mais influentes eventos desse tipo da América Latina (GUTIÉRREZ, C. A.; WAGENBERG, 2013, p. 299-300), a obra de Albertina Carri ganhou o prêmio de melhor filme da competição "Cine argentino: lo nuevo de lo nuevo"; uma menção especial do júri oficial; além do prêmio do público de melhor filme e uma menção especial do júri Signis. Em 2004, agora no contexto espanhol, Los rubios ainda conquistaria os prêmios de melhor filme no L'Alternativa: Festival de Cinema Independent de Barcelona e de melhor novo diretor no Festival Internacional de Cine Las Palmas de Gran Canaria.

É significativo que, no mesmo Bafici de 2003 em que Los rubios foi premiado nas principais seções competitivas, Che vo cachai (Laura Bondarevsky, Argentina, 2002) e Organizaciones horizontales (Fausta Quattrini, Argentina, 2002) eram exibidos na mostra "Huellas de lo real", dedicada exclusivamente ao documentário. No filme de Bondarevsky, como já ficou mencionado, a filha-diretora nascida no exílio retrai sua subjetividade para construir uma voz coletiva geracional dos militantes das organizações de hijos de Argentina, Uruguai e Chile. Já Quattrini é uma cineasta de origem suíça que se aproximou da organização H.I.J.O.S. e fez um documentário focado nos sentidos dos “escrachos". Nota-se que, antes mesmo dos prêmios, a própria hierarquia das seções para as quais os títulos são selecionados já dá indícios das preferências do circuito de festivais.

Che vo cachai chegou a ser lareado em outros contextos, recebendo o prêmio da crítica e do público no Festival Filmar en América Latina de 2003, em Genebra, Suíça; uma menção honrosa no festival mexicano Contra el Silencio, Todas las Voces de 2004, onde Papá Iván já fora premiado em 2000; além de outro prêmio do público em um festival de cinema jovem de Berlim.

Em todo caso, com sua pregnância reflexiva, Los rubios é tido por muitos autores como um marco do documentarismo intergeracional no Cone Sul, leitura que muitas vezes acaba resultando na projeção de sua radicalidade em um paradigma que definiria em bloco essa produção. Extrapolações à parte, fato é que ele não estava só nesse processo de chancela do tom subjetivo no contexto dos festivais. No mesmo ano de 2003, En algún lugar del cielo (Alejandra Carmona, Chile, 2003) conquistava o Grande Prêmio no Festival Internacional de Documentales de Santiago (Fidocs). Com uma subjetividade mais linear, menos disjuntiva em comparação com Los rubios, o média-metragem se aproximava estilisticamente de Papá Iván na narrativa do exílio da diretora com a mãe na República Democrática Alemã (RDA), 
enquanto seu pai ficara no Chile engajado na luta clandestina do Movimiento de Izquierda Revolucionaria (MIR), até seu assassinato pelo regime. ${ }^{43}$

Também em 2003, foi produzido Los huérfanos del Cóndor (Emilio Pacull, França / Uruguai, 2003), média-metragem que estilisticamente está entre o documentário clássico e as convenções da entrevista. Nele o experiente diretor franco-chileno conta a história da recuperação da identidade de filhos sequestrados pela ditadura argentina e abandonados pelos militares no Chile. Los huérfanos del Cóndor chegou a circular pelo Fidocs de 2004, em Santiago, e pelo Festival Internacional de Cine de Derechos Humanos (DerHumALC) de 2005, em Buenos Aires, sem haver conquistado prêmios. Seja como for, este título e En algún lugar del cielo colocavam o Uruguai e o Chile no mapa da produção de documentários intergeracionais sobre as ditaduras do Cone Sul, embora o peso da Argentina nessa cinematografia ainda fosse inequivocamente preponderante.

Isso se confirma na produção de 2004, com El tiempo y la sangre (Alejandra Almirón, Argentina, 2004), filme que, com toques de experimentalismo, acompanha a viagem de retorno de uma ex-militante montonera à região onde atuou no passado, defrontando-se com os questionamentos da geração dos filhos; Encontrando a Víctor (Natalia Bruschtein, México / Argentina, 2004), média-metragem em coprodução com o México, país do exílio familiar da filha-diretora, registrando seu retorno à Argentina natal em busca de reminiscências do pai desaparecido; ${ }^{44}$ e Nietos (identidad y memoria) (Benjamín Ávila, Argentina, 2004), em que o filho-diretor adota um olhar institucional ao dar voz aos filhos de desaparecidos que tiveram suas identidades recuperadas pela atuação da Asociación Abuelas de la Plaza de Mayo (ESTEVE, 2009, p. 374-386). Os primeiros dois títulos chegaram a circular por festivais internacionais, incluindo alguns de certo prestígio, sem, contudo, conquistarem prêmios. Nietos (identidade y memoria), por sua vez, com seu estilo mais convencional, conquistou o Terceiro Prêmio Coral na categoria documentário no Festival Internacional del Nuevo Cine Latinoamericano em Havana de 2004; além de outros prêmios em festivais da Argentina, Itália e Espanha.

Isso que se observa quanto aos lançamentos de 2004 poderia sugerir certa fragilidade da hipótese da legitimação no circuito de festivais da vertente mais subjetiva do documentarismo intergeracional. Mas o que ocorre nos anos seguintes reforça essa ideia. Não especialmente em 2005, ano de redução da marcha dessa filmografia. Apenas um título é

\footnotetext{
${ }^{43}$ Sobre En algún lugar del cielo, cf. BARRENHA, 2013a; BOSSY; VERGARA, 2010; JOHANSSON; VERGARA, 2014.

${ }^{44}$ Sobre El tiempo y la sangre e Encontrando a Víctor, cf. AMADO, 2009, p. 197-201; ESTEVE, 2009, p. 326333 e 409-418; ROS, 2012, p. 64-72.
} 
lançado, confirmando a preponderância argentina no terreno da produção. Trata-se de Hermanos de sangre (Fabián Vittola, Argentina, 2005), outro média-metragem que segue os códigos do documentário de entrevista para contar a história de apropriação de Martín Ogando Montesano, filho que iria ter sua identidade restituída dez anos depois da realização do filme. Alguns títulos lançados nos anos anteriores seguiam circulando em 2005, mas este é um ano no qual, salvo engano, não houve prêmios em festivais para os documentários do corpus.

A calmaria de 2005 precede o recorde de produções de 2006, quando se assiste ao surgimento de sete títulos, marca anual que só seria igualada dez anos depois, em 2016. Refluxos, picos, as cadências da formação dessa cinematografia vão se descortinando pela abordagem diacrônica. Vale lembrar que em 2006 o golpe argentino completava trinta anos, e aniversários desse tipo sempre têm um papel nas dinâmicas da produção memorialística. Desse ano, são produzidos na Argentina Nacimos en su lucha, viven en la nuestra: 10 años de H.I.J.O.S. La Plata (Camilo Cagni, Pablo Balut, Pablo Roesler e Juan Aíub, Argentina, 2006), média-metragem que reconstitui a história da organização de filhos de La Plata quando esta completava dez anos, junto com os trinta anos do golpe; Mansión Seré (Jorge Bianchini, Argentina, 2006), longa-metragem que acompanha as indagações da filha de um militante torturado no centro de clandestino que intitula o filme; e Diario argentino (Lupe Pérez García, Argentina / Espanha, 2006), no qual a diretora faz uma viagem de retorno à Argentina, de onde emigrara para a Espanha após a crise econômica de 2001, e coloca a geração precedente diante das consequências de suas escolhas políticas do passado. ${ }^{45}$

Mas a produção de 2006 não se concentra toda na Argentina. De fato, a partir desse ano, observa-se uma presença mais consistente de outros países do Cone Sul no documentarismo intergeracional. Do Uruguai, vem HIJOS Uruguay (Lucas Silva e Víctor Burgos Barreiro, Uruguai, 2006), curta-metragem com depoimentos de filhos militantes desta organização, junto com tomadas de protestos de rua por verdade e justiça. No Chile, surge Reinalda del Carmen, mi mamá y yo (Lorena Giachino Torréns, Chile, 2006), no qual a diretora acompanha a própria mãe na tentativa de resgatar a memória de sua melhor amiga, desaparecida grávida pela ditadura de Pinochet em $1976 .{ }^{46}$ De 2006, há ainda dois casos de títulos que não têm países do Cone Sul como coprodutores, mas cujas histórias narradas se deram no contexto das ditaduras da região. Trata-se de Semillas de utopía (Rodolfo Colombara e Emanuela Peyretti, Itália, 2006), longa-metragem fundado em entrevistas que, a

\footnotetext{
${ }^{45}$ Sobre Diario argentino, cf. ESTEVE, 2009, p. 334-341; PIEDRAS, 2014; ROS, 2012, p. 86-91.

${ }^{46}$ Sobre Reinalda del Carmen, mi mamá y yo, cf. BOSSY; VERGARA, 2010; ROS, 2012, p. 144-154.
} 
partir da história de uma filha de desaparecido da ditadura argentina, aborda a luta dos movimentos por direitos humanos no país platino. E El telón de azúcar (Camila Guzmán Urzúa, França / Cuba / Espanha, 2006), título que, dentre os lançamentos de 2006, tem a carreira mais substantiva no circuito de festivais. A diretora é filha do célebre cineasta chileno Patricio Guzmán. Nessa coprodução, Camila Guzmán Urzúa realiza uma viagem de retorno a Cuba, tempos depois de ter deixado a ilha onde passara sua infância no exílio. A conjuntura com a qual ela se depara no presente é contraposta a suas memórias dos anos 1970 e 1980, quando a revolução teria vivido seus "anos dourados". Com sua câmera em punho, a diretora visita a escola onde estudou, entrevista antigos colegas de turma, sua mãe, refletindo sobre as condições do país que agora reencontra.

El telón de azúcar foi laureado em prestigiosos festivais pelo mundo. Em março de 2007, o documentário recebeu o prêmio Louis Marcorelles no festival Cinéma du Réel, em Paris, o prêmio Signis na categoria documentário no Cinélatino: Rencontres de Toulouse, ambos na França, e, ainda, uma menção especial no Festival del Cinema Africano, d'Asia e America Latina, em Milão, na Itália; em abril do mesmo ano, o título conquistava o prêmio da Federação Internacional de Críticos de Cinema (Fipresci) no Bafici, em Buenos Aires; em agosto, era a vez de o Festival de Cine de Lima: Encuentro Latinoamericano de Cine, no Peru, conferir ao filme de Camila Guzmán Urzúa o Segundo Prêmio do Júri para o documentário; no mesmo mês, o título conquistaria os prêmios de melhor diretor e Signis na competição internacional do Festival Internacional de Cine de Santiago (Sanfic), no Chile; e também os prêmios L'Île d'Or e do público no Festival International du Film Insulaire, em Île de Groix, França; em setembro, o filme chegou a ser reconhecido em um festival da Nova Caledônia, na Melanésia, recebendo o prêmio Ânûû-rû âboro do Festival du cinéma des peuples; em dezembro, coroando essa carreira nos festivais de 2007, El telón de azúcar foi consagrado com o Primeiro Prêmio Coral para o documentário no Festival Internacional del Nuevo Cine Latinoamericano de Havana.

Até aquele momento, nenhum título do corpus havia recebido tantos prêmios em tantos festivais, incluindo alguns dos mais relevantes no campo do cinema latino-americano ou documental. Não seria descabido supor que o fato de a realizadora ser filha do célebre Patricio Guzmán tenha atraído mais atenção para El telón de azúcar. Seja como for, este não é um caso isolado, há aí uma coerência com a chancela dada pelos festivais à modalidade subjetiva e reflexiva do documentário. A profusão de prêmios conferidos a esse título consagra uma obra marcadamente em primeira pessoa, na qual a voz em over da filha-diretora 
diz "eu" e já a câmera, sempre na mão da própria realizadora, convoca o espectador para o ponto de vista subjetivo daquela que rememora (fig. 30).

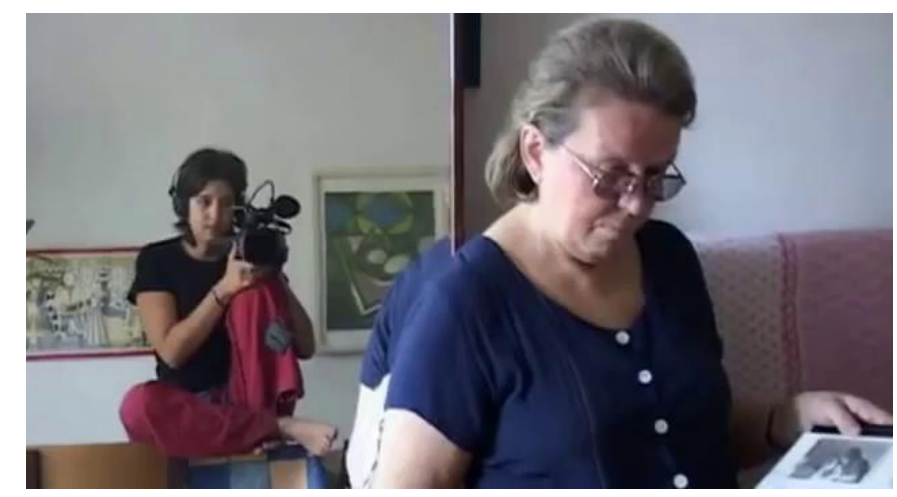

Figura 30 - A realizadora entrevista a mãe com câmera na mão diante do espelho: subjetividade e reflexividade. Fonte: El telón de azúcar (Camila Guzmán Urzúa, 2006).

O ano de 2007 foi também pródigo em novas produções, repetindo a tendência do ano anterior. Nele surgiram seis títulos, em uma balança geográfica que aos poucos começava a se equilibrar. Três tinham origem argentina: Argenmex: exiliados hijos (Violeta Burkart Noë e Analía Miller, Argentina, 2007), média-metragem que entrevista e reúne em um jantar filhas e filhos de militantes argentinos exilados no México, incluindo uma das diretoras, Violeta Burkart Noë, com todos compartilhando suas experiências de vida; ¿Quién soy yo? Los niños encontrados de Argentina (Estela Bravo, Argentina / EUA / Reino Unido, 2007), longametragem que segue o modelo das "cabeças falantes", justapondo depoimentos de filhos cujas identidades foram recuperadas e imagens de arquivo; e $M$ (Nicolás Prividera, Argentina, 2007), já aludido acima, este na chave do "documentário de busca", com o diretor levando adiante em primeira pessoa suas investigações sobre o desaparecimento da mãe. Dois títulos são de origem chilena: Héroes frágiles (Emilio Pacull, Chile / França, 2007), no qual o realizador parte do suicídio do padrasto no calor do golpe de 1973 - ele era colaborador próximo de Salvador Allende -, refletindo sobre os impactos da ditadura no Chile contemporâneo; e La promesa de mi madre (Marianne Hougen-Moraga, Dinamarca / Chile / Reino Unido, 2007), documentário de 36 minutos em que a diretora indaga a mãe sobre o périplo empreendido por ela para recuperar os restos mortais da irmã exilada. ${ }^{47}$ De origem uruguaia, mas também em coprodução, surgia naquele ano Secretos de lucha (Maiana Bidegain, Uruguai / França, 2007), longa-metragem no qual a filha-diretora acompanha o pai

\footnotetext{
${ }^{47}$ Sobre Héroes frágiles e La promesa de mi madre, cf. BOSSY; VERGARA, 2010.
} 
em uma viagem de retorno ao Uruguai, após anos de ausência motivada pelo exílio no País Basco. $^{48}$

Desses títulos produzidos em 2007, $M$ sem dúvida foi o que mais se destacou nos festivais. Naquele mesmo ano, a obra de Nicolás Prividera recebeu os prêmios de melhor filme da competição latino-americana e Fipresci no Festival Internacional de Cine de Mar del Plata, na Argentina; uma menção especial no Festival Internacional de Cine de Santiago (Sanfic), no Chile; um segundo prêmio no Yamagata International Documentary Film Festival, no Japão; uma menção especial do júri no Festival Internacional de Cine de Gijón, na Espanha; além de, já em 2008, o prêmio de melhor documentário da Mostra de Cinema Llatinoamericá de Catalunya, também na Espanha. Com efeito, em outro âmbito, o acadêmico, $M$ se tornaria uma referência dessa cinematografia, sempre lembrado quando o assunto é o documentário realizado por filhos de militantes vítimas das ditaduras.

Secretos de lucha conquistou um número menor de prêmios quando comparado a $M$, mas a relevância de alguns deles merece menção. A coprodução de Maiana Bidegain ganhou o prêmio de melhor documentário no Festival de Biarritz: Cinémas et Cultures d'Amérique Latine, na França; além de outro prêmio neste país, no Festival International du Film d'Histoire de Pessac; e ainda mais um, em 2008, na Austrália, no Sydney Latin American Film Festival.

Vale ademais prestar atenção nos prêmios recebidos por ¿Quién soy yo? Los niños encontrados de Argentina no Festival Internacional del Nuevo Cine Latinoamericano de Havana de 2007. Ali, na mesma edição em que o subjetivo El telón de azúcar conquistava o principal prêmio na categoria documentário, o mosaico convencional de entrevistas de Estela Bravo, realizadora estadunidense radicada em Cuba, ganhava alguns prêmios secundários: Prêmio Coral de Documentário de um Realizador não Latino-Americano sobre a América Latina; Prêmio Documentário Memória; Prêmio do Cibervoto ao documentário; Prêmio do Canal Telesur. Quatro prêmios no total, mas quase todos colaterais. A hierarquização dos estilos se revela também aí.

O volume de produções de 2008 confirma a dinâmica de fluxos e refluxos na formação do documentarismo intergeracional. Só dois títulos surgiram nesse ano, após os números de lançamentos acima da média de 2006 e 2007. São eles D.F. (destino final) (Mateo Gutiérrez, Uruguai, 2008), longa-metragem que traz um coral de entrevistas com o qual o filho-diretor reconstitui a história de vida e as circunstâncias do assassinato do pai, um proeminente

\footnotetext{
${ }^{48}$ Sobre Secretos de lucha, cf. FUICA, 2014.
} 
político uruguaio, durante o exílio da família na vizinha Argentina; e Victoria (Adrián Jaime, Argentina, 2008), documentário observacional que segue de perto os passos de Victoria Donda Pérez, nascida na Escuela de Mecánica de la Armada (Esma) em 1977 e apropriada por um militar, em sua descoberta da verdadeira família e seu ativismo no presente. ${ }^{49}$ São dois títulos de 2008, um seguindo as convenções do documentário de entrevista, outro se aproximando do documentário direto. Eis dois exemplos que reforçam a ideia de que a tendência dessa cinematografia em direção ao tom subjetivo e reflexivo não é inexorável. Significativamente, esses filmes circularam por festivais da América Latina e da Europa sem terem conquistado prêmios.

O ano de 2009 teve três lançamentos, todos de origem chilena, sendo duas coproduções: Mi vida con Carlos (Germán Berger-Hertz, Chile / Espanha, 2009) e La quemadura (René Ballesteros, Chile / França, 2009), um longa e um média-metragem configurados de acordo com os recursos básicos do documentário subjetivo às voltas com uma busca ao mesmo tempo familiar e histórica. Como já foi mencionado, no primeiro, o filho-diretor viaja e conversa com parentes na reconstrução da memória de seu pai desaparecido. No segundo, o enigma é a ausência da mãe do realizador, alguém que trabalhava em uma editora ligada à Unidade Popular e, sem que os filhos saibam o porquê, abandonou a família e vive há anos fora do país. ${ }^{50} \mathrm{O}$ terceiro título daquele ano é El memorial (Andrés Brignardello Valdivia, Chile, 2009), este de estilo mais convencional, trazendo entrevistas de filhos dos presos e desaparecidos políticos homenageados no memorial de Valparaíso.

El memorial chegou a ser premiado no Festival de Cine Social y de Derechos Humanos de Valparaíso de 2009. Mas isso é bem pouco se comparado ao êxito alcançado pelos outros dois títulos de 2009, ambos de corte subjetivo. Mi vida con Carlos recebeu o principal prêmio na categoria documentário do Festival de Biarritz: Cinémas et Cultures d'Amérique Latine de 2009, repetindo o feito de Secretos de lucha na edição de 2007 e adiantando o que aconteceria no ano seguinte com Diário de uma busca, que recebera o mesmo prêmio em 2010. Como ficou descrito acima, surgidos em 2009, os filmes de Germán Berger-Hertz e René Ballesteros tiveram também seu quinhão no recorde de prêmios conferidos aos títulos do corpus naquele ano de 2010. De fato, esse olhar retrospectivo para as

\footnotetext{
${ }^{49}$ Sobre D.F. (destino final), cf. FUICA, 2014; ROS, 2012, p. 181-190; RUFFINELLI, 2013, p. 64-65. Sobre Victoria, cf. APREA, 2015, p. 252-261.

${ }^{50}$ Sobre Mi vida con Carlos e La quemadura, cf. BELLO, 2011; BOSSY; VERGARA, 2010; DIGIOVANNI, 2013; JOHANSSON; VERGARA, 2014; LLANOS, 2014; ORTEGA, 2010, p. 95; RAMÍREZ, 2010; ROS, 2012, p. 144-154; TANGE, 2013.
} 
idas e vindas dos lançamentos e das premiações no circuito de festivais, ano a ano, desde 1996, joga luz sobre as intrincadas dinâmicas por trás do adensamento do fenômeno do documentário intergeracional do Cone Sul identificado em 2010. Antes que um marco fixo, 2010 deve ser visto como um dos momentos do processo de formação dessa cinematografia.

Um processo que não parou por aí e que segue em suas oscilações. Pois 2011 assiste a uma nova retração da produção, repetindo o número de dois títulos surgidos no ano: o longametragem Marighella (Isa Grinspum Ferraz, Brasil, 2011), o qual, como já ficou comentado, estrutura-se como um documentário de entrevista convencional, embora traga em suas imagens certas marcas da subjetividade da sobrinha-diretora; e A contrarreloj (Pablo Sobrino, Uruguai, 2011), na verdade uma espécie de videoclipe de cinco minutos produzido pela agrupação HIJOS Uruguay com referências aos desaparecidos daquele país, baseado em uma canção de Ismael Collazo. Marighella, mesmo com o apelo de seu protagonista, teve uma circulação discreta no circuito de festivais, sem prêmios.

Em 2011, os títulos surgidos no prolífico ano anterior eram os que colhiam prêmios no circuito de festivais. El edificio de los chilenos (Macarena Aguiló e Susana Foxley, Chile / Cuba / França / Bélgica, 2010) seguia em sua exitosa carreira, conquistando mais prêmios em festivais na Colômbia, no México, no próprio Chile, na Espanha, na Bélgica e nos Estados Unidos. Mas é Abuelos (Carla Valencia Dávila, Equador / Chile, 2010) que se destaca no quesito prestígio dos reconhecimentos conquistados em 2011, ganhando o principal prêmio ao documentário no Festival de Biarritz: Cinémas et Cultures d’Amérique Latine, a terceira edição consecutiva em que um título do corpus recebe tal distinção no festival francês; além de um prêmio colateral, Documentário e Memória, no Festival Internacional del Nuevo Cine Latinoamericano, em Havana, na mesma edição em que Diário de uma busca havia levado também o prêmio especial do júri na categoria documentário. Não custa lembrar outros prêmios recebidos pelo filme de Flavia Castro em 2011, em Punta del Este e Lisboa. El eco de las canciones (Antonia Rossi, Chile, 2010) foi também premiado nesse ano no Festival de Cine Documental de Chiloé, no Chile. E mesmo Mi vida con Carlos (Germán Berger-Hertz, Chile / Espanha, 2009), produzido dois anos antes, ainda era premiado no Festival Internacional de Cine del Norte de Chile (Ficnor). Em termos estilísticos, todos estes títulos colocam em primeiro plano os traços da subjetividade de seus realizadores. Em 2011, portanto, observa-se certo refluxo no campo da produção, com o surgimento de Marighella e seu mal resolvido lugar do "eu" que enuncia. Mas os festivais prosseguiam em seu impulso de consagrar os títulos vinculados à forma do documentário em primeira pessoa. 
Apenas dois títulos são produzidos também em 2012, ambos com origem no Brasil: a coprodução internacional Repare bem (Maria de Medeiros, Brasil / Portugal / Espanha, 2012) e Elena (Petra Costa, Brasil, 2012). No primeiro, como já ficou apontado, a narrativa é conduzida pela montagem dos depoimentos de Eduarda Ditta Crispim Leite e Denise Crispim, respectivamente filha e ex-companheira de "Bacuri". 51 O segundo é uma bem-acabada produção que leva a subjetividade ao paroxismo, quando o "eu" da realizadora oscila entre o lugar de enunciação e a inflação do ego. Repare bem, mais próximo das convenções da entrevista, até que teve uma carreira razoável nos festivais, chegando a receber, no Festival de Gramado de 2013, o prêmio de melhor longa-metragem estrangeiro (vale lembrar, trata-se de uma coprodução internacional dirigida pela portuguesa Maria de Medeiros); e, em 2014, o título conquistaria ainda o primeiro prêmio na competição internacional de longas-metragens no Festival Internacional de Cine Político (FICiP) de Buenos Aires. Além dos prêmios, Repare bem teve uma inserção considerável nesse circuito, tendo sido selecionado em festivais de Cuba, México, Estados Unidos e Portugal.

Nada mal. Mas esse percurso nem de longe pode ser comparado com a projeção de Elena nesse contexto. De todos os títulos do corpus expandido, o filme de Petra Costa foi um dos que mais prêmios recebeu e que mais circulou por festivais ao redor do mundo. No que concerne ao recorte desta pesquisa, é verdade que a temática da ditadura é tangencial em Elena. Mencionando de passagem a militância dos pais da realizadora, sua narrativa está muito mais centrada na fusão das trajetórias de vida de Petra Costa e da irmã Elena, sob o espectro da tragédia do suicídio no seio familiar. De todo modo, trata-se de um título que chama atenção por sua passagem hiperbólica pelo circuito de festivais. Elena esteve presente em cerca de cinquenta festivais, tendo sido laureado em ao menos dez deles. Para ficar apenas nos prêmios mais expressivos: no Festival de Brasília do Cinema Brasileiro de 2012, na categoria documentário, recebeu o prêmio de direção, montagem e direção de arte, além de ter sido escolhido como melhor documentário pelo júri popular; no Festival Internacional del Nuevo Cine Latinoamericano de Havana de 2013, levou o primeiro prêmio da categoria documentário - na seção competitiva em que disputava com Os dias com ele (Maria Clara Escobar, Brasil / Portugal, 2013), o qual conquistaria uma menção colateral, e na mesma edição em que Repare bem fora selecionado para uma mostra paralela; no Festival Internacional de Cine en Guadalajara (FICG) do mesmo ano, Elena obteve uma menção especial na categoria documentário ibero-americano; e outra menção especial, na competição

\footnotetext{
${ }^{51}$ Sobre Repare bem, cf. FERNANDES, J. V. S., 2018.
} 
internacional, agora no Festival Internacional de Documentários ZagrebDox, na Croácia; mais um prêmio, de fotografia, no Planete+ Doc Film Festival, em Varsóvia, Polônia. E, ainda, em festivais com recorte mais específico: em 2013, melhor documentário no Festival de Films de Femmes de Créteil, na França; melhor documentário no Los Angeles Brazilian Film Festival, nos Estados Unidos; melhor música original no $7^{\circ}$ Cine Música - Festival de Cinema de Conservatória, no estado do Rio de Janeiro. Já em 2014, Elena levou o prêmio de melhor documentário no Arlington International Film Festival, novamente nos Estados Unidos; além de outro prêmio de melhor documentário, pela votação do público, no Festival Sesc Melhores Filmes.

Quanto às circulações, Elena foi selecionado pelos mais variados tipos de festivais entre 2012 e 2014, dos mais globais aos mais locais, no Brasil, na Argentina, em Cuba, no México, no Peru, no Uruguai, no Panamá, nos Estados Unidos, no Canadá, na França, nos Países Baixos, na Suécia, na Polônia, na Itália, na Islândia, na Grécia, na Croácia, na Espanha, na Irlanda, na Inglaterra, na China, em Israel, no Marrocos, na Austrália, portanto, nos cinco continentes. Das principais vitrines do cinema internacional aos eventos em municípios pelo interior do Brasil, as premiações e as circulações de Elena dão mostras do fôlego que a chancela a esse documentarismo familiar e subjetivo vinha alcançando no circuito de festivais. Para além do forte investimento em sua promoção, é como se o filme de Petra Costa correspondesse de forma certeira às expectativas estéticas predominantes nesse e noutros contextos. $^{52}$

As duas produções de 2013 consolidam a participação brasileira nessa filmografia. São desse ano Os dias com ele (Maria Clara Escobar, Brasil / Portugal, 2013) e Em busca de Iara (Flavio Frederico, Brasil, 2013). Ambos dão mais um passo no terreno da abordagem da ditadura em tom familiar e subjetivo, embora existam flagrantes diferenças entre os filmes. No primeiro, Maria Clara Escobar lança mão de um dispositivo minimalista, quase caseiro: uma câmera registrando os embates entre filha e pai encerrados na residência dele. A montagem tem um papel primordial ao dar forma fílmica a esses atritos familiares. ${ }^{53} \mathrm{Já}$ Em busca de Iara adere aos códigos básicos do documentário subjetivo, com a sobrinha protagonizando a reconstituição da história de Iara Iavelberg, entrando em cena visitando lugares e conduzindo as entrevistas, com grande peso dos depoimentos na construção da

\footnotetext{
${ }^{52}$ Para além dos festivais, Elena contou também um respaldo significativo da crítica. Cf. a coletânea de textos TERRON; LAUB, 2014; além de FRANÇA; MACHADO, 2014a; MORAES; OLIVEIRA, 2015; SILVA, S. R. R.; MOUSINHO, 2016.

${ }_{53}$ As referências sobre Os dias com ele serão mobilizadas no último capítulo deste trabalho.
} 
narrativa ${ }^{54}$ Este último título conquistou uma menção honrosa na disputa nacional do É Tudo Verdade: Festival Internacional de Documentários de 2013, no Brasil. Os dias com ele, por sua vez, teve uma carreira de maior fôlego no circuito de festivais. Em 2013, além da já citada menção especial no Prêmio Documentário Memória no Festival de Havana, o filme de Maria Clara Escobar destacou-se na Mostra de Cinema de Tiradentes (prêmios da crítica e do júri jovem); no Doclisboa (prêmio de melhor primeiro ou segundo longa-metragem da competição portuguesa - vale lembrar que se trata de uma coprodução); e, já em 2014, no Festival Internacional de Cine de Murcia (IBAFF), na Espanha (menção especial na categoria melhor primeiro filme).

A esta altura, os ventos parecem soprar com força no rumo do documentarismo intergeracional em primeira pessoa. Os lançamentos de tom familiar e íntimo sobre as ditaduras vão se consagrando nos festivais. Mesmo os filmes estruturados de forma mais convencional buscam dar ares contemporâneos às narrativas, incluindo toques de subjetividade em suas imagens. E eis que em 2014 nenhum novo título desponta no horizonte. No universo do corpus desta pesquisa, apenas o ano 1999 havia sido zerado em termos de lançamentos. As dinâmicas inerentes à produção cinematográfica (dificuldades para captação de recursos, adiamentos forçados dos projetos etc.) certamente têm seu papel nesse cenário. Fato é que o adensamento observado nos anos mais recentes, principalmente após 2010, não anula a possibilidade de uma rarefação momentânea dessa filmografia.

Mas os números por si só não dizem tudo. A ausência de produções inéditas naquele ano não representou um vazio do fenômeno. Afinal, alguns títulos surgidos anteriormente continuavam circulando e sendo premiados (Repare bem, Elena e Os dias com ele) em 2014. A calmaria não significou marasmo, e em 2015 surgiam novos títulos que agitaram mais uma vez a atmosfera do documentarismo intergeracional do Cone Sul. Foram seis ao todo, um número acima da média da produção anual desse corpus: Allende mi abuelo Allende (Marcia Tambutti, Chile / México, 2015), em que a neta de Salvador Allende decide remexer na vida privada do avô, um tema incômodo sobre o qual ela teima em inquirir e que a família insiste em evitar; Tiempo suspendido (Natalia Bruschtein, México / Argentina, 2015), médiametragem com o qual Natalia Bruschtein retorna às memórias de sua família sobre a ditadura argentina, mais de uma década depois da realização de Encontrando a Víctor, agora enfocando sua avó, Laura Bruschtein Bonaparte, uma das fundadoras das Madres de Plaza de Mayo e que, na velhice, após anos de luta pela memória dos familiares desaparecidos, está

\footnotetext{
${ }^{54}$ Sobre Em busca de Iara, cf. também MAIA, 2015b.
} 
perdendo a própria memória; La parte por el todo (Roberto Persano, Santiago Nacif Cabrera e Andrés Martínez Cantó, Argentina, 2015), que aborda o tema das apropriações de bebês na Argentina a partir da história de três netos que tiveram suas identidades restituídas; Tus padres volverán (Pablo Martínez Pessi, Uruguai, 2015), que colhe os testemunhos de seis dos 154 filhos de exilados que, em 1983, foram enviados em um voo da Europa para o Uruguai para que conhecessem seu país de origem e como forma de pressão contra o regime; Todos somos hijos (Esteban Barja e Carlos Conti, Uruguai, 2015), documentário que segue as buscas de Valentín Enseñat acerca do desaparecimento de seu pai, entrevistando ex-companheiros da geração anterior e dando voz a militantes de HIJOS Uruguay; e Orestes (Rodrigo Siqueira, Brasil, 2015), trazendo Naasaindy Barrett de Araújo às voltas com a elaboração do trauma do desaparecimento da mãe, entre outras tramas que entrelaçam o presente com o passado autoritário.

Desse conjunto de títulos de 2015, Allende mi abuelo Allende e Tiempo suspendido são aqueles que seguem mais de perto o repertório estético-narrativo do documentário subjetivo e familiar contemporâneo. Não por acaso, tiveram uma notável carreira no circuito de festivais. O filme da neta de Salvador Allende - fato que por si só já tem um apelo considerável - ganhou o L'Eil d'or de melhor documentário no Festival de Cannes de 2015, naquela que foi a primeira edição do prêmio exclusivamente dedicado ao documentário no prestigioso festival francês. Ainda em 2015, Allende mi abuelo Allende venceu o prêmio do público no Festival Internacional de Cine de Santiago (Sanfic); e, no Festival Internacional de Cine de Mar del Plata, na Argentina, levou o segundo prêmio da Reunión Especializada de Autoridades Cinematográficas y Audiovisuales del Mercosur (Recam); em 2016, ganhou como melhor documentário no Festival Internacional Cine del Mar, realizado em Punta del Este, Uruguai.

Todavia, no comparativo com a produção de 2015, Tiempo suspendido foi o que acumulou a maior quantidade de êxitos no circuito. No México, país coprodutor, o título foi premiado nos festivais internacionais de cinema de Guadalajara e de Guanajuato; no Festival de la Memoria: Documental Iberoamericano, em Cuernavaca; e no Certamen Internacional de Cine Documental sobre Migración y Exilio, na Cidade do México. Fora de casa, sempre em 2015, o documentário de Natalia Bruschtein conquistou o prêmio de melhor documentário no Budapest International Documentary Film Festival, na Hungria; uma menção especial no Chicago International Film Festival; outra no Festival de Mar del Plata; e, ainda, levou o prêmio da Federación de Escuelas de la Imagen y el Sonido de América Latina (Feisal) no Festival de Havana (onde concorria na mesma seção com Allende mi abuelo Allende). 
Todos somos hijos mobiliza o tópico da busca de um filho sobre o desaparecimento do pai, mas não se trata propriamente de um documentário em primeira pessoa, seus diretores acompanham Valentín Enseñat em suas andanças e conversas. Este título circulou apenas em festivais no próprio Uruguai. Já Tus padres volverán está mais próximo da reconstituição de uma experiência coletiva pela montagem de entrevistas, tendo sido premiado em festivais menores no Brasil, na Argentina, na República Dominicana, na França (Rencontres du Cinema Sud-Américaine de Marseille) e na Suíça (Festival Filmar en América Latina). Orestes, por sua vez, é um dos títulos de mais difícil classificação de todo o corpus. Sua mescla de testemunho e psicodrama, teatro e encenações de justiça fazem dele uma espécie de objeto estranho nesse conjunto. O filme de Rodrigo Siqueira chegou a passar pelo É Tudo Verdade, no Brasil, e pelo Festival de Havana, entre outros, sem ter conquistado prêmios.

Ora, os importantes prêmios conferidos aos títulos mais formatados de acordo com os códigos do documentário em primeira pessoa dão força à hipótese de que a chancela dos festivais prioriza uma das vertentes do documentarismo intergeracional. Isso, porém, não anula o fato de que obras realizadas seguindo outros moldes continuaram aparecendo ao longo dos anos, inclusive em datas mais recentes.

Os títulos surgidos em 2016 chamam a atenção para as dinâmicas nacionais dessa filmografia. Com eles, a Argentina retornava com força à cena da produção - não por acaso, no aniversário de quarenta anos do golpe. Em 2015, o país platino se fazia presente com $L a$ parte por el todo e como coprodutor de Tiempo suspendido. Antes disso, o último título do corpus com origem ou participação argentina era de 2008: Victoria (Adrián Jaime, Argentina, 2008). Existe aí, portanto, um hiato argentino de sete anos, entre 2008 e 2015, após a inequívoca predominância das produções desse país no período imediatamente anterior. Podese conjecturar que, após o florescimento do documentarismo de filhos observado até 2008, o panorama cinematográfico argentino tenha ficado saturado de títulos nessa chave. Simultaneamente, nesse intervalo entre fins dos anos 2000 e a segunda metade da década seguinte, outros países foram aumentando sua presença na filmografia, com destaque para Chile e Brasil, muitas vezes em coprodução com países terceiros.

Mas agora, em 2016, dos sete títulos lançados, seis contavam com participação argentina: 70 y Pico (Mariano Corbacho, Argentina, 2016), em que o neto-diretor examina o grau de colaboracionismo do avô "Pico", alguém que, durante a ditadura, foi nomeado decano da Faculdade de Arquitetura da Universidade de Buenos Aires (UBA) ao mesmo tempo que era professor na Escuela de Mecánica de la Armada (Esma); La guardería (Virginia Croatto, Argentina, 2016), no qual a diretora se debruça sobre sua experiência na creche criada pelos 
montoneros em Cuba para abrigar os filhos durante o retorno dos militantes em uma contraofensiva ao regime - uma história bem próxima daquela antes vista em El edificio de los chilenos; Retour: volver (Martin Bourgault, Canadá / Argentina, 2016), que acompanha o regresso à Argentina do cantor Tomás Jensen, forçado ao exílio em 1976, quando tinha apenas seis anos, e hoje radicado no Canadá; El padre (Mariana Arruti, Argentina, 2016), em que a realizadora questiona a versão da morte acidental do pai sindicalista nos anos 1970, uma história por tanto tempo intocada pela própria família; El (im)posible olvido (Andrés Habegger, Argentina / Brasil / México, 2016), com o qual Andrés Habegger, dezesseis anos após (h) Historias cotidianas, finalmente assume a enunciação em primeira pessoa, voltandose para sua experiência pessoal em um documentário francamente subjetivo na busca por superar bloqueios e reconstituir a imagem do pai desaparecido no Rio de Janeiro; e Cuatreros (Albertina Carri, Argentina, 2016), em que Albertina Carri, mais de uma década após Los rubios, alinhava com sua própria voz over ensaística uma torrente de imagens de arquivo, tomando como ponto de partida a história do bandoleiro "pré-revolucionário" narrada pelo pai desaparecido, Roberto Carri (2011), em seu livro Isidro Velázquez: formas prerrevolucionarias de la violencia. Estes dois últimos lançamentos coroam o retorno da Argentina ao corpus: Andrés Habegger e Albertina Carri são dois cineastas que já haviam dirigido filmes relevantes nos primórdios dessa produção e, nesse novo ciclo argentino, retomam a temática da memória intergeracional. O sétimo título de 2016 é o chileno Venían a buscarme (Álvaro de la Barra, Chile, 2016), em que o diretor conta a história dos pais militantes assassinados pela ditadura quando iam buscá-lo no jardim de infância.

Os títulos de 2016, em geral, adotam o prisma íntimo e familiar em seu olhar para a ditadura. Nesse grupo, La guardería foi aquele que, de saída, mais se destacou nos festivais, ganhando o prêmio de Melhor Longa-Metragem de Direitos Humanos no Festival Cinematográfico Internacional del Uruguay de 2016; no mesmo ano, o primeiro prêmio na Competição Oficial Argentina de Longas-Metragens no Festival Internacional de Cine Político, ocorrido em Buenos Aires; além de uma menção honrosa na Seção Memória do Festival de la Memoria: Documental Iberoamericano, em Cuernavaca, México. Venían a buscarme também recebeu certa atenção do circuito, havendo conquistado o prêmio de melhor filme de estreia no Festival Internacional de Documentales de Santiago (Fidocs) e uma menção honrosa no Festival Internacional de Cine de Derechos Humanos (DerHumALC), na Argentina.

Em 2017, o Chile toma a dianteira da produção, com Guerrero (Sebastián Moreno, Chile, 2017), filme que acompanha a trajetória de Manuel Guerrero, cujo pai foi um dos três 
militantes do Partido Comunista do Chile assassinados pela ditadura, em 1985, naquele que ficou conhecido como o "caso degollados"; El color del camaleón (Andrés Lübbert, Chile / Bélgica, 2017), no qual o filho faz uma viagem de retorno ao Chile com o pai, alguém que, antes de se exilar na Europa, fora obrigado a colaborar com as forças de repressão da ditadura daquele país; Mute (Claudia Aguilera, Chile, 2017), em que a cineasta explora as fitas cassete nas quais os tios gravavam cartas orais enviadas para seu pai exilado na França; além de $E l$ pacto de Adriana (Lissette Orozco, Chile, 2017), título que se soma a 70 y Pico, do ano anterior, ambos sinalizando os primeiros passos do enfrentamento de um assunto até então ausente no documentarismo intergeracional do Cone Sul: as responsabilidades e colaborações com os regimes ditatoriais no seio da própria família. Se Mariano Corbacho indagava o papel de seu avô dentro da Esma, Lissette Orozco revolve a atuação de sua tia, Adriana Rivas, na Dirección de Inteligencia Nacional (Dina) durante a ditadura chilena. Foragida na Austrália, a tia é acusada pela Justiça em casos de tortura, sequestro e desaparecimento.

Pelo que indicam os prêmios conferidos a El pacto de Adriana, o circuito de festivais parece disposto a acolher essa inversão de foco da figura do militante para a do perpetrador no documentário subjetivo familiar sobre as ditaduras. Só em 2017, este título recebeu o prêmio especial do júri no Festival Internacional de Cine en Guadalajara (FICG); uma menção especial na competição de direitos humanos no Buenos Aires Festival Internacional de Cine Independiente (Bafici); o prêmio de melhor filme na competição de direitos humanos no Festival Cinematográfico Internacional del Uruguay; o "prêmio da paz" na Berlinale: Internationalen Filmfestspiele Berlin; o prêmio Signis na competição de documentários do Cinélatino: Rencontres de Toulouse; além do prêmio do júri de melhor filme na categoria "novos diretores" na Mostra Internacional de Cinema de São Paulo.

Altas e baixas no número de títulos produzidos a cada ano. A maior participação de um ou outro país no conjunto de lançamentos. A convivência de estilos documentais díspares, às vezes em uma mesma obra. A permanência do peso das convenções da entrevista. As dinâmicas observadas entre 1996 e 2017 fragilizam a interpretação do fenômeno do documentário intergeracional do Cone Sul nos termos da "guinada". Tampouco saem ilesas as leituras que pensam a questão a partir de um viés evolutivo, delineando as supostas "fases" desse documentarismo. A formação dessa cinematografia é um processo histórico e, como tal, deve ser esquadrinhada em suas cadências e vicissitudes ao longo do tempo. Com isso, no lugar de um marco divisório superdimensionado ou de "etapas" estanques, enxergam-se os fluxos, refluxos, deslocamentos, hiatos, adensamentos, paralelismos, continuidades e retomadas, com seus intrincados vetores. 
Mas os lançamentos e as circulações desses documentários no correr dos anos não se caracterizam apenas por sua complexidade. A atenção a esses fatores revela, igualmente, uma força atuante na configuração do documentário intergeracional da região: as premiações nos festivais, que privilegiam e chancelam uma vertente específica dentre as possibilidades existentes. O corpus expandido desta pesquisa deixa claro que o documentário intergeracional não é "intrinsecamente" subjetivo e reflexivo. Há muitas "cabeças falantes" nessa cinematografia, em filmes dirigidos por terceiros, mas também em retratos geracionais coletivos realizados por filhos de vítimas das ditaduras, sem que sua voz em primeira pessoa entre em cena. Existem inclusive os casos em que a roupagem afinada com as marcas contemporâneas do "eu" não chega a disfarçar uma estrutura convencional que reitera matrizes de rememoração já consagradas. Após o mergulho nos meandros do transnacionalismo guiado pela análise de Diário de uma busca, o olhar de conjunto lançado nesta seção mostra que documentários como o de Flavia Castro são uma dentre outras tendências no interior dessa filmografia. Aquela que, emergente, costuma ser legitimada no circuito de festivais, o que acaba retroalimentando o prisma íntimo e familiar de revisão da memória das ditaduras no cinema. Definir o documentário intergeracional em bloco como subjetivo e reflexivo é confundir uma das forças em jogo com a totalidade do processo.

Observadas as cadências históricas do fenômeno e suas implicações estéticas ao longo dos anos, resta ainda mencionar outra dimensão que se delineia nas circulações dos títulos do corpus pelos festivais. Pois, além das dinâmicas no tempo, esses fluxos iluminam a abrangência espacial dessa filmografia. A esta altura, já ficou patente que também aqui se está na esfera transnacional. Vale, contudo, tomar um último fôlego no esforço de qualificar essa espacialidade (ANDREW, 2010, p. 64).

Caso se tomasse por base exclusivamente os países de produção dos filmes ano a ano, poderia ficar a impressão de que a Argentina foi uma espécie de epicentro a partir do qual se difundiu o fenômeno do documentário intergeracional sobre as ditaduras. Efetivamente, no universo de filmes do corpus, a predominância de títulos de origem argentina é flagrante, representando mais da metade do total. Entretanto, a abordagem aqui, desde o início, tem se desdobrado nos termos do Cone Sul, recorte já consagrado para se referir às histórias das ditaduras em nível regional. Ao ir além do elenco de países de origem das obras, a atenção às circulações e transferências culturais busca, exatamente, superar a pauta da "influência" ou da identificação de um suposto "centro irradiador" (ESPAGNE, 2013; WEINSTEIN, 2013, p. 17). Afinal, a articulação da memória familiar na revisão de períodos históricos traumáticos não é algo que tenha surgido no documentarismo argentino, e parece inócuo tentar identificar 
um eventual lugar de "origem", onde quer que seja, dessa vertente. Porém, ao mesmo tempo, seria um erro cair no extremo oposto, idealizando um espaço global amorfo e homogêneo (ĎUROVIČOVÁ, 2010a, 2010b). Daí ser fundamental esboçar uma segunda cartografia, ainda que sumária, agora das circulações dos títulos do corpus, levando em conta as distintas escalas geográficas em questão (MIDDENTS, 2013).

Começando pela maior delas. Porque o levantamento realizado deixou claro que a abrangência das circulações desses documentários vai muito além do Cone Sul. Há títulos do corpus que passaram por festivais da Austrália e da Nova Caledônia, na Oceania; do Japão, da China, de Israel e da Coreia do Sul, na Ásia; de Burkina Faso, do Egito e do Marrocos, na África. Se, por um lado, esses exemplos dão a ver o alcance global da presença do documentarismo do Cone Sul no circuito de festivais, por outro, é preciso também esclarecer que as circulações nesses países longínquos são rarefeitas, com poucas ocorrências de seleção e menos ainda de premiação. Tais casos revelam os confins do fenômeno, os pontos extremos onde os filmes chegaram, restando ainda pendente a tarefa de se traçar as subdivisões no interior desse espaço.

Em escala continental, existem as zonas em que as circulações são mais densas, primeiramente a própria América Latina. Pois bem, era de se esperar que os documentários do Cone Sul circulassem localmente, e o levantamento confirmou a preponderância dos festivais de Argentina e Brasil nesse recorte, seguidos pelos do Chile e, depois, do Uruguai. Mas vale observar que as circulações na América Latina extrapolam esta sub-região mais específica, com grande destaque para o México, seguido por Cuba, algo que em certo sentido reverbera o papel destes dois países como coprodutores de títulos da filmografia. Ainda no contexto latino-americano, observaram-se circulações, em ordem decrescente, no Peru, na Colômbia, no Equador, na Bolívia, no Panamá, na República Dominicana, na Costa Rica, na Guatemala e na Venezuela.

A Europa é o segundo continente em densidade de circulações por festivais do documentarismo intergeracional do Cone Sul, algo que em grande medida se deve ao influxo de França e Espanha. Além do fato de o continente europeu possuir um circuito de festivais bem estruturado, em geral atento ao chamado "world cinema", as coproduções internacionais são um fator que também entram em jogo nesse caso. Seguindo a mesma lógica dos vínculos oriundos do exílio observada com relação a México e Cuba, França e Espanha são os maiores coprodutores extracontinentais dessa filmografia, concentrando, ao mesmo tempo, a maior parte das circulações e premiações na Europa. O restante desse universo inclui passagens de títulos do corpus, em ordem decrescente, por Itália, Alemanha, Países Baixos, Suíça, 
Inglaterra, Bélgica, Portugal, Grécia, Polônia, Turquia, Áustria, Croácia, Dinamarca, Irlanda, Noruega, Estônia, Finlândia, Hungria, Islândia, República Checa, Sérvia, Suécia e Ucrânia.

Já na América do Norte, se comparadas aos fluxos em festivais latino-americanos e europeus, as circulações são bem mais tímidas. Esta é uma zona de circulações moderadas, com os Estados Unidos à frente, seguido pelo Canadá, com maior peso dos festivais de cinema "latino". Depois, vêm as já mencionadas zonas com circulações rarefeitas: na ordem, Ásia, Oceania e, em último lugar, África.

Reduzindo mais um degrau nas escalas geográficas, é preciso levar em conta a dimensão nacional dessas circulações. Os filmes do corpus, como era de se supor, têm bastante visibilidade nos festivais de seus países de origem. Os prêmios "em casa" são frequentes, em distintas categorias, desde as seções competitivas nacionais, passando pelas dedicadas ao documentário ou aos direitos humanos. E diversos são também os festivais por onde os títulos passam em seu próprio território, dos mais cosmopolitas até aqueles de recorte específico ou promovidos em cidades menores - algo que leva a pensar em uma escala geográfica ainda mais delimitada, a dos localismos dentro do contexto nacional. Ainda assim, em cada país, existem os festivais que se destacam na atenção que prestam a essa cinematografia. Na Argentina, esse é o caso do Buenos Aires Festival Internacional de Cine Independiente (Bafici) e do Festival Internacional de Cine de Mar del Plata. No Brasil, do Festival de Gramado e do É Tudo Verdade: Festival Internacional de Documentários. No Chile, do Festival Internacional de Cine de Santiago (Sanfic) e do Festival Internacional de Documentales de Santiago (Fidocs). No Uruguai, do Festival Cinematográfico Internacional del Uruguay e do Festival Internacional de Cine de Punta del Este. O fato de os festivais de cada país do Cone Sul serem vitrines privilegiadas das produções (ou coproduções) "nativas" corrobora a ideia de que o nacional não é anulado pela dimensão transnacional. Antes, existe aí um jogo de escalas, no qual cada uma delas se caracteriza por uma irredutibilidade recíproca em relação às outras (GINZBURG, 2011b). A perspectiva transnacional, como já ficou indicado, não está aqui a serviço da neutralização das particularidades locais.

Isso leva às escalas mais circunscritas deste panorama. Primeiro, aquela dos festivais específicos que condensam circulações e premiações do documentarismo intergeracional do Cone Sul. Porque se, por um lado, observa-se uma pulverização das passagens desses títulos por uma miríade de festivais, no bojo da proliferação desses eventos observada nos últimos tempos (GOETSCHEL; HIDIROGLOU, 2013, p. 11); por outro, há determinados festivais que se destacam nesse universo, concentrando um maior volume de circulações e premiações dessa cinematografia. O Festival Internacional del Nuevo Cine Latinoamericano de Havana, 
sem dúvida, foi aquele que de pronto acolheu e que mais vezes premiou os filmes do corpus ao longo dos anos. Ao menos treze títulos foram ali premiados, entre 2000 e 2017, na seção competitiva principal de documentários ou em prêmios colaterais. ${ }^{55}$ Havana presta uma atenção consistente ao documentarismo intergeracional do Cone Sul, assumindo a dianteira como um dos principais "pontos nodais" (DE VALCK, 2007, p. 15, tradução nossa) da chancela a essa tendência. O Bafici também se destaca nesse cenário, sendo, certamente, uma vitrine para o conjunto de filmes argentinos, mas também premiando títulos dos demais países do Cone Sul. De fato, existem diferentes níveis de atenção que os festivais prestam às obras do corpus, indo de um grau consistente, passando por um grau médio, até aqueles em que as circulações são eventuais. Alguns festivais são verdadeiros “entroncamentos" dessas circulações, com Havana à frente. Outros, por seu turno, são lugares onde os filmes fazem apenas visitas esporádicas. E tudo isso está relacionado com os recortes específicos dos eventos: se são festivais latino-americanos, de direitos humanos, de documentários, entre outras classificações possíveis, questão que leva a discussão de volta para o delineamento das subdivisões internas desta cartografia (cf. APÊNDICE A).

\section{A formação transnacional de um fenômeno cinematográfico e de memória}

O trajeto percorrido neste capítulo visitou diversas paragens, desde a enunciação do problema da "guinada subjetiva", passando pela proposição da solução transnacional, e com este norte foram cruzadas as veredas do pré-fílmico, do fílmico e do pós-fílmico. O caminho foi longo porque a ideia era substituir o amplo diagnóstico conceitual pelo gesto de alcance histórico, colocando a descrição historiográfica no lugar da definição abstrata. Com isso, ao

\footnotetext{
${ }^{55}$ Em Havana, foram premiados: Papá Iván (María Inés Roqué, México / Argentina, 2000): Primeiro Prêmio Coral ao Documentário, 2000; H.I.J.O.S.: El alma en dos (Carmen Guarini e Marcelo Céspedes, Argentina, 2002): Menção especial na categoria documentário, 2002; Nietos (identidad y memoria) (Benjamín Ávila, Argentina, 2004): Terceiro Prêmio Coral ao Documentário, 2004; El telón de azúcar (Camila Guzmán Urzúa, França / Cuba / Espanha, 2006): Primeiro Prêmio Coral ao Documentário, 2007; ¿Quién soy yo? Los niños encontrados de Argentina (Estela Bravo, Argentina / EUA / Reino Unido, 2007): Prêmio Coral de Documentário de um Realizador não Latino-Americano sobre a América Latina, Prêmio Documentário Memória, Prêmio do Cibervoto ao Documentário e Prêmio do Canal Telesur, também em 2007; El edificio de los chilenos (Macarena Aguiló e Susana Foxley, Chile / Cuba / França / Bélgica, 2010): Segundo Prêmio Coral ao Documentário, 2010; Cuchillo de palo (Renate Costa, Paraguai / Espanha, 2010): Menção Especial ao Documentário, também em 2010; Abuelos (Carla Valencia Dávila, Equador / Chile, 2010): Prêmio Documentário Memória, 2011; Diário de uma busca (Flavia Castro, Brasil / França, 2010): Prêmio Especial do Júri ao Documentário, também em 2011; Elena (Petra Costa, Brasil, 2012): Primeiro Prêmio Coral ao Documentário, em 2013; Os dias com ele (Maria Clara Escobar, Brasil / Portugal, 2013): Menção no Prêmio Documentário Memória, também em 2013; Tiempo suspendido (Natalia Bruschtein, México / Argentina, 2015): Prêmio da Federación de Escuelas de la Imagen y el Sonido de América Latina (Feisal), 2015; El color del camaleón (Andrés Lübbert, Chile / Bélgica, 2017): Prêmio Documentário Memória, 2017. Sobre o Festival de Havana, cf. GUTIÉRREZ, C. A.; WAGENBERG, 2013 , p. 298-299.
} 
invés de simplesmente introduzir preliminarmente um contexto, tratou-se de recuperar a profundidade temporal e a abrangência espacial do fenômeno do documentário intergeracional do Cone Sul. De pensá-lo, afinal, nos termos de uma formação paulatina, um processo que remonta às dinâmicas transnacionais já identificáveis nas histórias de repressão, resistência e exílio; na militância dos filhos; nas trajetórias de vida e nas carreiras de muitos realizadores; na lógica das coproduções internacionais. Tais dinâmicas ganham expressão no específico fílmico, seja nas imagens itinerantes ou nos paradeiros da memória visíveis nos documentários. E seguem seu curso nas circulações dessas obras pelos festivais ao redor do mundo.

Eis aí uma "grande narrativa" historiográfica sobre a inflexão da memória das ditaduras observada no cinema documentário produzido na região nas duas últimas décadas. Não custa alertar neste ponto que a crítica da ideia de "guinada subjetiva" está longe de querer negar em bloco as mudanças. O tom menor com o qual Diário de uma busca se encerra oferece um contraste tocante frente à matriz celebrativa da memória da resistência. Celso Castro voltou do exílio e não conseguiu assimilar a derrocada do projeto revolucionário. Ele não via motivos para a euforia dos anistiados com o retorno consentido pelos algozes. A reinvenção profissional era difícil. A atuação partidária não o satisfazia. A redemocratização não se tornou para ele um novo ideal apto a ressignificar a militância passada. Sua morte atípica irrompe como o desfecho de uma espiral melancólica que o levava para bem longe do abrigo da versão do triunfo da luta democrática. "Parece que ninguém se dá conta e, o que é pior, ninguém quer entender que voltamos derrotados, que houve uma concessão da ditadura e que, se nos permitiram voltar, é porque nos derrotaram. E, se houve uma abertura, é porque eles foram os vitoriosos", ouve-se o filho ler em voz over o texto deixado pelo pai. O olhar afetuoso e introspectivo da filha é o que revela esse ressentimento que ficou por tantos anos soterrado pelo monumento à resistência (cf. SELIPRANDY, 2013). O percurso deste capítulo tratou de dar concretude a esse deslocamento da memória intergeracional, sem ignorar os fatores que complicam o panorama. Porque é patente que o viés subjetivo e íntimo vem ganhando peso nas obras recentes voltadas ao passado autoritário. Acontece que isso não é fruto de um "espírito" natural da contemporaneidade. Essa nova matriz de rememoração calcada nas vivências familiares das gerações mais jovens foi construída historicamente, tal como as outras matrizes da memória coletiva.

O quadro retrospectivo construído nestas páginas é multifacetado, mas não é o caso de se perder nessa complexidade. Assim como a "guinada subjetiva", o transnacionalismo também não é um dado, muito menos um dado neutro. $\mathrm{O}$ espaço-tempo que surge dessa 
trajetória não é amorfo, a palavra "transnacional" diria muito pouco se fosse apenas uma generalização alternativa. Pois há variadas escalas em jogo na formação dessa cinematografia, dos filmes específicos aos confins das circulações pelos festivais (HIGBEE; LIM, 2010; HJORT, 2010; MIDDENTS, 2013; NEWMAN, 2010; RADSTONE, 2011). O próprio circuito de festivais não é um ente unívoco: nele variam os graus de prestígio e impacto dos eventos, seus alcances geográficos (os festivais locais, os globais, com o peso das relações Norte-Sul) e recortes temáticos (no universo aqui estudado, oscilando principalmente entre os festivais generalistas, os especializados em documentário, em cinema latino-americano ou aqueles dedicados à agenda dos direitos humanos). Ademais, cada festival já é, em si mesmo, um palco de disputas no qual distintos grupos se embatem em torno de interesses estéticos, econômicos, geopolíticos, turísticos etc. (DE VALCK, 2007, p. 16 e 38-41). ${ }^{56}$ E, por fim, constitutivamente em fricção com o caráter multiforme dos festivais, existe uma linha de força atuante ao longo desse processo, uma valoração da subjetividade reflexiva que, antes que um dado de época, é o vetor da chancela de uma determinada vertente entre outras do documentarismo intergeracional. Mais do que uma "guinada", o que se percebe nesse cenário é a inclinação de certos atores do campo cultural a enfatizar o prisma subjetivo.

Com seus prêmios, os festivais de cinema, em sua diversidade, são instâncias decisivas dessa legitimação de certo tipo de documentário e de memória intergeracional: aquele das buscas hesitantes pelas lembranças familiares que digam algo sobre essas histórias de ditaduras. Como se verá no Capítulo III, o impulso histórico de consagração dessa tendência emergente do cinema documental tem suas implicações estéticas: a formatação de uma poética "globalizada" da busca subjetiva não isenta do risco da homogeneização dos meios de expressão cinematográfica (cf. FALICOV, 2010, 2013; LEFERE; LIE, 2016, p. 13-14; MIDDENTS, 2013, p. 156-157). Talvez seja esta a grande encruzilhada dos fluxos espaçotemporais descritos: um movimento de seleção e codificação estilística que é indissociável desse circuito transnacional e, dialeticamente, está em franca contradição com suas múltiplas facetas.

Mas é preciso dizer que, além dos festivais, há outros atores em cena. Porque a valoração estética das rememorações subjetivas na esfera do documentarismo intergeracional depende também daquilo que a academia escreve sobre essa filmografia. E, no âmbito

\footnotetext{
${ }^{56}$ Feita essa ponderação, cabe esclarecer que seria inviável lidar com todos esses fatores neste capítulo. Com efeito, os festivais de cinema são nesta tese uma das entradas para se compreender o fenômeno do documentário intergeracional em escala transnacional, e não o objeto central da pesquisa. De todo modo, a lista detalhada de prêmios e circulações dos títulos do corpus pelos festivais por país consolidada no APÊNDICE A oferece uma visão global das inúmeras ramificações desse universo.
} 
acadêmico, a própria noção de "guinada subjetiva" é parte desse processo, ao chamar mais atenção para certa modalidade do cinema documentário (justamente, aquela que segue as formas emergentes da subjetividade), ao desconsiderar outras (as mais convencionais, que continuam sendo produzidas). A ideia de "guinada subjetiva" faz mais sentido quando se reconhece estas premissas: a expressão que tenta definir o fenômeno do documentário intergeracional é, em si, parte do fenômeno; o conceito acadêmico, mais do que descrever, favorece um viés específico. Ocorre aí a extrapolação de uma preferência estilística, a qual é elevada à condição de postulado global sobre o que deveria ser o documentário contemporâneo. Pois, no fundo, as análises guiadas pela ideia de "guinada subjetiva" carregam uma agenda, um programa estético-epistemológico que tem seus agentes e suas instâncias de legitimação (o circuito de festivais, a bibliografia acadêmica). A reivindicação da subjetividade reflexiva, vale esclarecer, é absolutamente justificável. De fato, em grande medida, o papel dos festivais e da crítica (inclusive acadêmica) é esse mesmo: selecionar obras, identificar novidades, consagrar tendências, hierarquizar relevâncias, celebrar certas poéticas. O problema se dá quando esses gestos bem concretos são apresentados como se fossem a natureza definidora da sensibilidade de uma época. Independentemente do valor estético que se atribua aos documentários menos arrojados, goste-se ou não das convencionais "cabeças falantes", o fato é que eles seguem presentes nessa filmografia, afora os casos em que a enunciação em primeira pessoa não vai muito além de uma impostação da voz. Tudo isso faz parte do fenômeno da memória intergeracional no documentarismo do Cone Sul. Incluindo-se as leituras desse cinema propostas nos livros e artigos, nas dissertações e teses aqui citados. Incluindo-se esta tese. Assim desdobrada, a "guinada" marca não tanto um "antes" e um "agora" do documentário e da memória, mas um voltar-se reflexivo do campo acadêmico para o papel de suas próprias interpretações nesse panorama. 


\section{CAPÍTULO II}

\section{A MEMÓRIA INTERGERACIONAL E SEUS MÚLTIPLOS VETORES ${ }^{57}$}

Ao longo de todo o primeiro capítulo, as expressões "documentário intergeracional" e "memória intergeracional" foram empregadas com uma função sobretudo descritiva. Chega afinal o momento de promover um debate conceitual acerca da definição desse fenômeno ao mesmo tempo cinematográfico e mnemônico. As referências ao documentarismo ou à memória intergeracional são o resultado de um posicionamento refletido a ser explicitado nas próximas páginas. Trata-se de uma opção terminológica que busca um distanciamento crítico em relação à noção mais empregada para definir produções culturais dessa natureza: "pósmemória". O uso do prefixo "inter-" - agora, sim, no lugar de "trans-", como em transnacional $^{58}$ - quer ressaltar a dinâmica das interações nos processos de rememoração aqui em pauta, mantendo no horizonte o papel ativo da geração dos descendentes frente à memória da geração militante. Se, por um lado, os mais velhos protagonizaram a oposição às ditaduras do Cone Sul, por outro, os mais jovens são os agentes de uma revisão daquele passado no presente. Certos legados são transmitidos, mas há também os gestos de apropriação. Surge daí um circuito intergeracional com vetores multifacetados.

De saída, a própria ideia de "geração" merece algumas considerações. O leitor perceberá que todo o esforço deste capítulo se dá no sentido de desnaturalizar o debate sobre a memória da geração dos descendentes. A própria categoria de "geração" não poderia sair incólume. Como alerta Jean-François Sirinelli (1998, p. 133):

Certamente a geração, no sentido "biológico", é aparentemente um fato natural, mas também um fato cultural, por um lado modelado pelo acontecimento e por outro derivado, às vezes, da autorrepresentação e da autoproclamação: o sentimento de pertencer - ou ter pertencido - a uma faixa etária com forte identidade diferencial. Além disso, e a constatação vai no mesmo sentido, a geração é também uma reconstrução do historiador que classifica e rotula.

Eis porque o viés aqui adotado é mais histórico do que biológico, comportando uma elasticidade que inclui indivíduos de idades bem distintas em uma mesma conjuntura cultural de rememoração. O exemplo da ditadura brasileira, com seus longos 21 anos de duração,

\footnotetext{
${ }^{57}$ Uma versão preliminar deste capítulo foi publicada em forma de artigo (SELIPRANDY, 2015b).

${ }^{58}$ Vale mencionar que, no campo disciplinar da psicologia, existem debates que se dão nos termos do "trauma transgeracional”: cf. RODRÍGUEZ; ESPINOZA, 2006; SCHWAB, 2010.
} 
deixa patente esse aspecto. Caso fossem adotados critérios rigidamente etários, seria difícil sustentar que Flavia Castro, nascida em 1965, e Maria Clara Escobar, nascida em 1988, fazem parte da mesma geração. Entretanto, seus filmes, Diário de uma busca, de 2010, e Os dias com ele, de 2013, sim, estão inseridos em uma mesma tendência cinematográfica de revisão da ditadura. Desde que assim maleável, a categoria de "geração" é pertinente nesse contexto de discussão, e por alguns motivos que podem ser elencados sumariamente: porque a identidade geracional muitas vezes é reivindicada pelos próprios atores dessa memória, filhas e filhos à frente; porque a categoria de "geração" é um fato analítico que não pode ser ignorado, dada sua forte presença na bibliografia dedicada a essa produção cultural; e, principalmente, porque essa é uma ideia operacional para agregar um conjunto de experiências compartilhadas pelos descendentes de militantes no âmbito do Cone Sul (a infância na clandestinidade e no exílio; a orfandade de matriz política; as lutas coletivas pela memória etc.). Sobre tudo isso, Marc Bloch (2001, p. 151-152) já ponderava:

Os homens que nasceram num mesmo ambiente social, em datas próximas, sofrem necessariamente, em particular em seu período de formação, influências análogas. A experiência prova que seu comportamento apresenta, em relação aos grupos sensivelmente mais velhos ou mais jovens, traços distintivos geralmente bastante nítidos. Isso até em suas discordâncias, que podem ser das mais agudas. Apaixonar-se por um mesmo debate, mesmo em sentidos opostos, ainda é assemelhar-se. Essa comunidade de marca, oriunda de uma comunidade de época, faz uma geração. [...]

Quanto à periodicidade das gerações, é evidente que, a despeito dos devaneios pitagóricos de certos autores, nada tem de regular. Segundo a cadência mais ou menos viva do movimento social, os limites se cerram ou se distendem. [...]

A noção de geração é portanto muito flexível, como todo conceito que tenta exprimir, sem deformá-las, as coisas do homem. Mas corresponde também a realidades que sentimos bem concretas.

Pois bem, repassados sucintamente os significados do prefixo "inter-" e da raiz "geração", entra-se enfim no debate central deste capítulo: aquele que diz respeito propriamente à memória, ou melhor, aos vetores dessas conexões de memória. Los rubios (Albertina Carri, Argentina, 2003) é o título a partir do qual as reflexões serão desenvolvidas. Sem dúvida, essa foi a obra que atraiu mais atenção e suscitou as maiores polêmicas dentre os documentários do corpus aqui estudado. E isso em grande medida porque a radicalidade estética desse filme se cruza com um obstinado questionamento das versões herdadas. Albertina Carri é filha de Roberto Carri e Ana María Caruso, ambos desaparecidos em 1977, quando ela tinha apenas três anos de idade. Em Los rubios, a filha-diretora contrapõe o caráter 
fugidio de suas memórias infantis à memória consolidada da geração anterior. Frente ao desaparecimento dos pais, narrar não é uma solução simples. De fato, o documentário é muito mais o registro de um impasse. A subjetividade da diretora desdobra-se na atuação de uma atriz (Analía Couceyro), os depoimentos concedidos são exibidos sempre na opacidade da tela, algumas testemunhas-chave recusam-se a falar diante da câmera, o retorno aos lugares de memória é titubeante, as fotografias de família são furtivamente enquadradas, as recordações da infância confundem-se com a fantasia da animação, a imagem dos pais não se esboça, as identidades assumidas são postiças.

A análise de tudo isso que é visível em Los rubios será a via para a problematização de um tópico analítico recorrente neste campo de estudos: a noção de "pós-memória", tal qual elaborada por Marianne Hirsch (1993, 1997, 2008, 2012). A autora cunhou essa concepção no contexto dos debates estadunidenses sobre a rememoração da Shoah pela geração seguinte à das vítimas, sendo ela mesma filha de sobreviventes do nazismo. Com frequência, o termo é evocado nas análises de Los rubios e dos demais documentários dessa filmografia. É importante ser explícito neste ponto: a reflexão aqui proposta não assume para si a noção de "pós-memória". Porém, ela leva a ideia a sério, bem como a sua presença na bibliografia dedicada a essa produção documental no Cone Sul. As páginas seguintes se distanciam da fórmula da "pós-memória" ao realizar uma imersão crítica em seus modos de apropriação, suas premissas internas, suas transformações e incongruências no confronto com as imagens de Los rubios. Porque, vale adiantar, ao serem colocados frente a frente com o filme de Albertina Carri, os pressupostos da "pós-memória" se esgarçam e tomam novos rumos. O objetivo do capítulo é, justamente, que tal esgarçamento da definição mais reiterada nessa esfera de estudos seja o ponto de partida para um alargamento do debate conceitual acerca dessas práticas de memória.

Evita-se, assim, a crítica apressada da noção, um descarte precipitado baseado no argumento segundo o qual, no contexto das ditaduras da região, não é exato dizer que os filhos compõem a geração que sucedeu à geração das vítimas (cf. APREA, 2015, p. 240-241; CIANCIO, 2015; FABRIS, 2014, p. 330; PEREZ, 2013, p. 8-9). Ora, isso é verdade, quando ainda eram crianças ou adolescentes, a maior parte desses filhos viveu os anos autoritários e carrega efetivamente seus traumas. Eles experimentaram na pele a ausência dos pais, as indefinições da vida clandestina, a rotina de visitas à prisão, o desenraizamento do exílio. Tantos foram inclusive detidos junto com os pais e obrigados a vê-los desfigurados pela tortura, outros nasceram em centros clandestinos de extermínio (cf. COMISSÃO DA VERDADE DO ESTADO DE SÃO PAULO "RUBENS PAIVA", 2014). No Uruguai, por 
exemplo, em 2007 surgia uma agrupação denominada Niños en Cautiverio Político, reunindo jovens que, na tenra idade, passaram pelos cárceres políticos com os pais (LEVEY, 2014). Em suma, não há dúvidas de que as filhas e os filhos são vítimas em primeira mão das ditaduras do Cone Sul, e não uma geração subsequente ao trauma, como define a noção de "pósmemória".

Diante dos fatos, essa ressalva preliminar à "pós-memória" de Marianne Hirsch é pertinente, mas também é insuficiente, por duas razões básicas. A primeira é de ordem propriamente etária: esses filhos passaram por essas experiências a reboque das escolhas políticas e de vida dos pais. Ou seja, se, por um lado, essa memória não lhes é exatamente indireta, por outro, ela é uma memória infantil que seria elaborada somente anos depois. Tal ponderação de forma alguma sugere que ter sofrido os eventos seja um dado menor dessas reelaborações memorialísticas. O ponto é que, também nesses casos, existe um deslocamento temporal geracional em operação. Em tais situações, há quem defenda o uso da noção de “geração 1.5”, seguindo a proposta de Susan Rubin Suleiman (2002) ${ }^{59}$ (CIANCIO, 2015, p. 511; FUICA, 2014, p. 6; LEVEY, 2014). O fracionamento decimal das gerações, contudo, soa como outra solução demasiadamente apressada para a complexa equação entre sujeito e experiência. De todo modo, não parece estar aí a inconsistência da "pós-memória".

A segunda razão já diz respeito às dinâmicas das ideias: a evocação do tópico da "pósmemória" no contexto de análise de obras que lidam com as ditaduras da região é um fato cultural que merece atenção. Afinal, as ideias sempre viajam e, nesse circuito em especial, o traslado da "pós-memória" está conectado a uma tendência muito mais ampla de expansão do arcabouço teórico constituído nos estudos da Shoah para a indagação acerca de outras experiências traumáticas pelo globo (HUYSSEN, 2014, p. 14; JELIN, 2010a, p. 74-75; RADSTONE, 2011). A própria Marianne Hirsch (1997, p. 22, tradução nossa) havia escrito: “Desenvolvi essa noção em relação aos filhos de sobreviventes do Holocausto, mas acredito que ela pode descrever de forma útil outras memórias de segunda geração de eventos e experiências culturais ou coletivas traumáticas.” A argentina Ana Amado (2005b, p. 229, tradução nossa) concordara: "Hirsch desenvolve essa noção em relação aos filhos dos sobreviventes do Holocausto, mas a considero adequada para descrever a memória de outras segundas gerações de eventos e experiências culturais ou coletivas de índole traumática.” Tal

\footnotetext{
${ }^{59}$ Nas palavras de Suleiman (2002, p. 277, grifo da autora, tradução nossa): "por geração 1.5 eu quero designar crianças sobreviventes do Holocausto, novas demais para terem uma compreensão adulta do que estava acontecendo com elas, mas com idade suficiente para terem estado lá durante a perseguição nazista aos judeus."
} 
passagem de um contexto a outro, com as refrações causadas pelas diferenças de cada experiência, é o aspecto mais interessante a ser compreendido.

Se o Capítulo I esteve dedicado aos circuitos transnacionais dessa filmografia, este segundo capítulo agora se debruça, em primeiro lugar, sobre as circulações e transferências das ideias que gravitam as análises do documentário de Albertina Carri. Trata-se de empreender um exame paciente e aprofundado que começa pelos usos locais da noção de "pós-memória"; repassa seus limites intrínsecos; avalia suas discrepâncias frente às imagens de Los rubios; e, por último, mas não menos importante, pondera as metamorfoses de suas premissas frente à matéria audiovisual específica. O descarte precipitado da ideia de "pósmemória" motivado por sua inadequação factual, paradoxalmente, abre mão de indagar essa historicidade do conceito, as releituras concretas e as apropriações ativas que o fazem ter ressonância, a despeito de eventuais problemas, em outras paragens. Em um deslocamento final de foco, a argumentação se afasta da noção de Hirsch e se volta para as circulações culturais rastreáveis na imanência das imagens fílmicas.

\section{Os usos da noção de "pós-memória"}

Uma das passagens mais comentadas nas análises de Los rubios é aquela em que Analía Couceyro, a atriz que atua como duplo de Albertina Carri, recebe e lê o fax do Instituto Nacional del Cine y Artes Audiovisuales (Incaa) com o parecer negativo ao projeto do documentário. O teor da avaliação do órgão oficial argentino de fomento ao cinema desencadeia a tematização explícita do abismo entre as expectativas de cada geração acerca da memória. De seu lado, o instituto pede "maior rigor documental", ressalvando que "a história, tal como está formulada, põe o conflito de ficcionalizar a própria experiência”. E conclui o parecer tocando justamente na questão geracional:

A reivindicação da protagonista quanto à ausência de seus pais, embora seja o eixo, requer uma busca mais exigente de testemunhos próprios, que se concretizariam com a participação dos companheiros de seus pais, com afinidades e discrepâncias. Roberto Carri e Ana María Caruso foram dois intelectuais comprometidos nos anos 1970, cujo destino trágico merece que este trabalho se realize. (apud CARRI, A., 2007, p. 6, tradução nossa).

As demandas e sugestões do Incaa deixam patente aquilo que o órgão espera do filme: um documentário testemunhal, que dê voz à memória da geração anterior, a imagem de um monumento. 
Por outro lado, a leitura do fax, em si mesma, já segue a linha da radical reflexividade cinematográfica que guia a obra como um todo. A atriz que encena o papel da diretora, duplicando-a na tela, lê o documento que nega apoio à produção do filme que o espectador vê pronto diante de seus olhos. Na imagem seguinte, a lógica da exposição do processo de produção do documentário se mantém, e agora a equipe discute em grupo o teor do parecer, com o aparato de filmagem à mostra, em tomadas de câmera na mão em preto e branco. Albertina Carri (a própria, e não a atriz) diz para os colegas: "Este é o filme que eles necessitam, essa é a verdade, como geração, e eu os entendo. O que acontece é que é um filme que outro tem que fazer, não eu." (tradução nossa). A distância entre as representações da memória de uma geração e outra é verbalizada em imagens construídas de modo a gerar um distanciamento reflexivo na representação cinematográfica. A filha Albertina Carri não quer herdar a memória da geração anterior, e já o modo como constrói as imagens de seu filme indica esse desejo de ruptura com a representação consolidada. A memória épica dos pais não é assumida como de próprio direito. Há, no lugar de uma transmissão, uma cisão geracional da memória.

Esse impulso de distanciamento mantém a contundência ao longo de todo o filme e se impôs como chave de leitura já desde a primeira hora. Um exercício interessante é pensar a dinâmica com que a noção de "pós-memória" foi aos poucos sendo vinculada à definição dessa distância geracional em Los rubios. Em termos práticos, a revisão cronológica de suas análises escritas permite um rastreamento, quase que uma filologia dos usos da noção de "pós-memória" nas interpretações do documentário de Carri - junto com outras obras dessa cinematografia intergeracional. O objetivo aqui não é tanto sumarizar a fortuna crítica do filme, mas sobretudo identificar as vias de entrada dessa noção forjada em outro campo de estudo.

As primeiras resenhas na imprensa, alusivas à exibição do filme no Buenos Aires Festival Internacional de Cine Independiente (Bafici) ou à sua estreia comercial na Argentina (respectivamente, em 23 de abril e 23 de outubro de 2003), foram pródigas em destacar a novidade geracional de Los rubios. Dos títulos ao corpo dos artigos, os termos dessa leitura são vários: "novo olhar"; "nova perspectiva"; "quebra geracional”; "nova forma de fazer cinema sobre o tema dos desaparecidos"; "modo nada convencional"; "novo modo de narrar a história"; "filme fora do normal"; "singular experimento"; "Los rubios tem a virtude de escapar de todos os lugares-comuns do tratamento cinematográfico do tema dos desaparecidos" (MOUJÁN, 2003, p. 61, tradução nossa). Algumas afirmações colocam a obra em perspectiva com a produção cinematográfica da geração anterior: “Los rubios amplia o 
campo discursivo do cinema político na Argentina como nenhum filme o havia feito desde $L a$ hora de los hornos [(Octavio Getino e Fernando Solanas, Argentina, 1968)]” (LERER, 2003, tradução nossa). Ou ainda: "Los rubios, pode-se supor, está contado desde o olhar de uma parte da juventude dos anos 1990 não presente até hoje no cinema sobre desaparecidos"; também: “Albertina Carri mostra que as linguagens (do cinema e da política) de gerações anteriores não servem aos da sua geração. [...] Há algo de reprovação e mostra uma grande quebra entre a geração dos 1970 e a dos 1990." (MORETTI, 2003, p. 17, tradução nossa). ${ }^{60}$ No calor do lançamento do filme, a crítica na imprensa já chamava atenção para a questão do distanciamento geracional em Los rubios. A noção de "pós-memória" ainda era uma grande ausente nas resenhas jornalísticas.

Há que se levar em conta, claro, a possibilidade de que a expressão estivesse então circunscrita aos meios acadêmicos, de que o termo "pós-memória" não tivesse repercussão fora do círculo de especialistas. Pois bem, também nesse campo discursivo, a noção tampouco surgiu de pronto, sendo interessante seguir a cadência de suas aparições nas análises do documentário de Albertina Carri.

A crítica de Martín Kohan (2004a) a Los rubios publicada em Punto de vista - a célebre revista cultural argentina existente entre 1978 e 2008 - foi uma das primeiras análises mais aprofundadas do filme. Incluído no número de abril de 2004, o título do artigo é eloquente: "La apariencia celebrada." Não é o caso aqui de entrar nos meandros da sofisticada argumentação de Kohan. O fato é que sua leitura vai na contracorrente da calorosa recepção ao filme, suscitando duradouras polêmicas. No que toca mais diretamente ao tema do distanciamento geracional, a interpretação de Kohan inverte os polos daquilo que era visto por muitos como uma bem-vinda novidade. O autor leva em conta o exercício fílmico de demonstração da impossibilidade de aproximação em relação ao passado para enxergar o lado avesso de uma "prática do distanciamento". Em suas palavras: “[...] já não se pode dizer que [Los rubios] alcance ou deixe de alcançar seu objeto: o que faz é afastá-lo. Afastá-lo, colocálo longe, deixá-lo de lado; não excluí-lo, porque o afastamento é diferente da exclusão, mas apartá-lo.” (KOHAN, 2004a, p. 27-28, tradução nossa). É através desse prisma que Kohan vê um "regime de descortesia" ao qual são submetidos os testemunhos dos companheiros de militância dos pais. Na atuação da atriz Analía Couceyro, Kohan (2004a, p. 28, tradução nossa) enxerga "um vasto mostruário de modos da desconsideração: dá as costas à imagem

\footnotetext{
${ }^{60}$ As expressões pinçadas nesse parágrafo foram extraídas da compilação de recortes de matérias de imprensa reunida na pasta relativa a Los rubios do arquivo da biblioteca da Escuela Nacional de Experimentación y Realización Cinematográfica (Enerc), em Buenos Aires. Apenas as citações mais consistentes foram referenciadas.
} 
gravada dos que falam, ignora, não presta atenção, ensaia gestos ou se põe a fazer outra coisa".

A dura crítica de Martín Kohan não ficou sem resposta. No número de Punto de vista de dezembro de 2004, Cecilia Macón é uma das primeiras a evocar a noção de "pós-memória" para descrever esse distanciamento geracional que tanto incomodou Kohan. A autora rebate que, em Los rubios:

Não se trata já de pôr em funcionamento a memória do genocídio, mas sua pós-memória: é o trauma transmitido ao longo de gerações e aí mesmo modificado, não meramente em seus modos de representação, mas também nos próprios atributos que o definem como trauma. (MACÓN, 2004, p. 45, tradução nossa).

Macón (2004, p. 45, grifo da autora, tradução nossa) define Marianne Hirsch como a "gestora da noção de pós-memória", articulando em sua réplica trechos de Family frames: photography, narrative and postmemory, livro no qual Hirsch (1997) havia postulado os termos da "pós-memória".

A tréplica de Martín Kohan, publicada no mesmo número da revista, é de uma acidez inclemente. Ele escreve que, em defesa de Los rubios, Cecilia Macón:

[...] consagra algum "pós" (neste caso, a pós-memória) e com esse prefixo faz um corte que determina o caráter "retrô" de todo aquele que não o subscreva (alguém peca automaticamente por ter ficado ainda na memória, ainda no sujeito, ainda na representação, ainda no moderno). (KOHAN, 2004b, p. 47, tradução nossa, grifo do autor).

E prossegue: "Nada me parece tão inconsistente, porém, nem mais injusto para a singularidade do filme de Carri, que a noção de 'geração' que Macón emprega, e que é a espinha dorsal de sua abordagem sobre o trauma e a pós-memória.” (KOHAN, 2004b, p. 48, tradução nossa).

Nesses primeiros debates em torno de Los rubios, as polêmicas acerca da pertinência da noção de "pós-memória" vinham no bojo das divergentes interpretações do distanciamento geracional no filme de Albertina Carri. Entretanto, antes das discordâncias sobre seus sentidos, parece que o distanciamento, em si, sempre foi um consenso nas análises. Essa matriz de leitura na chave do corte geracional atravessa os textos analíticos que foram surgindo no universo acadêmico. As formulações nesse sentido, como era de se esperar, são múltiplas, mas são reiteradas as conclusões em torno desse afastamento do filme em relação à memória da geração precedente. A tendência geral da crítica universitária se inclina a saudar 
esse novo olhar como uma ruptura desejável em relação aos discursos consolidados da memória, em um movimento análogo ao da primeira acolhida do documentário na imprensa.

Ora, o que chama atenção nas análises pioneiras de origem acadêmica é o fato de que o uso da noção de "pós-memória" era ainda muito rarefeito nas primeiras definições desse distanciamento geracional em Los rubios. Ana Amado, uma das autoras que mais se dedicou ao tema, tornando-se referência incontornável nessa bibliografia, já escrevia sobre o documentarismo de filhos na Argentina desde antes do surgimento de Los rubios (vale mencionar que o nome de Ana Amado está incluído na lista de agradecimentos nos créditos finais de Los rubios). Em artigo publicado no início de 2003, ela discute a questão geracional em Papá Iván (María Inés Roqué, México / Argentina, 2000), um dos precursores dessa cinematografia na região, sem fazer qualquer menção ao termo de Marianne Hirsch (AMADO, 2003). Em um texto subsequente, incluído no livro organizado por ela e Nora Domínguez publicado em abril de 2004, Ana Amado (2004) integra a análise do documentário de Roqué à de Los rubios, ainda sem qualquer referência à "pós-memória".

Por um lado, não é improvável que essas ausências fossem uma decorrência do ritmo das circulações das ideias. A primeira formulação da "pós-memória" foi esboçada por Marianne Hirsch em um artigo de 1993. Só mais tarde, em um livro de 1997, a noção ganharia maior consistência, tendo sido retomada e desenvolvida em outros textos ao longo dos anos posteriores (HIRSCH, 1993, 1997, 2008, 2012). A ideia não era exatamente nova quando Los rubios foi lançado, mas sua elaboração estava em processo, para dizer de algum modo. ${ }^{61}$ Àquela altura, a referência da "pós-memória" ainda não havia desembarcado de vez no Cone Sul, onde o próprio fenômeno da produção cultural dos descendentes era então incipiente.

Por outro lado, não se poderia jamais ignorar a possibilidade de essa ausência estar ligada a uma escolha conceitual. Ora, os autores podem simplesmente ter optado por analisar o distanciamento geracional em Los rubios sem recorrer à noção de "pós-memória". Aos mais atentos, Cecilia Macón (2004) já havia "divulgado" a noção de Hirsch no contexto do debate sobre o documentário de Albertina Carri. Uma divulgação conturbada, ironizada por Martín Kohan (2004b) dentro de uma dura polêmica, mas que, em todo caso, potencialmente já colocava a noção no horizonte das análises. Em seu artigo sobre Los rubios, por exemplo, Verónica Garibotto e Antonio Gómez (2006, p. 109) fazem menção à "pós-memória” apud Macón, reconstituindo essa controvérsia. Mesmo assim, desde então e até hoje, não são

\footnotetext{
${ }^{61}$ Para um relato sobre a gênese da noção de "pós-memória" na trajetória acadêmica de Marianne Hirsch, cf. a Introdução de HIRSCH, 2012.
} 
poucos os autores que passaram longe dos termos da "pós-memória", ainda que enfatizando o corte geracional visível na obra (AGUILAR, 2007a, 2010, p. 175-191; ALONSO, 2007; ARFUCH, 2014; BERNINI, 2004; BRECKENRIDGE, 2008; CAMPO, 2013; DIELEKE; BRAVO, 2007; IBAZETA, 2010; KRIGER, 2007; NORIEGA, 2009; OLIVEIRA, 2013; PEREIRA, 2009; RIERA, 2009; RUFFINELLI, 2005, p. 324-338, 2007; SOUZA, 2007; WAGNER, 2005).

Ou seja, se o tema do distanciamento geracional parece se impor às análises de Los rubios, não se pode dizer o mesmo sobre o viés conceitual para a interpretação desse tópico. Uma nota de rodapé em um artigo de Gonzalo Aguilar (2007b) oferece um indício acerca dessa dimensão da escolha dos conceitos. Nela, fazendo referência à bibliografia sobre Los rubios - filme que, segundo escreve, gerou “inumeráveis, rigorosos e sugestivos ensaios [...] (algo bastante inusual para a crítica de cinema na Argentina)"-, ele cita, entre outros textos, um artigo de Gabriela Nouzeilles (2005) intitulado "Postmemory cinema and the future of the past in Albertina Carri's Los rubios" (AGUILAR, 2007b, p. 18, tradução nossa). A noção, portanto, estava "disponível" para Gonzalo Aguilar, mas em seu texto ela fica confinada em uma referência indireta de rodapé. Talvez por ser considerada uma ferramenta prescindível para o contraponto que ele estabelece entre a melancolia de Cazadores de utopías (David Blaustein, Argentina, 1995) e a novidade manifesta no documentário de Albertina Carri, junto com $M$ (Nicolás Prividera, Argentina, 2007). De todo modo, seria muito arriscado, se não estéril, ficar aqui aventando hipóteses sobre as escolhas conceituais de cada autor. Mais vale neste ponto explicitar a seguinte ressalva: se é verdade que a noção de "pós-memória" foi ganhando um espaço substantivo nos debates sobre essa cinematografia de filhos acerca das ditaduras do Cone Sul, como se verá, isso não quer dizer que ela seja onipresente.

O caso de Ana Amado é elucidativo nesse sentido. Se, em seus textos de 2003 e 2004, a noção de "pós-memória" estava ausente, em 2005 a noção passa a frequentar seus escritos, inclusive com certa centralidade. Um artigo publicado por ela em junho daquele ano intitulase "Escenas de post-memoria" (AMADO, 2005a), uma reflexão sobre cinco documentários realizados por filhas - em alguns de seus textos, Amado mobiliza a questão de gênero - de pais desaparecidos na Argentina. Em um capítulo de livro que compartilha muitas das formulações desse artigo, também de 2005, Ana Amado (2005b) inclui um tópico dedicado à "Memória e pós-memória", agora com foco na análise de El tiempo y la sangre (Alejandra Almirón, Argentina, 2004), dentro de uma reflexão mais ampla sobre a produção cultural, mais uma vez, de filhas. Nos dois textos, ela repete que esses documentários se constituem: 
[...] em um documento de memória dos sobreviventes e de pós-memória dos descendentes.

Tomo o termo "pós-memória" de Marianne Hirsch - mesmo ciente do risco que o prefixo "pós" pode implicar em relação à memória - para designar aquela [memória] que se desdobra desde uma distância geracional e desde outra conexão pessoal com a história. Hirsch desenvolve essa noção em relação aos filhos dos sobreviventes do Holocausto, mas a considero adequada para descrever a memória de outras segundas gerações de eventos e experiências culturais ou coletivas de índole traumática. (AMADO, 2005a, p. 118; AMADO, 2005b, p. 229, tradução nossa).

Em ambas as passagens, Amado faz referência a uma edição de 2002 de Family frames: photography, narrative and postmemory (HIRSCH, 1997).

Também em 2005, mas agora no contexto acadêmico estadunidense, Gabriela Nouzeilles (2005), professora na Universidade de Princeton, publica seu já mencionado artigo sobre Los rubios. Desde o título, a noção de "pós-memória" se projeta para definir uma tipologia, o "cinema de pós-memória". Refletindo sobre as "mais recentes manifestações da rememoração na Argentina pós-ditatorial”, a autora esclarece:

Refiro-me aqui ao trabalho simbólico de pós-memória, entendendo por tal não um "pós" do mnemônico - embora também possa significar isso -, mas, antes, a nova configuração e passagem ao ato (acting out) de uma memória secundária, pós-geracional, a qual difere da memória traumática por sua distância geracional e da história por sua forte conexão pessoal e emocional com o passado. (NOUZEILLES, 2005, p. 265, tradução nossa).

Na sequência, Nouzeilles cita também um trecho de Family frames, de Hirsch (1997). Ainda em 2005, Joanna Page (2005, p. 37, tradução nossa), agora no contexto universitário britânico, também mobiliza a definição de "pós-memória" ao analisar o documentário de Albertina Carri: “O exame da 'pós-memória' feito por Marianne Hirsch tem uma notável semelhança com a exploração da experiência da segunda geração em Los rubios."

Somando-se à série de 2005, Beatriz Sarlo desdobra a polêmica sobre Los rubios iniciada por Martín Kohan. Naquele ano, era publicado na Argentina o seu livro Tempo passado: cultura da memória e guinada subjetiva, cujo quinto capítulo está inteiramente dedicado à "pós-memória”, tal qual formulada por Marianne Hirsch (1997) e assumida por James Young (2000) - este último autor acolhe com entusiasmo a ideia "tão apropriadamente nomeada" pela primeira, principalmente com base em Hirsch (1993), também registrando em nota de rodapé a "excelente elaboração" de Hirsch (1997) (YOUNG, 2000, p. 2, 15 e 224, tradução nossa). A carga crítica que Beatriz Sarlo (2007, p. 105) volta contra a noção de "pósmemória" atinge em cheio Los rubios, filme escolhido pela autora como exemplo a ser 
problematizado frente aos contraexemplos de outras reconstituições realizadas por filhos naquele país. A argumentação de Sarlo (2007, p. 90-91) não recorre às meias-tintas. Ela escreve: “Marianne Hirsch chama de 'pós-memória' esse tipo de 'lembrança' [vicária], dando por inaugurada uma categoria cuja necessidade deve ser provada.”. Afinal, Sarlo (2007, p. 93, grifo da autora) prossegue:

Mas mesmo caso se admita a necessidade da noção de pós-memória para descrever a forma como um passado não vivido, embora muito próximo, chega ao presente, é preciso admitir também que toda experiência do passado é vicária, pois implica sujeitos que procuram entender alguma coisa colocando-se, pela imaginação ou pelo conhecimento, no lugar dos que a viveram de fato. Toda narração do passado é uma representação, algo dito no lugar de um fato. O vicário não é específico da pós-memória.

Para Sarlo (2007, p. 94), os atributos que costumam ser vinculados à "pós-memória" (sua natureza fragmentária, vicária, lacunar, mediada) não lhe são exclusivos. Sarlo (2007, p. 98) dilui a pretensa especificidade da noção ao ampliar a escala de observação para os debates sobre a memória que vêm ocorrendo "desde o momento em que entraram em crise as grandes sínteses e as grandes totalizações: desde meados do século XX, tudo é fragmentário". A fórmula da "pós-memória" não seria mais do que o resultado da "inflação teórica" contemporânea, fruto de um gesto teórico "mais amplo que necessário", uma entre outras “modas teóricas difundidas como tendências culturais" (SARLO, 2007, p. 95 e 103).

Quando se volta para a questão no contexto argentino, Beatriz Sarlo (2007, p. 105) concentra suas atenções justamente em Los rubios, filme que, segundo escreve, "reúne todos os temas atribuídos à pós-memória de uma filha sobre seus pais assassinados”. Todos os temas e todos os problemas, pois, segundo a autora: "O filme de Carri é um exemplo quase que repleto demais da forte subjetividade da pós-memória [...]." (SARLO, 2007, p. 110). A objeção central levantada por Sarlo (2007, p. 106) é precisamente o distanciamento buscado pela diretora em relação à geração dos pais:

Distante das ideias políticas que levaram seus pais à morte, ela procura, antes de mais nada, reconstituir a si mesma na ausência do pai [...]. A indiferença, e mesmo a hostilidade, diante do mundo de seus pais exacerba a distância que o filme mantém em relação ao que se diz deles e aos amigos sobreviventes que dão seu testemunho.

Beatriz Sarlo (2007, p. 111) não hesita em vincular essa postura distanciada da filhadiretora à origem social de sua família, contrapondo-a aos esforços de reconstituição da memória dos pais feitos por filhos de desaparecidos de condição humilde. Ela compara essas atitudes divergentes para daí concluir: "Não há, então, uma 'pós-memória', e sim formas da 
memória que não podem ser atribuídas diretamente a uma divisão simples entre memória dos que viveram os fatos e memória dos que são seus filhos." (SARLO, 2007, p. 112).

As contundentes críticas de Beatriz Sarlo não desencorajaram outros autores a seguir empregando a noção de "pós-memória" na avaliação do documentário intergeracional da região. Ao invés disso, Sarlo acabou se tornando, ironicamente, uma espécie de divulgadora contrariada de Marianne Hirsch por meio de Tempo passado: cultura da memória e guinada subjetiva, livro que logo se tornaria referência nas discussões sobre os processos de rememoração das ditaduras do Cone Sul - não sem controvérsias políticas, sobretudo no contexto argentino. Isso fica patente, por exemplo, na forma como a noção entra na análise de Julieta Roitman (2007) dedicada aos "ensaios autobiográficos no cinema" argentino, incluindo Los rubios. Escrevendo desde o ambiente acadêmico brasileiro, Roitman (2007, p. 118-119) introduz as ideias de Hirsch e Young em sua dissertação via Beatriz Sarlo (com base na edição original argentina de 2005), sem passar pelos textos daqueles autores. Roitman (2007, p. 119) chega a escrever que "Sarlo utiliza Los rubios como exemplo do que seria um trabalho de pós-memória", como se o "exemplo" em questão não fosse negativo, "um exemplo quase que repleto demais da forte subjetividade da pós-memória” (SARLO, 2007, p. 110). A tradução de Tempo passado no Brasil, que seria lançada em maio daquele mesmo ano de 2007, só viria a reforçar essa tendência por aqui. Sem descurar das ressalvas feitas pela intelectual argentina, é também apud Beatriz Sarlo que Mariana Duccini Junqueira da Silva (2015) faz referência à "pós-memória" ao analisar conjuntamente Los rubios e Diário de uma busca.

Nesse universo bibliográfico, Laia Quílez Esteve é uma das pesquisadoras que mais ênfase vem dando à "pós-memória" como noção-chave de suas análises dessa produção. Em um artigo de 2007, ela escreve que essa cinematografia de filhos se move em uma órbita que "pode ser lida sob o prisma do que Marianne Hirsch denominou, com relação aos descendentes das vítimas do Holocausto, com o termo "pós-memória'.” (ESTEVE, 2007, p. 74, tradução nossa). Em outro texto, do ano seguinte, Esteve (2008, p. 85, tradução nossa) propõe uma nova leitura de Los rubios, junto com outros documentários contemporâneos, "sob o prisma do que muitos estudiosos das obras dos descendentes das vítimas do Holocausto cunharam com o termo de "pós-memória"”. Mas é em sua tese de doutorado, de 2009, que a noção assume uma função efetivamente estruturante. Intitulada La representación de la dictadura militar en el cine documental argentino de segunda generación, nela Laia Quílez Esteve (2009, p. 71, tradução nossa) dedica-se a um abrangente debate teórico sobre o fenômeno da memória de segunda geração, esclarecendo que a ideia de "pós-memória", tal 
qual formulada por Marianne Hirsch, é "a etiqueta que, até hoje, mais êxito teve entre os especialistas neste âmbito e [será] a que utilizaremos de agora em diante para nos referir a esse tipo de artefatos literários, audiovisuais e artísticos." Beatriz Sarlo não discordaria quanto ao "êxito" dessa "etiqueta". Porém, como sustenta em sua crítica, mais do que a justificativa para uma adesão, isso deve ser encarado como um problema: "Mas os estudos de memória (nos últimos anos desenvolvidos em quantidades industriais, sobre todos os temas e identidades) citam a noção de 'pós-memória' (sobretudo tal como Hirsch a apresenta) como se ela possuísse alguma especificidade heurística [...]” (SARLO, 2007, p. 96). Laia Quílez Esteve posiciona-se nesse debate, sustentando a validade da etiqueta "pós-memória" nas 43 páginas em que reconstitui os principais debates teóricos sobre o tema. De fato, a pesquisadora incorpora a "pós-memória" na sequência de sua tese, descrevendo o contexto mais amplo dos "trabalhos de pós-memória na Argentina" para, por último, organizar suas análises dos documentários intergeracionais daquele país em uma espécie de tipologia da "pós-memória": "pós-memórias solapadas"; "pós-memórias em terceira pessoa"; "pósmemórias sepulcrais"; "pós-memórias indignadas" (ESTEVE, 2009, passim, tradução nossa).

Já no caso da apropriação da noção de “pós-memória” feita por Verena Berger (2008), é curioso notar como Sarlo e Hirsch são mencionadas lado a lado, como se concordassem. Tal é a impressão que fica diante da afirmação de que as indagações e os novos enfoques dos filhos de desaparecidos na Argentina se dão "desde o ponto de vista do que, segundo Beatriz Sarlo, 'seria a memória dos filhos sobre a memória dos pais', ou a pós-memória, termo utilizado por Marianne Hirsch para referir-se à memória dos filhos dos sobreviventes do Holocausto" (BERGER, 2008, p. 26, tradução nossa). Citada fora do contexto da polêmica, Beatriz Sarlo se transforma em uma porta-voz a contragosto da "pós-memória". Ou, ainda, em alguém que ampliou a definição, como sugere Nohora Viviana Cardona Núñez (2014, p. 1, tradução nossa): "Partimos empregando o conceito de pós-memória postulado por Marianne Hirsch, mas também a ampliação deste, que Beatriz Sarlo propõe ao considerar o caso argentino [...]."

Nas análises de Los rubios, a noção de "pós-memória" de Hirsch é evocada ainda por Michael J. Lazzara (2009), incorporada já no próprio título de seu artigo. Para esse autor, Albertina Carri seria uma entre outros cineastas que "refletem sobre o passado recente de seu país desde uma posição de "pós-memória"” (LAZZARA, 2009, p. 149, tradução nossa). Ele chega a aludir que o termo havia sido "recentemente criticado por Beatriz Sarlo", mas o teor dessa crítica vai sumarizado apenas em uma nota de referência no fim do artigo (LAZZARA, 
2009, p. 157). Além da citação de Marianne Hirsch, Lazzara (2009, p. 149-150) descreve em seu texto os desdobramentos da noção realizados por James Young (2000).

$\mathrm{Na}$ mesma época, Ana Amado (2009) entra novamente no debate. Assim como acontecera com Martín Kohan (2004a), não ficaram sem resposta as contundentes críticas de Beatriz Sarlo a Los rubios e à noção de "pós-memória" (que acabavam atingindo as análises anteriores de Amado). Em seu livro La imagen justa: cine argentino y política (1980-2007) derivado da tese de doutorado defendida em junho de 2008 na Universidade de Leiden, nos Países Baixos (AMADO, 2008) -, Ana Amado (2009, p. 162, tradução nossa) rebate diretamente a interpretação que Beatriz Sarlo (2007) fizera de Los rubios, observando que, no texto de Sarlo, "os argumentos éticos - e em certa medida morais - prevalecem sobre o olhar estético que toda obra artística solicita". Nessa passagem, Amado se refere especificamente ao fato de Sarlo ter tomado a origem social dos filhos como parâmetro para a valoração de suas abordagens do passado da geração precedente.

Polêmicas à parte, vale prestar atenção ao modo como Ana Amado retoma a noção de “pós-memória” em seu livro. Pois a ideia de Marianne Hirsch, embora siga sendo reivindicada por Amado, parece ter sido realocada para um lugar mais marginal em suas análises. De fato, em uma obra que contém uma parte de 66 páginas dedicadas às "estratégias de memória e filiação", Amado (2009, p. 199-200) concentra suas menções à "pós-memória” (seis no total) em duas páginas - reproduzindo algo que já ocorria na tese (AMADO, 2008, p. 177-178). Não é um dado menor o fato de justamente essas duas páginas do livro (e da tese) serem uma reformulação de trechos do tópico "Memória e pós-memória" de um de seus artigos anteriores (AMADO, 2005b, p. 227 e 229). No livro, incluindo novos títulos no horizonte das considerações, Ana Amado (2009, p. 200, tradução nossa) reescreve que esses filmes de filhos:

[...] constituem-se em um documento de memória dos sobreviventes e de pós-memória dos descendentes. Marianne Hirsch chama de "pós-memória" aquela [memória] que se desdobra desde uma distância geracional e desde outra conexão pessoal com a história. Pensada com relação aos filhos dos sobreviventes do Holocausto, a noção resulta adequada para descrever a memória de outras segundas gerações de eventos e experiências culturais ou coletivas de índole traumática. ${ }^{62}$

Se, nessa nova publicação, a adesão de Ana Amado à "pós-memória" é reiterada, ela não deixa de trazer também algo de residual. Esse excerto conserva uma referência

\footnotetext{
${ }^{62}$ Cotejar com a citação de AMADO, 2005b, p. 229 acima.
} 
incorporada por Amado em uma análise elaborada originalmente anos antes, como se essa citação pontual de Hirsch houvesse ficado congelada no tempo. ${ }^{63}$

Jens Andermann (2015) é outro autor que entra na controvérsia sobre Los rubios, confrontando abertamente as críticas feitas por Martín Kohan (2004a) e Beatriz Sarlo (2007). De acordo com Andermann (2015, p. 198, tradução nossa): "Ironicamente, ao mesmo tempo que acusam Carri de haver colocado a intimidade da família acima da compreensão histórica da política dos anos setenta, críticas como as de Kohan e Sarlo tentam impor à memória da militância e da ditadura uma política da família." No fundo, prossegue Andermann (2012, p. 198, tradução nossa), as objeções de ambos não estariam fazendo mais do que reafirmar os valores da "modéstia filial", exigindo "respeito aos mais velhos". No lugar disso, sustenta o autor, Los rubios recusa as "certezas tranquilizadoras", sendo uma obra que, ao lado de outros "documentários de pós-memória" argentinos, põe em cena uma "aporia constitutiva" (ANDERMANN, 2015, p. 190, 192 e 195, tradução nossa). A "influente formulação de Marianne Hirsch" (ANDERMANN, 2015, p. 180, tradução nossa) comparece nas páginas do livro de Jens Andermann enfeixando em tal viés de leitura Los rubios, Papá Iván (María Inés Roqué, México / Argentina, 2000) e M (Nicolás Prividera, Argentina, 2007).

A filiação conceitual a Hirsch pode ocorrer ainda por outras vias. Kristi Wilson (2013, p. 94, tradução nossa) convoca de passagem a noção para analisar Los rubios pelo prisma do que ela denomina "pós-memória e disjunções pós-modernas". E o faz citando Gabriela Nouzeilles (2005), algo que novamente sinaliza para as leituras em cascata que vão se desdobrando a cada entrada da "pós-memória" nessa bibliografia. A menção às críticas de Sarlo, também nesse caso, são relegadas a uma nota explicativa no final do artigo (WILSON, 2013, p. 99).

Existem, contudo, aqueles textos em que a evocação da "pós-memória" ocorre sem que haja uma efetiva adesão ao termo, nem residual, nem indireta. Jordana Blejmar (2013, p. 52, tradução nossa) menciona alguns exemplos de autoras (AMADO, 2004; NOUZEILLES, 2005; ESTEVE, 2008) as quais, “entre muitos outros acadêmicos, leram Los rubios como um exemplo do que Marianne Hirsch (1997) chamou famosamente (has famously called) de 'pósmemória"”. Ao mesmo tempo, Blejmar (2013, p. 53, tradução nossa) declara: "Concordo com Sarlo que todas as memórias são mediadas e vicárias e que, dentro de um mesmo grupo etário,

\footnotetext{
${ }^{63}$ Há que se levar em conta que, depois do livro de Marianne Hirsch de 1997, seu artigo posterior dedicado a definir melhor a "pós-memória" é da primavera de 2008 - entre março e junho no Hemisfério Norte. A tese que deu origem ao livro de Ana Amado foi defendida em junho de 2008, concomitantemente ao surgimento desse novo artigo de Hirsch. O livro, por sua vez, terminou de ser impresso em maio de 2009, sendo razoável supor que o intervalo entre a entrega dos originais e a publicação tenha inviabilizado a inclusão da referência bibliográfica de Hirsch de 2008.
} 
há diversas posturas quanto ao passado, bem como diversas maneiras de abordá-lo na forma artística." Neste caso, a polêmica surtiu seus efeitos, a alusão à "pós-memória" no texto de Blejmar é reticente. Não se ignora a presença da "famosa" noção de Hirsch na bibliografia, porém, à luz da crítica de Beatriz Sarlo, já não se reivindica uma filiação conceitual.

Mas a situação inversa também ocorre. Erica Miller Yozell (2011, p. 55, tradução nossa), logo ao introduzir a noção de "pós-memória" em sua análise de Los rubios, pondera: “O termo 'pós-memória' é agora amplamente aplicado ao contexto da pós-ditadura na Argentina, mas também já foi meticulosamente criticado por Beatriz Sarlo.” Yozell (2011, p. 55, tradução nossa) reconhece que "a crítica de Sarlo é válida”, porém, insiste: “Ainda assim, ao mesmo tempo, alguns aspectos da 'pós-memória' de Hirsch podem contribuir para a conceitualização das perspectivas geracionais da memória desenvolvidas em Los rubios [...].” No mesmo sentido, David Winks Gray (2015, p. 32, tradução nossa), em sua tese dedicada a Los rubios e outros dois títulos chilenos, avisa: "Em minha discussão sobre esses três filmes de pós-memória, estou consciente da crítica de Beatriz Sarlo à pós-memória tal qual teorizada por Marianne Hirsch e James Young.” Justamente por isso, Gray (2015, p. 32, tradução nossa) ressalva que escolheu filmes diversos em seus modos de lidar com a "pós-memória e as diferenças geracionais", "mas que, ainda assim, são ilustrativos da utilidade do conceito de pós-memória $[\ldots]$ ".

No sentido oposto, a citação distanciada da "pós-memória" pode se dar também de forma colateral. Em seu livro dedicado a El cine documental en primera persona na Argentina, Pablo Piedras (2014) não chega a entrar nesse debate conceitual, algo plenamente compreensível, afinal, o documentário intergeracional está dentro, mas não é o foco de seu recorte temático mais amplo, o documentário em primeira pessoa. Piedras remete essa discussão sobre a "pós-memória", em nota de rodapé, ao trabalho de Laia Quílez Esteve (2008, 2009). A referência surge quando ele define, de passagem, os filmes Los rubios, $M$, Papá Iván e Fotografías (Andrés Di Tella, Argentina, 2006) como "exercícios de pósmemória" (PIEDRAS, 2014, p. 78, tradução nossa). A segunda menção de Piedras à "pósmemória" sinaliza sua relação distanciada com essa ideia. Ela se dá quando o autor justifica a inclusão em determinado recorte, junto com documentários de filhos de desaparecidos, de outros títulos que não abordam especificamente a ditadura, "[...] em busca de que a análise das narrativas do eu transcenda os limites do conceito de 'geração' e as indagações sobre pósmemória do terrorismo de Estado [...]." (PIEDRAS, 2014, p. 114, tradução nossa). Dessa menção à "pós-memória" em nome de uma superação, deduz-se porque, nas páginas restantes do livro, o termo tenha simplesmente desaparecido. De fato, Marianne Hirsch não é referência 
bibliográfica no livro de Piedras. A definição de "pós-memória" que ele cita em nota de rodapé é de Mónica Szurmuk e Robert McKee Irwin, do Diccionario de estudios culturales latinoamericanos (PIEDRAS, 2014, p. 78).

No fundo, é comum que os autores façam um uso instrumental do termo "pósmemória", adotando-o como uma ferramenta que confere operacionalidade à prática analítica, sem maiores considerações sobre os meandros de suas premissas. William R. Benner (2017) deixa isso bem claro em seu texto. Tendo Los rubios no horizonte, ele afirma: "A segunda geração depende de pós-memórias para construir memórias coerentes sobre o passado traumático". Uma nota de rodapé inserida nesse ponto esclarece a origem da ideia (HIRSCH, 2008), sumariza as objeções de Beatriz Sarlo (2007) e, no final, alerta: "Este artigo não entra no debate sobre o uso do termo pós-memória, e sim examina a importância de sua função para distinguir entre memórias que são vividas e memórias que são reconstruídas com a ajuda dos demais." (BENNER, 2017, p. 126, tradução nossa).

O percurso de leituras acima traçado dá uma dimensão da frequência com que a noção cunhada por Marianne Hirsch comparece na farta bibliografia sobre Los rubios. Para além das análises dessa obra específica, há ainda uma série de outras apropriações da ideia de "pósmemória" nas publicações acadêmicas dedicadas ao documentarismo intergeracional da região em geral. A lista de autores que lidam com a formulação de Hirsch, em chaves distintas, poderia ser ampliada caso o recorte fosse estendido para o Chile (BARRIL, 2013; BOSSY; VERGARA, 2010; DIGIOVANNI, 2013; LABBÉ, 2012a, 2012b; LLANOS, 2014; PINTO, 2012; TANGE, 2013), o Uruguai (FUICA, 2014; LEVEY, 2014) ou o Brasil (COQUET, 2014), para citar alguns casos. Na introdução a um dossiê publicado em uma revista acadêmica britânica com o título "Revisiting postmemory: the intergenerational transmission of trauma in post-dictatorship Latin American culture”, Jordana Blejmar e Natalia Fortuny (2013, p. 2, tradução nossa, grifo das autoras) já diagnosticavam:

\footnotetext{
A noção de "pós-memória" se tornou, de fato, um ponto de referência comum em trabalhos sobre os legados do passado ditatorial na região. Porém, vale perguntar em que medida esses estudos se vinculam criticamente a essa noção, e quais aspectos dos casos locais são obliterados ou realçados quando os abordamos sob as lentes da pós-memória.
}

O elenco das entradas no contexto de análise de Los rubios corrobora essa impressão das autoras de que nem sempre a filiação à "pós-memória" se dá de maneira refletida. Como se viu, a polêmica nesse terreno é candente, tendo gerado seus efeitos de mediações e matizações. Contudo, há aí também muito de repetição de uma fórmula preconcebida, seja 
para rotular a priori uma tendência cultural, seja por razões práticas, em função da operacionalidade vocabular oferecida pelo termo. Quando se segue a pista das alusões a Hirsch presentes na fortuna crítica do documentário de Albertina Carri, compreende-se melhor a historicidade da circulação dessa ideia "estrangeira" nestas paragens da memória. Algumas dinâmicas já se esboçam de saída: a chegada da "pós-memória" nesse recorte bibliográfico do Cone Sul é paulatina e multifacetada, com distintos "graus" de adesão ou refutação; os usos podem ser acessórios ou estruturantes, a referência está entranhada no texto ou é relegada às notas de rodapé; e, o mais interessante, as leituras são plenas de cruzamentos. Na sequência, o capítulo se debruçará, justamente, sobre as metamorfoses pelas quais a noção passa nessa ciranda de releituras em torno do documentário intergeracional da região. Antes disso, no entanto, vale a pena ler o que escreveu a própria Marianne Hirsch.

\section{A "pós-memória" e os elos palpáveis da transmissão}

Em certo ponto de Los rubios, a atriz que duplica Albertina Carri caminha de um lado para o outro diante de um grande painel coberto por fotografias de família afixado na parede do escritório. Ela observa as fotos enquanto se escuta o depoimento concedido por uma das companheiras de militância dos pais da diretora:

Eu sinto que eles fizeram uma grande tentativa de assumir essa vida distinta com filhos e tudo, coisa que muita gente não fez. E fizeram isso comprometendo toda a vida com a militância política. Então, o que eu tenho são imagens dos encontros em que sempre estavam as crianças, em que obviamente estavam os ferros, as crianças, tudo misturado." (tradução nossa).

A atriz segue revisando outra entrevista na televisão conectada a um videocassete, na qual também se faz alusão a essa escolha de vida dos pais de Albertina Carri. Ela senta-se na cadeira diante da mesa de trabalho e, com um caderno em mãos, escreve. Entra sua voz em over:

Minha irmã Paula não quer falar em frente à câmera. Andrea diz que, sim, quer fazer a entrevista, mas que tudo de interessante ela diz quando desligo a câmera. A família, quando pode evitar a dor da ausência, recorda de uma maneira em que mamãe e papai se convertem em duas pessoas excepcionais, lindos, inteligentes. Os amigos de meus pais estruturam a recordação de forma tal que tudo se converte em uma análise política. Gostaria de filmar meu sobrinho de seis anos dizendo que, quando souber quem matou os pais de sua mamãe, vai matá-los, mas minha irmã não deixa. Tenho que pensar em algo, algo que seja filme. A única coisa que tenho é minha recordação difusa e contaminada por todas essas versões. Creio que, em qualquer 
tentativa que eu faça de me aproximar da verdade, vou estar me distanciando. (tradução nossa).

As fotografias de família. A escuta das lembranças da geração precedente. A infância marcada pela militância dos pais, em meio a reuniões e armas. O legado de uma memória idealizada pelos familiares ou politizada pelos velhos companheiros dos pais. O sobrinho, a terceira geração, que, sem maiores formulações (sem idealizações ou análises políticas), diz que vai matar os que mataram seus avós. A recordação difusa da filha contaminada por todas essas versões. Essa passagem de Los rubios coloca os tópicos centrais do tema da transmissão da memória, indissociável, nesse caso, do distanciamento geracional, tão comentado pela crítica.

A evocação do termo "pós-memória" sem que ele fosse propriamente definido até este ponto do capítulo foi absolutamente intencional. O objetivo de saída era rastrear as ocorrências da ideia na bibliografia local, em uma espécie de histórico de suas evocações que antecedesse à crítica interna. A proposta desta seção é, finalmente, à luz dos usos situados, debruçar-se sobre as linhas centrais da formulação de Marianne Hirsch.

A noção de "pós-memória" surgiu nos escritos de Hirsch em um artigo publicado no inverno (setentrional) de 1992 para 1993 sobre Maus: a história de um sobrevivente, romance gráfico em dois volumes de Art Spiegelman (2009) acerca da experiência de seu pai nos campos nazistas. O foco daquela análise era a inclusão de fotografias familiares em meio aos desenhos com os quais o autor representava o trauma do pai. Segundo Hirsch (1993, p. 8, tradução nossa), essas imagens conectavam:

[...] o passado e o presente, a história do pai e a história do filho, pois essas fotografias familiares são documentos tanto da memória (do sobrevivente) quanto daquilo que eu gostaria de chamar "pós-memória" (a do filho do sobrevivente cuja vida é dominada por memórias daquilo que precedeu seu nascimento).

Àquela altura, Hirsch (1993, p. 8, tradução nossa) admitia: "Proponho o termo 'pósmemória' com alguma hesitação, consciente de que o prefixo 'pós' poderia trazer implícito o sentido de que estamos para além da memória e, portanto, talvez, [...] puramente na história." E completava esclarecendo que a "pós-memória" certamente não leva a um lugar para além da memória, "mas é distinta da memória pela distância geracional e da história pela profunda conexão pessoal." (HIRSCH, 1993, p. 8, tradução nossa).

Em seu já mencionado livro de 1997 (o mais citado na bibliografia acima comentada), Hirsch retoma e desdobra a formulação do artigo publicado no inverno de 1992/1993. 
Algumas modificações da escrita merecem atenção. A autora repete o excerto acima transcrito, no qual declara sua hesitação ao propor o termo "pós-memória", reproduzindo ainda a distinção que estabelece entre "pós-memória", memória e história. Mas é digna de nota a diferença entre as frases imediatamente subsequentes a esse trecho. Antes, Hirsch (1993, p. 8-9, tradução e grifo nossos) havia escrito que a "pós-memória" “[...] é distinta da memória pela distância geracional e da história pela profunda conexão pessoal. A pósmemória deve refletir de volta sobre a memória, revelando-a como igualmente construída, igualmente mediada pelos processos de narração e imaginação.” Alguns anos depois, Hirsch (1997, p. 22, tradução e grifo nossos) reformula:

[...] é distinta da memória pela distância geracional e da história pela profunda conexão pessoal. A pós-memória é uma forma poderosa e muito particular de memória precisamente porque sua conexão com seus objetos ou suas fontes é mediada não pela rememoração, mas por um investimento imaginativo e pela criação. Isso não quer dizer que a memória, em si, seja imediata, mas que ela é mais diretamente conectada ao passado.

A alteração não é menor. Ela opera a passagem de uma situação de equivalência do "grau" de mediação entre "pós-memória" e memória para um desdobramento de dupla ordem: de um lado, a "pós-memória" é elevada à condição de "forma poderosa" de memória justamente por causa do "investimento imaginativo" e da "criação"; de outro, a memória, embora se reconheça que não é imediata, passa a ser vista como "mais diretamente conectada ao passado". O curioso é que movimento que poderia soar como uma quebra do equilíbrio da formulação original ("igualmente construída, igualmente mediada") estabelece, no fundo, uma equivalência de outra natureza: aquela entre a "pós-memória" como uma "forma poderosa" e a memória como uma conexão mais direta com o passado. O saldo final da reformulação é um novo nivelamento da "pós-memória" e da memória, agora em um patamar mais concreto: o parâmetro deixa de ser a inevitabilidade da mediação para se condensar no fortalecimento dos nexos com a experiência passada.

Esse deslocamento em relação à primeira formulação já esboça as feições palpáveis que a noção assumirá dali em diante. O termo "pós-memória" vinha frequentando os textos de Marianne Hirsch desde 1992/1993, ${ }^{64}$ mas foi apenas em um artigo de 2008, intitulado "The generation of postmemory" - depois reformulado e publicado como capítulo em livro (HIRSCH, 2012) -, que a autora dedicou-se de modo mais metódico a defini-lo. Nesse artigo, Hirsch reconhece de saída que o debate está pontuado por controvérsias. Em sua opinião, tais

\footnotetext{
${ }^{64}$ Para um histórico mais abrangente do termo, incluindo outros autores, cf. ESTEVE, 2009, p. 70-83. Muitos dos artigos de Marianne Hirsch foram depois compilados em HIRSCH, 2012.
} 
polêmicas e mesmo a profusão de expressões voltadas à definição do fenômeno estariam ligadas à contradição que lhe é inerente. De um lado, o fato de que os descendentes "conectam-se tão profundamente com as lembranças do passado da geração anterior que eles necessitam chamar tal conexão de memória e que, portanto, em certas circunstâncias extremas, a memória pode ser transmitida para aqueles que não estavam de fato lá para viver um evento." De outro, o fato de que, ao mesmo tempo, "essa memória recebida é distinta da lembrança das testemunhas e dos participantes contemporâneos aos fatos. Daí a insistência no ‘pós' ou 'posterior' [...]”. (HIRSCH, 2008, p. 105-106, grifo da autora, tradução nossa).

A autora esclarece que o prefixo "pós-" não sugere meramente uma posterioridade temporal. No fundo, ela afirma, a "pós-memória" compartilha as complexas sobreposições da “era dos pós-" que caracterizaria a virada do século XX para o XXI (HIRSCH, 2008, p. 106, tradução nossa). Enfim, após as ressalvas, Hirsch (2008, p. 106-107, grifo da autora, tradução nossa) define a noção, desenvolvendo suas formulações prévias:

Pós-memória descreve a relação que a geração posterior àquela que testemunhou traumas culturais e coletivos carrega acerca da experiência daqueles que vieram antes, experiências que eles "lembram" apenas por meio das histórias, imagens e comportamentos entre os quais cresceram. Mas essas experiências lhes foram transmitidas de modo tão profundo e afetivo que parecem constituírem memórias de próprio direito. A conexão da pós-memória com o passado não é, portanto, de fato mediada pela lembrança, mas pelo investimento imaginativo, pela projeção e pela criação. Crescer com essas esmagadoras memórias herdadas, ser dominado por narrativas que precedem o nascimento e a consciência, isso é arriscar ter as próprias histórias e experiências deslocadas, mesmo esvaziadas, por aquelas da geração prévia. Ser moldado, embora indiretamente, por eventos traumáticos é o que ainda desafia a reconstrução narrativa e excede a compreensão. Tais eventos aconteceram no passado, mas seus efeitos continuam no presente. Essa é, acredito, a experiência da pós-memória e o processo de sua geração.

Até esse ponto, o artigo de 2008 lidava com ressalvas e definições. Na sequência, a autora se propõe a examinar os três pressupostos que estruturam sua formulação: a memória, a família e a fotografia. É em torno dessa tríade que os limites da noção de "pós-memória" se manifestam com mais clareza.

Em sua defesa da manutenção do termo "memória" no contexto do fenômeno de segunda geração, Hirsch (2008, p. 109, tradução nossa) reconhece que a "pós-memória não é idêntica à memória: ela é 'pós', mas, ao mesmo tempo, aproxima-se da memória em sua força afetiva". Para a autora, "a quebra na transmissão resultante de eventos históricos traumáticos necessita de formas de rememoração que reconectem e reencarnem (reembody) um tecido de 
memória intergeracional que foi rompido pela catástrofe" (HIRSCH, 2008, p. 110, tradução nossa). ${ }^{65}$ No fundo:

O trabalho da pós-memória, eu quero sugerir - e esse é o ponto central de meu argumento nesse ensaio - luta para reativar e reencarnar (reembody) as estruturas de memória mais distantes (social/nacional e arquivística/cultural) ao reinvesti-las com potentes (resonant) formas individuais e familiares de mediação e expressão estética. (HIRSCH, 2008, p. 111, grifo da autora, tradução nossa).

Hirsch (2008, p. 111, tradução nossa) insiste que aquilo que é "pós-" é ainda memória justamente porque fica assim destacada "essa presença da experiência incorporada (embodied) no processo de transmissão", sinalizando "um laço afetivo com o passado, precisamente o sentido de uma 'conexão viva' incorporada (embodied 'living connection')".

Quando se dedica ao pressuposto familiar da noção de "pós-memória", Hirsch segue ancorando seus argumentos em ideias ligadas à materialidade corporal. Ela escreve: "A linguagem da família, a linguagem do corpo: atos de transferência não verbais e não cognitivos ocorrem mais claramente dentro de um espaço familiar, frequentemente na forma de sintomas.” (HIRSCH, 2008, p. 112, tradução nossa). Essa memória corpórea que é transmitida seria uma espécie de memória somática:

A ficção, a arte, as memórias e o testemunho da segunda geração são moldados (shaped) pela tentativa de representar os efeitos de longo prazo de viver em estreita proximidade com a dor, a depressão e a dissociação de pessoas que testemunharam e sobreviveram a traumas históricos massivos. (HIRSCH, 2008, p. 112, tradução nossa).

A "pós-memória" se incorpora e tem seus sintomas. Ela flui pelos laços consanguíneos: "A perda da família, do lar, de um sentimento de pertencimento e segurança no mundo 'sangra' de uma geração para a outra”, escreve Hirsch (2008, p. 112, tradução nossa), fazendo referência ao subtítulo do primeiro volume de Maus, "meu pai sangra história" (SPIEGELMAN, 2009). A autora até chega a vislumbrar a possibilidade de um alcance da "pós-memória" para além do círculo privado mais estrito. Quanto a isso, Hirsch (2008, p. 114-115, grifo da autora, tradução nossa) estabelece uma distinção entre duas “estruturas de transmissão": a "pós-memória familiar" e a "pós-memória afiliativa". A primeira circunscreve a "segunda geração literal", para a qual a "identificação intergeracional vertical entre filho e pai” ocorre no interior da família. A segunda diz respeito a uma

\footnotetext{
65 A tradução do verbo "embody" para o português não é das mais simples. As palavras "encarnar", "corporificar", "personificar", "materializar", "incorporar" ou "plasmar" estariam dentro de sua esfera semântica. Seja como for, todas gravitam em torno de uma ideia de concretude.
} 
"identificação intrageracional horizontal que torna essa posição de filho mais amplamente disponível para outros contemporâneos". De todo modo, embora a "pós-memória" possa, segundo concede Hirsch, ultrapassar o meio familiar, em uma "rede orgânica de transmissão" que inclua imaginários e arquivos oriundos da esfera pública, não deixa de haver nesse circuito uma relação de subordinação: “As estruturas familiares de mediação e representação facilitam os atos afiliativos da pós-geração. O idioma da família pode se tornar uma lingua franca acessível, facilitando a identificação e a projeção através da distância e da diferença." No fim das contas, o aceno a uma "memória afiliativa" ampliada não vai muito além de uma ressalva colateral. A argumentação logo restitui o primado do ambiente familiar e seu idioma íntimo como um dos vetores que garantem a identificação e a transmissão da "pós-memória". Ainda que, prossegue Hirsch (2008, p. 115) em mais uma ponderação, isso implique em certas armadilhas, com o risco de que tal foco no espaço da família personalize e individualize demasiadamente o trauma, obliterando o contexto histórico público.

Já na argumentação dedicada ao peso da fotografia na transmissão da "pós-memória", a premissa da ontologia técnica do meio vem se somar aos vínculos encarnados nas relações familiares. É nesse ponto que Hirsch deixa transparecer com mais ênfase sua confiança nas possibilidades de transmissão de uma memória palpável entre as gerações. Afinal, nessa esfera, além da conexão viva da memória e dos laços de sangue, opera o nexo indicial da fotografia. Ela escreve:

Mas é a tecnologia da fotografia em si, e a crença na referência que ela engendra, que conecta a geração do Holocausto com a geração posterior. A promessa da fotografia de oferecer um acesso ao próprio evento, junto com sua fácil suposição de poder icônico e simbólico, faz dela um meio inigualavelmente poderoso para a transmissão de eventos que permanecem inimagináveis. (HIRSCH, 2008, p. 107-108, tradução nossa).

Ou ainda:

Através do nexo indicial que une a fotografia a seu objeto ( subject $)$ - aquilo
que Roland Barthes chama o "cordão umbilical" feito de luz -, a fotografia
[...] pode aparecer para solidificar os tênues laços que são moldados pela
necessidade, pelo desejo e pela projeção narrativa. (HIRSCH, 2008, p. 111,
tradução nossa).

A fotografia, para Hirsch (2008, p. 115, tradução nossa), é o ingrediente que traz à tona de maneira mais direta a materialidade da "pós-memória": "Ela nos permite, no presente, não apenas ver e tocar o passado, mas também tentar reavivá-lo ao desfazer o caráter definitivo da 'tomada' fotográfica." Repetindo a lógica de ir enxertando ressalvas à medida 
que avança sua argumentação, Hirsch (2008, p. 116, tradução nossa) convoca Georges DidiHuberman (2012) e Roland Barthes (1984) para lembrar que nem tudo é objetividade na imagem fotográfica, que ela comporta simultaneamente "verdade e obscuridade, exatidão e simulacro", o "isso foi" e a "desrealização". Mas a autora logo volta à fluidez da "pósmemória", salientando o polo concreto da questão, pela via dos afetos: "Diferentemente das imagens públicas ou das imagens da atrocidade, contudo, as fotografias de família, bem como os aspectos familiares da pós-memória, tenderiam a diminuir a distância, a recobrir a separação, além de facilitar a identificação e a afiliação.” (HIRSCH, 2008, p. 116, tradução nossa). A fotografia, enfim:

[...] é uma prática de memória "inscritiva" (arquivística) que conserva uma dimensão "incorporativa" (corporificada): como documentos de arquivo que inscrevem aspectos do passado, as fotografias suscitam certos atos corpóreos (bodily) do olhar e certas convenções do ver e do compreender que acabamos por tomar como dados, mas que moldam e aparentemente reincorporam (reembody), tornam material o passado o qual estamos buscando entender e receber. (HIRSCH, 2008, p. 117, tradução nossa).

A insistência nas citações de Marianne Hirsch é proposital. Trata-se de prestar atenção aos pressupostos da noção, relendo as formulações da "pós-memória" em si, sem entrar nas polêmicas locais e indo além da mera alusão ao termo, seja ela instrumental, indireta ou irrefletida. Levando em conta a descrição que faz Hirsch das três premissas centrais de sua proposição, chega-se a algumas conclusões. Quanto à defesa de que a "pós-memória" é ainda uma memória, nota-se que o cerne do argumento é o estabelecimento de uma "conexão viva" com o passado. No que toca ao âmbito familiar da "pós-memória", o foco da autora está nos laços carnais, consanguíneos. No que diz respeito à função da fotografia nesse processo, evoca-se abertamente a força do vínculo indicial da imagem com o passado fotografado. Juntos, a conexão viva da lembrança, os laços consanguíneos e o nexo indicial da fotografia seriam os elos da transmissão da memória de geração a geração. Esses três elos, no entanto, estão fundados em uma concepção por demais naturalizada da rememoração. Como se esta fosse um páthos reificado que afeta sensorialmente a segunda geração, a carga esmagadora do trauma que vem dos pais e acomete os filhos, subjugando suas histórias. Para Hirsch, a memória que se transmite é como um fardo pesado, bem palpável, que as gerações seguintes recebem em suas mãos.

Ora, em um campo de estudos tão marcado pela ideia de "irrepresentável", a ênfase no “momento objetal da memória" (RICEUR, 2007, p. 23) seria um mérito de Hirsch caso suas premissas não flertassem com a reificação dos vetores da passagem à "pós-memória". Porque 
há uma distância enorme entre, de um lado, a afirmação de que é necessário, apesar de todas as aporias em jogo, manter uma visada referencial que tente enxergar a historicidade do trauma e, de outro, uma formulação da "pós-memória" que coisifica os nexos da transmissão. Buscar os vestígios concretos que atestem o horror, mesmo diante de todos os impasses da rememoração, é um imperativo. Bem diverso disso é o gesto conceitual que naturaliza a "pósmemória" como uma sequela inexorável. ${ }^{66}$

As ressalvas e ponderações que Marianne Hirsch vai enxertando ao longo de sua argumentação não resolvem essa limitação instalada no núcleo da noção. De fato, em suas análises, a autora sempre vai oscilando entre as potencialidades e os riscos que rondam a "pós-memória". Ela se pergunta: "Qual a melhor forma de levarmos adiante suas [das vítimas] histórias sem nos apropriarmos delas, sem chamarmos atenção para nós mesmos indevidamente, e sem, por sua vez, termos nossas próprias histórias deslocadas pelas deles?" (HIRSCH, 2008, p. 104, tradução nossa). A "pós-memória”, a autora alerta, tal como outras manifestações da "era dos pós-", "reflete uma turbulenta oscilação entre continuidade e ruptura." Ainda assim, sustenta, "ela é uma estrutura de transmissão inter- e transgeracional de conhecimento e experiência traumáticos." (HIRSCH, 2008, p. 106, grifo da autora, tradução nossa). Já no próprio parágrafo em que define a noção, como se viu, ela pondera, de um lado, que o impacto da "pós-memória" na segunda geração está mediado "pelo investimento imaginativo, pela projeção e pela criação"; de outro, aponta-se o risco de a segunda geração "ter as próprias histórias e experiências deslocadas, mesmo esvaziadas, por aquelas da geração prévia" (HIRSCH, 2008, p. 107, tradução nossa). Até os laços solidificados pela fotografia, segundo Hirsch (2008, p. 111, tradução nossa), "são moldados pela necessidade, pelo desejo e pela projeção narrativa." E a autora não ignora certa ambiguidade nisso: "Enquanto autenticação e projeção podem trabalhar uma contra a outra, os poderosos tropos da familiaridade podem também, e às vezes problematicamente, obscurecer sua distinção.” (HIRSCH, 2008, p. 117, tradução nossa). Ela chega inclusive a declarar: "Meu objetivo neste ensaio é precisamente expor os atrativos e as armadilhas da transmissão familiar." (HIRSCH, 2008, p. 115, tradução nossa). Hirsch não é uma "positivista" ingênua nesse debate. Pelo contrário, ela está em constante diálogo com as principais correntes de pensamento desse campo de estudos, sempre sinalizando as problemáticas que cercam sua definição de "pós-memória".

\footnotetext{
${ }^{66}$ O Capítulo IV deste trabalho se debruçará com mais vagar sobre a questão do "irrepresentável” e da visada referencial.
} 
Ocorre que, ao que tudo indica, ela quer situar a "pós-memória" em uma zona que esteja aquém dos impasses conceituais: nas sensações corporais, nos laços consanguíneos, no nexo indicial da imagem fotográfica, enfim, naquilo de irrefletido e inconsciente que deriva de um cerne traumático (nesse ponto, caberia perguntar se não há uma confusão entre a formulação conceitual elaborada pela acadêmica Marianne Hirsch e a experiência vivida pela Hirsch filha de sobreviventes). ${ }^{67}$ Os acenos feitos às teorizações do trauma se dão desde esse lugar pré-cognitivo onde se funda a naturalização do postulado da "pós-memória". Para usar uma imagem, a argumentação de Marianne Hirsch avança pendulando entre a fluidez e os percalços da "pós-memória" (a identificação e o distanciamento, a empatia e a alteridade, a repetição e a elaboração etc.). Contudo, o eixo dessa enunciação pendular, aparentemente reflexiva, é a transmissão somática do trauma. No fundo, Hirsch está sustentando a existência de uma estrutura de transmissão calcada em vetores bem concretos, mas se vê constantemente forçada a tecer ponderações que mitiguem o excessivo imediatismo da "viva conexão" na base do enunciado. O vaivém das ressalvas, porém, não chega a abalar os pilares da "pósmemória”. Os nexos palpáveis no cerne da noção, curiosamente, acabam oferecendo uma solução de objetividade imersa na deriva infinita (relativista, cabe dizer) que marca a lógica corrente na "era dos pós". ${ }^{68}$ Em Hirsch, as formulações acerca da "pós-memória" avançam derivando entre potências e problemas, mas seguem sempre ancoradas na concretude dos nexos de transmissão, carregados demais de afeto. Como se verá, essas flutuações na matriz da proposição terão seus efeitos nos modos como a ideia foi assimilada na bibliografia dedicada a Los rubios.

\section{A memória tateante em Los rubios}

À luz de todas essas apropriações e formulações da "pós-memória", chega enfim o momento de a reflexão mergulhar nas imagens de Los rubios. O adiamento até aqui da análise propriamente fílmica não se deu em nome de uma "revisão bibliográfica" ou de uma apresentação prévia do “estado da questão”. O movimento das páginas anteriores tenta ir além dessas fórmulas da escrita acadêmica. Tratou-se muito mais de deixar pelo caminho os

\footnotetext{
${ }^{67}$ Quanto a isso, a crítica de Beatriz Sarlo (2007, p. 96-97) não é nada polida. Comentando as análises feitas por Hirsch com base em seus próprios álbuns familiares, a argentina escreve: “A inflação teórica da pós-memória se reduplica, assim, num armazém de banalidades pessoais legitimadas pelos novos direitos da subjetividade, que se exibem não só no espaço trágico dos filhos do Holocausto, mas naquele mais amável de imigrantes centroeuropeus que se deram bem na América do Norte e encontram poucos traumas em seu passado que não se refiram a como integrar-se aos novos costumes e modas (pelo menos essa é a versão de Hirsch, que passa pelo centro exato do que aconteceu com sua própria família)."

${ }^{68}$ Para uma crítica da "deriva infinita" da interpretação professada pelo desconstrucionismo, cf. ECO, 2015.
} 
questionamentos que pautarão a análise fílmica, buscando uma abordagem que confronte as imagens e o fenômeno crítico em torno delas.

Já ficaram descritas duas passagens em que Los rubios dá visibilidade, sempre em chave problemática, aos temas do distanciamento geracional e da transmissão da memória. Esses dois tópicos, como se viu, são centrais nas leituras que foram feitas do documentário de Albertina Carri (cf. AGUILAR, 2010, p. 175-191; PIEDRAS, 2014, p. 121-124). Adicionalmente, cabe notar que Los rubios põe em tela os três elos palpáveis da transmissão da memória supostos por Marianne Hirsch: a conexão viva da lembrança, os laços consanguíneos e o nexo indicial da fotografia. Põe em tela, mas para desestabilizá-los.

O mais patente dentre os três é a relação entre a memória da geração dos protagonistas e a da segunda geração. Sentada em uma praça com um parquinho infantil ao fundo, a atriz usa a peruca loira que serve de emblema da identidade postiça em Los rubios - uma identidade distorcida, estigma de um não pertencimento de classe, que no filme é atribuída aos Carri pela vizinha do bairro humilde que admite ter indicado aos homens da repressão a localização exata do aparelho onde vivia a família de "loiros". Ouve-se a voz da atriz em over:

\footnotetext{
Vivo em um país cheio de fissuras. O lugar que foi o centro clandestino onde meus pais permaneceram sequestrados hoje é uma delegacia. A geração dos meus pais, os que sobreviveram a uma época terrível, reivindicam ser protagonistas de uma história que não lhes pertence. Os que vieram depois, como Paula L. ou minhas irmãs, ficaram no meio, feridos, construindo suas vidas a partir de imagens insuportáveis. (tradução nossa).
}

Em um primeiro olhar, os componentes da "pós-memória" estariam aí manifestos: o protagonismo dos sobreviventes, as imagens insuportáveis a partir das quais os mais jovens devem construir suas vidas. Mas é de cisão que se trata. A expressão do distanciamento, que adquire uma série de configurações (estéticas e narrativas) ao longo do filme, ganha nessa passagem em over uma explicitação pouco comum em Los rubios. Ficam aí escancaradas as fissuras entre o passado e o presente, entre a geração dos sobreviventes e aqueles que vieram depois. Os primeiros insistem em reivindicar um protagonismo e mesmo a "propriedade" daquele passado. Os segundos tentam reconstruir suas vidas em uma espécie de limbo entre as imagens insuportáveis de ontem e o presente. Nos termos colocados por Albertina Carri, parece inviável que ocorra qualquer coisa próxima de uma transmissão, ainda que os ingredientes da "pós-memória" estejam em jogo.

É nessa chave que pode ser interpretada a pouca atenção dedicada pela filha aos testemunhos dos familiares e companheiros de militância dos pais. Como visto, não foram 
nada amenas as polêmicas acerca dessa performance marcada pelo descaso quanto àquilo que diziam os entrevistados. De fato, o documentário interpõe uma cascata de mediações entre aquilo que se vê e a voz das testemunhas: a tela da televisão com os depoimentos dentro da tela fílmica; os gestos de avançar ou retroceder as fitas VHS; as notas tomadas pela atriz em um caderno; sua atenção flutuante enquanto revê os registros; a ausência de legendas que informem a identidade dos entrevistados (só indicada nos créditos finais). Todos esses são artifícios voltados a cobrir com o manto da opacidade a autoridade daquele que viveu na pele. Em Los rubios, a recusa do uso convencional das entrevistas é uma forma de romper o fluxo naturalista da palavra como legado testemunhal.

$\mathrm{Na}$ lógica fílmica, a indiferença quanto às falas da geração precedente está em franco contraste com a atenção dada à palavra das crianças. Com efeito, em Los rubios o olhar infantil manifesta-se reiteradamente, de distintas formas. Em primeiro lugar, e de modo mais óbvio, vem o registro daquilo que dizem as crianças: o sobrinho de Albertina Carri, cuja voz surge indiretamente no documentário, por meio do relato em over da atriz sobre o desejo do menino de vingar a morte dos avós; as crianças da rua Húsares, onde ficava o último aparelho dos Carri, "entrevistadas" pela equipe de filmagem e dando testemunho de sua inevitavelmente curta memória - Um dos garotos diz: "Eu, quando era pequenininho, tinha cinco anos." A atriz ri: "Quando era pequenininho tinha cinco anos? E agora, quantos tem?" Ele responde: "Seis." (fig. 31).

Em segundo lugar, vem a impostação de uma voz infantil por parte da própria Albertina Carri, quem, já adulta, emula estética e narrativamente a confusão das recordações da menina de três anos que era quando tudo aquilo aconteceu. Em termos formais, isso se dá principalmente pelo recurso à animação em stop motion com bonecos Playmobil, cujas inserções trazem cenas da vida da garota Albertina no campo, em um cotidiano no qual se confundiam o lúdico e a angústia da espera pelo aparecimento dos pais (fig. 32). A animação, enfim, dá visualidade à memória infantil de Albertina Carri, remontando ao olhar inocente da menina. A análise que Jordana Blejmar $(2013,2016)$ faz de Los rubios concentra-se nesse uso dos bonecos Playmobil nas sequências de animação. Segundo a autora, a obra "recorre à habilidade das memórias lúdicas (playful memories) para enfrentar os tabus sociais por meio de um olhar 'infantilizado' ( $a$ ‘child-like' gaze)” (BLEJMAR, 2013, p. 49, tradução nossa). O clímax da expressão de tal ingenuidade é a representação do episódio do desaparecimento dos pais como uma abdução análoga à dos filmes de ficção científica - opção que não passou imune à crítica de Martín Kohan (2004a). 


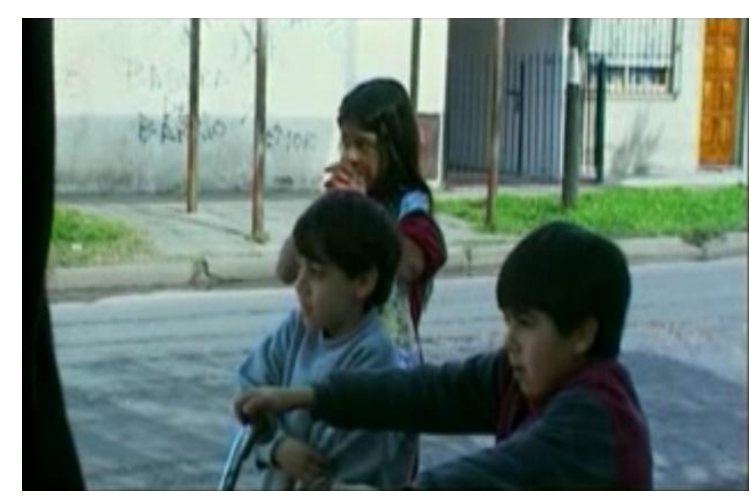

Figura 31 - Crianças da rua Húsares. Fonte: Los rubios (Albertina Carri, 2003).

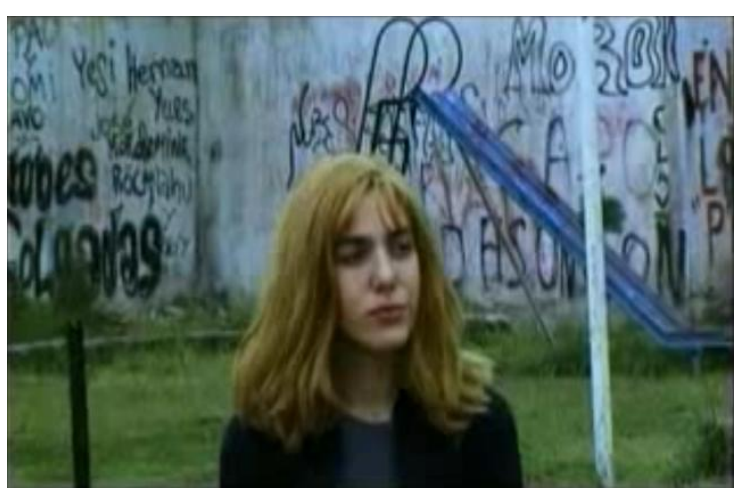

Figura 33 - Escorregador ao fundo, signo da infância. Fonte: Los rubios (Albertina Carri, 2003).

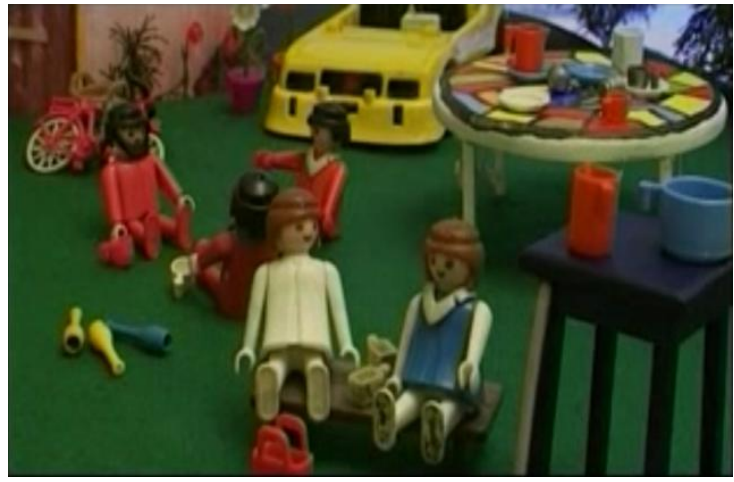

Figura 32 - Animação com bonecos Playmobil. Fonte: Los rubios (Albertina Carri, 2003).

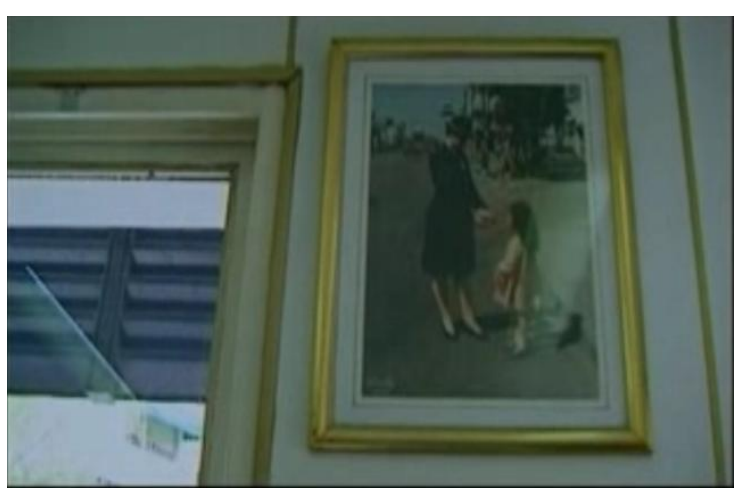

Figura 34 - Criança em quadro na delegacia. Fonte: Los rubios (Albertina Carri, 2003).

O recurso à animação, portanto, é fundamental à impostação infantil assumida em Los rubios, mas é apenas sua face mais visível. Afinal, em meio a essas inserções esparsas, fica reiterada toda uma lógica do olhar pueril ao longo da narrativa. Uma sequência em especial deixa claro o modo como a montagem fílmica estrutura essa perspectiva infantil. Imediatamente após a passagem da conversa com as crianças da rua Húsares, a equipe está dentro do carro, revisando fotografias e papéis. Ouve-se a voz over:

Primeiro me disseram que estavam trabalhando em outro país. Para mim, nessa época, trabalhar era ser médico ou advogado. Em vez disso, me diziam que minha mãe era formada em Letras e meu pai, sociólogo e jornalista. Algo de tudo isso me parecia suspeito. Creio que, quando fiz doze anos, alguém tentou me explicar algo sobre uns senhores maus e uns senhores bons, algo dos peronistas, dos descamisados, dos operários, dos militares, dos montoneros. Não entendi nada de tudo o que me disseram, nem uma só palavra. A única coisa de que me lembro daquela conversa é que comecei a pensar em armas, tiros e heróis. (tradução nossa).

No carro em movimento, a equipe ri comentando as incoerências ditas pelas crianças do bairro. Logo após essa passagem, entra uma inserção de animação na qual os bonecos 
Playmobil estão em uma festa na casa de campo, com música animada: eles nadam na piscina, escutam rádio, fazem piquenique, jogam vôlei de areia.

Em outro momento do filme, o tema do olhar pueril da Albertina garota é retomado novamente. A atriz está acompanhando o trabalho com o gado em um curral. Ouve-se a voz over narrando a decisão de que as irmãs Carri fossem viver no campo:

Andrea tinha quatorze anos e Paula, treze. O choque cultural e social para elas foi muito grande. Eu tinha cinco anos e me apaixonei facilmente pelas vacas, pelos cavalos, por meu tio Federico e por levantar-me cedo, na alvorada, para acompanhar todos esses homens fortes e rústicos nas tarefas do campo. (tradução nossa).

Um gaucho orienta a atriz sobre como aplicar a vacina em uma vaca. A voz over prossegue, sobreposta a imagens da lida campestre:

Minhas irmãs estavam muito deprimidas quando nos mudamos para cá. Eu, ao contrário, estava descobrindo a felicidade de ser uma menina malcriada em todos os aspectos. A única coisa que eu odiava era o jardim de infância, com todos esses meninos de olhinhos cruéis me perguntando: "Por que você vive com seus tios? E seu papai e sua mamãe, onde estão?" (tradução nossa).

Entra uma nova inserção de animação, agora com dois bonecos Playmobil sobrepostos a uma tomada fílmica, ambos avançando pela estrada de terra. Mais adiante, a voz over repete a mesma lógica, quando se refere às lembranças de Albertina Carri sobre o último bairro em que viveu com os pais. $\mathrm{Na}$ praça, a atriz está vestindo a peruca loira em primeiro plano, ao fundo se vê o escorregador de um parquinho, outro signo da infância inscrito sutilmente na imagem (fig. 33):

O que eu recordo do bairro é do homem do saco e da minha amiga Rosita, uma menina da vila que me ensinou a estalar os dedos e que, segundo minha avó, me passou piolhos. Ela insistiu tanto com os piolhos de Rosita que hoje a vejo montada em sua bicicleta com um piolho caminhando na testa. Talvez se chamasse María, não sei. (tradução nossa).

Esses trechos reforçam a ideia da memória infantil inocente, a qual registra as coisas que normalmente preocupam as crianças. Uma lembrança difusa, sem grandes elucubrações. Os traços desse olhar cândido da menina vão ganhando densidade mais para o final do filme, quando essa ingenuidade se desdobra nos termos de uma incompreensão radical.

A atriz grita em meio a árvores no campo, uma imagem que surge sobreposta pela voz over, que diz: 
Custa-me entender a escolha de mamãe. "Por que não se foi do país?", me pergunto uma e outra vez. Ou às vezes me pergunto por que me deixou aqui, no mundo dos vivos. E quando chego a essa pergunta, me revolve a ira, e recordo, ou nisso creio, Roberto, meu pai, e sua ira ou seu labor incansável até a morte. Onde estão as almas dos mortos? Todos os mortos compartilham o mesmo lugar? Ou os assassinados transitam em outros lugares? As almas dos mortos estão em nós que viemos depois? Naqueles de nós que tentam recordá-los? E essa recordação? Quanto tem de preservação e quanto de capricho? (tradução nossa).

Simultaneamente à fala em over da atriz em primeira pessoa, ouve-se seu grito prolongado, duplicando a voz do duplo de Albertina Carri. A panorâmica em 360 graus encontra Analía Couceyro entre as árvores daquele pequeno bosque. Ela grita, abre os braços, fica quieta, grita novamente, a câmera gira freneticamente. Um contra-plongée enquadrando a atriz estabiliza a imagem, vê-se a sombra do crepúsculo nela e nas árvores. Novamente, vem o berro desesperado, da atriz que grita em nome da filha abandonada no mundo dos vivos, que "custa a entender" as escolhas dos pais, que sente ira. Esse grito insistente, acompanhado do teor da fala em over e da câmera inquieta, desponta como um símbolo da incapacidade de elaboração da memória. Essa impotência é o que, no fundo, vem sendo tematizado insistentemente com a construção do tom infantil em Los rubios.

Mais à frente, a passagem em que a atriz é dirigida por Albertina Carri dando testemunho sobre seus três desejos de menina - "que a mamãe volte, que o papai volte, e que voltem logo" (tradução nossa) - repõe o tópico da inocência infantil e suas consequências. A performance do relato desses desejos ganha forma fílmica em uma sequência de tomadas repetidas em que a atriz e a diretora buscam a melhor entonação para a cena. Os próprios desejos da menina eram, em si, uma reiteração: "[...] passei muitos anos desejando sempre o mesmo [...]. Na realidade, é um só desejo, mas sempre o estruturei em três partes para que tivesse mais força." (tradução nossa). Incapaz de elaborar aquela experiência, resta à garota (e à cineasta) a pulsão da repetição (FREUD, 2010b).

Adulta, Albertina Carri repete em Los rubios os traços infantis de suas primeiras lembranças. O documentário atualiza a memória da filha que, assim como as crianças da rua Húsares, à época dos eventos estava mais preocupada em brincar. É uma memória que agora se plasma na animação com bonecos Playmobil. Recordações de quem não entendia nada sobre peronistas, descamisados, operários, militares ou montoneros. Evocações difusas da menina que, a despeito da ausência dos pais, encantava-se com a vida no campo. Que registrou, em primeiro lugar, a lenda do homem do saco e o piolho da amiga Rosita. As palavras do sobrinho ou das crianças da rua Húsares ecoam as reminiscências da garota 
Albertina Carri: sua memória sem formulação, cuja dimensão temporal é de outra ordem. Em suma, uma memória da incompreensão.

O grito da atriz no presente é o meio de expressão mais angustiante da incompreensão que a filha carrega desde a infância. Mas também pode ser o sinal de um enfado. Pois se, por um lado, a Albertina Carri diretora repete em seu filme o olhar pueril da Albertina Carri menina, por outro, essa preponderância da perspectiva infantil não deixa de trazer consigo o impulso de fazer tábula rasa de tudo aquilo que a geração anterior tem para dizer. Os familiares e ex-militantes são ouvidos sem atenção, os depoimentos que, segundo a filha, idealizam seus pais como indivíduos e guerrilheiros exemplares são encobertos pela opacidade cinematográfica. Às crianças, que não têm memória daquele passado, escuta-se com paciência. E é, afinal, a rememoração da Albertina garota que conduz a narrativa. $\mathrm{O}$ distanciamento geracional se configura nesse desequilíbrio entre a palavra de adultos e crianças. É aí que se percebe a lógica por trás da recusa da filha em compreender, em assimilar as fórmulas heroicas preconcebidas de uma herança envelhecida.

O que dizer, então, a respeito do tratamento dado em Los rubios à questão dos laços consanguíneos, o segundo elo da transmissão da "pós-memória" delineado por Marianne Hirsch? Enquanto repassa algumas fotografias de família soltas, a atriz que representa o duplo de Albertina Carri telefona para a Equipe Argentina de Antropologia Forense (EAAF). A atriz diz estar buscando dados sobre os pais, desaparecidos em 1977. A atriz informa os sobrenomes dos dois, Carri e Caruso (note-se que são coincidentes as iniciais de Albertina Carri e Analía Couceyro). No plano seguinte, a atriz chega ao escritório da entidade. Depois, em uma espécie de pré-cena em preto e branco, é a equipe que entra no escritório, carregando os equipamentos de filmagem. Novamente em cores, a atriz observa alguns quadros com esquemas do esqueleto humano, e logo acompanha o funcionário na busca no banco de dados computadorizado. Em seguida, a atriz tem o dedo picado para a coleta de amostras de seu sangue. No fim, a atriz observa o funcionário da EAAF preenchendo um formulário com o nome de Albertina Carri. Em corte seco, entram tomadas em preto e branco, como em um pós-cena, e agora é a própria Albertina Carri quem tem o dedo picado e recolhe amostras de seu sangue. Nessa passagem, a herança consanguínea também é submetida à diluição ficcional que guia Los rubios: a atriz é quem enuncia os sobrenomes dos pais; a atriz é quem acompanha a busca no banco de dados; a atriz é quem primeiro fornece o sangue para a coleta de DNA. Ou seja, nem a prova mais cabal da filiação sai ilesa do jogo da fabulação proposto pelo filme. E a filha-diretora também dá seu sangue, duplicando o laço, embaralhando a descendência, mostrando as faces encenada e genuína dos nexos geracionais. 
O terceiro elo da transmissão da "pós-memória" suposto por Marianne Hirsch, o nexo indicial da fotografia, é igualmente desestabilizado em Los rubios. No episódio do telefonema à EAAF, a atriz já manuseava as fotos soltas de passagem, quase distraída enquanto se informava sobre a visita àquela instituição. Enquanto ela fala ao telefone, um movimento de câmera vai revelando um amontoado de fotografias de família esparramado sobre a mesa, junto com publicações do pai, no que parece ser uma espécie de corpus arquivístico - um tanto desordenado - da pesquisa realizada para o documentário. ${ }^{69}$

Em outros momentos, as fotografias estão afixadas em painéis de isopor na parede, dispostas de modo a que se sobreponham, misturadas aquelas que são em preto e branco e as em cores, as mais antigas e as mais recentes, sem qualquer legenda informativa. Em uma dessas passagens, a câmera vai percorrendo o painel em uma deambulação em close-up, as fotos se encobrem parcialmente umas às outras, sem distinção entre imagens da infância dos pais ou da infância das filhas. Já em outro segmento, as fotos de família são exibidas em planos sucessivos, também em close-up, reforçando a lógica do embaralhamento. Logo em seguida a essas tomadas, entra um trecho de pós-cena, em preto e branco, quando a equipe de filmagem está em um intervalo descontraído. Aí é possível ver mãos que escrevem em um painel de isopor com fotografias. A própria Albertina Carri afixa esse painel na parede do escritório, acima da mesa de trabalho. Pela rapidez do plano, só congelando a imagem é possível ler o que está escrito ali: “Autoficcionalidade / Identificação - mecanismos de distanciamento" (tradução nossa).

De fato, o uso da fotografia de família durante todo o filme passa longe da restituição do passado pela imagem. Ao espectador é negada a figuração do que desapareceu pela presença do traço de luz no papel. Termina o documentário e não se tem ideia de como eram os rostos de Roberto Carri ou Ana María Caruso. Não há retratos dos pais inseridos no filme, ao menos não de quando eram adultos. Em mais um signo da preponderância infantil na obra, nenhuma das fotografias vistas nesses planos descritos mostra a face de qualquer pessoa adulta. A sobreposição das fotos nos painéis é feita de modo a sempre ocultá-las. Nesse álbum embaralhado de família, apenas as crianças têm rostos (fig. 35-36).

O corte geracional sugerido metaforicamente por essa supressão da face dos adultos ganha expressão quase literal na passagem em que a atriz recorta as fotografias de família. Afastando-se mais uma vez da reverência que a memória das vítimas solicita, a filha dessacraliza o álbum familiar, não hesitando em lançar mão da tesoura para fazer uma

\footnotetext{
${ }^{69}$ A inclusão das publicações paternas nesse plano será analisada adiante.
} 
intervenção definitiva nas imagens dos pais (fig. 37). A atriz, em nome de Albertina Carri, recorta-lhes a silhueta, colando-as em uma folha de papel sobre a mesa. Significativamente, bonecos Playmobil repousam sobre essa mesma folha, sobre essa mesma mesa onde estão espalhadas as fotos desse álbum caótico (fig. 38). Ficam no mesmo plano, portanto, as figuras dos pais recortadas e os bonecos de plástico de feições invariáveis; a autenticidade corrompida da imagem e o emblema das fantasias infantis. Nesse mesmo gesto, corta-se a indicialidade fotográfica como vetor da transmissão da memória.

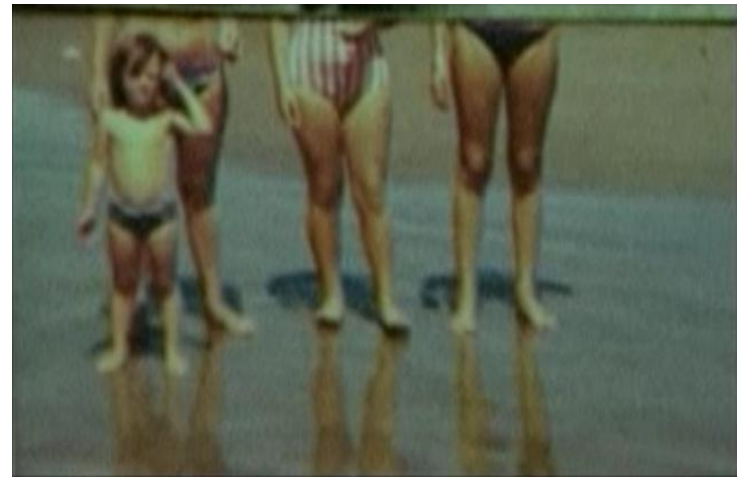

Figura 35 - Um álbum embaralhado de adultos sem face. Fonte: Los rubios (Albertina Carri, 2003).

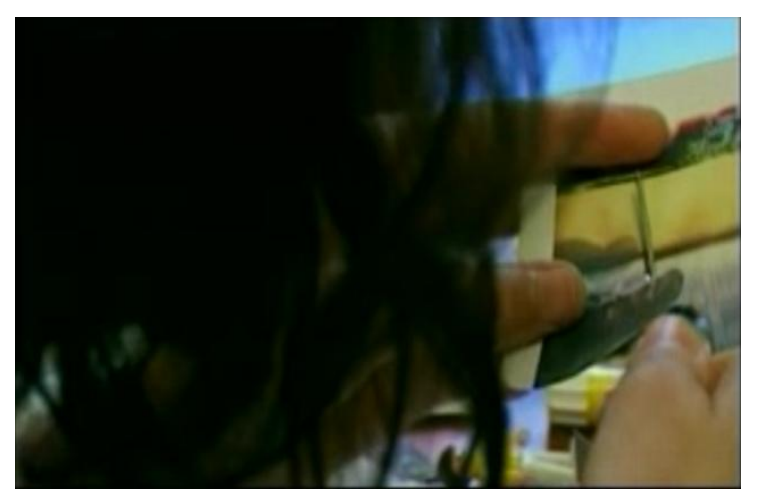

Figura 37 - Álbum familiar recortado. Fonte: Los rubios (Albertina Carri, 2003).

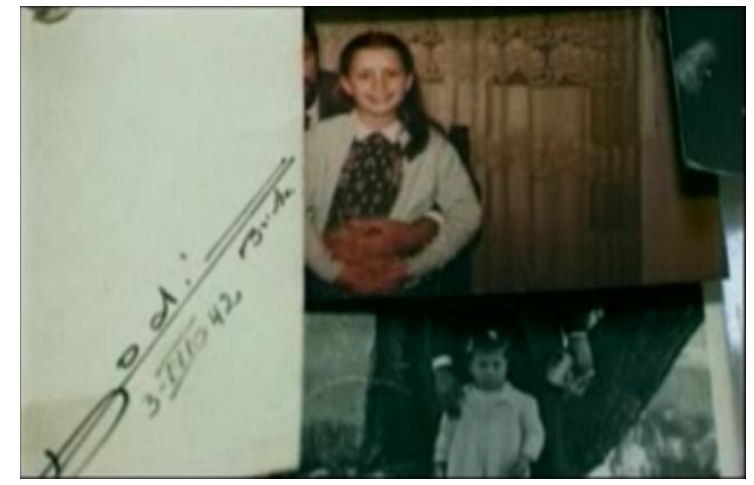

Figura 36 - Adultos sem rosto nas fotos sobrepostas. Fonte: Los rubios (Albertina Carri, 2003).

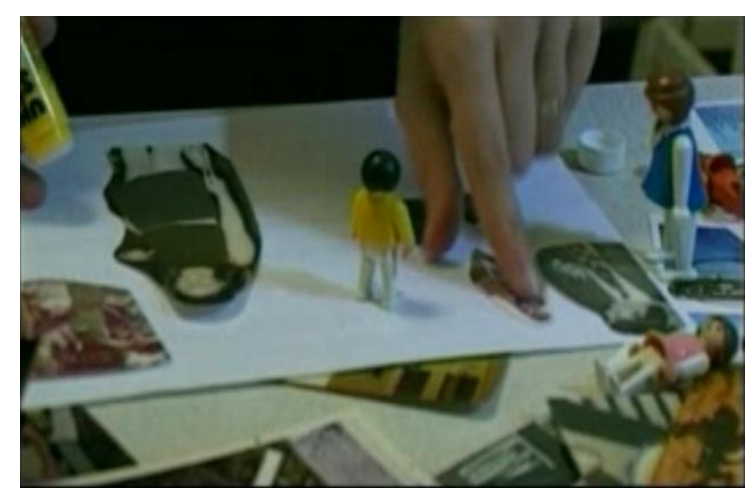

Figura 38 - Fotos dos pais e Playmobil no mesmo plano. Fonte: Los rubios (Albertina Carri, 2003).

Em Los rubios, a insistência no emprego de estratégias estéticas de distanciamento se dá em nome da reiterada afirmação do distanciamento geracional. Na lógica fílmica, esses dois níveis de distanciamento são inseparáveis. Quando põe em tela os componentes que Marianne Hirsch elenca como os três vetores concretos da "pós-memória", a abordagem de Los rubios não abandona seu impulso de ruptura. Olhando de perto, nota-se que aquilo que está inscrito em suas imagens vai na contracorrente da noção de "pós-memória" tal qual professada por Hirsch. Afinal, o que estrutura o filme não é tanto uma transmissão somática, ainda que ressalvada, mas, ao contrário, um ato radical de cisão: com o legado direto da 
memória e, ao mesmo tempo, com as relações imediatas entre representação e realidade. Los rubios manipula a carga dos elementos referenciais (os testemunhos, o sangue, as fotografias) para embaralhar e dissolver os nexos intergeracionais. No filme, vê-se o tatear de uma história em busca da ruptura. No conceito, a naturalização dos elos palpáveis da transmissão da "pósmemória".

\section{As transferências conceituais da "pós-memória"}

Há um curto-circuito entre os três elos palpáveis da transmissão da memória traumática, descritos acima na leitura de Marianne Hirsch, e aquilo que se vê nas imagens de Los rubios. Onde estaria, afinal, a transmissão da "pós-memória" no filme, quando o que nele se destaca é, ao contrário, a ruptura? Simplesmente decretar a impertinência da noção de Hirsch para a análise do documentário de Albertina Carri não resolve a questão. Porque as interpretações do filme na chave da "pós-memória", como se viu, são um fato, e parece mais interessante compreender esse movimento de apropriação do que descartá-lo como um mero despropósito.

Nesse sentido, vale a pena retomar os autores que mobilizam a "pós-memória" para interpretar Los rubios, elencados algumas páginas acima. Agora não mais em função de um panorama dos modos de entrada do termo na bibliografia local, mas sim buscando os significados de fundo das apropriações. Ora, naquele primeiro levantamento dos usos da noção, foi proposital a omissão dos trechos de Marianne Hirsch citados nas análises do filme. Era interessante ver antes o que dizia Hirsch em suas próprias formulações para, daí sim, avaliar os modos como seu texto é assimilado. A ideia de "transferências conceituais" guiará essa releitura das leituras de Hirsch no Cone Sul. Neste ponto, é indispensável explicitar duas inspirações. A primeira, mais indireta, é metodológica e vem das releituras que faz Carlo Ginzburg (2006a) das leituras do moleiro Domenico Scandella, o Menocchio, rastreando as transmutações surgidas na intersecção entre distintas tradições culturais. A segunda, mais próxima, é conceitual e vem da noção de "transferência cultural" ( "transfert culturel" no original), com a qual Michel Espagne (2013) leva a reflexão sobre as trocas culturais para além das ideias de movimento (circulações) ou de fluidez das fronteiras (transnacionalismo). Nos termos deste autor, mais importantes do que os fluxos em si são as metamorfoses, as assimilações e as releituras dos bens culturais em contextos alheios a sua produção. Para captá-las, é necessário partir de uma perspectiva não hierárquica, abolindo-se as ideias de influência, de autenticidade e de originalidade. Nas palavras de Espagne (2013, p. 2, tradução 
nossa): "Transferir não é transportar, mas, antes, metamorfosear, e o termo não se reduz em caso algum à questão mal circunscrita e muito banal das trocas culturais. É menos a circulação dos bens culturais que sua reinterpretação o que está em jogo.” Como se verá, Marianne Hirsch pode até ter sido aquela que cunhou a noção de "pós-memória". A partir daí, os caminhos tomados pela ideia vão seguindo uma complexa dinâmica de ressignificações.

O exercício a seguir lança mão de uma transferência conceitual específica (da “transferência cultural”, de Espagne) para pensar outra transferência conceitual (da "pósmemória", de Hirsch). Em linhas gerais, a releitura daquele conjunto de textos sobre Los rubios sugere um movimento comum de "inversão de ênfase", para dizer de algum modo, entre os polos da transmissão e do distanciamento já implícitos na noção de "pós-memória". É o caso de verificar como essa "metamorfose" acontece na prática. O foco agora passa a ser o modo como o texto de Marianne Hirsch é citado pelos autores que analisam Los rubios. Para evitar uma terceira tradução (do inglês para o espanhol e do espanhol para o português), as citações serão mantidas na língua em que surgem. Afinal, logo se verá, a tradução também é um modo fundamental de transferência.

Cecilia Macón (2004) foi o primeiro caso apontado acima de uso da noção de "pósmemória" no contexto da interpretação de Los rubios. Ela cita da seguinte maneira a definição de Hirsch (1997), extraída da página 22 de Family frames: photography, narrative and postmemory:

Marianne Hirsch - gestora de la noción de postmemoria - ha señalado que este concepto "se distingue de la memoria por una distancia generacional, y de la historia por una profunda conexión personal. La postmemoria caracteriza la experiencia de aquellos que crecieron dominados por las narrativas anteriores a su nacimiento, cuyas historias tardías son evacuadas por las historias de la generación anterior moldeadas por eventos traumáticos que no pueden ser comprendidos ni recreados". (MACÓN, 2004, p. 45, grifo nosso).

Da mesma página 22 do mesmo título de Hirsch (1997), Ana Amado faz a seguinte citação direta (com recuo à esquerda e aspas) em seu capítulo de livro "Las nuevas generaciones y el documental como herramienta de la historia" (AMADO, 2005b):

Postmemoria es una poderosa y muy particular forma de memoria precisamente porque su conexión con su objeto o su fuente está mediada no a través de la recolección, sino por su instalación, su investidura y creación. Esto no implica decir que la memoria en sí misma no sea mediatizada, sino que ésta se conecta al pasado más directamente. (HIRSCH, 1997, p. 22 apud AMADO, 2005b, p. 229, grifo nosso). 
Já no artigo "Escenas de post-memoria" (AMADO, 2005a), esse mesmo trecho de Hirsch deixa de ser destacado graficamente como citação direta para se tornar uma paráfrase. Ana Amado (2005a, p. 118, grifo nosso) reelabora:

La post-memoria es una particular forma de memoria precisamente porque su conexión con su objeto o su fuente está mediada de diversas maneras. Esta mediación actúa menos, quizás, respecto a la recolección de los datos de la historia que en cuanto a su instalación, su investidura, la creación y recreación que imprime a aquello que conoce por narraciones y relatos.

Nesses dois textos de 2005, continuando a referência à autora estadunidense, Ana Amado (2005a, p. 118, 2005b, p. 229, grifo nosso) reproduz paráfrases agora coincidentes:

Post-memoria, por lo tanto, sería la que caracteriza las experiencias de
aquellos que crecieron dominados por narrativas que precedieron su
nacimiento, cuyas propias historias son modeladas con retraso por las
historias de la generación previa y labradas por eventos traumáticos que, por
lo general no pueden ser ni comprendidos del todo, ni recreados. O
recreados bajo sus propias versiones y condiciones.

Vale a pena olhar minuciosamente para a tradução e as paráfrases de Ana Amado, pois elas já carregam o gérmen da "inversão de ênfase" mais ampla observável na bibliografia. A redação original de Marianne Hirsch (1997, p. 22, grifo nosso) é esta:

Postmemory is a powerful and very particular form of memory precisely because its connection to its object or source is mediated not through recollection but through an imaginative investment and creation. This is not to say that memory itself is unmediated, but that it is more directly connected to the past. Postmemory characterizes the experience of those who grow up dominated by narratives that preceded their birth, whose own belated stories are evacuated by the stories of the previous generation shaped by traumatic events that can be neither understood nor recreated.

Curiosamente, Amado (2005b, p. 229, grifo nosso) traduz "but through an imaginative investment and creation" por "sino por su instalación, su investidura y creación". E, quando transforma a citação direta vertida para o espanhol em paráfrase, Ana Amado (2005a, p. 118, grifo nosso) mantém essa escolha de tradução: "su instalación, su investidura, la creación y recreación". Na citação e na paráfrase, a substituição de "imaginative investment" por "su instalación, su investidura" subtrai o teor de imaginação da formulação em inglês. Algumas páginas acima, já ficou apontado como, nessa construção de Hirsch, o "investimento imaginativo" implícito à "pós-memória" a transformava em uma "forma poderosa" apta a fortalecer os nexos com o passado. Em sua tradução, Ana Amado prescinde dessa força da imaginação. Mas acaba conferindo uma concretude de outra natureza à definição, uma vez 
que troca a ideia de "investimento imaginativo" por dois substantivos ("instalação", "investidura") os quais, também em espanhol, remetem à ideia de algo que se coloca, alguma coisa que se reveste. Compreende-se melhor esse deslocamento da tradução quando se olha para a paráfrase que vem em seguida, repetida nos dois textos de 2005. Nela, a autora argentina opera uma segunda supressão: trocando "whose own belated stories are evacuated" (HIRSCH, 1997, p. 22, grifo nosso) por "cuyas propias historias son modeladas con retraso" (AMADO, 2005a, p. 118; AMADO, 2005b, p. 229, grifo nosso). Note-se que a paráfrase reposiciona o verbo "shaped", que no original se refere às histórias da geração precedente moldadas pelos eventos traumáticos, para substituir o verbo "evacuated", o qual caracteriza as "belated stories" da segunda geração. Com isso, necessita encontrar um outro sinônimo em espanhol para "shaped": "labradas". Todas essas trocas fazem com que, na paráfrase, a "pósmemória", embora ainda "dominada" e "moldada" pela memória da primeira geração, deixe de ser "evacuada". Algo se instala ("su instalación, su investidura"), portanto, naquilo que para Hirsch estava esvaziado. E esse algo vem expresso no desfecho da paráfrase: "O recreados bajo sus propias versiones y condiciones." (AMADO, 2005a, p. 118, AMADO, 2005b, p. 229). Na verdade, essa última linha é uma adição de Ana Amado, sem equivalente no trecho original de Marianne Hirsch.

Em síntese, na formulação de Marianne Hirsch, reproduzida por Cecilia Macón, a segunda geração cresceu dominada pelas narrativas da geração precedente, tendo suas próprias histórias evacuadas. Nesses termos, a segunda geração assemelha-se a um recipiente esvaziado apto a receber a memória que lhe transmite a geração que viveu o trauma na pele. Os filhos até podem imaginar e criar, mas apenas para que seja mais poderosa a conexão com o passado traumático dos pais. Em suas minúcias, a tradução e as paráfrases de Ana Amado efetuam uma alteração de ênfase considerável na "pós-memória". Na reformulação da autora argentina, a segunda geração continua sendo moldada pelas histórias dos sobreviventes, mas não é evacuada. Mais do que a imaginação, existe algo que se instala nesse espaço: aquilo que os filhos recriam "sob suas próprias versões e condições".

Esta análise densa em torno das leituras da página 22 do livro de Marianne Hirsch (1997) mostra que, como tantas vezes ocorre, o significativo está no detalhe (cf. GINZBURG, 2007c). Vale explorar um pouco mais aquilo que cerca essa página de Hirsch, na medida em que ela vai se revelando como o epicentro da propagação da noção de "pós-memória" nos estudos do documentário intergeracional no Cone Sul. Afinal, essa mesma página 22 é também citada por Gabriela Nouzeilles (2005). Nesse caso, não há questões de tradução, pois esta autora também escrevia em inglês. Especificamente, Nouzeilles cita: 
According to Marianne Hirsch, postmemory is "a very particular form of memory precisely because its connection to its object or source is mediated not through recollection but through an imaginative investment and creation". (NOUZEILLES, 2005, p. 265).

Chama atenção agora o fato de que Nouzeilles inicie sua citação justamente no ponto em que Hirsch escreve que a "pós-memória" seria "a powerful and very particular form" (HIRSCH, 1997, p. 22). No recorte de Nouzeilles, contudo, fica suprimida essa dimensão "powerful” da "pós-memória", cujo sentido de fortalecimento dos nexos com o passado já ficou discutido anteriormente. Para aquela que cita, a "pós-memória” é, em primeiro lugar, "a very particular form" cuja ênfase está no papel ativo da segunda geração: justamente, o investimento imaginativo e a criação. A interpretação de que Nouzeilles acentua o papel ativo dos filhos em sua releitura de Hirsch ganha corpo quando se observa que a continuação do texto original, não citada, descreve a segunda geração como dominada e evacuada pelas narrativas precedentes.

Algo análogo ocorre quando Verena Berger (2008, p. 26) evoca a mesma página 22 de Hirsch (1997). A autora introduz a definição de "pós-memória" parafraseando - ou seja, assimilando com suas próprias palavras - a ideia do gesto imaginativo da segunda geração. Ela escreve: "En estos casos - generaciones siguientes a las que padecieron o protagonizaron los acontecimientos - no existe una memoria directa, sino una reconstrucción a partir de la imaginación, de la creación individual, ante la incapacidad de comprender." (BERGER, 2008, p. 26, grifo nosso). Ora, na redação de Hirsch, a menção ao "investimento imaginativo" e à “criação" era uma ponderação - mais uma - que tentava dar conta do caráter indireto da "pósmemória". O investimento imaginativo e criativo da segunda geração era ali o componente que fortalecia o nexo pessoal dessa rememoração vicária, substituindo a lembrança própria. Se é verdade que existe aí um papel ativo da geração seguinte, trata-se de um gesto de vinculação. Na paráfrase de Verena Berger, a ressalva vinculante de Hirsch adquire o estatuto de uma afirmação da segunda geração: a palavra "investimento", que acena para a conotação da energia psíquica ligada ao traço somático da "pós-memória", torna-se "reconstrução"; a palavra "criação" que encerrava a frase ganha o qualificativo "individual". O gesto criativo dos descendentes se desdobra nessa releitura, transformado em uma reconstrução individual, e não mais o "investimento" psíquico que, suprindo a falta de lembranças diretas, sujeitava os filhos vicariamente à carga da memória herdada. Curioso é que, na imediata sequência dessa reelaboração, a autora inclua a citação direta extraída da página 22 de Hirsch (1997), mantendo o original em inglês, justamente da frase sobre os descendentes que cresceram 
dominados, que tiveram suas histórias esvaziadas pelos traumas da geração prévia. O que resulta daí, entre a paráfrase que valoriza a ação e a citação direta que aponta para o esvaziamento, é a síntese feita por Berger no fechamento desse seu parágrafo. Ao concluir sua evocação da "pós-memória", ela projeta uma interferência construtiva para o âmbito social: "Desde la perspectiva personal y la mirada subjetiva, la postmemoria interfiere en la construcción de la memoria colectiva o histórica de la sociedad en su conjunto" (BERGER, 2008, p. 26).

Por sua vez, Michael J. Lazzara (2009) faz uma releitura ainda menos literal da definição de Marianne Hirsch, invertendo de forma mais abrupta a ênfase na transmissão ao ressaltar aquilo que agora se torna o "caráter imaginativo" da "pós-memória". Lazzara escreve (2009, p. 149) em inglês, fazendo referência a Hirsch (1997) sem especificar a página:

Hirsch's definition hinges on her observation that even though all memories are communicated through acts of mediation and representation, the "imaginative character" of memory becomes all the more intense when generational distance is in play. It is this generational distance, coupled with the indirect, fragmentary, and imaginative qualities of post-memory, that, for Hirsch, makes it a theoretical category worthy of distinction in its own right.

Em um lance de ressignificação, o "investimento imaginativo", que em Hirsch supria a distância geracional ao se colocar como vetor substitutivo apto a fortalecer o vínculo com a memória de eventos não vividos, transforma-se em "caráter imaginativo", o qual se torna tanto mais intenso à medida que a distância geracional está em jogo. $\mathrm{O}$ foco vai, assim, para as "qualidades indiretas, fragmentárias e imaginativas da pós-memória". As ressalvas de Hirsch tomam aqui o lugar da asserção de fundo, a força do vínculo da "pós-memória" perde espaço para tudo aquilo que é mediação nesse processo.

Erica Miller Yozell (2011, p. 55) enfatiza graficamente a dimensão do "imaginative investment and creation" ao adicionar um grifo seu nessas palavras de Hirsch (1997) quando cita o célebre trecho da página 22. Em sua leitura desse parágrafo de Hirsch, Yozell (2011, p. 55) retira o poder de "esvaziamento" das histórias das novas gerações exercido pela "dominação" da memória herdada. Ecoando o que se vê nas imagens de Los rubios (vale lembrar das sugestões feitas pelo Incaa via fax), para essa autora, é a codificação das abordagens admitidas do passado traumático - e não propriamente o "esvaziamento" causado pelo legado traumático - o que gera tensões entre as narrativas das gerações mais velhas e as histórias posteriores da segunda geração. No final das contas, prevalece, aí também, o polo ativo da "pós-memória". Yozell (2011, p. 56, tradução e grifo nossos) conclui: “O filme de 
Carri assume esse grau mais elevado de 'investimento imaginativo' ao mesmo tempo como um desafio e um potencial para a agência."

Jens Andermann (2015), também ressaltando o polo ativo da segunda geração, pinça exatamente essa mesma passagem da página 22 em que Hirsch (1997) menciona o "investimento imaginativo". Ele escreve, na versão em espanhol de seu livro publicado originalmente em inglês:

Según la influyente formulación de Marianne Hirsch, la posmemoria no es un estado de olvido "posterior" o "más allá" de la memoria. Más bien, lo particular que tiene es que su relación con el objeto rememorado - en este caso, las luchas de los años setenta y su violenta represión - "no está mediada a través del recuerdo, sino a través de una carga de imaginación y creación". (ANDERMANN, 2015, p. 180, grifo nosso).

Mais uma vez, aquilo que em Hirsch era uma entre tantas ressalvas é elevado à categoria de traço distintivo da "pós-memória": justamente, a "carga de imaginação e criação", outra variante que elude a conotação psicossomática vinculante da palavra "investimento".

David Winks Gray (2015, p. 55, grifo nosso) repete esse movimento, citando a mesma página 22 de Hirsch (1997):

Hirsch writes that postmemory "is distinguished from memory by generational distance and from history by deep personal connection," and that its power derives from the fact that "its connection to its object or source is mediated not through recollection but through an imaginative investment and creation." Albertina Carri's Los rubios (2003) is a postmemory film, and explores the different ways in which an absence of memory forces the postmemorial acts of imaginative investment and creation described by Hirsch.

Agora, Los rubios se transforma em um caso exemplar de "filme de pós-memória" exatamente pelo fato de explorar a ausência de lembranças próprias por meio de "atos de investimento imaginativo e criação". Com a adição da palavra "atos" nesse ponto, novamente, é o papel ativo dos filhos que sai destacado, desaparecendo as menções à dominação e ao esvaziamento da segunda geração pelos traumas herdados. E eis que vai se esboçando uma fundamentação alternativa da "pós-memória" nessas releituras, uma redefinição que se concentra nos gestos imaginativos e criativos dos descendentes, deixando em segundo plano a passividade daqueles cujas histórias supostamente seriam esmagadas pelo fardo recebido.

Já não surpreende o fato de as análises de Laia Quílez Esteve (2007, p. 74, 2009, p. 74 [sic]) trazerem citações da mesma página 22 de Family frames (HIRSCH, 1997) quando 
introduzem a noção de "pós-memória". Assim como, mais uma vez, é esta a página de Hirsch (1997, p. 22) citada na tese e no livro de Ana Amado (2008, p. 177-178, 2009, p. 200), retomando aquela paráfrase de seus artigos anteriores (AMADO, 2005a, p. 118, 2005b, p. 229), com todas as suas reinterpretações. Do mesmo modo que os textos de Claudia Barril (2013, p. 28) - via Esteve (2009, p. 74), sem citá-la - ou de Nohora Viviana Cardona Núñez (2014, p. 38) também se fixam nessa página 22 de Hirsch (1997). É curioso que esse labirinto de referências em apud tenda a levar a um mesmo ponto: o parágrafo específico em que Marianne Hirsch (1997, p. 22, tradução e grifo nossos) começa expressando "certa hesitação" quanto ao termo "pós-memória", pois o prefixo "pós-" poderia dar a impressão de que se estaria "além da memória e, portanto, talvez, [...] puramente na história". Querendo evitar esse mal-entendido, ela esclarece que a "pós-memória é distinta da memória pela distância geracional e da história pela profunda conexão pessoal". E, de modo a caracterizar a "pósmemória" como "uma forma poderosa e muito particular de memória", ela faz a ressalva da mediação, da substituição da lembrança de primeira mão pelo "investimento imaginativo e criação". Este é o ingrediente que fortalece a conexão da "pós-memória" "com seu objeto ou fonte". É só após garantir, recorrendo ao vetor do "investimento imaginativo e a criação", o vínculo da "pós-memória" com a memória, retirando-a do terreno da "pura história", que Hirsch pode levar adiante sua definição nos termos da "experiência daqueles que cresceram dominados por narrativas que precedem seus nascimentos, cujas próprias histórias posteriores são esvaziadas por histórias da geração anterior moldadas por eventos traumáticos que não podem ser nem entendidos, nem recriados." Vindo na sequência das ponderações, tal é o núcleo propositivo do enunciado de Hirsch. Quando se faz uma leitura mais sistemática da página 22 de Hirsch (1997) - não para cravar uma intepretação supostamente "correta", mas para compreender globalmente a dinâmica das releituras -, nota-se que o postulado fundamental da "pós-memória" é esse esvaziamento traumático da experiência da geração dos descendentes. $^{70}$

\footnotetext{
${ }^{70}$ Ainda que a redação se altere ao longo dos anos, Marianne Hirsch sempre conserva essa ideia de dominação e esvaziamento na essência da definição da "pós-memória". Vale cotejar diacronicamente os fragmentos nesse sentido: “[...] daquilo que eu gostaria de chamar 'pós-memória' (a do filho do sobrevivente cuja vida é dominada por memórias daquilo que precedeu seu nascimento)." (HIRSCH, 1993, p. 8, tradução e grifo nossos); "[...] experiência daqueles que cresceram dominados por narrativas que precedem seus nascimentos, cujas próprias histórias posteriores são esvaziadas por histórias da geração anterior moldadas por eventos traumáticos [...]." (HIRSCH, 1997, p. 22, tradução e grifo nossos); "Crescer com essas esmagadoras memórias herdadas, ser dominado por narrativas que precedem o nascimento e a consciência, isso é arriscar ter as próprias histórias e experiências deslocadas, mesmo esvaziadas, por aquelas da geração prévia. Ser moldado, embora indiretamente, por eventos traumáticos [...]." (HIRSCH, 2008, p. 107, tradução e grifo nossos); "Crescer com essas esmagadoras memórias herdadas, ser dominado por narrativas que precedem o nascimento e a consciência, isso é
} 
Embora esse seja o cerne da noção, a deriva entre ressalvas e asserções que, como ficou indicado acima, atravessa este e outros textos de Hirsch, por si só, já abre o campo para as inversões de ênfase identificadas na bibliografia sobre Los rubios. O gesto radical de distanciamento observado no filme atua como uma espécie de força gravitacional dentro dessa margem intrínseca ao vaivém da argumentação se Hirsch. As análises de Los rubios incluem muitas polêmicas e divergências frontais, mas algo é praticamente consensual entre os autores: o documentário de Albertina Carri traz a marca de uma radical afirmação do distanciamento geracional. A filha se recusa a herdar as versões preexistentes da memória, esforçando-se para esboçar, a todo custo, uma perspectiva que lhe seja própria. Em outras palavras, Albertina Carri não aceita ser "dominada por narrativas que precedem seu nascimento", tampouco permite que sua própria história seja "esvaziada por histórias da geração anterior" (HIRSCH, 1997, p. 22, tradução e grifo nossos). Mesmo com todo o seu peso, a memória da incompreensão vista em Los rubios está longe de ser a narrativa de uma filha "dominada" ou "esvaziada" pelo passado dos pais - uma exceção nesse quadro é a análise de Joanna Page (2005, p. 37, tradução nossa), autora que recorre à "pós-memória" de Hirsch para incluir o filme de Albertina Carri em um panorama cinematográfico argentino marcado pela "falta de agência histórica da geração mais jovem", em produções que testemunham "uma cultura jovem à deriva desprovida de uma causa maior". O contraexemplo existe, mas a tendência geral na bibliografia é que a ruptura flagrante em Los rubios atraia as atenções para o polo ativo da segunda geração, deixando em segundo plano o jugo do trauma transmitido no núcleo da definição de Marianne Hirsch. As imagens, assim, exercem um efeito de sentido quando seus comentadores vão àquela página 22 de Hirsch (1997): o gesto imaginativo por meio do qual a filha se impõe ganha projeção, ofuscando a ideia de esvaziamento e dominação no eixo do postulado tantas vezes citado. Surge, conscientemente ou não, uma noção híbrida de "pós-memória".

Cabe esclarecer que o rastreamento dessa mudança de ênfase sob nenhuma circunstância quer sugerir que os autores que escreveram sobre Los rubios recorrendo à noção de "pós-memória" "distorceram" a formulação "original" de Marianne Hirsch. As reelaborações são uma faceta constituinte das circulações de ideias e das "transferências culturais", as apropriações sempre acabam sendo assimilações. Conforme ficou indicado acima, não existe ideia "autêntica" ou "deturpada" nesse jogo (ESPAGNE, 2013). Quando, na crítica interna que faz da "pós-memória", Beatriz Sarlo (2007) refuta a noção acusando uma 
moda teórica que carece de justificativa, ela abre mão de compreender essas dinâmicas. Porém, é no emaranhado das transferências conceituais que é possível discernir, em alguma medida, a variedade dos usos e a vitalidade das metamorfoses das ideias - ainda que uma ideia seja, por si mesma, frágil.

A palavra "uso" neste ponto assume um significado particular: ela quer descrever os contatos mais flutuantes com as proposições de Hirsch, as citações que fazem de seu texto um estímulo para desenvolver as análises de Los rubios. Na bibliografia aqui discutida, é esse uso livre da noção de "pós-memória" o que ocorre na maioria das vezes. Não há nesses casos a preocupação com uma interpretação da estrutura global dos textos de Hirsch, levando em conta as estratégias intrínsecas de sua argumentação. Neste capítulo, ao contrário, sem que se faça "uso" da noção (ou seja, sem haver uma filiação de qualquer tipo a ela), empreende-se uma interpretação da formulação de Hirsch, tentando delinear seus parâmetros básicos, as asserções centrais e a deriva das ponderações (ECO, 2004, p. 43-44). E não para acusar “deturpações”, mas, justamente, para identificar os modos de uso da ideia nesse panorama. Há que se dizer que estes incluem - e as repetições observadas na bibliografia são um indício forte nesse sentido - o uso da "pós-memória" como um rótulo, uma etiqueta redutora que agrega um conjunto de obras as quais, embora tenham essa origem geracional comum, apresentam matizes nos vínculos com a geração precedente que complicam o terreno. Mas existem também, é claro, os usos menos simplistas, feitos por aqueles autores que se vinculam à noção tendo consciência de seus problemas intrínsecos e das polêmicas locais. Por fim, resta comentar os casos que ultrapassam o uso, isto é, quando há uma proposta explícita de reinterpretação dos termos da "pós-memória" no contexto analítico do Cone Sul.

Em sua tese sobre as narrativas de filhos chilenos e argentinos exilados no Reino Unido, Alejandra Serpente (2013, p. 93-94, tradução nossa) faz uma adesão crítica à "pósmemória", buscando "expandir o conceito para um novo contexto", que não só vai "além do modelo dominante do Holocausto", como também "pode ser estendido para além do quadro traumático familiar”. E afirma abertamente: “o conceito será usado para dissipar a ideia de que os integrantes da segunda geração são agentes passivos e receptores da memória traumática". No lugar disso, a autora prossegue, eles "estão criativamente posicionados em relação a essa memória, com suas próprias definições e subjetividades políticas.” A inversão de ênfase nesse caso é programática, operada à luz das especificidades observadas no novo recorte analítico.

De modo análogo, no contexto uruguaio, duas propostas de reinterpretação da "pósmemória" partem da premissa de que a noção não pode ser simplesmente transplantada para a 
análise das produções culturais da segunda geração do Cone Sul. Beatriz Tadeo Fuica (2014, p. 2, tradução nossa) adverte que seu artigo busca lidar com "a obra de Hirsch de modo a explorar as especificidades da segunda geração do Cone Sul. Mais precisamente, ele busca mostrar que a aplicabilidade desse arcabouço nos casos do Cone Sul nem sempre é direta [...].” Cara Levey $(2014$, p. 8, tradução nossa) tece considerações no mesmo tom:

Embora a própria Hirsch sinalize que o fenômeno da pós-memória é relevante para além do Holocausto, poucos estudos que lidam com o Cone Sul problematizam o controverso termo, uma tarefa necessária justamente por conta de sua transferência para uma configuração temporal e geográfica diferente, bem como por sua complexidade.

A despeito da premissa comum, as soluções encontradas por cada uma dessas autoras vão em sentidos opostos. De sua parte, Beatriz Tadeo Fuica (2014, p. 2, tradução nossa) sustenta que as análises dispostas a mobilizar a categoria cunhada por Hirsch devem verificar se a experiência do filho em questão corresponde às "características da pós-memória". Segundo a autora, "ser membro da segunda geração não basta para ter uma pós-memória. A diversidade das experiências vividas por esses filhos tem um impacto no modo como eles rememoram" (FUICA, 2014, p. 5, tradução nossa). O problema aí é que, ao se pautar pela observância da correspondência entre experiências específicas locais e postulado "original”, a saída proposta por Beatriz Tadeo Fuica acaba engessando a categoria e descartando os hibridismos. Levar em conta a pluralidade das histórias dos filhos do Cone Sul em função de um critério restritivo de aplicabilidade significa, no fundo, abrir mão de reinterpretar a noção. Qualquer análise que se ocupe da validação do uso da categoria de "pós-memória" em certos casos e da interdição em outros, no fim das contas, terminará adotando uma postura conceitual normativa que estreita o debate.

A solução de reinterpretação encontrada por Cara Levey (2014) acarreta em um problema diametralmente oposto ao da restrição do uso. Frente à diversidade das vivências dos filhos no Uruguai, Levey (2014, p. 25 e 27, tradução nossa) propõe "uma compreensão mais nuançada do conceito", "abrangendo uma ampla gama de experiências". Buscando escapar da ênfase exagerada nos laços consanguíneos, a autora salienta a "significativa interação entre as dimensões familiar e afiliativa da memória”, esta última tendo um maior alcance social (LEVEY, 2014, p. 27, tradução nossa). Na realidade, de acordo com Cara Levey (2014, p. 30, tradução nossa), “a divisão entre as dimensões afiliativa e familiar é talvez menos útil do que pode parecer à primeira vista, pois as fronteiras entre as duas esferas são nebulosas [...]." Para a autora, cabe enfatizar que a "pós-memória" não é exclusiva à 
segunda geração literal, tampouco diria respeito apenas aos descendentes de vítimas da ditadura. Afinal, segundo escreve: "Se reconhecermos que uma mistura de subjetividade, posicionalidade e mediação do passado no presente é central para a pós-memória, potencialmente qualquer pessoa pode se tornar parte da geração pós-memorialística." (LEVEY, 2014, p. 30-32, tradução nossa). Embora a ampliação desse debate seja uma agenda oportuna, com tal movimento, a reinterpretação abrangente de Cara Levey acaba levando a "pós-memória" para tão longe da definição de Hirsch a ponto de não restar qualquer especificidade na noção.

Restrição da aplicabilidade, expansão da abrangência. Mesmo indo além do mero uso ao lançar um bem-vindo olhar problematizante para a noção de "pós-memória" no contexto do Cone Sul, ao fim e ao cabo, estas duas últimas propostas de reinterpretação ficam presas à questão da "elasticidade" da formulação de Hirsch. Novas fragilidades conceituais surgem dessas releituras: a normatividade tipológica, de um lado; a perda da especificidade heurística, de outro.

Em suma, por vias distintas, Alejandra Serpente, Beatriz Tadeo Fuica e Cara Levey ${ }^{71}$ tentam revisar a noção de "pós-memória" à luz das experiências locais com o objetivo de manter a pertinência de uma categoria analítica já frágil na origem. Outro será o caminho percorrido nas próximas páginas. Um novo mergulho nas imagens de Los rubios se dedicará a expandir o horizonte de análise ao se afastar de vez da noção de "pós-memória". Trata-se, enfim, de examinar os vínculos geracionais a partir de outro prisma, explorando um campo que está além do debate conceitual.

\section{Transmissão, distanciamento e transferências culturais}

A análise fílmica até aqui vem se desdobrando em torno do distanciamento reflexivo e geracional patente em Los rubios. Esse duplo impulso de ruptura leva a obra de Albertina Carri para a esfera da irrepresentabilidade do trauma, matriz teórica que será detidamente examinada no Capítulo IV. A memória da incompreensão visível em Los rubios é mais do que a atualização performática da experiência da filha que, tendo vivido tudo aquilo na tenra idade, não tinha condições de entender as vicissitudes históricas que se abatiam sobre a família. Ela é, ao mesmo tempo, a figuração estética dos dilemas da representação do passado doloroso, empreendida anos depois por Albertina Carri na condição de cineasta. A postura

\footnotetext{
${ }^{71}$ Mariana Achugar (2016, p. 7-9) repassa sumariamente essas tentativas de releitura da noção de "pós-memória" no Cone Sul.
} 
analítica adotada a partir deste ponto, contudo, já adianta uma reivindicação que será desenvolvida no quarto capítulo: a interpretação fílmica deve ir além da mera constatação de um “irrepresentável” absoluto; é preciso enxergar nas imagens não só as cisões e os vazios do trauma, mas também os traços referenciais da carga do passado, dobrando a aposta historiográfica frente às aporias da representação - embora sem jamais cair na naturalização somática e reificante, como o faz Hirsch. Pois a linguagem radicalmente disjuntiva de Los rubios está plena de referências culturais, e é a partir delas que a análise tenta reconstituir um espaço mnemônico preenchido por um denso circuito intergeracional. Em suma, a ruptura do “irrepresentável” sem dúvida ganha expressão contundente em Los rubios, mas há outros elementos nessa obra que também merecem atenção.

Nesse sentido, as reflexões seguintes revolvem o terreno das alusões intertextuais mais concretas em Los rubios. Ora, a transferência da noção de "pós-memória", no fim, é um movimento externo ao filme, efetuado por certa vertente da crítica. Mas existem ainda as “transferências culturais" (ESPAGNE, 2013) que estão inscritas em suas próprias imagens. Aí também operam os termos da herança e da ruptura, mas os vetores são mais complexos, apontado para direções que extrapolam a dualidade entre primeira e segunda geração. Antes que a condição geracional, aqui entra em jogo a atmosfera de signos mobilizada por Los rubios.

Uma intertextualidade de saída evidente é a citação direta do livro de Roberto Carri, pai de Albertina, já nos primeiros minutos do filme. A atriz Analía Couceyro, no que parece ser o terraço de um edifício em Buenos Aires, lê em voz alta um trecho de Isidro Velázquez: formas prerrevolucionarias de la violencia, publicado originalmente em 1968. Pelo aspecto do volume que ela tem em mãos, descobre-se que se trata de uma edição recente do livro, de 2001 (citada nesta tese em reimpressão de 2011). Contudo, o mais revelador diz respeito ao teor do que é lido. Ou melhor, o detalhe de que, na verdade, a atriz lê não o texto de autoria de Roberto Carri, e sim uma das epígrafes de seu livro, extraída da obra Historia de las agitaciones campesinas andaluzas, escrito por Juan Díaz del Moral (1967, p. 43-44 apud CARRI, R., 2011, p. 27). Martín Kohan (2004a, p. 29) já havia chamado a atenção para esse deslocamento, incorporando-o em sua censura ao tipo de distância que a filha busca em relação ao passado dos pais. Aqui a ideia é destacar outra faceta dessa leitura em voz alta: o fato de ser uma epígrafe em abismo, ou seja, a epígrafe do livro do pai que serve de epígrafe ao documentário da filha. O distanciamento aí ocorre de forma bem mais mediada do que uma simples recusa daquilo que poderia dizer o pai ou do que descreve o texto de Juan Díaz del Moral: basicamente, a paulatina transformação da massa resignada e dispersa em ser coletivo, 
quando "as vontades individuais se fundem e submergem na vontade geral", dando origem a uma nova personalidade que abandona a condição de rebanho e "dirige-se reta ao seu objetivo, tal como a um alvo" (MORAL, 1967, p. 43-44 apud CARRI, R., 2011, p. 27, tradução nossa). Ao longo de Los rubios, fica patente que a filha se afasta absolutamente dessa retórica cara às esquerdas dos anos 1960. Ainda assim, vale a pena olhar com calma para a configuração específica dessa tomada que serve de epílogo (fig. 39).

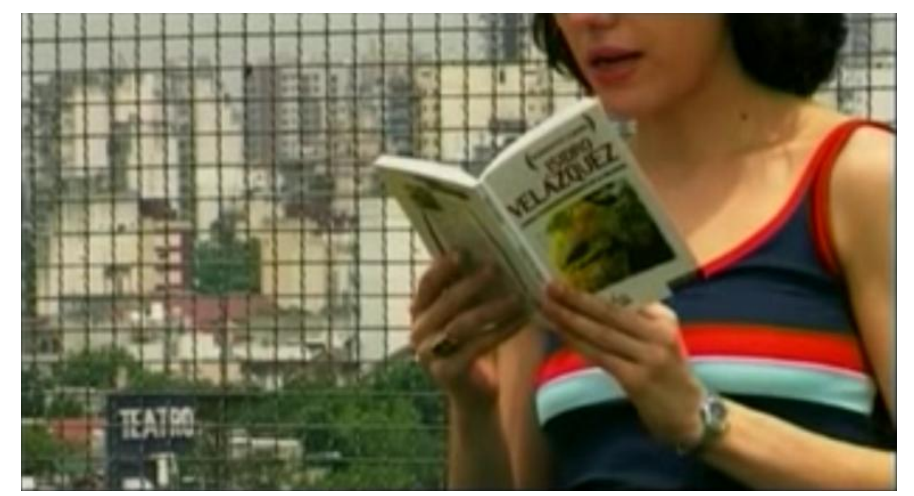

Figura 39 - Epígrafes em abismo: o livro do pai e o teatro. Fonte: Los rubios (Albertina Carri, 2003).

Os abismos se multiplicam nessa imagem: além da epígrafe na epígrafe, existe a duplicação mais óbvia da atriz que lê como se fosse a filha (Analía Couceyro por Albertina Carri). Menos visível é a palavra "teatro" que é possível distinguir no canto inferior esquerdo da paisagem em segundo plano, pintada em uma parede ao longe. O trecho citado do livro do pai não é de autoria dele; a pessoa que lê representa a filha; a inscrição "teatro" sugere a situação encenada, a performance que conduz a rememoração. Todos esses desvios ressignificam o teor do texto lido: o excerto que antes abria a análise do bandoleirismo como fenômeno pré-revolucionário passa a ser a introdução das fabulações da memória que se seguirão no filme. Com isso, o conteúdo do legado intelectual do pai acaba deslocado nas mãos da filha. Resta uma afinidade de postura, o cinema disjuntivo de Albertina Carri ecoando de longe a sociologia iconoclasta de Roberto Carri, com sua crítica mordaz aos formalismos acadêmicos - treze anos depois, na abertura de Cuatreros (Albertina Carri, Argentina, 2016), filme ensaístico de arquivo cujo ponto de partida é o livro de Roberto Carri, a filha finalmente leria, com sua própria voz em over, um trecho do prólogo redigido pelo pai: "Evidentemente, o material utilizado [no estudo sobre o bandoleirismo] pode ser questionado pelos pesquisadores sérios, mas não tenho nenhum inconveniente em declarar que isso me importa muito pouco.” (CARRI, R., 2011, p. 30, tradução nossa). 
Em Los rubios, o livro do pai surge ainda em outro momento, quando a atriz está telefonando para o escritório da equipe de antropologia forense. Primeiro, vê-se aquela mesma edição de 2001 sobre a mesa, junto com fotografias e outros papéis (fig. 40). Um movimento de câmera vai percorrendo os materiais esparramados na escrivaninha até encontrar outro volume de Isidro Velázquez: formas prerrevolucionarias de la violencia, mas agora na edição de 1968 (fig. 41).

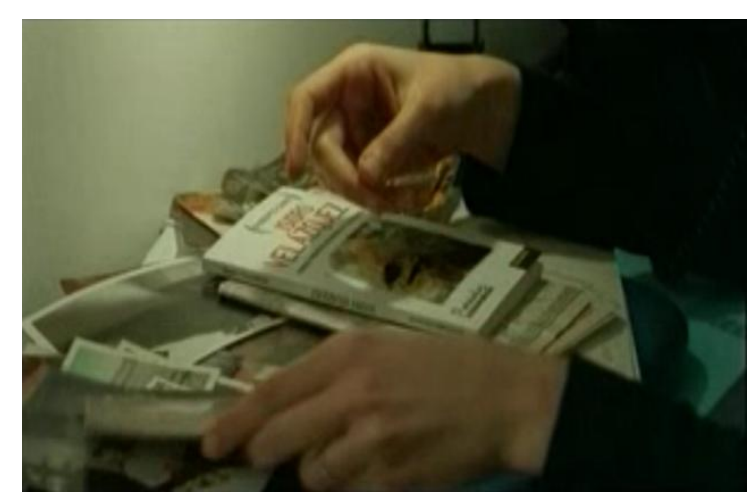

Figura 40 - Legado intelectual paterno, edição de 2001. Fonte: Los rubios (Albertina Carri, 2003).

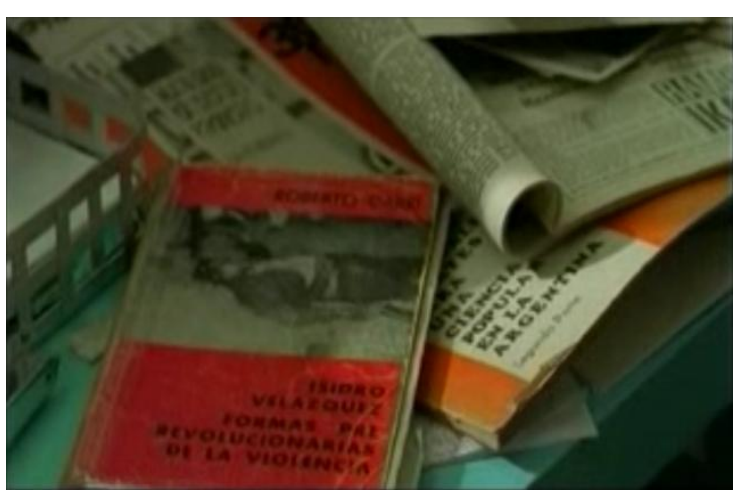

Figura 41 - Legado intelectual paterno, edição de 1968. Fonte: Los rubios (Albertina Carri, 2003).

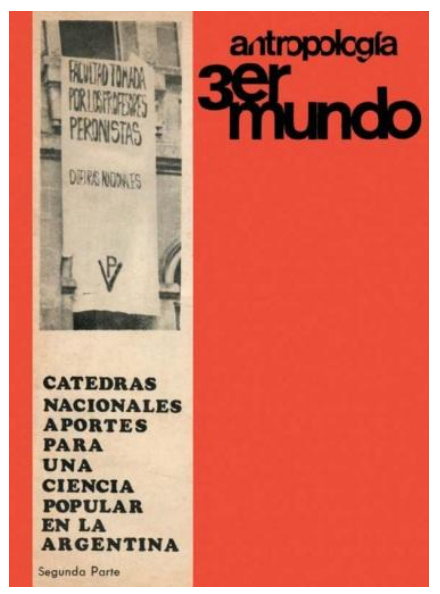

Figura 42 - Antropología 3er Mundo, n. 6, [1970]. Fonte: www.ruinasdigitales.com

Um olhar mais atento vê, sob a edição de 1968, o número seis da revista Antropología 3er Mundo, de 1970 (fig. 42). Roberto Carri foi um dos colaboradores mais frequentes dessa publicação, criada no contexto da institucionalização das Cátedras Nacionais da Universidade de Buenos Aires (DUHALDE, 2011; FAIGÓN, 2012). De autoria do pai de Albertina, esse número seis traz a segunda parte do artigo "Poder y dependencia", no qual o sociólogo faz uma "análise civil e política" dos "sistemas de poder na sociedade dependente", tece "considerações gerais sobre o poder", discorre sobre o "poder na sociedade latino-americana e especialmente na argentina", tudo isso tendo como epígrafe uma declaração do general Juan 
Domingo Perón (CARRI, R., 1970, p. 97 e 105, tradução nossa). A grandiloquência temática do texto do pai contrasta com a tomada fugaz em que a filha capta essa publicação, de passagem, parcialmente encoberta por outros materiais.

Los rubios afasta-se da retórica totalizante e prefere amalgamar uma miríade de referências de origens variadas, sem diferenciar discursos oficiais ou poéticos, sem discriminar alta e baixa cultura. Por um lado, a atriz lê em over a passagem do relatório Nunca más, da Comisión Nacional sobre la Desaparición de Personas (2011, p. 114), com a descrição, de tom marcadamente técnico, das dependências do "Sheraton", centro clandestino de detenção onde estiveram sequestrados os pais de Albertina Carri. A citação, explicitada apenas nos créditos finais, surge quando o carro da equipe passa em frente ao edifício onde funcionava o centro clandestino, que à época das filmagens abrigava uma delegacia de polícia. Por outro, em certo momento entram os intertítulos que reproduzem, sem indicar a “autoria”, a famigerada frase atribuída ao ex-general e governador de facto da província de Buenos Aires, Ibérico Saint-Jean: "Primeiro mataremos os subversivos. Depois, seus colaboradores. Depois, seus simpatizantes. Depois, os que permaneçam indiferentes. E, por último, mataremos os indecisos." (tradução nossa).

Também comparecem as referências acadêmicas e literárias, recitadas em voz over ou grafadas nos intertítulos: Régine Robin e suas reflexões sobre os dilemas da identidade em Identidad, memoria y relato: la imposible narración de sí mismo; a prosa poética de Olga Orozco em También la luz es un abismo; o trecho do romance de Stanisław Ignacy Witkiewicz, Adiós al otoño. Citações que não são esclarecidas no instante em que ocorrem no filme, autores que são nomeados apenas nos créditos finais e no roteiro publicado alguns anos depois (CARRI, A., 2007, p. 22, 43, 50, 60).

Los rubios faz ainda alusões diretas à cultura pop - algo que Martín Kohan (2004a, p. 29) interpretou como mais um traço de frivolidade no filme, ao que Gonzalo Aguilar (2010, p. 182-183) respondeu reinterpretando essa mesma frivolidade como um antídoto de Albertina Carri para superar as encruzilhadas da memória. A mais óbvia dessas referências são os bonecos Playmobil, brinquedo ícone dos anos 1970 e 1980. Na banda sonora, a cena de animação que representa o desaparecimento dos pais da diretora como uma abdução alienígena é acompanhada pela trilha de The day the Earth stood still (Robert Wise, EUA, 1951), composta por Bernard Herrmann. O desfecho da narrativa traz a canção Influencia, em versão em espanhol escrita e interpretada pelo famoso músico argentino Charly García (a canção original em inglês é de Todd Rundgren). Também aí, o último plano geral da equipe 
avançando por uma estrada em campo aberto não deixa de ser uma alusão irônica ao clichê cinematográfico que encerra tantos filmes.

Mas a referência à cultura de massa que chama mais atenção em Los rubios é aquela que vem indicada pela presença de uma versão francesa do cartaz do filme Cecil B. DeMented (John Waters, França / EUA, 2000) na parede do escritório onde trabalha a atriz (fig. 43). Em si, esse título já faz alusão a Cecil B. DeMille, produtor e diretor considerado um dos fundadores da indústria cinematográfica hollywoodiana. Com muito absurdo e deboche, o filme de John Waters conta a história de um grupo de cinéfilos fanáticos que monta uma célula guerrilheira contrária ao cinema comercial. Realizando seu próprio filme de arte, o grupo sequestra uma grande estrela (interpretada por Melanie Griffith) e a obriga a atuar nas ações armadas que são, ao mesmo tempo, as cenas da grande obra de DeMented. A atriz refém do grupo tem seu cabelo tingido de um loiro artificial que remete imediatamente à peruca loira usada por Analía Couceyro em Los rubios (fig. 44-45).

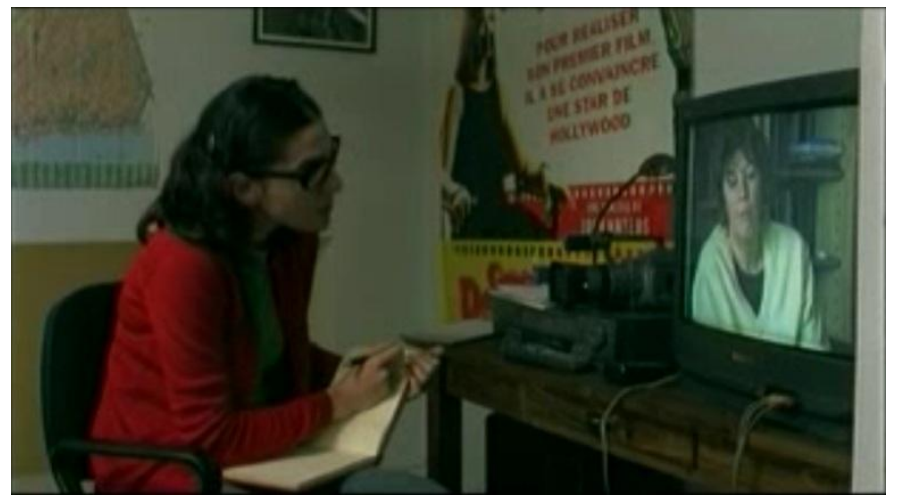

Figura 43 - Ao fundo, o cartaz francês de Cecil B. DeMented. Fonte: Los rubios (Albertina Carri, 2003).

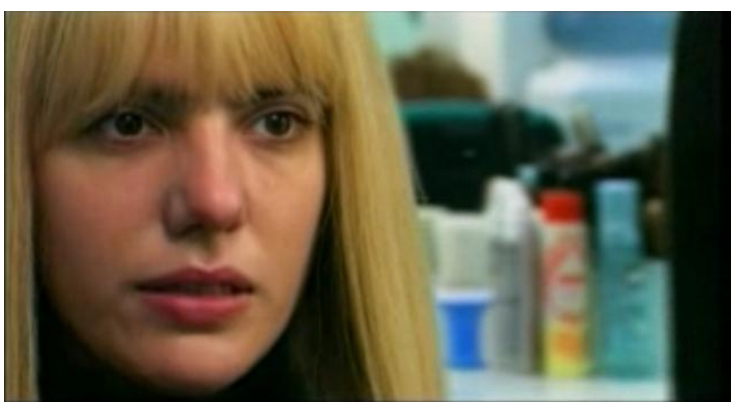

Figura 44 - Analía Couceyro de peruca. Fonte: Los rubios (Albertina Carri, 2003).

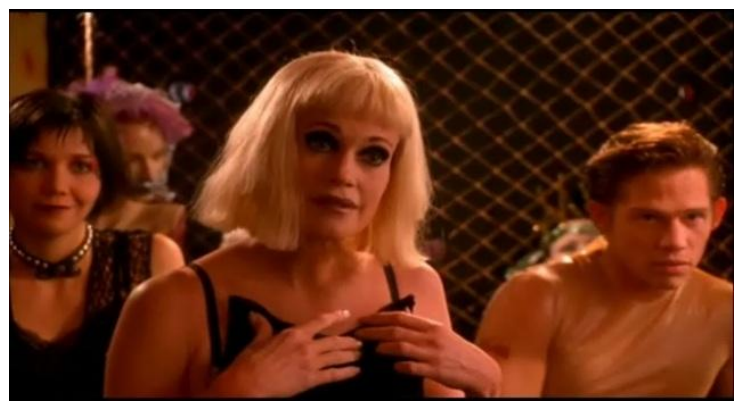

Figura 45 - Melanie Griffith tingida. Fonte: Cecil B. DeMented (John Waters, 2000). 
Os paralelos possíveis entre os dois filmes não se limitam ao tópico do cabelo loiro das atrizes. Outros elementos dão sentido à citação de Cecil B. DeMented por Los rubios: a reflexividade radical e a oposição aos clichês do cinema convencional; o tom provocativo da crítica; o engajamento armado dos pais de Albertina Carri nos anos 1970 em contraste com a guerrilha satírica em prol do cinema independente no filme de John Waters. Gonzalo Aguilar já havia descrito essa afiliação de Los rubios ao cinema "trash e paródico de Waters, de uma frivolidade que potencializa o sinistro" (AGUILAR, 2010, p. 181). O autor notara essa faceta irônica do documentário, a abordagem irreverente de um tema que demanda solenidade. Janis Breckenridge (2008, p. 12, tradução nossa), cuja análise de Los rubios dedica uma atenção mais consistente a essa referência, escreve: "O tributo a Cecil B. DeMented coloca-se como um testemunho silencioso da recusa lúdica, não obstante categórica, da diretora a aderir às normas previstas para o cinema documental.” Ana Amado (2004, p. 70, tradução nossa), embora sem remeter sua análise a Cecil B. DeMented, também identificou "improviso, ironia, insolência e liberdade [...] de um filme em que o jogo e o riso, componentes da infância, unem-se à gravidade do imperativo por recordar”. Há mesmo quem já tenha analisado Los rubios como uma comédia, na medida em que a obra constrói uma nova sociabilidade geracional. $^{72}$ De modo mais global, segundo Jordana Blejmar (2013, p. 45, tradução nossa), essa seria mesmo uma tendência crescente na cultura da memória argentina, manifesta em obras que cada vez mais "adotam uma abordagem lúdica, dessacralizada, não solene e desmonumentalizante do passado traumático".

Esse caldeirão de referências não hierarquizadas complica os vetores da transmissão e do distanciamento em Los rubios, levando ao paroxismo a tensão entre a herança que vem dos outros e aquilo que é reivindicação própria. Tudo fica ainda mais intrincado uma vez que as citações diretas não são identificadas ao longo do filme, estando listadas somente nos créditos finais. Tanto mais quando as alusões ocorrem de maneira sutil, no plano de fundo, às vezes quase indiscerníveis.

Já ficou descrita na abertura deste capítulo a passagem em que Analía Couceyro lê o fax do Incaa com o parecer negativo ao projeto de Los rubios. O momento é realmente forte. Como se viu, o documento torna patente a distância entre as expectativas institucionais por uma memória monumentalizante e a problemática da representação que vinha pautando

\footnotetext{
${ }^{72}$ Nicolás Lavagnino fez uma apresentação intitulada "Los rubios: una comedia” no VII Seminario Internacional Políticas de la Memoria, 2014, Buenos Aires. Resumo disponível em: 〈https://goo.gl/TDqTnV〉. Acesso em: 22 nov. 2015. Cf. ainda o texto assinado por Nyv Olagan (2012), cujas coincidências com o teor da apresentação de Lavagnino levam à conclusão de que se trata de seu pseudônimo.
} 
Albertina Carri. O que se gostaria de destacar agora, contudo, não é bem a questão que fica explícita nessa sequência, mas, sim, o segundo plano da tomada.

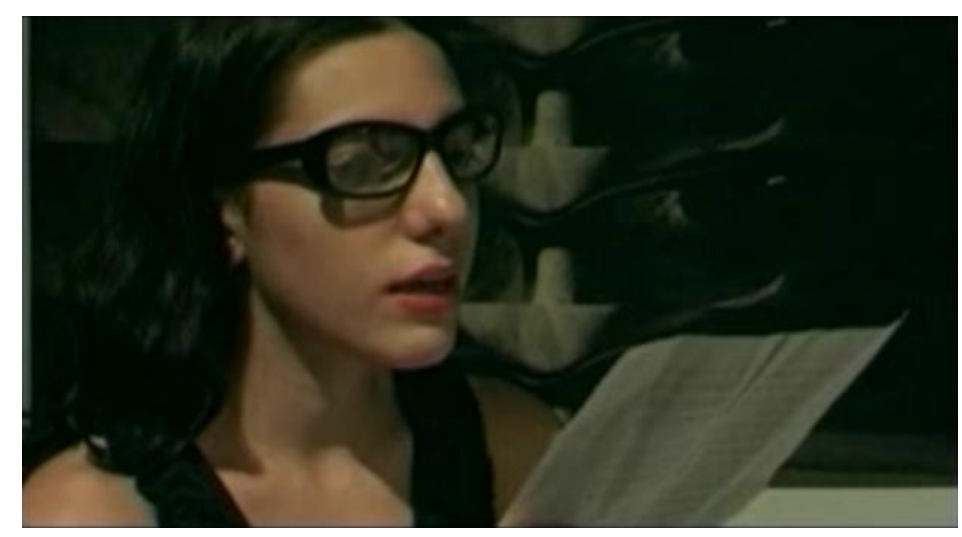

Figura 46 - A atriz Analía Couceyro lê o fax com a negativa do Incaa diante de um pôster de Jean-Luc Godard. Fonte: Los rubios (Albertina Carri, 2003).

A imagem que se vê ao fundo no exato instante em que a atriz lê o fax em voz alta é o rosto multiplicado de Jean-Luc Godard em um cartaz (fig. 46). Os óculos que Couceyro usa são similares aos de Albertina Carri, mas também se parecem com os óculos do diretor franco-suíço. Esses pormenores foram notados por Gonzalo Aguilar (2010, p. 180-181, tradução nossa), quem os interpretou no sentido de uma "afiliação com o cinema de vanguarda de Godard", em contrapeso à referência a Cecil B. DeMented. Ambas são afiliações estéticas, segundo Aguilar, reivindicadas pela diretora de cinema ao mesmo tempo que a filha põe em suspenso as filiações genealógicas. Pablo Piedras (2014, p. 142-143, tradução nossa) retoma essa análise de Aguilar, propondo uma interpretação complementar das citações dos cartazes em Los rubios como "cenas de leitura" que incluem os "suportes da formação afetiva e intelectual da cineasta e também como chaves interpretativas do documentário".

O detalhe desse pôster merece ainda um pouco mais de atenção. A partir desse pequeno indício, visto no filme em segundo plano, abre-se em Los rubios um horizonte de referências a Godard, principalmente o Godard da série Histoire(s) du cinéma (Jean-Luc Godard, França / Suíça, 1988-1998). Guardadas as devidas proporções, as analogias vão se descortinando: em Los rubios e em Histoire(s) du cinéma, como que expondo o momento de elaboração das obras, a atriz digita ao computador, assim como Godard datilografa na máquina de escrever (fig. 47-48). 


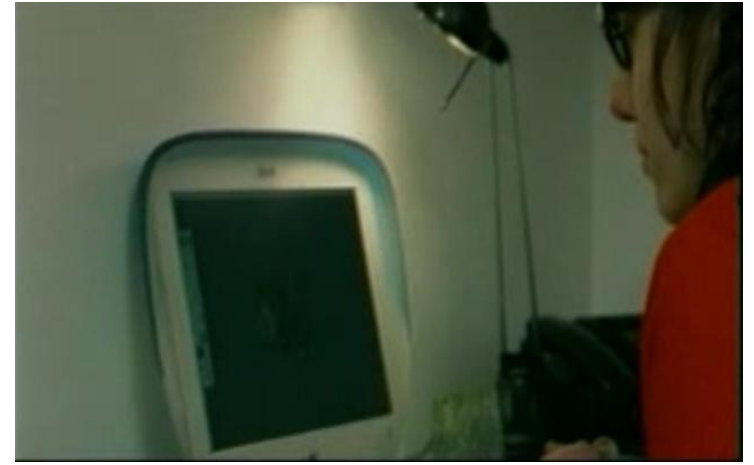

Figura 47 - A atriz digita. Fonte: Los rubios (Albertina Carri, 2003).

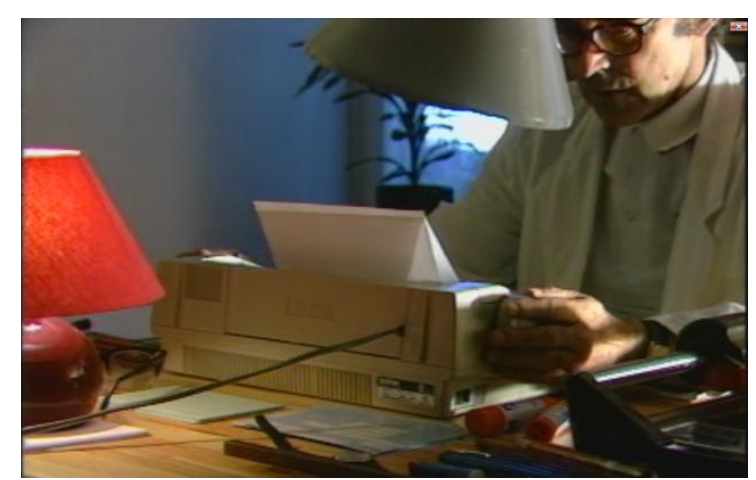

Figura 48 - Godard datilografa. Fonte: Histoire(s) du cinéma (Jean-Luc Godard, 1988-1998).

Para além do ato central, outros elementos também são análogos nesses dois planos: prossegue a semelhança dos óculos de aros grossos; em ambos, luminárias estão presentes. Há mais tomadas em Los rubios que sugerem paralelos com Histoire(s) du cinéma: Couceyro revê livros, avança e rebobina fitas de VHS; Godard revê livros em sua biblioteca, avança e rebobina filmes em uma moviola. Nos dois casos, tais recursos se dão na chave da reflexividade, da exposição do processo de produção do discurso, da revelação dos artifícios do próprio cinema (STAM, 1992).

Em Histoire(s) du cinéma, é fortíssima a presença do enunciador Godard: ele lê, redige, fala. Justapostos à sua figura e voz vão surgindo, sucessivamente, simultaneamente, repetidamente, os vestígios das imagens do cinema do século $\mathrm{XX}$, as citações de autores, letreiros, músicas, ruídos, falas de filmes. A impressão é de que se está assistindo ao processo de elaboração da série, como se o produto final fosse a própria formulação mental da obra, como se fosse possível visualizar o fluxo intrincado da imaginação e da memória do enunciador no instante exato em que ocorre (cf. DIDI-HUBERMAN, 2012, p. 155-190; GERVAISEAU, 2012, p. 305-432; RANCIÈRE, 2012, p. 43-78). Em Los rubios, a atriz duplica a presença da diretora Albertina Carri, encenando o processo de elaboração do projeto, revendo os depoimentos dos entrevistados, olhando fotografias de família, lendo, escrevendo. Os acenos a Godard em Los rubios ultrapassam, pois, as analogias em paralelo. Eles se esboçam na configuração das imagens do filme, em segundo plano, na composição dos quadros, nos gestos, revelando, como em um clin d'œil ao espectador, essa transferência cultural subjacente. Tais pormenores inscritos na matéria audiovisual permitem neste ponto uma mudança de foco das alusões às conexões, da forma fílmica aos cruzamentos históricos.

Gonzalo Aguilar (2010, p. 181) menciona de passagem que o cartaz de Godard visível em segundo plano em Los rubios havia sido elaborado para uma retrospectiva do realizador. Em março e abril de 2001, os quatro episódios de Histoire(s) du cinéma foram exibidos na 
íntegra em Buenos Aires, no contexto de um ciclo de conferências organizado por David Oubiña na unidade da New York University (NYU) então existente na capital argentina. Os conferencistas foram: Beatriz Sarlo, Jorge La Ferla, Rafael Filippelli e Eduardo Grüner.

Em 2003, era publicada em Buenos Aires a primeira edição de Jean-Luc Godard: el pensamiento del cine, livro que compila as quatro conferências daquela ocasião, além de trazer uma filmografia, um levantamento bibliográfico sobre a obra de Godard e a ficha técnica da série (OUBIÑA, 2005). No contexto do lançamento do livro, novamente foram exibidos, entre 26 e 29 de maio de 2003, todos os episódios de Histoire(s) du cinéma (BERNADES, 2003). Um mês antes, em 23 de abril de 2003, Los rubios era exibido no Bafici, na seção oficial competitiva, tendo saído do evento com os prêmios do público de melhor filme, o de melhor filme argentino, além de menções especiais do júri oficial e do júri Signis.

Em outubro de 2003, no contexto da repercussão na imprensa da estreia comercial de Los rubios no circuito argentino, ao menos um crítico já colocava a obra de Jean-Luc Godard no horizonte de referências de recepção do filme. Pablo Schanton (2003, n.p., tradução nossa), quando comenta a cartela de Los rubios que diz "mecanismos de distanciamento identificação", escreve: "como se fosse necessário expor a filiação com Bertolt Brecht e o cinema de J.-L. Godard”. Nesse mesmo cenário de repercussão midiática ligada ao lançamento da obra, a própria Albertina Carri reconhecia essa e outras referências em entrevista concedida a María Moreno (2003, p. 4, tradução nossa): "Quando fiz Los rubios, pensei, antes, em filmes como Sans soleil, de Chris Marker, ou os de Godard, nos quais se enfrenta a própria representação.” Mais tarde, outras análises fariam menção a Godard trazendo a referência de fora das imagens de Los rubios, muitas vezes junto com Brecht, em analogias genéricas com a obra dos dois ícones da arte reflexiva (RUFFINELLI, 2005, p. 333, 2007, p. 150; ALONSO, 2007, p. 164).

Seis meses depois da estreia comercial, em abril de 2004, o número 78 da revista Punto de vista publica a contundente crítica de Martín Kohan (2004a) a Los rubios. No final do texto, o autor registra uma nota de agradecimento, esclarecendo que o "artigo surgiu no marco das discussões sobre cinema" de um grupo que contava, entre outros nomes, com David Oubiña, organizador da conferência sobre Godard de 2001 e do livro resultante, de 2003, e mais dois palestrantes daquela ocasião, Rafael Filippelli e Beatriz Sarlo (os quais, sendo casados, possuem conexões para além das intelectuais). A nota informa ainda que uma das reuniões do grupo foi dedicada a Los rubios (KOHAN, 2004a, p. 30). Os debates realizados nesses encontros, ocorridos durante o ano de 2004 na sede da Punto de vista, foram 
depois sintetizados e editados por Beatriz Sarlo, tendo sido publicados em duas partes, nos números 81 e 82 da revista, respectivamente, em abril e agosto de 2005. No material selecionado, a obra de Godard é mencionada diversas vezes, havendo ao menos uma referência específica a Histoire(s) du cinéma (BECEYRO et al., 2005a; BECEYRO et al., 2005b).

Antes disso, a polêmica em torno de Los rubios havia prosseguido nas páginas de Punto de vista, cujo número 80 - portanto, imediatamente anterior aos dois números que traziam a súmula dos debates do grupo sobre documentário - publicava a resposta de Cecilia Macón (2004) à crítica de Martín Kohan (2004a), seguida da tréplica de Kohan (2004b).

Como se viu, Beatriz Sarlo (2007) leva adiante a controvérsia acerca de Los rubios, agora fora das páginas de Punto de vista, revista da qual foi umas das fundadoras e que dirigiu ao longo de toda sua existência, entre 1978 e 2008. Em 2005, ela publica na Argentina o livro Tiempo pasado: cultura de la memoria y giro subjetivo. Una discusión, cuja crítica ao filme de Albertina Carri já ficou comentada acima. O dado novo é que Sarlo havia debatido Los rubios em reunião do grupo sobre o cinema documentário agregado em torno da revista que dirigia. Não por acaso, a autora faz uma longa citação da análise de Martín Kohan (2004a) publicada em Punto de vista, retomando algumas das questões levantadas por esse crítico (SARLO, 2007, p. 105-109).

O levantamento desses cruzamentos culturais pode ser interrompido neste ponto. Cabe agora alinhar o elenco de fatos conectados na busca de um desfecho para a trilha aberta pela inscrição da imagem de Jean-Luc Godard em segundo plano durante a leitura do fax do Incaa em Los rubios. Eis a primeira proposição: tudo leva a crer que a obra de Godard estava de algum modo no horizonte próximo dos personagens envolvidos nas controvérsias acerca de Los rubios.

Do lado da produção, Albertina Carri dá pistas claras nesse sentido: ela inclui o cartaz com o rosto do diretor franco-suíço como pano de fundo de um momento crucial do filme; ela sugere analogias na composição das tomadas e nos gestos da atriz; por fim, a própria cineasta declara em entrevista que pensava em Marker e Godard quando realizou Los rubios. Em 2001, quando Los rubios era já um projeto em curso (CARRI, A., 2007, p. 9), a série Histoire(s) du cinéma foi exibida e debatida em Buenos Aires. O mínimo que se pode dizer é que isso dá fôlego às discussões sobre a obra de Godard no cenário cinematográfico da cidade, no qual a diretora à época elaborava Los rubios.

Do lado da recepção, dois dos maiores críticos de Los rubios, Beatriz Sarlo e Martín Kohan, vinham debatendo a obra de Godard, seja diretamente, como Sarlo, que analisou 
Histoire(s) du cinéma nas conferências de 2001, seja de modo mais indireto, como Martín Kohan, que discutiu Godard, junto com Sarlo, no grupo sobre documentários da Punto de vista. Também não deve ser subestimado o impacto do lançamento, em 2003, da primeira edição do livro compilando as conferências de 2001 (OUBIÑA, 2005), junto com a nova exibição de Histoire(s) du cinéma em Buenos Aires, eventos quase concomitantes à presença de Los rubios no Bafici.

Chama atenção ainda o fato de que os críticos mais contundentes de Los rubios tenham saído do círculo de intelectuais ligados à revista Punto de vista e, mais especificamente, dentre aqueles que tomaram parte nas reuniões para debater o cinema documentário ao longo de 2004. Sabe-se que o filme de Albertina Carri foi discutido nesse fórum. Tal núcleo e a própria revista acabaram se constituindo em um veículo importante da controvérsia em torno de Los rubios na Argentina.

Amarrado a esses circuitos extrafílmicos, o fio da alusão a Godard conduz ainda ao vetor propriamente estético do distanciamento em Los rubios. A reflexividade radical de sua abordagem do passado familiar e nacional tem conexões rastreáveis com a poética disjuntiva de representação da história do cinema elaborada pelo diretor franco-suíço. As transferências culturais logo acima descritas iluminam algo tanto sobre a forma desconstrucionista adotada no documentário de Albertina Carri quanto acerca dos bastidores da construção coletiva de certas críticas a essa mesma forma.

A intertextualidade de Los rubios prolonga-se no tempo, e não apenas por todos os escritos que suas imagens suscitaram e continuam suscitando. A própria Albertina Carri (2007) lançou posteriormente, em 2007, um livro intitulado Los rubios: cartografía de una película, o qual traz os materiais de cada fase de produção do documentário. Primeiro, estão os textos que a filha-diretora redigiu durante a pré-produção do filme, mesclando recordações em primeira pessoa com intenções quanto aos artifícios formais de distanciamento a serem empregados. Alguns trechos desses escritos prévios depois entrariam no documentário em voz over. Em segundo lugar, vem o roteiro indicativo, com a transcrição das observações e ajustes que iam ocorrendo à diretora durante as filmagens. Uma terceira parte inclui entrevistas, diálogos e tomadas descartadas na etapa de pós-produção. E também a reprodução das cartas enviadas da prisão por Ana María Caruso às filhas, bem como as respostas das três meninas (Andrea, Paula e Albertina Carri), uma troca epistolar que não havia entrado no filme. Por fim, o livro traz uma entrevista concedida pela diretora a Fernando Martín Peña, abordando temas ligados ao lançamento do filme: a repercussão, o circuito de festivais, os elogios e as reações contrárias de Kohan e Sarlo, sem abrir mão de esclarecer certos pontos polêmicos. 
Vale notar que muitas das referências que estão nas imagens de Los rubios não estavam previstas no roteiro. Ao mesmo tempo, o livro como um todo traz outras tantas alusões que acabaram não sendo citadas no corte final do filme: autores mencionados por Albertina Carri nos textos da pré-produção; associações de ideias anotadas no roteiro; indicações de leitura que a mãe fizera às irmãs mais velhas da diretora (CARRI, A., 2007).

As linhas das transferências culturais identificáveis no documentário de Albertina Carri configuram uma tessitura complexa. O percurso desde os textos paternos, atravessando uma miríade de citações (a memória oficial do Nunca más, as ameaças dos militares, a literatura, produtos da cultura de massa, Godard e a publicação dos materiais por trás do filme), dá novos contornos ao tratamento do passado autoritário em Los rubios. Nesse horizonte ampliado de referências, a chave interpretativa da "pós-memória" acaba redimensionada, sendo apenas mais uma das transferências a gravitar em torno da obra. No mesmo movimento, as ideias de transmissão e ruptura revestem-se de novos significados, os quais vão além do fluxo genealógico para abranger conexões as mais inusitadas. Dito de outro modo, o legado dos pais é insistentemente deslocado em Los rubios em função de distanciamentos que se operam em diferentes sentidos: o afastamento da retórica grandiloquente paterna; a renúncia a qualquer hierarquia dos enunciados culturais; a inversão do tom reverente da memória; a forma cinematográfica disjuntiva; o desdobramento de uma obra que tem seu próprio percurso. Trazer todos esses elementos para o debate não significa promover uma dispersão da análise. No lugar disso, trata-se de ampliar a escala de observação para vislumbrar os intrincados vetores atuantes nas relações intergeracionais.

\section{Um circuito de laços intergeracionais}

Quando a análise lança um olhar para além da linhagem consanguínea suposta na noção de "pós-memória", abre-se o panorama de um emaranhado de intercâmbios culturais. É sobre essa teia de alusões e analogias que a filha constrói sua própria memória em Los rubios. Para entender tal processo em sua complexidade, a ideia de um circuito de laços intergeracionais parece ser mais operacional do que o eixo da transmissão do trauma que fundamenta o postulado de Marianne Hirsch.

Beatriz Sarlo (2007, p. 102) já havia escrito que “o discurso único da 'pós-memória' sempre encontra o que procura e, por conseguinte, é monótono em seu descuido programático das diferenças entre relatos". Embora tenha uma boa dose de razão, essa crítica de Sarlo acaba resvalando em um exagero de contundência. Ao longo destas páginas, viu-se que, apesar da 
repetitividade observada em torno da "pós-memória", quando as transferências em jogo são levadas em conta, seu discurso não soa assim tão monótono. Quanto a isso, a crítica à "pósmemória" elaborada neste capítulo diferencia-se da acusação de nulidade em bloco feita por Beatriz Sarlo. Afinal, mesmo que a "pós-memória" seja uma "moda teórica", vale a pena tentar compreender essa "moda", também ela, como um fenômeno de memória, com seus deslocamentos e hibridismos, suas nuances e sedimentações. As reflexões aqui se afastam $a$ posteriori da noção de "pós-memória", só depois de mergulhar no debate conceitual, historicizando a entrada dessa ideia na bibliografia sobre Los rubios e examinando suas metamorfoses. É dessa imersão que desponta o impulso final no sentido de sair do enredo da transmissão do trauma para vislumbrar o horizonte que, a partir das imagens fílmicas, conduz ao terreno das conexões culturais da memória.

A ideia de circuito intergeracional sugerida nesta conclusão não quer se impor como uma fórmula conceitual substitutiva da "pós-memória". Se alguma ressonância está em questão aqui, não é a da "criação" de um novo conceito, mas sim a das reverberações culturais que passam a ser identificáveis pelo corpo a corpo com as obras, pela exploração dos veios históricos sinalizados nas imagens. A palavra "intergeracional” é corrente nesse debate. Ela pode até ser objeto de maiores elaborações, ${ }^{73}$ mas seu emprego predominante se dá de modo mais trivial (cf. AMADO, 2009, p. 156; BLEJMAR; FORTUNY, 2013, p. 1; DIGIOVANNI, 2013, p. 72; ESTEVE, 2009, passim; JOHANSSON; VERGARA, 2014, p. 93; LEVEY, 2014, passim; SERPENTE, 2013, passim; YOZELL, 2011, p. 55). Seu valor heurístico estaria exatamente nesse traço prosaico: levar a discussão para o "rés do chão" das interações geracionais, ou melhor, para perto das imagens fílmicas e dos cruzamentos históricos nelas inscritos, sem trazer consigo os embaraços das formulações da "pós-memória". Falar em "circuito intergeracional" é colocar a prática historiográfica no lugar da inflação teórica da "pós-memória", com seu superávit de polêmicas e reiterações. A expressão é teoricamente modesta para dar conta da riqueza multifacetada dos vetores da rememoração, os quais

\footnotetext{
${ }^{73}$ Uma formulação em particular de Aleida Assmann (2006) tem destaque quando se quer definir uma memória "intergeracional". Ao desenvolver uma tipologia dos "formatos da memória" (individual, social, política e cultural), Aleida Assmann (2006, p. 215, grifo da autora, tradução nossa) escreve: "Enquanto as formas sociais de memória são intergeracionais, as formas de memória política e cultural são designadas como transgeracionais." Segundo a autora, os primeiros casos (memórias individual e social) estão fundados na experiência viva, nas interações efetivas entre seres humanos (intergeracionais). As demais formas da memória (política e cultural) dependeriam das mediações institucionais (transgeracionais). Essa tipologia de Aleida Assmann é retomada por Marianne Hirsch (2008, p. 110-111) e Mariana Achugar (2016, p. 7). Esta última autora adota a ideia de "transmissão intergeracional" como eixo de suas análises no contexto da rememoração da ditadura uruguaia pelas gerações mais jovens (ACHUGAR, 2016, p. 3-4). O trabalho de Ana Ros (2012, p. 6-10) sobre a produção cultural da geração "pós-ditadura" de Argentina, Chile e Uruguai também articula a pauta da "transmissão intergeracional" de maneira mais estruturante.
} 
escapam aos apriorismos e às esferas de chancela dessa filmografia (festivais e crítica à frente). Em suma, ela conceitua menos para enxergar mais. ${ }^{74}$

As últimas páginas deste capítulo dão mostras do vigor do circuito intergeracional em Los rubios, abrindo mão de forjar um novo rótulo a partir de premissas abstratas. O universo de alusões visíveis nessa obra descortina a atmosfera de referências simbólicas que cabe na sucessão genealógica da memória. Eis um exemplo concreto de circuito intergeracional no cinema, um dos mais complexos do corpus, seguramente não paradigmático, mas que, justamente por seu caráter extremo, permite que se amplie a abordagem. Ao se revolver esse terreno, o objetivo básico é manter em vista a carga histórica dessas conexões intergeracionais. Pois toda rememoração, direta ou indireta, inclui as vicissitudes de sua historicidade. Os documentários de filhos olham para as experiências maternas e paternas tendo os pés fincados em uma temporalidade densa, plena de referências culturais e polêmicas de memória. É evidente, portanto, que o que está em causa aí não é uma transmissão que flui naturalmente por seu próprio peso - embora essa transmissão possa ser francamente reivindicada pelos filhos, como se verá em Mi vida con Carlos, caso que não é isolado nessa produção. Assumir uma herança é uma das atitudes possíveis nesse tabuleiro da memória. Contudo, isso está bem longe de significar o esvaziamento da segunda geração pelo fardo recebido. Afinal, se a ausência dos pais está no núcleo da lembrança de Albertina Carri e de tantos outros filhos, também é verdade que muita coisa invade esse terreno de interações: legados, apropriações, recusas, aproximações, transmissões e transferências conceituais ou culturais. Tudo isso em uma dinâmica de posturas contrastantes e vetores intrincados, prospectivos, retrospectivos e em sentidos que não estão dados de saída.

\footnotetext{
74 Paul Veyne (1998, p. 99) já alertava o historiador sobre a "armadilha da abstração": "Quando uma trama é elevada a tipo e recebe um nome, a tendência é esquecer o definido e conservar a definição [...]; a teoria parece então se colocar no lugar dela mesma."
} 


\section{CAPÍTULO III}

\section{FORMAS E TENSÕES ESTÉTICAS DO DOCUMENTÁRIO INTERGERACIONAL}

O emaranhado de laços intergeracionais examinado no capítulo anterior não deve enredar a reflexão, paralisando-a. Essa memória não é um objeto disforme, e sim um fenômeno multifacetado. Este terceiro capítulo dedica-se, justamente, à descrição detalhada das formas cinematográficas mobilizadas como meios de expressão nesse documentarismo. A esta altura, já terá ficado claro para o leitor que a indeterminação é um traço saliente nessa filmografia, marcando as dinâmicas espaçotemporais de sua formação histórica e as interações no circuito entre protagonistas e descendentes. Acontece que, de modo geral, as análises se concentram de tal maneira nesse aspecto que acabam descurando do outro polo em jogo: o das formas, e mesmo das fórmulas do documentário contemporâneo visíveis nas imagens. Assim como no primeiro capítulo, as indagações voltam a avançar na abordagem macro do corpus expandido, visando a uma apreciação comparativa. O objetivo é rastrear paralelismos formais, matizes e contradições estéticas, partindo de uma ampla decupagem analítica (o que de antemão justifica a extensão deste terceiro capítulo) guiada pela consideração mais detida de Mi vida con Carlos (Germán Berger-Hertz, Chile / Espanha, 2009). O jogo de escalas segue sendo o norte metodológico. Pois a análise desse título em particular joga luz sobre uma tensão que atravessa o repertório de recursos do cinema documental articulado no corpus ampliado: aquela entre forma e indeterminação, entre convenções básicas e desconstrução reflexiva, entre as estruturas narrativas cerradas e a abertura de sentido das obras, entre a consolidação e a novidade das pautas de rememoração. No fim das contas, a organização dos símbolos dessa vasta constelação de artifícios cinematográficos depende do lugar de enunciação assumido pela primeira pessoa em cada filme.

\section{Leituras da indeterminação formal}

A sequência de abertura de Mi vida con Carlos já introduz alguns dos tópicos mais pregnantes do documentarismo intergeracional. A câmera perscruta em travelling o solo do deserto chileno. O ruído do vento que sopra reforça o vazio da paisagem. Surge na tela um filme doméstico em super-8, o jovem Carlos corre em câmera lenta rumo ao mergulho no 
mar. Em voz over, seu filho, Germán Berger-Hertz, dirige-se ao pai desaparecido: “A primeira vez que te vi foi nesta imagem de super-8. Nunca vi teu corpo em movimento, ou melhor, não o lembro." (tradução nossa). Corta para um plano em close-up da mão do filho que percorre as etiquetas de caixas de arquivo morto em uma estante. A câmera se fixa naquela que traz o nome do pai do realizador, Carlos Berger Guralnik, junto da indicação da operação repressiva que o assassinou, a Caravana da Morte. O filho segue em over: "Eu não podia te recordar porque ninguém nunca me falou de ti. Eu tinha um ano quando te mataram e tu tinhas trinta." (tradução nossa). Novo plano fechado, as mãos do filho vão passando envelopes codificados, até que retiram aquele correspondente ao pai do realizador. Ele continua: "Quando eu completei trinta anos, me dei conta do quão jovem eras, do muito que te faltava por viver. Quis saber quem havias sido.” (tradução nossa). Entra a trilha sonora incidental. As mãos abrem o envelope. Dali retiram um retrato fotográfico em preto e branco de Carlos. O espectador é apresentado ao rosto do pai desaparecido desde o ponto de vista do filho, o plano subjetivo reproduz a perspectiva daquele cujas mãos seguram a fotografia.

$\mathrm{O}$ vazio. O filme amador em super- 8 . A voz over em primeira pessoa do diretor que se dirige ao pai na segunda pessoa, ${ }^{75}$ como em um diálogo imaginado, uma carta endereçada ao desaparecido. A imagem fugidia do pai. A falta de memórias próprias. A procura por informações sobre essa morte determinada pelos eventos históricos dos anos ditatoriais. O silêncio da família sobre o ente desaparecido. A chegada à idade adulta e o impulso de romper esse silêncio. A fotografia como gatilho da busca subjetiva. Esses poucos minutos descritos de Mi vida con Carlos condensam uma série de elementos que em geral são tidos como característicos da produção documental de filhos e outros descendentes de militantes vítimas dos regimes do Cone Sul. O prosseguimento do filme continua carregado desses traços. Berger-Hertz entrevista sua mãe e seus tios acerca do pai e das circunstâncias históricas que se abateram sobre a família. Revê álbuns, projeta filmagens domésticas em super-8. Ele vai aos lugares mais significativos dessa memória: viaja para o Canadá, para onde um dos tios se mudou e de onde volta pela primeira vez para reencontrar a família diante da câmera do sobrinho; regressa com a mãe, Carmen Hertz, a Barcelona, cidade que visitara com ela durante o exílio europeu de ambos e onde, depois, Berger-Hertz se estabeleceria; vai com o tio até Chuquicamata, no norte chileno, onde Carlos Berger Guralnik trabalhava como chefe de comunicações da mineradora estatal Codelco durante a Unidade Popular, cargo que fez dele uma vítima da Caravana da Morte pouco depois do golpe de 11 de setembro de 1973. O

\footnotetext{
${ }^{75}$ É por essa razão que se optou por manter a segunda pessoa na tradução para o português brasileiro, variante na qual, na maioria das regiões, o pronome "você" substitui o "tu" no uso corrente para designar o interlocutor.
} 
diretor também registra momentos descontraídos com suas filhas e esposa, experimentando como pai uma vida familiar que não teve como filho. Recupera a militância da mãe em prol dos direitos humanos como advogada junto à Vicaría de la Solidaridad no Chile. Enfim, as conversas com os parentes, a revisão do acervo doméstico, as idas e vindas, a família própria, o papel público da mãe, tudo isso vai compondo uma espécie de carta fílmica ao pai desaparecido, a afirmação de uma vida possível com a memória de Carlos. Imagens, vozes e materiais vão sendo alinhavados pela busca do filho.

"Documentário de busca" é uma definição cunhada por Jean-Claude Bernardet (2005) que adquiriu projeção nas análises do documentarismo contemporâneo no contexto brasileiro. A partir de dois títulos específicos, 33 (Kiko Goifman, Brasil, 2003) e Um passaporte húngaro (Sandra Kogut, Brasil / França / Hungria / Bélgica, 2001), Bernardet (2005, p. 144) identificava os traços de uma tendência então incipiente de "projetos que partem de um alvo bastante preciso, bastante determinado, mas os cineastas não sabem se esse alvo será ou não atingido e não sabem de que forma será atingido. Portanto, a filmagem tende a ser a documentação do processo." Os alvos eram, nos dois casos, uma recuperação identitária familiar: Kiko Goifman, filho adotivo, ao completar 33 anos se propunha a encontrar sua mãe biológica em 33 dias; Sandra Kogut, de ascendência húngara, tentava obter a nacionalidade e o passaporte daquele país. O documentário de busca teria, seguindo Bernardet, esse traço de saída: um objetivo determinado que, porém, lida com a imprevisibilidade do resultado do processo.

A ideia de busca é uma linha de força na fortuna crítica de Mi vida con Carlos, embora não haja aí citações específicas do texto de Bernardet (2005). A partir dessa noção básica, porém, variam as interpretações sobre os desdobramentos dessa busca. Alguns autores identificam com mais precisão os alvos de Germán Berger-Hertz, reconhecendo em seus esforços uma positividade e mesmo o êxito no fim do processo.

Mi vida con Carlos (2009) é uma viagem ao encontro de um pai ausente. O diretor, Germán Berger, parte em busca de Carlos Berger, assassinado em 1973 pela Caravana da Morte. O realizador propõe seu projeto fílmico como um meio de reconstrução da vida de seu progenitor e de sua própria história. (BELLO, 2011, n.p., tradução nossa).

Próximo dessa linha mais determinada de análise, Alison Tange (2013, p. 72, tradução nossa) escreve: "O filme de Berger também sublinha a importância da identidade em sua busca por reconstruir e reivindicar a memória de seu pai com os demais membros de sua família." Em outra passagem, o autor destaca a faceta exitosa dessa busca: 
Berger cria ativamente a memória de Carlos usando imagens para reconstruir sua vida como pai, marido, irmão, filho e militante, desafiando o desaparecimento de seu corpo perpetrado pelo Estado militar [...]. Em suma, Berger molda com sucesso a memória de Carlos Berger e também inicia com sucesso a transmissão dessa memória [...]. (TANGE, 2013, p. 68, tradução nossa).

Na leitura de Lisa Renee Digiovanni (2013, p. 67 e 72, tradução nossa), o bom termo da busca também é ressaltado:

O documentário se abre no lugar do crime, o Deserto de Atacama, uma paisagem desolada onde os restos do pai do cineasta foram secretamente desovados. A luz natural de baixa intensidade sugere o crepúsculo ou a aurora, o final de uma vida e o início de uma busca. [...] Mi vida con Carlos constitui uma importante contribuição para o campo dos estudos da memória no Cone Sul. O filme amplia o horizonte para avançar discussões sobre as dimensões entrecruzadas do íntimo e do intercontinental da violência ditatorial; sobre como lidar com as memórias e os legados da resistência na pós-ditadura sem ser por eles imobilizado.

Analisando Mi vida con Carlos junto com outros títulos chilenos análogos, Juliette Goursat (2015, p. 115, tradução nossa), de modo semelhante, parte da ideia de busca para levar sua interpretação a uma conclusão mais demarcada:

A especificidade dessas narrativas é adotar a forma de uma busca que objetiva recuperar a memória e/ou submetê-la a diversas interpretações ou significados. Por meio desse processo, o cineasta revela a reflexividade de uma busca da memória por uma clara e justa representação do passado e uma tentativa de extrair lições dele. A presença de seu corpo na tela atesta mais do que a subjetividade de um ponto de vista definido; ela autentica a narrativa, a qual deve ser considerada como um testemunho completo com valor histórico.

O curioso é que o mesmo filme que suscita essas conclusões sobre o processo de busca calcadas em terrenos mais determinados também dá margem para as leituras que vão no sentido oposto. Análises, enfim, que acentuam aquilo que a busca tem de imprevisível, a incerteza dos resultados, os alvos intangíveis. Michelle Bossy e Constanza Vergara (2010, p. 35-36, tradução nossa) se aproximam desse campo de interpretação quando consideram $M i$ vida con Carlos como parte de um conjunto de documentários autobiográficos chilenos cuja:

[...] narrativa se constrói como uma interrogação, um processo de busca, uma forma de fazer frente à ausência e, sobretudo, como uma maneira de empreender um processo de reparação. $\mathrm{O}$ silêncio, o esquecimento e a possibilidade de narrar coerentemente a relação entre o passado e o presente são algumas das temáticas exploradas por esses filmes. [...] Na maioria dos casos, a solução não vem, a figura não se completa e não se encontra o que 
tanto se busca. Contudo, o próprio processo de realização do documentário funciona como uma espécie de resposta, um ensaio de narrativa coerente (já não completa) sobre a vida de seus autores.

Em outro texto, María Teresa Johansson e Constanza Vergara (2014, p. 90, tradução nossa) escrevem que En algún lugar del cielo (Alejandra Carmona, Chile, 2003) e Mi vida con Carlos levam "a cabo um processo de busca pessoal que também envolve uma experiência coletiva". Os dois títulos, elas avaliam, "representam novas operações em torno da autorrepresentação, do trauma, da memória e das possibilidades de elaboração do luto, expondo $[\ldots]$ a fratura de uma narrativa linear [...]." Segundo as autoras, as últimas cenas de ambos os filmes, com os realizadores indagando seus próprios filhos (a terceira geração) sobre a memória dos avôs desaparecidos, "projetam finais inconclusos, que mantêm a elaboração do luto em um estado de abertura" (JOHANSSON; VERGARA, 2014, p. 96 e 104, tradução nossa).

No mesmo diapasão, Claudia Barril (2013, p. 34, tradução nossa) aponta que, em Mi vida con Carlos, "o relato do passado é assumido como uma interrogação, um processo de busca e uma forma de fazer frente à ausência do pai arrebatado na infância”. A autora conclui sua análise sustentando que o documentário de Berger-Hertz, bem como outros dois títulos chilenos - novamente En algún lugar del cielo, além de Abuelos (Carla Valencia Dávila, Equador / Chile, 2010) -, são "relatos do passado aproximados e imprecisos, em que os descendentes buscam ensaiando versões possíveis desse passado. E os vazios e silêncios terminam sendo importantes achados.” (BARRIL, 2013, p. 38, tradução nossa).

Não é arbitrária essa disparidade de interpretações identificável na fortuna crítica de Mi vida con Carlos. As oscilações das leituras entre o palpável e o intangível, o êxito e o impossível, o desfecho e a abertura derivam de uma tensão latente nesse tipo de documentário. O filme de Berger-Hertz é esteticamente muito bem-acabado, uma produção impecável cujo arco narrativo converge para a conclusão do trabalho de luto do filho - e nisso ele contrasta tanto com a melancolia de Diário de uma busca quanto com o desconstrucionismo de Los rubios. Na ponta final do relato, fechando a carta ao pai em uma leitura plena de emotividade no meio do deserto, o filho anuncia a superação do silêncio familiar e a inauguração de uma vida na qual tenha lugar a memória de Carlos - a "vida com Carlos" do título do filme. Simultaneamente, a estrutura da busca que vai alinhavando a história, ao menos em princípio (eis uma ressalva importante), daria margem para a contingência dos resultados, deixando aberta a possibilidade do fracasso ou, caso se queira, do vazio como grande achado no fim do processo. A definição de Jean-Claude Bernardet (2005) 
já prenunciava essa tensão entre clareza (naquele caso, do alvo da busca) e imprevisibilidade (de seu resultado). A argumentação neste ponto se desdobra para desvelar, no cerne do documentário de busca, um aspecto fundamental apontado por Umberto Eco (2016, p. 16, tradução nossa) em seu clássico Obra aberta: forma e indeterminação nas poéticas contemporâneas:

[...] o problema de uma dialética entre "forma" e "abertura": ou seja, de definir os limites dentro dos quais uma obra possa alcançar a máxima ambiguidade e depender da intervenção ativa daquele que a consome sem, contudo, deixar de ser "obra". Entendendo-se por "obra" um objeto dotado de propriedades estruturais definidas que permitam mas também coordenem a alternância das interpretações, o deslocamento das perspectivas.

Ora, já a proposição da existência de um espaço de interações multifacetadas entre as gerações da memória que encerra o capítulo anterior conduz a essa questão acerca da indeterminação. Em um primeiro olhar, a miríade de posturas (estilísticas, culturais, mnemônicas, identitárias etc.) possíveis da geração dos descendentes em relação às lembranças dos pais (e tios e avós) pareceria ganhar forma adequada em obras marcadas pelo hibridismo estético, pela abertura narrativa, pelo imponderável, pelo risco do insucesso etc. E, de fato, a bibliografia é pródiga em ressaltar a carga de incertezas do documentário intergeracional ligado à forma da busca, muito além dos textos dedicados a Mi vida con Carlos. Vale revisar algumas passagens nesse sentido.

Por exemplo, Ana Amado (2009, p. 141, tradução nossa), autora argentina referência nesse campo, avalia que "[...] as produções memorialísticas dos familiares das vítimas deixam entrever modos muito diversos - inclusive em sua multiplicação e na pluralidade de suas vias de execução - de alterar e, ainda, de fissurar as narrações estabelecidas e sua exposição plena dos fatos trágicos." Analisando Papá Iván (María Inés Roqué, México / Argentina, 2000), Amado (2009, p. 184-185, tradução nossa) mais uma vez enfatiza essa faceta indeterminada das expressões da segunda geração: "Se um luto realizado supõe o passado como algo já concluído no próprio núcleo de sua representação, a indefinição de sua saída narrativa sugere que para ela esta é ainda uma operação em suspenso." Sobre El tiempo y la sangre (Alejandra Almirón, Argentina, 2004), a mesma autora escreve:

A continuidade narrativa é entrecortada com testemunhos fragmentários, citações fílmicas, filmagens caseiras, imagem instável e montagem acelerada, entre outros procedimentos que delatam o dispositivo ficcional da trama documental e, ao mesmo tempo, registram materialmente o modo espasmódico e descontínuo pelo qual a nova geração recebe os relatos. Vozes, rostos, olhares, movimentos e trajetos incessantes, saturação de 
elementos até a própria anulação do sentido pleno distribuem e desorganizam a cronologia das versões, no lugar de simplesmente comunicálas. (AMADO, 2009, p. 201, tradução nossa).

Gabriela Nouzeilles (2005, p. 268-269, tradução nossa), escrevendo sobre Los rubios (Albertina Carri, Argentina, 2003), segue uma linha similar:

O título do filme, Los rubios, ironicamente ressalta a inconclusividade fundamental da memória e da identidade. O quebra-cabeça contém muitas peças, algumas das quais estão faltando, enquanto outras não se encaixam ou poderiam ser montadas de mais de uma maneira. O que resta é uma profusa colagem de fragmentos e pontas soltas.

A formulação de Michael J. Lazzara (2009, p. 150, tradução nossa) sobre a produção cultural de segunda geração em geral faz eco a essa ideia:

Dito de outro modo, obras que põem em relevo as dificuldades da representação, especialmente aquelas produzidas por artistas que se encontram a uma distância geracional da experiência "direta" do trauma, comunicam uma ética baseada na convicção de que as memórias não devem ser fechadas e que a arte não deve oferecer interpretações costuradas da história.

Analisando El eco de las canciones (Antonia Rossi, Chile, 2010) e El edificio de los chilenos (Macarena Aguiló e Susana Foxley, Chile / Cuba / França / Bélgica, 2010), Catalina Donoso Pinto (2012, p. 28, tradução nossa) observa:

Ambos os trabalhos reivindicam o lugar da infância e desde essa posição privilegiam uma narrativa não linear, baseada na fragmentação e na tensão entre essa energia independente do parcial e as intenções de alcançar certo grau de coesão. Nesse sentido, a linguagem fílmica, que não mascara suas artimanhas, mas sim faz presente a materialidade de seus componentes, inscreve-se em uma apresentação da viagem mnemônica como questionamento da identidade no sentido de um formato rígido ou de um recipiente que não admite transbordamentos. Ao contrário, essa forma de nomear o "eu" permite que este se situe nos espaços do ambíguo, do incompleto e do inconcluso.

Em uma seção intitulada "Estéticas e éticas da pós-memória" de seu abrangente trabalho sobre o documentário argentino de segunda geração, Laia Quílez Esteve (2009, p. 101, tradução nossa) descreve alguns dos procedimentos formais tidos como característicos dessas obras:

[...] os trabalhos englobados dentro do guarda-chuva da pós-memória optam por distanciar-se [...] dos mecanismos da representação realista para recorrer, no lugar disso, a um conjunto de estratégias pelas quais o real e o fictício, a pessoa e o personagem, o original e a cópia se confundem 
apagando limites e fronteiras. [...] as estratégias estéticas e narrativas às quais recorrem tais obras perseguem, necessariamente, o transgenérico, o híbrido, o fragmentário, o ambivalente, o autorreflexivo, o irônico. Assim, frente às narrativas clássicas, que priorizavam a uniformidade e a homogeneidade em um relato fechado de antemão, os 'sutis pretéritos' [...] que dão forma aos discursos gestados na pós-memória se caracterizam pela ambiguidade, pela descontinuidade e pela mescla. São relatos que [...] se apresentam como aproximações que, longe de serem conclusivas e absolutas, tratam, antes, de indagar certas passagens do passado de um modo provisório e parcial e, portanto, completamente reinterpretável e intersubjetivo.

A atribuição de uma inerência, de uma necessidade intrínseca dos artifícios reflexivos na produção de obras intergeracionais já seria, por si só, um paradoxo. Afinal, tal caracterização acaba tomando como naturais de uma tendência fílmica os atributos estéticos dedicados justamente a romper como naturalismo. O problema em foco aqui, entretanto, é de outra ordem. Interessa, antes, apontar a insistência com que os documentários intergeracionais são descritos com os termos da indeterminação. ${ }^{76}$

No calor das polêmicas em torno de Los rubios nas páginas de Punto de vista, Martín Kohan (2004a, 2004b) já fazia uma crítica cáustica a essa abordagem. Na tréplica que escreve à reação de Cecilia Macón (2004) a "La apariencia celebrada" (KOHAN, 2004a), ele considera que esse "enfoque crítico" tinha como traço saliente a:

[...] sua notória monotonia: tende a dizer o mesmo de qualquer objeto que se coloque ao seu alcance. Nos objetos mais diversos, vê sempre incertezas, limites frágeis, instabilidade, pluralidade, alteridades. Vê sempre o mesmo: é essa a verdadeira voz monológica da teoria e da crítica dos últimos anos (ainda que em seu conteúdo postule multiplicidades). (KOHAN, 2004b, p. 47 , tradução nossa).

Beatriz Sarlo (2007, p. 101-102), desdobrando essa mesma controvérsia, faz referência ao "contraste entre o discurso do 'aberto', do 'fragmentário' e do 'irresolvido"”, por parte da crítica, e, no campo artístico, aquilo que ela chama de "decálogo internacional unificado e fortemente criador de consenso" da "pós-memória".

Algo que a retórica do indeterminado nem sempre menciona é que, em todos os casos, a busca visível nos filmes é também uma forma cinematográfica. Ou seja, não se trata de uma

\footnotetext{
${ }^{76}$ No contexto brasileiro, embora o recorte não seja o documentário intergeracional sobre a ditadura, a tese de Ilana Feldman (2012a, p. 14) se aproxima dessas leituras da indeterminação: "Na contramão, portanto, dessa tendência realista que tem pautado o cinema de ficção e operando na indeterminação entre autenticidade e encenação, pessoa e personagem, público e privado, intimidade e invisibilidade, processo e obra, experiência e jogo, vida e performance, diversos documentários brasileiros contemporâneos, que constituem o foco de nosso interesse, têm investido na opacidade, na explicitação das mediações, na reposição da distância e na tensão entre as subjetividades e seus horizontes ficcionais - destilando dúvidas a respeito da imagem documental, colocando sob suspeita seus próprios procedimentos, métodos e premissas ou produzindo suas próprias esquivas." De fato, um dos capítulos do trabalho de Feldman ("A indeterminação sob suspeita") avança o debate, apontando as armadilhas ideológicas dos usos midiáticos e instrumentais da indeterminação.
} 
miscelânea de signos audiovisuais justapostos de modo aleatório. Está em jogo, em pé de igualdade com o imponderável, uma configuração calcada em certos recursos específicos da linguagem documental, a organização de uma narrativa que delineia o grau de abertura da obra (de fato, chegando muitas vezes a fechá-la). Se há algo intrínseco a essa filmografia (na verdade, a qualquer obra de arte), é essa dialética entre o gesto formativo e a abertura dos significados - uma margem para a interpretação que pode ser residual, nos casos das formas que tendem à univocidade, ou programática, nas obras que convidam ativamente o espectador à polissemia (ECO, 2016). Que uma obra tenha uma forma, por mais aberta que seja, parece um princípio estético de base, uma obviedade até. Mas, na prática analítica, o que se vê em muitas leituras da indeterminação é um afastamento desse polo formativo em nome de um superdimensionamento da abertura.

Relendo a bibliografia fundamental sobre o cinema subjetivo em geral, documental ou de ficção, nota-se que essa tensão entre forma e indeterminação é rastreável já nos debates da década de 1980 acerca de um fenômeno audiovisual que naquele momento começava a ser decodificado. Muito se falava, e ainda hoje se fala, em "cinema autobiográfico", terminologia que por si só revela o peso dos estudos literários nas primeiras definições do cinema contemporâneo em primeira pessoa. Em linhas gerais, duas vertentes teóricas se esboçavam nos textos inaugurais sobre o tema. Do lado da forma - ou melhor, do lado da norma estavam os autores que, em artigos pioneiros, debruçaram-se sobre as possibilidades do cinema autobiográfico: Elizabeth W. Bruss (1980) e Philippe Lejeune (2008 - original de 1987). Do lado da indeterminação, estavam outros dois artigos que deram sequência àquela discussão sobre o cinema autobiográfico: um de Raymond Bellour (1988) e outro de Michael Renov (2004b - original de 1989). Vale se deter por um instante nessa discussão seminal dos anos 1980, com o objetivo de iluminar nuances ainda vigentes na bibliografia sobre o documentário contemporâneo que remontam àquele momento.

O texto de Elizabeth W. Bruss, de 1980, deu o pontapé inicial de uma polêmica que iria reverberar no fim da década. É curioso que o primeiro passo desse debate não era nada entusiasta com as possibilidades da autobiografia no cinema. Muito pelo contrário, Bruss (1980, p. 296-297, tradução nossa) entrevia o desaparecimento do gênero autobiográfico em sua passagem da literatura para o meio audiovisual:

Se o filme e o vídeo efetivamente chegam para substituir a escrita como nosso principal meio de registro, informação e entretenimento, e se (como eu espero mostrar) não existe um equivalente cinematográfico real para a autobiografia, então o ato autobiográfico tal qual o temos conhecido pelos 
últimos quatrocentos anos poderia, de fato, tornar-se cada vez mais invisível até, afinal, chegar à extinção.

O diagnóstico sombrio de Bruss sobre o fim da autobiografia em um mundo da imagem explica-se quando se olha para os rígidos parâmetros do gênero estipulados pela autora. Isto é, aquilo que, segundo ela, uma autobiografia "deve ter" para "contar como autobiografia": "valor de verdade"; "valor de ato"; e "valor de identidade" (BRUSS, 1980, p. 299-300, tradução nossa). Dado que os critérios de definição são extraídos da prática da autobiografia escrita, sua transposição para um meio distinto, o meio cinematográfico, só poderia ser malfadada. E, de fato, Bruss realiza um cotejamento entre linguagem escrita e cinema no qual a primeira sempre leva vantagem no cumprimento das premissas da autobiografia clássica. Ora, visto que um dos elementos da comparação era, ao mesmo tempo, o parâmetro, não haveria como ser diferente. Se, para Bruss, o "dever ser" da autobiografia é a literatura, a expressão audiovisual, com suas evidentes diferenças em relação à escrita, nunca chegaria a ser adequada. Partindo de uma concepção ontológica da imagem fílmica, a autora na verdade pensa o audiovisual como um meio essencialmente anti-autobiográfico: "O cinema parece carecer da mesma capacidade de auto-observação e autoanálise que associamos à linguagem e à literatura." (BRUSS, 1980, p. 298, tradução nossa). O problema todo nesse caso é a definição normativa do gênero, fundada no texto literário, algo que impede que Bruss sequer vislumbre a possibilidade de transferência da autobiografia para outro meio de expressão.

Philippe Lejeune (2008) adota uma postura menos cética em um texto de 1987 no qual contesta abertamente Elizabeth W. Bruss (1980). O autor francês refuta a tese da "morte" da autobiografia no cinema, apontando, por um lado, as limitações das premissas de Bruss e enxergando, por outro, as potencialidades do cinema para a expressão autobiográfica. Contudo, nem por isso Lejeune deixava de se inquietar com as confusões, os titubeios e os "problemas de vocabulário" causados pela passagem dos termos da autobiografia do texto escrito para o meio audiovisual. E não era de se estranhar que o autor sentisse algum desconcerto frente às dificuldades de classificação da autobiografia em seu novo suporte, o cinematográfico. Afinal, no campo dos estudos literários, Lejeune (1996) é o fiador do "pacto autobiográfico", uma definição rigorosa do gênero cuja normatividade chega ao paroxismo nas tabelas e nas fórmulas tipológicas traçadas ao longo da argumentação. ${ }^{77}$ Ainda assim, e a

\footnotetext{
${ }^{77}$ A célebre definição de autobiografia proposta por Philippe Lejeune (1996, p. 14, tradução nossa), formulada em seu clássico Le pacte autobiographique, livro publicado originalmente em 1975, é a seguinte: "Relato retrospectivo em prosa que uma pessoa real faz de sua própria existência, quando ela enfatiza sua vida individual, em particular a história de sua personalidade."
} 
despeito das dificuldades de classificação, Lejeune (2008, p. 24, tradução nossa) reconhecia que a passagem da autobiografia para o meio audiovisual era uma realidade que se impunha: “O cinema autobiográfico começa, pois, a existir, diferente da autobiografia escrita, mas também diferente do cinema de ficção, a meio caminho entre o cinema amador e o cinema de ensaio." É verdade que seu olhar para o fenômeno nascente carregava um grau de condescendência: "O cinema autobiográfico está ainda em seus inícios, certamente veremos outras realizações mais convincentes”. (LEJEUNE, 2008, p. 25, tradução nossa). Mas não abria mão da esperança: "E eis o cinema que por sua vez diz 'eu'. A autobiografia só pode enriquecer-se, é uma aventura que se deve seguir com curiosidade...” (LEJEUNE, 2008, p. 26, tradução nossa). Em suma, lá na segunda metade da década de 1980, Lejeune ficava perplexo, mas nem por isso incrédulo, diante da "confusão" gerada pelo cinema no terreno da autobiografia.

Entre o ceticismo de Bruss (1980) e a perplexidade de Lejeune (2008), há toda uma diferença de postura. Mas ambos os autores coincidem em fundar suas reflexões no terreno da normatividade. Em Bruss, a suposta inadequação do cinema ao "dever ser" da autobiografia levava à conclusão da impossibilidade do gênero no novo suporte. Para Lejeune, as confusões tipológicas causadas por essa transposição suscitavam um desconcerto esperançoso frente a um fenômeno que se impunha. Nos dois casos, as indefinições do cinema autobiográfico eram vistas com ressalvas. Se para o leitor de hoje essas abordagens normativas soam datadas, isso, por si só, é um indício de qual corrente daquelas discussões acabou prevalecendo: justamente, o prisma diametralmente oposto adotado pelos autores que já então enxergavam a indeterminação como a grande potência da expressão subjetiva no cinema.

É com essa visão que Raymond Bellour (1988) entra no debate com Elizabeth W. Bruss (1980) e Philippe Lejeune (2008). Segundo Bellour (1988, p. 336-337, tradução nossa), mesmo levando em conta a "posição severa e aparentemente unívoca" adotada por Bruss, fato é que a "argumentação bem pragmática" de Lejeune não respondia à questão de fundo levantada pela autora: o cinema aprendeu a dizer "eu", mas não o diz da mesma maneira que a autobiografia literária.

De modo que, sob a diferença das palavras, dos humores e das atitudes, a distância acaba por parecer sutil entre aquela que declara impossível a autobiografia no cinema e aquele que se encanta ao vê-la aí triunfar, sugerindo que, sem dúvida, ela se torna bastante diferente de si mesma, mas sem dizer uma só palavra que busque sugerir aquilo que tal mutação introduz (ou não) na subjetividade contemporânea. (BELLOUR, 1988, p. 337, tradução nossa). 
Bellour enfrenta a empreitada, e o faz ressaltando as instâncias de fragmentação, desestabilização e volatilização do "eu" no cinema, até contrapor dois modos de tratamento da experiência subjetiva no audiovisual: a autobiografia, "que no cinema se torna fragmentária, limitada, dissociada, incerta - assolada por essa forma superior de dissociação que nasce dos travestimentos da ficção" (BELLOUR, 1988, p. 341, tradução nossa); e o autorretrato, em um grau de indeterminação ainda maior, pois escapa da lógica narrativa e se aproxima da analogia, do metafórico e do poético, tanto mais quando seu suporte é o vídeo.

O autorretratista parte de uma questão que testemunha uma ausência de si, uma questão à qual nada pode chegar a responder; ele passa, assim, sem transição, de um vazio a um excesso, e não sabe claramente nem aonde ele vai, nem aquilo que ele faz, ao passo que a autobiografia é contida por uma plenitude limitada que vincula o sujeito ao programa de sua própria vida. (BELLOUR, 1988, p. 342, tradução nossa).

Já Michael Renov (1989), em um artigo do ano seguinte, parte da ideia de ensaio - a qual viria a prosperar nesse campo de estudos (LIANDRAT-GUIGUES; GAGNEBIN, 2004) -, passa pela filosofia pós-estruturalista para propor, enfim, sua própria noção da autobiografia no cinema e no vídeo:

Se aquilo que estou chamando de "a nova autobiografia" tem alguma pretensão de precisão teórica, isso se deve a esse trabalho de construção da subjetividade como um lugar de instabilidade - fluxo, deriva, revisão perpétua - mais do que de coerência. [...] A versão pós-estruturalista de subjetividade, portanto, diverge da tradição ocidental que, desde Descartes, coloca o "eu" do cogito como a âncora e o fundamento do ser, o lugar de uma certeza que reflete em miniatura a soberania de deus. (RENOV, 2004b, p. 110, tradução nossa).

Também aqui, a ênfase recai sobre a instabilidade do sujeito, e a descrição que Renov faz dos filmes autobiográficos a partir dessa matriz vai enfileirando uma série de adjetivações colhidas no vocabulário da indeterminação. São obras, pois, que o levam "a reconsiderar a declaração de Elizabeth W. Bruss sobre a autobiografia fílmica.” E a recusar aquele ceticismo em nome de uma postura que não disfarça o entusiasmo com o horizonte aberto pelo cinema subjetivo:

Minha própria posição seria a de que a autobiografia, longe de ser uma espécie em extinção, mostra novos sinais de vida. Ela é o lugar de uma viva iniciativa criativa sendo realizada por cineastas e videomakers ao redor do mundo, algo que está transformando os modos de nos pensarmos e de nos representarmos para nós mesmos e para os outros. (RENOV, 2004b, p. 111, tradução nossa, grifo do autor). 
Toda essa digressão não é uma mera prestação de contas sobre alguns dos textos seminais do debate sobre o cinema subjetivo ou autobiográfico. O resgate das discussões pioneiras dos anos 1980 serve para mostrar que os termos aqui debatidos têm raízes profundas na história desse campo de estudos. A bibliografia específica sobre Mi vida con Carlos e outros títulos do documentário intergeracional, mobilizada mais acima, não deixa de ecoar, direta ou indiretamente, uma reflexão que vem de longe. Simultaneamente, esse olhar retrospectivo esclarece certos aspectos dos polos da dialética da forma e da indeterminação que guia este capítulo. Por um lado, quando se fala em trazer para a discussão a questão das formas do documentarismo intergeracional, não se está com isso professando uma abordagem regressiva pautada por uma normatividade tipológica. Por outro, ao se defender o redimensionamento dos graus da abertura nessa filmografia, trata-se de fazer um alerta quanto às distorções que podem surgir nas leituras exageradamente entusiasmadas pela indeterminação. É o caso de manter a dialética ativa: ter em conta as formas, mas sem cair na normatividade; reconhecer a indeterminação, sem ficar na mera apologia da abertura.

Porque é preciso dizer que o tom laudatório de muitas leituras centradas na indeterminação acaba por desviar a atenção das questões propriamente formais em jogo nessa produção intergeracional: os principais recursos audiovisuais mobilizados; os afastamentos e as aproximações com as tradições do cinema documentário; aquilo que as imagens enquadram nos esforços de rememoração; os modos de estruturação das narrativas; os tópicos de memória que se destacam; e, por último, mas não menos importante, a consolidação de certas fórmulas cinematográficas. A proposta deste capítulo vai no sentido de olhar para as imagens sem lhes impor a indeterminação como pauta estética a priori. Afastar-se, enfim, do diapasão apologético para tentar enxergar nas obras as tensões entre as formas e o horizonte da abertura.

\section{Mi vida con Carlos e o repertório estético-narrativo do documentário intergeracional}

Se no primeiro capítulo há uma reivindicação da abordagem diacrônica voltada a compreender a formação dessa cinematografia ao longo dos anos, agora a análise se dá em chave sincrônica, colocando os filmes lado a lado para identificar paralelos formais. Mi vida con Carlos é a porta de entrada para a descrição do repertório estético-narrativo do documentarismo intergeracional. Isso porque o título dirigido por Germán Berger-Hertz está impregnado dos recursos expressivos da busca subjetiva, percorrendo as veredas mais transitadas dessa tendência estilística, correspondendo às principais linhas das cartografias 
propostas por autores dedicados aos modos de inscrição da primeira pessoa no documentário contemporâneo (ÁLVAREZ, 2005; GÁLVEZ, 2008; LABBÉ, 2012b; LLANOS, 2014; ORTEGA, 2008, 2010; PIEDRAS, 2014; PINTO, 2012; RENOV, 2004a).

Esta seção propõe uma decupagem analítica sistemática do material audiovisual, segmentando: os elementos da banda sonora (vozes, trilha musical, sonoplastia); os recursos da linguagem cinematográfica (enquadramentos, movimentos de câmera, texturas, cores, reflexividade, inserções, intertítulos, legendas, animação etc.); aquilo que é visível nos filmes (pessoas, lugares e intertextualidades); os arquivos mobilizados (públicos ou privados, incluindo fotografias, imagens em movimento, áudios, documentos escritos); os tópicos específicos da memória intergeracional (com questões que vão desde as vivências de infância até os embates identitários no presente); além dos modos de estruturação das narrativas (busca, itinerância, disjunção, coesão etc.). Como ficou dito, este levantamento parte de $M i$ vida con Carlos, mas a proposta é comparativa, abrangendo o corpus expandido, fazendo um esforço para dar conta dos artifícios fílmicos e das pautas de rememoração mais salientes nessa filmografia. Não se trata, porém, simplesmente de apresentar uma listagem. A indagação acerca das tensões entre forma e indeterminação se mantém no cerne da empreitada descritiva.

\section{Banda sonora}

\section{- Voz over em primeira pessoa}

A voz over da diretora ou do diretor em primeira pessoa é um dos meios de expressão da subjetividade mais diretos nessa filmografia. Em Mi vida con Carlos, a particularidade no uso de tal recurso vem do fato de que a voz que diz "eu" também diz "tu", recitando uma carta ao pai desaparecido. Essa voz epistolar do filho Germán Berger-Hertz vai conduzindo a reconstituição da trajetória do pai Carlos ao longo de todo o documentário, em algumas passagens se aproximando de uma explicitação didática de informações genealógicas (por exemplo, quando reitera os laços de parentesco entre os membros da família) ou históricas (ao esclarecer a importância dos arquivos da Vicaría de la Solidaridad, quando explica o que foi a Caravana da Morte). Essa primeira pessoa em voz over que se dirige a uma segunda pessoa ausente se repete em Elena (Petra Costa, Brasil, 2012), no qual a diretora como que vai falando com a irmã morta ao longo do filme. 
Existem, contudo, os casos em que certas instâncias de mediação se interpõem entre aquele que é dono da voz e a pessoa do discurso. O exemplo mais evidente nesse sentido é Los rubios (Albertina Carri, Argentina, 2003), em que a voz over que diz "eu" pertence à atriz Analía Couceyro, que também se coloca em cena duplicando a filha-diretora. Albertina Carri viria a usar sua própria voz over em Cuatreros (Albertina Carri, Argentina, 2016), no qual, ao contrário, sua fala constante, quase monocórdia, desfiando do início ao fim considerações de cunho ensaístico e introspectivo, como que inunda as imagens de arquivo que vão se sucedendo em um fluxo vertiginoso. Já em El eco de las canciones (Antonia Rossi, Chile, 2010), a mediação prescinde da corporeidade observada em Los rubios, e a voz em primeira pessoa que se escuta em over alinhavando sensações e fragmentos de lembranças do exílio, também em chave ensaística, não é a da filha-diretora Antonia Rossi, e sim a da atriz Angélica Riquelme, algo que o espectador só vai descobrir nos créditos finais do filme.

Ocorre a situação em que a voz de uma atriz ou de um ator em over não assume a primeira pessoa, mas recita o texto de cartas ou outros materiais privados. Tal é o caso em Marighella (Isa Grinspum Ferraz, Brasil, 2011), em que a voz over subjetiva da sobrinha do protagonista se alterna com a locução de Lázaro Ramos, informando contextos em tom objetivo, tal qual a voz desencarnada do saber do documentário clássico, mas também lendo cartas e poemas assinados por Carlos Marighella. Em Repare bem (Maria de Medeiros, Brasil / Portugal / Espanha, 2012), há inserções em que a voz da atriz Ana Petta lê em over cartas de "Bacuri" e outros documentos privados.

Diário de uma busca (Flavia Castro, Brasil / França, 2010) não conta com a voz de um profissional da interpretação. Nesse caso, a voz over em primeira pessoa de Flavia Castro vai se revezando com a de seu irmão, João Paulo Castro, que lê em over as cartas enviadas pelo pai naquele período. Em tantos outros filmes, é a voz do próprio realizador que lê esses materiais do arquivo familiar. Para ficar em dois exemplos: em Papá Iván (María Inés Roqué, México / Argentina, 2000), a filha recita em over, em segmentos distribuídos ao longo da narrativa, a íntegra da carta deixada pelo pai explicando para os filhos sua opção pela luta clandestina - que o levaria à morte; em Tiempo suspendido (Natalia Bruschtein, México / Argentina, 2015), a neta lê, também ao longo do filme, um dos discursos da avó, fundadora das Madres de Plaza de Mayo.

Mais rara nessa filmografia, mas nem por isso ausente, é a voz over do documentário clássico, aquela que enuncia um saber em terceira pessoa, cujas afirmações não têm a origem explicitada - a “voz de Deus”, como já a chamou Bill Nichols (2010, p. 167-171). Na sua manifestação original, em que um locutor profissional e desencarnado declama um texto de 
maneira impostada, essa voz se faz presente em Hermanos de sangre (Fabián Vittola, Argentina, 2005) e Semillas de utopía (Rodolfo Colombara e Emanuela Peyretti, Itália, 2006). No entanto, como ficou sinalizado, existem as situações em que a voz do próprio realizador do filme assume esse papel da asserção de informações objetivas sobre os eventos narrados (PIEDRAS, 2014, p. 165). O exemplo de Emilio Pacull chama atenção nesse sentido, nos dois títulos em que este diretor lida com a memória intergeracional: Los huérfanos del Cóndor (Emilio Pacull, França / Uruguai, 2003), em que ele se debruça sobre o caso da apropriação dos irmãos Anatole e Victoria Julien; e Héroes frágiles (Emilio Pacull, Chile / França, 2007), no qual se coloca às voltas com a lembrança de seu padrasto, Augusto Olivares, assessor de Salvador Allende que se suicidou junto com o presidente durante o bombardeio do Palácio de La Moneda. Tanto na abordagem da história alheia quanto na rememoração de eventos que afetaram sua família, a voz do cineasta em over oscila entre a terceira e a primeira pessoa, tendendo mais para as asserções sobre o mundo histórico do que para as indagações privadas. Outros realizadores, em graus distintos, também operam com essa alternância entre a voz subjetiva e a voz objetiva na locução em over. Por exemplo, em Secretos de lucha (Maiana Bidegain, Uruguai / França, 2007), a enunciação em primeira pessoa da filha-diretora, sempre em tom suave, em algumas passagens assume claramente a função da voz clássica que contextualiza os fatos.

Em síntese, é inegável que a expressão da voz over em primeira pessoa seja preponderante no documentarismo intergeracional do Cone Sul. Mas vale a pena levar em conta as variantes desse recurso identificáveis no conjunto das produções, indo dos usos mais clássicos da "voz de Deus" aos hibridismos e oscilações entre a voz subjetiva e a voz objetiva (cf. PIEDRAS, 2014, p. 83-87). E cabe pensar ainda sobre todos os títulos do corpus que simplesmente prescindem da voz over. Seja porque se aproximam de tradições estilísticas que, em princípio, costumam recusar a voz over - o que incluiria o experimentalismo de En memoria de los pájaros (Gabriela Golder, França / Argentina, 2000) ou de Orestes (Rodrigo Siqueira, Brasil, 2015), bem como os acenos ao documentário observacional em Victoria (Adrián Jaime, Argentina, 2008) ou La quemadura (René Ballesteros, Chile / França, 2009) -; seja porque o discurso assertivo está encarnado no coral de vozes dos entrevistados, editadas de modo a construir um relato coeso ou mesmo unívoco dos eventos (RAMOS, 2008, p. 24 e 41) - e os exemplos desse tipo são numerosos na filmografia.

\section{- Trilha musical}


Menos evidente do que a voz over, a trilha musical é o recurso sonoro extradiegético mais utilizado no conjunto de títulos do corpus. Principalmente na forma da música incidental, com uma melodia instrumental soando ao fundo, adicionando certa ambiência às imagens, no mais das vezes acompanhando as inserções (de planos de arquivo, de travellings, de tomadas da paisagem, de reconstituições ficcionais, em alguns casos junto com a voz over) que se intercalam às sequências com as entrevistas. Em Mi vida con Carlos, a trilha incidental soa tão logo surgem na tela as fotografias com a figura do pai de Germán Berger-Hertz: de início, quando ele encontra o retrato de Carlos no arquivo público que consulta na abertura do filme; logo em seguida, durante as inserções das fotografias da família vistas enquanto a mãe vai descrevendo ao filho-diretor os atributos do pai desaparecido. Mais adiante, uma variação do mesmo tema melódico acompanha a primeira viagem de regresso ao Chile do tio Eduardo, que se estabelecera no Canadá após o desaparecimento do irmão Carlos. A trilha volta quando, sobreposta a tomadas em close-up de fotos da família que vão fluindo submersas em água, a voz over de Berger-Hertz faz menção ao suicídio de seus avós como consequência do desaparecimento de Carlos. E, mais uma vez, o tema soa quando a câmera segue em travelling o diretor, que anda de bicicleta em um dia de sol levando sua filha na garupa. A música continua em fusão com a próxima sequência, que traz imagens com textura de super-8 da esposa e das filhas de Berger-Hertz. Nesse momento, sua voz over faz menção à dor que sentia no dia dos pais durante a infância e à experiência de se tornar, ele mesmo, pai. $\mathrm{O}$ recurso vai se repetindo: a trilha surge sobreposta à nova projeção da tomada em super-8 do mergulho do jovem Carlos no mar; quando a mãe do realizador visita o Memorial do Preso Desaparecido e do Executado Político, em Santiago; quando o cineasta visita com o tio a prisão por onde o pai passou em Calama. A atmosfera sonora gerada pela música incidental vai oscilando entre o ameno e o sombrio, de acordo com o episódio narrado. Até que, na conclusão da narrativa, assim que Berger-Hertz termina de ler, aos prantos, a carta ao pai no meio do deserto, entra um novo tema que aumenta a carga de sentimentalismo no fim do documentário. Nesse desfecho, acentua-se o apelo emotivo que vinha se anunciando a cada entrada das melodias incidentais em Mi vida con Carlos. ${ }^{78}$

Além da trilha de fundo, a filmografia traz também ocorrências de canções que dialogam de modo mais direto com as histórias relatadas. Em Diário de uma busca, como já ficou comentado, as canções de diferentes artistas vão pontuando os momentos do exílio de Flavia Castro. A contrarreloj (Pablo Sobrino, Uruguai, 2011) é, em si, uma espécie de

\footnotetext{
${ }^{78}$ A música de Mi vida con Carlos é de Miranda y Tobar, dupla chilena especializada na produção de trilhas sonoras para obras audiovisuais.
} 
videoclipe da canção homônima de Ismael Collazo. Os usos das canções são múltiplos no corpus, havendo também as situações em que a música não é adicionada na fase de pósprodução, mas está inserida na própria diegese do documentário. Por exemplo, quando Carlos Henrique Escobar revela para a filha o desejo de que em seu funeral toquem Fita amarela, de Noel Rosa, e alguém coloca a canção para soar no ambiente. Ou quando, em meio a entrevistas, surge o registro de uma apresentação da banda dos colegas cubanos da diretora em El telón de azúcar (Camila Guzmán Urzúa, França / Cuba / Espanha, 2006). Já em Retour: volver (Martin Bourgault, Canadá / Argentina, 2016), o mote do filme é o regresso à Argentina em turnê do músico e filho exilado Tomás Jensen.

Raras são as vezes em que as análises do documentarismo intergeracional levam a abordagem da dimensão sonora para além daquilo que é dito em voz over ou nos depoimentos dos entrevistados. O foco da atenção se mantém no teor das palavras, e os usos da trilha musical em geral são deixados de lado, salvo em algumas ocorrências mais chamativas como no caso de Los rubios, em que a canção Influencia, em versão de Charly García, ${ }^{79}$ encerra o filme como um comentário explícito ao distanciamento geracional que atravessa o documentário. As canções muitas vezes têm essa função mais narrativa, mais vinculada aos desdobramentos da trama, como se viu. Mas são as melodias incidentais que, justamente por soarem ao fundo, quase que "naturalmente", operam como potentes instrumentos da construção da fluidez de sentidos e ambiências emocionais, tanto mais em obras que se rendem ao apelo do "melos" para narrar histórias familiares dramáticas (BROOKS, 1995, p. 14 e 48).

\section{- Sonoplastia}

Ainda menos observados são os efeitos de sonoplastia incluídos em muitos títulos do corpus. Quanto a esse aspecto, Mi vida con Carlos revela um esmero naturalista na articulação de ruídos e outros recursos sonoros, inserindo em pós-produção barulhos específicos em prol da composição da cena, da reiteração do teor daquilo que é dito ou da intensificação da atmosfera sentimental aludida. Esse movimento se revela já desde o primeiro plano do filme, quando o lento travelling que esquadrinha o terreno desértico é acompanhado de um rumor de vento forte que potencializa a impressão de vazio suscitada por aquela paisagem. Essa adição de ruídos "naturais" se repete ao longo do filme: ouve-se o

\footnotetext{
${ }^{79}$ A composição original é de Todd Rundgren, Influenza, de 1982. A versão de Charly García data de 2002.
} 
barulho de água corrente quando o tio Eduardo está pensativo à margem do rio Ottawa; em uma sequência de planos de arquivo, a voz over de Berger-Hertz faz menção às imigrações prévias da família, o travelling em preto e branco tomado desde um barco em movimento se conjuga com o som do mar, o canto de gaivotas e a buzina de um navio ao fundo; a voz prossegue, narra a vinda da família da Hungria para o Chile, em 1936, fugindo da perseguição antissemita, surge o plano de arquivo de um trem e logo se escuta o sino que alerta para a passagem da locomotiva; as imagens de arquivo, agora em super-8, mostram crianças em um parque, eis inseridos o vozerio de crianças, o cricrilar de grilos, o canto de pássaros; uma última filmagem de arquivo desta sequência revela uma praia, soa o ruído da onda que quebra. Nessa passagem em especial, chama atenção o esforço de sonorização naturalista de planos de arquivo silenciosos na origem.

Já em outros momentos, a sonoplastia serve sobretudo para reforçar sensações. Em outra sequência, a mãe do realizador lê em over uma carta sua enviada em 1974 à sogra, Dora Guralnik, relatando a dor pela queda do marido, os pensamentos obsessivos sobre a morte do filho Germán, a distância e as perdas do exílio. A câmera passeia em close-up por fotografias da família, cai uma chuva diante das fotos. A leitura da carta vai sendo entrecortada por estrondos de trovões, clarões na tela os acompanham. Aqui os ruídos da natureza adicionam uma atmosfera tempestuosa no exato momento em que a narrativa se aproxima de temas mais graves. $^{80}$

Tais recursos vão se repetindo no restante de Mi vida con Carlos, e é de se notar que esse impulso de construção de uma ambiência sonora naturalista e dramática está presente em outros títulos da filmografia aqui estudada. Algumas recorrências nesse campo chamam atenção: a adição de ruído de helicóptero ou de fortes estalidos nos momentos em que sobe a tensão da narrativa sobre a repressão; o barulho destacado do projetor de super- 8 quando surgem inserções de filmagens domésticas nessa bitola. ${ }^{81}$

Contudo, é preciso dizer que os ruídos também são usados de modo não reiterativo nos documentários intergeracionais. Pois há casos em que os rumores mais intrigam do que ilustram, surgindo como sons estranhos cuja origem não fica muito clara para o espectador. É curioso que Los rubios também se inicie com uma sonoplastia de vento forte, mas em registro disjuntivo, e não naturalista. Tudo leva a crer que o barulho incômodo, de difícil identificação, que acompanha os créditos de abertura desse filme seja do vento que bate

\footnotetext{
${ }^{80}$ Para uma análise de Mi vida con Carlos a partir de seus recursos sonoros, cf. OSBORNE, 2017.

${ }^{81}$ Roger Odin (2010, p. 54, tradução nossa) identifica o ruído do projetor como um "signo, uma marca do cinema doméstico".
} 
diretamente no microfone. Normalmente, isso seria considerado uma falha técnica da captação do som direto, mas aqui se trata de mais uma faceta da reflexividade em Los rubios, um artifício sonoro de exposição do dispositivo cinematográfico. Esse ruído vai ressoar em outros momentos-chave da narrativa: quando os intertítulos fornecem dados sobre o desaparecimento dos pais da realizadora; na passagem em que a atriz vai coletar a amostra de sangue para o teste de DNA no escritório da Equipe Argentina de Antropologia Forense (EAAF), suspendendo momentaneamente o som ambiente; na ocasião em que o carro da equipe de filmagem atola na estrada de terra do interior; junto com os intertítulos que, citando versos de Olga Orozco, interrompem a vizinha que testemunha como ocorreu a operação de captura dos pais de Albertina Carri - ela mesma revelando, no final de sua fala, que indicara aos agentes da repressão a casa dos militantes procurados; em outra citação, agora da frase da ditadura que estabelece a "sequência" daqueles que deveriam ser assassinados; quando a equipe de filmagem entra no centro de detenção em que ficaram sequestrados os pais da cineasta.

Em Diário de uma busca, a sonoplastia em geral tende mais para o naturalismo, mas o plano de abertura também traz um ruído difícil de identificar. Antes de qualquer palavra, o espectador ouve suaves batidas repetidas, sobrepostas ao detalhe da fotografia de jornal com o corpo do pai de Flavia Castro. Esse barulho pontua os segmentos em que a câmera vai enquadrando, em planos fechados, notícias de jornal e documentos da época da morte de Celso Castro, introduzindo os episódios mais investigativos da trama. Até que uma das tomadas das idas e vindas de Flavia Castro revela o que parece ser sua origem: um super close-up do para-brisa molhado do carro deixa entrever o limpador que vai e vem, emitindo o ruído repetido que agora pode ser reconhecido. É o som que vai marcando o compasso da busca da filha.

Em graus distintos, a sonoplastia nestes dois últimos casos traz elementos que geram tensão sem serem meramente ilustrativos. Os barulhos estranhos adicionam uma camada de significados às imagens afastando-se delas, suspendendo provisoriamente a lógica auditiva, instaurando certo distanciamento entre aquilo que se vê e o que se ouve. No entanto, esse é um uso bem específico da sonoplastia no conjunto de obras do documentário intergeracional. De modo geral, os efeitos sonoros adicionados em pós-produção nessa filmografia pendem para o registro identificado em Mi vida con Carlos, voltado à composição de uma ambiência naturalista e para a reiteração da dramaticidade dos pontos fortes das narrativas.

\section{Linguagem cinematográfica}




\section{- Travelling itinerante}

O primeiro capítulo já discutiu alguns dos possíveis significados do travelling a partir das imagens de Diário de uma busca: as marcas da itinerância; a dimensão transnacional dos fluxos; os acenos ao gênero road movie. Neste ponto da argumentação, trata-se mais de registrar a recorrência desse tipo de tomada no documentarismo intergeracional. Os planos realizados desde a janela de automóveis, ônibus, trens, aviões ou barcos em movimento são abundantes nessa filmografia. Como visto, muitos autores já identificaram esse recurso como um traço saliente do cinema documental contemporâneo, em geral relacionando essas imagens deambulantes às derivas subjetivas, às errâncias da busca, à crise da narração (ANDERMANN, 2015, p. 190-191; BELLO, 2011, p. 79; ESTEVE, 2009, p. 373; JOHANSSON; VERGARA, 2014; LIE; PIEDRAS, 2014). Em Mi vida con Carlos, esses travellings surgem para pontuar os caminhos percorridos pelo filho-diretor: tomados de dentro do carro do tio Eduardo, captando a paisagem outonal de Ottawa (fig. 49); através da janela do avião, quando o diretor regressa ao norte do Chile, onde o pai desapareceu (fig. 50); pelas ruas vazias de Chuquicamata (fig. 51); e pela estrada no deserto, quando a mãe narra em off o dia em que a família soube que Carlos havia sido assassinado (fig. 52).

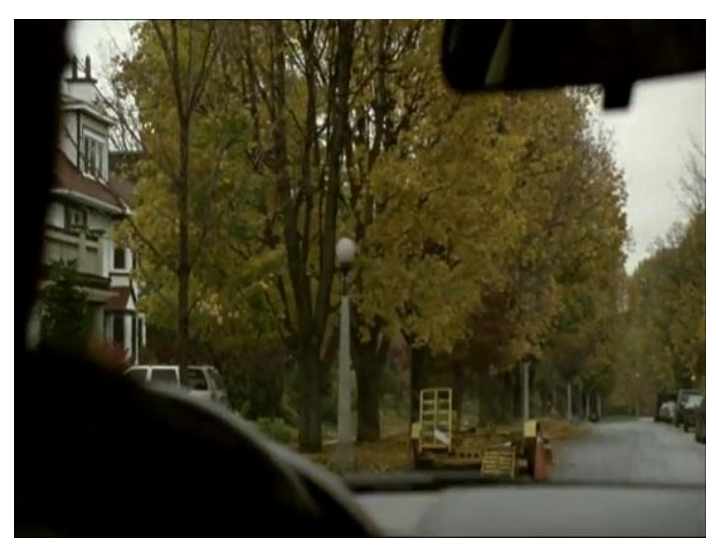

Figura 49 - Travelling itinerante, Ottawa. Fonte: Mi vida con Carlos (Germán Berger-Hertz, 2009).

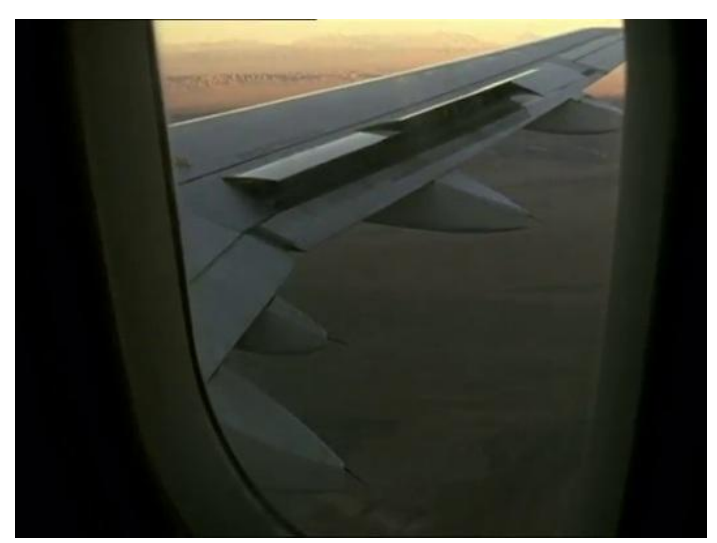

Figura 50 - Travelling itinerante, de avião rumo ao norte chileno, onde o pai desapareceu. Fonte: Mi vida con Carlos (Germán Berger-Hertz, 2009). 


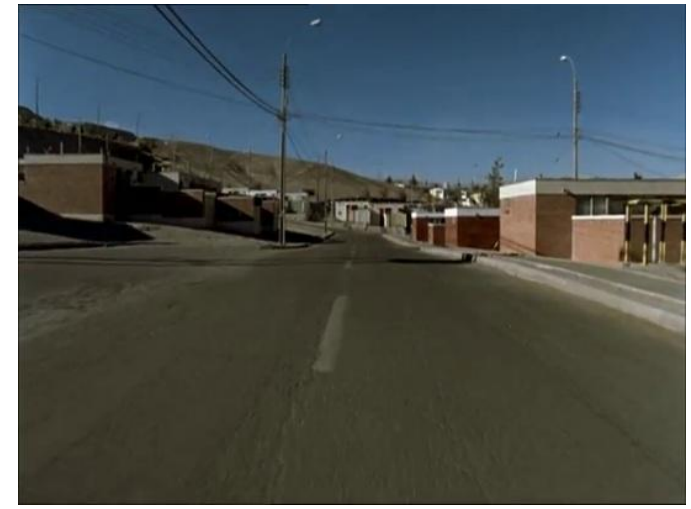

Figura 51 - Travelling itinerante, ruas de Chuquicamata. Fonte: Mi vida con Carlos (Germán Berger-Hertz, 2009).

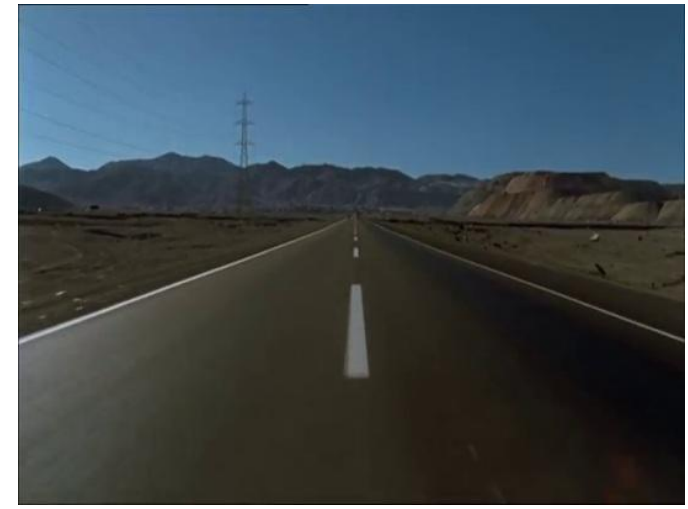

Figura 52 - Travelling itinerante, estrada deserta do Norte. Fonte: Mi vida con Carlos (Germán BergerHertz, 2009).

A observação sistemática do corpus aqui analisado, porém, revelou que essa forma de simbolizar a mobilidade não é exclusiva à vertente mais íntima e hesitante dessa produção, fazendo-se presente também em documentários intergeracionais de estilística mais "sedentária": a das "cabeças falantes", dos testemunhos que se encadeiam em planos estáticos (LIE; PIEDRAS, 2014, p. 73). De fato, a copiosa reiteração dos travellings tomados desde veículos na filmografia faz pensar sobre uma das manifestações específicas da dialética entre forma e indeterminação nessas obras. Pois salta aos olhos a impressão de que essa figuração de uma itinerância aberta ao mundo tenha se transformado em um lugar-comum do documentário contemporâneo (cf. BERNINI, 2004).

\section{- Entrevistas}

Essa consideração conduz a análise para um exame mais detido de uma questão que já ficou esboçada ao longo do texto: a dependência do recurso à entrevista que se observa no documentarismo intergeracional. É verdade que as circunstâncias dos depoimentos e a formas de sua captação variam. O corpus inclui entrevistas em situação de diálogo, em que entrevistador e entrevistado estão juntos diante da câmera, ou quando o que se vê é o registro de uma conversa envolvendo um grupo maior de pessoas. No primeiro caso, fica explicitada a presença daquele que faz as perguntas, inscrevendo o testemunho em uma relação recíproca entre dois indivíduos. Quando se trata de entrevistas com familiares próximos, a interlocução na maioria das vezes se desenrola no ambiente doméstico. Em Mi vida con Carlos, o filho conversa com a mãe na sala do apartamento dela, os dois sentados à mesa ou no sofá, e já a postura corporal de Berger-Hertz sinaliza para o clima relaxado do diálogo (fig. 53-54). Em Allende mi abuelo Allende (Marcia Tambutti, Chile / México, 2015), essa atmosfera intimista 
chega ao ponto em que neta e avó estão deitadas na cama, enquanto Tambutti faz suas perguntas; ou quando filha e mãe conversam serenamente deitadas juntas em uma rede (fig. $55-56)$.

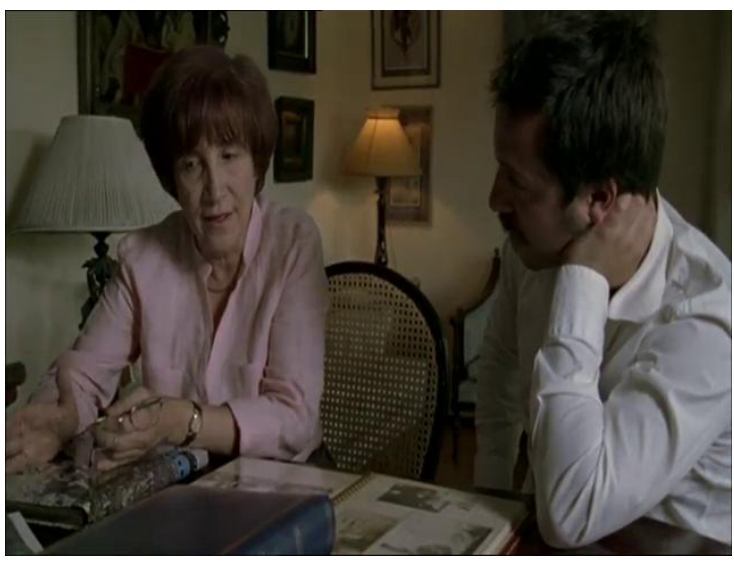

Figura 53 - Entrevista como diálogo doméstico entre mãe e filho. Fonte: Mi vida con Carlos (Germán Berger-Hertz, 2009).

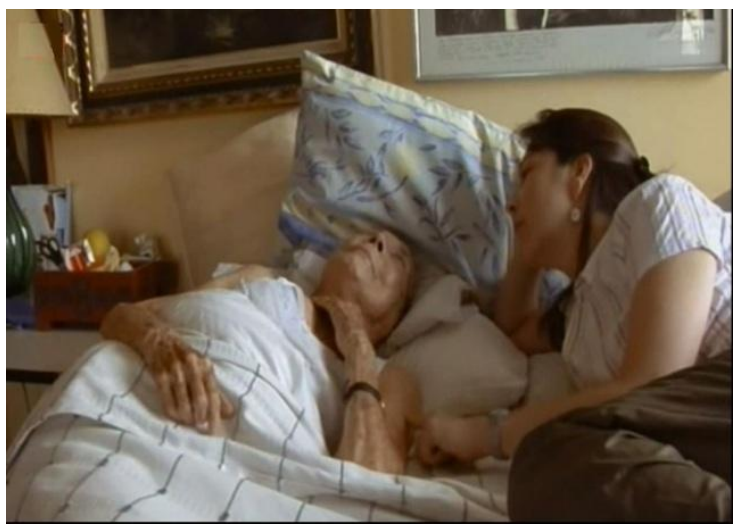

Figura 55 - Entrevista como diálogo íntimo com a avó. Fonte: Allende mi abuelo Allende (Marcia Tambutti, 2015).

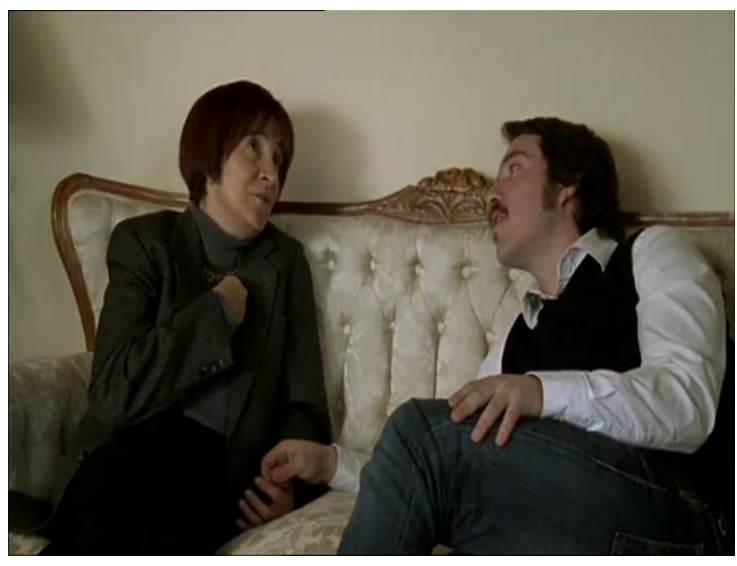

Figura 54 - Entrevista como diálogo relaxado entre mãe e filho. Fonte: Mi vida con Carlos (Germán Berger-Hertz, 2009).

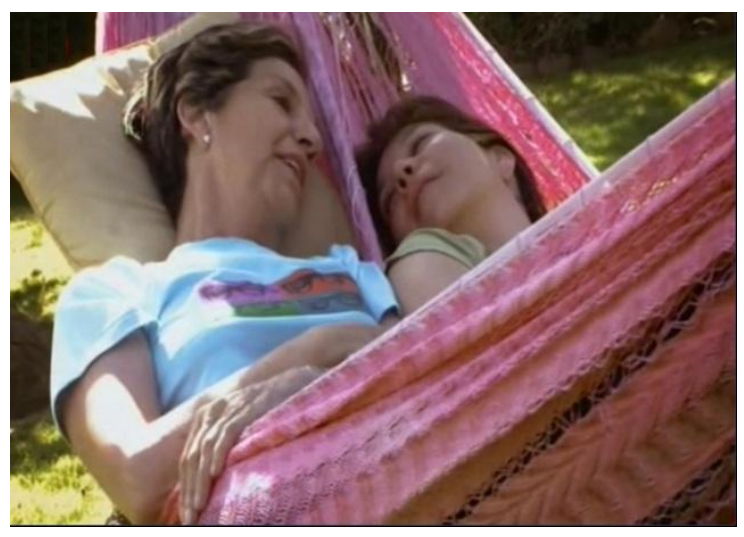

Figura 56 - A conversa de mãe e filha juntas na rede. Fonte: Allende mi abuelo Allende (Marcia Tambutti, 2015).

Mas esses diálogos familiares também atingem picos de alta tensão. No mesmo Allende mi abuelo Allende, por vezes a cineasta é repreendida pelos parentes, que consideram que ela estaria abusando da saúde e dos recalques da avó. Em Cuchillo de palo (Renate Costa, Paraguai / Espanha, 2010), a diretora não se esquiva de confrontar as opiniões machistas e homofóbicas do pai sobre o destino do irmão perseguido pela ditadura Stroessner por causa de sua orientação sexual. Por razões bem distintas, filha e pai também entram em colisão no ambiente doméstico em Os dias com ele (Maria Clara Escobar, Brasil / Portugal, 2013).

Essas conversas em família podem incluir mais pessoas além do par entrevistador e entrevistado. Nessa circunstância, o diálogo assume a forma da interlocução coletiva, outra 
modalidade de entrevista comum no documentário intergeracional. Mi vida con Carlos apresenta os dois tios do realizador ao lado de suas respectivas famílias nucleares: primeiro, o tio Ricardo, junto com os seus no quintal gramado de casa, no Chile, sob a sombra de uma árvore, todos sentados conversando ao redor da mesinha com frutas e refrescos (fig. 57); depois, o tio Eduardo, com sua esposa e filhas à mesa de jantar no apartamento da família em Ottawa, o jogo de chá posto, os pais falando em espanhol, as moças em inglês (fig. 58). Nos dois casos, a câmera vai se movendo e os planos se alternam seguindo a dinâmica de fala entre os interlocutores. A situação da conversa em torno da mesa produz uma espécie de reunião familiar pró-fílmica, estimulando o intercâmbio entre as gerações diante das câmeras.

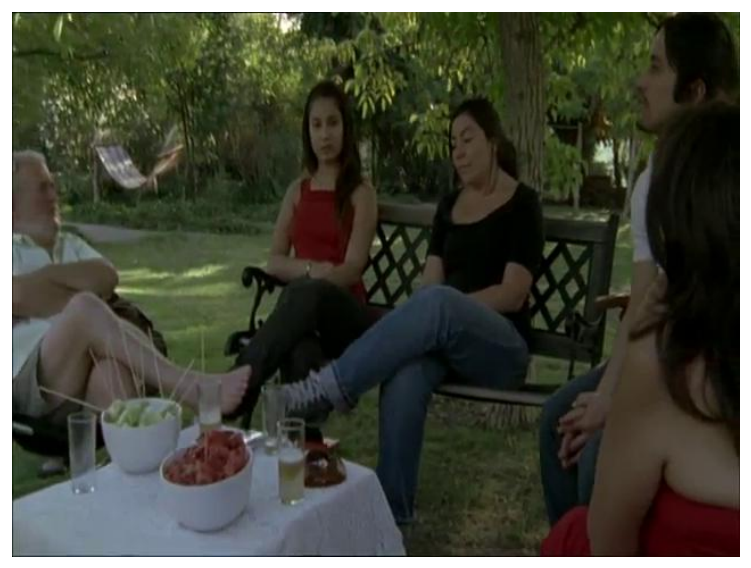

Figura 57 - Conversa coletiva, família de tio Ricardo. Fonte: Mi vida con Carlos (Germán Berger-Hertz, 2009).

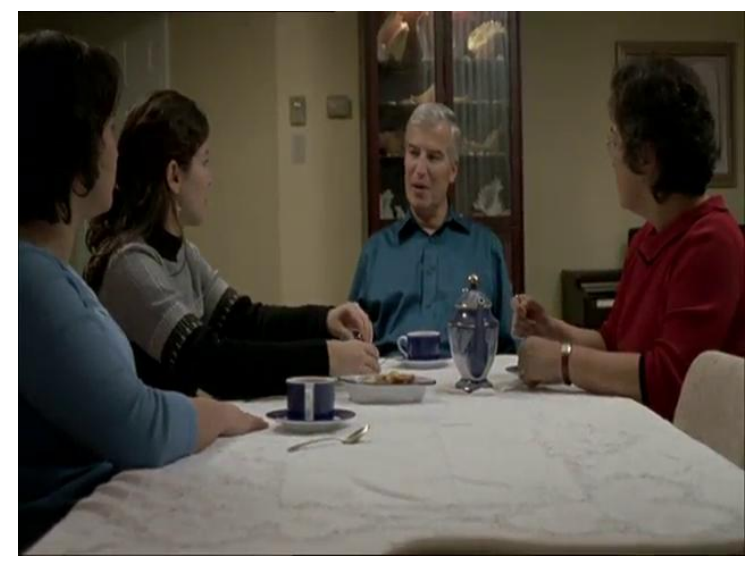

Figura 58 - Conversa coletiva, família de tio Eduardo. Fonte: Mi vida con Carlos (Germán Berger-Hertz, 2009).

A comensalidade como fator catalisador do relato é outra faceta dos diálogos em forma de interlocução coletiva. Alguns títulos do corpus promovem o encontro de filhos com trajetórias análogas em churrascos e jantares, buscando com isso propiciar a rememoração e a troca de experiências. Nesses casos, o círculo se amplia, extrapolando os laços consanguíneos para abranger uma comunidade de memória para além da família. Em Che vo cachai (Laura Bondarevsky, Argentina, 2002), os jovens partilham vivências e discutem os rumos das agrupações de hijos enquanto preparam churrasco e tomam vinho. Argenmex: exiliados hijos (Violeta Burkart Noë e Analía Miller, Argentina, 2007) tem como eixo a reunião de filhos argentinos exilados no México ocasionada por um jantar com cardápio composto por tacos, guacamole e tequila.

Alternativamente, esses encontros pró-fílmicos também se desenrolam em circunstâncias mais sóbrias. Além das reuniões familiares, Mi vida con Carlos promove uma discussão coletiva com os ex-integrantes da Vicaría de la Solidaridad, na qual as falas vão traçando um balanço do papel dessa entidade na luta pelos direitos humanos no Chile. Saindo 
do espaço doméstico, o encontro tem lugar na sede histórica da Vicaría, o Palácio do Arcebispo, na Praça de Armas de Santiago. O ambiente interno é minimalista, com paredes de tijolo aparente, sem qualquer outro móvel além das cadeiras nas quais o grupo se senta. As testemunhas vestem roupas formais, os senhores de gravata, as senhoras bem produzidas (fig. 59). Essas reuniões de caráter mais público se repetem na filmografia. Por exemplo, em $M$ (Nicolás Prividera, Argentina, 2007), na passagem em que os ex-colegas de trabalho de Marta Sierra no Instituto Nacional de Tecnologia Agropecuária (Inta) rememoram juntos, diante do filho, o cotidiano da mãe na época de seu desaparecimento (fig. 60).

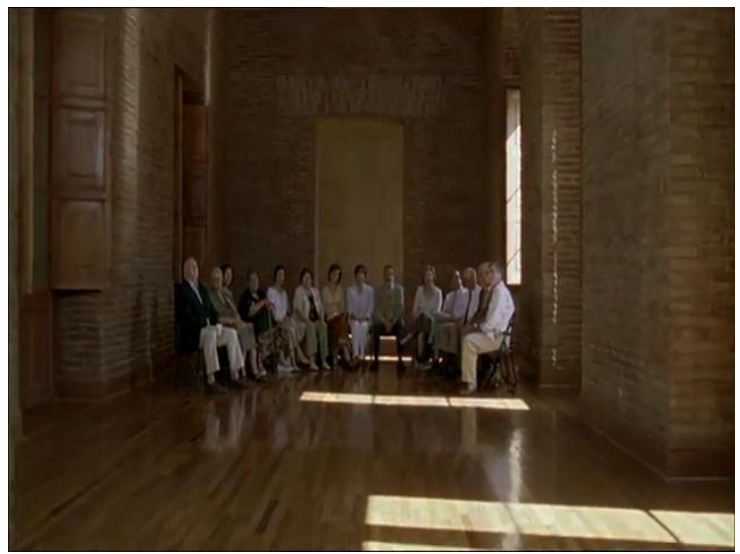

Figura 59 - Interlocução coletiva, integrantes da Vicaría de la Solidaridad. Fonte: Mi vida con Carlos (Germán Berger-Hertz, 2009).

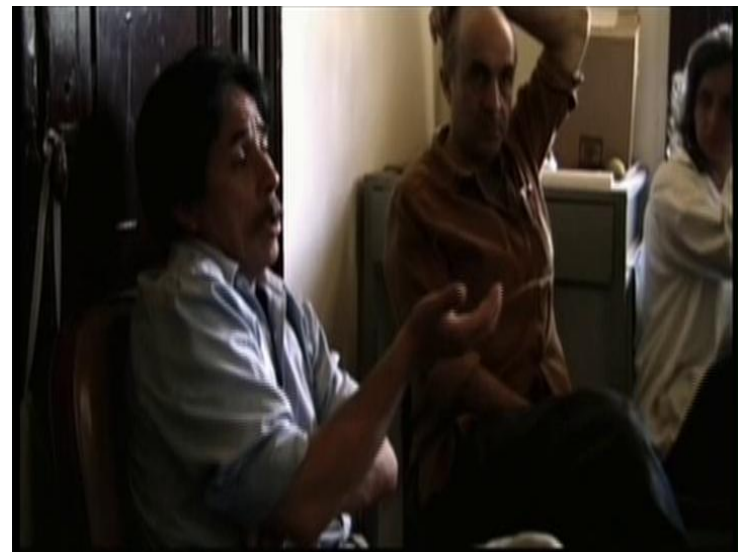

Figura 60 - Interlocução coletiva, ex-colegas de Marta Sierra. Fonte: $M$ (Nicolás Prividera, 2007).

Além da entrevista em situação de diálogo, a dois ou em grupo, outra modalidade presente na filmografia é a da entrevista deambulante: quando o testemunho é registrado enquanto a pessoa que fala está em movimento. As variantes nesse campo se conjugam seja com a situação de diálogo, seja com o recurso do travelling itinerante. Mi vida con Carlos tem mais de um momento ligado ao primeiro caso: Berger-Hertz e seu tio Ricardo conversam ao mesmo tempo que caminham, lado a lado, pelo galpão da fábrica de papel gerenciada pelo último; o sobrinho entrevista o outro tio, Eduardo, agora durante um passeio por um bosque canadense; mãe e filho trocam impressões sobre a experiência do exílio andando pelas vielas do Bairro Gótico de Barcelona. Nessas circunstâncias, a interlocução se associa a um dinamismo espacial, afastando o contexto da enunciação do isolamento e da imobilidade da entrevista em modo "cabeças falantes".

Além do aspecto mais propriamente cinematográfico, essas interlocuções deambulantes se dão ainda em função do retorno aos lugares de memória. Nas ruas de Chuquicamata, o tio Eduardo indica ao sobrinho o ponto exato onde funcionava a transmissora de rádio em que Carlos trabalhava. Ali Eduardo narra os episódios locais do 11 
de setembro, a resistência do irmão ao golpe que acabou resultando em sua prisão (fig. 61). Adiante, ambos vão ao presídio de Calama, onde Carlos cumpria pena até ser executado pela Caravana da Morte. No pátio, sobrinho e tio caminham lado a lado, a câmera vai os precedendo de perto em um travelling para trás, Eduardo revela um sentimento de culpa em torno da morte do irmão (fig. 62).

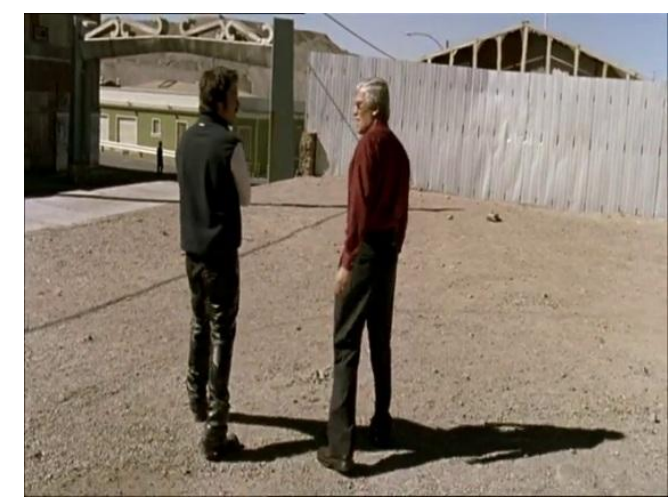

Figura 61 - Entrevista deambulante, guiado pelo tio em Chuquicamata. Fonte: Mi vida con Carlos (Germán Berger-Hertz, 2009).

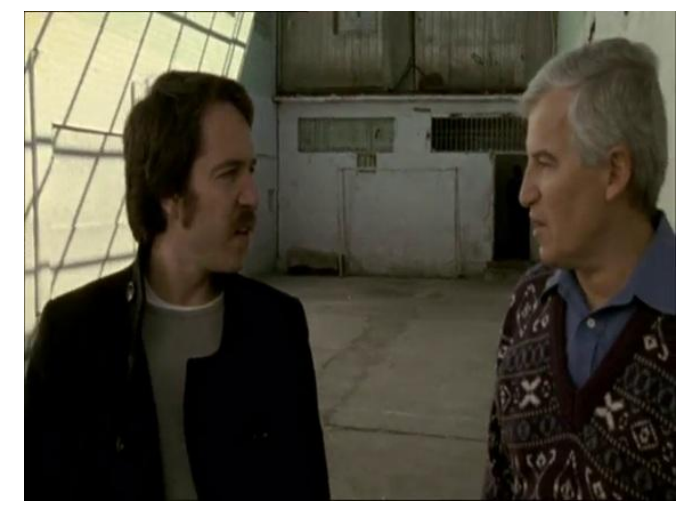

Figura 62 - Entrevista deambulante, visita ao presídio onde o pai cumpriu pena. Fonte: Mi vida con Carlos (Germán Berger-Hertz, 2009).

Em Mi vida con Carlos, seja em prol de um maior dinamismo cinematográfico, seja em função do regresso aos lugares carregados de recordações, os deslocamentos daqueles que dialogam ocorre a pé. Em outros títulos do corpus, a entrevista deambulante se dá também no interior de veículos em movimento, algo que aproxima a situação da fala dos significados dos travellings itinerantes já analisados (fig. 63-66).

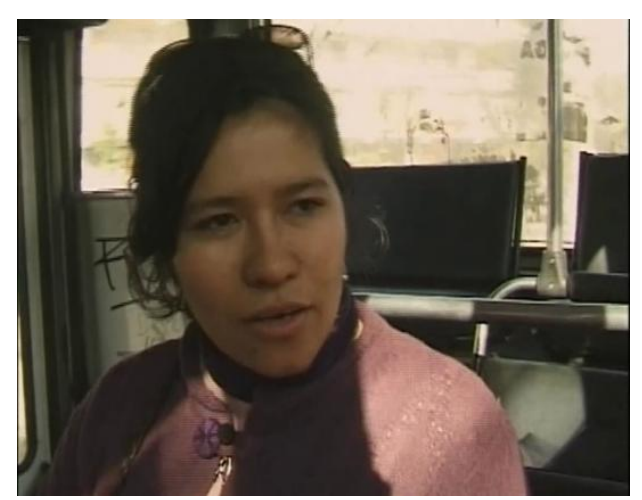

Figura 63 - Entrevista em ônibus. Fonte: Che vo cachai (Laura Bondarevsky, 2002).

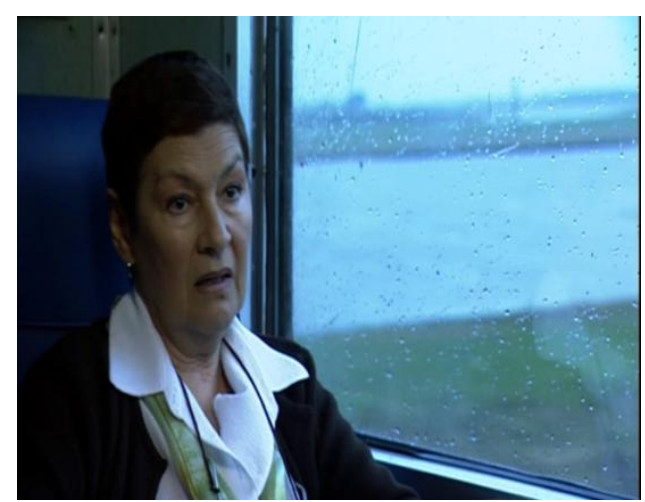

Figura 64 - Entrevista em trem. Fonte: Diario argentino (Lupe Pérez García, 2006). 


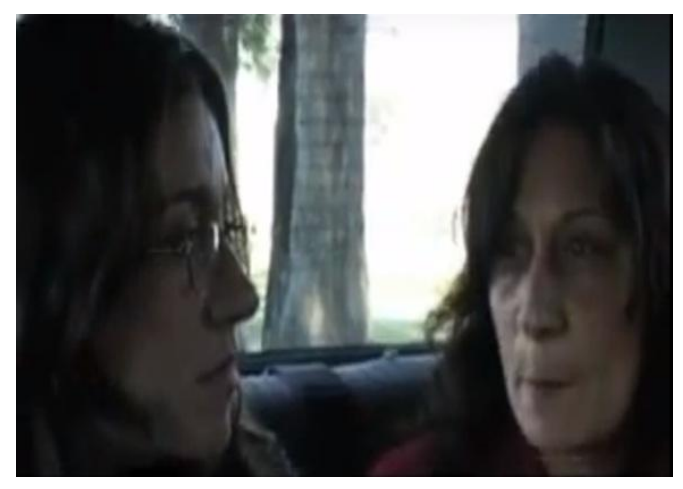

Figura 65 - Entrevista em automóvel. Fonte: Mansión Seré (Jorge Bianchini, 2006).

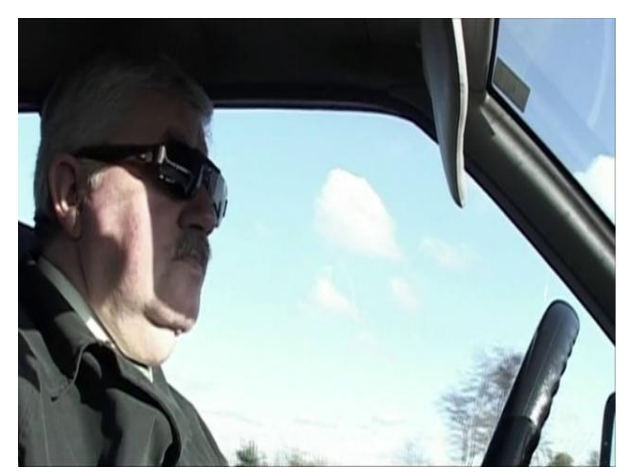

Figura 66 - Pai entrevistado enquanto dirige. Fonte: $\mathrm{La}$ quemadura (René Ballesteros, 2009).

Mais rara, existe também a forma da entrevista opaca, isto é, quando o documentário expõe à audiência o dispositivo da entrevista, interpondo camadas de mediação entre a palavra testemunhal e seu registro audiovisual. Em Los rubios, o gesto da atriz de rebobinar e avançar as fitas ao rever os relatos dos ex-companheiros dos pais de Albertina Carri é uma das ocorrências mais patentes dessa forma (fig. 67). El tiempo y la sangre (Alejandra Almirón, Argentina, 2004) também traz planos em que os testemunhos são enquadrados na tela do computador, em uma janela do programa de edição fílmica (fig. 68). En memoria de los pájaros (Gabriela Golder, França / Argentina, 2000) exibe a entrevista em um dos lados da tela subdividida, enquanto a outra janela vai encadeando imagens de arquivo de origens diversas (fig. 69). Em certos depoimentos, Che vo cachai (Laura Bondarevsky, Argentina, 2002) desnaturaliza o cenário da entrevista por meio do jogo de iluminação e do movimento constante da câmera (fig. 70). A filha-diretora registra a entrevista com a mãe operando a câmera diante de um espelho em El telón de azúcar (Camila Guzmán Urzúa, França / Cuba / Espanha, 2006), como se viu no primeiro capítulo (fig. 30). Os dias com ele (Maria Clara Escobar, Brasil / Portugal, 2013) inclui em suas imagens os instantes prévios ao que deveria ser a entrevista propriamente dita, dando a ver os ajustes de som e imagem, junto com os desacordos entre pai e filha (fig. 71).

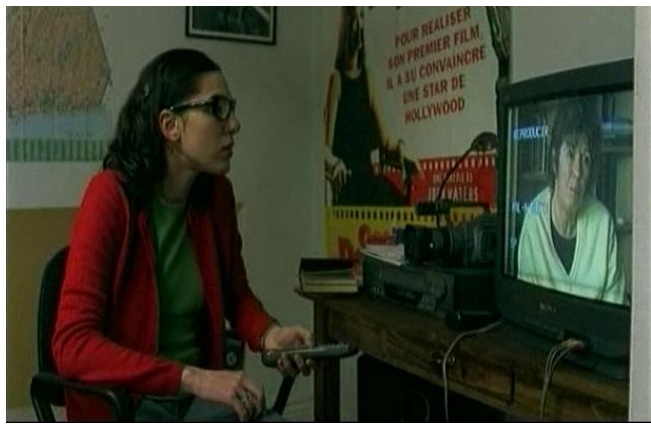

Figura 67 - Atriz assiste às fitas com as entrevistas. Fonte: Los rubios (Albertina Carri, 2003).

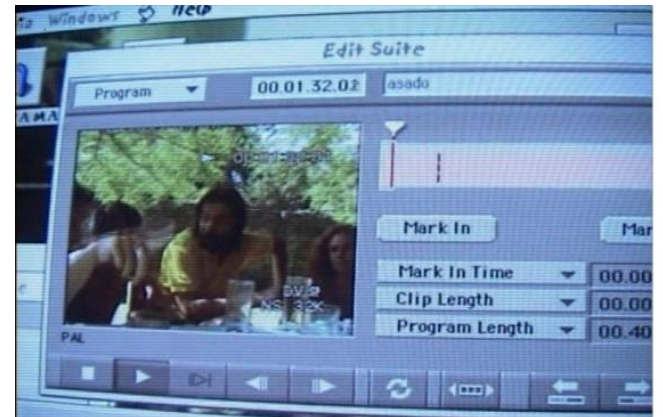

Figura 68 - Testemunhos no programa de edição. Fonte: El tiempo y la sangre (Alejandra Almirón, 2004). 


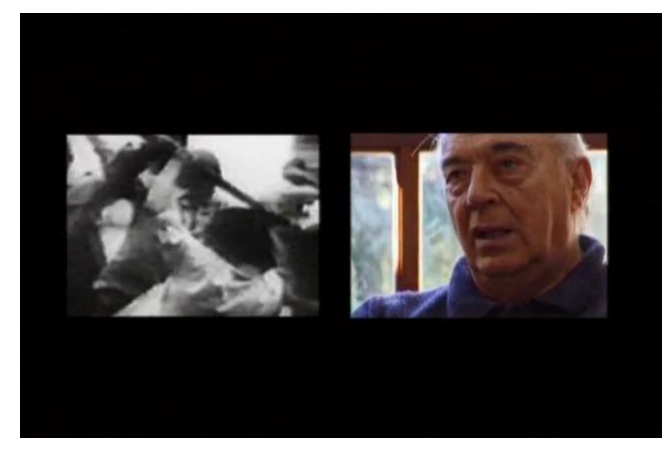

Figura 69 - Entrevista em tela subdividida. Fonte: En memoria de los pájaros (Gabriela Golder, 2000).

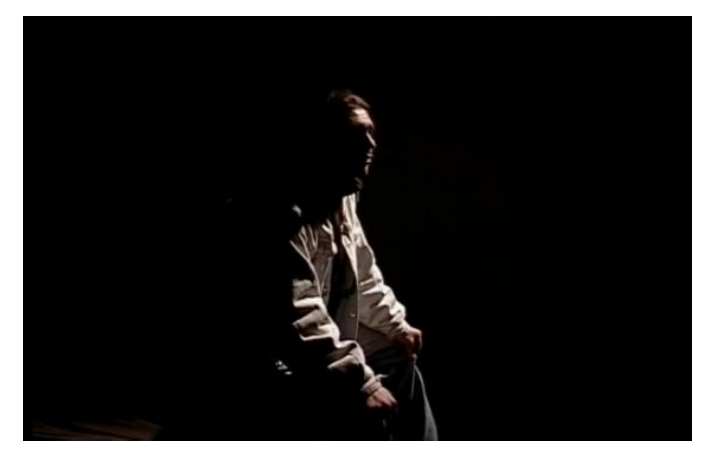

Figura 70 - Iluminação desnaturalizada da entrevista. Fonte: Che vo cachai (Laura Bondarevsky, 2002).

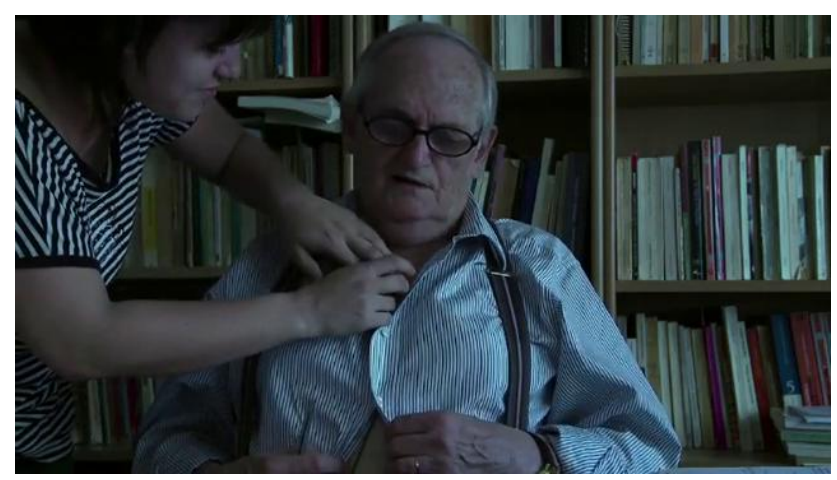

Figura 71 - Preparação do entrevistado. Fonte: Os dias com ele (Maria Clara Escobar, 2013).

Da conversa a dois à interlocução coletiva, da deambulação a pé ao deslocamento motorizado, passando pelas marcas da opacidade. Todas essas formas são variantes da entrevista presentes no documentário intergeracional, algo que por si só dá uma amostra da relevância desse recurso narrativo nessa filmografia. Contudo, além dos registros alternativos, salta aos olhos a recorrência com que a entrevista convencional é usada nos títulos do corpus. De fato, no que toca a esse terreno específico, o modo das “cabeças falantes” é predominante.

Em Mi vida con Carlos, as entrevistas se dão sempre em situação de diálogo, porém, mesmo nesse caso, a alternância entre planos de conjunto e planos fechados no rosto de quem fala não deixa de aproximar certos enquadramentos da configuração mais típica do documentário de entrevista. É verdade que esses primeiros planos das testemunhas ainda contêm elementos que denunciam a presença do outro da interlocução no espaço fora de campo. No fundo, a dinâmica dos olhares e dos movimentos de câmera, um ombro visível no canto do quadro e, sobretudo, a justaposição das tomadas acabam gerando um efeito de campo e contracampo (fig. 72-73). 


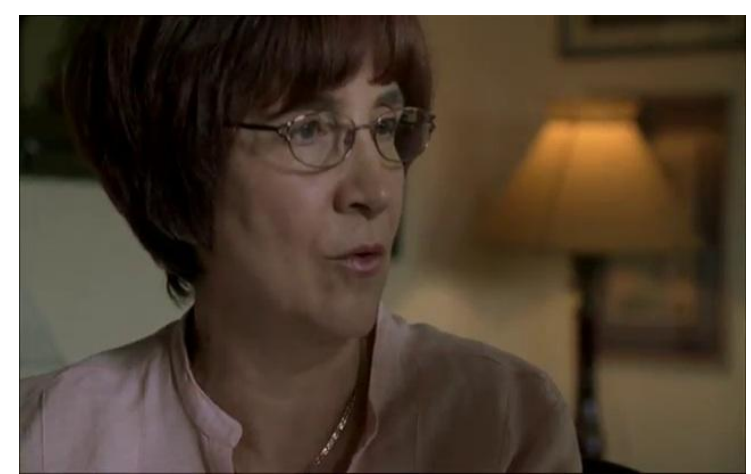

Figura 72 - Plano fechado na situação de diálogo com a mãe. Fonte: Mi vida con Carlos (Germán Berger-Hertz, 2009).

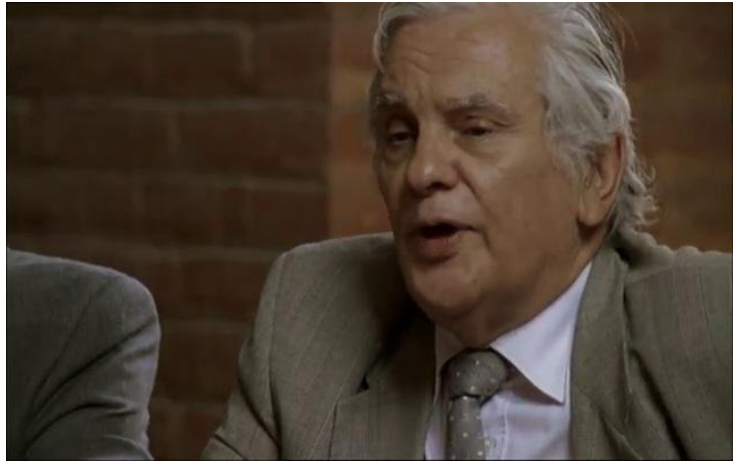

Figura 73 - Plano fechado no debate entre integrantes da Vicaría de la Solidaridad. Fonte: Mi vida con Carlos (Germán Berger-Hertz, 2009).

Se no filme de Berger-Hertz apenas se entrevê uma relação de analogia entre certos planos e a convenção das "cabeças falantes", em muitos filmes esse padrão se impõe como a principal modalidade de registro das entrevistas. Contrariando o que se poderia imaginar, o enquadramento frontal em primeiro plano da pessoa que dá seu relato mais ou menos diretamente para a câmera (e para o espectador) é uma das formas visuais mais disseminadas no documentário intergeracional sobre as ditaduras do Cone Sul, ao longo de todo o recorte temporal. E isso não apenas nas obras mais tradicionais, menos afinadas com a estilística contemporânea. Mesmo as narrativas conduzidas pela busca pessoal em aberto estão repletas desses planos fechados no rosto de quem testemunha (fig. 74-93).

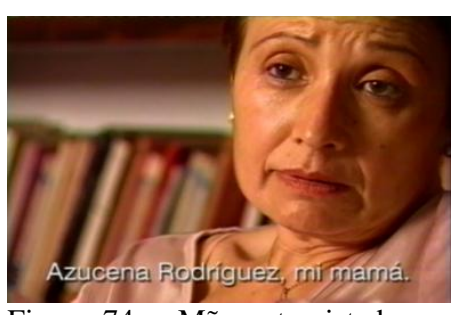

Figura 74 - Mãe entrevistada em modo convencional. Fonte: Papá Iván (María Inés Roqué, 2000).

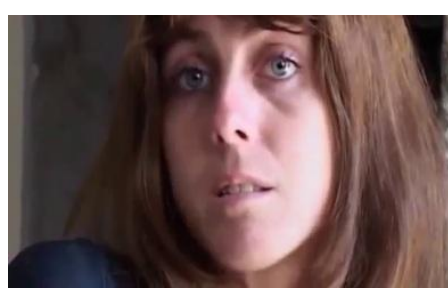

Figura 77 - Amiga de infância entrevistada. Fonte: El telón de azúcar (Camila Guzmán Urzúa, 2006).
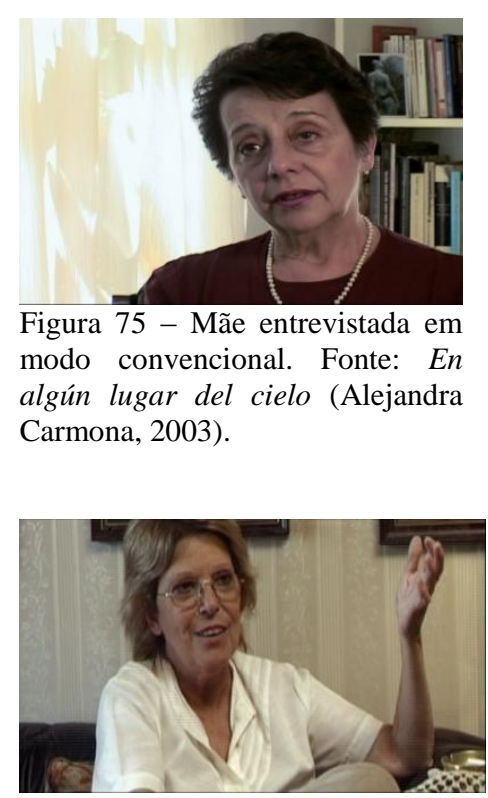

Figura 78 - Amiga da mãe em entrevista convencional. Fonte: $M$ (Nicolás Prividera, 2007).

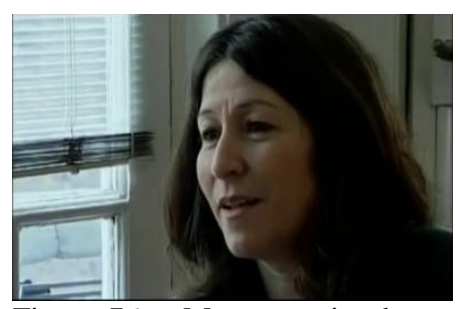

Figura 76 - Mãe entrevistada em modo convencional. Fonte: Encontrando a Víctor (Natalia Bruschtein, 2004).

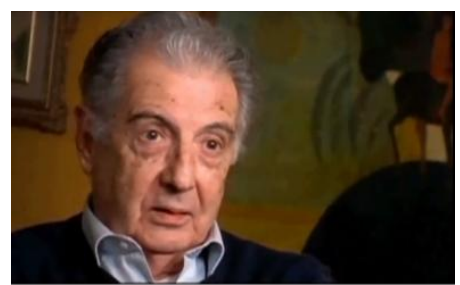

Figura 79 - Amigo do padrasto em entrevista convencional. Fonte: Héroes frágiles (Emilio Pacull, 2007). 


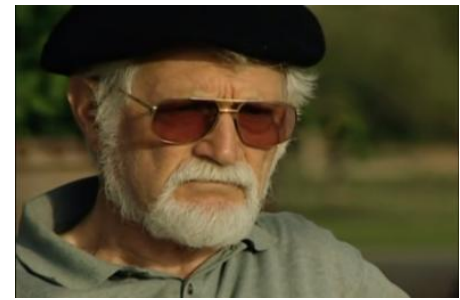

Figura 80 - Pai em entrevista convencional. Fonte: Secretos de lucha (Maiana Bidegain, 2007).

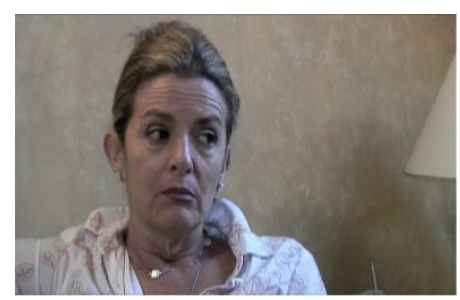

Figura 83 - Tia em entrevista convencional. Fonte: Abuelos (Carla Valencia Dávila, 2010).

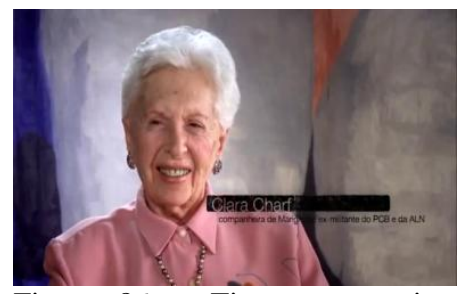

Figura 86 - Tia em entrevista convencional. Fonte: Marighella (Isa Grinspum Ferraz, 2011).

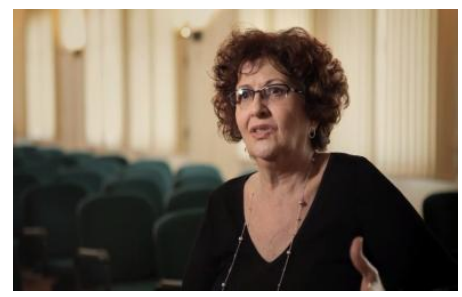

Figura 89 - Entrevista conduzida por Mariana Pamplona com a mãe, Rosa Iavelberg. Fonte: Em busca de Iara (Flavio Frederico, 2013).

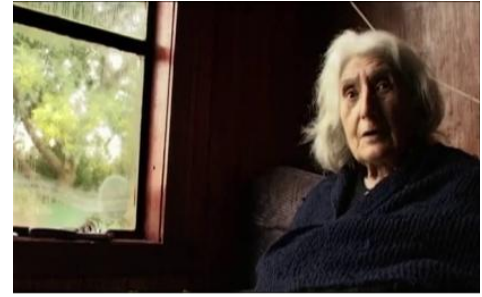

Figura 81 - Avó em entrevista convencional. Fonte: La quemadura (René Ballesteros, 2009).

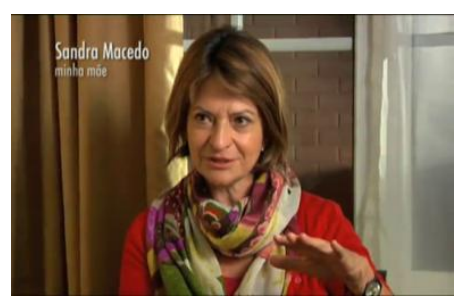

Figura 84 - Mãe em entrevista convencional. Fonte: Diário de uma busca (Flavia Castro, 2010).

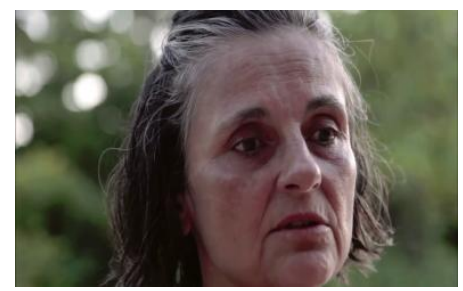

Figura 87 - Mãe em plano convencional da entrevista. Fonte: Elena (Petra Costa, 2012).

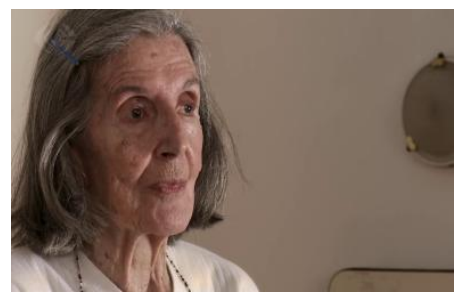

Figura 90 - Avó em entrevista convencional. Fonte: Tiempo suspendido (Natalia Bruschtein, 2015).

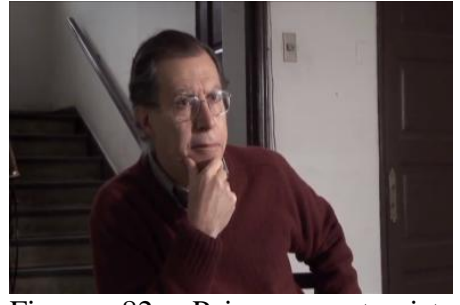

Figura 82: Pai em entrevista convencional. Fonte: El edificio de los chilenos (Macarena Aguiló e Susana Foxley, 2010).

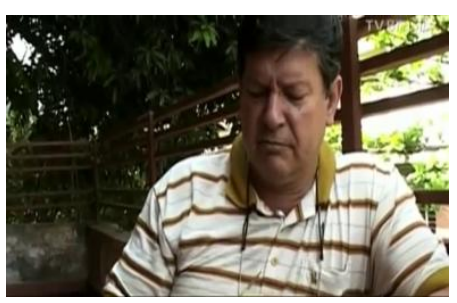

Figura 85 - Pai em entrevista convencional. Fonte: Cuchillo de palo (Renate Costa, 2010).

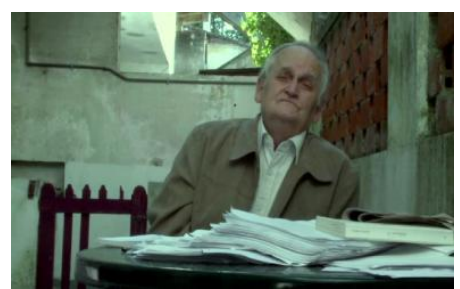

Figura 88 - Pai em plano convencional da entrevista. Fonte: Os dias com ele (Maria Clara Escobar, 2013).

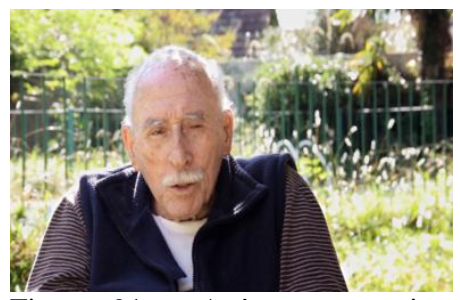

Figura 91 - Avô em entrevista convencional. Fonte: 70 y Pico (Mariano Corbacho, 2016).

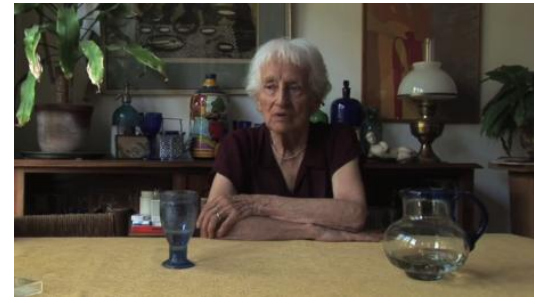

Figura $92-$ Avó em entrevista convencional. Fonte: Venían a buscarme (Álvaro de la Barra, 2016).

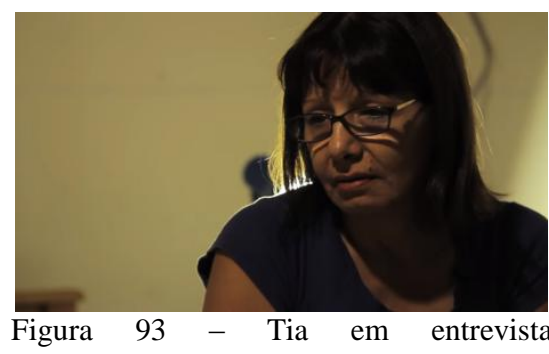

convencional. Fonte: El pacto de Adriana (Lissette Orozco, 2017). 
Todos esses são títulos em que a indagação subjetiva e familiar dá o tom do relato, em que as testemunhas ouvidas são pessoas próximas. Contudo, nem por isso seus diretores prescindem da convenção mais básica do documentário de entrevista, ainda que possam alterná-la com as demais variantes acima descritas. Nesse sentido - e tal qual um "barômetro" da atmosfera cinematográfica de seu entorno -, o mesmo Jean-Claude Bernardet que identificou a tendência do documentário de busca (BERNARDET, 2005) também diagnosticara, pouco antes, em um apêndice à reedição de 2003 de seu clássico Cineastas e imagens do povo, a transformação da entrevista em "feijão com arroz", em "cacoete" do documentário contemporâneo brasileiro (BERNARDET, 2003, p. 285). Isso incluía a "repetição ad nauseam" de seu dispositivo elementar:

[...] o entrevistado fica no campo da câmera, geralmente de frente (de costas apenas quando o depoente não quer ser identificado); seu olhar passa rente à objetiva, à direita ou à esquerda, em direção ao entrevistador, que costuma ser o próprio realizador e que faz a pergunta à qual o entrevistado responde (é o tal 3/4 frente). Que este seja um sem-teto ou um sociólogo que fala dos sem-teto, seja o cego ou a vidente, o dispositivo espacial é o mesmo. (BERNARDET, 2003, p. 286).

As principais consequências desse uso quase automático das entrevistas, conforme o autor, eram um empobrecimento "da dramaturgia e das estratégias narrativas" do cinema documental, uma "predominância do verbal" em detrimento da capacidade de observação, relegando as interações entre as pessoas filmadas a um segundo plano (BERNARDET, 2003, p. 286-287).

Naquele cenário, Bernardet pinçava exemplos de filmes que expunham fissuras no sistema da entrevista convencional - Casa de cachorro (Thiago Villas Boas, Brasil, 2001) e $\grave{A}$ margem da imagem (Evaldo Mocarzel, Brasil, 2002). Atento aos lances nos quais as relações entre cineastas e entrevistados se desestabilizavam, o crítico antevia inclusive uma "crise do filme documentário de entrevistas" (BERNARDET, 2003, p. 296) - desvelando a agenda subjacente a essa sua intervenção no debate. Acontece que, desde então, embora o documentário de busca venha se adensando como vertente estética, e não só no Brasil, apontando novos rumos de rememoração, isso não tem levado a uma superação da entrevista como matéria fundamental das obras. Os fotogramas logo acima emparelhados demonstram que o documentário de busca segue sendo, também, um documentário de entrevista. Mais uma vez, o que está em jogo é a convivência, nem sempre harmônica, de diferentes tradições do cinema documental. Boa parte da produção intergeracional do Cone Sul assume essa nova roupagem da busca. Porém, ainda assim, a dependência do dispositivo básico da entrevista 
continua grande. Ora, é claro que as relações entre entrevistador e entrevistado variam caso a caso, envolvendo uma maior ou menor "co(i)mplicação" (RENOV, 2004a, p. 218, tradução nossa) dos sujeitos, aspecto que será abordado mais adiante. Certamente, o teor de muitos desses depoimentos traz novidades na paisagem da memória das ditaduras, mesmo em ocasiões nas quais as falas estão captadas no modo mais convencional. 15 filhos (Maria Oliveira e Marta Nehring, Brasil, 1996) e (h) Historias cotidianas (Andrés Habegger, Argentina, 2000) são apenas dois exemplos em que o mosaico testemunhal das vozes dos filhos traz à luz uma série de experiências até então raramente abordadas pelas matrizes de memória mais consagradas. Para que fique claro: o que se está indagando neste momento da análise é a forma de registro cinematográfico, e não o teor dos testemunhos. Quando se presta atenção a essa dimensão mais estritamente formal, nota-se uma recorrência daquela configuração elementar descrita por Bernardet no corpus aqui analisado, e isso tem seus efeitos de sentido. De fato, o olhar global para o repertório estético do documentário intergeracional revela que a entrevista convencional está tão presente quanto o travelling itinerante. Eis aí um contraste que novamente aponta para dialética entre forma (o padrão da “cabeça falante" isolada no quadro) e indeterminação (a figuração da errância da busca, da deriva subjetiva etc.) latente nessa filmografia.

\section{- Inserções}

Essa convivência entre os tropos da subjetividade contemporânea e os recursos de linguagem herdados da tradição do cinema documental é um aspecto marcante que emerge da observação sistemática do conjunto de títulos do corpus. O modo como as inserções são articuladas nos filmes ilumina outras facetas dessa questão. ${ }^{82}$ A começar pelo uso predominantemente ilustrativo das imagens inseridas, seja para cobrir os momentos de repouso da narrativa, seja para reiterar aquilo que é dito pela voz over ou pelos entrevistados. Eis outro traço do documentário mais clássico que se replica na filmografia aqui analisada.

Em Mi vida con Carlos, o emprego das inserções se concentra na articulação das imagens de arquivo (familiares e públicas, fixas e em movimento). Pode-se adiantar que aí também a função ilustrativa sobressai, mas as inserções de arquivo são um caso à parte e, dada sua relevância no corpus, serão analisadas em uma seção específica. Por ora, a atenção se volta para as inserções menos evidentes. Em primeiro lugar, as inserções de repouso:

\footnotetext{
${ }^{82}$ O termo "inserção" é aqui empregado em sentido lato, abrangendo os planos ou segmentos específicos inseridos em continuidades narrativas mais amplas (AUMONT; MARIE, 2009, p. 168).
} 
aqueles planos que surgem nos momentos de distensão da narrativa, sem que tenham uma vinculação estreita com os eventos relatados. São tomadas, em geral fixas, de paisagens ou ambientes vazios que oferecem um "respiro" para a audiência, muitas vezes no intervalo entre as sequências fílmicas. O destaque vai para as imagens de parquinhos infantis com brinquedos desocupados, um tópico que se repete no documentário intergeracional (fig. 94-99). Ou, em outro viés, os registros dos fluxos de transeuntes e automóveis no ambiente urbano. Nesses casos, a espacialidade visível é mais alusiva do que referencial, remetendo a uma noção vaga de infância passada (o vazio dos brinquedos dando o tom da melancolia) ou de cotidiano presente. Antes que demarcar uma topografia da rememoração, essas inserções de repouso sugerem ideias genéricas que gravitam as histórias narradas.

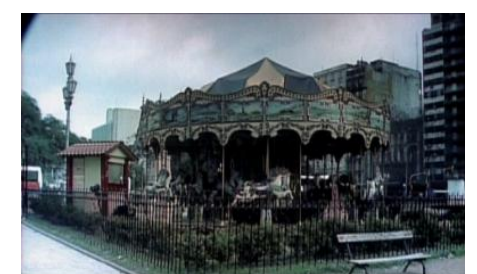

Figura 94 - Inserção com carrossel vazio. Fonte: Nietos (identidad y memoria) (Benjamín Ávila, 2004).

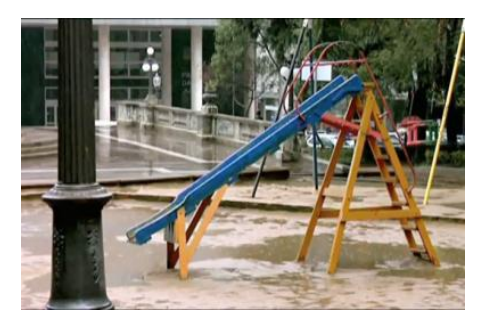

Figura 97 - Parquinho em dia chuvoso. Fonte: Diário de uma busca (Flavia Castro, 2010).

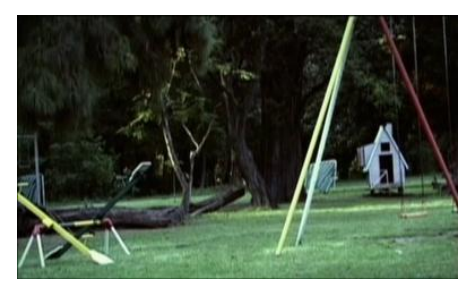

Figura 95 - Parquinho infantil vazio. Fonte: $M$ (Nicolás Prividera, 2007).

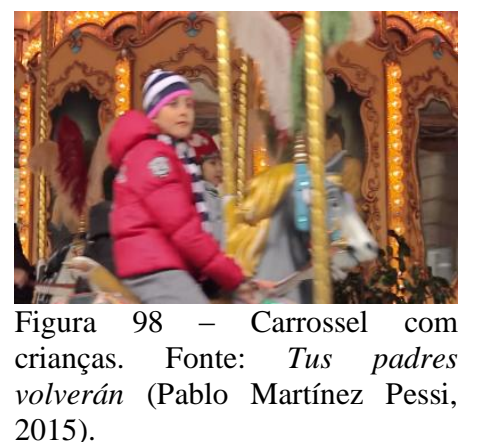

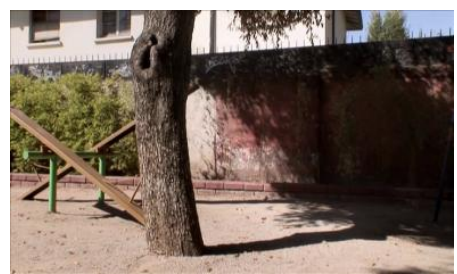

Figura 96 - Parquinho vazio. Fonte: El edificio de los chilenos (Macarena Aguiló e Susana Foxley, 2010).

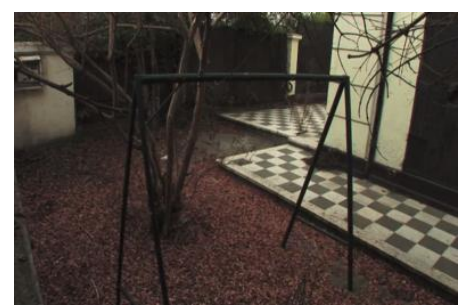

Figura 99 - $\mathrm{O}$ balanço arruinado. Fonte: Venían a buscarme (Álvaro de la Barra, 2016).

As inserções ilustrativas são mais diretas. Elas acompanham o andamento do relato, não se detendo em seus interstícios. A voz over ou os entrevistados mencionam prisões e torturas, surgem na tela planos realizados em antigos centros de detenção e extermínio. Muitas vezes, a fala daquele que relata prossegue em off enquanto a câmera vai vasculhando as instalações carcerárias, em um artifício que sincroniza o teor testemunhal e a matéria visual. Outra recorrência nessa chave é a inserção de tomadas feitas em escolas tão logo as vozes façam referência à vida estudantil na infância.

A ilustração da narrativa assume ainda a forma das inserções ficcionais: sequências breves em que atores encenam episódios aludidos nos relatos (ORTEGA, 2005, p. 213). Essa modalidade é menos frequente do que a pauta analítica do hibridismo entre documentário e 
ficção faz supor. Com efeito, no corpus ampliado, são poucos os títulos que lançam mão de reconstituições encenadas, em representações que podem ser mais ou menos diretas. Generación golpe (Fabián Agosta e Lisandro Costa, Argentina, 2001), Secretos de lucha (Maiana Bidegain, Uruguai / França, 2007) e El memorial (Andrés Brignardello Valdivia, Chile, 2009) trazem cenas que reconstroem ações passadas da militância ou da repressão. Por sua vez, El tiempo y la sangre (Alejandra Almirón, Argentina, 2004), Mansión Seré (Jorge Bianchini, Argentina, 2006) e El edificio de los chilenos (Macarena Aguiló e Susana Foxley, Chile / Cuba / França / Bélgica, 2010) incluem cenas que aludem de modo mais difuso ao universo infantil. Em quase todos os casos, as imagens dessas inserções ficcionais são tratadas de modo a apresentarem uma textura de época. Já Los rubios é um caso distinto, pois nele a ficcionalização da experiência não se restringe a segmentos pontuais, sendo o elemento central da problematização da rememoração. No filme de Albertina Carri, a encenação se dá em nome da reflexividade, e não da ilustração.

Por último, há nessa filmografia as inserções de animação. Novamente, Los rubios é um exemplo sempre lembrado nesse terreno, e o segundo capítulo já propôs uma interpretação da lógica do olhar pueril ligada às inserções em stop motion com os bonecos Playmobil nessa obra. Assim como ocorre com as inserções ficcionais, aqui também o apriorismo da mescla de suportes no documentário contemporâneo acaba superdimensionado o peso do emprego da animação no conjunto de filmes analisados. Além de Los rubios, outros poucos títulos do corpus fazem uso de inserções de animação. De modo mais substantivo, a narrativa de $E l$ edificio de los chilenos (Macarena Aguiló e Susana Foxley, Chile / Cuba / França / Bélgica, 2010) vai sendo costurada por segmentos de animação que buscam transmitir o sentimento de abandono das crianças deixadas em Cuba pelos pais militantes. Nesse caso, os desenhos são de autoria de Néstor Gerardo Pérez, um dos “irmãos sociais” entrevistados no documentário. Em El tiempo y la sangre (Alejandra Almirón, Argentina, 2004), o uso da animação é mais fugidio e se dá em meio à miríade de referências articuladas nas imagens. Os desenhos também são de alguém que está no documentário, María Giuffra - filha de Sonia Severini, exmilitante que conduz a busca do filme, e Rómulo Giuffra, desaparecido -, e fazem alusões à militância montonera e à paternidade, quando não propõem jogos abstratos entre formas e cores. Em Marighella (Isa Grinspum Ferraz, Brasil, 2011), as animações surgem nas inserções de leitura dos poemas juvenis de Carlos Marighella feita em voz over pelo ator Lázaro Ramos. São traços brancos sobre o quadro negro que vão ilustrando, com gráficos e esquemas, a "prova em versos" de física escrita quando o biografado estudava no Ginásio da Bahia. Já em Nacimos en su lucha, viven en la nuestra: 10 años de H.I.J.O.S. La Plata 
(Camilo Cagni, Pablo Balut, Pablo Roesler e Juan Aíub, Argentina, 2006), a animação é rudimentar, surgindo na abertura e no encerramento do documentário: vê-se um militar escrachado em frente à televisão na sala de sua casa.

A observação da filmografia em conjunto mostra que, em suas variantes e de forma mais ou menos aprimorada, o recurso das inserções tende a um uso ilustrativo nos documentários intergeracionais. É clássica na tradição do documentário essa função das inserções de preencher a tela com imagens que confirmam aquilo que é dito pelas vozes em over ou testemunhais. Além de não serem tão consistentes no corpus expandido como seria de se supor, mesmo as manifestações mais híbridas, que mesclam ficção e documentário, que lidam com suportes não referenciais, na maioria das vezes acabam se inclinando a esse uso ilustrativo.

\section{- Intertítulos e legendas informativas}

O peso das formas tradicionais do cinema documental nessa filmografia se faz sentir ainda no uso dos intertítulos e das legendas informativas. A comparação extensiva dos documentários intergeracionais revela que é minoritária a conjugação em primeira pessoa nesses textos de apoio. É verdade que muitas obras simplesmente abrem mão desse recurso, não adicionando qualquer tipo de dado textual às imagens. Quanto a isso, Mi vida con Carlos se encontra em um meio-termo. Nele, as legendas demarcam os lugares por onde a história vai passando (Ottawa, Santiago, Barcelona, Chuquicamata); em uma única ocorrência, a legenda identifica a imagem de arquivo da entrevista concedida por Germán Berger-Hertz aos nove anos de idade. Afora isso, é a voz over do diretor que se encarrega de apresentar os personagens e situar os episódios históricos mencionados. Essa substituição de intertítulos e legendas pela voz over como canal mais diretamente informativo é algo que se observa em outros exemplos que prescindem ou fazem um uso pontual dessas inscrições nas imagens.

De todo modo, é significativa a parcela de filmes do corpus que, sim, lança mão desse recurso. Nesse universo, merecem atenção as dinâmicas textuais entre a enunciação subjetiva e a apresentação de dados objetivos. (h) Historias cotidianas (Andrés Habegger, Argentina, 2000) abre a via para a reflexão nesses termos. Nele, o protagonismo é dos seis filhos de desaparecidos que partilham suas experiências em um mosaico de entrevistas, compondo um retrato geracional coletivo. Habegger se mantém invisível, no papel do entrevistador atrás da câmera. A testemunha fala e a subjetividade do realizador fica fora de campo. É apenas nas dedicatórias do filme, em um intertítulo de fundo negro, que o espectador fica sabendo que o 
cineasta também foi atingido pessoalmente pela violência da ditadura. O "eu" de Andrés Habegger, retirado das imagens, fica circunscrito a um elemento paratextual, a dedicatória escrita que surge antes mesmo dos créditos iniciais (fig. 100).

Mas a escrita em primeira pessoa também se integra às imagens e ao fluxo da narrativa (PIEDRAS, 2014, p. 81-82). Encontrando a Víctor (Natalia Bruschtein, México / Argentina, 2004) dispensa qualquer tipo de voz over e, em compensação, mobiliza de forma mais substancial os intertítulos e as legendas. Desde o plano de abertura e ao longo do documentário, os textos vão entrelaçando as informações básicas sobre episódios de violência durante a ditadura com os impactos sobre a família da realizadora, que teve sete membros assassinados, entre pai, avô, tias e tios. A redação vai oscilando entre dados objetivos e enunciação subjetiva. Um dos intertítulos iniciais faz referência ao golpe de 1976 na Argentina e aos 30.000 desaparecidos, incluindo os parentes de Bruschtein nesse cômputo (fig. 101). Os entrevistados são apresentados por legendas que destacam os laços consanguíneos com a cineasta, na intimidade do primeiro nome: "Minha mãe, Shula"; "Tio Luis, irmão do meu pai”; "Vó Laura"; "Tia Ana, cunhada do meu pai"; e também, sobre o plano que mostra a própria diretora: "Eu, Natalia" (fig. 102). No caso dessas legendas de apresentação, a grafia simula a letra manuscrita, em outro signo da escrita íntima.

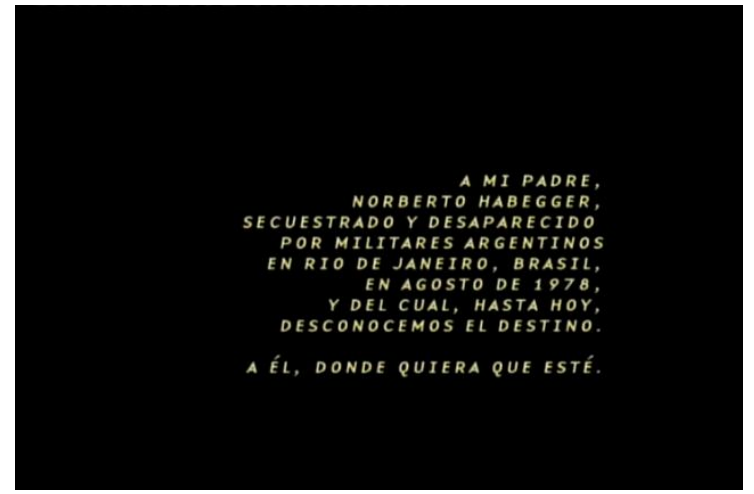

Figura 100 - Dedicatória ao pai desaparecido. Fonte: $(h)$ Historias cotidianas (Andrés Habegger, 2000).

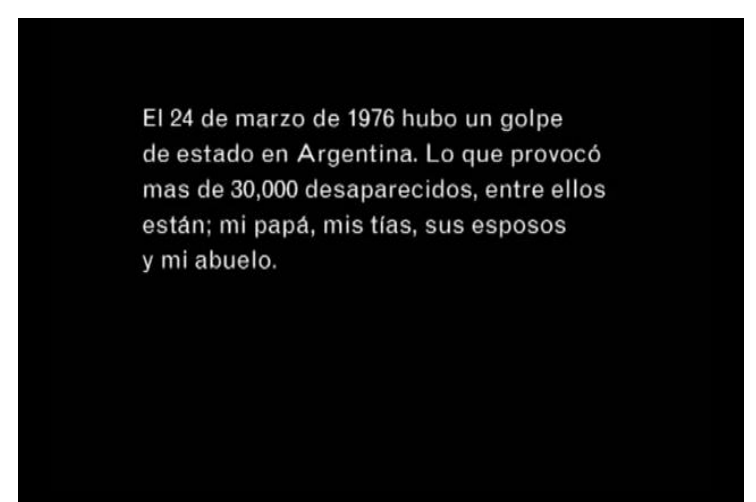

Figura 101 - A história e a família. Fonte: Encontrando a Víctor (Natalia Bruschtein, 2004).

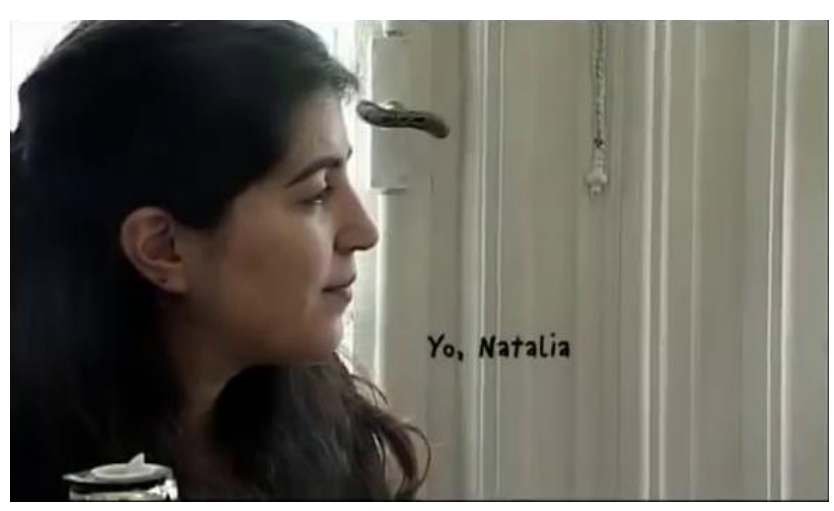

Figura 102 - A legenda em primeira pessoa. Fonte: Encontrando a Víctor (Natalia Bruschtein, 2004). 
Esse jogo de enunciação por meio de intertítulos e legendas tem outras variantes na filmografia. Algumas mais inventivas, como em Papá Iván (María Inés Roqué, México / Argentina, 2000), filme que desdobra o artifício básico da legenda em prol de um diálogo mais cerrado com a matéria audiovisual. Como em outros títulos do documentário intergeracional, as legendas aí também surgem em primeira pessoa, em tom familiar (“Azucena Rodríguez, minha mãe”) (fig. 74); ou apresentam os ex-companheiros do pai entrevistados no filme com nome e sobrenome, organização guerrilheira à qual pertenciam e função na estrutura clandestina. Também surgem as legendas que esclarecem para a audiência o jargão da militância setentista durante a fala das testemunhas, termos cifrados que aquela geração emprega com naturalidade ("Quebra-se / cantar: dar informação ao inimigo"; "Marcar: assinalar, delatar"; "Levantar: abandonar uma casa de segurança"). Mas é na apresentação de uma pessoa em particular que a correspondência entre legenda e imagem atinge um pico de tensão. No plano que enquadra a face do entrevistado, os dados básicos do engajamento passado são complementados com a informação que reveste a palavra testemunhal com a suspeita da traição (AMADO, 2009, p. 182-183): “Miguel Ángel Lauletta, militante de FAR e Montoneros. Acusado de colaborar com os militares enquanto esteve sequestrado na Escuela de Mecánica de la Armada (Esma).” (fig. 103).

En memoria de los pájaros (Gabriela Golder, França / Argentina, 2000), título marcado pelo experimentalismo, articula as legendas de forma ainda mais dinâmica. A moldura negra da janela bipartida é o espaço pelo qual passam as frases escritas. As legendas paralelas às imagens e aos sons vão desfiando impressões em primeira pessoa, sem que haja aí qualquer vínculo informativo. No lugar dos dados de referência, as palavras nesse caso sugerem livres associações em torno da memória e do desaparecimento (fig. 104).

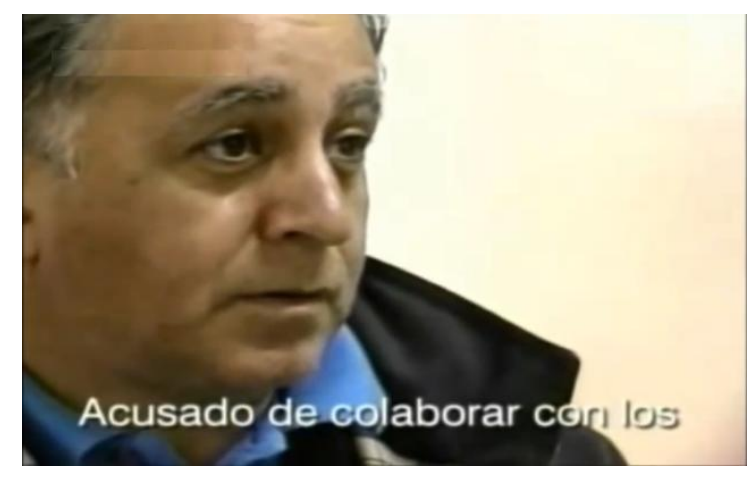

Figura 103 - A suspeita sobre o testemunho. Fonte: Papá Iván (María Inés Roqué, 2000).

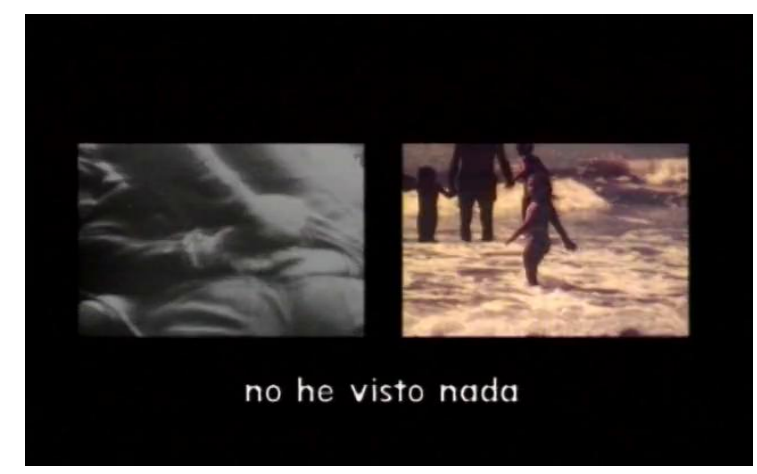

Figura 104 - Livres associações. Fonte: En memoria de los pájaros (Gabriela Golder, 2000). 
Os intertítulos podem ser ainda o suporte de citações textuais, em epígrafes que precedem o relato audiovisual, como nos casos de En algún lugar del cielo (Alejandra Carmona, Chile, 2003), M (Nicolás Prividera, Argentina, 2007) El memorial (Andrés Brignardello Valdivia, Chile, 2009), Repare bem (Maria de Medeiros, Brasil / Portugal / Espanha, 2012) e La guardería (Virginia Croatto, Argentina, 2016). Ou, como se viu na análise de Los rubios, promover uma intertextualidade mais complexa, com citações não identificadas soltas ao longo do filme.

Os exemplos comentados até este ponto tendem a uma articulação mais sugestiva dos intertítulos e das legendas. Contudo, é preciso reconhecer que, na maioria das ocorrências na filmografia, a inclusão desses textos se enquadra em raias mais estritas, assumindo as funções mais diretas de: contextualização dos eventos; demarcação de lugares e datas; apresentação dos personagens; identificação dos materiais de arquivo; indicação da temática a ser abordada na sequência seguinte. Usos clássicos, objetivos, às vezes pendendo para o didatismo, dentro dos padrões mais tradicionais do cinema documental, manifestando-se no corpus em obras de distintas estilísticas (fig. 105-111).

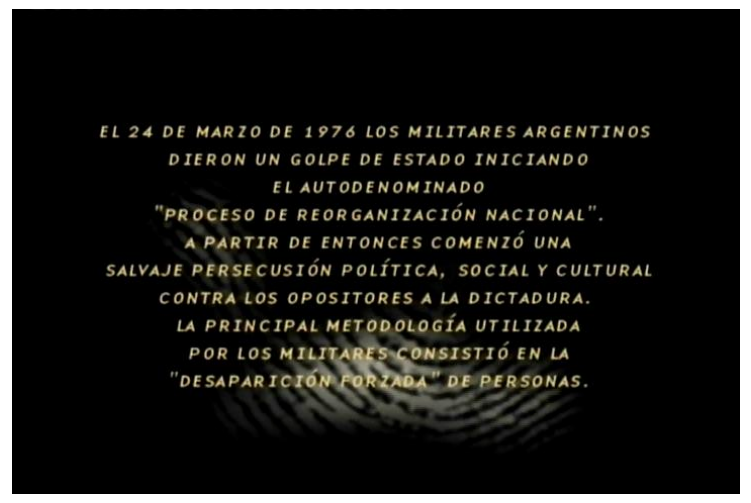

Figura 105 - Clássico intertítulo de contextualização. Fonte: (h) Historias cotidianas (Andrés Habegger, 2000).

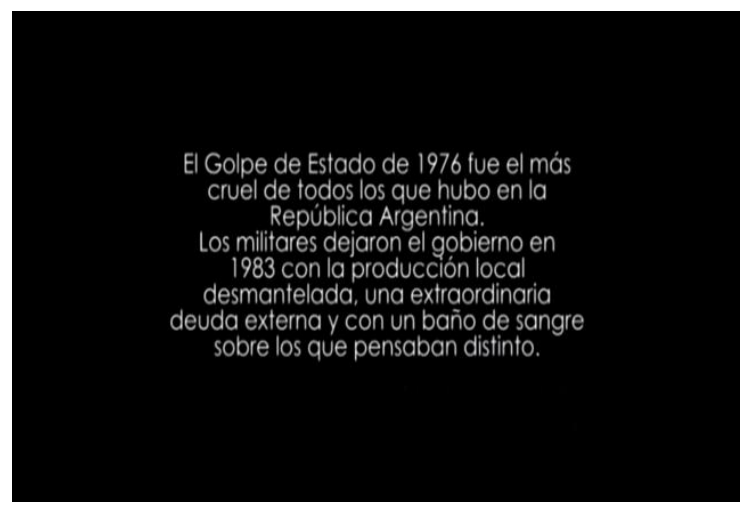

Figura 107 - Intertítulo oferece panorama histórico. Fonte: Hermanos de sangre (Fabián Vittola, 2005).

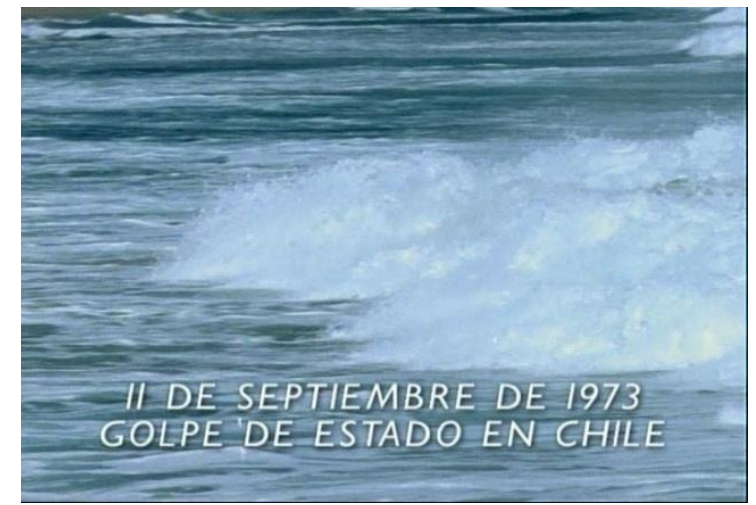

Figura 106 - Legenda pontuando data do golpe chileno. Fonte: En algún lugar del cielo (Alejandra Carmona, 2003).

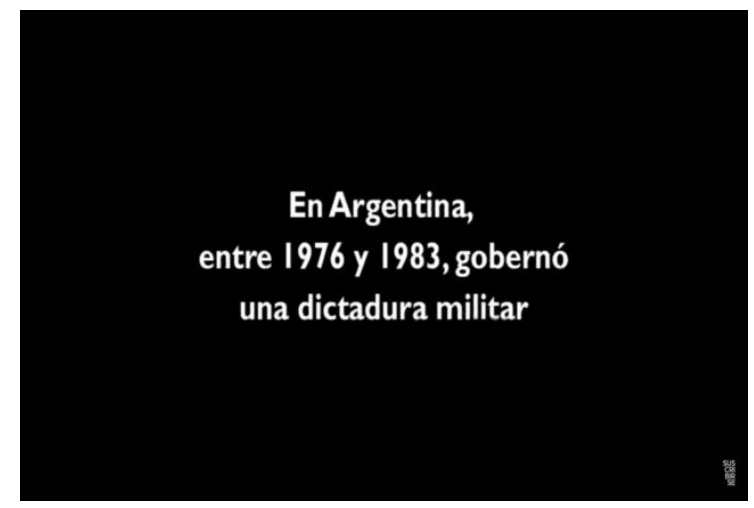

Figura 108 - Intertítulo com marcos temporais. Fonte: ¿Quién soy yo? Los niños encontrados de Argentina (Estela Bravo, 2007). 


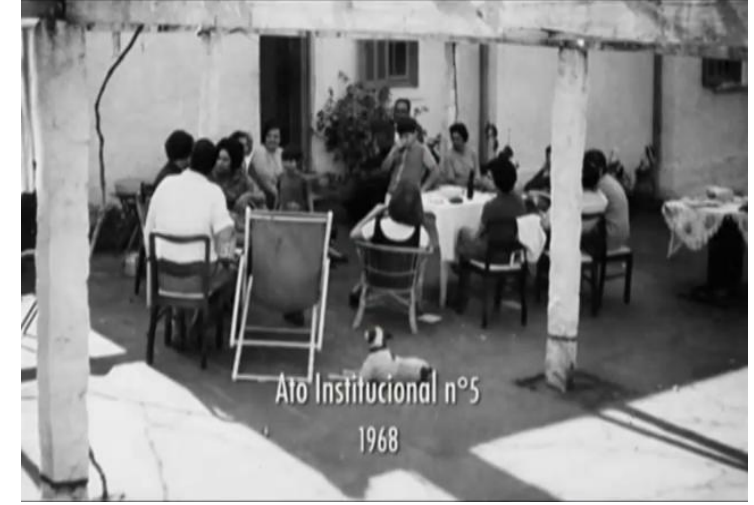

Figura 109 - Demarcação do fato canônico sobre fotografia de família. Fonte: Diário de uma busca (Flavia Castro, 2010).

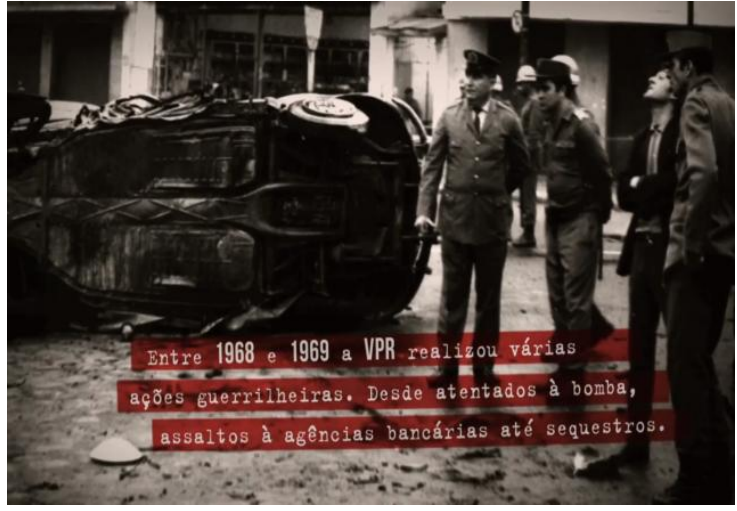

Figura 110 - Legenda de contextualização sobre fotografia do arquivo público. Fonte: Em busca de Iara (Flavio Frederico, 2013).

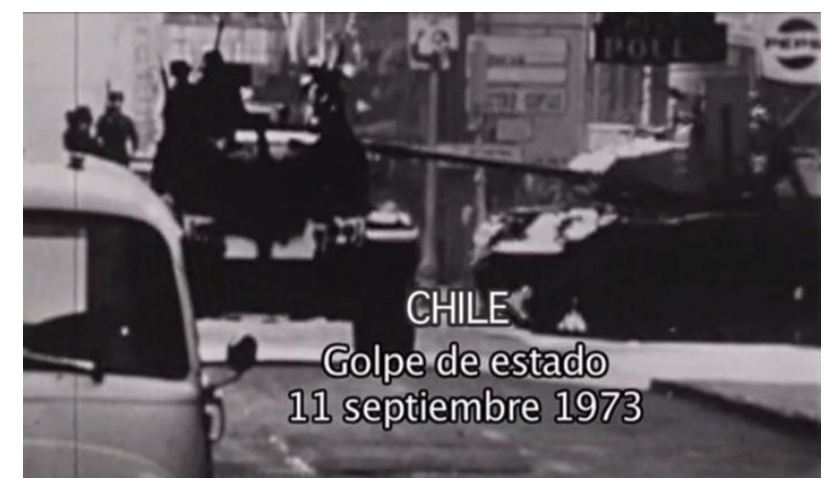

Figura 111 - Golpes como fatos básicos a serem indicados. Fonte: Venían a buscarme (Álvaro de la Barra, 2016).

Afora essas ocorrências mais patentemente convencionais, encontradas tanto em filmes de "cabeças falantes" quanto em documentários de busca, existem alguns exemplos que fazem aflorar uma espécie de curto-circuito entre a subjetividade e a objetividade da enunciação. Em D.F. (destino final) (Mateo Gutiérrez, Uruguai, 2008), no intertítulo que abre o filme, o diretor informa o mês e o ano da morte de seu pai. O "meu pai" do texto é apresentado com nome, sobrenome e cargo político, ao lado dos dados das pessoas junto às quais foi assassinado. Na sequência da obra, um documentário de entrevista dos mais canônicos que avança um retrato biográfico do pai linear, as testemunhas ouvidas, os personagens das imagens de arquivo e os lugares revisitados vão sendo imediatamente apresentados por legendas objetivas. Não só pela forma direta da redação desses textos, mas sobretudo pela estilística fílmica, a primeira pessoa de Gutiérrez parece ficar restrita àquele “meu pai” do intertítulo introdutório (fig. 112). Já En algún lugar del cielo (Alejandra Carmona, Chile, 2003) é um documentário francamente subjetivo, carregado com as marcas da busca pessoal. Ainda assim, quando a mãe da diretora é entrevistada, no modo "cabeças falantes", a legenda que a apresenta se afasta da intimidade familiar, informando nome, 
sobrenome, profissão e, o mais curioso, referindo-se à realizadora na terceira pessoa: "mãe de Alejandra" (fig. 113).

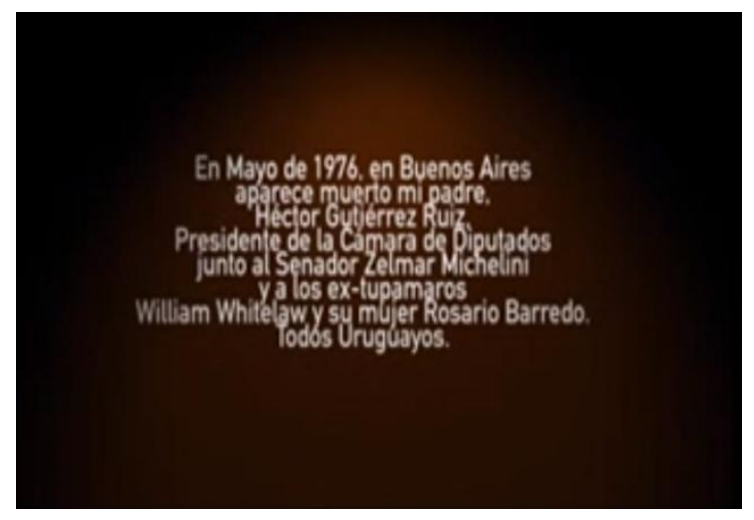

Figura 112 - Rastro fugaz da primeira pessoa: "meu pai”. Fonte: D.F. (destino final) (Mateo Gutiérrez, 2008).

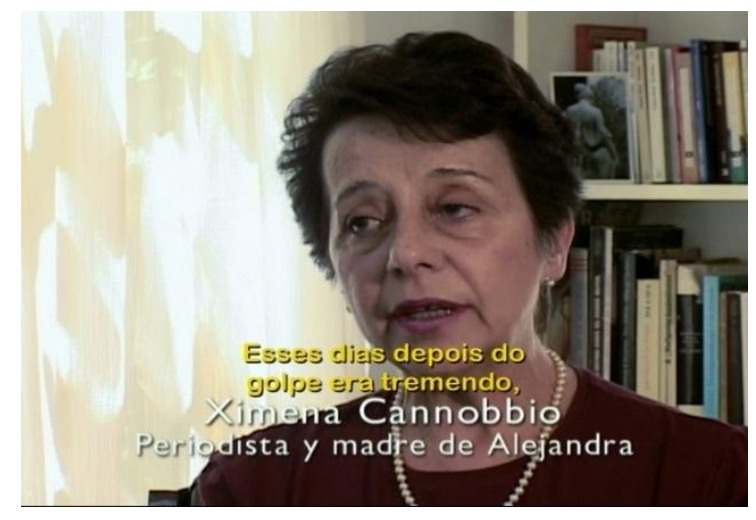

Figura 113 - Subjetividade na terceira pessoa: "mãe de Alejandra". Fonte: En algún lugar del cielo (Alejandra Carmona, 2003).

Relações intrincadas entre laços consanguíneos e papéis sociais; derivações entre a primeira e a terceira pessoa; fricções com as imagens e reiterações dos códigos básicos da tradição documental. Com frequência desconsiderada pelas análises, a gama de empregos de intertítulos e legendas revela outras facetas das contradições latentes no repertório formal do documentarismo intergeracional sobre as ditaduras do Cone Sul.

\section{- Cores e suportes alternativos}

São comuns as reflexões que atribuem o impulso à produção contemporânea de corte íntimo e familiar ao surgimento de câmeras cada vez mais portáteis, começando com o vídeo e, depois, com o cinema digital (cf. BELLOUR, 1988; RENOV, 2004c). A relação entre inovações técnicas e inflexões estéticas não é o que está em pauta nesta seção. Aqui a atenção se volta para a mobilização de cores e suportes fílmicos como elementos colaterais de expressão na filmografia estudada. Ainda não se trata de abordar as inserções de planos de arquivo de outras bitolas, e sim as tomadas feitas especialmente para o documentário, atuais, porém, com traços que remetem à textura das imagens do passado.

O uso do formato super-8 se destaca nesse terreno. Além dos trechos em que Mi vida con Carlos inclui as filmagens em super-8 do arquivo familiar do diretor, o documentário traz ainda duas inserções de tomadas contemporâneas realizadas nesse suporte. Na primeira delas, ocorre uma passagem do momento em que a mãe está mostrando o álbum da família ao filho para inserções de planos de Germán Berger-Hertz com sua filha. Os planos detalhe das fotografias do pai, Carlos Berger, segurando o bebê Germán no colo são justapostos a 
filmagens em super-8 de Germán, adulto, com sua filha nos braços. As fotografias são captadas em preto e branco, a imagem é granulada (fig. 114). Logo em seguida, surgem as imagens em movimento com o aspecto característico do super-8 colorido (fig. 115). Os créditos finais do filme registram Germán Berger-Hertz como operador da câmera super-8 nova e Sergio Badilla, de uma câmera super-8 antiga. Existe uma diferença cromática entre o close-up em preto e branco das fotos fixas do passado, de um lado, e, de outro, os planos em movimento do super-8 atual. Mas há uma convergência de texturas retrô que se associa ao paralelismo de gestos (a criança no colo do pai) e feições (Carlos de barba e bigode; Germán de bigode e costeletas). Tudo isso embaralha as temporalidades, funde o arquivo familiar com a rodagem doméstica recente, espelhando a relação pai-filho de outrora com o afeto pai-filha no presente. De fato, o espectador menos atento pode até vir a pensar que todas as imagens dessa sequência datam daquele passado familiar mais longínquo - Lisa Renee DiGiovanni (2013, p. 72, tradução nossa) já havia apontado esse efeito de confusão entre as temporalidades gerado pela "estética anos 1970" dessas imagens em Mi vida con Carlos.

A segunda inserção de tomadas em super- 8 contemporâneas surge no ponto em que a voz over de Berger-Hertz reitera essa passagem geracional do filho tornado pai: "Depois que minhas filhas nasceram, teu fantasma cresceu. Agora eu sabia o que era ser pai. Agora sabia como minha avó havia te amado, e como tu havias me amado." (tradução nossa). As imagens que acompanham essa fala são típicas filmagens de família (ODIN, 2010): os primeiros passos do bebê; a esposa grávida; um dia com as crianças na praia; outro à beira do rio; um piquenique no jardim (fig. 116-119). Imagens características de uma família feliz, nada de estranho nisso, não fosse esta uma família dos anos 2000 filmada em super-8. A rememoração aqui se reveste de uma espécie de nostalgia vintage, reforçada pela trilha incidental melodiosa.

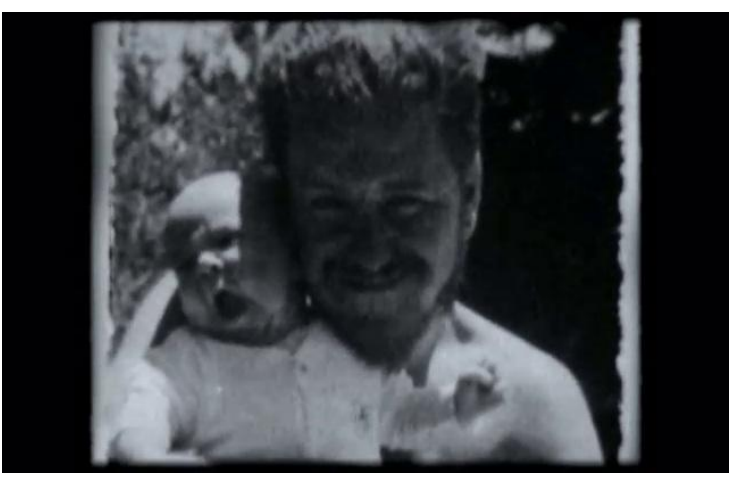

Figura 114 - Plano detalhe da foto do diretor bebê no colo do pai desaparecido. Fonte: Mi vida con Carlos (Germán Berger-Hertz, 2009).

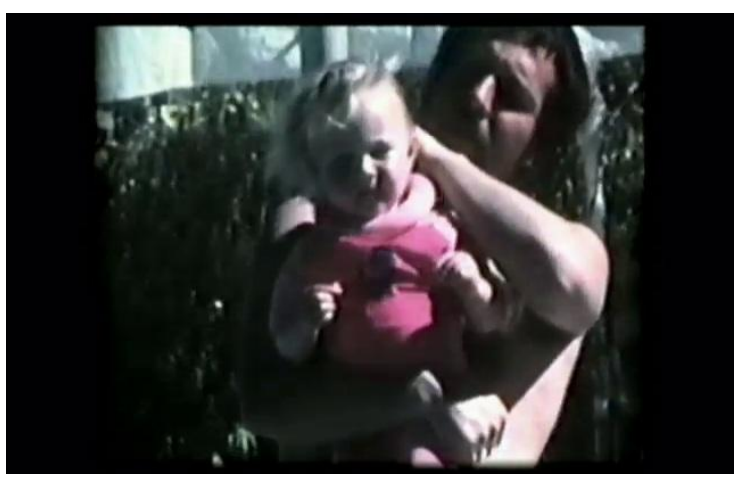

Figura 115 - Filmagem em super-8 recente do diretor com a filha no colo. Fonte: Mi vida con Carlos (Germán Berger-Hertz, 2009. 


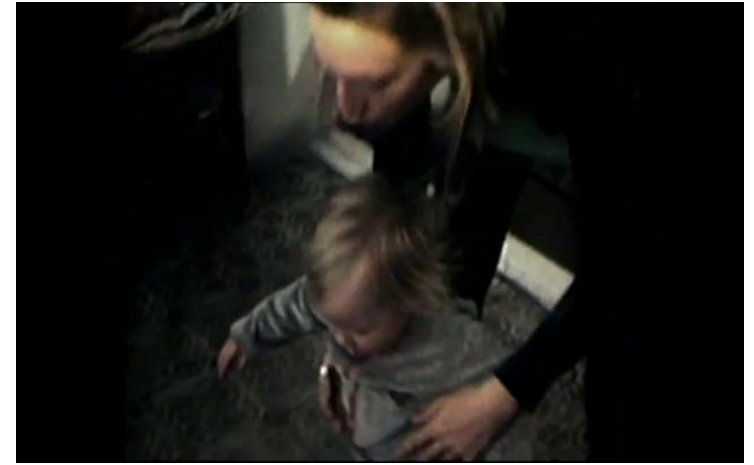

Figura 116 - Filmagem atual em super-8 com os primeiros passos da filha do diretor. Fonte: Mi vida con Carlos (Germán Berger-Hertz, 2009).

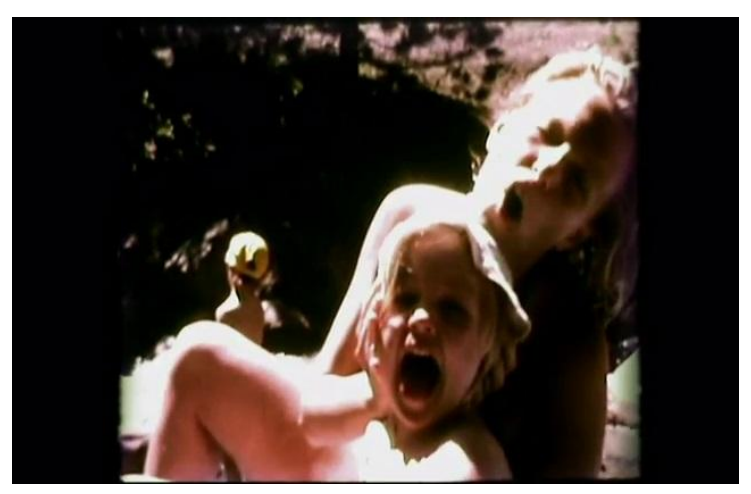

Figura 118 - Um dia à beira do rio. Fonte: Mi vida con Carlos (Germán Berger-Hertz, 2009).

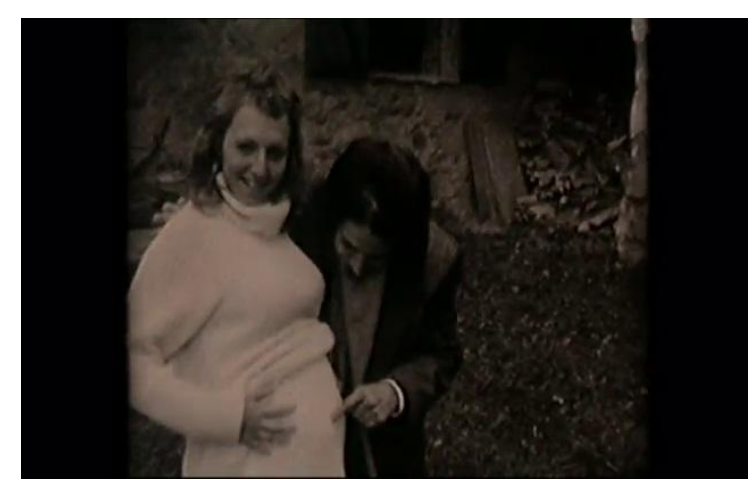

Figura 117 - Super-8 em preto e branco registra a gravidez da esposa. Fonte: Mi vida con Carlos (Germán Berger-Hertz, 2009).

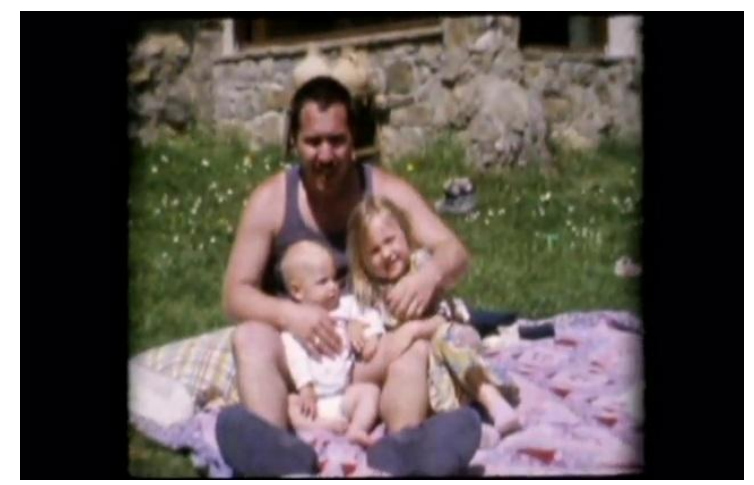

Figura 119 - Piquenique em família. Fonte: Mi vida con Carlos (Germán Berger-Hertz, 2009).

Por sua vez, El (im)posible olvido (Andrés Habegger, Argentina / Brasil / México, 2016) faz um uso menos naturalizado das filmagens atuais em super-8. A sobreposição de temporalidades nesse caso é explicitada por Habegger: o diretor retorna aos lugares de sua infância portando uma câmera super-8. Diante das mesmas paisagens onde, menino, fora fotografado junto com o pai, Andrés Habegger não se lembra de nada. As fotos antigas, reenquadradas nos locais do passado, não servem como gatilho para sua memória. O cineasta, adulto, postado em um lugar onde já esteve com o pai anos atrás, não se recorda. E, frente ao esquecimento, Habegger filma. Mas não com uma câmera qualquer. Em um desses momentos, surge um plano geral em super-8 do Rio de Janeiro onde o pai desapareceu: a coloração é característica desse formato, é possível ver a perfuração lateral da película no canto do quadro (fig. 120). Logo em seguida, um novo plano revela o diretor operando a filmadora super-8 (fig. 121). Essas tomadas duplicadas revestem com uma textura do passado a paisagem visitada pelo filho no presente. A película se coloca como uma espécie de ponte entre o agora do cineasta que busca com a câmera na mão e o passado do menino que recalcou as memórias do pai desaparecido. 


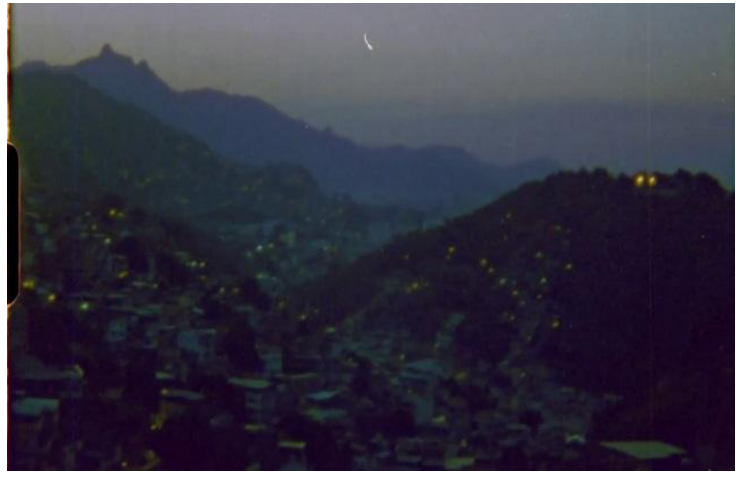

Figura 120 - Tomada em super-8 da cidade onde o pai desapareceu. Na margem, a perfuração da película. Fonte: El (im)posible olvido (Andrés Habegger, 2016).

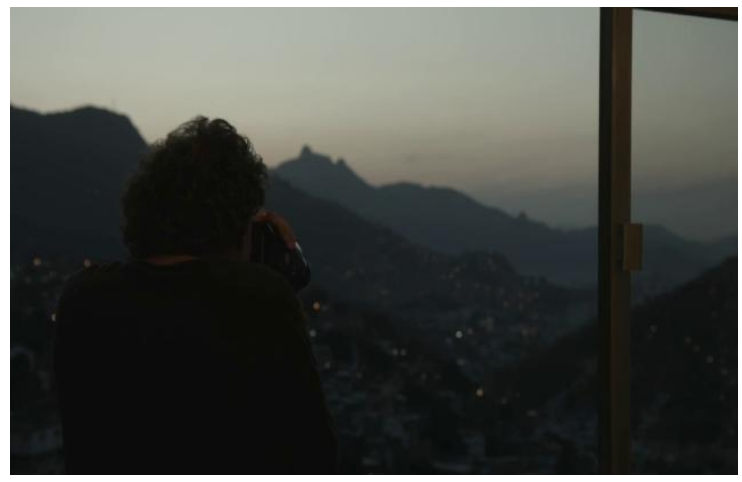

Figura 121 - Novo plano revela o diretor operando a filmadora super-8. Fonte: El (im)posible olvido (Andrés Habegger, 2016).

Mas nem sempre há esse uso efetivo de equipamentos e películas de outras épocas. $\mathrm{Na}$ maioria dos casos, pelo que indicam as fichas técnicas dos filmes, o que ocorre é o tratamento das imagens feitas em formatos contemporâneos (captadas originalmente em vídeo, em digital e, mais raro, em $35 \mathrm{~mm}$ ) com efeitos voltados a conferir-lhes um aspecto de imagens antigas. As variantes nesse campo merecem atenção.

Existem os títulos que recorrem ao preto e branco de maneira mais simples, sendo a ausência de coloração a única intervenção nas imagens. Em 15 filhos (Maria Oliveira e Marta Nehring, Brasil, 1996), todos os planos das entrevistas são em preto e branco, do início ao fim do curta-metragem. Por sua vez, (h) Historias cotidianas (Andrés Habegger, Argentina, 2000), H.I.J.O.S.: El alma en dos (Carmen Guarini e Marcelo Céspedes, Argentina, 2002) e Todos somos hijos (Esteban Barja e Carlos Conti, Uruguai, 2015) fazem um uso mais pontual do preto e branco, em inserções esparsas ao longo dos relatos. A exceção nesse subgrupo é, mais uma vez, Los rubios (Albertina Carri, Argentina, 2003), no qual o preto e branco tem uma função reflexiva, servindo para demarcar aquelas que seriam as cenas dos bastidores do documentário.

O mais usual, porém, é a adição de outras camadas no tratamento das imagens, tendendo a aproximá-las da estética do filme doméstico em super-8. Três movimentos se destacam nesses casos. Primeiro, a reprodução das características intrínsecas aos formatos analógicos: o preto e branco ou o cromatismo esmaecido; a granulação da imagem; a cintilação da projeção. Segundo, a simulação das marcas da passagem do tempo na película: ranhuras, falhas e clarões de fotogramas deteriorados. Por último, a emulação do modo de filmar amador: tomadas trepidantes; enquadramentos desajeitados; cortes abruptos entre os planos; movimentos bruscos de câmera. Nessa chave, tais artifícios estão presentes em: Papá 
Iván (María Inés Roqué, México / Argentina, 2000); En memoria de los pájaros (Gabriela Golder, França / Argentina, 2000); El tiempo y la sangre (Alejandra Almirón, Argentina, 2004); La quemadura (René Ballesteros, Chile / França, 2009); El memorial (Andrés Brignardello Valdivia, Chile, 2009); El edificio de los chilenos (Macarena Aguiló e Susana Foxley, Chile / Cuba / França / Bélgica, 2010); El eco de las canciones (Antonia Rossi, Chile, 2010); Cuchillo de palo (Renate Costa, Paraguai / Espanha, 2010); Marighella (Isa Grinspum Ferraz, Brasil, 2011); Elena (Petra Costa, Brasil, 2012); Em busca de Iara (Flavio Frederico, Brasil, 2013). Todos esses títulos contêm sequências em que a adição de "impurezas" às imagens constrói uma espessura significante. Os traços materiais, os desgastes físicos e as "imperfeições" técnicas acrescentados às filmagens atuais funcionam como um "sistema de figuras" estilísticas apto a gerar um "efeito de cinema doméstico" (ODIN, 2010, p. 44, tradução nossa). Em outros termos, pode-se dizer que esse conjunto de códigos dá forma visual à memória familiar abordada nos documentários.

Trata-se aqui de uma forma que acarreta em uma indeterminação de outra natureza. Afinal, seja no caso dos planos rodados com películas antigas, seja no das imagens em vídeo ou digitais tratadas com efeitos de envelhecimento, uma das consequências dessa mobilização de cores e suportes alternativos é a confusão entre tomadas contemporâneas e materiais de arquivo. No fluxo da edição, as temporalidades se mesclam, a filmagem da rememoração se reveste com as marcas analógicas dos registros que vêm do passado. Para o espectador, muitas vezes fica difícil distinguir o antigo do vintage.

\section{- Reflexividade}

Los rubios (Albertina Carri, Argentina, 2003) não só foi o título que gerou a maior quantidade de análises nessa filmografia, como também é muitas vezes tido como um caso emblemático do documentarismo intergeracional sobre as ditaduras do Cone Sul. No entanto, seria um equívoco projetar a reflexividade patente em suas imagens como uma característica paradigmática dessa produção. A análise comparada do corpus estendido demonstra que, tal como ocorre com outros quesitos, os lances de metalinguagem nessa filmografia são mais tímidos do que faz supor a agenda contemporânea da subjetividade. Realizar um documentário em primeira pessoa não significa necessariamente filmar em chave reflexiva. Quanto a isso, vale lembrar a ressalva feita por Jay Ruby (1988b, p. 65, tradução nossa, grifo do autor): 
Pode haver certa confusão entre reflexividade e termos que às vezes são usados como sinônimos: autobiografia, autorreferência e autoconsciência. Em uma obra autobiográfica, embora o produtor - o "eu" - seja o centro da obra, ele pode ser inconsciente em sua autoapresentação. O autor claramente teve que ser autoconsciente no processo de elaboração do produto (isto é, a autobiografia), mas é possível que ele mantenha essa consciência para si e simplesmente siga as convenções estabelecidas desse gênero.

Nesse sentido, é elucidativo o tópico da presença do corpo do documentarista diante da câmera, sem dúvida um dos traços mais pregnantes dessa produção. Tal presença pode ser uma estratégia de explicitação do dispositivo fílmico, de problematização da rememoração, e a duplicação da persona de Albertina Carri em Los rubios leva esse recurso ao paroxismo. Mas esse corpo visível pode ser também, como em Mi vida con Carlos e tantos outros exemplos do documentário intergeracional, uma forma cinematográfica de avalizar o "pacto autobiográfico" de Philippe Lejeune (1996). Nesses casos, a presença do realizador no quadro não geraria opacidade, e sim a identificação entre diretor, narrador e personagem.

Feitas as ponderações, vale a pena se debruçar sobre as variantes de imagens configuradas de modo propriamente reflexivo nesse conjunto de obras. Aqueles planos que, ao menos em princípio, expõem a mediação do aparato técnico, que subvertem a transparência da representação, fazendo irromper as instâncias de construção do discurso fílmico (STAM, 1992). Começando pelo artifício reflexivo mais básico da tomada rodada com uma segunda câmera, expondo a situação de filmagem ao redor daquilo que supostamente seria o objeto central a ser enquadrado: o "por trás das câmeras" que revela o espaço do "antecampo" (BRASIL, A., 2013). Mi vida con Carlos tem um único plano nessa chave. Ele ocorre durante o registro de um ato público que celebrava a morte do ditador Augusto Pinochet, em 2006. O clima é festivo, as pessoas saltam e cantam na praça em frente ao Palácio de La Moneda. As primeiras tomadas dessa sequência são realizadas em meio à multidão, cabeças e bandeiras passam diante da objetiva, os planos são tremidos, os movimentos de câmera buscam detalhes da situação (cartazes, rostos). E eis que surge um plano mais aberto, filmado com a segunda câmera, que mostra Germán Berger-Hertz operando ele mesmo uma câmera, ladeado pela técnica que porta o microfone boom para captação do som direto. Enquanto filma, o cineasta está envolvido em uma bandeira vermelha, similar a tantas outras agitadas pelos manifestantes (fig. 122). A próxima tomada já não é mais feita por essa segunda câmera. Agora, um plano geral em plongée, trepidante, rodado de algum ponto alto em torno da praça, dá a dimensão da massa que festeja. A imagem volta para o meio da multidão: ali está Berger-Hertz, não mais no papel de cineasta, mas celebrando junto com as pessoas, saltando, agitando sua bandeira vermelha, cantando a plenos pulmões (“Jamais, jamais, jamais esqueceremos esse assassino 
chamado Pinochet"). Ele deixa de festejar e sai caminhando em meio à multidão, a câmera o segue de perto esgueirando-se entre as pessoas. O manifestante Berger-Hertz aproxima-se do painel com fotografias dos desaparecidos. Para e observa o retrato de seu pai, flanqueado pela câmera, a qual fecha o quadro na imagem de Carlos Berger.

Na sequência descrita, o plano realizado com a segunda câmera, exibindo o aparato técnico, parece afasta-se da opacidade reflexiva. Tal como está inserida, essa tomada, única no filme, passa muito mais a ideia do registro in loco de um evento histórico, do testemunho em primeira mão de um fato relevante. Mais do que isso, nesse caso, o diretor não só testemunha como toma parte no ato, misturando-se à massa como mais um que celebra em êxtase a morte do genocida. No lugar da desconstrução do discurso, o registro aqui é autenticado pela presença do diretor no quadro operando a câmera, junto com a técnica de som. Nessa passagem, os fatores que em princípio marcariam a reflexividade se deslocam a ponto de funcionarem como as figuras do "estilo reportagem" descritas por Roger Odin (1990, p. 119, tradução nossa): "presença de imagens tremidas, desfocadas, desenquadradas, golpes de zoom hesitantes, rupturas brutais no desenrolar dos planos e no encadeamento das sequências [...], planos deixando ver o gravador de som, o operador de microfone boom, a sombra da câmera etc.” Odin (1990, p. 119, tradução nossa) prossegue: “A função dessas figuras é clara: marcar no próprio filme a existência do operador, testemunhar a realidade de sua presença no próprio lugar da ação, seu engajamento físico no evento, dar a ver os riscos que ele assumiu."

O uso da segunda câmera pode ainda se manifestar de outros modos. Seja no registro pontual da equipe de televisão que entrevista os irmãos Prividera no início de $M$ (Nicolás Prividera, Argentina, 2007) (fig. 123). Seja, segundo já ficou dito, na exposição do diretor que opera a câmera super-8, como em El (im)posible olvido (Andrés Habegger, Argentina / Brasil / México, 2016) (fig. 121). Seja, enfim, de maneira insistente, como no caso de Em busca de Iara (Flavio Frederico, Brasil, 2013), filme que traz planos de segunda câmera enquadrando a equipe de filmagem que segue Mariana Pamplona, sobrinha da protagonista, nas andanças de sua busca (fig. 124); ou, nas situações de entrevista dessa mesma obra, quando a montagem vai alternando planos convencionais e tomadas com segunda câmera que mostram a primeira câmera fixa, o microfone boom, o refletor, a sobrinha no papel de entrevistadora (fig. 125). A inclusão dessas imagens não chega a romper o fluxo coeso da narrativa de Em busca de Iara, a exposição do aparato técnico parece aí mais um maneirismo do documentário contemporâneo do que um artifício desencadeador de opacidade. André Brasil (2013, p. 586) já havia identificado na produção brasileira os casos nos quais, "quando o antecampo se 
expõe, o recurso surge como uma espécie de jargão desgastado, excessivamente controlado", desprovido, enfim, de força expressiva.

Esta última observação conduz a outra ponderação neste campo de análise: em certos casos, as marcas da reflexividade devem ser lidas a contrapelo. Pois, a rigor, as inscrições metalinguísticas nas imagens não possuem um valor anti-ilusionista a priori (STAM, 1992, p. 13-17, 2007, p. 151-153). É preciso levar em conta as distintas formas de inclusão desses traços na narrativa fílmica, o contexto das tomadas, entre outros fatores, de modo a perceber os variados sentidos que as configurações supostamente reflexivas podem assumir: desde a certificação do registro in loco, como em Mi vida con Carlos, até o uso banalizado, como no exemplo de Em busca de Iara.

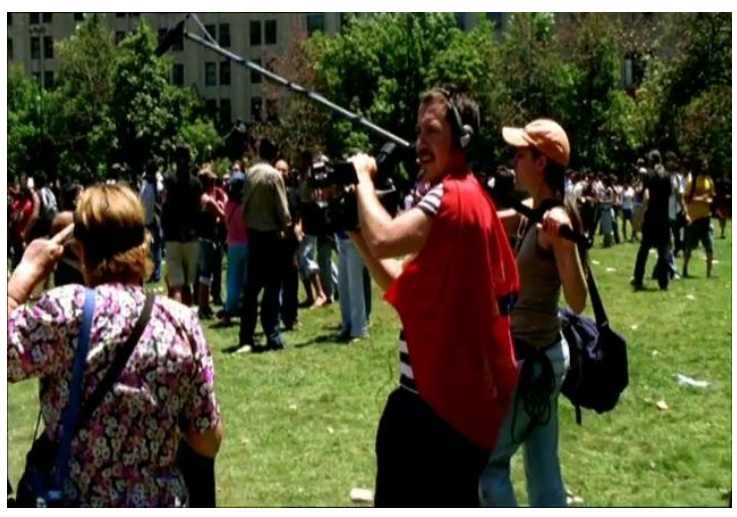

Figura 122 - Segunda câmera e atestação da presença no fato. Fonte: Mi vida con Carlos (Germán Berger-Hertz, 2009).

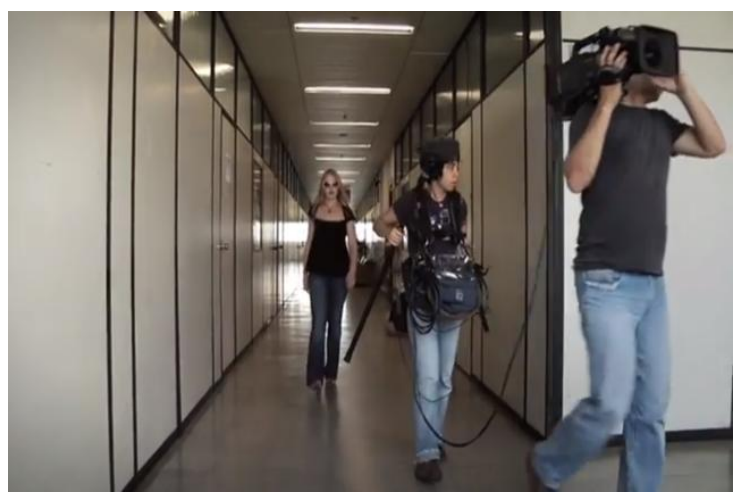

Figura 124 - A sobrinha Mariana Pamplona acompanhada pela equipe de filmagem. Fonte: Em busca de Iara (Flavio Frederico, 2013).

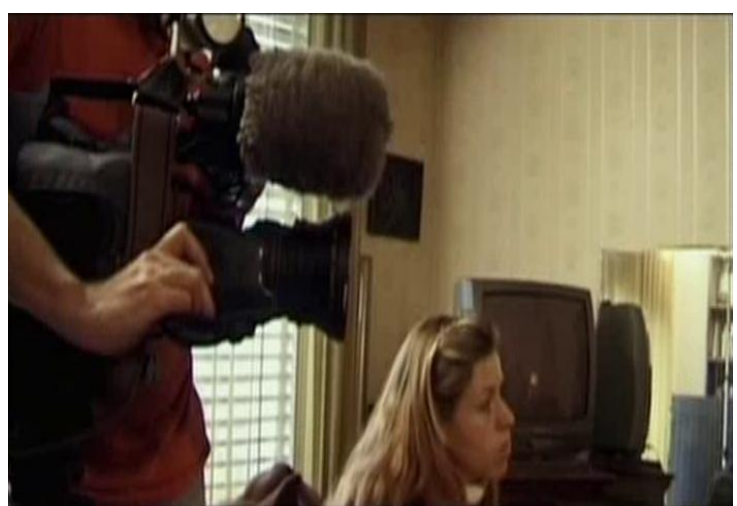

Figura 123 - Segunda câmera registra entrevista para TV com irmãos Prividera. Fonte: $M$ (Nicolás Prividera, 2007).

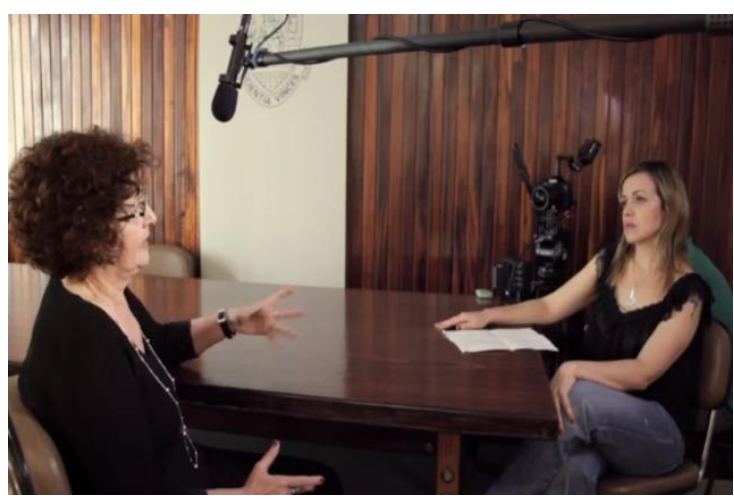

Figura 125 - Segunda câmera expõe o aparato da entrevista feita por Mariana Pamplona com sua mãe. Fonte: Em busca de Iara (Flavio Frederico, 2013).

Por sua vez, Argenmex: exiliados hijos (Violeta Burkart Noë e Analía Miller, Argentina, 2007) traz ocorrências que abrem o horizonte de outra modalidade nesse conjunto: quando a segunda câmera provoca uma reflexividade acidental. Trata-se de situações nas 
quais “esses elementos aparentemente reflexivos”, nas palavras de Jay Ruby (1988b, p. 73, tradução nossa), são fruto de:

[...] um acidente do momento: uma reviravolta inesperada dos eventos durante a filmagem, ao invés do resultado do planejamento deliberado da pré-produção. O que é interessante e, de fato, representa um distanciamento das convenções do documentário, é que esses "acidentes" sejam mantidos na versão final do filme.

Em Argenmex: exiliados hijos, durante a filmagem do jantar promovido com o grupo de filhos ex-exilados, o enquadramento por vezes encontra outra câmera no ambiente, a qual registra simultaneamente a conversa. As aparições do equipamento cinematográfico são fugazes nesses planos, os técnicos operam discretamente suas câmeras em volta da mesa, à margem da ação principal. A reflexividade aqui está mais próxima de uma irrupção inadvertida (fig. 126).

Para além do espelhamento direto com a segunda câmera, a reflexividade acidental manifesta-se também por vias mais sutis. Ainda na esfera da técnica, Diário de uma busca (Flavia Castro, Brasil / França, 2010) contém outro exemplo de "acidente", prontamente corrigido pela equipe fora de campo: a margem superior de um enquadramento convencional de entrevista é invadida por um átimo pelo microfone boom, mas este logo desaparece da tela (fig. 127).

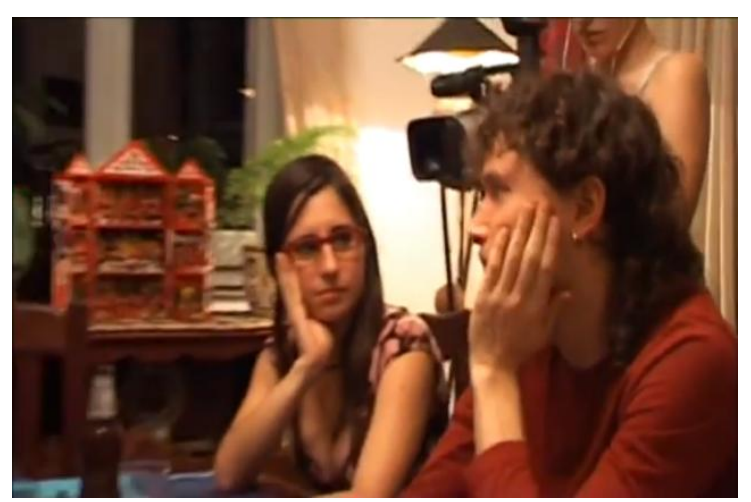

Figura 126 - Segunda câmera encontra outra câmera no ambiente. Fonte: Argenmex: exiliados hijos (Violeta Burkart Noë e Analía Miller, 2007).

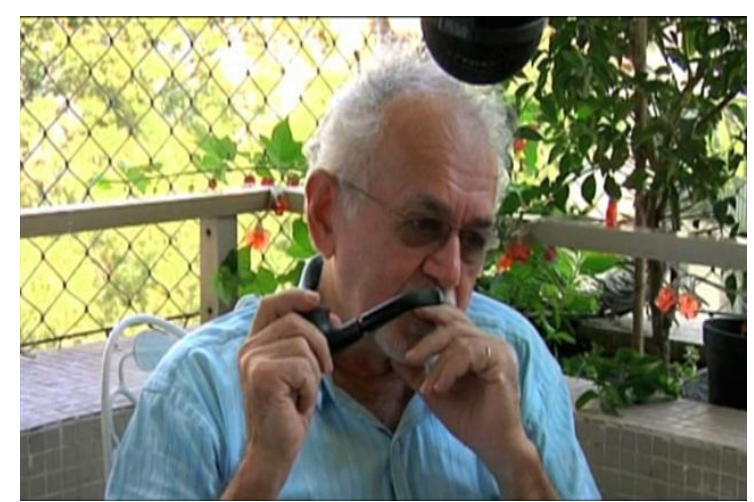

Figura 127 - Microfone invade acidentalmente o quadro convencional. Fonte: Diário de uma busca (Flavia Castro, 2010).

Uma situação curiosa nesse sentido vem de Cuchillo de palo (Renate Costa, Paraguai / Espanha, 2010). A diretora está entrevistando uma antiga amiga de seu tio morto. Ela está de saída, vai à missa. A conversa vai se desenvolvendo e começa a soar um bipe insistente de alerta. De repente, a tela fica escura, restando apenas o áudio. Ouve-se em off Renate Costa 
que pergunta se ficaram sem bateria, uma outra voz responde que sim. A entrevistada, com pressa, com a tela ainda escura, diz que se vai porque está na hora de sua novena.

Já outros "acidentes" são provocados não pelos equipamentos, mas pelas reações das pessoas filmadas. É este o caso quando a mãe de Flavia Castro pede, no meio da entrevista, para a filha não incluir no filme seu relato de quando, no Chile pré-golpe, ela ia aos cordões industriais de salto alto e casaco de couro para propor a via armada aos operários. A manutenção da anedota no corte final de Diário de uma busca mostra que a filha decidiu não obedecer ao pedido da mãe. Em Allende mi abuelo Allende (Marcia Tambutti, Chile / México, 2015), a certa altura, a avó da realizadora está se retirando após uma entrevista. Ela olha em direção à equipe fora do quadro e se despede: “Até logo, jovens. Muito obrigada.” As vozes respondem em off: “Obrigado à senhora.” A presença dos técnicos atrás da câmera é revelada inesperadamente nessa troca de gentilezas.

Jay Ruby (1988b, p. 73-74) considera que, embora tenham sido mantidas no resultado final, essas intrusões acidentais da mediação fílmica são reflexivas apenas na aparência. Aqui entra em jogo novamente a leitura a contrapelo do material audiovisual. Nestes últimos exemplos descritos, as irrupções do dispositivo cinematográfico são esporádicas, pontuais, a percepção de algumas delas depende de uma atenção toda especial por parte do espetador. Em geral, o teor reflexivo desses lances acaba diluído no fluxo da narrativa fílmica global. Mais ainda, pode surgir daí uma espécie de "estética descontrolada", na qual os "acidentes" serviriam como indicativo de que o diretor não cerceou a realidade registrada pelas câmeras (RUBY, 1988b, p. 73, tradução nossa). O imponderável dos eventos, nesse caso, ganha expressão em uma forma apta a abarcar a indeterminação, ecoando a dialética que vem guiando estas reflexões.

É possível distinguir melhor tais ambiguidades ao se comparar esses "acidentes" com as situações em que a reflexividade é programática. Ou seja, quando o estranhamento não é mero lampejo, e sim uma opacidade revestindo as imagens de forma mais substancial. Los rubios, por certo, é o exemplo mais flagrante desse recurso à reflexividade como elemento estruturante da obra. Com efeito, no documentário de Albertina Carri, as instâncias de mediação fílmica se sobrepõem de tal maneira ao gesto de rememoração que cabe ponderar se o objeto central da busca aí não seria a própria forma cinematográfica. Afinal, se, de um lado, estão a pouca atenção dada aos testemunhos dos ex-militantes, a recusa em oferecer uma imagem dos pais desaparecidos, junto com a adoção de uma identidade postiça simbolizada pelas perucas loiras; de outro, salta aos olhos a proeminência dos artifícios reflexivos, desde a presença da atriz, passando pela exposição do aparato técnico, até a ficcionalização dos 
próprios meandros da busca. Nessa balança, o impulso de memória parece sucumbir ao desconstrucionismo radical da linguagem cinematográfica. Frente a tamanha indeterminação, a indagação formal termina se impondo (cf. KOHAN, 2004a).

Entretanto, não custa lembrar, no universo aqui analisado, a tentativa de implosão da representação é particularidade de Los rubios. Afora as ocorrências colaterais já discutidas, a reflexividade no documentário intergeracional, mesmo quando é programática, costuma ser bem mais comedida. De todo modo, a ponderação feita no parágrafo anterior aponta para as duas outras vertentes identificadas neste tópico. Em primeiro lugar, as marcas da reflexividade da busca. Trata-se das situações nas quais o que está em jogo é menos a opacidade cinematográfica e mais as vicissitudes da indagação pessoal empreendida. É claro que há, também aí, uma explicitação do discurso fílmico, mas esta vem na esteira da exposição do processo de busca.

As figurações nessa chave concentram-se nas ações dos protagonistas das investigações fílmicas, que podem ser os diretores ou outros personagens ligados às experiências passadas. Em títulos diversos, esse agente da busca é visto: trabalhando no projeto do documentário diante do computador (fig. 128-129); montando as peças do quebracabeça em painéis em seu escritório (fig. 130-131); fazendo telefonemas em contatos prévios com os indivíduos a serem entrevistados ou para combinar encontros de outra natureza (fig. 132-135); dialogando com alguém próximo sobre os rumos da história narrada no filme (fig. 136-137). Não deixa de haver aí a repetição de certos artifícios que apresentam o documentário como obra em processo. A abertura da busca se reitera em determinadas formas.

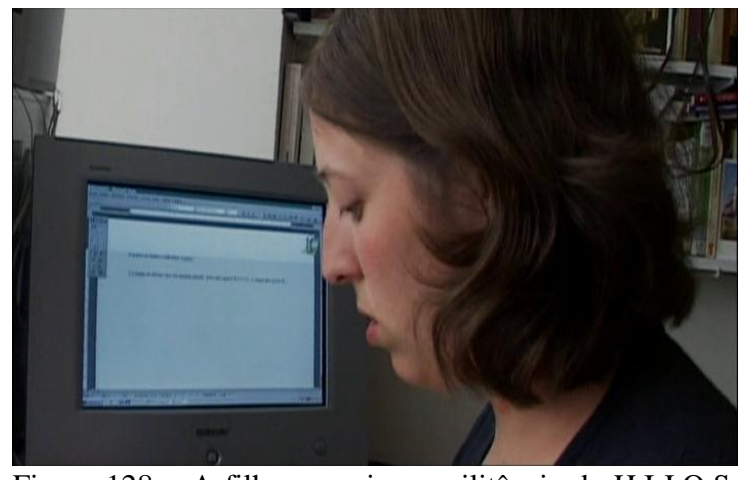

Figura 128 - A filha pesquisa a militância de H.I.J.O.S. Fonte: H.I.J.O.S.: El alma en dos (Carmen Guarini e Marcelo Céspedes, 2002).

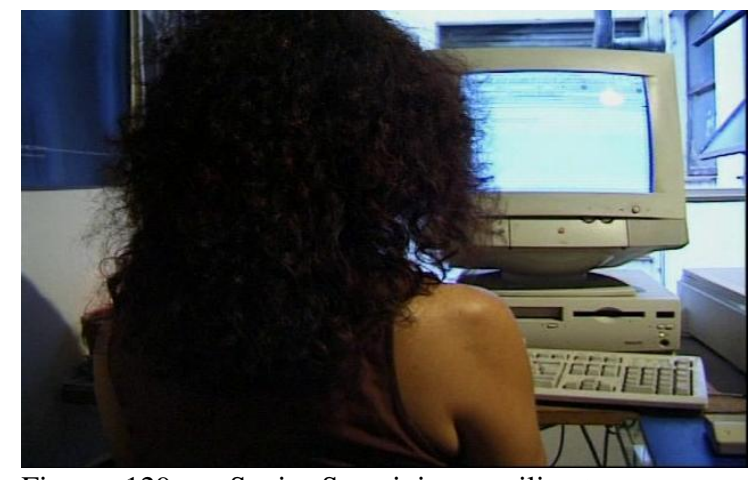

Figura 129 - Sonia Severini, ex-militante, em suas buscas. Fonte: El tiempo y la sangre (Alejandra Almirón, 2004). 


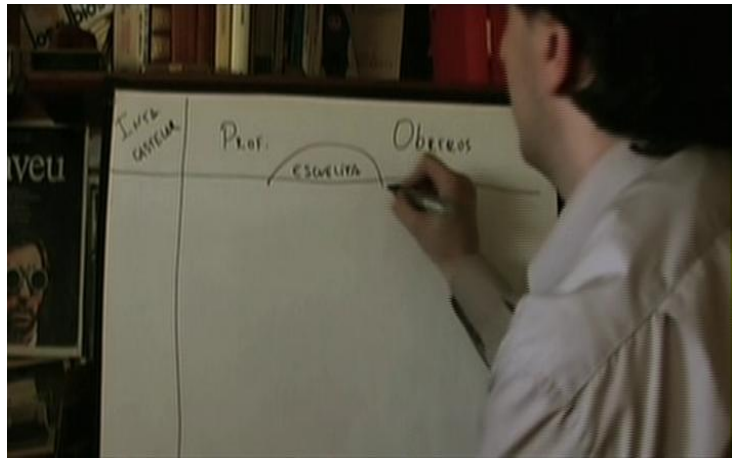

Figura 130 - O diretor monta um esquema com os elementos da busca. Fonte: $M$ (Nicolás Prividera, 2007).

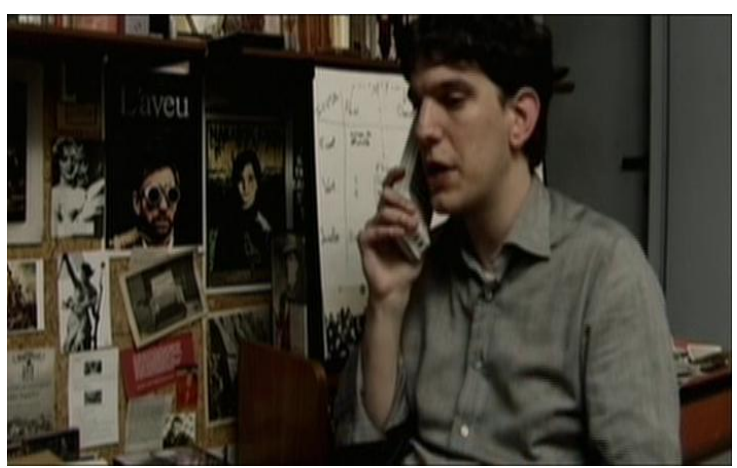

Figura 132 - Diretor faz contatos para o filme. Fonte: $M$ (Nicolás Prividera, 2007).

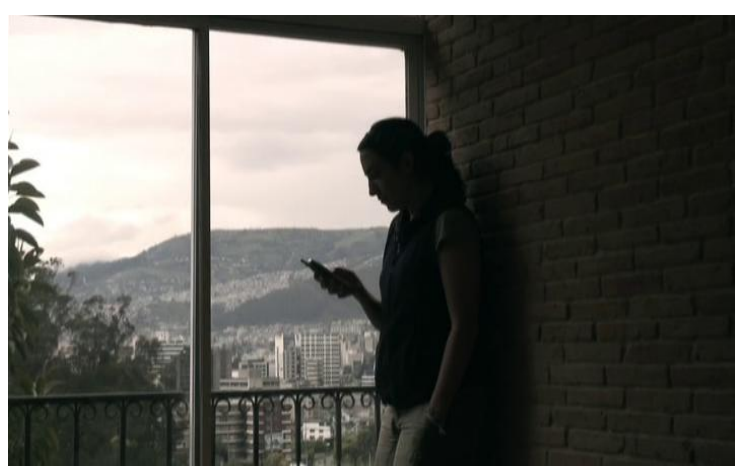

Figura 134 - Telefonema à procura de equipamento para rodar material antigo. Fonte: Abuelos (Carla Valencia Dávila, 2010).

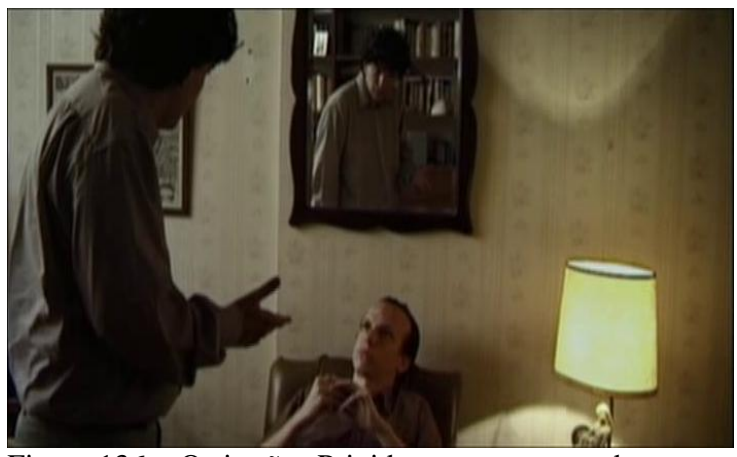

Figura 136 - Os irmãos Prividera conversam sobre o que se vê no filme, com reflexo de Nicolás no espelho. Fonte: $M$ (Nicolás Prividera, 2007).

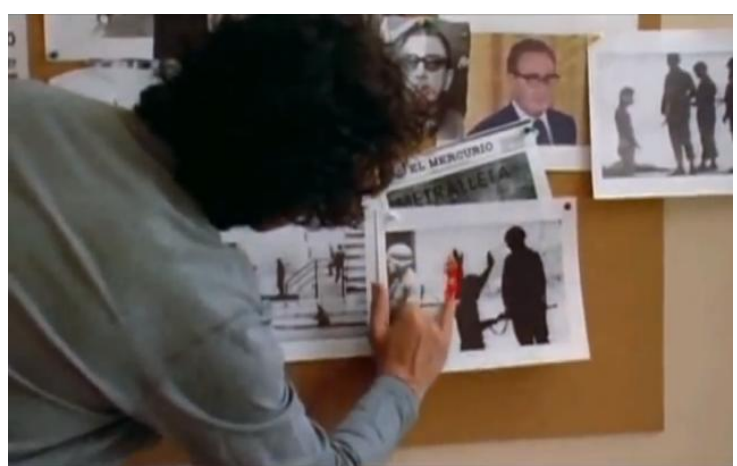

Figura 131 - Outro painel de montagem do quebracabeça da busca. Fonte: Héroes frágiles (Emilio Pacull, 2007).

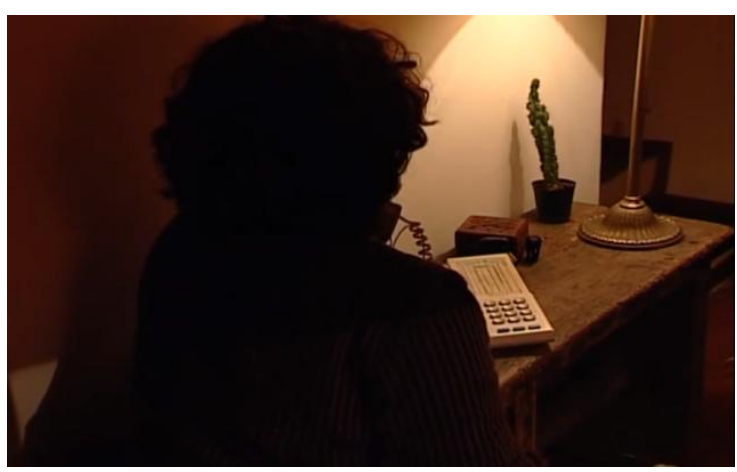

Figura 133 - Filha contata o torturador do pai pelo telefone. Fonte: Secretos de lucha (Maiana Bidegain, 2007).

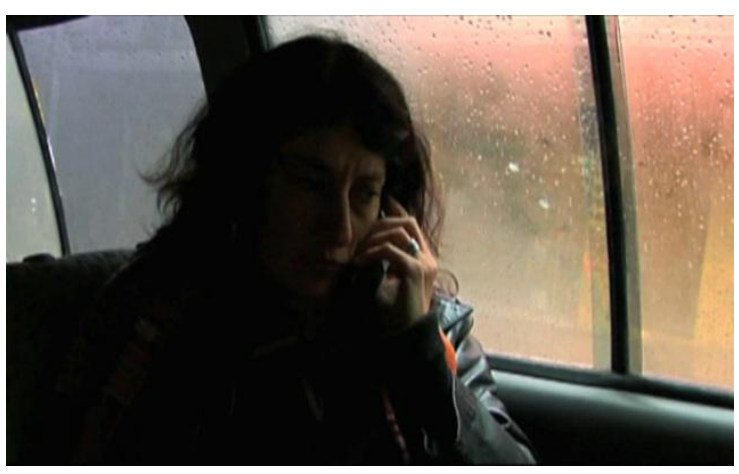

Figura 135 - Por telefone, testemunha desiste de dar entrevista. Fonte: Diário de uma busca (Flavia Castro, 2010).

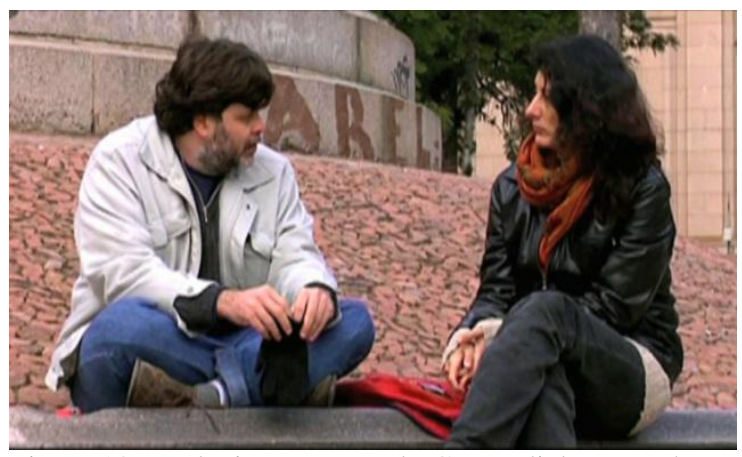

Figura 137 - Flavia e João Paulo Castro dialogam sobre o documentário e a memória do pai. Fonte: Diário de uma busca (Flavia Castro, 2010). 
A segunda expressão de um prisma anti-ilusionista mais consistente no documentário intergeracional diz respeito à reflexividade cinematográfica em sentido estrito. Ou seja, quando as marcas da enunciação estão mais diretamente calcadas na exposição do dispositivo técnico (AUMONT; MARIE, 2009, p. 254). Ao invés de maneirismos ou acidentes, nesses casos é possível identificar os acenos feitos à tradição do documentário reflexivo. São imagens que trazem para a obra acabada as etapas básicas do processo de produção cinematográfica, desde a fase de projeto, passando pela filmagem e pela montagem, até a própria exibição.

A etapa do projeto fílmico entra em tela, como se viu, nos momentos em que o condutor das indagações escreve ao computador, havendo aqui uma sobreposição com a reflexividade da busca. Nessa esfera, a passagem da leitura do fax do Incaa negando financiamento a Los rubios é o exemplo mais patente.

Por seu turno, são variadas as expressões que assinalam a fase das filmagens já como momento de construção da obra. Começando pela integração dos instantes pré e pós-cena no corte final do documentário. Além de Los rubios, Os dias com ele (Maria Clara Escobar, Brasil / Portugal, 2013) está todo atravessado por esse recurso, mostrando as conversas prévias entre pai e filha sobre o que a entrevista deveria abordar ou comentando o relato recém-concluído (cf. FELDMAN, 2014, p. 339). Também entram os ajustes dos equipamentos antes da fala ou sua desmontagem quando a entrevista supostamente teve fim (fig. 138), o pai perguntando se pode começar o depoimento, bem como a marcação da claquete improvisada pela diretora. Já outros títulos contêm ocorrências mais pontuais nessa chave. Em Abuelos (Carla Valencia Dávila, Equador / Chile, 2010), em uma visita à vala comum de Pisagua, no norte chileno, a tia pergunta à sobrinha-diretora se o microfone de lapela está ligado. Em El (im)posible olvido (Andrés Habegger, Argentina / Brasil / México, 2016), a rodagem da entrevista com a mãe do cineasta tem um rápido prólogo nessa chave: ela posa para a câmera, o filho fala com a mãe em tom descontraído, enquanto ajusta o equipamento. Antes, a sequência de abertura deste título já mostrava Habegger e sua equipe dentro de um carro rodando em vão à procura do lugar exato de uma fotografia do passado. Alguém da equipe alerta sobre as restrições de segurança para se filmar naquela área de aeroporto, a cinegrafista avisa que precisa de novas tomadas, em ângulos melhores.

Além de exibir aquilo que supostamente viria antes da "ação" e depois do "corta", a filmagem em si, enquanto está "valendo", também é desnudada. Primeiro, como já se viu, pela exposição de câmeras, microfones e refletores, enfim, dos bastidores da tomada. Um artifício distinto pode ser observado em El tiempo y la sangre (Alejandra Almirón, Argentina, 
2004): neste título, há planos nos quais a opacidade da filmagem vem das indicações digitais do visor da câmera mantidas na tela (fig. 139).

O labor na etapa de montagem também aparece em alguns desses documentários. A referência pode ser à técnica analógica, por exemplo, quando se vê, no plano de abertura de En memoria de los pájaros (Gabriela Golder, França / Argentina, 2000), o close-up de uma mão segurando uma película, os rolos sobre a mesa em segundo plano (fig. 140). Já a montagem digital se faz presente nos planos detalhe da tela do computador com o programa de edição em El tiempo y la sangre (Alejandra Almirón, Argentina, 2004) (fig. 68). Ou, em Argenmex: exiliados hijos (Violeta Burkart Noë e Analía Miller, Argentina, 2007), no qual, a certa altura, vê-se a equipe trabalhando na ilha de edição (fig. 141).

De fato, neste último título, o registro na ilha de edição precede a exibição do copião do material filmado para o grupo de filhos ex-exilados que havia se reunido durante o documentário. Os entrevistados se veem, reagem diante de sua própria figura na tela, e assim se conclui Argenmex: exiliados hijos: com a exibição da obra para seus protagonistas (fig. 142).

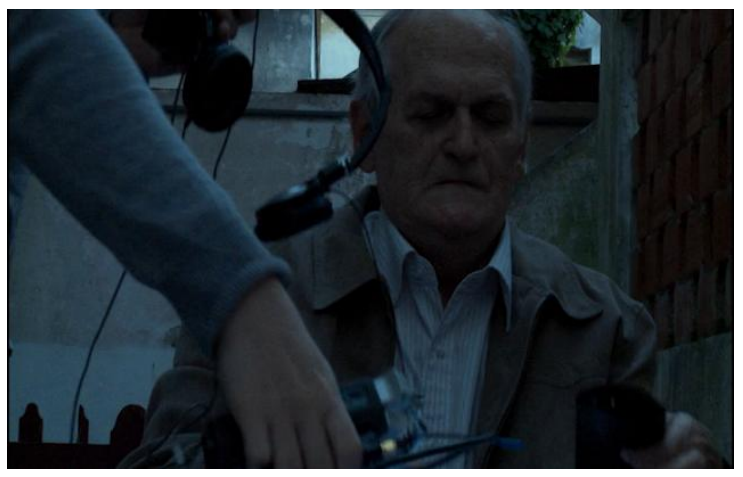

Figura 138 - Diretora desmonta equipamento após entrevista. Fonte: Os dias com ele (Maria Clara Escobar, 2013).

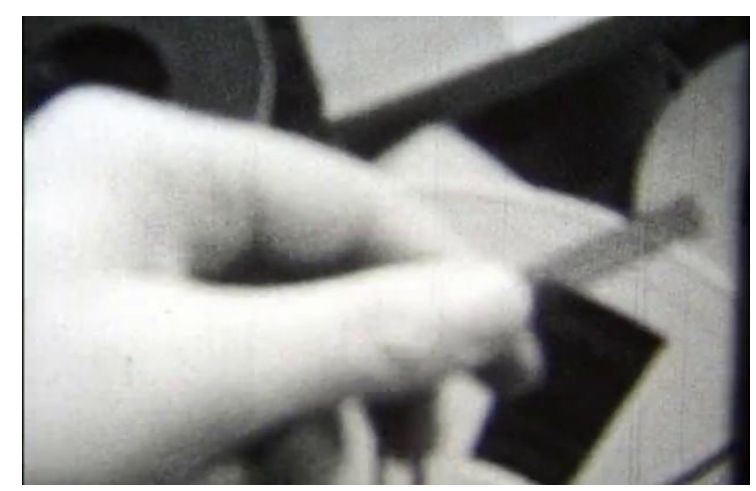

Figura 140 - Manipulação da película: Fonte: En memoria de los pájaros (Gabriela Golder, 2000).

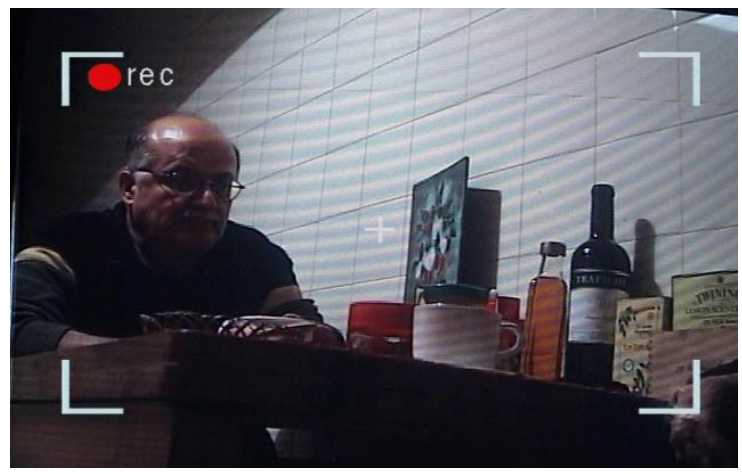

Figura 139 - Marcas do visor da câmera, enquadramento fora do eixo convencional. Fonte: El tiempo y la sangre (Alejandra Almirón, 2004).

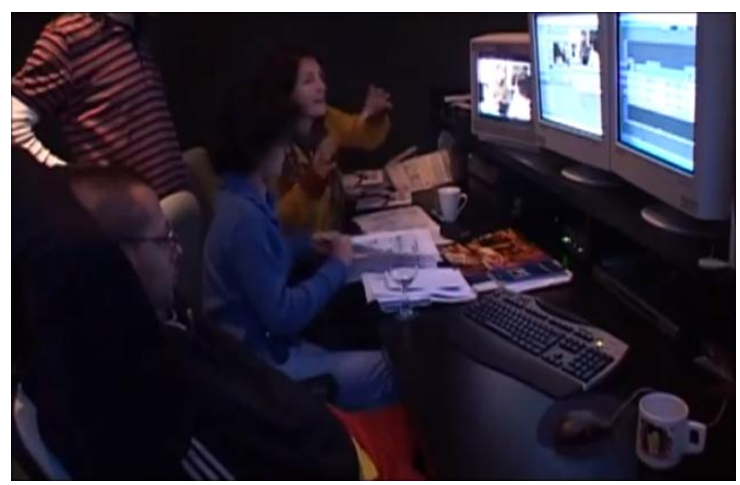

Figura 141 - Trabalho na ilha de edição. Fonte: Argenmex: exiliados hijos (Violeta Burkart Noë e Analía Miller, 2007). 


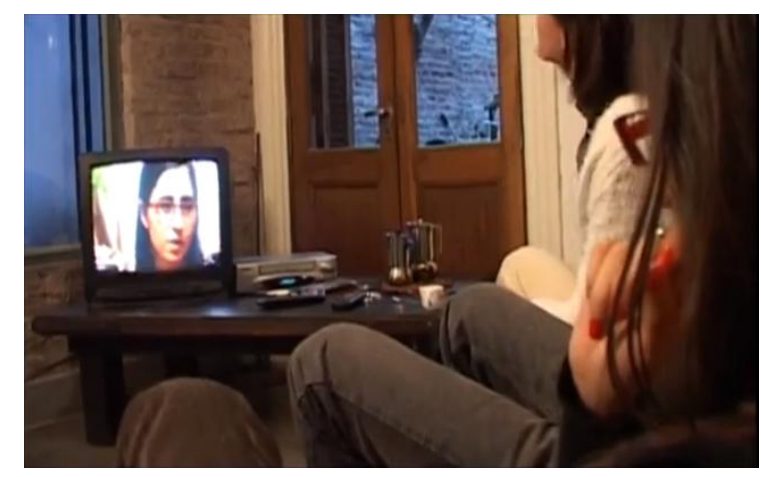

Figura 142 - Testemunhas assistem ao copião do documentário. Fonte: Argenmex: exiliados hijos (Violeta Burkart Noë e Analía Miller, 2007).

Essa descrição do repertório de artifícios reflexivos no documentário intergeracional deixa claro que seria um equívoco atribuir qualquer valor intrínseco a essas imagens. Em seu aspecto, os recursos até podem ser análogos, mas seu emprego em cada caso é passível de distintas interpretações: desde a certificação do registro até o desconstrucionismo radical; do uso banalizado até a repetição de determinados tópicos; do acidente à estruturação programática da obra. Dito de outro modo, a reflexividade visível nesses filmes pode ser lida em distintas chaves: uma delas é a opacidade efetiva, que logra suscitar no espectador uma consciência discursiva; outra, bem distinta, é a codificação de certas marcas da indeterminação.

\section{O visível}

\section{- A presença do documentarista diante da câmera}

A presença do diretor frente às câmeras de seu próprio documentário já ficou mencionada acima como uma das características marcantes da produção intergeracional - e contemporânea em geral. Naquele ponto, o que estava em pauta era a oscilação dos sentidos dessa presença: da interposição da mediação subjetiva à garantia do "pacto autobiográfico" (LEJEUNE, 1996). Depois da descrição das formas audiovisuais que se destacam no corpus (passando pelos usos da banda sonora e por configurações específicas das imagens), esta nova seção está dedicada àquilo que é enquadrado por essas formas (pessoas, lugares, objetos, referências). Dito de outro modo, até aqui a análise vinha esmiuçando o plano da expressão (o como se filma); doravante, trata-se de entrar no plano do conteúdo (quem e o que são filmados). Trata-se de distinguir o campo do visível nessa filmografia. Nas palavras de Pierre 
Sorlin (1985, p. 62, tradução nossa): “As imagens de um filme contêm o que é 'visível' para os contemporâneos ou o que, até então 'invisível', está se fazendo visível." No "panorama iconográfico" (SORLIN, 1985, p. 58) composto pelas imagens do documentarismo intergeracional, o corpo do cineasta surge em primeiro plano.

Essa constatação de saída deve ser matizada, porém. Pois os documentaristas se colocam diante da câmera de diferentes modos, e quanto a isso a noção de performance soa pertinente. De fato, "documentário performativo" é uma categoria mobilizada com frequência na bibliografia sobre o documentário contemporâneo, em geral remetendo a duas referências básicas. Em primeiro lugar, Bill Nichols (1994, 2010), que inclui o "modo performativo" em sua clássica grade de modos do documentário, elencando prós e contras (NICHOLS, 2010, p. 210-211). Na definição deste autor: "O documentário performativo sublinha a complexidade do nosso conhecimento do mundo ao enfatizar suas dimensões subjetiva e afetiva." (NICHOLS, 2010, p. 202, tradução nossa). Outro trabalho sempre lembrado nesse campo de estudos é o de Stella Bruzzi (2006), cuja abordagem, mais do que simplesmente categorizar, eleva a performance ao estatuto de corolário do novo documentarismo. Nesse sentido, ela escreve: "Recentemente, estão surgindo muitos mais documentários que partem do princípio da existência e da inevitável presença de seus realizadores, demonstrando diretamente a performatividade inerente do cinema de não ficção.” (BRUZZI, 2006, p. 198, tradução nossa).

Vale esclarecer que a análise empreendida nestas páginas não adota a noção de performance como matriz conceitual, e sim como ferramenta descritiva. ${ }^{83}$ Longe de etiquetar os filmes, como o faz Nichols, ou de ver na performance um valor intrínseco ao documentário contemporâneo, como o faz Bruzzi, trata-se aqui de delinear alguns dos matizes performáticos identificáveis quando os cineastas estão diante das câmeras. De refletir, enfim, sobre quais papéis eles assumem em seus documentários, entre a pessoa e o personagem.

Em sua reflexão sobre o documentário de busca, Jean-Claude Bernardet (2005, p. 148149) toca nesse ponto, sublinhando as ambiguidades e indistinções que cercam a autorrepresentação dos cineastas em seus filmes. Ele escreve: "Essas pessoas-personagens obedecem a uma construção dramática." E conclui: "Então, creio que podemos falar de uma vida pessoal que se molda conforme as regras de ficção. Ou de uma ficção que se alimenta diretamente da vida pessoal; eu diria uma ficção que coopta a vida pessoal.” (BERNARDET, 2005, p. 149).

\footnotetext{
${ }^{83}$ Entre os trabalhos que lidam com o documentário intergeracional pelo viés conceitual da performance, cf. BRECKENRIDGE, 2008; FRANÇA; MACHADO, 2014b; LAZZARA, 2009; MOLFETTA, 2011a, 2011 b.
} 
Pablo Piedras (2014, p. 89), examinando a figuração do corpo dos realizadores no documentário argentino recente, discorda frontalmente dessa indefinição sugerida por Bernardet. Piedras (2014, p. 90, tradução nossa, grifo do autor) escreve: "Considero que as diferentes políticas de exposição do corpo dos diretores [...] se conformam no eixo de dois polos: pessoa e personagem." De acordo com o autor, como pessoa, o cineasta na tela expõe a fragmentação do sujeito, seguindo uma vocação "de negar ou frustrar a possibilidade de construir sua subjetividade como identidade homogênea, estável e encerrada." Já como personagem, o realizador se impõe como ente uniforme, moldado por regras dramáticas clássicas: linearidade, evolução orgânica da narrativa, centralidade do ponto de vista do protagonista etc. (PIEDRAS, 2014, p. 90). De um lado, está o sujeito cindido (a pessoa); de outro, o sujeito coeso (o personagem).

As descrições propostas a seguir se colocam em um meio-termo entre a indiscernibilidade da "pessoa-personagem" sinalizada por Bernardet e a polarização entre pessoa versus personagem professada por Piedras. O termo latino persona soa mais adequado neste contexto de análise, condensando as contradições latentes nesse terreno. Diferente de "pessoa", palavra usada por Bernardet, e do vocábulo espanhol "persona", empregado por Piedras, a forma latina persona abarca em si tanto o sentido da imagem com que uma pessoa qualquer se apresenta em público quanto a ideia de um personagem ficcional em que um autor se encarna (HOUAISS, [2001]). Adotando esse prisma, a identificação das distintas personae presentes em alguns exemplos do documentarismo intergeracional mantém no horizonte a tensão entre as idiossincrasias dos cineastas (ou seja, aquilo que é peculiar ao indivíduo) e suas figurações em cena (o personagem construído). Dito de outro modo, trata-se de refletir sobre a persona que surge na performance.

$\mathrm{O}$ diretor como persona serena é o tipo mais comum na filmografia aqui estudada. $\mathrm{Na}$ maior parte dos casos, essa serenidade se manifesta já desde o tom da voz over. Na tela, o cineasta vai procedendo passo a passo, indo aos lugares de memória, encontrando testemunhas, revendo materiais de arquivo. O sujeito assume o papel de condutor da busca pessoal, sem ser exatamente o protagonista das cenas. Mas não se deve confundir essa placidez com frieza. Se, por um lado, em El (im)posible olvido (Andrés Habegger, Argentina / Brasil / México, 2016), o filho-diretor reage com um lacônico "É algo" aos esclarecimentos fornecidos pela Comissão Nacional da Verdade (CNV) brasileira sobre o desaparecimento de seu pai no Rio de Janeiro; ${ }^{84}$ por outro, Diário de uma busca (Flavia Castro, Brasil / França,

${ }^{84} \mathrm{O}$ caso do desaparecimento de Norberto Habegger está relatado em COMISSÃO NACIONAL DA VERDADE, 2014, p. 256-260. 
2010) e El edificio de los chilenos (Macarena Aguiló e Susana Foxley, Chile / Cuba / França / Bélgica, 2010) trazem passagens em que as filhas-diretoras são surpreendidas por picos de emotividade que irrompem em lágrimas discretas, desestabilizando por um instante a persona serena. Tampouco é o caso de tomar a placidez por apatia. Em Cuchillo de palo (Renate Costa, Paraguai / Espanha, 2010), a filha-diretora não sobe o tom em nenhum momento, mas nem por isso deixa de se contrapor aos preconceitos do pai. Nestes e em outros exemplos, a presença dos diretores e das diretoras frente às câmeras tende a ser contida, a subjetividade se resguarda em alguma medida, mas não chega a ser indevassável. O agente (ou ator) da busca está ali, sempre atuante. Sereno, embora nunca impassível, sem tentar atrair para si todas as atenções.

Já em Mi vida con Carlos, a postura assumida por Germán Berger-Hertz destoa dessa serenidade. Ele também tem o papel de condutor da busca, porém, sua figura ocupa mais espaço em cena, ao longo de todo o filme. E, sobretudo, seu choro frontal para a câmera, em primeiro plano, enquanto conclui a leitura da carta ao pai no meio do deserto, contrasta fortemente com as lágrimas constrangidas de Flavia Castro e Macarena Aguiló. Não se contendo, a persona de Berger-Hertz se projeta na tela, saturando as imagens com sua presença.

Isso é bem diferente do que acontece em Los rubios, no qual a persona estridente de Albertina Carri se espelha no corpo de Analía Couceyro. A atriz grita no meio do campo, a câmera gira inquieta, ouve-se o berro que, como sugerido no capítulo anterior, expressa a incapacidade da filha de elaborar a memória. Aqui o distanciamento em relação à serenidade segue outro rumo. Ao se duplicar na tela, Albertina Carri não se limita à super-representação da persona, como ocorre em Mi vida con Carlos. A saturação das imagens com a presença simultânea da filha-diretora e da atriz-filha gera a espessura da opacidade, problematizando a representação do passado, sobrepondo reflexivamente ficção e rememoração.

Em $M$ (Nicolás Prividera, Argentina, 2007), o realizador escolhe outro caminho. Não o da estridência, mas o da contundência encarnada na persona do investigador exasperado. $\mathrm{O}$ diretor caminha pelas ruas vestindo sua gabardina impermeável (o figurino icônico dos detetives no cinema). Em casa, seu corpo se duplica nos espelhos (fig. 136). Na sua busca, Prividera se impõe, levanta a voz, mas não para gritar uma incompreensão insuperável, como em Los rubios. Sua fala incisiva é bem articulada nas acusações que dirige contra a sociedade 
cúmplice da ditadura; contra os dirigentes montoneros que teriam usado os militantes da base; contra o presente que prefere o esquecimento. ${ }^{85}$

A desobediência é outra postura que se manifesta nessa filmografia de descendentes de militantes. Em Os dias com ele (Maria Clara Escobar, Brasil / Portugal, 2013), a diretora acaba assumindo a persona da filha desobediente, a qual se recusa a fazer o filme que o pai quer lhe impor. O desfecho da cena da cadeira vazia é o ápice dessa indisciplina: após a acalorada discussão em off, a filha assume o proscênio, senta-se na cadeira originalmente destinada ao pai e lê, contrariando a vontade dele, o documento da ditadura com seu mandado de prisão. No embate de gerações, Maria Clara Escobar se afirma frente às tentativas do pai de ditar o rumo de seu documentário.

Mas a desobediência pode se afastar do gesto de autoafirmação para se tornar uma afetação cênica. Tal é a sensação que fica diante da insistência de Marcia Tambutti, no seu Allende mi abuelo Allende (Marcia Tambutti, Chile / México, 2015), ao remexer em assuntos familiares espinhosos, tais como os desencontros do casal Allende ou o suicídio da tia "Tati", Beatriz Allende. No documentário, o arco dramático da neta-diretora depende dessa teimosia, a qual faz avançar a transformação da persona de Tambutti: daquela que decide enfrentar os tabus da família, fazendo as perguntas difíceis e enfrentando a resistência dos mais velhos, a alguém que, no final do percurso, reconhece que certos silêncios devem ser respeitados. Não deixa de haver um descompasso etário entre a performance rebelde da neta e a figura de Marcia Tambutti, nascida em 1971 e, portanto, já bem adulta quando rodou o documentário.

Se em Allende mi abuelo Allende a neta-diretora afeta uma postura obstinada, em Diario argentino (Lupe Pérez García, Argentina / Espanha, 2006), ao contrário, o papel assumido pela realizadora se constrói sob o signo da desorientação. A dislexia de Lupe Pérez García, a confusão que faz entre esquerda e direita, é o mote para sua atuação como persona desnorteada ao longo de todo o documentário: a filha se perde no aeroporto; não encontra seu armário no vestiário; não dá entrada nos trâmites burocráticos que motivaram seu retorno à Argentina; não sabe se quer voltar para a vida de imigrante na Espanha. Tudo isso é filmado com uma mise en scène apurada: enquadramentos compostos com esmero; justaposições de campo e contracampo, inserções de planos detalhe etc. (cf. PIEDRAS, 2014, p. 92). Em suma, o titubear da persona de Lupe Pérez García é muito bem produzido, a performance da falta de determinação se enquadra nas formas clássicas da linguagem cinematográfica.

\footnotetext{
${ }^{85}$ Para uma análise destas e outras questões em $M$, a partir da presença do corpo do cineasta, cf. AGUILAR, 2007a. Cf. também ESTEVE, 2009, p. 456-477, que analisa $M$ a partir do prisma da "pós-memória indignada" ("posmemoria airada"); e PIEDRAS, 2014, p. 218-220, que faz ressalvas quanto à ética da postura inquisitória de Prividera.
} 
Por último, vale mencionar uma modalidade menos evidente da presença dos documentaristas diante da câmera. Trata-se dos exemplos nos quais os cineastas surgem na tela furtivamente, em inserções breves, sem que sejam identificados, em aparições mais próximas de um cameo do que do protagonismo da busca. Papá Iván (María Inés Roqué, México / Argentina, 2000); En memoria de los pájaros (Gabriela Golder, França / Argentina, 2000); El tiempo y la sangre (Alejandra Almirón, Argentina, 2004): esses são casos nos quais, mais do que construir uma persona fílmica, a presença discreta das diretoras sinaliza para a figura do narrador do documentário. A entrada do corpo em cena aqui demarca sobretudo a instância enunciativa.

Da serenidade à super-representação; da estridência à exasperação; da desobediência à desorientação; chegando até a discrição análoga à de um cameo. Os tipos de personae identificáveis no documentarismo intergeracional dão uma ideia dos distintos significados que a performance dos cineastas pode assumir quando estes resolvem ir para a frente das câmeras. Nada garante que essa persona seja a expressão de um "eu" cindido, de um sujeito reflexivo, havendo os casos de patente construção dramática em função de determinadas formas narrativas.

\section{- Os entrevistados}

Reiterando a dinâmica entre o impulso da busca pessoal e o peso das convenções da entrevista, a presença das testemunhas é tão marcante quanto à dos próprios cineastas nas imagens do documentarismo intergeracional. Na seção dedicada aos recursos de linguagem cinematográfica, as formas de registro das entrevistas foram o objeto da análise. Agora, a atenção se volta para o quem é entrevistado.

Nesse quesito, Mi vida con Carlos é mais restrito. Com exceção da passagem pontual em que os ex-integrantes da Vicaría de la Solidaridad dão rápidos depoimentos, apenas os familiares do círculo mais próximo de Germán Berger-Hertz são entrevistados: sua mãe, Carmen Hertz; e seus dois tios, irmãos de seu pai, Ricardo e Eduardo Berger Guralnik. Os membros das famílias nucleares destes últimos (ou seja, tias, primas e primos de BergerHertz) também falam algo nas sequências de apresentação de ambos. Mas o foco das entrevistas, aquelas testemunhas que são ouvidas ao longo de todo o filme, sem dúvida são a mãe e os tios.

Essa não é a regra no corpus estendido, porém. Em geral, mesmo os documentários pautados pelo prisma familiar trazem um universo mais amplo de entrevistados. Ainda no 
círculo de intimidade do realizador, outros parentes próximos costumam ter uma presença mais substantiva. No fundo, revolvendo as histórias de militância de pais, tios ou avós, os cineastas acabam oferecendo ao mesmo tempo um retrato de sua família (ÁLVAREZ, 2005, p. 245-249; ORTEGA, 2010, p. 89-96), reunindo os integrantes das diferentes gerações: a primeira (pais e tios), a segunda (irmãos e primos) e, estendendo o horizonte para a geração seguinte, a terceira (os filhos dos filhos) - some-se aí uma geração extra nos casos dos filmes de netos de militantes. Com efeito, as tomadas incluindo as crianças dos diretores compõem outro tópico recorrente nessa filmografia, sugerindo ou mesmo explicitando a ideia de continuidade da cadeia intergeracional da memória. Em Mi vida con Carlos, as filhas de Germán Berger-Hertz são vistas em momentos específicos no decorrer de todo o documentário: seja no travelling em que ele leva a filha na garupa da bicicleta; seja nas filmagens domésticas contemporâneas em super-8 que sucedem este plano, conforme já observado; seja, ainda, na sequência em que o diretor faz um piquenique no campo com sua família nuclear (esposa e duas filhas pequenas). No piquenique, o pai conduz um jogo em que a filha mais velha deve encontrar um pirulito na floresta. Junto com o doce, a garota encontra um bilhete, logo lido pelo pai em voz alta. É uma mensagem de Carlos, o avô desaparecido, obviamente uma invenção dentro do jogo, explicando que o pirulito era um prêmio pelo bom comportamento da menina. A filha mais nova, então com menos de um ano, também recebe o seu suposto bilhete do avô, na mesma chave. Os recados naqueles papéis estabelecem uma conexão lúdica entre as crianças e o avô, cuja memória o documentário trata de resgatar. No fim da narrativa, a última tomada do filme arremata esse movimento: um zoom in vai fechando lentamente o enquadramento nos porta-retratos sobre a penteadeira da mãe, Carmen Hertz. Em primeiro plano, uma ao lado da outra, estão a fotografia de Carlos Berger (a mesma do início da história) e de Germán Berger-Hertz bebê, ambas em preto e branco (fig. 143). Em off, ouve-se a voz o diretor, que pergunta a uma das filhas: "Você sabe quem é ele?" A menina: “É Carlos." O cineasta insiste: "E quem é Carlos?” Ela: “Seu papai” (tradução nossa). Soa a música incidental ao fundo. Os sentidos ficam claros: o filho, que logo antes havia declarado em sua carta ao pai que podia, enfim, ter uma vida com Carlos, agora se certifica de que essa memória será transmitida para a neta. Diante dos olhos, os retratos de família.

Esse recurso de mostrar as crianças "filhas dos filhos" de vítimas das ditaduras como signo da ponte intergeracional se repete em outros títulos (cf. BOSSY; VERGARA, 2010, p. 47; DIGIOVANNI, 2013, p. 72; GOURSAT, 2015, p. 118-119; JOHANSSON; VERGARA, 2014, p. 103-104; LLANOS, 2014, p. 220). Em certas obras, é mais a presença no cotidiano, e 
não tanto o teor das falas dos pequenos, o que se coloca em tela, como em Diario argentino (Lupe Pérez García, Argentina / Espanha, 2006), El edificio de los chilenos (Macarena Aguiló e Susana Foxley, Chile / Cuba / França / Bélgica, 2010), Repare bem (Maria de Medeiros, Brasil / Portugal / Espanha, 2012) ou Tiempo suspendido (Natalia Bruschtein, México / Argentina, 2015). Já outros cineastas repetem o gesto de fazer questões aos próprios filhos ligadas à genealogia. No final de En algún lugar del cielo (Alejandra Carmona, Chile, 2003), a diretora, após a tomada em que está com a filha ao pé do mausoléu da família, pergunta à garota quem mora no céu, ao que ela responde: "Seu papai, que morreu." (tradução nossa). Andrés Habegger, em uma das filmagens domésticas rodadas em super-8 para El (im)posible olvido (Andrés Habegger, Argentina / Brasil / México, 2016), pede para a filha dizer o sobrenome da família. Nestes últimos casos, as filhas não são exatamente entrevistadas, mas elas entram no retrato familiar delineado pelo mosaico de entrevistas com os parentes dos diretores. A presença das crianças nesse retrato simboliza a afirmação da vida sobre a morte, uma espécie de vitória da linhagem sobre o desaparecimento forçado.

Em Secretos de lucha (Maiana Bidegain, Uruguai / França, 2007), a composição do retrato familiar chega a ser literal. Encerrando a narrativa, durante a festa da família em um quintal gramado, uma tomada em panorâmica registra o momento em que as gerações se perfilam para a grande foto dos Bidegain. Um novo plano, geral, mostra velhos, jovens e crianças ali juntos. Esta imagem é congelada, fica em preto e branco, é reenquadrada, a filmagem do documentário se converte em um grande retrato de família (fig. 144). Tendo sido apresentado aos parentes da diretora no correr das entrevistas individualizadas, o espectador pode enfim situá-los no panorama genealógico que conclui a história.

O reconhecimento da menina diante dos porta-retratos no plano final de Mi vida con Carlos. A grande foto de família construída por Maiana Bidegain no desfecho de Secretos de lucha. Nestes casos, fica indicado que a cadeia da transmissão da memória segue seu curso entre as gerações. Os mais velhos, aqueles que viveram de perto os eventos, são as testemunhas que, no papel de entrevistados, legam as recordações que atravessam as linhagens. Entretanto, como se viu no capítulo anterior, a transmissão intergeracional nem sempre tem essas feições plácidas. Um retrato de família costuma ocultar tensões latentes. Michael Renov (2004a, p. 218, tradução nossa) já chamou a atenção para as “co(i)mplicações" em jogo quando se trata de voltar a câmera para o seio doméstico. Isto é, para o fato de que, em geral, os documentários que enfocam o círculo íntimo dos cineastas trazem consigo a "complexidade e a interpenetração das identidades de sujeito e objeto". Nesse sentido, mais uma vez, Los rubios é eloquente. Vale recapitular por esse novo ângulo 
alguns lances do documentário de Albertina Carri: a certa altura, a voz over da atriz informa que Paula, uma das irmãs da cineasta, recusa-se a falar perante a câmera. Já Andrea, a outra irmã, aceita gravar a entrevista, mas considera que só diz coisas interessantes quando a câmera está desligada. A voz over continua: "Gostaria de filmar meu sobrinho de seis anos dizendo que, quando souber quem matou os pais de sua mãe, vai matá-los, mas minha irmã não deixa.” (tradução nossa). A família própria não dá entrevistas, a exposição da terceira geração é vetada. O que surge, no final de Los rubios, é um retrato forjado, a parentela postiça composta pela equipe de filmagem vestindo perucas loiras. De costas para a câmera, eles se afastam no campo aberto, "posando" para um antirretrato de família (fig. 145). Toca-se aqui novamente na questão dos vetores intrincados da memória intergeracional: se há filmes que se empenham em dar a ver esse movimento de transmissão entre as linhagens; outros, por sua vez, desfiguram esses laços em retratos que indicam outras direções.

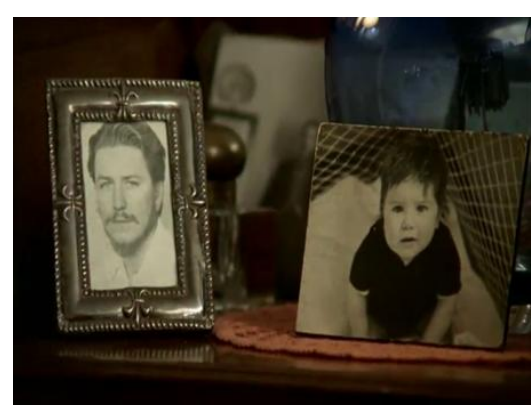

Figura $143-$ Porta-retratos e transmissão da memória. Fonte: $M i$ vida con Carlos (Germán BergerHertz, 2009).

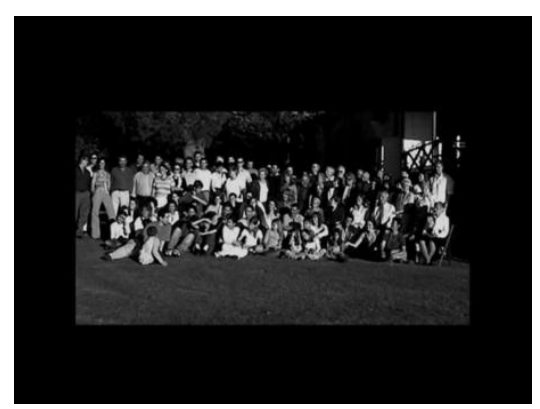

Figura 144 - A montagem do retrato de família. Fonte: Secretos de lucha (Maiana Bidegain, 2007).

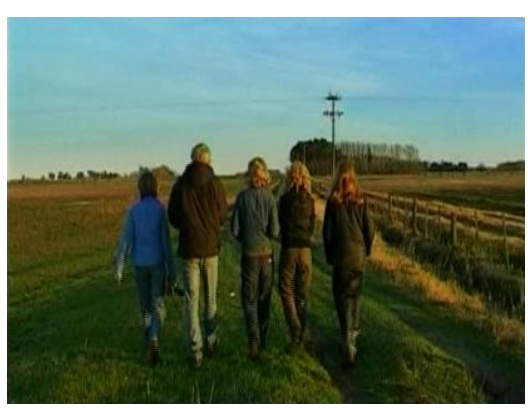

Figura 145 - Antirretrato da família postiça. Fonte: Los rubios (Albertina Carri, 2003).

Pois é fato que o universo de entrevistados no documentário intergeracional não se restringe ao âmbito familiar. Mesmo o círculo próximo dos cineastas às vezes inclui testemunhos de amigos e colegas de infância ou adolescência: os companheiros de geração no exílio de En algún lugar del cielo (Alejandra Carmona, Chile, 2003); a amiga que ficou no país em Diario argentino (Lupe Pérez García, Argentina / Espanha, 2006); a turma de escola no exílio cubano da diretora em El telón de azúcar (Camila Guzmán Urzúa, França / Cuba / Espanha, 2006); também o colega de escola durante o exílio no México do realizador em El (im)posible olvido (Andrés Habegger, Argentina / Brasil / México, 2016). Nessa esfera, El edificio de los chilenos (Macarena Aguiló e Susana Foxley, Chile / Cuba / França / Bélgica, 2010) faz a ponte entre o retrato de família e o retrato geracional, reunindo os depoimentos do grupo de filhos de militantes que compartilharam a experiência do "Proyecto Hogares" com a diretora Macarena Aguiló. 
De fato, são muitos os títulos que se afastam dos laços de intimidade para compor um retrato geracional mais amplo. Nesses exemplos, os filhos entrevistados falam menos como membros de uma família em particular e mais como integrantes de uma coletividade. O lugar genealógico aqui se reveste de um estatuto social: filhos de desaparecidos (ou de exilados, torturados, assassinados). A experiência compartilhada traz em seu núcleo o vínculo consanguíneo, mas acaba extrapolando-o. ${ }^{86} 15$ filhos (Maria Oliveira e Marta Nehring, Brasil, 1996); (h) Historias cotidianas (Andrés Habegger, Argentina, 2000); Panzas (Laura Bondarevsky, Argentina, 2000); Generación golpe (Fabián Agosta e Lisandro Costa, Argentina, 2001); H.I.J.O.S.: El alma en dos (Carmen Guarini e Marcelo Céspedes, Argentina, 2002); Nietos (identidad y memoria) (Benjamín Ávila, Argentina, 2004); Nacimos en su lucha, viven en la nuestra: 10 años de H.I.J.O.S. La Plata (Camilo Cagni, Pablo Balut, Pablo Roesler e Juan Aíub, Argentina, 2006); HIJOS Uruguay (Lucas Silva e Víctor Burgos Barreiro, Uruguai, 2006); Argenmex: exiliados hijos (Violeta Burkart Noë e Analía Miller, Argentina, 2007); El memorial (Andrés Brignardello Valdivia, Chile, 2009); Tus padres volverán (Pablo Martínez Pessi, Uruguai, 2015): todos esses são títulos que podem ser interpretados como retratos geracionais no corpus aqui analisado. A forma cinematográfica, nesses exemplos, afasta-se da busca pessoal e vincula-se mais diretamente à composição do coral de vozes dos filhos entrevistados.

Avós e mães também falam desde seu papel social. É esse o caso quando dão entrevistas a respeito de sua militância em prol dos direitos humanos e da busca pela restituição da identidade das crianças apropriadas pelos repressores. Esse lugar de enunciação ocorre em alguns títulos, ficando mais evidente em Nietos (identidad y memoria), documentário cuja produção está diretamente ligada à agrupação Abuelas de Plaza de Mayo, tendo sido dirigido por um filho de desaparecidos, Benjamín Ávila - que anos depois realizaria a ficção Infancia clandestina (Benjamín Ávila, Argentina / Espanha / Brasil, 2011).

Para além da esfera dos laços consanguíneos, sem dúvida os ex-companheiros de militância das gerações precedentes são as figuras mais visíveis entre os entrevistados. Nesse

\footnotetext{
${ }^{86}$ Quanto a isso, vale relembrar que Marianne Hirsch (2008, p. 114-115, tradução nossa) estabelece uma distinção entre "pós-memória familiar" e "pós-memória afiliativa". Entre uma e outra haveria a "diferença entre uma identificação intergeracional vertical de filho e pais ocorrendo no interior da família e a identificação horizontal intrageracional, que torna essa posição de filho mais amplamente disponível para outros contemporâneos". Na bibliografia dedicada ao fenômeno no Cone Sul, em alguns casos é possível identificar essa tendência de ampliar a abordagem, incluindo a produção de jovens que não necessariamente tiveram familiares atingidos pela violência das ditaduras. Nessa chave, cf. ROS, 2012, trabalho no qual o uso da noção de "geração pós-ditadura" já opera esse alargamento da perspectiva; e SERPENTE, 2013, p. 95-109, que, problematizando as formulações de Hirsch, propõe a extensão da noção de "pós-memória" de modo a dar conta de outras vozes da segunda geração.
} 
grupo, a proximidade com os parentes dos cineastas se manifesta nas relações de amizade e cumplicidade no contexto do engajamento passado. Essas vozes trazem à luz o outro lado da história, o avesso do retrato de família, uma imagem das ações de pais, tios e avós no círculo da clandestinidade.

Já em outro nível, mais distanciado, estão os entrevistados que poderiam ser categorizados como "testemunhas genéricas" dessas histórias: velhos amigos dos familiares, mas também conhecidos, ex-colegas de trabalho, vizinhos etc. Em geral, o papel desses entrevistados é coadjuvante, servindo para esclarecer flashes do retrato do parente em foco. Novamente, a exceção gritante é Los rubios, no qual a senhora vizinha do aparelho onde viviam os Carri deixa de ser uma entrevistada qualquer quando revela ter protagonizado a indicação do esconderijo dos "loiros" para os agentes da operação repressiva que enfim os capturou.

Os depoimentos de especialistas não estão ausentes da produção intergeracional aqui estudada. Essas figuras clássicas do documentário de entrevista são ouvidas em alguns títulos, incluindo procuradores de justiça, antropólogos forenses, historiadores, sociólogos etc. O destaque nesse campo vai para o depoimento do médico legista Francisco Benfica, em Diário de uma busca (Flavia Castro, Brasil / França, 2010), alguém que, com seu discurso competente, desmonta a versão do suicídio de Celso Castro, interpretando com argúcia os detalhes do laudo oficial sobre a causa da morte do pai da realizadora. Em busca de Iara (Flavio Frederico, Brasil, 2013) traz uma passagem similar, quando a sobrinha Mariana Pamplona também vê a versão do suicídio da tia ser desmentida pelo perito do Instituto de Criminalística, inclusive com um teste de balística realizado em frente às câmeras.

Mais raras, mas não por isso inexpressivas, são as entrevistas com perpetradores. Em Diário de uma busca, Flavia Castro se encontra com os policiais envolvidos na operação que resultou na morte de seu pai. Sem revelar que era filha de Celso Castro, a realizadora fica frente a frente com aqueles homens, perguntando detalhes sobre o episódio e ouvindo versões montadas e respostas evasivas. No caso de Secretos de lucha (Maiana Bidegain, Uruguai / França, 2007), a filha-diretora não chega a se encontrar com o militar que torturou seu pai. Ela faz um telefonema para ele (fig. 133), apresenta-se com nome e sobrenome, quer entrevistá-lo para o documentário. Do outro lado da linha, o senhor se dá conta de que está falando com a parente de alguém que torturou e diz que não está disposto a aparecer em nenhum tipo de documentário. Em suma, quer se manter na invisibilidade. Mas não deixa de perguntar se Jean Paul Bidegain está vivo, diz que o conhece há muitos anos, desde antes de haver se tornado militar, que se alegra por ele estar bem, manda-lhe uma saudação, alegando que aquele 
passado é uma etapa "superada", que, "lamentavelmente", alguns caminhos se distanciaram, ele só “cumpria ordens". Por fim, despedindo-se educadamente, não deixa de reiterar a saudação àquele que torturou. Como se quisesse reverter seu papel nesse filme, esquivando-se do lugar do perpetrador, exato antípoda do afeto dos círculos próximos.

De outra natureza são os títulos nos quais é o familiar do cineasta quem possui conexões com as forças repressivas. Em 70 y Pico (Mariano Corbacho, Argentina, 2016), o neto tem uma conversa com o avô, Héctor Corbacho, "Pico" para os íntimos, figura que foi simultaneamente decano da Faculdade de Arquitetura da UBA e instrutor na Esma em plena ditadura. Em uma espécie de montagem paralela, Mariano Corbacho entrevista também professores e integrantes do movimento estudantil perseguidos durante a gestão de seu avô. No caso de El pacto de Adriana (Lissette Orozco, Chile, 2017), a sobrinha se põe às voltas com o papel da tia, Adriana Rivas, na Dirección de Inteligencia Nacional (Dina), onde trabalhou durante a ditadura de Pinochet. A tia nega veementemente as acusações, tenta manipular o documentário de modo a transformá-lo em uma peça de defesa, e o voto de confiança inicialmente dado pela sobrinha cineasta vai se esfacelando no turbilhão dessas investidas da acusada. Eis aí uma faceta cuja visibilidade começa a despontar no documentarismo intergeracional: as responsabilidades civis nos regimes autoritários da região.

Tal elenco das pessoas entrevistadas dá uma ideia dos atores sociais que se fazem presentes nessa produção intergeracional: os parentes e amigos do círculo próximo dos cineastas, mas também os familiares de vítimas como coletividade na esfera pública; os exmilitantes, aqueles que tiveram um envolvimento direto nos eventos, e ainda as testemunhas coadjuvantes; os especialistas, figura tão comum no documentário de entrevista, mas também os perpetradores, que prefeririam se manter na invisibilidade. Surge daí um panorama humano complexo que ultrapassa a moldura do retrato de família.

\section{- Os lugares}

O primeiro capítulo se debruçou sobre um dos aspectos da espacialidade no documentário intergeracional. Àquela altura, a análise partia de Diário de uma busca para refletir sobre os diversos caminhos do transnacionalismo nessa filmografia. Neste ponto, cabe ressaltar que a dinâmica transnacional manifesta-se de modo consistente em uma parcela significativa dos títulos do corpus, ao longo de todo o recorte temporal: desde Che vo cachai (Laura Bondarevsky, Argentina, 2002), que mostra a militância dos hijos na Argentina, no 
Uruguai e no Chile; ou H.I.J.O.S.: El alma en dos (Carmen Guarini e Marcelo Céspedes, Argentina, 2002), no qual a integrante do braço da agrupação em Paris vai ao encontro de seus companheiros em Buenos Aires; passando por Mi vida con Carlos, no contexto do exílio de Germán Berger-Hertz junto com sua mãe; até El (im)posible olvido (Andrés Habegger, Argentina / Brasil / México, 2016), com as idas e vindas do filho argentino exilado no México em sua busca por superar o esquecimento do pai desaparecido no Rio de Janeiro. Isso para citar apenas alguns exemplos cronologicamente distantes e com estilísticas diversas. Como ficou apontado, as histórias de resistência, repressão e exílio narradas nos filmes, em si, já atravessavam fronteiras. A pregnância do transnacionalismo nas imagens do documentário intergeracional, com distintos matizes formais, em grande medida deriva desse fato de base.

Também naquele capítulo, a análise complementava esse mapa da memória com a atenção às tomadas realizadas em lugares específicos: os endereços da experiência dos Castro, bem como os espaços com significados mais coletivos. Nessa linha, há que se acrescentar que os monumentos às vítimas das ditaduras são vistos com frequência no documentarismo aqui estudado, dando materialidade à dimensão pública das rememorações privadas. El memorial (Andrés Brignardello Valdivia, Chile, 2009), inclusive, tem como eixo narrativo o processo de construção do Monumento aos Presos, Desaparecidos e Executados Políticos da Região de Valparaíso, inaugurado em 2008. Os entrevistados no documentário são os filhos das vítimas cujos nomes estão ali inscritos. Já $M$ (Nicolás Prividera, Argentina, 2007) tem como desfecho a cerimônia na qual os filhos descerram a placa que, enfim, passava a incluir o nome de Marta Sierra no marco em homenagem aos desaparecidos do instituto onde ela trabalhava. Outros títulos mostram visitas a monumentos com as listas que incluem o nome do familiar atingido, tal como ocorre em Mi vida con Carlos, quando Carmen Hertz leva flores ao memorial dos desaparecidos e executados da ditadura no Cemitério Geral de Santiago (fig. 146-149).

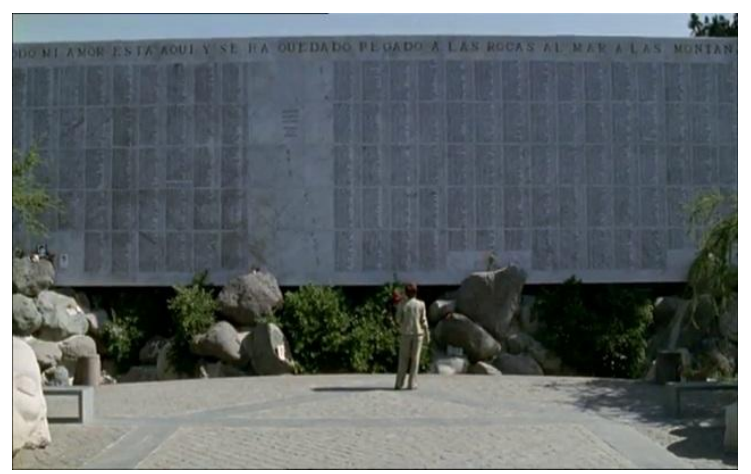

Figura 146 - Carmen Hertz diante do Memorial do Preso Desaparecido e do Executado Político, em Santiago. Fonte: Mi vida con Carlos (Germán Berger-Hertz, 2009).

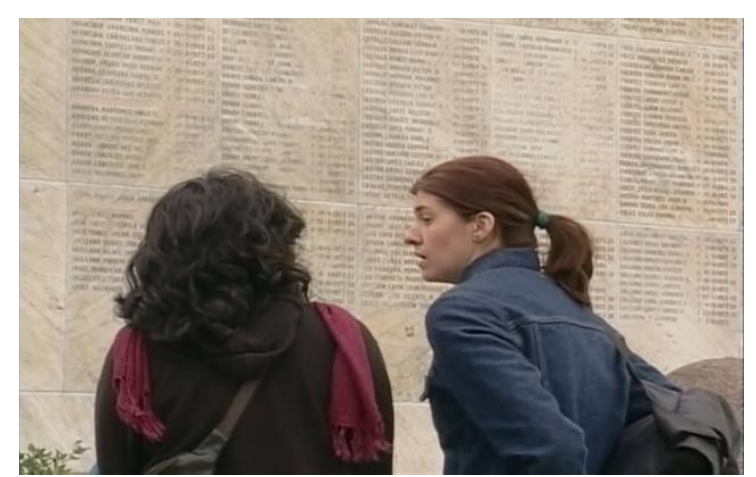

Figura 147 - As filhas de Uruguai e Chile se encontram e visitam o memorial. Fonte: Che vo cachai (Laura Bondarevsky, 2002). 


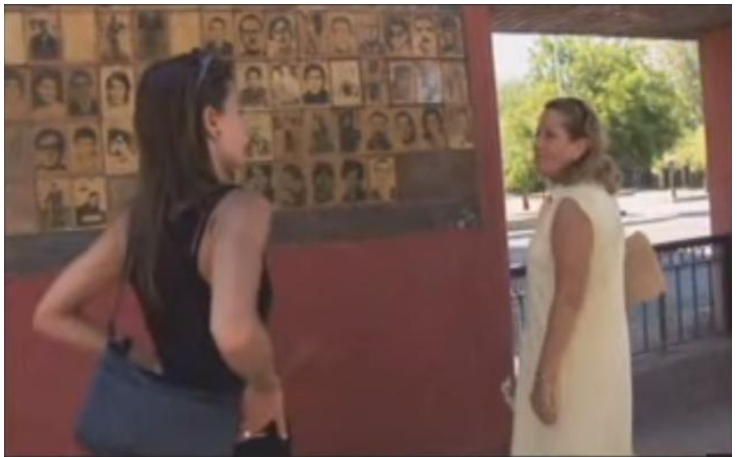

Figura 148 - A cineasta e a mãe diante do Muro da Memória, em Santiago. Fonte: Reinalda del Carmen, mi mamá y yo (Lorena Giachino Torréns, 2006).

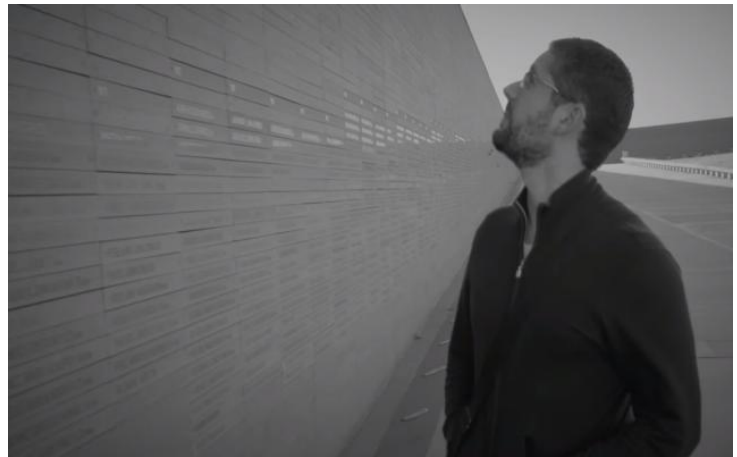

Figura 149 - Valentín Enseñat no Parque da Memória, em Buenos Aires. Fonte: Todos somos hijos (Esteban Barja e Carlos Conti, 2015).

As visitas a antigos centros de detenção e tortura transformados em espaços de memória (cf. VIOLI, 2014) aproximam-se desses exemplos. Uma cartografia da repressão vai surgindo nessas imagens: o lugar onde funcionava o "Club Atlético", em Buenos Aires, visto em Encontrando a Víctor (Natalia Bruschtein, México / Argentina, 2004); a Mansión Seré (Jorge Bianchini, Argentina, 2006), outro centro portenho, que dá título ao referido documentário; e, sem dúvida, a Escuela de Mecánica de la Armada (Esma), lugar onde Victoria Donda nasceu e ao qual retornava pela primeira vez, no contexto da rodagem de Victoria (Adrián Jaime, Argentina, 2008); além do neto que vai à Esma onde atuava o avô, em 70 y Pico (Mariano Corbacho, Argentina, 2016). Por sua vez, as idas a lugares onde se perpetraram violações durante as ditaduras em Los rubios (Albertina Carri, Argentina, 2003) e Orestes (Rodrigo Siqueira, Brasil, 2015) escancaram uma faceta inquietante das dinâmicas espaciais da memória. Nestes casos, tanto o centro clandestino conhecido como "Sheraton", na Grande Buenos Aires, quanto a sede da Operação Bandeirante (Oban), na rua Tutoia, em São Paulo, seguiam funcionando normalmente como estruturas do aparato policial.

Por fim, algumas paisagens podem assumir ainda a função de metáforas topográficas. Em Mi vida con Carlos, as tomadas no deserto no norte chileno fazem referência direta ao lugar do desaparecimento de Carlos Berger e outras vítimas do regime daquele país. O filme chega a incluir planos de membros da Agrupación de Familiares de Ejecutados y Detenidos Desaparecidos Políticos de Calama revolvendo o solo árido em busca dos restos mortais de seus entes queridos. As vistas do rio da Prata se revestem de sentidos análogos, remetendo às vítimas atiradas em suas águas pelos voos da morte. A primeira imagem de $M$ (Nicolás Prividera, Argentina, 2007) é um plano fixo daquele rio filmado através de uma cerca de arame. Na banda sonora, ouve-se o ruído de um avião que passa. Já a Pampa argentina é o lugar do isolamento do exílio interno em Los rubios. Em suma, toda uma geografia da memória, literal ou simbólica, é dada a ver no documentarismo intergeracional. 


\section{- Intertextualidades}

Além de pessoas e lugares, o espectro do visível no documentarismo intergeracional abarca ainda remissões a outras obras. Os títulos dirigidos por Albertina Carri se destacam nesse quesito. Cuatreros (Albertina Carri, Argentina, 2016) é um ensaio fílmico originado de uma videoinstalação de Albertina Carri (Investigación del cuatrerismo, montada no Parque de la Memoria de Buenos Aires em 2015). Como já mencionado, seu ponto de partida é o livro Isidro Velázquez: formas prerrevolucionarias de la violencia, de autoria do pai da realizadora, Roberto Carri (2011). Esse ensaio sociológico, por sua vez, anos antes já havia inspirado o filme Los Velázquez, rodado entre 1971 e 1972 e jamais finalizado, com direção de Pablo Szir, também desaparecido político. O roteiro dessa adaptação cinematográfica, lido em voz over por Albertina Carri em Cuatreros, inicia-se com cenas radicalmente reflexivas. Algo que, afinal, surpreende a cineasta pela semelhança com seu próprio filme, Los rubios. A análise de Los rubios proposta no segundo capítulo tentou dar conta dos possíveis sentidos da miríade de citações presentes nessa obra. Da cenografia às frases dos intertítulos, tudo ali compunha um circuito intrincado de referências culturais. Gonzalo Aguilar (2007a, p. 171) já notara alguns dos diálogos de $M$ (Nicolás Prividera, Argentina, 2007) com outros documentários argentinos contemporâneos. De fato, o espectador mais atento notará que, entre as reproduções e os cartazes de filmes afixados na estante de Nicolás Prividera, há inclusive um panfleto de Los rubios, um pequeno detalhe em segundo plano (fig. 150).

Mas é claro que existem os casos de citações audiovisuais bem mais explícitas. Variam, porém, as funções simbólicas assumidas por essas inserções de imagens de obras alheias. Em El eco de las canciones (Antonia Rossi, Chile, 2010), não se trata tanto de citar, mas sobretudo de justapor uma constelação de imagens de origens e bitolas múltiplas (filmagens domésticas e tomadas do arquivo coletivo, ao lado de desenhos animados e anúncios publicitários) no universo de associações acerca da experiência do exílio. As inserções de trechos de ficções e animações em El tiempo y la sangre (Alejandra Almirón, Argentina, 2004) estão próximos desse viés mais alusivo.

Em outros exemplos, as referências são mais diretas, inclusive com vínculos palpáveis com as histórias narradas. Venían a buscarme (Álvaro de la Barra, Chile, 2016) traz imagens de Queridos compañeros (Pablo de la Barra, Chile / Venezuela, 1977), ficção dirigida pelo tio do documentarista, que o criara no exílio após o assassinato de seus pais. Repare bem (Maria de Medeiros, Brasil / Portugal / Espanha, 2012) inicia-se com uma sequência de Una giornata 
particolare (Ettore Escola, Itália / Canadá, 1977) filmada nos Palazzi Federici, um grande conjunto de blocos residenciais em Roma, dos anos 1930, onde a família comprou um apartamento com a indenização recebida em reparação pela morte de Eduardo Collen Leite, o “Bacuri”. Já em Marighella (Isa Grinspum Ferraz, Brasil, 2011), as inserções de obras de ficção entram na torrente ilustrativa desse documentário: mal uma testemunha faz alusão a alguma ideia, surgem as imagens que lhe darão visibilidade.

As intertextualidades não se limitam à cultura audiovisual. Outras artes entram no circuito de referências do corpus, incluindo os quadrinhos, por exemplo, como ocorre em $(h)$ Historias cotidianas (Andrés Habegger, Argentina, 2000). Nesse caso, um dos filhos entrevistados, Martín Mórtola Oesterheld - cujos pais e o avô, o quadrinista Héctor Germán Oesterheld, são desaparecidos -, faz menção a Pétition: à la recherche d'Osterheld et de tant d'autres!, editado pela Anistia Internacional em 1986. Surge na tela uma inserção com páginas da novela gráfica.

Para além das referências pontuais, chama atenção nessa filmografia as citações do ensaio fotográfico de Lucila Quieto chamado Arqueología de la ausencia. Exposta entre 2000 e 2001 em Buenos Aires e outras cidades europeias (AMADO, 2009, p. 173), a série tem um dispositivo tecnicamente simples, mas simbolicamente potente: fotos antigas dos pais desaparecidos são projetadas ampliadas em uma parede; os filhos se postam diante da projeção, uma nova foto é tirada, em preto e branco. Como se, com tal gesto, a segunda geração pudesse entrar naquele registro passado. Ou como se fosse possível estar no presente em companhia dos pais ausentes. Em H.I.J.O.S.: El alma en dos (Carmen Guarini e Marcelo Céspedes, Argentina, 2002), ocorre mais do que uma citação do trabalho de Lucila Quieto. A fotógrafa argentina, à época militante da agrupação H.I.J.O.S., é uma das protagonistas nesse filme: ela dá depoimentos sobre sua experiência ao longo de todo o documentário; é vista organizando "escrachos"; explica o projeto de Arqueología de la ausencia; revela e manuseia as fotografias do ensaio diante da câmera de Guarini e Céspedes; suas fotos entram como inserções no documentário (fig. 151). Nos casos de Encontrando a Víctor (Natalia Bruschtein, México / Argentina, 2004) e $M$ (Nicolás Prividera, Argentina, 2007), os cineastas reproduzem o dispositivo do ensaio de Quieto (fig. 152-153) (cf. AMADO, 2009, p. 173-176; ESTEVE, 2009, p. 228-232; DE HAUWERE, 2012; MAUAD, 2017). 


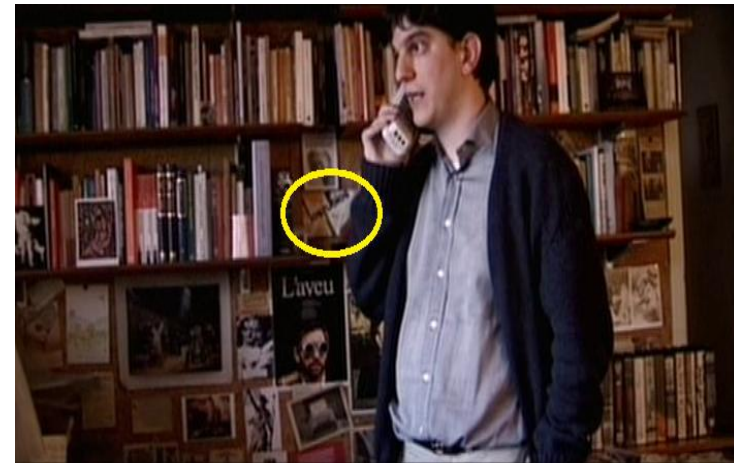

Figura 150 - Detalhe de panfleto de Los rubios afixado em segundo plano. Fonte: $M$ (Nicolás Prividera, 2007).

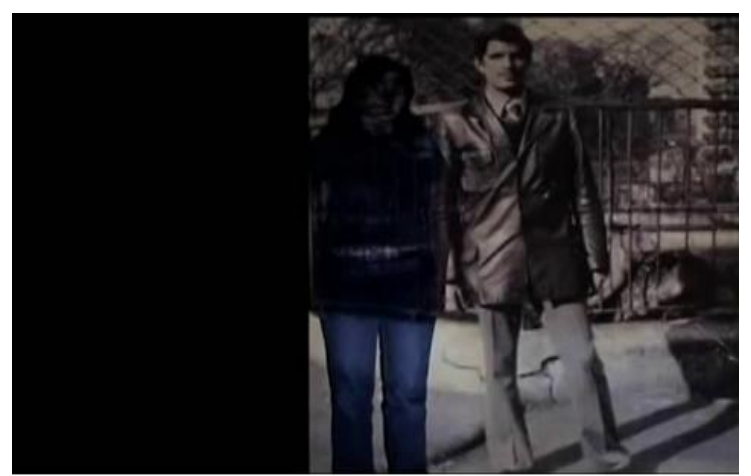

Figura 152 - Bruschtein reproduz o dispositivo de Lucila Quieto. Fonte: Encontrando a Víctor (Natalia Bruschtein, 2004).

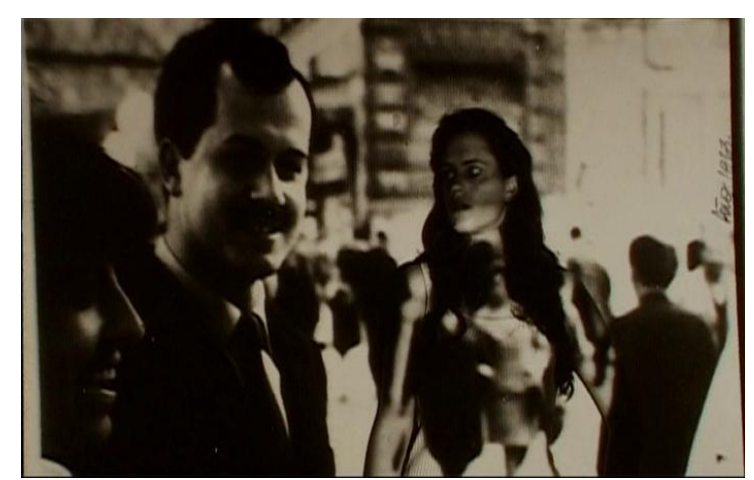

Figura 151 - Inserção de fotografia de Lucila Quieto, também personagem do documentário. Fonte: H.I.J.O.S.: El alma en dos (Carmen Guarini e Marcelo Céspedes, 2002).

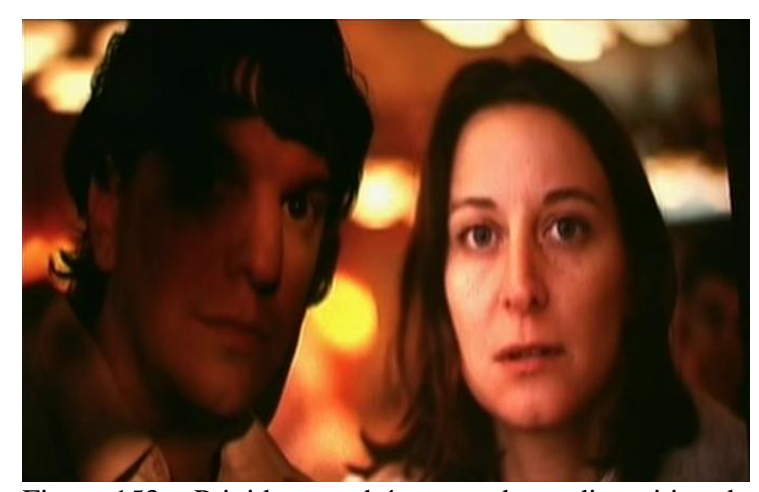

Figura 153 - Prividera também reproduz o dispositivo de Lucila Quieto. Fonte: $M$ (Nicolás Prividera, 2007).

Analisando Arqueología de la ausencia, Ana Amado (2009, p. 174, tradução nossa) toca em um ponto central neste debate: “A experimentação visual propõe uma cerimônia de encontro para refazer fotos impossíveis de um álbum familiar desfeito há 25 anos [...]”. Das constelações expandidas de referências até a reconstrução da linhagem pela fotografia, as intertextualidades visíveis no documentário intergeracional, mais uma vez, apontam para múltiplas direções. Uma delas é o álbum de família.

\section{Materiais de arquivo}

\section{- O baú da família}

$\mathrm{O}$ arquivo privado dos cineastas ou dos entrevistados tem um lugar preponderante no documentarismo intergeracional. Esse dado de saída não diz muito além daquilo que se esperaria de uma cinematografia focada nas experiências familiares. Entretanto, a observação 
atenta, primeiro, dos atos de revisão desse arquivo e, segundo, dos materiais específicos que o compõem revela facetas bem menos óbvias nesse terreno.

Com efeito, um problema inicial que deve ser apontado é justamente a naturalização do impulso de revisar os arquivos privados nesses filmes. A abertura do "baú" da família um baú literal ou metafórico - é um tópico que atravessa o corpus (cf. CARRI, A., 2007, p. 115; ESTEVE, 2009, p. 368; LLANOS, 2014, p. 221-222; ORTEGA, 2010, p. 95). O manuseio de álbuns, cartas, diários, desenhos da infância e documentos pessoais é o gesto mais repetido nas imagens da produção intergeracional aqui estudada (fig. 154-183).

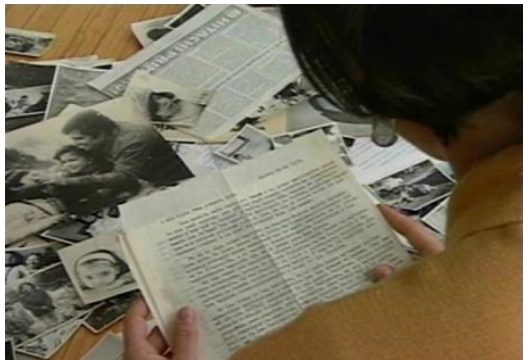

Figura 154 - Filha relê carta do pai. Figur 2000)

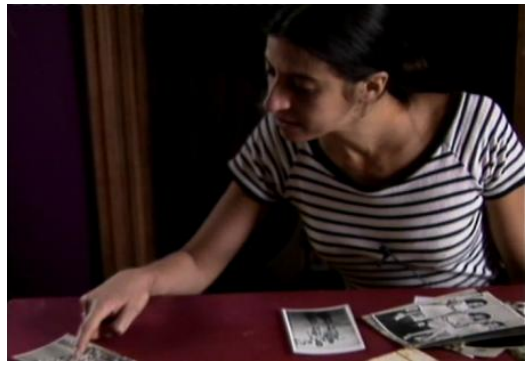

igura 155 - Filha abre seu envelope de Figura 156 - Revisão de fotos e escritos (Andrés Habegger, 2000).

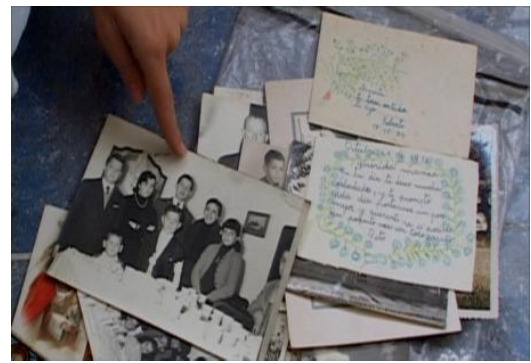
dos (Carmen Guarini e Marcelo Céspedes, 2002).
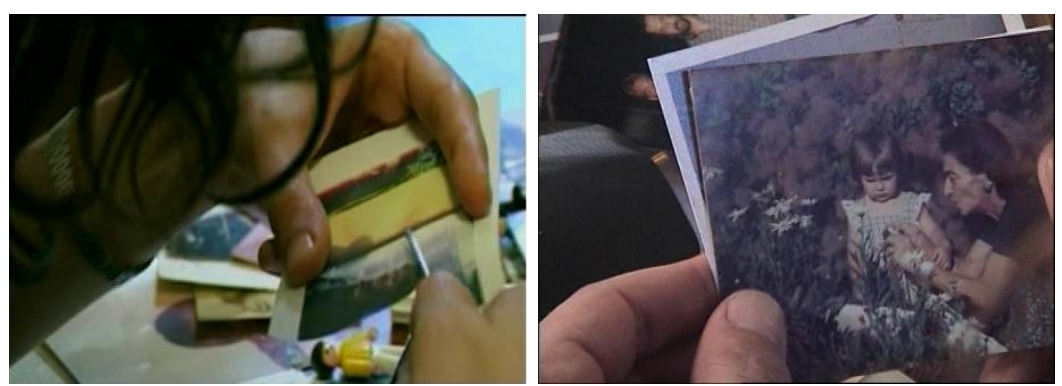

Figura 157 - Atriz recorta a foto Figura 158 - Manuseio das fotos Figura 159 - Revisão do álbum de familiar. Fonte: Los rubios (Albertina privadas. Fonte: El tiempo y la sangre família. Fonte: Nietos (identidad y Carri, 2003).
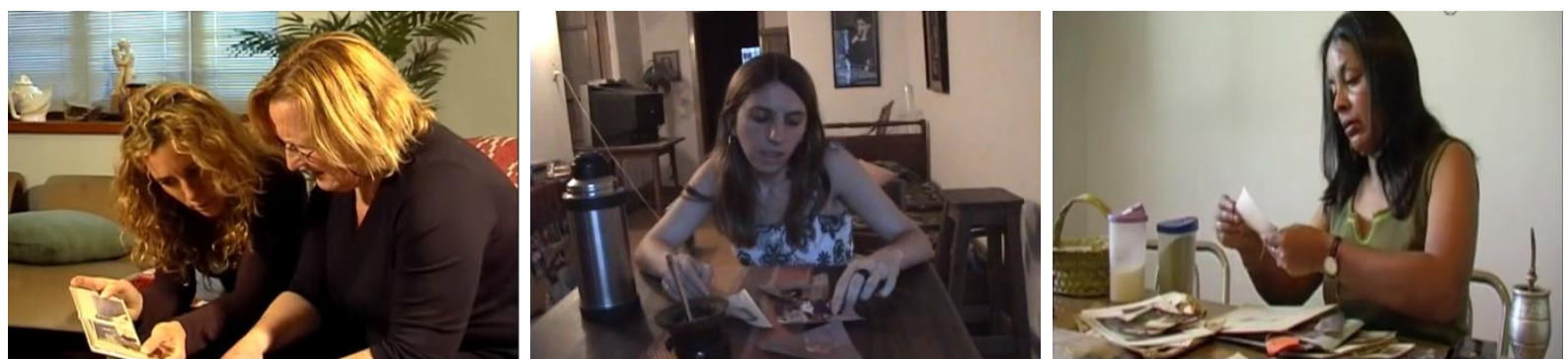

Figura 160 - Revisão conjunta das fotos Figura 161 - Filha mostra suas fotos. Figura 162 - Revisão das fotos privadas. privadas. Fonte: Hermanos de sangre Fonte: Nacimos en su lucha, viven en la Fonte: Semillas de utopía (Rodolfo (Fabián Vittola, 2005). nuestra (Camilo Cagni, Pablo Balut, Colombara e Emanuela Peyretti, 2006). Pablo Roesler e Juan Aíub, 2006). 

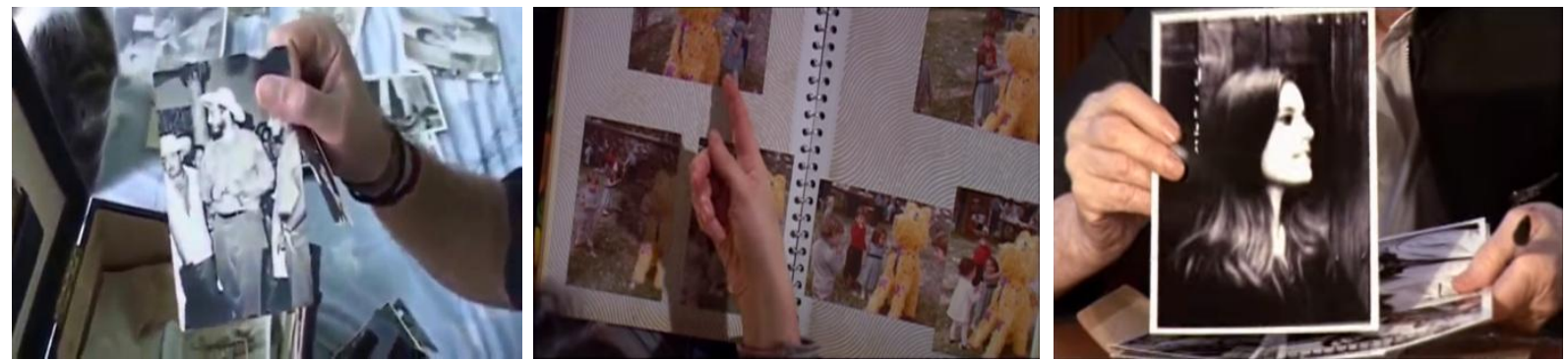

Figura 163 - Abrindo a caixa de fotos Figura 164 - Revendo o álbum de Figura 165 - Mostrando foto de privadas. Fonte: El telón de azúcar família. Fonte: Argenmex: exiliados desaparecida. Fonte: ¿Quién soy yo? Los (Camila Guzmán Urzúa, 2006). hijos (Violeta Burkart Noë e Analía niños encontrados de Argentina (Estela Miller, 2007).

Bravo, 2007).

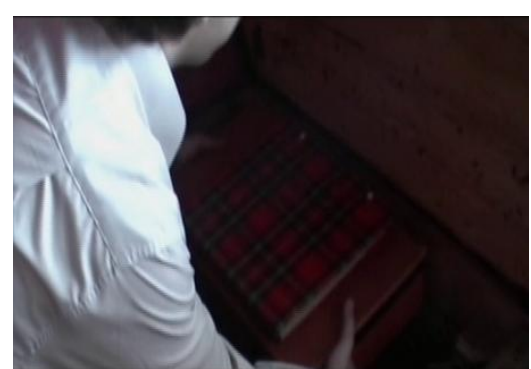

Figura 166 - Filho abre o baú da família. Fonte: $M$ (Nicolás Prividera, 2007).
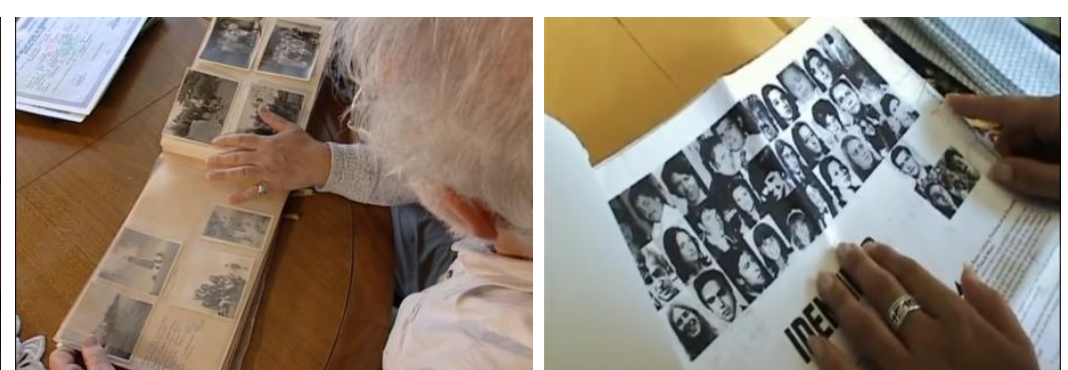

Figura 167 - Revendo o álbum. Fonte: Figura 168 - Filha restituída olha Secretos de lucha (Maiana Bidegain, material guardado pela avó. Fonte: 2007).
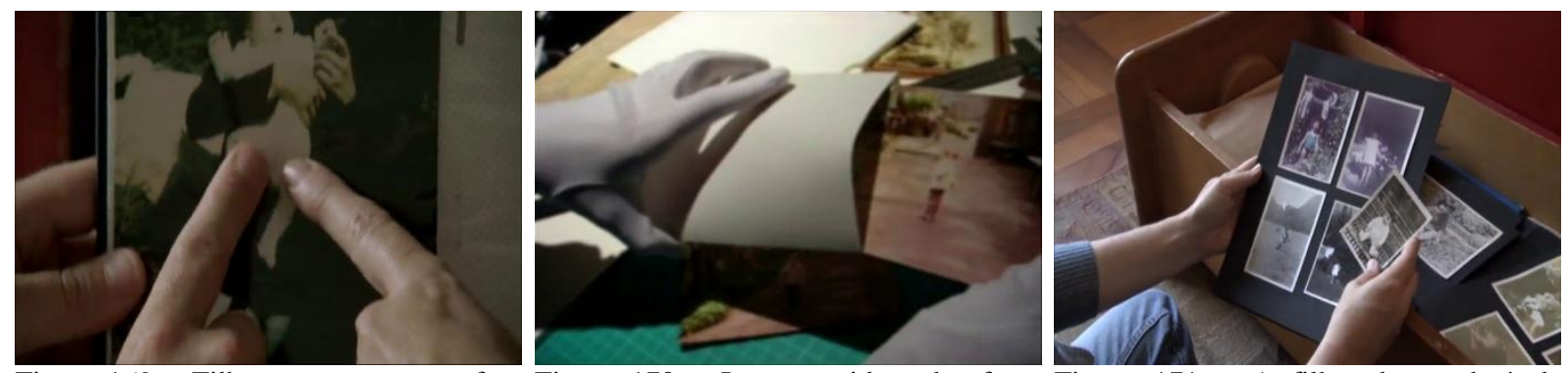

Figura 169 - Filho e mãe apontam foto Figura 170 - Irmãos cuidam das fotos Figura 171 - A filha abre o baú da no álbum, em plano subjetivo. Fonte: Mi privadas. Fonte: La quemadura (René família. Fonte: El edificio de los chilenos vida con Carlos (Germán Berger-Hertz, Ballesteros, 2009). 2009).

(Macarena Aguiló e Susana Foxley, 2010).
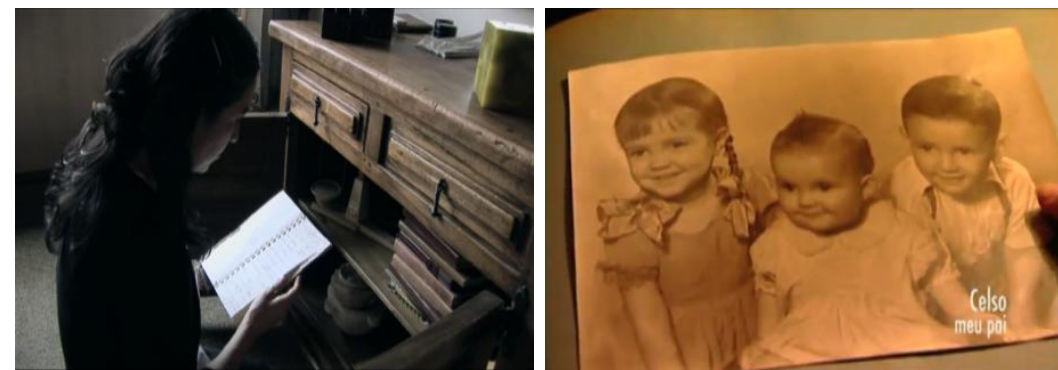

Figura 172 - A neta abre o armário com Figura 173 - Revendo o álbum familiar. Figura 174 - Amiga do tio mostra suas os objetos do avô. Fonte: Abuelos (Carla Fonte: Diário de uma busca (Flavia fotos. Fonte: Cuchillo de palo (Renate Valencia Dávila, 2010).

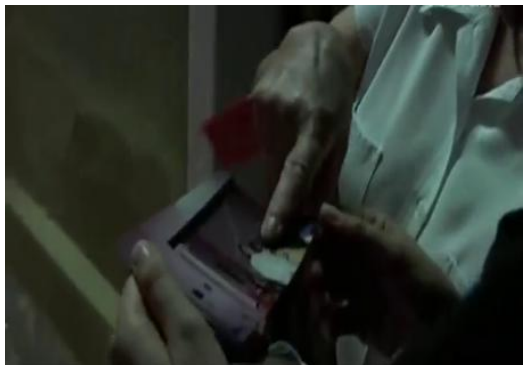
Costa, 2010). 

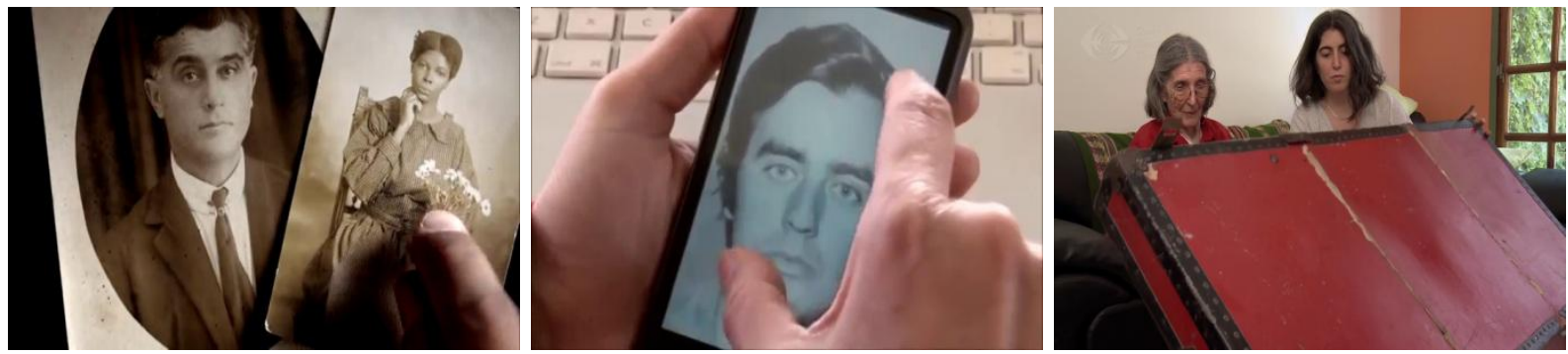

Figura 175 - Apontando para fotos dos Figura 176 - Filha manuseia foto Figura 177 - Neta e avó abrem juntas o antepassados. Fonte: Marighella (Isa digitalizada do pai na tela do celular. baú. Fonte: Tiempo suspendido (Natalia Grinspum Ferraz, 2011). Fonte: Repare bem (Maria de Medeiros, Bruschtein, 2015) 2012).

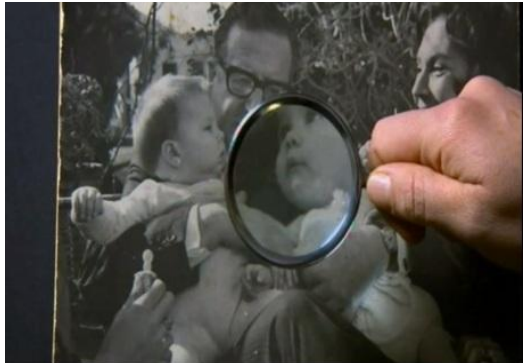

Figura 178 - Neta observa com lupa foto Figura 179 avô. Fonte: Allende mi abuelo quando bebê, rasgada. Fonte: Orestes câmera. Fonte: Tus padres volverán Allende (Marcia Tambutti, 2015). $\quad$ (Rodrigo Siqueira, 2015).
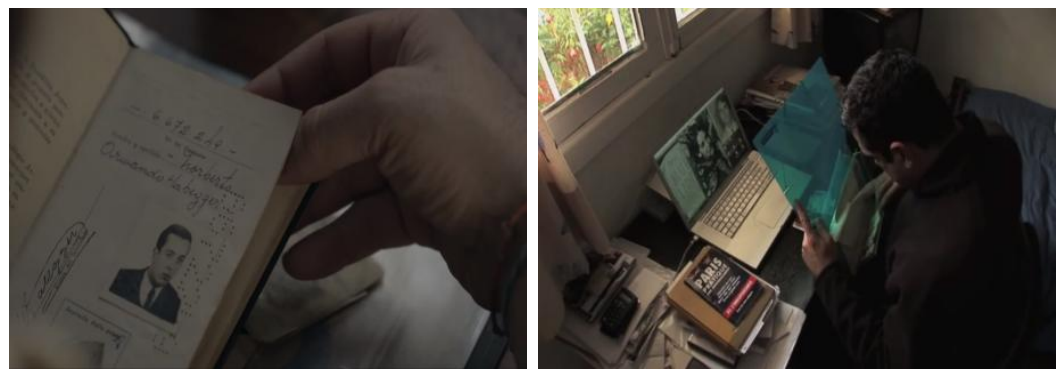

Figura 181 - Filho folheia documento Figura 182 - Filho abre sua pasta Figura 183 - Sobrinha revê álbum da pessoal do pai. Fonte: El (im)posible pessoal. Fonte: Venían a buscarme família. Fonte: El pacto de Adriana olvido (Andrés Habegger, 2016).

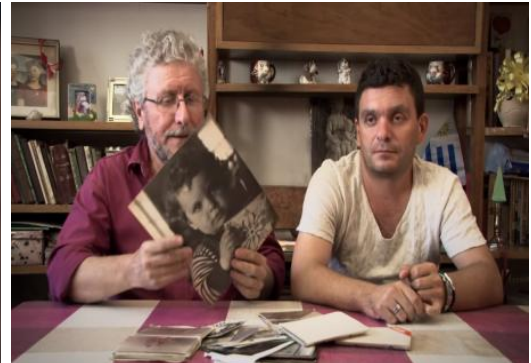

(Pablo Martínez Pessi, 2015).

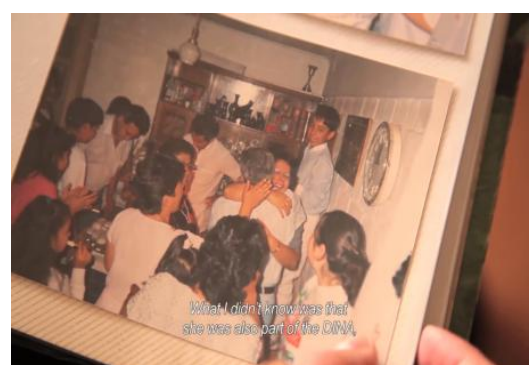

(Lissette Orozco, 2017).

Dentre os materiais revistos no acervo privado, os álbuns têm uma preponderância inequívoca, e tal recorrência em boa medida deriva da centralidade que a fotografia assume nas rememorações privadas de eventos traumáticos. Em Allende mi abuelo Allende (Marcia Tambutti, Chile / México, 2015), a reconstituição dos álbuns familiares perdidos com o golpe de 1973 no Chile é o que impulsiona a busca da neta. Com isso, ela quer recuperar a imagem do avô "Chicho" por trás das fotografias públicas e cartazes políticos de Salvador Allende. No final da narrativa, Tambutti monta e entrega para os parentes um álbum com as fotos encontradas pelo caminho. No caso de Tiempo suspendido (Natalia Bruschtein, México / Argentina, 2015), o Alzheimer da avó bloqueia a eclosão da rememoração. Ao lado da neta, Laura Bonaparte olha para as fotografias no álbum, mas sequer reconhece seus filhos, tampouco se lembra de seu passado de Madre de Plaza de Mayo. Os álbuns nesse caso 
existem. É a memória que está perdida, não havendo mais ali qualquer gatilho disparador das reminiscências. Em Los rubios, como ficou discutido no capítulo anterior, não se trata de bloqueio, mas da insistência da filha em se distanciar das versões herdadas. Revisando as fotografias da família, a atriz as recorta com uma tesoura, em um gesto radical de ruptura (fig. 157).

No capítulo anterior, já se discutiu o contraste entre esse gesto anômalo visto em Los rubios e o lugar basilar atribuído por Marianne Hirsch (1997, 2008, 2012) à fotografia em sua definição da "pós-memória" - a ponto de Hirsch (2008, p. 108) ter inclusive identificado certo risco de consolidação de determinados tropos de memória preestabelecidos a partir do uso de fotos icônicas. Mais autoras se debruçaram sobre os usos da imagem fotográfica no documentário contemporâneo ou outras produções culturais memorialísticas, destacando sua função de desencadear lembranças e restituir ausências (DE HAUWERE, 2012; GUIMARÃES, 2017; MAUAD, 2017; ORTEGA, 2008, p. 75-78; VALE, 2016). Roland Barthes (1984) é uma referência teórica fundamental nesse campo. O debate sobre a potência da fotografia nos esforços de recordação vistos nos documentários é, sem dúvida, fértil e oportuno. Mas, na prática analítica, a reiteração em série do manuseio dos álbuns de família nos títulos do corpus não deixa de causar impressão. Fica a sensação de que o gesto, em princípio pertinente e potente, vem se ritualizando, tornando-se um lugar-comum cinematográfico.

Esta última palavra conduz a uma associação entre os temas da repetição do gesto e do artifício técnico mais usado para filmá-lo. O exame atento dos fotogramas acima reproduzidos revela que grande parte dessas imagens são rodadas em tomadas subjetivas, com a câmera colocada em um ângulo coincidente com o ponto de vista do indivíduo que manuseia as fotos (cf. BORDWELL; THOMPSON, 1997, p. 240; AUMONT, MARIE, 2009, p. 237). Ora, tratando-se de documentários pessoais, a opção por tal recurso de linguagem poderia ser tida como a mais adequada. Afinal, essa forma seria condizente com o:

[...] novo papel que as fotografias têm no documentário contemporâneo. Enquanto sua função probatória da história se ofusca, elas se revelam como autênticas reativadoras da memória. A referencialidade e a evidência do suporte fotográfico, para poder significar, necessitam agora da mediação do sujeito. (PIEDRAS, 2014, p. 127, tradução nossa).

Acontece que o plano subjetivo convida a uma leitura que vai na contramão da interposição de uma mediação opaca. Mais uma vez, o problema está na naturalização, agora não do gesto, mas da perspectiva. Pois o ato de rever o arquivo íntimo não apenas se repete. 
Ele se reitera dentro de uma configuração que induz o espectador a identificar-se com aquele que olha, com a pessoa que abre o baú, que tem em mãos o álbum etc. À ritualização do impulso, portanto, adiciona-se uma composição visual que dá margem à assimilação transparente entre o ponto de vista da audiência e o do indivíduo que rememora.

Em Mi vida con Carlos e tantos outros exemplos, esse efeito de identificação com as lembranças alheias se intensifica pela articulação entre tomadas subjetivas e inserções, em tela cheia, das fotografias vistas pelos personagens em cena. Germán Berger-Hertz traz para a mãe a pilha de álbuns. Eles se sentam lado a lado à mesa, vão passando as páginas e ela vai rememorando. A voz da mãe segue em off enquanto o quadro é preenchido pelas inserções das fotos antigas. A imagem volta para a sala onde ambos estão, um plano subjetivo fechado mostra as páginas do álbum, as mãos apontam detalhes nas fotografias (fig. 169). Pelo jogo dos planos, o espectador mergulha, junto com os dois, na rememoração ali desencadeada.

Justamente para manter no horizonte a potência da revisão das fotografias como gatilho da memória no documentário intergeracional, cabe aqui problematizar a naturalização deste que também é, afinal, um recurso estético-narrativo. Nesse sentido, vale fazer a pergunta sobre o que ocorre quando o gesto que simboliza a centelha que faz eclodir a lembrança, o primeiro passo rumo às vicissitudes da rememoração, torna-se, contraditoriamente, um rito irrefletido que se repete em série.

Após essa consideração sobre o gesto e sua forma cinematográfica, resta agora elencar sucintamente os materiais que saem do baú da família. Além das fotografias privadas dos álbuns, os retratos em $3 \times 4$ dos parentes desaparecidos têm uma presença marcante no documentário intergeracional. Originalmente destinado aos usos burocráticos e de identificação oficial, este tipo de foto acabaria se tornando um ícone da luta por direitos humanos desde o ocaso das ditaduras do Cone Sul.

Indo para o âmbito das imagens em movimento, as filmagens domésticas são mobilizadas em uma parcela significativa de títulos do corpus. É verdade que elas surgem com menos frequência do que os álbuns, com toda probabilidade porque as filmadoras eram um bem menos acessível às famílias na comparação com o custo de uma máquina fotográfica. Mas sua relevância nesse universo do acervo privado é inequívoca. Em Mi vida con Carlos, a tomada em super-8 que mostra Carlos Berger mergulhando no mar é o ponto de partida da história. Em voz over, o filho informa que só viu o pai em movimento naquela imagem: um plano breve, exibido em câmera lenta, repetido ao longo do documentário, revertido, congelado. Um garoto que corre para o mar, lança um olhar para a câmera, conferindo se seu 
feito está sendo registrado. E salta contra a onda. Aquele corpo é muito jovem para ser o de um pai, aquela imagem é plena de significados para o filho.

As tomadas amadoras dos Berger surgem ainda em um momento específico de $\mathrm{Mi}$ vida con Carlos, na passagem que demarca o reencontro em Santiago dos irmãos Ricardo e Eduardo com Carmen Hertz, mãe do cineasta. Todos se reúnem para uma sessão caseira de antigos rolos de super-8. Germán aciona o projetor, eles sorriem, os tios se reconhecem nas imagens, identificam aquela praia. Campo e contracampo se alternam mostrando a película projetada e as expressões nos rostos daqueles que a veem. É um típico filme de família de um dia feliz em um longínquo verão. $\mathrm{O}$ dia do mergulho de Carlos, quando ninguém ali podia imaginar todo o mal que a história lhes reservava. Por um lado, estão visíveis os traços estilísticos característicos desse tipo de registro: a fotografia animada; os saltos entre os planos; a dispersão narrativa; a relação paradoxal com o espaço; os olhares para a câmera. Própria da pragmática do cinema doméstico é também a circunstância da projeção privada: os membros da família falam enquanto assistem às imagens, tendo suas recordações reavivadas, interagindo com os planos e entre si na reconstrução de uma experiência comum (ODIN, 2010). Por outro lado, há que se levar em conta a apropriação desse material no documentário contemporâneo, a transformação do filme de família em imagem de arquivo, a reorganização dessas tomadas em um fluxo narrativo, bem como sua exibição para um público além do círculo íntimo. Todas estas são operações que, por si só, já subvertem as marcas distintivas do cinema doméstico, conferindo novos significados e ampliando as ressonâncias dessas filmagens (ÁLVAREZ, 2008, 2010a, 2010b). ${ }^{87}$

O baú da família comporta ainda outros materiais além das imagens, fixas ou em movimento. Dele saem também os áudios domésticos, no mais das vezes o registro das vozes das crianças em fita cassete, podendo ganhar inclusive centralidade no relato, como em Elena (Petra Costa, Brasil, 2012) e Mute (Claudia Aguilera, Chile, 2017). Desenhos infantis guardados por anos. Objetos variados: o sapatinho de bebê de Eduarda e a camisa de "Bacuri" em Repare bem (Maria de Medeiros, Brasil / Portugal / Espanha, 2012); os livros da coleção da mãe do cineasta em La quemadura (René Ballesteros, Chile / França, 2009); gibis e moedas em El (im)posible olvido (Andrés Habegger, Argentina / Brasil / México, 2016); entre outros exemplos. Na intersecção entre a individualidade (do sujeito) e o registro oficial (do cidadão), os documentos pessoais de identificação dos personagens retratados também

\footnotetext{
${ }^{87}$ Sobre o cinema amador no contexto brasileiro, cf. FOSTER, 2016.
} 
emergem do baú familiar, com destaque para o passaporte, emblema da itinerância do exílio. Além, é claro, dos escritos privados: em primeiro lugar as cartas, seguidas dos diários.

De fato, estes gêneros da escrita íntima têm uma presença marcante no documentarismo intergeracional. Viu-se que Mi vida con Carlos se organiza como uma carta ao pai desaparecido do cineasta. A forma epistolar é uma modalidade sempre lembrada nas abordagens do documentário subjetivo contemporâneo (cf. BOSSY; VERGARA, 2010, p. 44; DIGIOVANNI, 2013, p. 70; LABBÉ, 2012b, p. 17; LLANOS, 2014, p. 220). Nos títulos do corpus, são variados os recursos expressivos ligados a essa vocação missivista: a leitura das cartas em voz over em momentos-chave do relato; as inserções em close-up dos papéis antigos, a câmera passeando pelas linhas enquanto se escuta o teor do texto; o manuseio dos originais em planos subjetivos (fig. 154). Em El edificio de los chilenos (Macarena Aguiló e Susana Foxley, Chile / Cuba / França / Bélgica, 2010), Macarena Aguiló transcreve as velhas folhas manuscritas ao computador, entregando em seguida para a mãe uma coletânea de cartas impressas e encadernadas. No caso de El (im)posible olvido, na fase final de rodagem, a mãe de Andrés Habegger lhe entrega as cartas que o pai enviara ao México. Ele as relê, mas continua sem se lembrar de nada daquele período.

Já a forma diário chega a ser anunciada nos próprios títulos de Diario argentino (Lupe Pérez García, Argentina / Espanha, 2006) e Diário de uma busca (Flavia Castro, Brasil / França, 2010). A rigor, nem estes nem outros filmes do corpus seguem a organização padrão do diário filmado. Ou seja, a "modalidade que se baseia na rodagem de acontecimentos diários durante um período de tempo determinado e em sua posterior montagem seguindo uma estrutura cronológica e narrativa” (ÁLVAREZ, 2005, p. 225, tradução nossa). No plano enunciativo, trata-se muito mais de um aceno difuso para a ideia de registro do processo de busca pessoal. Por seu turno, os diários reais do passado, quando surgem, costumam se inserir nos relatos como um dentre os materiais saídos do baú privado. Tal como as cartas, eles são lidos em over, têm suas páginas enquadradas em close-up, são folheados pelos cineastas. A leitura que Andrés Habegger faz de seus diários de infância em El (im)posible olvido surte um efeito dramático forte. O cineasta vai repassando as entradas nas quais anotava com minúcias seu cotidiano de menino no exílio: as horas solitárias em casa esperando pela mãe; as refeições que tinha que preparar para si; o tempo que passava diante da televisão; seus medos. Mas o diretor, adulto, nem mesmo se lembrava de que havia escrito aquelas páginas. Quando Habegger abre o que seria o terceiro caderno destes registros infantis, relativo ao período subsequente ao desaparecimento do pai, ele se depara com rabiscos e números sem sentido 
nas primeiras páginas. Em seguida, as folhas todas em branco. Uma imagem que serve de emblema do esquecimento que ronda a narrativa do documentário.

\section{- Os arquivos públicos}

Seria um erro pensar que todo o material de arquivo do documentário intergeracional cabe no baú da família (cf. BOSSY; VERGARA, 2010, p. 48). Filmagens, fotografias, áudios, textos, os suportes encontrados no acervo privado têm seus equivalentes saídos das coleções públicas. Mesmo o impulso inicial de "abrir o baú" possui um gesto análogo na ida até as instituições dedicadas à conservação de documentos. Mi vida con Carlos traz, em sua sequência de abertura, imagens em que Germán Berger-Hertz está esquadrinhando caixas e gavetas do arquivo da Vicaría de la Solidaridad. Mais adiante, quando a militância de Carmen Hertz nesta entidade é abordada, o cineasta é visto consultando papéis diante de uma mesa coberta de caixas, pastas e fotografias (fig. 184). A voz over de Berger-Hertz informa que aquele arquivo havia sido declarado Patrimônio da Humanidade pela Unesco. A dinâmica da construção dessa tomada reforça o efeito de mergulho na busca do filho: o plano geral do ambiente, filmado em plongée, vai se fechando lentamente em zoom in até que o quadro seja todo preenchido por uma fotografia específica, em preto e branco, mostrando integrantes da Vicaría perfilados sob uma faixa. Após a imersão no álbum da família, agora o olhar do espectador é lançado dentro de um arquivo que não só é público, como foi declarado Patrimônio da Humanidade.

Nicolás Prividera faz todo um périplo por instituições ligadas à salvaguarda da memória da ditadura argentina no início de $M$ (Nicolás Prividera, Argentina, 2007), procurando em vão por informações sobre sua mãe (fig. 185). Flavia Castro, em Diário de uma busca, consulta microfilmes do acervo do jornal Zero Hora, tentando entender o episódio que levou seu pai à morte (fig. 186). Andrés Habegger, nas idas e vindas de El (im)posible olvido (Andrés Habegger, Argentina / Brasil / México, 2016), faz uma visita às instalações da Comissão da Verdade do Rio de Janeiro, onde lhe são dadas pistas sobre o desaparecimento do pai (fig. 187). Renate Costa, em Cuchillo de palo (Renate Costa, Paraguai / Espanha, 2010), encontra prontuários sobre a detenção de seu tio no banco de dados sobre memória e direitos humanos da Justiça paraguaia. Inclusive Albertina Carri vai até o escritório da Equipe Argentina de Antropologia Forense (EAAF), sem abrir mão, mesmo aí, do labirinto de mediações que marca Los rubios. E esses são apenas alguns exemplos. Com efeito, em suas 
buscas pessoais, os diretores transitam com fluidez entre os acervos familiares e oficiais, procurando as peças do quebra-cabeça onde quer que elas estejam.

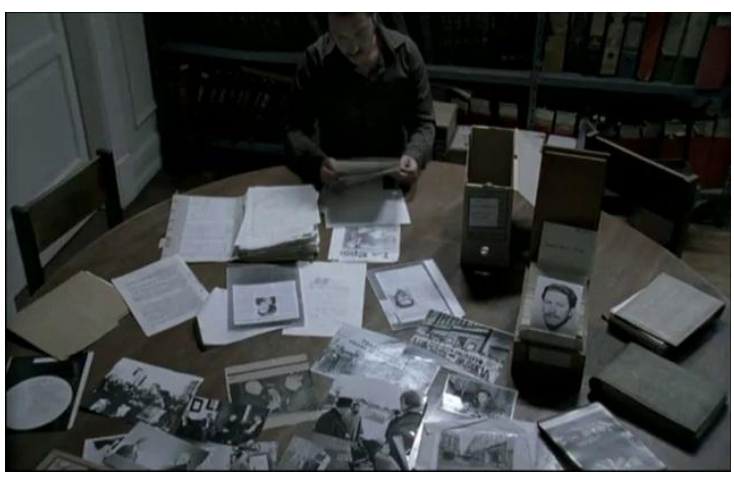

Figura 184 - O filho consulta o arquivo da Vicaría de la Solidaridad. Fonte: Mi vida con Carlos (Germán BergerHertz, 2009).

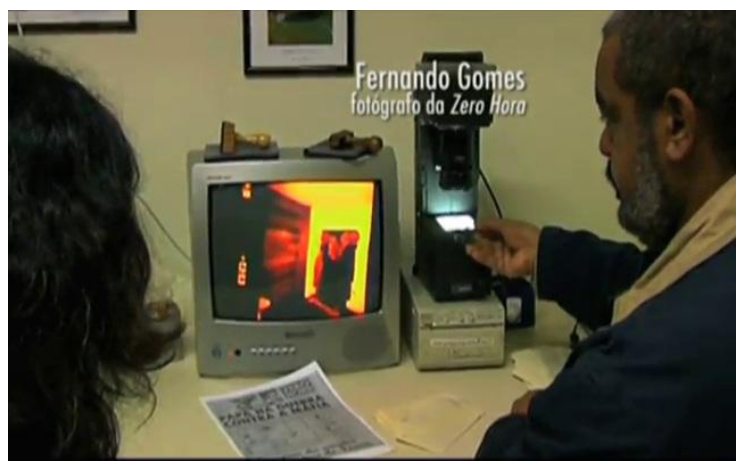

Figura 186 - A filha consulta o acervo do jornal. Fonte: Diário de uma busca (Flavia Castro, 2010).

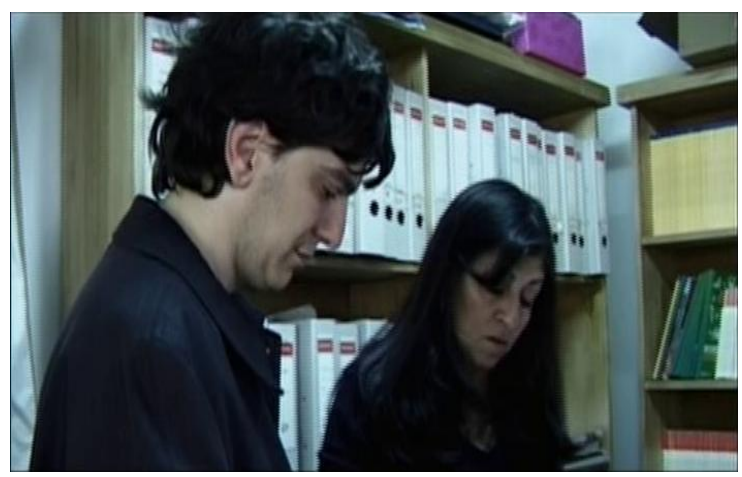

Figura 185 - O filho em périplo por arquivos públicos. Fonte: $M$ (Nicolás Prividera, 2007).

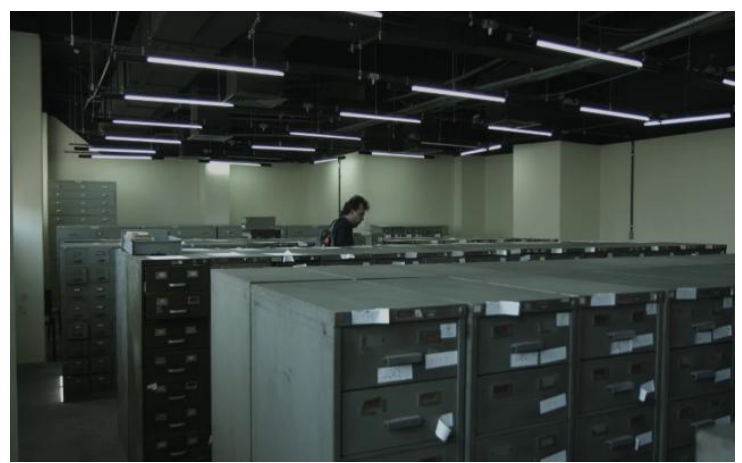

Figura 187 - O filho nos arquivos da Comissão da Verdade carioca. Fonte: El (im)posible olvido (Andrés Habegger, 2016).

Cabe observar, porém, que os materiais oriundos dos repositórios institucionais costumam ser integrados às narrativas seguindo padrões tradicionais do cinema documentário. A filmografia intergeracional traz uma profusão de inserções de imagens de arquivo extraídas do repertório iconográfico compartilhado: trechos de cinejornais, de telejornais, de documentários anteriores, de filmes produzidos pelas organizações de direitos humanos, isso no campo das imagens em movimento. As fotografias fixas também se fazem bem presentes, sobretudo as provenientes da imprensa de época. O uso ilustrativo é majoritário nessa esfera, principalmente para demarcar as alusões aos eventos-chave do período, os golpes e os fatos fundamentais daquelas histórias (o bombardeio do La Moneda, o Cordobazo, as mobilizações estudantis de 1968, o AI-5, a luta de madres e abuelas na Argentina, os protestos na reta final da ditadura chilena, o retorno dos anistiados e as greves do $\mathrm{ABC}$ no Brasil etc.). Tomadas e fotos de arquivo tendem a aparecer nos documentários intergeracionais como "imagens canônicas" da história, isto é, aquelas "imagens de tal forma incorporadas em nosso 
imaginário coletivo, que as identificamos rapidamente" (SALIBA, 2007, p. 88). Reconhecíveis, convencionais, as imagens da História vão se encaixando no arco biográfico dos familiares retratados nos filmes.

É verdade que Abuelos (Carla Valencia Dávila, Equador / Chile, 2010) tem uma passagem que inverte em alguma medida essa lógica. Nela, a cineasta empreende em voz over uma indagação dos planos de arquivo que mostram presos do campo de Pisagua marchando e cantando perfilados. A neta diz que olha para aquelas imagens tentando reconhecer seu avô; ela supõe que aqueles homens filmados o conheceram, ou ao menos o viram antes de seu desaparecimento; que seguramente todos ali foram torturados e que muitos devem ter tido um destino semelhante ao do seu avô. Uma derradeira tomada dessa sequência em preto e branco enquadra uma porta por onde os prisioneiros passam. Ela conjectura que aquela deve ter sido a última porta por onde saiu o avô, antes da execução sentenciada pela Caravana da Morte. Ocorre aqui um lampejo de diálogo mais substantivo com as imagens do passado.

Mas a exceção notável na mobilização das imagens do arquivo audiovisual público é Cuatreros (Albertina Carri, Argentina, 2016), cuja proposta ensaística coloca o espectador diante de um turbilhão fugidio de planos de época, na tela por vezes subdividida em até cinco quadros.

Outras inserções que chamam atenção são aquelas que trazem entrevistas concedidas anos antes pelos personagens dos documentários. Em Mi vida con Carlos, vê-se Germán Berger-Hertz, então um menino de nove anos, falando sobre a falta que sentia do pai. Em Diário de uma busca, vê-se Flavia Castro, com quatorze anos, sendo entrevistada às vésperas do retorno do exílio. A sequência de Mi vida con Carlos com registros antigos nos quais Carmen Hertz fala incisivamente, rodeada de jornalistas ou em programas de televisão, sobre os crimes da ditadura dá uma dimensão do papel público da mãe do diretor como advogada em defesa dos direitos humanos no Chile. Em Tiempo suspendido (Natalia Bruschtein, México / Argentina, 2015), as entrevistas de arquivo em que Laura Bonaparte fala, cheia de eloquência, como madre da Praça de Maio contrastam fortemente com a senilidade capturada pelas lentes da neta.

Ainda assim, de modo geral, mesmo a mobilização dos outros suportes não se afasta muito do impulso ilustrativo e canônico. Os áudios de arquivo ouvidos nos filmes igualmente reiteram a crônica clássica das ditaduras (o último e dramático pronunciamento de Allende; os anúncios das tomadas do poder pelos militares; a notícia radiofônica do AI-5; a famigerada declaração de Videla sobre a inexistência dos desaparecidos etc.). As inserções de páginas e recortes de jornais da época, outro recurso bem tradicional do cinema documentário, mostram 
as manchetes que confirmam os episódios repassados. O enquadramento de outros documentos escritos (papéis da repressão ou dos movimentos de esquerda, livros publicados etc.) segue essa mesma linha. Outra exceção destacada, neste último caso, é a tentativa de Maria Clara Escobar de fazer o pai ler seu próprio mandado de prisão em Os dias com ele (Maria Clara Escobar, Brasil / Portugal, 2013), algo que leva a tensão entre os dois a um clímax pleno de significados, como se verá no próximo capítulo. A entrada desse documento oficial no filme, porém, é bem peculiar: não há inserção em close-up, e sim a leitura desobediente feita pela filha.

Em suma, os modos de articulação dos arquivos privados e públicos na produção intergeracional aqui estudada revelam a convivência de novas e velhas convenções: de um lado, a abertura do "baú" e o manuseio do acervo familiar (fotos à frente) são gestos insistentemente reiterados como ícones do primeiro passo da busca subjetiva; de outro, as inserções ilustrativas e canônicas dos suportes da memória coletiva tendem a seguir os padrões do documentário mais tradicional. Tudo isso não impede, entretanto, que em alguns casos esses materiais iluminem meandros menos trilhados dessas histórias.

\section{Tópicos da memória intergeracional}

Sons, estilos de filmar, o visível, os arquivos. A abordagem das configurações cinematográficas desses elementos já deu uma boa ideia do teor das rememorações elaboradas nos documentários. Vale, porém, fazer um esforço de síntese de modo a compilar os principais tópicos da memória intergeracional que emergem no corpus.

\section{- Vivências de época}

Começando pelas vivências de infância recuperadas pela segunda ou terceira geração. O exílio acompanhando pais ou outros familiares desponta como uma das experiências mais abrangentes nessas histórias, tendo tocado a muitos dos filho(a)s, sobrinho(a)s e neto(a)s de militantes com diferentes graus de engajamento e atingidos de distintas maneiras pela repressão. Existem os filmes que colocam essa vivência no centro da narrativa, tais como En algún lugar del cielo (Alejandra Carmona, Chile, 2003); El telón de azúcar (Camila Guzmán Urzúa, França / Cuba / Espanha, 2006); Argenmex: exiliados hijos (Violeta Burkart Noë e Analía Miller, Argentina, 2007); El edificio de los chilenos (Macarena Aguiló e Susana Foxley, Chile / Cuba / França / Bélgica, 2010); El eco de las canciones (Antonia Rossi, Chile, 
2010); Tus padres volverán (Pablo Martínez Pessi, Uruguai, 2015); ou La guardería (Virginia Croatto, Argentina, 2016), por exemplo. Mas tantos outros relatos carregam a marca do desenraizamento forçado ainda durante a infância.

O sentimento de orfandade, presumivelmente, é outra cicatriz manifesta da memória intergeracional, estando no cerne das histórias de filhas e filhos de assassinados e desaparecidos pelas ditaduras (cf. LLANOS, 2014, p. 220). É nesse ponto que afloram as tensões entre política e afetos, entre o engajamento dos pais nas organizações revolucionárias e a deserção radical dos laços familiares (AMADO, 2009, p. 184). Em Papá Iván (María Inés Roqué, México / Argentina, 2000), a voz over da filha toca na questão com franqueza: "Eu uma vez disse que preferiria ter um pai vivo a um herói morto" (tradução nossa). No caso de Encontrando a Víctor (Natalia Bruschtein, México / Argentina, 2004), a filha faz a pergunta diretamente para a mãe sobrevivente: "Quando você e o papai decidiram ter um filho, depois que eu nasci, os dois continuavam participando em ações..." A mãe completa: "Armadas?" Esta esclarece a cronologia do engajamento armado do casal em paralelo com a gravidez e o nascimento de Natalia. A filha insiste: "Nunca tiveram medo de que acontecesse alguma coisa? Ou seja, decidiram ter um filho e não cuidavam um pouco mais da própria vida para que o filho não ficasse órfão?" (tradução nossa). Em El tiempo y la sangre (Alejandra Almirón, Argentina, 2004) e El (im)posible olvido (Andrés Habegger, Argentina / Brasil / México, 2016), a pergunta é basicamente a mesma, mas construída de modo invertido. Algo do tipo "Por que tinham três filhos se os aparelhos estavam caindo um atrás do outro?", "Se iam se engajar na luta revolucionária, se iam correr esse risco, por que tinham filhos?”. A geração dos pais sempre se esforça para explicar que eles entraram na luta para ganhar, não para serem dizimados. Que acreditavam sem vacilações no projeto revolucionário. Que eram outros tempos, quando eles ainda estavam absolutamente convictos de que seus filhos viveriam em um mundo melhor. Para a geração militante, a morte e a orfandade não deveriam ter sido o resultado de suas opções políticas (AMADO, 2009, p. 198-199; APREA, 2015, p. 249-250).

A sensação de abandono também pode suscitar um exercício de avaliação da utopia revolucionária por parte da segunda geração. Nesses casos, a cobrança direta dá lugar às tentativas de assimilação daquele contexto no qual os ideais se sobrepunham aos afetos privados. A convicção quanto à pertinência da decisão dos pais enunciada por um dos filhos entrevistados em El edificio de los chilenos (Macarena Aguiló e Susana Foxley, Chile / Cuba / França / Bélgica, 2010) destoa frente às vozes mais hesitantes dos demais deixados aos cuidados das "famílias sociais" miristas em Cuba. Os integrantes das agrupações de hijos 
ouvidos nos filmes vão ainda além, ao reelaborarem a entrega política dos pais em nome da atualização do impulso militante, agora depurado das armas (AMADO, 2009, p. 160-161; LLANOS, 2014, p. 218-219). Demandas afetivas, compreensão do sacrifício, releituras da luta: as posturas assumidas pela segunda geração na balança entre a política e os afetos são mais uma expressão da complexidade dos vetores da memória intergeracional.

A infância imersa na clandestinidade dos pais é outra vivência marcante nas representações do corpus. O olhar cândido da criança, incapaz de compreender o mundo político dos adultos, é um tópico presente em Los rubios, como se viu, e em alguns outros títulos. O cotidiano nos aparelhos, em meio a armas e reuniões, a interdição de enunciar os nomes reais da família, todos estes são aspectos que vêm à tona nas rememorações das vivências de época dos descendentes de militantes.

A "perda da inocência” em alguns casos ocorreu de modo drástico. Em 15 filhos (Maria Oliveira e Marta Nehring, Brasil, 1996), Telma e Denise Lucena rememoram a fria execução do pai diante delas duas, então meninas pequenas. Elas e também Janaína e Edson Teles, todos crianças levadas para a prisão, contam que tiveram que ver as mães desfiguradas pela tortura. Macarena Aguiló, de El edificio de los chilenos, foi mantida como refém pela Dina por dias para que seu pai se rendesse. Afora, claro, a violência da apropriação de bebês largamente perpetrada pela ditadura argentina, tema que emerge em parcela significativa dos títulos daquele país.

\section{- Questões identitárias}

As representações da memória intergeracional aqui examinadas trazem em seu núcleo as indagações identitárias dos filhos e demais descendentes. A constituição de uma imagem dos pais (ou tios e avós) assassinados ou desaparecidos é um dos primeiros passos dessas buscas. Como já ficou analisado, os retratos e as filmagens do passado, incluindo a escassez ou inexistência de tais registros, têm um papel fundamental nesse exercício. Mas a palavra "imagem" assume conotações menos estritas. Ela diz respeito ao super-8 do jovem Carlos mergulhando visto e revisto em Mi vida con Carlos. Ou ao flagrante único de uma imagem em movimento do pai garimpado por Andrés Habegger entre as tomadas de arquivo de um protesto, em El (im)posible olvido (Andrés Habegger, Argentina / Brasil / México, 2016). Ou, ainda, ao dispositivo fotográfico criado por Lucila Quieto e replicado por alguns diretores. Mas também pode ser fruto da imaginação da filha Eduarda Ditta Crispim Leite diante da camisa de "Bacuri" que lhe fora presenteada por um ex-companheiro de militância do pai, em 
Repare bem (Maria de Medeiros, Brasil / Portugal / Espanha, 2012). O espelhamento das semelhanças fisionômicas entre filhos e pais, tantas vezes destacado nos filmes, é outro tópico na órbita da busca por uma imagem dos progenitores. Além dos contornos que se delineiam no mosaico de testemunhos da geração anterior.

Por um lado, essa construção multifacetada de uma imagem dos pais tenta preencher as lacunas daquelas histórias: o enigma em torno das circunstâncias das mortes e a incapacidade de apontar responsáveis, questões enfrentadas com serenidade em Diário de uma busca (Flavia Castro, Brasil / França, 2010) e com exasperação em $M$ (Nicolás Prividera, Argentina, 2007); a suspeita da traição que teria resultado na morte do pai, em Papá Iván (María Inés Roqué, México / Argentina, 2000); os longos silêncios das famílias sobre os caminhos políticos e os destinos trágicos dos ausentes, outro tema recorrente na filmografia; as recordações difusas e pouco confiáveis da infância, aspecto que ganha expressão radical na amnésia de Andrés Habegger vista em El (im)posible olvido; a imaterialidade da morte dos desaparecidos, a falta do corpo para o trabalho de luto, simbolizadas pelo vazio do deserto em Mi vida con Carlos e abordadas em tantos outros documentários. Por outro, tais esforços procuram redimensionar uma presença monumental. Germán Berger-Hertz o enuncia em over com clareza: “Antes de tua morte, nossa família era como qualquer outra. Minha mãe tinha 27 anos quando enviuvou. A partir desse momento, a família fomos só ela e eu e, entre nós, teu fantasma, tua figura heroica." (tradução nossa). Em 15 filhos (Maria Oliveira e Marta Nehring, Brasil, 1996), a fala de Tessa Moura Lacerda é ainda mais eloquente:

Eu tentar construir essa imagem, porque eu não sei nada. Eu não sei como o meu pai era, eu não sei as coisas mais banais. Eu sei o que ele fez e, sempre, na minha cabeça, fica uma coisa grandiosa, de herói. Porque, afinal de contas, ele morreu por um ideal e ele estava disposto a isso. Enfim, fica aquela coisa gigantesca, que até me oprime um pouco. ${ }^{88}$

Nesse mesmo sentido, Los rubios pode ser interpretado como uma extremada recusa da versão épica do sacrifício dos pais. Enfim, a segunda geração constrói imagens dos ascendentes para conhecê-los de algum modo. Mas também o fazem para sair da sombra do monumento aos caídos na luta passada. Há mais coisa em jogo aí do que o lugar-comum do retrato do "homem por trás do mito". Entre as lacunas privadas e a epopeia revolucionária, a rememoração pelo viés familiar é também um meio de encontrar espaço, no presente, para a afirmação de uma identidade própria (cf. SELIPRANDY, 2013).

\footnotetext{
${ }^{88}$ Para um relato escrito em primeira pessoa sobre esse caso, cf. LACERDA, 2014.
} 
No caso daqueles que foram sequestrados ainda bebês e apropriados ilegalmente por homens e mulheres do círculo da ditadura argentina, esse tópico se reveste de tintas dramáticas. Aí não se trata "apenas" - como se fosse pouco - de elaborar psicologicamente uma identidade. Antes de tudo, os netos e filhos apropriados necessitam recuperar sua identificação como pessoa física. A coleta de sangue para o exame de DNA é um dentre os passos desse processo. Além da cena de Los rubios que mostra a atriz e Albertina Carri dando amostras de sangue na sede da EAAF, Victoria (Adrián Jaime, Argentina, 2008) também traz uma passagem em que a protagonista do documentário, Victoria Donda, tem seu DNA coletado. Nascida na Esma, a restituição de sua verdadeira identidade, confirmada em 2004 após análise junto ao Banco Nacional de Datos Genéticos (BNDG), foi fruto de uma ação coordenada entre H.I.J.O.S. e Abuelas de Plaza de Mayo.

Revolvendo um passado fragmentário, premidas sob o monumento épico, espoliadas até do nome próprio, as novas gerações buscam, de diversas formas (incluindo as do cinema documental), constituir uma identidade. O movimento de Mi vida con Carlos é revelador nesse sentido. Ao longo da obra, o filho lida com muitas dessas complicações da memória intergeracional. Todavia, no desfecho do documentário, como já ficou indicado acima, ele pode anunciar que teve êxito no trabalho de luto. Lendo a carta ao pai no deserto que simboliza a ausência do desaparecido, entre lágrimas e suspiros, Berger-Hertz declara que pode, afinal, ter sua própria vida:

Quero que saibas que desde pequeno prometi a mim mesmo e coloquei como meta seguir adiante, não acabariam com a minha vida. Teu assassinato se transformaria em um impulso vital. Poderia amar, rir e dançar. [...] A justiça em parte chegou e a capacidade de recordar é algo muito leve. Eu estou bem, tenho uma mulher que me ama e uma filha bonita, sinto-me seguro, sou capaz de ter sonhos e capaz de querer bem. [...] Poderia dizer que sou um homem de muita sorte. Hoje estamos aqui fazendo um exercício de memória. Hoje Carmen, Ricardo e Eduardo se atrevem a te recordar, recuperam tua essência, tua identidade, tuas histórias e aventuras. Hoje Carmen se emociona com teus ideais e teus irmãos riem e se divertem contigo. Estão resgatando tuas lembranças, estão enfrentando a dor, estão recuperando a alegria de ter te conhecido. Eles abrem sua memória e eu preencho minha folha em branco. Eu começo, então, a ter minha vida com Carlos. (tradução nossa).

Se a identidade é uma elaboração árdua, se Los rubios eleva essa dificuldade ao nível da impossibilidade, não é verdade que só exista fracasso no final desses processos. Como se a derrota do projeto revolucionário dos pais na origem das buscas dos filhos só pudesse levar a narrativas perpetuamente em crise (cf. AMADO, 2009, p. 184-185 e 190-191; APREA, 2015, p. 241; ANDERMANN, 2015, p. 197; BOSSY; VERGARA, 2010, p. 36; MACHADO, I., 
2015, p. 228). Ora, essa seria uma leitura da indeterminação formal que se nega a si mesma. Nesses termos, o colapso identitário e a abertura da obra, paradoxalmente, tornam-se condições necessárias, fechando a questão de antemão. De modo a manter os horizontes efetivamente abertos, é preciso dizer que a imprevisibilidade das buscas empreendidas pela segunda geração inclui também a possibilidade do êxito, da configuração de uma identidade própria por meio das variadas nuances formais do cinema.

Mais ainda. O impulso identitário não só contém algo de construtivo, como muitas vezes se expressa com a assertividade das reivindicações. Em 15 filhos, Janaína de Almeida Teles não deixa dúvidas quanto a isto: "Eu achava que a sociedade me devia alguma coisa. Porque, se não tivessem deixado o golpe acontecer, eu não tinha sofrido isso.” E, logo adiante: "Quero vingar, quero punir e quero reparar a dor que me impuseram." No caso de D.F. (destino final) (Mateo Gutiérrez, Uruguai, 2008), a contundência vem da montagem paralela que, no fim do documentário, coloca uma sequência de fotografias de corpos destroçados de militantes, entre os quais o pai do diretor, junto a tomadas que mostram os perpetradores livres pelas ruas. De saída, Repare bem (Maria de Medeiros, Brasil / Portugal / Espanha, 2012) é uma produção ligada ao Projeto Marcas da Memória, da Comissão de Anistia do Ministério da Justiça brasileiro. O desfecho que exibe o registro da cerimônia na qual a filha Eduarda Ditta Crispim Leite é reconhecida pelo Estado como anistiada política ecoa o título do documentário (cf. FERNANDES, J. V. S., 2018). Orestes (Rodrigo Siqueira, Brasil, 2015) traz todo um segmento que encena, com grande pompa, o julgamento do personagem-título, sobrepondo tragédia grega e a história do famigerado Cabo Anselmo, o agente duplo que entregou à morte a própria companheira, Soledad Barrett Viedma, mãe de Nasaindy Barrett de Araújo. ${ }^{89}$ Neste exemplo, a enunciação fílmica é plena de mediações, mas a tese central é clara: a violência de Estado no presente é a continuidade da violência de Estado passada garantida pela impunidade perpetuada pela Lei de Anistia de 1979. Já em $M$ (Nicolás Prividera, Argentina, 2007), o filho levanta a voz para acusar a sustentação social do regime autoritário e a preferência da maioria pelo esquecimento no presente.

Além das reivindicações avulsas, as vozes que demandam verdade, justiça e reparação também se unem na militância incisiva dos hijos (cf. AMADO, 2009, p. 157). No conjunto de títulos ligados a essas agrupações, os tópicos da memória intergeracional são também a pauta do engajamento político. Em meio aos depoimentos de seus integrantes ou ao registro de reuniões, os "escrachos" se destacam nessa vertente, visíveis em (h) Historias cotidianas

\footnotetext{
${ }^{89}$ Para detalhes sobre esse caso, cf. ARAÚJO, 2014, p. 101-103; COMISSÃO NACIONAL DA VERDADE, 2014, p. 1154-1160.
} 
(Andrés Habegger, Argentina, 2000); Panzas (Laura Bondarevsky, Argentina, 2000); Che vo cachai (Laura Bondarevsky, Argentina, 2002); H.I.J.O.S.: El alma en dos (Carmen Guarini e Marcelo Céspedes, Argentina, 2002); Nacimos en su lucha, viven en la nuestra: 10 años de H.I.J.O.S. La Plata (Camilo Cagni, Pablo Balut, Pablo Roesler e Juan Aíub, Argentina, 2006); além de Semillas de utopía (Rodolfo Colombara e Emanuela Peyretti, Itália, 2006). Nesses casos, as mobilizações documentadas nos filmes são o motor da construção de uma identidade coletiva: "filhos de desaparecidos".

Mas o lado avesso da memória intergeracional começa a despontar nesse cenário. 70 y Pico (Mariano Corbacho, Argentina, 2016) e El pacto de Adriana (Lissette Orozco, Chile, 2017) são dois documentários realizados por aqueles que por muito tempo preferiram não serem identificados: os descendentes de pessoas ligadas à estrutura repressiva das ditaduras. Tais representações não estão isoladas de uma tendência social que vem se esboçando na Argentina. Ali, em 2017, filhas e filhos de genocidas começaram a se organizar em torno de Historias Desobedientes, repudiando os atos de seus genitores naquele período e em defesa dos direitos humanos (ARENES; PIKIELNY, 2017; CURIA, 2017).

Por fim, o contraste entre dois títulos específicos ilumina questões de fundo nesse panorama dos tópicos da memória intergeracional. O primeiro filme é uma exceção em pelo menos dois sentidos. Cuchillo de palo (Renate Costa, Paraguai / Espanha, 2010) é o único documentário do corpus de origem paraguaia, retratando aspectos de um regime muitas vezes esquecido quando se fala em ditaduras do Cone Sul. Não bastasse isso, sua temática central é igualmente sem precedente nessa filmografia: a perseguição aos homossexuais pelas forças repressivas, havendo o tio da diretora sido uma das vítimas nesse grupo invisibilizado nas versões dominantes sobre a violência daquele período (GREEN; QUINALHA, 2014). O segundo título é 15 filhos (Maria Oliveira e Marta Nehring, Brasil, 1996), o qual, já em 1996 - o leitor terá percebido -, repassava em seus poucos minutos os temas que ao longo dos anos ganhariam consistência no documentarismo intergeracional: a infância na clandestinidade; a perda da inocência frente à violência contra os pais; o desenraizamento do exílio; a orfandade e os desejos de reparação; o fantasma heroico dos caídos; o vazio do desaparecimento. Tratase de um vídeo breve, formalmente convencional, mas denso no teor dos testemunhos. Quando se contrapõe a exceção ao pioneirismo, é possível entrever algo das dinâmicas de conformação dos "lugares de memória" (NORA, 1984) do documentário intergeracional sobre as ditaduras do Cone Sul: os países em evidência, as experiências destacadas, as identidades mais visíveis. 


\section{Estruturas narrativas}

Resta fazer um exame das principais formas de organização dos elementos audiovisuais até aqui decompostos. Ou seja, avaliar os modos pelos quais as obras estruturam os sons, as imagens, o campo do visível, os materiais de arquivo e os tópicos rememorados.

Ora, a própria busca, por mais imponderável que possa ser, é já uma modalidade de organização da enunciação fílmica. Como ficou indicado acima, a abertura de uma obra não significa ausência de gesto formativo. Ao fim e ao cabo, é esse gesto o que faz com que um documentário específico seja uma obra, e não um aglomerado de filmagens aleatórias (ECO, 2016). Quanto a isso, Jean-Claude Bernardet (2005, p. 152) fazia um alerta desde suas formulações seminais sobre o documentário de busca: "Essa busca do passado, que em geral se diz ser uma busca de identidade, não precisa ser realizada através de um filme. Mas quando passa pelo filme, ela só funciona quando consegue se enquadrar dentro de determinadas formas narrativas."

A busca dos documentaristas é um impulso pessoal, mas também se coloca como fio condutor dos relatos, articulando um repertório próprio de figuras: 1) o mote do silêncio, do segredo ou do enigma no seio da família, variações do quebra-cabeça privado a ser decifrado pela revisão dos vestígios saídos do baú enfim reaberto e pelas perguntas que obrigam os mais velhos a falar (cf. BOSSY; VERGARA, 2010, p. 36; ORTEGA, 2008, p. 78, 2010, p. 95-96); 2) as viagens de retorno ou de descoberta rumo aos espaços significativos das histórias familiares, incluindo os lugares de origem, do exílio ou da tragédia, com seus encontros e desencontros (cf. BOSSY; VERGARA, 2010, p. 38-43; ORTEGA, 2008, p. 67-70); 3) as idas e vindas da busca, ainda no diapasão da itinerância, agora não tanto na forma de uma longa viagem para um lugar e um passado específicos, mas sim os vaivéns das investigações e hesitações do processo fílmico: os trajetos urbanos (a pé ou motorizados), a procura por endereços, as chegadas aos arquivos, às casas dos entrevistados, aos monumentos etc. (cf. LIE; PIEDRAS, 2014); 4) as entrevistas com os parentes próximos, nas configurações anteriormente discutidas. Conjugando essas figuras básicas, organizando-as em uma forma cinematográfica, o fio narrativo das buscas pode ser emaranhado ou francamente linear. Em todos os casos, há um caminho sendo percorrido, uma travessia com graus variados de risco e indeterminação.

O que chama atenção na observação ampliada do corpus é que, na maioria das vezes, a estrutura da busca se apoia na segurança da coesão narrativa. A voz over indicando sentidos, o sincronismo da banda sonora, o encadeamento das falas dos entrevistados, os usos 
naturalizados e ilustrativos dos materiais de arquivo, o passo a passo concatenado do relato: todas essas são convenções do cinema documental que servem como um corrimão discursivo ao longo da jornada das buscas pessoais. Mi vida con Carlos é um exemplo eloquente disso, uma produção esmerada que repassa cada uma das figuras da busca, todas elas confluindo harmonicamente para o encerramento do trabalho de luto do filho. Germán Berger-Hertz não está só nessa via. A esta altura já terá ficado claro para o leitor que existe toda uma caravana de títulos os quais, partindo de uma indagação pessoal, segue adiante orientada pelos padrões da tradição documentária. Justamente aqueles padrões tidos como superados pelas leituras que celebram a indeterminação formal. A decupagem minuciosa da matéria audiovisual empreendida nestas páginas contraria tal apriorismo teórico. Junto com outros recursos estéticos, a profusão de travellings nessa filmografia mapeia não tanto um labirinto, e mais um sistema de canais de expressão já bastante trafegados.

Sem dúvida, o principal desses canais é a entrevista. As situações dos diálogos, os enquadramentos e as implicações interpessoais apresentam variações, claro, mas a configuração predominante é a das "cabeças falantes". Não se trata apenas de uma aparência convencional. Neste ponto da argumentação, o que está em debate são os impulsos estruturantes na articulação das falas dos entrevistados: a fragmentação dos depoimentos individuais em função do relato fílmico, o coral de vozes editado de forma coesa, com os blocos temáticos progredindo linearmente. O documentário de entrevista stricto sensu é toda uma vertente nessa produção intergeracional, incluindo títulos dirigidos por filhos de militantes que optam por eludir o "eu", diluindo sua subjetividade na coletividade das vozes testemunhais da primeira e da segunda geração: 15 filhos (Maria Oliveira e Marta Nehring, Brasil, 1996); (h) Historias cotidianas (Andrés Habegger, Argentina, 2000); Panzas (Laura Bondarevsky, Argentina, 2000); Che vo cachai (Laura Bondarevsky, Argentina, 2002); Los huérfanos del Cóndor (Emilio Pacull, França / Uruguai, 2003); Nietos (identidad y memoria) (Benjamín Ávila, Argentina, 2004); D.F. (destino final) (Mateo Gutiérrez, Uruguai, 2008); El memorial (Andrés Brignardello Valdivia, Chile, 2009); La guardería (Virginia Croatto, Argentina, 2016). Esse conjunto de filmes compõe um caso à parte, diferente daquelas obras que, colocando a busca subjetiva em primeiro plano, ainda dependem de maneira substantiva do arcabouço do documentário de entrevista (cf. BOSSY; VERGARA, 2010, p. 48). Globalmente, fora desse corte mais imediatamente vinculado ao padrão coeso do documentário de entrevista, o ramo dominante do documentário de busca no corpus é constituído por híbridos estéticos, obras nas quais as convenções básicas da montagem de depoimentos alheios ainda subjazem como uma força organizadora das narrativas 
autorreferentes. Nesse campo estão alguns dos títulos centrais dessa filmografia: Papá Iván (María Inés Roqué, México / Argentina, 2000); En algún lugar del cielo (Alejandra Carmona, Chile, 2003); Diario argentino (Lupe Pérez García, Argentina / Espanha, 2006); $M$ (Nicolás Prividera, Argentina, 2007); Secretos de lucha (Maiana Bidegain, Uruguai / França, 2007); El edificio de los chilenos (Macarena Aguiló e Susana Foxley, Chile / Cuba / França / Bélgica, 2010); Abuelos (Carla Valencia Dávila, Equador / Chile, 2010); Diário de uma busca (Flavia Castro, Brasil / França, 2010); Em busca de Iara (Flavio Frederico, Brasil, 2013); Allende mi abuelo Allende (Marcia Tambutti, Chile / México, 2015); 70 y Pico (Mariano Corbacho, Argentina, 2016); El (im)posible olvido (Andrés Habegger, Argentina / Brasil / México, 2016). Em todos esses documentários de busca, a edição bem concatenada das entrevistas não é um fator residual, mas estruturante. Um eixo que agrega a constelação de recursos cinematográficos acima descrita de modo a compor um relato coeso, cujo roteiro tende a desembocar em um final alegadamente aberto.

A contradição aí fica patente, levando à seguinte pergunta: dado que a chegada ao desfecho aberto é garantida pelas trilhas da coesão fílmica, o quão indeterminados são esses documentários de busca? Seguramente, não há como anular aquela indeterminação que toca a todo produto artístico, mesmo o mais orgânico e zeloso com a univocidade: a abertura de primeiro grau distinguida por Umberto Eco (2016, p. 60, 89 e 92-93), a margem de interpretação que sempre se mantém, inclusive quando o espectador está perante uma obra "fechada", variável conforme o arcabouço cultural daquele que frui e as relações idiossincráticas que estabelece com a obra. $\mathrm{O}$ horizonte se estreita, contudo, quando se pensa nos termos de uma abertura de segundo grau: aquela programática, a indeterminação forjada já no gesto formativo da obra propriamente aberta, o convite explícito à fruição inquieta, à intervenção ativa do espectador frente à gama de sugestões simbólicas (ECO, 2016, p. 65, 8990 e 92-93).

Esses últimos casos são bem mais raros no corpus aqui estudado. Los rubios é um deles, certamente. E, em um movimento que diz muito sobre as expectativas estéticas operantes nesse campo de estudos, este que é um exemplo limite muitas vezes é projetado à condição de paradigma do documentário intergeracional. No substrato dessa projeção está atuando, novamente, o apriorismo analítico da indeterminação. Todavia, não são tantas as outras obras dessa filmografia cujas imagens podem ser lidas, com pertinência, nos termos da disjunção programática sustentada, da abertura de segundo grau descrita por Umberto Eco (2016). Essa lista incluiria En memoria de los pájaros (Gabriela Golder, França / Argentina, 2000), um vídeo experimental curto que, na tela bipartida, exibe um fluxo paralelo de imagens 
heterogêneas e pensamentos escritos, em uma dinâmica de associações livres acerca da memória dos desaparecidos. Também El tiempo y la sangre (Alejandra Almirón, Argentina, 2004), no qual o processo de busca é simbolizado pelo jogo de memória Simon (brinquedo clássico dos anos 1980, no Brasil conhecido como Genius) e as entrevistas têm seu fluxo sempre interrompido pela profusão de inserções díspares (registros de arquivo públicos e privados, trechos de desenhos animados, encenações ficcionais alusivas, sequências de imagens congeladas, o trabalho ao computador, as marcas do visor da câmera etc. - com acenos à poética videográfica de Chris Marker). Em El eco de las canciones (Antonia Rossi, Chile, 2010), mais próximo do filme-ensaio (cf. CATALÁ, 2005; FELDMAN, 2012a), a voz over vai desfiando impressões e reflexões pessoais sobre o desenraizamento do exílio frente à miríade de imagens das mais diversas origens. Cuatreros (Albertina Carri, Argentina, 2016), também na linha do filme-ensaio de arquivo, lança um verdadeiro desafio à apreensão com seu caleidoscópio de planos simultâneos e uma locução vertiginosa em over. Por fim, o caso de Orestes (Rodrigo Siqueira, Brasil, 2015) chama atenção nessa vertente mais experimental do corpus. Trata-se de um exercício explosivo que coloca frente a frente vítimas e algozes de ontem e de hoje: a filha de mãe desaparecida; o ex-militante torturado; mães e pais da periferia cujos filhos foram executados pela polícia em casos recentes de "resistência seguida de morte"; a defensora pública; o policial; a porta-voz da elite conservadora raivosa. Traumas, traições, vinganças e ódios são os ingredientes das sessões de psicodrama promovidas para o filme, ocasiões em que os personagens assumem e invertem papéis da arena social brasileira. O debate sobre direitos humanos adquire aí uma forma cinematográfica inusual, extrapolando gêneros, temporalidades e consensos sociais, escapando até mesmo às cartografias das práticas contemporâneas do documentário. No desfecho do filme, assiste-se à encenação de um julgamento que enfrenta impunidades históricas pela via do teatro grego.

Esses, sim, são exemplos minoritários que:

[...] apostam mais decididamente em um enfoque experimental em sua representação da subjetividade, diluindo ocasionalmente a armação narrativa-argumentativa do retrato e trabalhando dentro de esquemas mais próximos do cinema de vanguarda ou das práticas contemporâneas da videocriação. (ÁLVAREZ, 2005, p. 243, tradução nossa).

Ainda no âmbito das formas menos frequentes, vale tecer um comentário sobre o “modo observacional” (NICHOLS, 2010, p. 172-179) na filmografia aqui estudada. A rigor, apenas Victoria (Adrián Jaime, Argentina, 2008) está estruturado do início ao fim nessa chave (cf. APREA, 2015, p. 253). Ao longo de uma hora e vinte e cinco minutos, a câmera de 
Adrián Jaime vai seguindo discretamente os passos de Victoria Donda: suas idas a instituições de memória, sua participação em atos em prol dos direitos humanos, a viagem ao Canadá para o primeiro encontro com a avó, as visitas aos lugares marcantes da história dos pais desaparecidos, suas conversas com testemunhas mais velhas. Nesse caso, os depoimentos, fundamentais para a narrativa, não são exatamente entrevistas, mas registros recuados de diálogos nos ambientes pelos quais a filha vai perambulando, escutando mais do que falando (BERNARDET, 2003, p. 281). Já outros filmes não estão organizados globalmente segundo esse dispositivo, mas trazem passagens no modo observacional. Nietos (identidad y memoria) (Benjamín Ávila, Argentina, 2004); La quemadura (René Ballesteros, Chile / França, 2009); Cuchillo de palo (Renate Costa, Paraguai / Espanha, 2010); Os dias com ele (Maria Clara Escobar, Brasil / Portugal, 2013): estes títulos contêm lances em que a câmera, discreta e minimalista, filma atividades cotidianas dos personagens, em segmentos inseridos no fluxo de estilísticas várias.

O panorama dos modos de estruturação das narrativas vai se esboçando. $O$ documentário típico de entrevista, o das "cabeças falantes" montadas linearmente, tem uma presença relevante nessa produção intergeracional, mas costuma atrair menos o interesse da fortuna crítica. Os experimentos disjuntivos, com formas programaticamente abertas, são minoria, mas acabam adquirindo uma projeção maior nesse debate. O modo observacional é colateral, aparecendo esporadicamente na filmografia. Esquivando-se das leituras apriorísticas, a observação sistemática dos recursos estético-narrativos do corpus ampliado revela a pregnância de uma forma contraditoriamente híbrida entre o documentário de busca (supostamente aberto) e o documentário de entrevista (organicamente coeso). A indeterminação formal é um pressuposto com vasta ressonância nesse campo de estudos, mas a prática analítica mostra que esse não é um programa estético assim tão consistente nessas obras. Sem ignorar os contrapontos significativos desse cenário, um balanço final dá a ver a prevalência de estruturas coerentes, de enredos concatenados, de relatos de arcos claros (cf. APREA, 2015, p. 258-260; BERNINI, 2004; PIEDRAS, 2014, p. 165 e 192). Mesmo as marcas reflexivas da subjetividade, disseminadas nas imagens desses filmes, em muitos casos têm sua potência de choque diluída em usos naturalizados, tratando-se mais de "efeitos pontuais que dinamizam o ritmo visual ou narrativo, dentro de uma moldura geral relativamente convencional" (ÁLVAREZ, 2005, p. 241, tradução nossa). As leituras pautadas pela indeterminação têm um problema quando fazem desta uma chave interpretativa que escancara todo e qualquer documentário de busca, superdimensionando a abertura e se esquecendo dos códigos formais que alicerçam tais obras. 
Não custa esclarecer que o motor destas ressalvas não é o polemismo. Tampouco a interpretação a contrapelo da abertura dos documentários de busca poderia desembocar aqui em seu extremo oposto: a afirmação peremptória de um "fechamento" das obras. Ir na contracorrente das análises que põem toda a ênfase na indeterminação não significa anular em bloco esse horizonte. Trata-se, isto sim, de chamar a atenção para o outro polo da questão: o das formas, incluindo tanto os recursos estilísticos que se repetem com frequência no documentário intergeracional quanto a prevalência de modos coesos e orgânicos de estruturação dos relatos. Surge daí uma dialética que vislumbra as contradições entre forma e indeterminação.

Essas tensões estéticas se manifestam com vigor no hibridismo formal do documentário de busca dependente das convenções da entrevista e bem lapidado pela coesão narrativa. A pergunta de Jean-Claude Bernardet (2005, p. 146) poderia muito bem ser dirigida a Mi vida con Carlos e tantos outros títulos aqui estudados: "que documentário de busca é esse, na ocasião da montagem, quando não há mais imprevisibilidade?” Vale aqui arriscar uma resposta: é esse documentário coeso de busca, cujo repertório de figuras próprias já vai se consolidando (segredos privados, viagens de retorno, itinerâncias titubeantes), que repete uma série de artifícios cinematográficos (com destaque para a voz over em primeira pessoa, os travellings itinerantes, a presença do cineasta na tela e a revisão em plano subjetivo dos álbuns), sem se desvincular do "cacoete” da entrevista (BERNARDET, 2003, p. 285).

Essa não é uma tendência exclusiva ao documentarismo intergeracional do Cone Sul. De fato, o documentário coeso de busca, focado nas memórias familiares, contando histórias de maiores ou menores implicações coletivas, vem consolidando seus traços no documentário contemporâneo em escala muito mais ampla. Os aspectos analisados nos capítulos I e II se chocam no terreno estético-narrativo dessa cinematografia. De um lado, é possível identificar aí uma poética transnacional compartilhada, afinada com os parâmetros dos circuitos globais do documentário "de arte" (FALICOV, 2010, 2013; LEFERE; LIE, 2016, p. 13-14; MIDDENTS, 2013, p. 156-157). A homogeneização é um risco que sempre ronda as estilísticas globalizadas (HJORT, 2010). De outro, as distintas posturas assumidas pelos descendentes (do radical distanciamento reflexivo de Los rubios à linearidade da transmissão de Mi vida con Carlos) abrem um espectro plural e contrastante de elaborações intergeracionais da memória. Trazendo para o debate estético deste terceiro capítulo aquilo que foi discutido nos capítulos anteriores, há que se considerar que, na equação da dialética entre forma e indeterminação, também entram a formatação transnacional do documentário de busca (referendada pelos festivais) e o circuito de laços intergeracionais (composto por 
vetores nem sempre previsíveis). Tudo isso leva a pensar se as contingências da busca subjetiva já não se estariam transformando, paradoxalmente, na nova grande fórmula do cinema documental.

\section{Conformações da memória: matizes e contradições da primeira pessoa no documentário intergeracional}

Mas esta não pode ser ainda a conclusão do capítulo. Porque seria igualmente redutor abrir mão do apriorismo da indeterminação formal em nome de uma leitura que, no fim do percurso, decretasse o determinismo da fórmula. Em ambos os casos, as imagens acabam relegadas ao segundo plano. Todo o esforço descritivo destas páginas vai no sentido oposto: olhar para as imagens com atenção, observá-las em seus mínimos detalhes. Se Mi vida con Carlos é um exemplo impregnado dos lugares-comuns do documentário coeso de busca, o contraste com a decupagem analítica dos demais títulos do corpus joga luz sobre um panorama mais amplo e multifacetado (cf. PIEDRAS, 2014, p. 192). O jogo de escalas (GINZBURG, 2011b) entre o filme específico e a filmografia expandida deixa como saldo a visão de um fenômeno cinematográfico pleno de matizes e tensões, feito de aberturas e coesões, exceções e recorrências, inovações e convenções, temas comuns e pautas à margem, formas e fórmulas.

A argumentação nesta altura se depara novamente com o risco da "complexidade indiferente" (WILLIAMS, 2005, p. 218). Estancar aí a reflexão significaria apresentar, por outros caminhos, uma leitura alternativa, a posteriori, da indeterminação. Não se chegaria muito longe do ponto de partida do capítulo nesse caso. É para superar esse risco que esta seção conclusiva desdobrará a empreitada descritiva em uma proposta de categorização desse leque de formas. O leitor familiarizado com os estudos do documentário terá percebido que aqui se evitou, na medida do possível, empregar a clássica tipologia dos modos de Bill Nichols $(1991,2010)$. As formulações deste autor citadas esporadicamente ao longo do texto surgiram sobretudo por conta de sua operacionalidade vocabular. Ou seja, na medida em que sintetizavam a descrição de um aspecto em particular no fluxo da decomposição analítica dos filmes, e não em função de um ordenamento classificatório. Além de desgastado pelo uso quase automático que dele se faz, o esquema de Nichols traz consigo aquele mesmo problema da normatividade antes identificado nas proposições de Philippe Lejeune (1996, 2008) e Elizabeth W. Bruss (1980) (BRUZZI, 2006, p. 3-5). 
No campo de estudos mais próximo ao documentarismo aqui em pauta, alguns autores já elaboraram tipologias dedicadas a classificar as variadas facetas dessa produção. Nem tudo é apologia da indeterminação nesse debate. Existem os textos que inclusive vão além do panorama cartográfico, do passeio pelas configurações manifestas do cinema documental recente (cf. ÁLVAREZ, 2005; LABBÉ, 2012b; ORTEGA, 2008, 2010; PINTO, 2012), adentrando em um exame mais cuidadoso dos meandros da subjetividade latentes nas obras. María Luisa Ortega (2005) propõe uma arguta crítica dos "limites da experimentação" ao longo da história do cinema documental, identificando os momentos nos quais as tradições vanguardistas mantiveram sua potência disjuntiva ou foram domesticadas em função de um discurso unívoco. Quando se debruça sobre a produção contemporânea, Ortega (2005, p. 203, tradução nossa) estabelece uma distinção entre subjetividades "supostas e genuínas", tendo como horizonte a "natureza epistemológica e comunicativa da primeira pessoa e seu papel na negociação do conhecimento acerca da realidade social". A autora considera que o "eu" do documentário contemporâneo está modulado "como um instrumento de investigação e interrogação do mundo das representações e das ações sociais que nos rodeiam", questionando os outros e a si mesmo, sendo, "antes de mais nada, mediador, tradutorintérprete privilegiado que honestamente desvela seu papel”. Porém, ela alerta: “Agora, nem todos os documentários performativos ou que manejam a primeira pessoa em alguma de suas formas se movem na tensão epistemológica e reflexiva apontada [...]” (ORTEGA, 2005, p. 204, tradução nossa). Mais ainda, teria surgido mesmo uma:

[...] forma de organização discursiva renovada que pretende converter-se em hegemônica no documentário social fundado nas intervenções e inscrições pessoais dos documentaristas: o itinerário e a busca, nos quais a realização do filme e as vias seguidas pelo diretor são o eixo de articulação central. Em alguns casos, o sujeito performativo e o processo de realização que ele guia, com frequência de maneira errática, pretenderá tão somente servir como um novo agente organizador [...] (ORTEGA, 2005, p. 206, tradução nossa).

Em síntese, para Ortega, nem toda primeira pessoa é genuinamente um fator de problematização epistemológica nas indagações empreendidas pelos documentários contemporâneos. Esse "eu" pode ser também um elemento de coesão, embora supostamente hesite nos itinerários da busca. Sem dúvida, é pertinente a distinção entre essas duas modulações da primeira pessoa, mas a formulação de María Luisa Ortega não deixa de trazer consigo um risco. Afinal, a dicotomia entre subjetividades genuínas e supostas acaba anulando a dialética entre forma (os fatores de coesão, por assim dizer) e indeterminação (de um "eu” titubeante). Nas considerações de Ortega, a subjetividade suposta está mais para um 
desvio, uma deturpação da reflexividade epistemológica que caracterizaria o documentário contemporâneo. O que este capítulo vem sustentando até aqui, ao contrário, é que as ambiguidades da primeira pessoa (as idiossincrasias em série, a abertura orgânica, o imponderável roteirizado) estão no cerne do documentário de busca. A questão, portanto, não se resolve com discriminações binárias, como se fosse possível separar o joio do trigo, os filmes de subjetividade suposta daqueles de subjetividade genuína. É claro que existem títulos melhores e piores no documentarismo intergeracional, mas a compreensão do fenômeno não iria muito longe caso a análise se pautasse por esse tipo de valoração opinativa.

Existem outros textos que expandem o leque de classificações dessa produção. $O$ trabalho de Michelle Bossy e Constanza Vergara (2010) sobre os “documentários autobiográficos" chilenos dos anos 2000 está a meio caminho entre a cartografia e a tipologia. O mapeamento elaborado pelas autoras identifica muitos dos recursos do repertório estéticonarrativo acima elencados, contribuindo para o debate nesse campo de estudos. Os recortes nos quais Bossy e Vergara agrupam as obras chilenas operam uma gradação de escalas intersubjetivas e temporais. Elas separam os documentários entre "relatos do presente", "retratos familiares" e "trabalhos da memória". Os títulos do documentarismo intergeracional chileno aqui abordados se concentram neste último tipo. A exceção é La quemadura, localizado como um retrato familiar, sendo nele a questão histórica, de fato, mais tangencial. Entretanto, como ficou antes discutido, essa filmografia intergeracional elabora a memória da ditadura dando a ver, de modo indissociável, retratos familiares. A tarefa de classificação costuma mesmo ser ingrata, as sobreposições sempre desafiarão os agrupamentos sugeridos, mesmo quando se professe, como o fazem as autoras, uma noção dinâmica de gênero cinematográfico (BOSSY; VERGARA, 2010, p. 7). Contudo, fica a impressão de que, nesse caso em particular, a gradação das escalas - e não propriamente um jogo recíproco - do indivíduo/presente subindo para a família/genealogia até chegar à geração/história tampouco dá conta da complexidade manifesta nesse panorama. Ao adotarem como eixo da categorização o "documentário autobiográfico" seguindo essa ampliação gradativa das relações entre os sujeitos no tempo, Bossy e Vergara acabaram deixando em segundo plano certos entrecruzamentos fundamentais entre indivíduo, família, geração, presente, genealogia, memória e história.

O tópico da gradação anuncia a lógica operando no substrato de outras tipologias propostas na bibliografia específica. Primeiro, a de Laia Quílez Esteve (2009). Em seu trabalho de fôlego e, sem dúvida, incontornável sobre o "cinema documental argentino de segunda geração", a análise da filmografia se subdivide de acordo com as modalidades de 
memórias identificadas pela autora. De saída, estão as "pós-memórias solapadas", categoria que agrega os documentários cujas diretoras não são filhas de vítimas das ditaduras. Nesses casos, segundo Esteve (2009, p. 306, tradução nossa), a "pós-memória [...] se apresenta aos olhos do espectador como algo velado (e às vezes apenas insinuado)". A palavra "solapada" tem este sentido nessa primeira adjetivação da rememoração: o de uma aproximação oblíqua, tangencial, que não toca o assunto de maneira patente, "talvez devido ao fato de que nenhuma das quatro realizadoras viu desaparecer algum de seus pais, tampouco teve que abandonar o país por medo dos militares [...]” (ESTEVE, 2009, p. 307, tradução nossa). Após descrever essa espécie de antessala da "pós-memória", Laia Quílez Esteve (2009, p. 342, tradução nossa) analisa os documentários de filhos de vítimas que ela agrega sob a categoria "pósmemórias em terceira pessoa". Aí estão contemplados os exemplos nos quais os realizadores “optaram por mascarar em seus trabalhos fílmicos suas respectivas vivências atrás da neutralidade aparente da terceira pessoa, isto é, a voz do 'outro"” (ESTEVE, 2009, p. 343, tradução nossa). Formalmente, estes são documentários de entrevista nos quais “a polifonia de vozes, solilóquios, argumentos e confissões que os compõem se enquadram, em sua ampla maioria, em uma mesma tonalidade: aquela que caracteriza o sentimento coletivo" da geração dos filhos de desaparecidos (ESTEVE, 2009, p. 344, tradução nossa). A terceira subdivisão de Esteve (2009, p. 388, tradução nossa) refere-se às "pós-memórias sepulcrais", reunindo obras que, às voltas com o luto desde o emotivo e o íntimo, "levam a cabo um trabalho de sentida e profunda introspecção". Trata-se de documentários "explicitamente subjetivos que giram em torno de uma transmissão transgeracional que não pode se desvincular da violência institucional nem do trauma” (ESTEVE, 2009, p. 390, tradução nossa). O quarto e último tipo analisado por Laia Quílez Esteve (2009, p. 420, tradução nossa) é definido como "pósmemórias indignadas". Nessa fronteira, as indagações fílmicas se radicalizam, a enunciação em primeira pessoa é contundente, o sujeito se fragmenta "para se converter em um 'eu' poliédrico e vicário cujo corpo - ferido por uma falta irreparável e, de certo modo, para ele inexplicável - sobrepõe-se - com frequência de forma conflituosa - ao corpo ausente intangível, mas indelével - do desaparecido" (ESTEVE, 2009, p. 429, tradução nossa). Passo a passo, a tipologia de Laia Quílez Esteve parte da não vivência e vai para a experiência própria mascarada detrás da coletividade; daí, cruza o luto carregado de emotividade para alcançar, no polo extremo, as indagações cindidas e indignadas. No fundo, essa classificação dos documentários intergeracionais segundo as modalidades de rememoração, embora esclarecedora, não deixa de estabelecer uma espécie de régua do grau de envolvimento subjetivo dos diretores, escalonada entre o tangencial, o ocultado, o sentimental e o pungente. 
Algo análogo ocorre na "taxonomia da primeira pessoa" elaborada por Pablo Piedras (2014, p. 77-81). Na bibliografia voltada ao Cone Sul - neste caso em particular, o recorte é o cinema documental em primeira pessoa argentino, incluindo os títulos intergeracionais, mas não restrito a eles -, o livro de Piedras traz uma das propostas mais arrojadas de categorização das modulações da subjetividade na produção contemporânea. Com efeito, em um campo de estudos demasiado fértil para o vocabulário da indeterminação formal, chama atenção que o autor reivindique expressamente a elaboração de uma "taxonomia", assim denominada. Muitos dos problemas discutidos nas páginas anteriores já estavam aí apontados, notadamente, ecoando María Luisa Ortega (2005), a possibilidade de as formas de inscrição da primeira pessoa se consolidarem em uma fórmula discursiva desprovida de potência reflexiva (PIEDRAS, 2014, p. 31, 80-81, 98, 155, 165, 192). Em sua "taxonomia", Piedras (2014, p. 77, tradução nossa) distingue “a existência de três modalidades nas quais a intervenção do realizador em primeira pessoa se plasma no cinema documental, tendo em conta a proximidade entre o objeto do discurso e o sujeito a quem se atribui este discurso". A primeira dessas três modalidades descritas pelo autor é a autobiográfica, com filmes "nos quais se estabelece uma proximidade extrema entre o sujeito e o objeto do relato", "nos quais a primeira pessoa se encarna na narrativa fílmica como uma identidade em crise e/ou em processo de introspecção e questionamento". Quanto aos dispositivos narrativos dos documentários autobiográficos, o autor considera que "a experimentação costuma ser a opção formal apropriada quando a experiência é a matéria discursiva da obra". Los rubios, de modo mais radical, mas também $M$ e Papá Iván são localizados dentro dessa categoria autobiográfica (PIEDRAS, 2014 p. 77-78, tradução nossa). A segunda modalidade é denominada "experiência e alteridade", quando "se produz uma retroalimentação entre a experiência pessoal do realizador e o objeto do discurso, percebendo-se uma contaminação entre ambos os níveis" (PIEDRAS, 2014, p. 78, tradução nossa). A terceira e última espécie de documentários delineada na "taxonomia" de Pablo Piedras (2014, p. 80, tradução nossa) é a "epidérmica", abrangendo os exemplos nos quais "o eu do cineasta é, em geral, uma presença desencarnada ou vinculada externamente com a história que se conta". O autor prossegue: "Não é simples discernir nessas obras se o objeto do discurso é uma mera escusa para a exibição da personalidade do realizador ou se a primeira pessoa é realmente essencial para contar uma história determinada, e não outra." (PIEDRAS, 2014, p. 80, tradução nossa).

Pois bem, esta exposição das categorizações previamente elaboradas na bibliografia sobre o documentário subjetivo no contexto do Cone Sul justifica-se por dois motivos a esta altura da argumentação. Primeiro, porque elas apontam problemas fundamentais discutidos 
até aqui, as oscilações da primeira pessoa, as posturas ora reflexivas, ora coesas, ora banalizadas. O diálogo com esses textos sem dúvida ilumina a decupagem do repertório estético-analítico acima empreendida. Entretanto - e aqui se chega à segunda razão destas longas citações -, ainda que o teor geral dessas formulações seja pertinente, há que se ressaltar a diferença basilar entre a lógica orgânica subjacente a essas tipologias e o impulso dialético que vem guiando as reflexões desde as primeiras páginas deste capítulo. Não é menor a distinção entre um prisma gradativo, que vai aferindo os níveis de "profundidade" da primeira pessoa, de um lado, e, de outro, uma abordagem que considera a ambiguidade instaurada no núcleo de toda e qualquer enunciação em primeira pessoa. Quando se fala em subjetividades genuínas ou supostas (ORTEGA, 2005); quando se opera um escalonamento gradual entre indivíduo, família e geração (BOSSY; VERGARA, 2010); ao se distinguir as memórias nos termos do tangencial, do mascaramento, da emotividade e da contundência (ESTEVE, 2009); quando a "taxonomia" (e esta palavra já traz, em si, uma conotação de organicidade) descreve as relações entre sujeito e objeto de acordo com a autorreferência, a intersubjetividade ou os nexos superficiais (PIEDRAS, 2014); frente às tipologias guiadas por tais critérios, é difícil não enxergar uma hierarquização orgânica das posturas da primeira pessoa no cinema documental. Em todos esses casos, existe uma escala estéticoepistemológica, uma régua imaginária que vai das formas inquietas às versões apaziguadas, do âmago à epiderme do "eu". Nesses termos, as subjetividades discutíveis (supostas, solipsistas, mascaradas ou epidérmicas) são como que imposturas, abusos, esquivas, banalizações em relação ao grau zero da "verdadeira" enunciação em primeira pessoa. Em suma, tais sintomas da enunciação subjetiva acabam sendo diagnosticados como efeitos colaterais, ressalvas, e não contradições constitutivas. ${ }^{90}$

Bem diferente é a perspectiva que vem sendo adotada até aqui, a qual encara esses problemas como algo instaurado no núcleo estético do documentário subjetivo, seja ele efetivamente introspectivo ou evidentemente frívolo. Essa dialética revela também a contradição interna às próprias tipologias orgânicas. Afinal, se, por um lado, é verdade que os autores citados avançam o debate para além da mera apologia da indeterminação, propondo categorizações que delineiem esse terreno; por outro, não deixa de haver nas gradações descritas a tendência à valoração das modalidades mais indeterminadas do documentário em primeira pessoa. Os "verdadeiros" documentários em primeira pessoa, aqueles nos quais a

\footnotetext{
${ }^{90}$ Nas argumentações de María Luisa Ortega (2005, p. 204) e Pablo Piedras (2014, p. 80 e 98), essa tendência de ver as formas mais superficiais da subjetividade como um problema extrínseco manifesta-se ainda na crítica da importação de modelos televisivos (notadamente, a figura do repórter que conduz in loco a investigação) para o cinema documental contemporâneo.
} 
"autobiografia" é "genuína" e "indignada", seriam os que trazem a marca formal da experimentação. Seguindo essa lógica, quanto mais entranhada a subjetividade, maior o grau de abertura da obra. Em outras palavras, as tipologias orgânicas dão um passo além da simples celebração da indeterminação, mas não chegam a significar uma superação de seus termos. Nenhuma dessas categorizações chega a ser normativa, mas é possível identificar nelas uma escala valorativa na qual seguem atuantes as leituras da indeterminação formal. Na "régua" da subjetividade, as obras mais hesitantes, mais abertas, mais experimentais sempre levam vantagem na comparação com os modos assertivos, coesos, convencionais - isto é, “superficiais". É curioso pensar que essas tipologias delimitam modalidades no panorama do documentário subjetivo para valorar aquelas mais indeterminadas e fazer ressalvas às mais fechadas. E que o parâmetro de valoração adotado (justamente, o impulso à indeterminação), em princípio, soaria contrário a qualquer esforço de categorização.

Vale esclarecer que essas críticas passam longe de fazer tábula rasa das tipologias previamente elaboradas. Tais formulações são seminais nesse debate, e a quantidade de referências a esses autores incluídas ao logo deste trabalho é um franco reconhecimento disso. Mantendo esse diálogo, cabe aqui, porém, levar adiante um esforço próprio de releitura dessas categorias de modo a superar as fragilidades da lógica orgânica. De manter operante, enfim, uma perspectiva dialética que não abre mão de identificar as contradições internas a cada modulação discursiva. No fundo, o limite fundamental das tipologias orgânicas é que um dos modos, aquele localizado no polo mais extremo da indeterminação, paradoxalmente, costuma equacionar as ambiguidades da expressão subjetiva. Como se existisse um grau zero da enunciação em primeira pessoa, um ponto ótimo no qual a cisão do "eu" atingisse sua plenitude - uma plenitude que levaria à negação dessa mesma cisão. Aqui, a proposição tipológica busca manter sempre presente o horizonte das problematizações. Trata-se de examinar, afinal, quais as tensões em jogo nas diferentes posturas estético-epistemológicas que a primeira pessoa assume na mobilização do repertório estilístico antes descrito.

Começando pela primeira pessoa testemunhal. A profusão de entrevistas no documentário intergeracional torna imprescindível pensar sobre esse sujeito que diz "eu" para dar testemunho de um passado vivido (RICCEUR, 2007; SARLO, 2007). Esse não é um lugar de enunciação menor nessa filmografia, como se pôde ver. Nesses casos, abundantes, a primeira pessoa que relata é um terceiro (um outro filho, um parente próximo, um exmilitante, mesmo um perpetrador etc.), alguém que fala para a câmera, que compartilha com o cineasta (e com o espectador) suas experiências, dentro de uma relação intersubjetiva que varia dependendo do interlocutor e da postura assumida pelo documentarista (PIEDRAS, 
2014, p. 208-234). Tal diálogo, como já ficou detalhado nas análises fílmicas, pode assumir diferentes configurações, das convenções mais básicas do documentário de entrevista à explicitação das "co(i)mplicações" da "etnografia doméstica" (RENOV, 2004a, p. 218, tradução nossa). A questão de fundo aqui diz respeito à tensão entre a subjetividade da testemunha e a do diretor. Afinal, a moldagem dessas vozes alheias ocorre em função de um discurso fílmico cuja concatenação depende em grande medida das opções do realizador no momento da edição. Sujeitas à fragmentação e à rearticulação, as vozes dos entrevistados entram nos documentários na encruzilhada entre o relato pessoal e a fala apropriada, o testemunho e a ventriloquia.

Essa encruzilhada remete ao segundo lugar de enunciação identificado na produção intergeracional: a primeira pessoa coesa. Isto é, quando o "eu" conduz um relato linear e bem-acabado, impondo-se como fonte de univocidade, em geral fazendo um uso narrativo das hesitações, com titubeios que entram na composição de uma trama que avança sem percalços. Mi vida con Carlos é um representante eloquente dessa tendência, uma das mais salientes no panorama aqui discutido. A contradição estético-epistemológica básica dessa postura é aquela já examinada na descrição do documentário coeso de busca: a abertura da indagação subjetiva termina encaixada em uma estrutura formal que fecha as pontas da história.

Diferente é o caso da primeira pessoa ornamental: nesses exemplos, ao invés da centralidade do "eu" como núcleo organizador do relato, ocorre uma impostação da voz subjetiva. Os traços da primeira pessoa surgem nas imagens como pinceladas, uma roupagem ao gosto contemporâneo que tenta travestir a forte dependência das convenções da entrevista. Marighella (Isa Grinspum Ferraz, Brasil, 2011), por exemplo, constrói-se nessa chave, com a voz da sobrinha fazendo digressões esporádicas acerca de suas memórias infantis do "tio Carlos", no fundo apenas demarcando uma narrativa biográfica (e hagiográfica) clássica, carregada de entrevistas e imagens ilustrativas (SELIPRANDY, 2016). A complicação aqui é que a primeira pessoa do cineasta sequer chega a constituir um lugar de enunciação. A fórmula estética prevalece sobre o impulso epistemológico, as marcas da introspecção se diluem em um verniz à la mode.

Também existe uma primeira pessoa narcísica nesse documentarismo: nesse caso, mais do que um ornamento, o "eu" do documentarista é o centro das atenções. Francis Vanoye (2006, p. 106-110, tradução nossa) sugere uma distinção esclarecedora nesse terreno: enquanto a empreitada autobiográfica é uma "busca de si" (pressupondo introspecção, perspectiva temporal, questionamento da unidade do sujeito, confronto com os outros e com o mundo), a empreitada narcísica seria "pura presença" (confirmando a unicidade corporal, 
negando o tempo, reduzindo os outros a espectadores, concentrando atenção na imagem própria como via de acesso à intensidade emocional e, ao mesmo tempo, estabelecendo uma ruptura com os outros e o mundo). Tal diferenciação proposta por Vanoye serve aqui como antídoto contra dois mal-entendidos que podem surgir quando se fala em narcisismo nesse contexto de debate. Primeiro, a confusão reducionista que vê em toda enunciação autorreferente uma pulsão ególatra. Segundo, a desqualificação simplória do narcísico como desvio abusivo (outro efeito colateral) da visada subjetiva desse documentarismo (VANOYE, 2006, p. 105-106 e 114). Nenhuma dessas opiniões ajuda a enxergar a fronteira, sempre tênue, entre a primeira pessoa como lugar reflexivo de enunciação, de um lado, e, de outro, a inflação do ego. Mais frutífero é "considerar aqui o narcísico e o autobiográfico sem defender um em detrimento do outro, enquanto processos de criação distintos que se articulam segundo processos distintos de consumo e de fruição dos filmes." (VANOYE, 2006, p. 106, tradução nossa). Em outras palavras, trata-se de considerar a forma narcísica como uma das posturas possíveis no documentário intergeracional, e não um contraexemplo, uma excrescência. Elena (Petra Costa, Brasil, 2012) destaca-se nesse sentido. No recorte brasileiro do corpus, este foi o título com mais público em salas de cinema e cuja recepção crítica foi das mais calorosas, por parte de nomes de peso da cena intelectual local (GUTFREIND; BARONE, 2015, p. 284; TERRON; LAUB, 2014). Ao mesmo tempo, as imagens de Elena deixam patente o modo como a cineasta se projeta nos passos da irmã para espelhar sua própria trajetória artística. Esse exemplo dá uma ideia do lugar da primeira pessoa narcísica na intrincada dinâmica de contradições em jogo: aí, o "Eu” que enuncia se sobrepõe a qualquer impulso epistemológico. É uma subjetividade que "não se coloca, no fundo, outra questão a não ser a da possibilidade do reflexo e de sua perenidade.” (VANOYE, 2006, p. 108, tradução nossa).

A primeira pessoa indiscreta acarreta outros problemas. Aqui não se trata da projeção de si mesmo, mas da exposição desmedida do outro, fazendo com que o espectador "se sinta um intruso, violentando a intimidade ou a memória de pessoas até então desconhecidas" (ÁLVAREZ, 2010a, p. 140, tradução nossa). A figura do segredo familiar, as entrevistas com parentes próximos, eis os elementos que podem dar margem para uma invasão de privacidade endógena. Em Allende mi abuelo Allende (Marcia Tambutti, Chile / México, 2015), é difícil escapar de uma sensação de mal-estar diante das entrevistas que a neta faz com a avó “Tencha". O espectador vê Hortensia Bussi, aos 92 anos, deitada na cama de pijama, com a voz fraca, respirando com o auxílio de aparelhos, a memória escassa (fig. 55). Ao seu lado, Marcia Tambutti pergunta, entre outras coisas, como ela lidava com as relações extraconjugais de Salvador Allende. Em outra situação de entrevista, a avó está composta, 
arrumada, sentada em uma cadeira. A neta, porém, mantém o tom, agora mostrando a ela fotografias da tia "Tati”, Beatriz Allende, a filha que se suicidara no exílio cubano em 1977. Hortensia Bussi alega que não consegue enxergar as fotos, interrompendo a entrevista. Logo no início do documentário, a avó já havia dito que a neta fazia perguntas difíceis. Fica para a audiência a dúvida: Seriam perguntas difíceis ou indiscretas? Uma memória privada incômoda deve necessariamente ser alvo de uma pergunta inconveniente a ser exibida para um público? A questão se agrava quando o "outro" da família é uma pessoa fragilizada (pela senilidade, pela doença). Em menor medida, o espectador também acaba se sentindo um intruso nos segmentos de Tiempo suspendido (Natalia Bruschtein, México / Argentina, 2015) em que a neta registra a avó em sua intimidade no quarto do asilo para idosos, ao despertar, sendo penteada, comendo, tomando remédios. A questão fundamental nesses casos diz respeito à responsabilidade de se evitar que o parente (tanto mais quando vulnerável) seja exposto em um grau eticamente questionável (RUBY, 1988a). De não fazer do segredo familiar o objeto de um voyeurismo invasivo, descolado do trabalho de rememoração com maiores ressonâncias coletivas.

A primeira pessoa reflexiva tampouco está imune às contradições. A subjetividade que se questiona a si mesma, que suspeita do alcance da memória, que recusa as asserções, que se expressa pela via da desconstrução do discurso: tais são as características em geral tidas como garantias contra os curtos-circuitos estéticos e epistemológicos recém-elencados. A introspecção incansavelmente problematizante de Los rubios (Albertina Carri, Argentina, 2003) desponta nesse cenário como um exemplo "paradigmático", como ficou comentado. Ora, é difícil não enxergar já nessa projeção uma primeira tensão: a paradoxal transformação de uma obra radicalmente desconstrucionista em modelo do documentário intergeracional. A elevação de Los rubios à categoria de padrão da subjetividade genuína, indignada, autobiográfica etc., no limite, acaba neutralizando a inquietação programaticamente aberta desse documentário. Mas há também uma segunda contradição, interna à própria obra e com ecos em sua vasta fortuna crítica. O ímpeto reflexivo de Los rubios coloca questões contundentes à memória intergeracional, porém, no final do percurso, o espectador termina privado de uma imagem, fugidia que fosse, dos pais desaparecidos de Albertina Carri. A ausência é irreversível, nenhuma imagem seria capaz de repará-la. Mas houve quem contrastasse essa subtração da imagem dos pais à multiplicação da persona da cineasta na tela, vendo aí um traço de frivolidade (KOHAN, 2004a) - e inaugurando uma frutífera polêmica (AGUILAR, 2010, p. 175-191; BERNINI, 2004, p. 45-48; PIEDRAS, 2014, p. 202; SARLO, 2007, p. 102-113). É curioso que a análise de Martín Kohan (2004a), uma das 
primeiras leituras mais detidas do documentário de Albertina Carri, tenha enxergado nesse filme não uma subjetividade "profunda", mas a celebração da aparência. Em suma, o exemplo de Los rubios ilumina as antinomias latentes mesmo nas formas aprimoradas de desconstrucionismo subjetivo (o oximoro é intencional). Novamente, não se trata aqui de desqualificar uma obra em particular, mas de entrever as contradições que tocam a cada uma das posturas que a primeira pessoa pode assumir no documentário intergeracional. Nesse caso, vale estar atento ao risco de a reflexividade ficar presa a um formalismo autossuficiente, colocando a estética do fracasso acima de uma abertura efetiva para a rememoração.

Pois bem, após a explosão dos recursos do repertório estilístico promovida pela decupagem analítica do corpus, esta categorização das posturas da primeira pessoa surge como uma orientação para o exame dos modos de articulação daquela miríade de signos cinematográficos. Umberto Eco (2016, p. 50) já escreveu que as formas artísticas bem podem ser vistas como metáforas epistemológicas. No contexto deste capítulo, trata-se de refletir sobre as configurações estéticas identificáveis nessa filmografia à luz dos impulsos epistemológicos dos sujeitos da rememoração. Se, por um lado, é vasto o universo dos artifícios de linguagem do documentário intergeracional, com novidades e permanências, aberturas e fórmulas em constante fricção; por outro, tratando-se de uma produção memorialística, a primeira pessoa está sempre atuando como núcleo organizador, uma espécie de força gravitacional nessa constelação audiovisual. Esse "eu" da rememoração direciona os significados a partir de diferentes lugares epistemológicos: do testemunho à coesão, do ornamento ao narcisismo, da indiscrição à reflexividade. Em cada um deles, não são poucas as tensões. A primeira pessoa sempre assume riscos na mobilização do repertório formal.

Delineia-se, afinal, uma tipologia estético-epistemológica do documentarismo intergeracional. Uma classificação que está em franco diálogo com outros esforços já empreendidos, substituindo, contudo, a lógica orgânica pelo prisma dialético. Esse prisma constantemente problematizante serve aqui, adicionalmente, como antídoto contra a normatividade. Multifacetado, contraditório, o documentário intergeracional não chega a constituir um gênero cinematográfico - mesmo que se adotasse um conceito dinâmico de gênero (MOINE, 2003). Ele comporta distintas tendências formais, ligadas a tradições diversas do documentário, nuances, paradoxos e pregnâncias que ganham contornos nas inflexões da primeira pessoa acima elencadas. Falar em tendências e inflexões é indicar princípios heurísticos voltados a conduzir a análise e identificar encruzilhadas, e não estabelecer tipos rígidos e estanques. Apresenta-se aqui um guia indicativo, fruto da observação do corpus, e não uma tabela classificatória predeterminada. De modo algum se 
pretende encerrar aí o debate. Sendo coerente com a dialética entre forma e indeterminação que vem pautando todo este capítulo, tais delineamentos conceituais buscam manter a discussão em aberto, embora já não perdida no labirinto da apologia da indeterminação.

Emerge no horizonte a questão das conformações da memória. A codificação das marcas da abertura reflexiva no documentário contemporâneo era a questão subjacente à discussão promovida nestas páginas. ${ }^{91}$ No caso da produção aqui estudada, essa antinomia não diz respeito apenas ao terreno estético. A tensão aí latente tem ressonâncias na arena social de rememoração dos anos autoritários. Mais especificamente, esses novos códigos da subjetividade de filhos, sobrinhos e netos trazem consigo novos - e não tão novos assim "lugares de memória" (NORA, 1984). A palavra "conformação" deve manter aqui sua polissemia: de um lado, ela quer ressaltar as formas renovadas que a memória das ditaduras do Cone Sul vai assumindo nesse documentarismo (os impactos da repressão sobre a infância, as buscas identitárias das jovens gerações, as perdas familiares indissociáveis das derrotas políticas, as ausências íntimas e os fantasmas heroicos, as fricções entre afetos e utopia); de outro, ela alerta para o risco de essa memória intergeracional se conformar dentro de determinadas fórmulas, resultando em uma atualização dos "enquadramentos" da memória (POLLAK, 1989).

\footnotetext{
${ }^{91}$ Para outros diagnósticos nesse sentido, além dos já discutidos mais detidamente neste capítulo, cf. APREA, 2015, p. 258-260; BERNINI, 2004; FELDMAN, 2012a; LABBÉ, 2012 b.
} 


\section{CAPÍTULO IV}

\section{APORIAS E APOSTAS do REPRESENTÁVEL}

A apologia da indeterminação formal tem como substrato teórico a pauta do irrepresentável. O desfecho do capítulo anterior já sinalizava as implicações epistemológicas das opções estéticas identificadas no documentarismo intergeracional. Chega o momento de encarar esse tema, levando a discussão para a problemática dos nexos entre representação e referencialidade. Consciente das aporias visíveis na filmografia aqui estudada, esta análise não abre mão de levar a interpretação para o terreno das apostas do conhecimento (GINZBURG, 2011b, p. 276). É nesse sentido que este capítulo propõe uma intervenção no debate em defesa da possibilidade de se dizer algo sobre o passado e o presente dos filmes, algo de tangível que supere o abismo do irrepresentável. A ideia é construir pontes, mesmo que provisórias, entre a representação e o referente, em um esforço para vislumbrar a densidade histórica das imagens dos documentários intergeracionais. Afinal, após a "perda da inocência" epistemológica (DIDI-HUBERMAN, 2012, p. 132), os impasses da representação são o ponto de partida de qualquer análise, mas não necessariamente devem ser o ponto de chegada. No fundo, essa agenda não deixa de ser também uma última reivindicação da especificidade do olhar historiográfico nesse campo de estudos.

\section{O abismo do irrepresentável: variações em torno de uma cadeira vazia}

Nesta reta final do trabalho, as reflexões se debruçarão sobre um único título: Os dias com ele (Maria Clara Escobar, Brasil / Portugal, 2013), no qual as entrevistas da filha-diretora com o pai, o filósofo, dramaturgo e ex-militante Carlos Henrique Escobar, transformam-se em uma queda de braço pelo controle do filme, uma acirrada disputa pelo retrato a ser construído, reverberando um passado e um presente de desencontros políticos e familiares. Em termos formais, esta obra em particular é extremamente simples: a filha com sua câmera filma o pai dentro de casa, com golpes de zoom abruptos, enquadramentos desajeitados, "caseiros", seguindo uma fatura fílmica muito próxima do cinema amador (ÁLVAREZ, 2010a; ODIN, 2010); os momentos supostamente anteriores e posteriores às entrevistas propriamente ditas são mantidos na edição final; a voz over da diretora só se manifesta esporadicamente, acompanhando algumas das inserções de filmagens amadoras em super-8 de famílias alheias, 
sem que aquela voz carregue a narrativa, sem que estes arquivos sobrecarreguem a tela; não há trilha sonora incidental extradiegética; nada de travellings, tampouco legendas ou intertítulos. No limiar da precariedade estilística, despojado dos bem-acabados artifícios (ou vícios) cinematográficos do documentário contemporâneo, Os dias com ele teria tudo para ser mais "um filme que você liga a câmera e coloca um entrevistado na frente" (BERNARDET, 2003, p. 286).

Mas não é esse o caso. Pois é justamente o flerte com o precário que faz com que a entrevista nunca seja asséptica nesse documentário. Ela traz consigo todos os ruídos do processo de filmagem, junto com as tensões entre campo e "antecampo" (BRASIL, A., 2013). O espectador tem diante de si as disputas escancaradas entre a cineasta (a filha que pena para dirigir seu filme) e o entrevistado (que jamais renuncia à autoridade patriarcal e intelectual). É dessa fricção que surge o interesse de Os dias com ele. A persona fílmica de Carlos Henrique Escobar insiste em se impor com sua arguta inteligência, ao mesmo tempo ranzinza e espirituosa. Maria Clara Escobar vai revelando aos poucos os sutis poderes de uma ingenuidade astuta. A montagem de Júlia Murat e Juliana Rojas, outro ponto forte do filme, organiza esse cabo de guerra de modo a que os vaivéns das rusgas nunca soem maçantes.

Tudo isso fez com que Os dias com ele fosse calorosamente acolhido nos círculos especializados, desde que despontou no panorama cinematográfico brasileiro. Logo de entrada, em janeiro de 2013, ele foi premiado na Mostra de Cinema de Tiradentes como melhor filme da seção Aurora, tanto pelo júri da crítica quanto pelo júri jovem. Depois vieram as análises em congressos e artigos acadêmicos, em abordagens monográficas ou comparativas. Não por acaso, é de uma de suas falas que derivou o título da mostra "Silêncios históricos e pessoais", ocorrida na capital paulista entre março e abril de 2014, a qual teve um importante papel na divulgação de documentários latino-americanos dessa vertente (BARRENHA; PIEDRAS, 2014).

Mais que todas as características acima descritas, uma passagem do filme em particular atraiu sobremaneira as atenções: aquela em que a diretora, tendo armado o quadro para que seu pai lesse, sentado em uma cadeira junto ao muro do quintal, o mandado de prisão expedido pelos militares contra ele em 1973, tem de lidar com a recusa veemente de Carlos Henrique Escobar. A câmera fixa o aguarda. Ele entra no campo e pega a cópia do documento sobre a cadeira. Percebendo logo do que se tratava, vai de encontro à câmera, contra a filha atrás da câmera, devolvendo-lhe a papelada. Indignado, ele diz: "Eu não preciso disso, preciso?" A voz de Maria Clara vem dos bastidores: "Não, eu quero que você leia.” O corpo dele de início vai se movendo colado à objetiva, até que sai de vez do campo. Começa então 
uma dura discussão invisível entre os dois, em off. Na tela, resta a cadeira vazia, em um longuíssimo plano (fig. 188). O espectador vai ouvindo as vozes que surgem de fora do campo: o pai se recusa a conceder a palavra a seus algozes por meio daquele documento oficial da ditadura; questiona com aspereza o projeto fílmico da filha, querendo saber quem é o verdadeiro retratado, se ele ou ela; refuta o papel de "meu papai", dizendo que a filha desconhece sua importância. Maria Clara reage como pode: diz que aquele é, sim, um filme sobre seu pai e seu país; retruca afirmando que não está em uma posição confortável naquelas filmagens. Carlos Henrique dá a discussão por encerrada, cruza o quadro e deixa a filha só detrás da câmera. A cena pensada pela diretora não se realizará. Ainda assim, em um gesto de desobediência, ela sai dos bastidores, invade o quadro, senta-se na cadeira e lê o mandado de prisão.

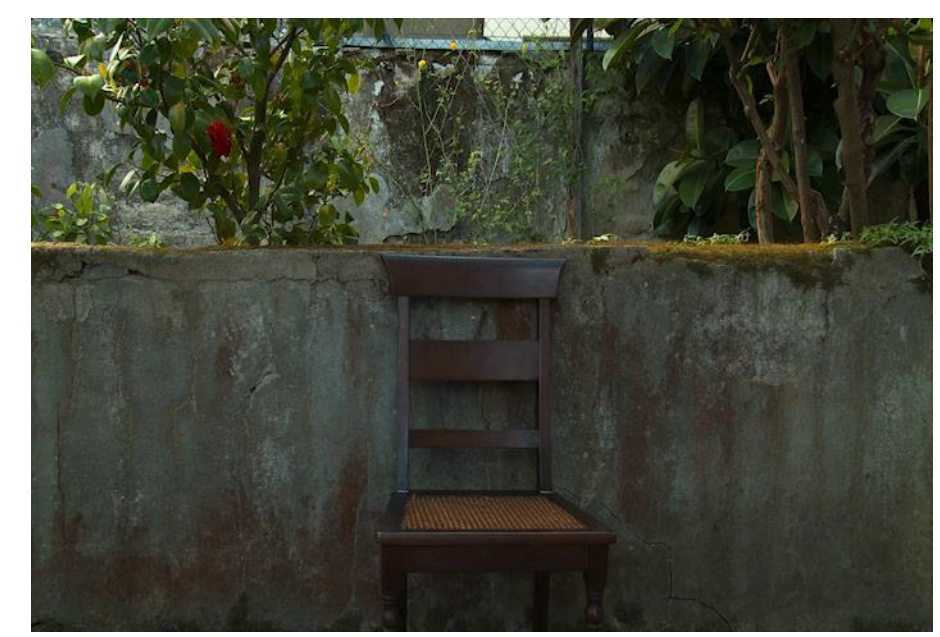

Figura 188 - A cadeira vazia, fotograma reproduzido com recorrência nas análises desse documentário. Fonte: Os dias com ele (Maria Clara Escobar, 2013).

O revés da reconstituição. O vazio da imagem. Essa passagem específica de $O$ s dias com ele parece concentrar as premissas centrais da ideia de irrepresentável, matriz teórica que permeia a bibliografia dedicada ao documentário intergeracional sobre as ditaduras do Cone Sul. Tendo atraído tanta atenção no contexto brasileiro, é como se essa cadeira vazia fosse o emblema de algo bem maior: as ausências no núcleo das rememorações elaboradas na cinematografia dos descendentes de militantes vítimas do autoritarismo na região. Aquela cadeira em particular é elevada, no limite, a símbolo de uma lacuna constitutiva, de um abismo intransponível entre memória e passado, entre linguagem e realidade. A crise epistemológica reveste-se aí com a dramaticidade da experiência traumática. As aporias se sobrepõem, o referente histórico não cabe nas representações. 
Esse é um longo debate. Remontando aos combatentes emudecidos que voltavam das trincheiras da I Guerra Mundial, passando pelas tentativas de elaboração da Shoah, o irrepresentável é um conceito-chave nos estudos da memória de experiências extremas, estendendo-se às ditaduras do Cone Sul (BENJAMIN, 1994, p. 114-115; SARLO, 2007, p. 23-44). Algumas das polêmicas acerca dessa pauta se tornaram célebres, seus termos se difundiram e seguem vigentes em contextos analíticos variados - incluindo a fortuna crítica sobre o documentarismo intergeracional -, as questões levantadas estão longe de terem sido superadas (cf. HUYSSEN, 2014, p. 13). O fogo cruzado sobre o irrepresentável vem de distintos lugares de saber, dos estudos literários, da filosofia, das reflexões sobre as imagens, da historiografia. Nomeadamente, no campo historiográfico, ressalta-se a discussão travada entre Carlo Ginzburg (2011e) e Hayden White (1992a) em torno dos "limites da representação" (cf. RICCEUR, 2007, p. 261-274). No terreno das imagens, é central a controvérsia sobre o "inimaginável” levada adiante por Georges Didi-Huberman (2012) com Claude Lanzmann e seus seguidores - Gérard Wajcman e Élisabeth Pagnoux (cf. FELDMAN, 2016a). No âmbito da estética, cabe evocar as refutações da "hipérbole especulativa do irrepresentável” formuladas por Jacques Rancière (1997, 2012, p. 119-149), tendo como alvo principal Jean-François Lyotard. Esses são apenas alguns exemplos, por ora aludidos de passagem, de acaloradas discussões suscitadas pela problemática do irrepresentável. Nessa arena, as referências se cruzam, as razões epistemológicas, estéticas e éticas estão intimamente entrelaçadas. Grosso modo, duas vertentes são aí identificáveis. De um lado, as formulações que, frente ao trauma incomensurável, diante do real inapreensível, acabam colocando toda a ênfase nas aporias da representação. Nessa linha, a realidade se torna indizível, inimaginável, entre outras variantes da intangibilidade do horror e do referente histórico. De outro, estão aqueles que insistem em enfrentar o desafio colocado pelo real, reivindicando o imperativo de uma aposta referencial. As representações, por mais inescapavelmente lacunares que sejam, oferecem, "apesar de tudo", um conhecimento possível do passado, incluindo o traumático. Como saldo fundamental dessa aposta, compreende-se também algo sobre o presente das rememorações.

Eis a simplificação de um debate complexo, é verdade, mas não seria o caso de reconstituir preliminarmente os meandros dessas discussões, adiando a entrada no objeto específico do capítulo. Ficam aqui indicadas as leituras que nortearão a análise de Os dias com ele. Ou melhor, a bibliografia que invadirá o cotejamento proposto entre o que se vê nesse documentário e as premissas das reflexões até agora existentes sobre ele. Trata-se, no fundo, de promover uma discussão teórica a partir do filme, dando primazia à fatura 
audiovisual para enfrentar o espinhoso tema dos impasses e das possibilidades do representável. Esta análise toma partido, claro, em mais de um sentido. Lidando com seus materiais, os historiadores têm por hábito insistir em desorganizar os arcabouços conceituais. Tal impulso está às voltas, justamente, com os limites das representações, com os esquematismos das categorizações, enfim, com os traços fugidios dos vestígios. A própria noção de irrepresentável não poderia sair ilesa dessa indagação.

Debruçando-se de vez sobre Os dias com ele e sua fortuna crítica, vale retomar aquilo que já foi escrito sobre a cadeira vazia. Começando por Andréa França e Patricia Machado (2014b, p. 72, grifo das autoras):

$\mathrm{O}$ assento vazio solicita a entrada em cena de Maria Clara que, vencida pela autoridade intelectual e paterna, senta-se no lugar que seria dele para realizar a tarefa. Invadir o plano é expor não só a "derrota" da diretora na sua relação com o espaço da cena, mas também expurgar o silêncio e as lacunas em torno da memória da ditadura, teatralizando no corpo situações, afetos, intensidades. Como se a falta se revelasse na simples presença da cadeira vazia e na entrada em cena da documentarista, cujo corpo torna-se locus de falas, gestos, imagens, memórias do que foi e/ou do que poderia ter sido ( $O s$ dias com ele).

No parágrafo seguinte, as autoras prosseguem, incluindo nas considerações outros títulos brasileiros que abordam a memória da ditadura em chave íntima:

Não se trata de revelar nada, nenhuma verdade histórica, mas mostrar um corpo em situação e uma câmera atenta às sensações nele inscritas e que dão sentido à sua atuação; mostrar a possibilidade de que esse corpo possa se sustentar no espaço vazio da falta; mostrar as sobrevivências e os espectros que afetam cada gesto, cada movimento, cada palavra. (FRANÇA; MACHADO, 2014b, p. 72, grifo das autoras).

E, concluindo o artigo:

À falta de imagens, de documentos, de verdade, soma-se a lacuna íntima. Em Os dias com ele, a cadeira vazia atualiza as tensões entre a recusa de performar do pai e a necessidade de performar da filha. O espaço da cena é então convocado, pela teatralização, a redimensionar as relações entre a interrupção do que se pode saber (as lacunas do tempo) e a interrupção do passado espectral (a imagem teatralizada da ausência). (FRANÇA; MACHADO, 2014b, p. 82, grifo das autoras).

Nos trechos citados, já despontam os tópicos centrais das leituras do irrepresentável nesse contexto analítico. Em primeiro lugar, o fracasso do projeto fílmico (a fillha vencida, a derrota da cena). Em seguida, um movimento concomitante: o esvaziamento do referente histórico (no qual só se vê lacuna, falta, vazio, espectros, interrupções, nenhuma verdade, 
nenhum documento) inversamente proporcional à projeção conferida à ficcionalização (tudo se torna cena, performance, teatralização). Dessas formulações de Andréa França e Patricia Machado (2014b), entre fracassos e lacunas, a única concretude que emerge é performática, do corpo que entra em cena, sustentando-se no vazio, mostrando "espectros". Uma noção fantasmagórica de história se revela aí. ${ }^{92}$

Outras análises da passagem da cadeira vazia de Os dias com ele ecoam tais premissas. Carla Maia (2015b, p. 403) escreve:

É uma cena importante para o argumento que buscamos construir. Há uma cadeira em quadro, vazia, e ouvimos a discussão dos dois, fora de campo. Maria Clara pede ao pai que leia sua ordem de prisão, e ele protesta com veemência [...]. A filha parece achar importante que conste no filme um documento que dê veracidade ao que soa absurdo demais para ter, de fato, ocorrido. Escobar, por sua vez, quer fazer a filha entender que não é a leitura do documento, a presença de uma prova, que irá ajudar a recuperar a história que ela tanto busca. É antes pelo não dito, pela impossibilidade, pela irrepresentabilidade (como a prisão de um pode falar pela de 10 mil?) que se pode dizer algo. Para o pai, a informação vulgariza a memória do que ocorreu, nada acrescenta. "Sua saída é fazer isso virar uma coisa estética, não o documento", ele diz, com lucidez desconcertante.

Uma "coisa estética" - algo que viesse não encontrar uma verdade, mas colocá-la à prova, suspender as respostas, não devolver à aparência algum sentido de realidade, mas mantê-la autônoma, como "forma de experiência sensível".

Mais uma vez, aquilo que diz respeito à esfera do documento, da verdade, da prova, da informação, da realidade, tudo isso seria inútil para uma recuperação daquela história. Resta o não dito, a impossibilidade, a irrepresentabilidade, a suspensão das respostas, a experiência sensível como realidade autônoma. ${ }^{93}$ As aporias se impõem nas interpretações até aqui citadas da passagem da cadeira vazia. Mas vale lembrar que a dimensão problemática da representação não está toda concentrada na imagem daquela cadeira. Outros momentos do filme trazem essa pauta à tona de modo explícito.

Bem antes, na primeira tentativa de Maria Clara Escobar em tocar no tema da tortura com o pai, o lapso auditivo de Carlos Henrique é eloquente: a filha pergunta sobre a questão da tortura; ele entende "cultura". A confusão com as palavras é apenas a primeira esquiva, talvez inconsciente, de Carlos Henrique ao ser convocado a rememorar a experiência dolorosa. Maria Clara repete, “tor-tu-ra". "Uma pergunta boa, entretanto, difícil”, Carlos

\footnotetext{
${ }^{92}$ As autoras fazem uma reformulação dessa análise em outro texto, enfatizando a instauração de uma "cena de dissenso", basicamente mantendo as mesmas premissas aqui apontadas: FRANÇA; MACHADO, 2014a, p. 228230.

${ }_{93}$ A autora elabora variações dessa mesma análise em MAIA, 2014, p. 149-150, 2015a, p. 9.
} 
Henrique introduz sua resposta. Para não responder. Filósofo, ele encontra refúgio na teoria: "O Derrida tem textos sobre testemunho. Ele mostra como é impossível um testemunho se aproximar da verdade." Anuncia em seguida: "Então, eu vou falar agora do que [a tortura] significou para mim." Mas, antes, vai desfiando uma série de considerações preliminares: sobre as especificidades da tortura ao longo da história, citando Marx; sobre as diferenças entre testemunhos de pessoas torturadas; para concluir: "Estamos falando de alguma coisa que a imagem não tem muito poder, estamos falando de alguma coisa em que as palavras se perdem através das metáforas e das singularidades". E justifica: "Levando em conta tudo isso para que o meu depoimento não tenha nenhuma pretensão de verdade." Tendo novamente anunciado seu relato pessoal, Carlos Henrique retorna aos preâmbulos. Fala sobre o caráter injustificável da tortura e volta a concluir: "Não é fundamental aqui entender. Já porque não existe verdade de nada. Mas o fundamental não é que eu diga alguma coisa próxima à verdade desta situação." As pernas agitadas e o insistente bater das mãos nos braços da poltrona são sinais corporais do desconforto desencadeado pela pergunta difícil da filha. A resposta sobre a experiência da tortura é suspensa, fica adiada pelos preâmbulos sobre a tortura em geral. O que Carlos Henrique vem repetindo até esse ponto é, justamente, a natureza irrepresentável da tortura: “As pessoas silenciam mesmo. É difícil alguém falar sobre isso. Eu falei que é difícil fazer imagem, é difícil fazer cena dramática, é difícil até escrever, são complicados os testemunhos, eu falei para você."

As leituras da cadeira vazia acima citadas concentram-se justamente nessa impossibilidade, como que ecoando aquilo que o entrevistado diz nesse momento específico do filme. De fato, o caráter problemático da representação não apenas é enunciado pelo pai, mas também está inscrito em certas opções formais e narrativas do documentário da filha. Seja na reflexividade implícita pela inclusão no corte final daqueles momentos que Carlos Henrique supõe serem o antes e o depois da entrevista; seja pela crueza dos enquadramentos; seja, ainda, pela reiterada frase "Este não é o meu pai" acompanhando as filmagens de arquivo em super-8 de famílias alheias - frase que, em certo sentido, ecoa a célebre provocação “Isto não é um cachimbo”, de René Magritte.

Por vias distintas, essas interpretações compartilham com o Carlos Henrique filósofo a matriz do irrepresentável, muitas vezes realizando um movimento análogo ao dele na passagem recém-descrita: colocar entre as imagens e sua discussão o anteparo da teoria. Não deixa de haver certa homologia entre as tergiversações abstratas de Carlos Henrique na primeira tentativa da filha de extrair dele um relato sobre a tortura e, por exemplo, esta outra análise proposta por Carla Maia (2015b, p. 407): 
O que ouvimos de Escobar evidentemente não dá conta de representar o que foi a tortura na ditadura militar. Porém, algo se elabora, quanto mais se desvia para afagar um gato, buscar uma palavra, deixar de lado algum detalhe, lembrar-se de outro. A descrição do evento por Escobar é, a um só tempo, minuciosa e imprecisa, não resultando numa representação estável, fixa, completa.

Maia (2015b, p. 407) continua: "A impossibilidade do testemunho é o que possibilita sua invenção, sua existência.” Para, em seguida, citar Jacques Derrida, assim como o havia feito Carlos Henrique. Em meio a uma miríade de outras citações ao longo de sua argumentação - que inclui, além de Derrida, Giorgio Agamben, Michel Foucault, Walter Benjamin, Jean-Louis Comolli, Jacques Rancière, Georges Didi-Huberman (cf. MAIA, 2014, 2015a, 2015b) -, o substrato conceitual mobilizado por Carla Maia ganha contornos mais claros na referência que ela faz à noção de "estética do fracasso", com base em Ilana Feldman (2012b). Sobre esse ponto em particular, Maia (2015b, p. 410) desenvolve:

Os sujeitos e a própria linguagem são dotados de uma opacidade irredutível que revela uma negatividade ontológica, enquanto condição inacabada, falha, lacunar e instável. [...] Falar em estética do fracasso, como explica Feldman, implica, portanto, em falar de uma estética da negatividade, na qual resta sempre uma tensão entre a forma das obras e o informe do Real (na esteira de Lacan), enquanto lugar do que não tem lugar, do que não pode ser simbolizado ou representado pela linguagem.

A própria Ilana Feldman (2014, p. 338) também propôs uma análise de Os dias com ele partindo das noções de "fracasso" e "opacidade" - aliás, em um seminário do qual também participou Carla Maia. Nessa obra, segundo Feldman (2014, p. 338), vê-se a figuração da "iminência do fracasso". A autora continua:

Os dias com ele é dotado de uma coragem: não evita o mal-estar, os desentendimentos e o desencontro, ao mesmo tempo que assume a dificuldade de compreensão e a opacidade da linguagem como elementos constitutivos não apenas das relações familiares em jogo, mas, sobretudo, de sua matéria fílmica. (FELDMAN, 2014, p. 338).

Logo após comentar a passagem do filme acima descrita, a do lapso entre "tortura" e “cultura", Ilana Feldman (2014, p. 340) reitera a ideia: "Os dias com ele trabalha a partir da opacidade do relato, seus incômodos, seus limites e suas fraturas." Ela prossegue: "Como

\footnotetext{
${ }^{94}$ Para outra análise de Os dias com ele da mesma autora, desdobrando-se sobre suas "lacunas constitutivas", cf. FELDMAN, 2016b. Em texto posterior, intitulado "Do pai ao país: o documentário autobiográfico em face do fracasso das esquerdas no Brasil" (FELDMAN, 2017), a autora retoma as formulações de FELDMAN, 2014 e FELDMAN, 2016b. Sobre a tese do "êxito do fracasso" no cinema brasileiro contemporâneo, cf. FELDMAN, $2012 b$.
} 
vimos, trata-se assim de uma beleza terrível e irreconciliada, em que [...] só se pode partilhar uma experiência pelo que há nela de intransferível, incompreensível e, no limite, impossível.” (FELDMAN, 2014, p. 340-341). Toda busca do documentário, toda busca do cinema, de acordo com Feldman (2014, p. 341), já partiria dessa impossibilidade: “Se o 'real' pode ser pensado como um 'desencontro', não deixa de ser verdade que o cinema em geral e o documentário em particular busca esse encontro impossível, mesmo que por meio do confronto.” A marca do político de Os dias com ele residiria justamente aí:

A política, portanto, é efetivada pela dimensão processual, inacabada e dissensual da cena, sempre aberta e ameaçada pelo risco de sua não realização, pelo risco do fracasso, potencial espaço de criação e produção. A política se faz presente por meio da própria negatividade constitutiva e produtiva, da linguagem e dos sujeitos. [...] O trabalho de luto está sendo feito. E a cadeira vazia não precisa ser, a todo custo, ocupada. (FELDMAN, 2014, p. 342).

A análise de Roberta Veiga (2016b, p. 201) segue uma linha análoga:

Mesmo quando [a memória é] reconstituída nos atos de fala que sustentam a longa entrevista nos dias que Maria Clara passa na casa do pai, ela vem em fiapos, permeada de lacunas, de recusa à lembrança, seja pela surdez, pelo silêncio, ou pelos desvios. Nessa conversa infinita, por meio da qual a filha procura saber do pai como foi sua experiência de tortura durante a ditadura, e também pelas pistas de suas relações familiares, principalmente com ela própria, o passado não poderá nunca se oferecer como um dado passível de ser cronologizado pela narrativa. Ele surge como fragmentos de um objeto inalcançável através dos questionamentos descosturados que a filha cineasta lança ao pai, sujeito filmado, e dos quais o pai sempre se esquiva, sempre desvia, e sempre devolve a ela na forma de recusas, de incompreensões, e de outras questões sobre a feitura do filme, o planejamento e o método, criando assim um campo de disputa pela direção do filme e de conflitos, sempre tenso e oscilante.

Ou, ainda, como se lê em outro artigo da mesma autora, em Os dias com ele "o cinema será então o acontecimento presente que impele a figuração de um passado misterioso e turvo de modo disforme e lacunar"; o filme acontece "numa dinâmica que parece sempre à espera do fracasso, à espera de não se realizar" (VEIGA, 2016a, p. 49 e 57).

Vazio, derrota, falta, nada, espectro, lacuna, recusa, interrupção, não dito, impossibilidade, irrepresentabilidade, suspeição, desvio, instabilidade, fracasso, opacidade, negatividade, inacabamento, falha, informe, não lugar, mal-estar, desentendimento, desencontro, dificuldade, incômodo, limite, fratura, inconciliação, intransferibilidade, incompreensão, confronto, inacabamento, dissenso, risco, silêncio, fragmento, inalcançabilidade, questionamento, descostura, esquiva, oscilação, turbidez. Há uma 
prolixidade do indizível nos exemplos acima elencados de análises de Os dias com ele. E essa espécie de redundância do irrepresentável não é incomum no contexto dos estudos do cinema documentário contemporâneo em geral e do documentarismo intergeracional do Cone Sul em particular (cf. AMADO, 2009; BERGER, 2008; ESTEVE, 2009; GUTIÉRREZ, G. M., 2008; LAZZARA, 2009; VERZERO, 2009). De fato, na bibliografia da região, a recusa da representação manifesta em Los rubios - excepcionalmente radical nessa obra em particular, destoando do panorama estético-narrativo do corpus -, é frequentemente extrapolada à condição de paradigma geral dessa cinematografia. Como se a irrepresentabilidade do trauma definisse de uma vez essa produção memorialística; como se a disjunção e o emaranhado do circuito intergeracional visíveis no filme de Albertina Carri resultassem em um imponderável absoluto. Tais premissas teóricas conectam-se ao âmbito estético pela via do apriorismo segundo o qual a indeterminação formal seria uma característica intrínseca a essas obras, como visto no capítulo anterior.

Ora, é inegável que tudo isso está inscrito nas imagens de Os dias com ele (ou de tantos outros títulos da filmografia aqui estudada), seja naquilo que se fala (nesse caso, nos embates e esquivas entre pai e filha), seja naquilo que se vê (na cadeira vazia, na crueza dos recursos cinematográficos, nas tensões entre campo e extracampo etc.). A questão que se coloca é outra. Não se está aqui recusando às imagens de Os dias com ele sua carga de impasses. Mas cabe perguntar se essas imagens só dão a ver aporias, e nada mais do que isso.

Em geral, essas análises na chave do irrepresentável mobilizam um robusto arsenal teórico (cf. FRANÇA; MACHADO, 2014a, 2014b; FELDMAN, 2014; MAIA, 2014, 2015a, 2015b; VEIGA, 2016a, 2016b). Já ficou indicado acima que, em certos casos, o aparato conceitual acaba ocupando em tal medida as análises a ponto de quase invisibilizar as imagens fílmicas. Nota-se aí também um esforço de elaboração de novos conceitos, principalmente pela hifenização em série de termos: "imagem-excesso", “imagem-fóssill", "imagem-dissenso", “imagem-sensação" (FRANÇA; MACHADO, 2014a); "imagemperformada", "imagem-atestação" (FRANÇA; MACHADO, 2014b); “eu-traço”, “devirmemória" (VEIGA, 2016b). Isso não deixa de ser um sintoma de certa "inflação teórica" (SARLO, 2007, p. 95) observável nesse campo de estudos. O saldo final é um déficit de historicidade, um exaurimento do horizonte referencial. Sobra o irrepresentável.

De forma alguma a leitura proposta neste capítulo busca uma interpretação da matéria audiovisual "expurgada" da teoria, como se fosse possível olhar para as imagens em sua pura concretude referencial. As “contra-análises” de Marc Ferro (2010), pioneiro dos cruzamentos entre cinema e história nos anos 1970, já estavam bem distantes da verificação imediata da 
fidedignidade de um filme. A análise historiográfica das imagens dos filmes se faz aqui com a teoria. Na verdade, com alguns dos mesmos teóricos correntemente citados em nome de um esvaziamento do referente. A presença constante de Jacques Rancière e Georges DidiHuberman na fundamentação dessas leituras do irrepresentável é algo que causa estranheza. Afinal, Rancière $(1997,2012)$ possui escritos que desenvolvem uma incisiva desconstrução dialética da "hipérbole" do irrepresentável. Didi-Huberman (2012), aquele que insiste em reivindicar o imaginável malgré tout, muitas vezes parece ser apropriado malgré lui. É intrigante que o discurso do indizível, do fracasso e do vazio possa tomar como referência aquilo que escrevem esses dois autores:

[...] sob que condições é possível declarar certos acontecimentos irrepresentáveis? Sob que condições pode-se dar esse a esse irrepresentável uma figura conceitual específica? Sem dúvida essa indagação não é neutra. É motivada por certa intolerância quanto ao uso inflacionista da noção de irrepresentável e da constelação de noções vizinhas: o não apresentável, o impensável, o intratável, o indesculpável. Esse uso inflacionista, de fato, engloba sob o mesmo conceito e envolve com uma aura de terror sagrado os mais diversos fenômenos, processos e noções [...]. A questão é saber como e em que condições é possível construir tal conceito que se propõe a abarcar univocamente todas as esferas da experiência. (RANCIÈRE, 2012, p. 119).

Essa inflação do irrepresentável tem um efeito claro para Rancière (2012, p. 122): "transformar os problemas de regulagem da distância representativa em problemas de impossibilidade de representação.” O autor prossegue: “[...] não há nenhuma propriedade do acontecimento que vete a representação, que interdite a arte no sentido próprio do artifício. Não há o irrepresentável como propriedade do acontecimento. Existem somente escolhas." (RANCIÈRE, 2012, p. 139). E, ainda: “A alegação do irrepresentável afirma que há coisas que só podem ser representadas num certo tipo de forma, por um tipo de linguagem própria à sua excepcionalidade. Stricto sensu, esta ideia é vazia." (RANCIÈRE, 2012, p. 147). Salta aos olhos a contundência com que Jacques Rancière refuta o irrepresentável.

Georges Didi-Huberman (2012) desenvolve essa polêmica em Imagens apesar de tudo, discutindo as quatro fotografias que documentam o horror em ato em Auschwitz, tiradas por membros do Sonderkommando ("comando especial" composto por judeus prisioneiros forçados a realizar as tarefas básicas do extermínio de seus semelhantes) com apoio da resistência polonesa. Igualmente incisivo em seu posicionamento "contra todo e qualquer inimaginável”, ele escreve:

Basta ter olhado uma vez para este resto de imagens, para este corpus errático de imagens apesar de tudo, para sentir que já não é possível falar em 
Auschwitz nos termos absolutos - geralmente bem-intencionados, aparentemente filosóficos, na realidade preguiçosos - do "indizível" e do "inimaginável". [...] Disse-se que Auschwitz era impensável. Mas [...] o ponto em que o pensamento fracassa é justamente aquele em que devemos persistir nele, ou, mais precisamente, imprimir-lhe uma nova direção. [...]

Nesta tarefa, o papel do historiador é seguramente capital. Ele não pode, nem deve "permitir que nos desembaracemos do problema representado pelo genocídio dos judeus relegando-o para o impensável [...]". (DIDIHUBERMAN, 2012, p. 41-42, grifo do autor). ${ }^{95}$

$\mathrm{O}$ autor desdobra incansavelmente seus argumentos contra as leituras do irrepresentável. "Certas obras de arte importantes suscitaram, entre os seus comentadores, generalizações abusiva sobre a 'invisibilidade' do genocídio". Contudo, há que se "refutar esta bela estética negativa”, essa hipertrofia que acaba resultando em uma desatenção para com as imagens. Se as imagens trazem uma carga de impossível, é necessário olhá-las: "graças a estas imagens, nós dispomos apesar de tudo de uma representação que, doravante, se impõe como a representação por excelência, a representação necessária [...]" (DIDIHUBERMAN, 2012, p. 44, 45, 53, 58-59, grifo do autor). É preciso:

Imaginar apesar de tudo, o que exige de nós uma difícil ética da imagem: nem o invisível por excelência (preguiça do esteta), nem o ícone do horror (preguiça do crente), nem o simples documento (preguiça do sábio). Uma simples imagem: inadequada mas necessária, inexata mas verdadeira. Verdadeira de uma verdade paradoxal, evidentemente. (DIDI-HUBERMAN, 2012, p. 60, grifo do autor).

Nas análises de Os dias com ele citadas mais acima, os numerosos substantivos que gravitam em torno da ideia de irrepresentável por vezes vêm acompanhados de adjetivos tais como "irredutível”, “ontológico", “constitutivo". Sobre isso, Didi-Huberman (2012, p. 94) escreve:

Estatuto ontológico? Sim, as imagens são "inapropriadas". As imagens não são "toda a verdade" [...], elas são, portanto, 'inadequadas' ao seu objeto. Eis o que é incontestável, mas cuja generalidade é tão grande que não autoriza nada mais do que um princípio de incerteza gnoseológica. Não será que a inadequação caracteriza tudo aquilo que utilizamos para ver e descrever o mundo?

Apesar disso, deve-se perseverar nas tentativas de conhecer o passado: "Se insisto tanto, nestas linhas, na expressão apesar de tudo, é porque cada fragmento existente - de imagens, de palavras ou de escritos - é arrancado a um fundo de impossível. Testemunhar é

95 A tradução portuguesa foi adaptada à ortografia brasileira. Em raros casos, certos vocábulos foram substituídos por sinônimos mais familiares ao leitor brasileiro, levando-se em conta o texto original em francês. 
contar apesar de tudo o que é impossível contar totalmente" (DIDI-HUBERMAN, 2012, p. 137, grifo do autor). Para a análise de uma imagem, de uma obra, de um filme, não basta ficar reiterando infinitamente esse impossível: “Todo o ato de imagem é arrancado à impossível descrição de um real. Os artistas, em particular, recusam vergarem-se ao irrepresentável [...].” (DIDI-HUBERMAN, p. 160). A hipérbole especulativa do indizível e suas variantes não faz mais do que repetir algo que já se sabe há tempos: toda representação é, por definição, inadequada ao real que representa. Querendo-se complexa, essa no fundo é uma visão que facilita as coisas, livrando-se do problema da representação ao relegar a realidade e seus horrores ao terreno de uma alteridade absoluta (o vazio, a falta, a lacuna etc.). Repisando incessantemente o impossível, as leituras do irrepresentável se contentam com uma mera estética negativa (DIDI-HUBERMAN, 2012, p. 195). “Tal como o irrepresentável e o impensável, o inimaginável resume-se amiúde a uma simples recusa de pensar a imagem, recusa que se autolegitima brandindo grandes hipérboles." (DIDI-HUBERMAN, 2012, p. 199, grifo do autor). Ora, sempre haverá uma "desproporção entre a experiência e o seu relato". E é justamente a partir dessa desproporção que é necessário trabalhar, interpretar. O inimaginável é uma:

[...] palavra frequentemente empregada para expressar, simplesmente, a nossa desorientação, a nossa dificuldade em compreender: aquilo que não compreendemos, mas cuja compreensão não queremos renunciar - aquilo que não queremos, em todo o caso, rejeitar para uma esfera abstrata que disso nos desembaraçaria facilmente" (DIDI-HUBERMAN, 2012, p. 203).

Como é possível incluir as obras de Jacques Rancière e Georges Didi-Huberman, mesmo que outros livros, entre as referências que sustentem as leituras do irrepresentável? Como evocar as ideias desses teóricos para tecer considerações que não vão muito além do vazio da cadeira de Os dias com ele? É certo que toda releitura, que toda passagem de uma teoria de um contexto analítico para outro trará sempre consigo uma transferência conceitual (ESPAGNE, 2013), como se viu no Capítulo II com relação à noção de "pós-memória". Mas há uma diferença substantiva entre a inevitável transferência de uma formulação e sua completa inversão. A impressão é que, de modo geral, faz-se um uso desmesuradamente livre dos textos desses teóricos, pinçando-se frases isoladas aqui e ali para estimular certas ideias, e não exatamente uma interpretação que leve em conta as estratégias que constituem globalmente a argumentação em pauta ${ }^{96}$ - algo análogo ao que ocorre nas apropriações de

\footnotetext{
${ }^{96}$ Sobre isso, Umberto Eco (2004, p. 44) já escreveu: "E um texto outra coisa não é senão a estratégia que constitui o universo de suas interpretações legitimáveis - se não 'legítimas'. Qualquer outra decisão de usar livremente um texto corresponde à decisão de ampliar o universo do discurso. A dinâmica da semiose ilimitada
} 
Marianne Hirsch (1997). No caso de Rancière e Didi-Huberman, esse tipo de "uso livre" ajudaria a explicar tal apropriação para defender exatamente aquilo que esses autores refutam em suas obras. Porém, uma leitura cerrada dos textos aqui mobilizados revela que ambos são duros nas críticas que fazem ao viés do irrepresentável. No fundo, a insistência com que os dois foram citados neste ponto do capítulo, essa leitura cuidadosa de suas formulações serve aqui justamente como antídoto contra a desatenção conceitual resultante da inflação teórica nas leituras do irrepresentável. ${ }^{97}$

Note-se que estas ponderações não entraram no mérito da transposição de reflexões elaboradas em torno da Shoah para o contexto da rememoração das ditaduras do Cone Sul. Refletindo sobre o boom testemunhal acerca do período autoritário argentino, Beatriz Sarlo (2007, p. 39-40) chega a questionar essa transferência de uma "qualidade inabordável" para “os testemunhos contemporâneos que não surgem de fatos comparáveis com aqueles que tornariam intocáveis os testemunhos do Holocausto". De todo modo, o uso do arcabouço teórico oriundo da memória do extermínio dos judeus da Europa para se compreender os processos de recordação do terrorismo de Estado latino-americano é uma realidade. Mais do que um fato cultural, essas transferências conceituais são, efetivamente, operacionais para o exame das dinâmicas de memória na região - desde que sejam transferências, e não aplicações diretas de conceitos; desde que não façam da memória da Shoah uma matriz hegemônica global que homogeneíze as experiências traumáticas locais (ASSMANN, 2010; JELIN, 2010a, p. 74-75; RADSTONE, 2011). Há que se considerar ainda que as referências à Shoah tampouco são algo distante do documentarismo intergeracional aqui estudado. Nesse sentido, é interessante observar que o trecho da peça de Carlos Henrique Escobar - Matei minha mulher (a paixão do marxismo: Louis Althusser) - lido em uma passagem de Os dias com ele (comentada mais adiante) faça referência aos campos nazistas. O enigma no cerne da morte do pai em Diário de uma busca (Flavia Castro, Brasil / França, 2010) diz respeito à invasão do apartamento de um suposto oficial nazista radicado em Porto Alegre. Em Mi vida con Carlos (Germán Berger-Hertz, Chile / Espanha, 2009), o diretor faz alusão à emigração dos avós para o Chile, em 1936, fugindo das perseguições antissemitas que ocorriam na Europa Central. A própria Beatriz Sarlo, em Tempo passado: cultura da memória e guinada

não o veda, e até chega a encorajá-lo. Mas cumpre saber se queremos exercitar a semiose ou interpretar um texto.” Agradeço a Paolo Demuru por essa indicação de leitura.

${ }^{97}$ Fora do contexto de análise de Os dias com ele, cumpre reconhecer que Ilana Feldman (2016a), em artigo no qual reconstitui a "querela das imagens" levada adiante por Didi-Huberman, parece ter recalibrado em alguma medida suas posturas sobre a estética do fracasso e o irrepresentável à luz da retomada dos textos deste autor e do filme $O$ filho de Saul (László Nemes, Hungria, 2015) - cujas imagens representam, de forma potente, o horror dos campos nazistas, inclusive reencenando a ocasião da tomada das quatro fotografias do Sonderkommando no cerne dessa polêmica teórica. 
subjetiva, recorre à bibliografia sobre a Shoah (incluindo Didi-Huberman, entre muitos outros teóricos), reelaborando-a em sua polêmica sobre o discurso testemunhal na Argentina. Eis o que os historiadores chamam de circulações de ideias, transferências culturais, histórias cruzadas (ESPAGNE, 2013; WERNER; ZIMMERMANN, 2003). ${ }^{98}$

Esse livro de Beatriz Sarlo (2007), em menor medida, também é citado nos textos brasileiros sobre Os dias com ele (cf. BARRENHA, 2013b; FELDMAN, 2014; FONTES, 2015). Na crítica contundente que Sarlo (2007, p. 98-99) faz à noção de "pós-memória", a ideia de vazio também acaba alvejada.

A teoria do vacuum ignora o fato de que esse vazio sempre marca qualquer experiência de rememoração, até a mais banal. [...] Arma-se assim uma espécie de corrente metonímica de um vazio para outro, embelezada por todos os prestígios teóricos, a que se poderiam acrescentar o vazio constitutivo do sujeito, o vazio de onde surge o enunciado, o vazio cuja lembrança é recortada com dificuldades etc. etc. Como é impossível contradizer a ideia de vazio deixada pelo Holocausto, essa evidência se transfere, sem maiores exames, a outros "vazios". Filosoficamente à la mode, essa corrente é mais sugestiva do que sólida.

O "vazio" entre a lembrança e aquilo que se lembra é ocupado pelas operações linguísticas, discursivas, subjetivas e sociais do relato da memória [...]. Mais que de um vazio, trata-se de um sistema de defasagens e pontes teóricas, metodológicas e ideológicas. Se alguém quer chamar esse sistema de "vazio", tem o direito de fazê-lo, na medida em que defina outro espaço (entre o fato e sua memória) onde ocorra o discurso e se operem as condições de possibilidade. É um vazio cheio de retórica e de avaliação.

A questão é que a reiteração do vazio está intimamente associada à celebração do fracasso da representação. Isso transforma as defasagens em um impossível, abdicando-se de antemão de qualquer tentativa de construir pontes entre o fato e sua memória. Nos termos de Sarlo (2007, p. 100): “[...] a teoria do vazio representacional e da qualidade lacunar da reconstituição memorialística forma um sistema com outro lugar-comum contemporâneo, que afirma que, quanto mais importantes são as perguntas, menos se pode pretender responder a elas.”

Ao contrário do que se diz, nas leituras do irrepresentável aqui discutidas, o fracasso nem chega a ser um risco porque ele já é um dado de saída. Por hipérbole, as distâncias, inadequações, desproporções, desorientações, dificuldades e defasagens no cerne de toda representação são transformadas em um impossível absoluto. Quanto a isso, vale esclarecer: é óbvio que esta crítica não se volta contra o indivíduo que vive uma experiência a qual

\footnotetext{
${ }^{98}$ Para uma ponderação filosófica sobre a singularidade irredutível ou a possibilidade de comparação da Shoah com outros eventos históricos, cf. RICEUR, 2007, p. 344-347.
} 
considera irrepresentável. O próprio Carlos Henrique Escobar manifesta esse sentimento, essa aporia, enquanto tergiversa diante da pergunta da filha sobre a tortura sofrida. O problema se dá quando esse irrepresentável da esfera da experiência individual é elevado à condição de dogma teórico por aqueles que se dedicam a interpretar as representações: filmes, livros, peças, instalações, fotografias etc. os quais, apesar de todos os impasses, foram realizados e estão disponíveis para a análise (DIDI-HUBERMAN, 2012, p. 86-87). A questão discutida nestas páginas é de ordem epistemológica, não custa lembrar. Ela diz respeito, de saída, ao limite interno de uma premissa teórica que, paradoxalmente, interdita a compreensão. Pois há um círculo tautológico no qual ficam presas as abordagens do irrepresentável. Quando a impossibilidade está instalada definitivamente no ponto de partida de todo esforço de representação, o ponto de chegada não pode ser outro senão o fracasso. E, assim, as análises partem da premissa da impossibilidade da representação para concluir, no fim do percurso analítico, pela impossibilidade da representação. Não se assume nenhum risco nesse tipo de leitura, não há qualquer tensão em jogo: apenas um fracasso assegurado a priori, uma pronta desistência frente ao desafio referencial, uma preguiça interpretativa que se contenta com o vazio.

Esta é uma limitação intrínseca às leituras do irrepresentável. Falta ainda examinar o problema externo desse viés teórico. Ou melhor, o problema extralinguístico, quando se descarta o "fardo" referencial em nome do império da ficção. Em seu arguto diagnóstico sobre a "estética do fracasso" no documentário contemporâneo, Paul Arthur (1993, p. 127, tradução nossa, grifo do autor) considera os casos em que "o fracasso da representação adequada da pessoa, do evento ou da situação social anunciada como tarefa explícita do filme funciona como uma garantia invertida de autenticidade". Esta seria, segundo Arthur (1993, p. 127-128, tradução nossa), "uma ramificação da estética pós-moderna", inserida em um contexto teórico pós-estruturalista no qual a arte bem-acabada e as ambições epistêmicas estão sob suspeita. "Os novos filmes afirmam uma garantida e, em última instância, naturalizada aposta na inadequação de qualquer sistema representativo para capturar a realidade vivida." (ARTHUR, 1993, p. 128, tradução nossa, grifo do autor). Não seria descabido dizer, retomando Umberto Eco (2016, p. 50), que a "estética do fracasso" é uma "metáfora epistemológica" do desconstrucionismo. Uma vez que é impossível representar "adequadamente" o que quer que seja, a única garantia de autenticidade de uma obra seria, "naturalmente", o fracasso da representação pretendida. Compreende-se porque, nos textos sobre Os dias com ele até aqui discutidos, tudo aquilo que gravita o eixo da verdade, da prova, do documento, enfim, da realidade, tudo isso é rapidamente repelido como algo inútil. 
Rancière (2012, p. 146) já analisou o modo como a doxa pós-moderna da impossibilidade da representação "adequada", no fundo, acaba reafirmando a ingenuidade epistemológica que quer rejeitar:

O irrepresentável, de modo paradoxal, se torna a forma última sob a qual se mantêm três postulados especulativos: a ideia de uma adequação entre forma e conteúdo da arte; a ideia de uma inteligibilidade total das formas da experiência humana, incluindo-se as mais extremas; e, enfim, a ideia de uma adequação entre a razão explicativa dos acontecimentos e a razão formadora da arte.

Fazer das defasagens da representação um impossível inescapável é pensar nos termos do tudo ou nada. Como não é possível saber todo o real, logo, não se sabe nada. Mas já o simples enunciado de que não se pode saber tudo "adequadamente" é de uma obviedade patente, há tempos. Didi-Huberman (2012, p. 89, 96 e 227) insiste neste ponto: a imagem nunca será tudo, mas tampouco ela é nada. É uma "imagem apesar de tudo". O que refuta o "tudo" da representação não é o "nada" absoluto, mas esse "apesar" contingente que coloca sempre no horizonte os obstáculos a qualquer pretensão de se obter uma representação "coincidente" com o real.

$\mathrm{Na}$ bibliografia sobre Os dias com ele em particular e sobre o documentário intergeracional em geral, essa dicotomia implícita entre o tudo e o nada muitas vezes se desdobra em duas visões sobre a história. Por um lado, a história (res gestae, os fatos acontecidos) não é nada, e o terreno dos eventos concretos se transforma em vazio, lacuna, falta etc. Tal postura ricocheteia na forma de um desdém em bloco pela história como saber (rerum gestarum, a escrita da história). Nas leituras de Os dias com ele centradas no irrepresentável, quando se quer invalidar os impulsos "historicistas" de indagação sobre a realidade, a verdade, o documento, a prova, costuma-se desenhar uma caricatura do conhecimento histórico, como se este ainda estivesse preso aos ditames positivistas do século XIX. Algo como: "Contrário a um historicismo marcado pela memória como um dever, uma obrigação social de preservação, que impõe uma única ordem dos fatos [...]" (VEIGA, 2016b, p. 203-204); “[...] suspeitando da noção cartesiana de sujeito universal, senhor de si e da verdade, que caminha ao lado da História oficial [...]”; "A filha [Maria Clara Escobar], com impulsos de historiadora, acha importante constar um documento que dê veracidade ao que soa absurdo demais para ter de fato ocorrido.” (MAIA, 2014, p. 143 e 149); “As imagens de arquivo, como os testemunhos, não devem ser entendidos como provas para validar ou contradizer um saber histórico [...]" (FRANÇA; MACHADO, 2014b, p. 76). É preciso dizer que esse tipo de afirmação genérica sobre o saber historiográfico simplesmente ignora os 
debates epistemológicos que vêm ocorrendo no campo há décadas. Lá nos anos 1930, a Escola dos Annales já fizera a crítica da ênfase factual do historicismo e seus métodos (DOSSE, 2003). Desde os anos 1970, a crescente consciência do peso da escrita historiográfica "contribuiu para arranhar a orgulhosa inocência dos historiadores" (GINZBURG, 2011e, p. 216). Com isso, "a certeza inicial do historiador positivista perdeu, por assim dizer, a sua inocência” (DIDI-HUBERMAN, 2012, p. 132). Faz tempo que a porta da aporia da representação já está aberta na historiografia, e toda vez que "os críticos do positivismo, os pós-modernistas céticos, os cultores da metafísica da ausência” (GINZBURG, 2011d, p. 82, tradução nossa) tentam arrombá-la nesses termos hoje eles soam, no mínimo, anacrônicos - para usar uma noção cara a esta disciplina.

Por outro lado, diante desse nada da história, tudo vira ficção. Ora, é patente que $O s$ dias com ele tem muita performance em suas imagens. Carlos Henrique Escobar, além de filósofo, é dramaturgo. Ele está sempre tentando roteirizar o documentário da filha: sugere cenas, imagina situações, dirige Maria Clara, inventa personagens. "Eu me chamo Viriato Correia, sou empregado da limpeza de Aveiro", ele diz, como que ensaiando diante da câmera. Os lances de fabulação são fundamentais nessa obra. O problema se dá quando as análises extrapolam desse traço o absoluto da ficção, descartando mais uma vez, por outra via, o referente. Vale se debruçar sobre esse ponto, desvendando esta segunda faceta das leituras do irrepresentável.

Em Os dias com ele, é potente a passagem em que, diante das evasivas teóricas do filósofo, Maria Clara recorre à ficção do dramaturgo, abrindo uma nova frente em sua tentativa de fazer o pai relatar a experiência nos porões da ditadura. Carlos Henrique vinha dizendo que é difícil representar a tortura. Maria Clara recorda que ele o havia feito na cena da tortura de Althusser de sua peça Matei minha mulher (a paixão do marxismo: Louis Althusser). O dramaturgo diz não se lembrar. Maria Clara insiste: "Sim, você descreve uma sessão de tortura muito parecida com a sua." Carlos Henrique suspira duas vezes. Ele pergunta a Ana Sachetti Escobar, sua esposa, que confirma a informação: "É no início." Carlos Henrique duvida: "Não, no início ele chega à estação." Ana esclarece: "Eu sei, mas depois tem uma recordação dele. A Clarinha está certa." Ele não ouve direito: "Uma importância?” Ana: “Uma recordação dele.” Carlos Henrique suspira novamente. Recordação, importância. Ele tem outro lapso auditivo no momento em que aflora a lembrança incômoda. Há um corte na entrevista e agora o dramaturgo tem o texto de sua peça em mãos (fig. 189). 


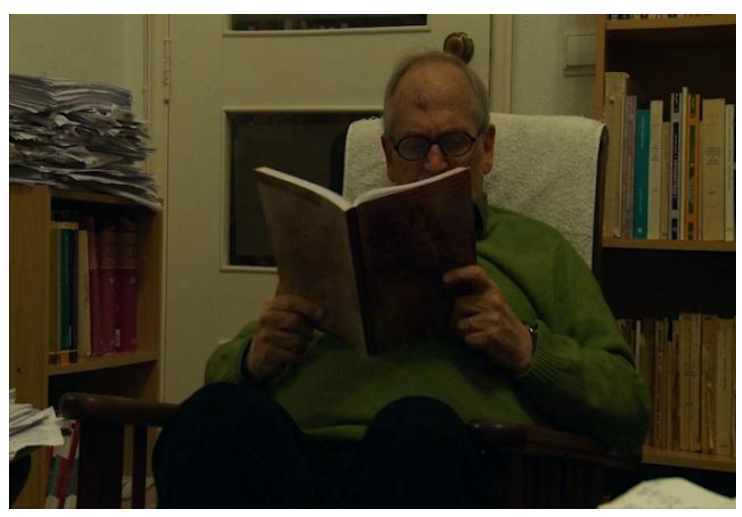

Figura 189 - Carlos Henrique Escobar lê cena de sua peça. Fonte: Os dias com ele (Maria Clara Escobar, 2013).

Sim, não há como negar, ele escrevera a cena, ele havia representado a tortura. E imediatamente começa a tecer considerações sobre as dificuldades que tinha de fazer o ator entender as modulações da atuação, que havia um momento de sofrimento presente e outro de recordação infantil do abandono. Em seguida, lê a peça, alternando ele mesmo as modulações da interpretação: "Era uma mania que me vinha desde criança. Eu sempre me perguntava quanto ainda podia suportar. Era uma forma de resistir a situações intoleráveis e medi-las, como se com isso eu fosse me conhecendo e me avaliando mais." Explica a mudança de tom e continua lendo, batendo a mão que está livre no braço da poltrona:

De quatro, nu, com um dos tímpanos estourados e os fios de choque no ânus, tiritando de frio e à espera que o oficial responsável pela tortura chegasse, pois só ele poderia autorizar o começo da sessão. Assim, nessa situação, eu procurava me controlar e estar outra vez como quando, criança, deixado no jardim congelado da minha casa, sem entrar e me perguntando: "Quanto eu ainda poderia suportar daquele frio?"

Um de seus gatos salta em seu colo, ele o acaricia. E prossegue a leitura, até que a voz over de Maria Clara se sobrepõe à dele: "Porque as torturas prosseguiam e o cristal em mim se partiu." Entra a inserção de planos em super-8: uma mãe caminha abraçada com o filho à beira de um canal. Maria Clara continua, agora só, em over: "Minha mãe me olhava com espanto e meu pai me colhia da terra e da relva gelada. Mas já era tarde." A câmera treme, operada de forma amadora. Outra tomada em super-8: um barco se aproxima do cais. A filha lê: "Então os soldados do campo com seus longos casacos, que me iam buscar pela manhã, já não encontravam um homem, mas uma criança que brincava." Uma panorâmica revela a criança no cais. A leitura em voz over de Maria Clara prossegue sobreposta a essas imagens de um dia feliz na vida de uma família qualquer. O texto que lê é ficção. A família das imagens é alheia. Há quem veja nisso uma ruptura dos nexos com o referente textual (a tortura 
do pai) e com a indicialidade das imagens (um dia feliz da sua família). Eis o que escreve Roberta Veiga (2016b, p. 201) sobre esse uso das imagens de arquivo:

[...] sabemos que tais fotos [sic] não são pessoais, mas perfazem um álbum qualquer de uma família em situações comuns. Por meio dessa estratégia formal, a cineasta não apenas aponta o lugar da falta, do vazio, a ausência de lembranças da infância com o pai, a ausência de uma memória comum a ambos, mas também a dimensão artificial, o engodo do dispositivo cinema, capaz de, ao construir um imaginário simbólico comum (através de momentos alegres de família), forjar uma memória sempre a mesma, rastro que, como tal, nunca reencontra a origem.

A leitura de Andréa França e Patricia Machado (2014a, p. 211) vai nesse sentido, projetando o espaço da cena para as imagens de todo o filme:

Situações, afetos, intensidades, marcas e traumas do passado são teatralizados de modo a permitir que as imagens sejam experimentadas não de um modo único, como revelação de uma evidência, mas como um processo lacunar onde elas só adquirem realidade na relação com o espaço da cena $[\ldots]$.

Para além da cena, resta a falta:

Mais do que isso, quando o dramaturgo lê o trecho de uma de suas peças, Matei minha mulher (a paixão do marxismo: Louis Althusser) (1983), em que descreve a tortura física e mental sofrida pelo personagem, sua voz é substituída gradualmente pela voz da filha que abandona a imagem paterna em prol de imagens caseiras, em super-8, onde se vê uma criança anônima na beira de um lago bucólico com sua mãe. A dureza do texto dramático é então tensionada pela leveza de uma memória que falta, a memória da infância de Maria Clara com o pai. (FRANÇA; MACHADO, 2014a, p. 227).

Os duros embates no fora de campo entre pai e filha na passagem da cadeira vazia tornam-se, também eles, uma cena:

A cadeira vazia e os desacordos entre pai e filha reconfiguram sem cessar as cenas de dissenso do filme. [...] É na relação entre o campo e o contracampo, jamais visto, que o espaço da cena se monta, cena cindida, desconfortável, em desacordo. É a cena do dissenso.

[...] A imagem da cadeira vazia é o único momento onde o entrevistado, depois da discussão em off, se retira, recusando-se a performar e exigindo com isso a entrada de Maria Clara. O embate - intelectual, afetivo, existencial - que se dá antes de sua retirada reforça a cenografia teatral assim como induz a uma reflexão a respeito da mesma. O que se representa aqui, o que se teatraliza? [...] Diante da câmera, não podemos esquecer, há entre outras coisas um dramaturgo, um homem do teatro. (FRANÇA; MACHADO, 2014a, p. 230-231). 
Mais uma vez, não há como discordar de que existe teatralização no documentário de Maria Clara Escobar. Neste ponto do filme - e esta especificação logo revelará sua importância -, Carlos Henrique lê a cena que escreveu no lugar de relatar sua tortura. A filha continua a leitura da ficção sobre imagens colocadas no lugar de suas memórias infantis. Afora outros momentos de aberta fabulação ao longo da obra, já sinalizados. Mas esses curtos-circuitos da representação não rompem de vez os nexos referenciais das imagens de $O s$ dias com ele. $\mathrm{O}$ teor de performance nessa obra não faz com que tudo seja ficção, restando apenas o vazio no espaço fora da cena. A questão diz respeito, novamente, ao absoluto do tudo ou nada.

A análise que María Marcela Parada (2015) faz de Os dias com ele - comparando-o com Hija (María Paz González, Chile, 2012) - segue essa mesma trilha. Parada (2015, p. 635, grifo da autora, tradução nossa) escreve: "E aquilo que resplandece nesses filmes é o encontro documental imaginário com figuras paternas imaginárias, de um eu que só pode constituir-se, por sua vez, imaginariamente." Tudo é imaginário. E Parada não deixa dúvidas sobre qual seja o antípoda desse imaginário total: o vazio constitutivo. Ela conclui: "Não temos, finalmente, mais do que algumas ficções, criações da falta que nos constitui." (PARADA, 2015, p. 635, tradução nossa).

A ideia de uma ficção que ocorre no presente e se mantém isolada no âmbito linguístico fica clara nesta outra formulação de Roberta Veiga (2016b, p. 202): “Trata-se, portanto, de um filme que, com o pretexto de voltar ao passado, de acessar as memórias do pai pra dizer de sua vida, acaba por se tornar o embate presente apanhando na auto mise en scène de ambos, onde os personagens se constroem pra obra e na obra." O passado se torna mero pretexto, expulso da obra. Tal ideia ecoa ainda na análise de Izabel Fontes (2015, p. 157):

Neste sentido, o preenchimento das lacunas presentes nas narrativas
familiares busca a reconstrução de uma cronologia da origem, da filiação,
para a partir disso dar início a um trabalho de autofabulação, que opera no
sentido oposto ao do testemunho, recusando a busca pela verdade através da
experiência, mas colocando em evidência as próprias falhas da memória.

Estes são apenas alguns exemplos da bibliografia específica (e tantos mais poderiam ser pinçados em textos dedicados a outros títulos do Cone Sul) que expressam uma filiação teórica indireta a "outro mainstream: o ceticismo radical do discurso pós-moderno em relação à história" (DIDI-HUBERMAN, 2012, p. 96). Não são muitas as análises da fortuna crítica sobre o documentário intergeracional que citam Hayden White (1987, 1992b, 1994) (cf. 
APREA, 2015, p. 245-246; ESTEVE, 2009, p. 41 e 43; PIEDRAS, 2014, p. 152 e 165), algo que só reforça a hipótese acima esboçada de que, em geral, critica-se o saber histórico sem que se conheça as discussões epistemológicas básicas do campo. White, não custa lembrar, foi o autor que, respirando o oxigênio do dito linguistic turn dos anos 1970, alvoroçou o terreno historiográfico com suas teses tropológicas, extrapolando suas reflexões sobre o peso da retórica na narrativa histórica a ponto de torná-la indistinguível da narrativa ficcional (WHITE, 1987, 1992b, 1994; RICEUR, 2007, p. 261-274). De todo modo, quer se tenha ou não consciência disso, o fato é que as ideias de Hayden White chegam com força no campo de estudos do documentário contemporâneo, principalmente via Michael Renov (2004c) (cf. CARROLL, 1996) e, em menor medida, via Robert Rosenstone (2010). O primeiro, cuja produção é referência sobre o cinema documental subjetivo, sempre citada na bibliografia específica aqui trabalhada, já se perguntou, evocando White entre uma série de outros teóricos estruturalistas e pós-estruturalistas: "Como se pode representar adequadamente a história ou um subgrupo etnológico, por meio da palavra escrita ou da reprodução de imagens e sons, sem recorrer à elaboração do enredo (emplotment), ao tropo ou à convenção narrativa?" (RENOV, 2004b, p. 108, tradução nossa, grifo do autor). Por sua vez, Rosenstone (2010, p. 16), que desdobrou as ideias de White na interface entre cinema e história, escreve: "Há quase quarenta anos, o brilhante teórico Hayden White notoriamente nos disse que a tão vangloriada 'arte' da história era constituída por livros escritos segundo o estilo dos romances britânicos do século XIX." As ideias circulam, as leituras se cruzam, a hipérbole da ficção chega por intrincados caminhos até as análises de Os dias com ele e da filmografia intergeracional.

Hayden White (1992a) é um dos protagonistas da querela em torno dos "limites da representação" da Shoah no campo historiográfico, manifestando-se em um artigo cujo título é eloquente: "Elaboração do enredo (emplotment) histórico e o problema da verdade". ${ }^{99}$ Nesse texto, White (1992a, p. 37, tradução e grifo nossos) anuncia de saída: "Existe uma relatividade inexpugnável em toda representação dos fenômenos históricos. A relatividade da representação é uma função da linguagem usada para descrever e, assim, constituir os eventos passados como possíveis objetos de explicação e entendimento." No fundo, ele está desdobrando nesse campo de debate suas teses tropológicas: a linguagem usada nas narrativas historiográficas jamais é transparente; toda afirmação factual é uma entidade linguística pertencente à ordem do discurso; os relatos históricos tradicionais selecionam e articulam os

\footnotetext{
99 A tradução de emplotment como "elaboração do enredo" se inspira na solução proposta por José Laurêncio de Melo em WHITE, 1992b, p. 12. O referido artigo de White foi publicado no Brasil como "Enredo e verdade na escrita da história", em uma tradução (problemática) de Carlos Oiti (cf. WHITE, 2006).
} 
acontecimentos de acordo com protocolos retóricos de gêneros literários herdados do realismo do século XIX; a elaboração do enredo é já uma interpretação dos fatos, não existindo uma trama dos eventos inerente à sua ocorrência na história (WHITE, 1992a, p. 37-39). O curioso é que White começa fazendo uma refutação a contrario do irrepresentável da Shoah, terminando por reafirmá-lo em termos essencialistas. Para ele, a rigor, não existe nenhum modo narrativo "inadequado" para representar esse evento, uma vez que os fatos não têm, em si mesmos, uma natureza trágica ou cômica, por exemplo. Assim, nenhum modo de elaboração do enredo estaria intrinsecamente interditado, não haveria, nesse sentido, "limites" para a representação do horror. Menos estilo, mais sobriedade, a crônica crua, nada disso resultaria em mais verdade, em mais fidedignidade. Na visão de White (1992a, p. 43, tradução nossa), a ideia segundo a qual apenas uma escrita "desnarrativizada" seria apropriada nesse caso deriva do "lugar-comum de que este evento ('Auschwitz', 'a Solução Final' e assim por diante) é de tal natureza que escapa ao alcance de qualquer linguagem para descrevê-lo, de todo meio para representá-lo." Mas a Shoah, para White, a despeito dessa ausência de limitação, dessa "relatividade inexpugnável", não é representável de qualquer jeito. Pois o realismo herdado do século XIX, este sim, é "inadequado à representação de eventos que, tais como o Holocausto, são, eles próprios, 'modernistas' por natureza.” (WHITE, 1992a, p. 50, tradução nossa). Somente uma escrita modernista estaria apta a representar uma realidade modernista. Em suma, não haveria uma forma imprópria para se representar a Shoah, desde que esta seja uma forma modernista: uma "escrita intransitiva", enfim, um realismo que expresse a opacidade do real, uma representação que dê a ver o irrepresentável (WHITE, 1992a, p. 48-53).

Não são poucas as contradições internas dessas formulações: o relativismo absoluto (a relatividade inexpugnável); o relativismo essencialista (a realidade do século XX é "moderna" por natureza); o relativismo normativo (somente a escrita intransitiva "moderna" dá conta de “irrepresentar" esse real). Apesar desses paradoxos fundamentais, fica patente que as proposições de White são mais complexas do que a mera afirmação de que "tudo é ficção". De todo modo, como já ficou anunciado, o nó da questão neste caso não é tanto intrínseco à teoria, mas extrínseco: a defesa de uma "escrita intransitiva" que se isola de tudo aquilo que está no terreno extralinguístico; a premissa de uma "natureza" irrepresentável dos fatos que repele definitivamente a visada referencial das raias da narração. Para White, no fundo, não é que a Shoah seja irrepresentável. Ela não é "mais irrepresentável do que qualquer outro evento da história humana” (WHITE, 1992a, p. 52, tradução nossa). A própria realidade (ainda mais a "moderna”) é, na essência, irrepresentável, e a historiografia só estará apta a dar 
conta disso quando adotar uma estilística que supere o velho realismo em nome de uma escrita que radicalize os procedimentos metalinguísticos a ponto de se tornar intransitiva. A escrita, nesse caso, não representa nada que lhe seja externo. Ela é a expressão autorreferente do irrepresentável. Se existe uma realidade, ela está apenas aí, constituída textualmente. No fundo, a suposta refutação do irrepresentável feita por Hayden White é de sinal trocado. Enquanto os teóricos citados mais acima, Didi-Huberman (2012) à frente, recusam o irrepresentável em favor de uma maior atenção à concretude histórica, White o faz em nome de uma subtração do referente. No final do caminho, portanto, reitera-se um irrepresentável ainda mais categórico, ainda mais absoluto, abrangendo toda a história além da Shoah.

Paul Ricœur (2007, p. 263), em A memória, a história, o esquecimento - outra obra que costuma ser citada na bibliografia sobre o documentário intergeracional -, não deixa de reconhecer: "A maior contribuição para a exploração dos recursos propriamente retóricos da representação histórica continua a ser de Hayden White.” Mas logo alerta:

Em compensação, lamento o impasse no qual se fechou H. White ao tratar das operações de composição da intriga como modos explicativos, tidos, na melhor das hipóteses, como indiferentes para os procedimentos científicos do saber histórico, na pior, como substituíveis por esses últimos. Existe aí um verdadeiro category mistake que gera uma suspeita legítima quanto à capacidade dessa teoria retórica de traçar um limite nítido entre narrativa histórica e narrativa de ficção. [...] torna-se urgente especificar o momento referencial que distingue a história da ficção. Ora, essa discriminação não pode ser feita sem sair do âmbito das formas literárias. É preciso articular pacientemente os modos da representação com os da explicação/compreensão e, através desses, com o momento documental e sua matriz de verdade presumida [...]. (RICEEUR, 2007, p. 266-267).

Se Ricœur pondera as teses de White quanto a suas contribuições (trazer à tona o peso da retórica no discurso histórico) e seus equívocos (ignorar os procedimentos da operação historiográfica e o momento referencial que a distingue da ficção), a resposta de Carlo Ginzburg (2011e) é inclemente. De fato, o historiador italiano levanta-se em um "protesto moral" (RICEUR, 2007, p. 271) pleno de urgência contra um relativismo epistemológico que, levado ao limite, abriu as comportas para a negação da existência dos campos de extermínio nazistas. Diante de tal ameaça cética, Ginzburg faz uma acalorada reivindicação do referente histórico: "a conexão entre provas, verdade e história [...] não pode ser descartada facilmente"; o historiador escreve, e sabe-se que sua escrita jamais é transparente, mas "não devemos nos desfazer da velha noção de 'realidade' [...]"; "[...] qualquer documento, a despeito de seu caráter mais ou menos direto, sempre guarda uma relação altamente problemática com a realidade. Mas a realidade ('a coisa em si') existe"; "uma 
atitude totalmente cética em relação às narrações históricas não tem fundamento" (GINZBURG, 2011e, p. 215-216, 229-230). Quem conhece minimamente a obra de Carlo Ginzburg sabe que estas não são as afirmações de um historiador que se aferre ingenuamente ao positivismo. Muito pelo contrário - e ironicamente -, Ginzburg talvez seja aquele que tenha levado mais longe o projeto de uma escrita "modernista" da história, justamente pelo método ao mesmo tempo minucioso e criativo de interpretação das fontes. Provas e possibilidades (GINZBURG, 2011c), indícios e conjecturas (GINZBURG, 2007c), retórica e prova (GINZBURG, 2014) sempre andam juntos em suas análises, iluminando-se reciprocamente, abrindo caminhos inusitados de leitura, fechando outros que não se sustentam frente à documentação disponível. Mas a inventividade de sua obra se contrapõe, incansavelmente, às "teses céticas baseadas na redução da historiografia à sua dimensão narrativa ou retórica"; ao pressuposto de que, "do mesmo modo que um romance, uma obra historiográfica constrói um mundo textual autônomo que não tem nenhuma relação demonstrável com a realidade extratextual à qual se refere" (GINZBURG, 2014, p. 13 e 52, tradução nossa). Sobre as fontes, tão menosprezadas nas análises até aqui citadas de Os dias com ele, Ginzburg (2014, p. 48-49, tradução nossa) escreve:

\footnotetext{
A ideia de que as fontes, se dignas de crédito, ofereçam um acesso imediato à realidade, ou ao menos a uma faceta da realidade, também me parece rudimentar. As fontes não são nem janelas escancaradas, como creem os positivistas, nem muros que obstruem o olhar, como creem os céticos: antes, poderíamos compará-las a vidros deformantes. A análise da distorção específica de cada fonte implica já um elemento construtivo. Mas a construção [...] não é incompatível com a prova [...]. O conhecimento (mesmo o conhecimento histórico) é possível.
}

O que está em jogo aqui é a afirmação da potencialidade cognitiva da imaginação, da construção, da retórica. A elaboração ficcional não está absolutamente apartada do mundo referencial, como creem as teses narrativistas vinculadas ao linguistic turn (RICEUR, 2007, p. 261-263). A criação ilumina a realidade e vice-versa. "Para saber é preciso imaginar-se", eis a primeira frase de Didi-Huberman (2012, p. 15) em Imagens apesar de tudo. Mais adiante, o autor desenvolve essa ideia:

A imaginação não é, como frequentemente acreditamos, abandono às miragens de um único reflexo, mas construção e montagem de formas plurais colocadas em correspondência: é por essa razão que, longe de ser um privilégio do artista, ou uma pura legitimação subjetivista, ela é parte integrante do conhecimento no seu movimento mais fecundo, ainda que porque - o mais arriscado. O seu valor heurístico é incomparável [...]. (DIDI-HUBERMAN, 2012, p. 155). 
Ecoando de longe as teses de Hayden White, viu-se como até aqui as análises de $O s$ dias com ele valorizam a performance em detrimento da prova, do documento, da atestação. Naquelas leituras, os termos das dicotomias são claros: o artifício contradiz o rastro; a teatralização seria o oposto da evidência; a imaginação seria o antípoda da realidade; a mise en scène estaria isolada do passado; a autofabulação seria o contrário do testemunho. Resta só o espaço da cena, desconectado do passado, tal qual as teses tropológicas dissociam a elaboração do enredo do mundo histórico. Consagra-se aí, nas palavras de Rancière (2009, p. 54), “o 'autotelismo' da linguagem, separada da realidade”. Como se a narração houvesse conquistado "sua intransitividade" (RANCIÈRE, 2012, p. 129). Como se ficções e fatos tivessem racionalidades absolutamente incomunicáveis. Rancière (2009, p. 55) desenvolve:

Todavia, essa ordenação literária dos signos não é de forma alguma uma autorreferencialidade solitária da linguagem. É a identificação dos modos de construção ficcional aos modos de uma leitura dos signos escritos na configuração de um lugar, um grupo, um muro, uma roupa, um rosto.

E, mais uma vez, a afirmação dessa potencialidade cognitiva da ficção está longe de decretar o império da ficção:

O real precisa ser ficcionado para ser pensado. Essa proposição deve ser distinguida de todo discurso - positivo ou negativo - segundo o qual tudo seria "narrativa" [...]. A noção de "narrativa" nos aprisiona nas oposições do real e do artifício em que se perdem igualmente positivistas e desconstrucionistas. Não se trata de dizer que tudo é ficção. (RANCIÈRE, 2009, p. 58).

No fundo, querer diminuir o conhecimento histórico por conta de sua dimensão narrativa é um equívoco. Vale retomar o que escreveu Carlo Ginzburg (2011c, p. 329, grifo do autor) nesse sentido:

Hoje, a insistência na dimensão narrativa da historiografia (de qualquer historiografia, ainda que em diferente medida) se faz acompanhar, como se viu, de atitudes relativistas que tendem a anular de fato qualquer distinção entre ficção e história, entre narrações fantásticas e narrações com pretensão de verdade. Contra essas tendências, ressalte-se, ao contrário, que uma maior consciência da dimensão narrativa não implica uma atenuação das possibilidades cognoscitivas da historiografia, mas, ao contrário, sua intensificação. ${ }^{100}$

100 Corrigiu-se aqui um lapso da tradução brasileira citada, que trocou o original "attenuazione" por "acentuação". 
Nota-se que duas aproximações contrastantes entre ficção e história despontam nesse debate. De um lado, o viés que, remontando ao desconstrucionismo e reverberando no contexto de análise de Os dias com ele, pensa nos termos de uma ficção autotélica, cujo impulso é centrípeto, autossuficiente, intransitivo, enredado na linguagem. De acordo com tal postura, para além da retórica só existe o vazio, o irrepresentável, algo que, no fim das contas, libera a narrativa para se moldar de acordo com seus próprios esquemas tropológicos - com todos os riscos que isso implica, entre eles, o negacionismo. De outro lado, está a defesa de uma ficção cognitiva, pautada por um impulso epistemológico centrífugo voltado à transitividade do referente histórico. Para essa visão, além da linguagem está o real, desafiando constantemente as representações que tentam, apesar de tudo, conhecê-lo. No fundo, ambas as posições valorizam a criatividade, a abordagem inventiva da história, mas uma diferença fundamental se instala no cerne das formulações: o descarte ou a busca da referencialidade.

Quando se lança uma visada cognitiva para a "teatralização" em Os dias com ele, é possível enxergar a carga histórica da fabulação. Maria Clara termina de ler em voz over a cena da peça escrita pelo pai, cessa a inserção de filmagens em super- 8 de famílias alheias. Há um corte seco para uma nova sequência: Carlos Henrique Escobar, diante da câmera da filha, encena um discurso inflamado. Ele, de pijama, está em sua escrivaninha, a estante lotada de livros em segundo plano. Seus gestos são amplos e incisivos, ora o dedo em riste, ora o golpe de punho na mesa, a impostação da voz é veemente:

Ter chegado até aqui, com esse grande público reunido aqui, na Barata Ribeiro, em Copacabana, deve ter observado que poder usar o microfone e poder dizer alguma coisa significava se aproximar na forma de uma luta corpo a corpo em particular com os stalinistas. Eles insistem que nós não devemos organizar a passeata em protesto contra a ditadura militar. Mas é um engano deles, não nesse momento, mas na própria constituição de organização pelo planeta. Eu quero fazer aqui um protesto público contra o senhor Ferreira Gullar, que, aproveitando a sua popularidade, que nós sabemos que não é devida à sua importância intelectual.

E Carlos Henrique continua seu monólogo desqualificando Ferreira Gullar como artista e militante de esquerda: "poeta médio"; "que politicamente nos trai"; "que se diz neutro frente à ditadura militar"; "que não é companheiro"; "que veio aqui sabotar o nosso movimento, a nossa organização para fazer a passeata que, como já se diz, é a Passeata dos Cem Mil”; "o esforço para tirar o microfone de nossas mãos, agredindo-nos, o temor de que nós passemos a constituir uma nova esquerda brasileira"; "num país onde os inimigos da ditadura são torturados e mortos”. E finaliza, em tom grandiloquente: "Eu quero saudar todos 
os companheiros e encontrá-los amanhã, e eu tenho certeza disso”. Ele para, termina a cena, não há corte. Explica para Maria Clara, que se mantém atrás da câmera, o contexto histórico e a intenção estética da performance. Sua voz retoma o tom cotidiano: "Você entende? Esse texto, é como se fosse em 1968, 1969. Você entendeu? Você percebeu o efeito? Nós temos um jogo para sair daquela monotonia."

De pijama em sua casa, Carlos Henrique Escobar leva o espectador a imaginar toda uma cenografia para seu discurso. Indicações precisas constroem a mise en scène: o "grande público reunido", o lugar (a rua Barata Ribeiro, em Copacabana), o microfone. Depois, ele viria a esclarecer a data $(1968,1969)$. Sua voz se projeta, seus gestos são enfáticos. Enfim, ele atua em prol da forma fílmica, tentando tirar o documentário "daquela monotonia". Falar em "teatralização" aqui é absolutamente pertinente. Mas esse teatro tem um teor, o "texto" dramatizado faz referência a uma conjuntura histórica definida: uma assembleia às vésperas da "Passeata dos Cem Mil", na qual a persona assumida por Carlos Henrique diverge do posicionamento político dos "stalinistas", em especial Ferreira Gullar. A cena, por si só, já traz essa carga de uma circunstância em particular da oposição à ditadura no Brasil. As divergências entre as correntes de esquerda naquele quadro emergem com força na fala e nos gestos de quem atua. A oratória encenada tem um nexo explícito com o passado. Só isso já seria suficiente para trazer à tona o fio histórico dessa performance visível em Os dias com ele.

Contudo, o esforço para se fazer da ficção uma entrada para o conhecimento histórico não precisa parar por aí. Afinal, para além da imanência das imagens, existem fontes extrafílmicas que ajudam a iluminar certos aspectos da historicidade dessa cena. Não haveria motivo para a análise simplesmente desprezar o fato de que o referente na origem dessa teatralização específica já foi registrado em outro lugar. Descobre-se, com isso, que o episódio não é mero fruto da imaginação de Carlos Henrique Escobar. A assembleia em que ele entrou em confronto com Ferreira Gullar efetivamente ocorreu, durante os acalorados debates acerca da organização da "Passeata dos Cem Mil”. Em seu clássico 1968: o ano que não terminou, Zuenir Ventura (2008, p. 137-138, grifo do autor) relata:

[...] os intelectuais e artistas saíram do [Palácio] Guanabara e foram quase todos para o Teatro Glaucio Gill, em Copacabana, armar a "Barraca de protesto". A primeira reunião entrou noite adentro e a assembleia permanente durou, pode-se dizer, até a madrugada de quarta-feira. Foram memoráveis discussões - uma interminável guerra oratória entre reformistas e revolucionários. Os primeiros, representados por Ferreira Gullar, Vianinha, Paulo Pontes, Teresa Aragão; os segundos, tendo à frente o psicanalista Chaim Samuel Katz e o filósofo Carlos Henrique Escobar. 
O cenário do monólogo ("esse grande público reunido aqui, na Barata Ribeiro, em Copacabana") remetia a um espaço concreto: o Teatro Glaucio Gill, localizado exatamente na rua Barata Ribeiro, em Copacabana. A data agora pode ser identificada com certa precisão: entre o dia seguinte à chamada "Sexta-Feira Sangrenta" e a véspera da "Passeata dos Cem Mil”, ou seja, entre 22 e 25 de junho de $1968 .{ }^{101}$ Mas a identificação dos dados factuais básicos não é o aspecto mais interessante desse cotejamento entre mise en scène e registro bibliográfico. O que chama atenção é que Carlos Henrique encena no documentário da filha aquela "interminável guerra oratória entre reformistas e revolucionários". Sua performance atualiza as pautas de outrora, revelando a força no presente de uma memória que assumiu a forma do ressentimento político (cf. BRESCIANI; NAXARA, 2001). Zuenir Ventura (2008, p. 138) informa na sequência de seu relato que a posição "revolucionária" encabeçada por Carlos Henrique Escobar foi vencida naquela assembleia pela proposta "reformista" do Partido Comunista Brasileiro (PCB), o "Partidão". Na última noite da reunião, Ferreira Gullar foi o porta-voz da negociação do PCB para que a passeata tivesse a anuência das autoridades, algo que implicava para o movimento aceitar a condição de um itinerário preestabelecido. Esses detalhes da crônica política de época ajudam a entender a insistência com que Carlos Henrique Escobar critica os "stalinistas" ao longo de Os dias com ele. Diante da câmera da filha, ele nunca perde a oportunidade de expressar seu rancor contra os integrantes do PCB, sem meias palavras: "Partido Comunista Brasileiro, onde havia subintelectuais"; "o quadro stalinista precisa ser um medíocre"; “eu sempre fui comunista, mas nunca comunista do Partido Comunista Brasileiro, que é uma farsa". No fundo, estas são as palavras da memória irreconciliada de alguém que, vencido na assembleia de 1968 no Teatro Glaucio Gill, reagindo no discurso encenado em Os dias com ele, não aceita as transações com o poder, as posturas conciliatórias dos "reformistas" do passado. ${ }^{102}$ Fato e ficção se iluminam reciprocamente. A radical intransigência de Carlos Henrique Escobar revela sua densidade histórica, manifestando sentidos que vão muito além da simples idiossincrasia de um velho ranzinza preso ao passado. A análise imanente da matéria fílmica se associa à pesquisa bibliográfica, e fica claro que isso não significa descurar daquilo que é performance. Diferentemente do que tantas vezes se supõe, o vestígio documental não surge contra a fabulação. A prova não é o "nada" inútil frente ao "tudo" da ficção. Pelo contrário, nesse

\footnotetext{
${ }^{101}$ Para uma análise detida desses eventos na esteira das mobilizações contra o regime ao longo de 1968, com foco no movimento estudantil, incluindo as divergências entre "reformistas e divisionistas", cf. VALLE, 2008, p. 97-164.

102 Sobre as críticas à linha política do PCB e as organizações dissidentes surgidas naquela conjuntura, cf. GORENDER, 1987; NAPOLITANO, 2014, p. 89-91; REIS FILHO, 1990; RIDENTI, 2010.
} 
caso, à luz do registro histórico, compreende-se melhor aquilo que está em jogo nessa "teatralização".

Maria Clara Escobar parece ter entendido que a ficção poderia ser uma via para tentar conhecer seu pai. Terminado o monólogo contra Ferreira Gullar, Carlos Henrique sugere ainda outra cena para dinamizar o documentário da filha. Agora ele não discursaria sozinho, ele convoca Maria Clara para participar da ação desde o antecampo, ditando-lhe uma pergunta: "O que eu quero perguntar ao dramaturgo - não precisa dizer... é, o dramaturgo, tem que dizer dramaturgo - ao dramaturgo Carlos Henrique Escobar..." Ele deseja que a encenação tenha como tema a sua obra teatral. Pensa em uma peça a ser abordada e continua ditando a pergunta para a filha: "é se ele realmente acredita, conforme o espetáculo demonstrou, que Euclides da Cunha tenha sido vítima ou até mesmo assassinado pelos militares." Carlos Henrique diz para Maria Clara memorizar a fala, indica as "rubricas" da cena, gesticula ao descrever o ambiente imaginário: "Você está sentada assim, acabou a peça, várias pessoas perguntam alguma coisa. Não se esforce." Maria Clara entra no jogo de espelhos das direções: o pai-dramaturgo dirige a filha-cineasta e vice-versa. Ela repassa o "texto", quer saber se o memorizou corretamente. Ele diz: "Cria!" Maria Clara, atrás da câmera, repete literalmente a pergunta sugerida por ele. Carlos Henrique se esforça para ouvila, sua audição, já se sabe, é limitada. Sentado em sua escrivaninha, ele assume a postura ereta do debatedor e começa a responder, a voz impostada: "A sua questão é ainda mais complexa do que a questão do senhor de óculos ali na primeira fila." Ele aponta para o fora de campo, indicando o figurante inventado para a cena. E começa a explicar o tema da peça Ana Clitemnestra. É sobretudo essa a imagem de si que ele quer legar por meio do documentário da filha. Mas esse não é exatamente o retrato que a filha busca do pai. No desacordo quanto ao projeto do documentário, essa performance combinada forja um diálogo por meio do qual os dois podem se aproximar.

Eis um caminho que vale a pena ser percorrido para evitar cair no abismo do irrepresentável. A esta altura, o leitor terá percebido que os conceitos e textos problematizados neste trabalho são levados a sério, relidos minuciosamente, e não barateados a priori em uma caricatura. Sem dúvida, a crítica que aqui se faz do irrepresentável reivindica o prisma historiográfico. Mas esta não é uma crítica feita desde "fora", não se faz tábula rasa da bibliografia específica ou das referências teóricas aí citadas em nome de um viés alternativo exógeno à discussão. Pelo contrário, trata-se de rever o filme, de repassar os textos e os teóricos, rastreando os limites intrínsecos às abordagens do irrepresentável. No fundo, 
existe aí uma franca proposta de diálogo nesse campo de estudos - no qual as análises de uma mesma obra tantas vezes são elaboradas em paralelo, ignorando-se mutuamente.

Partindo-se da cadeira vazia de Os dias com ele, algumas veredas interpretativas vêm se delineando. Em primeiro lugar, a celebração do fracasso, postura que acaba ficando presa a um circuito tautológico: o pressuposto da impossibilidade da representação leva à conclusão da impossibilidade da representação e suas variantes sempre irredutíveis. Em segundo lugar, está a afirmação de que "tudo é ficção" diante do "nada" referencial. O problema nesse caso diz respeito à suposição de um império da linguagem do qual a realidade esteja para sempre degredada. Por vias distintas, mas que se cruzam na esfera do absoluto, o que essas abordagens fazem é decretar o vazio, e só o vazio, do terreno histórico. O capítulo anterior esteve às voltas com o tema do "documentário de busca" (BERNARDET, 2005), mas o foco ali era a dialética entre aquilo que a busca tem de imprevisível e as fórmulas que ela assume no documentário intergeracional do Cone Sul. Ora, como já ficou indicado, a apologia da indeterminação formal tem uma relação umbilical com a matriz teórica do irrepresentável. Quanto a isso, é interessante observar que a questão da busca revela uma nova faceta ao ser levada do campo estético para o epistemológico. O problema agora passa a ser não tanto a codificação do imponderável, e sim a transformação da busca em um gesto que se esgota em si mesmo. Quando se faz do referente um "nada", quando o fracasso está assegurado de saída, quando a linguagem se fecha em seus próprios enredos, "buscar", curiosamente, transformase em um verbo intransitivo, sem objeto. ${ }^{103}$ Nesses termos, a busca se reduziria de vez à mera figura retórica. Se, por um lado, a busca nesses documentários, dependendo do caso, pode até chegar a ser isso mesmo, o artifício que estrutura um discurso unívoco, apenas mais um dentre os recursos de linguagem do cinema documental contemporâneo; por outro, uma interpretação historiográfica preocupada com os nexos da memória com o horizonte referencial não pode abrir mão de tentar identificar aquilo de extralinguístico inscrito nas imagens da busca. Vale lembrar que a busca tem uma dupla dimensão: ela é um esforço inconcluso, mas também é um impulso em direção a algo. Em outras palavras, é um gesto que contém uma negatividade, mas que carrega, ao mesmo tempo, uma potencialidade. Ao restituir a transitividade do verbo "buscar”, a interpretação se assume como parte, ela mesma, de uma busca. Um esforço analítico que, apesar dos pesares, não necessariamente está fadado ao fracasso.

\footnotetext{
${ }^{103}$ Vale citar, ainda que em nota de rodapé, um exemplo de formulação nos termos da busca intransitiva. Desdobrando a definição de "documentário de busca" de Bernardet (2005), Roberta Veiga (2016b, p. 205) escreve: "[...] o que parece interessar é a concepção da busca como um ato em si, no qual o fim é menos um ponto de chegada do que de saída, é a partida para que a busca vire processo e se faça filme. Não se trataria, portanto, de um 'fim que justifica os meios', porém dos meios eles mesmos, ou de um fim sem fim: uma vez é que o filme só existe enquanto processo de busca."
} 
Todas as leituras e releituras até aqui empreendidas se deram no sentido de mostrar que um outro percurso de análise é possível. A aporia da representação está no cerne das tentativas de se conhecer o passado, qualquer interpretação que não se queira ingênua deve começar por aí. Mas esse ponto de partida não é um beco sem saída. Tampouco a "perda da inocência" epistemológica significa a condenação a uma deriva cética infinita. Rever as imagens de Os dias com ele, retomar cuidadosamente suas análises e os teóricos nelas evocados, ir às fontes extrafílmicas, é claro que nada disso anula a margem de indeterminação que ronda toda interpretação. Mas interpretar as imagens em termos históricos, ainda assim, é possível. É desde esse lugar problemático que se inicia uma tateante caminhada. O nó da representação é o primeiro passo, mas cabe fazer uma aposta de que é possível dar alguns passos a mais, mesmo que titubeantes (DIDI-HUBERMAN, 2012, p. 134; GINZBURG, 2014, p. 11).

\section{Reconhecendo a potencialidade da representação}

Quando Maria Clara Escobar insiste em filmar o pai e perguntar-lhe sobre seu passado, de certa forma ela estaria acreditando nessa potencialidade da busca. A câmera observacional da filha perscruta Carlos Henrique em seus momentos mais corriqueiros. Em uma primeira sequência nessa chave, ele lê; anda pela casa; discute com o filho ao consertar uma janela; é cruel com os desencontros sentimentais da filha. Na segunda sequência dessas passagens observacionais, vê-se mais desses momentos prosaicos: o pai com seus gatos no quintal; Ana tentando organizar os arranjos do aniversário dele; Carlos Henrique lendo. Os enquadramentos são sempre um tanto desaprumados, a câmera, tremida, em geral está atrás de algum anteparo (uma cortina, um muro vazado, uma pilha de papéis). Os momentos são banais, mas Maria Clara insiste em buscar algo neles. Carlos Henrique está comendo no sofá, assistindo televisão. Nada mais trivial. Obstinada, a filha prossegue filmando. Terminada a refeição, o pai permanece no sofá, sem dar muita atenção ao televisor fora de quadro. Ele dirige-se à esposa: “Ana? Ana Maria?” Ela: “Hum?”. O pai fala como se a filha não estivesse no ambiente: "Desliga o negócio dela, porque eu não consigo nem ler." A esposa faz a mediação: “Clarinha, onde é que se desliga isso? Teu pai disse que não consegue ler.” Ele diz: “Aperta um botão qualquer." Ana: "Pronto, ela apertou." Corte.

A câmera constantemente ligada chega ao ponto de incomodar Carlos Henrique. A insistência de Maria Clara não é só a das perguntas, das tentativas de extrair do pai um testemunho nas entrevistas. Para além da palavra, Maria Clara busca algo nas imagens, 
filmando desajeitada e discretamente os momentos prosaicos, invadindo os dias dele. Pode ser que a filha tivesse pouca clareza acerca daquilo que ela mesma estava buscando. O pai faz questão de dizer isso a Maria Clara, de maneira dura, toda vez que indaga a filha sobre qual era o verdadeiro projeto de seu filme. Paul Arthur (1993, p. 126-134) já analisou o modo como a desorientação e a inaptidão técnica muitas vezes ostentadas por documentaristas contemporâneos podem constituir um tropo narrativo que confere uma espécie de autenticidade invertida às obras. As indecisões do cineasta, a falta de domínio do dispositivo audiovisual e as falhas na operação dos equipamentos seriam, em certos filmes, artifícios dramáticos, jargões retóricos da estética do fracasso. Não seria esse o caso de Os dias com ele. As dificuldades da cineasta Maria Clara, visíveis na forma e no teor das imagens, não parecem uma afetação estilística. Fora do filme, nas “Anotações sobre um processo" redigidas pela própria diretora, essa impressão se reforça. Maria Clara Escobar (2015, p. 18-20) sempre pontua as incertezas que atravessaram a fase das filmagens: "[...] minha coragem e clareza estavam superestimadas por mim naquele momento"; "Ainda então, métodos muito mais automáticos do que reflexivos. Quase nunca se tinha certeza de quando se estava filmando e o que se estava produzindo do atrito"; "Sem que fosse absolutamente consciente, e sem que tenha certeza do que digo agora [...]"; segundo ela relata, por boa parte do processo ela teve “vergonha do erro e do descontrole". Não se trata aqui de cometer o equívoco analítico primário de dar a última palavra sobre a obra a sua própria autora. Contudo, essas impressões retrospectivas de Maria Clara Escobar oferecem pistas sobre uma desorientação do projeto que está no cerne dos embates com o pai visíveis no resultado final de Os dias com ele. Cotejadas, tanto as imagens fílmicas quanto as impressões escritas fazem crer que as tentativas e os erros estavam entranhados no processo - dois exemplos já comentados servem aqui como contraste, aproximando-se em graus distintos do diagnóstico de Paul Arthur (1993): a performance desnorteada fortemente roteirizada da diretora em Diario argentino (Lupe Pérez García, Argentina / Espanha, 2006); a impostação da ingenuidade do olhar infantil em Los rubios (Albertina Carri, Argentina, 2003).

Em Os dias com ele, tudo indica que o erro é um passo no caminho, e não o roteiro de um fracasso incontornável. Ao repetir perguntas e continuar filmando os momentos mais prosaicos, Maria Clara parece acreditar que dos tropeços poderia surgir algo de significativo. A insistência da filha-cineasta diante dos obstáculos merece ser lida como o reconhecimento da potencialidade da representação. Maria Clara não desiste, ela não se contenta com a falência do filme. Naquelas mesmas "Anotações sobre um processo", ela relembra: 
[...] após a cena da cadeira vazia, mantida no corte final, eu pensei intensa e sinceramente em desistir do filme. Fiquei semanas sem filmar. Não sabia como restituir uma conexão entre a personagem e a documentarista. Estive a ponto de fazer as malas definitivamente, aceitar o fracasso. Foram semanas de horror. (ESCOBAR, 2015, p. 21-22).

Mas a cineasta logo entendeu "que desistir naquele ponto era demasiado simbólico e significava desistir dessa nova possibilidade de diálogo com o mundo (compreendendo o conflito)" (ESCOBAR, 2015, p. 22). E prosseguiu filmando. Ver Os dias com ele apenas pelo prisma do fracasso da cadeira vazia é desconsiderar os possíveis sentidos da persistência visível nas imagens desse documentário.

Existem as análises que reconhecem abertamente essa potencialidade. Cezar Migliorin, desenvolvendo uma leitura esboçada "a quente", no contexto da Mostra de Tiradentes que premiou o filme de Maria Clara Escobar (MIGLIORIN, 2013), apontava nessa direção:

Há uma cineasta que, sobretudo, se dispõe a lutar pelo seu filme, apesar do fracasso iminente. O filme está à beira do desabamento e talvez seja esta grande parte da experiência que o filme nos permite. A possibilidade de estarmos com palavras, ironias, gestos, histórias, apesar de tudo.

[...] é preciso lidar com o fracasso que ronda o esforço em fazer passagens entre o que é privado para o que é comum. (MIGLIORIN, 2015, p. 62-63).

Em texto publicado na revista Cinética, o crítico Raul Arthuso (2013, n.p.) logo enxergou também essa potencialidade:

O gosto pelo fracasso passa ao largo de Os dias com ele. [...] há aqui uma memória específica da ditadura e um testemunho possível da tortura quando Carlos relata sua experiência pessoal, um trunfo do filme e uma conquista da cineasta que insistira pelo relato do pai. [...] Nesse sentido, Os dias com ele alcança a política: é um filme-testemunho consciente das implicações de não se chegar à verdade, mas nunca um filme sobre a impossibilidade.

$\mathrm{Na}$ análise de Natalia Christofoletti Barrenha (2013b, p. 344), a passagem da cadeira vazia transcende o fracasso. Segundo essa autora, quando a filha invade o quadro, senta-se na cadeira e lê o mandado de prisão para sua própria câmera, "nesse ato de desespero, diante de mais uma recusa do pai", emerge uma afirmação ao mesmo tempo pessoal e referencial: "Ao enfrentar o aparelho, Maria Clara se afirma como uma pessoa e como uma cineasta capaz de nos dizer muito sobre nosso passado traumático." 
$\mathrm{Na}$ introdução do catálogo da já aludida mostra "Silêncios históricos e pessoais", os curadores Natalia Christofoletti Barrenha e Pablo Piedras (2014, grifo dos autores) consideram que certos traços de Os dias com ele sintetizam:

[...] as características distintivas de uma nova forma de cinema documental que indaga as tensões entre história e memória, entre o familiar e o social, o público e o privado, o íntimo e o coletivo, através do prisma subjetivo de um autor que interpela a realidade, o passado e os outros, expondo sua voz e seu corpo em primeira pessoa.

Interpelar, mais um verbo transitivo. Interpelar a realidade (note-se, sem aspas), o passado e os outros. Para Barrenha e Piedras, a primeira pessoa não prescinde da alteridade, daquilo que lhe é outro, seja alguém ou o passado.

Karla Holanda (2015) propõe uma leitura de Os dias com ele a partir da questão de gênero. Segundo a autora, a cineasta não se acanha frente à autoridade patriarcal e intelectual de Carlos Henrique Escobar. "Não é por sua fala ser mais frágil, hesitante, cheia de dúvidas, que Maria Clara Escobar se retrai. Ao longo do filme, vemos uma conquista gradual de seu espaço." (HOLANDA, 2015, p. 355). Na passagem da cadeira vazia, isso se confirmaria. Depois da tensa discussão fora de campo, Holanda (2015, p. 355) escreve, “ela própria sentase, ocupando o espaço vazio, e lê, fincando pé na sua proposta inicial, resistindo à resistência do pai. Ela não o convenceu por argumentos racionais, mas mostrou que, como diretora, tem outros poderes."

Mesmo Ana Rosa Marques (2015), cuja análise de Os dias com ele se concentra na construção dos personagens pela performance e pela montagem, não chega a cair na armadilha do "tudo é ficção". Justamente ao comentar a passagem da leitura em voz over da peça de Carlos Henrique por Maria Clara, ela concede que "a montagem e a performance tornam-se fundamentais também para dizer o que, a princípio, parece irrepresentável." (MARQUES, 2015, p. 427, grifo nosso).

Um segundo passo epistemológico é dado por essas abordagens que vão além do vazio, por essas análises que reconhecem uma potência latente entre aporias e tropeços da representação. O primeiro, como se viu na seção anterior, é a consciência do caráter problemático de toda representação. O segundo passo rompe a paralisia que esse problema pode gerar: ele confia que, apesar dos obstáculos, é possível avançar. Uma potencialidade surge, assim, no caminho. Entretanto, o segundo passo, embora imprescindível, é ainda um gesto incompleto. Resta mais um trecho a ser percorrido no sentido de realizar essa potência, o terceiro passo, o mais arriscado, rumo a uma aproximação com o referente: tentar descrever 
aquilo de concreto que a busca das imagens tateia. No campo da interpretação fílmica, trata-se de insistir em dizer algo sobre aquilo que toca à história.

André Brasil (2013, p. 591) indica um rumo promissor para esse terceiro passo quando escreve:

Se, enfim, o filme de Maria Clara Escobar não fracassa totalmente - se ele não finda a celebrar o próprio fracasso - será por dois motivos: primeiro, porque mesmo premida pela extrema dificuldade do diálogo, ela consegue expor algo da vida do personagem, situado à margem, exilado do contexto intelectual e político do Brasil.

O trecho oferece pistas sobre aquilo que está para além da potencialidade, sobre algo que a obra, desdobrando uma latência, dá a ver sobre o passado e o presente de Carlos Henrique, seu lugar à margem.

\section{Uma aposta no representável: a cadeira, o documento e a imaginação historiográfica}

Maria Clara não se dá por vencida. Ela persiste filmando, o pai chega ao ponto de pedir para que se desligue "o negócio dela". Corte. No plano seguinte, Carlos Henrique Escobar está sentado em sua poltrona, de jaqueta, chapéu e óculos escuros (fig. 190). Golpes de zoom in e zoom out ajustam o enquadramento. Carlos Henrique ajusta os óculos escuros no rosto. Ele respira ofegante. Outro corte: ele acerta novamente os óculos, ajeita o casaco. Seguem os golpes de zoom in e out, ele ergue o braço. Maria Clara diz: "Peraí. Tá ouvindo?". Preparam-se para a entrevista. A filha começa dizendo que repassou tudo o que filmaram juntos e que o pai não havia "respondido exatamente" a pergunta sobre sua prisão e tortura na época da ditadura. Ela aposta em uma segunda tentativa. Diz compreender os argumentos dele. Carlos Henrique parece impaciente, entrecortando as frases da filha: "Sei”, "tá", "tudo bem", "sei, sei". Ela segue ponderando, explica que entende o fato de ele não reconhecer isso como a faceta principal de sua história, fala que "o filme não é só sobre isso ou só esse momento", completando que compreende ainda o que ele "diz sobre as diversas versões e os testemunhos da história". Carlos Henrique escuta: "Sei." Maria Clara recorre então a um argumento sem dúvida de forte apelo para o intelectual: "Mas, ao mesmo tempo, eu continuo achando que existe, de alguma forma, a responsabilidade histórica de se falar sobre isso, de que as pessoas contem isso." E arremata dizendo que queria entender por que o pai "optou por não contar exatamente isso". Corte. Carlos Henrique, com os mesmos trajes, começa a falar: 
"Eu estou dando uma volta em um quarteirão às dez da noite com a Maria da Glória, aborrecidos os dois, discutindo. É tarde."

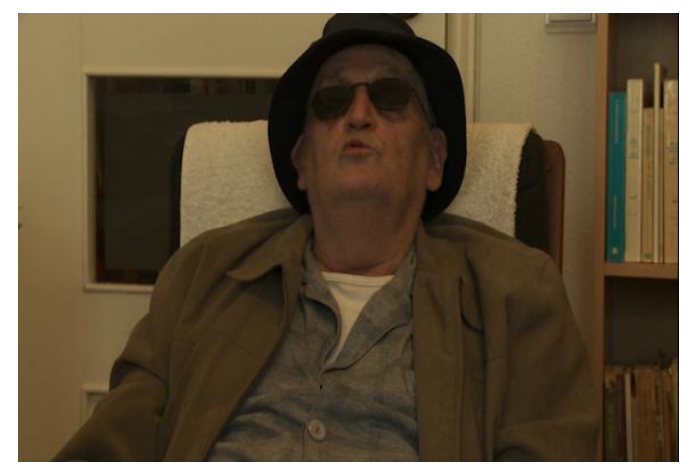

Figura 190 - Carlos Henrique Escobar relata a tortura sofrida. Fonte: Os dias com ele (Maria Clara Escobar, 2013).

Enfim, após mais de uma hora de documentário, a busca insistente de Maria Clara, afinal, desencadeia o relato possível da prisão e da tortura. O filósofo não mais recorre a Derrida. O dramaturgo deixa de lado sua peça. O testemunho começa com os dados básicos das circunstâncias da prisão: lugar, horário, situação. E flui. Carlos Henrique relata aquelas experiências terríveis com uma desenvoltura até então negada ao filme. Como se ele estivesse se sentindo protegido pela inusitada indumentária, os óculos escuros, o chapéu. Acompanhando a fala fluida, seus gestos vão ilustrando os eventos narrados. Pelos movimentos do seu corpo, entretanto, é possível notar que suas pernas estão agitadas fora de quadro. Mas o plano enfoca o seu rosto, os cortes são mais recorrentes nessa passagem, encadeando o fluxo do testemunho. O próprio documentário parece baixar por um instante a guarda da reflexividade. O diálogo tenso entre pai e filha, nesse instante capital, aproxima-se formalmente da concatenação da entrevista documentária mais convencional. Carlos Henrique narra, conta em minúcias os episódios da prisão e da tortura, e esses detalhes são justamente os indícios mais eloquentes. O mau cheiro do capuz, no carro, após ser preso com "Glorinha" (Maria da Glória Ribeiro da Silva, psicóloga e militante, companheira de Carlos Henrique à época). A náusea e a cegueira, "primeiro, porque não estava claro para mim o porquê de eu estar sendo preso. Não estava muito claro para mim." Nesse plano, ele surge sem os óculos escuros.

Novo corte: a narrativa agora adentra os porões. Carlos Henrique pode tirar o capuz. Recobrada a visão, ele vê sangue em Glorinha e fica apreensivo: “Apreensivo é uma coisa... Porque todos nós vamos reagir, tendemos a reagir, face a uma ameaça absoluta, com as fantasias da nossa infância." O dramaturgo Carlos Henrique Escobar, diante da tortura, reage com as lembranças da infância. O personagem Louis Althusser, diante da tortura, reagira com 
as lembranças da infância. O referente da cena teatral, a vivência que lhe deu substância, emerge no relato pessoal.

Outro corte, uma frase: "Vencer esse afluxo do inconsciente é para pessoas extremamente bem preparadas." Novo corte, outra frase: "Eu quase que me desorganizo." Corte. Sua salvação vem de um gesto simples, um detalhe: a mão de Glorinha na sua, a frase despojada de filosofia, "Fica tranquilo".

Os cortes prosseguem. Carlos Henrique reproduz o teor das perguntas e imita os golpes agressivos do torturador: "Qual o nome da revista em que você escreveu sobre o Estado Leninista? Vamos, fale! Eu não sei, eu escrevi tantas coisas sobre Marx, Lênin etc. Aí eu não sabia mesmo." Fala da demora de todo o processo, da intenção de esgotar o torturado. Corte: Carlos Henrique agora está mais reclinado na poltrona, vê-se sua perna cruzada na margem inferior do quadro. Seu corpo vai da sutil agitação nervosa à distensão. Nessa nova postura, sempre gesticulando para ilustrar o que diz, ele relata as "três grandes brutalidades" que sofreu. Primeiro, ter sido trancado em um compartimento escuro, a sirene em alto volume que deixou as sequelas auditivas, a surdez parcial flagrada em diversas passagens do documentário. “Ahhh! A toda força. Arrebentavam-me os ouvidos e, às vezes, eu gritava, por causa do... Eu fiz o... Vem cá, vem, lindinha! Vem cá, vem, bichinha!” Carlos Henrique, sorrindo, chama a gata que está fora de quadro, bate no braço da poltrona para atraí-la. A gata entra no campo, ele a acomoda no colo e a acaricia. Retoma de pronto o relato: “Ah, e isso me fez muito mal, de certa maneira me tirou quase toda a audição.” A interrupção da gata não chega a quebrar o delicado fio do relato. Carlos Henrique, enfim, está disposto a narrar e continua.

Corte: ele fala do pânico irreversível gerado pelos choques, a segunda grande brutalidade. "É um horror. E mata. Mata do coração também.” A gata ainda está em seu colo. Corte, terceira brutalidade: ele conta que o torturador o obrigou a amarrar em suas partes íntimas os fios que lhe dariam um choque "desproporcional", tendo sido forçado a repetir toda a operação para um novo choque.

Outro corte, o último dessa sequência. Agora Carlos Henrique faz uma espécie de balanço daquela experiência. Começa avaliando a dor sentida. Em seguida, dá sua opinião sobre o que se passou depois que saiu da prisão. Seu punho vai golpeando o braço da poltrona, ritmando a indignação de sua fala:

Nesse final, eu achava que eu tinha meus amigos de antes de ser preso e, quando eu saí, eram todos inimigos, ninguém queria que eu voltasse. Com medo de um outro grupo pegar a direção da coisa. Esses meus amigos, que 
eram stalinistas, eu estou falando meus amigos, eu disse, que eram professores, como eu, nas universidades, estão dirigindo até hoje as universidades e ganharam grandes empregos nos governos Lula e Dilma. Enquanto que os meus amigos que fizeram luta armada morreram... ou estão desempregados, ou o Lula e o Dirceu expulsaram do Partido dos Trabalhadores porque eles eram pessoas firmes. Isto é, tudo o que nós tínhamos de melhor e arriscamos pelo Brasil - eu não diria pelo Brasil no sentido nacionalista -, e arriscamos por quê? Por causa de um sofrimento geral, de pessoas, de animais, de tudo naquele país, foram os excluídos e são os temidos até hoje. Venceram: venceu o capital, venceram os banqueiros, venceram os torturadores, venceram os traidores. E eu não ponho a culpa disso numa fatalidade, eu ponho a culpa disso em nós, na nossa falta de preparo e de força para tê-los vencido. E então, somos nós que temos que mudar, você entende? É isso.

Corta. Quando Maria Clara confronta o intelectual com uma responsabilidade histórica, ele atende ao chamado e faz um esforço para superar os impasses do testemunho. A filha insiste, a experiência da tortura foi traumática, há um nervosismo de fundo que invade as bordas da imagem pela expressão corporal daquele que narra. Mesmo assim, Carlos Henrique leva adiante seu relato, aquela vivência dolorosa não fica invisível nos recônditos do irrepresentável. O pai enfim baixa a guarda e se dispõe a falar, e a forma fílmica o acompanha nessa fluidez, com uma série de cortes coesos que destoa dos planos-sequência que vinham dando a tônica reflexiva da montagem, principalmente pela inclusão dos embates pré e póscena. Nessa passagem, o espectador está diante de uma entrevista típica.

A análise de Os dias com ele desenvolvida por Reinaldo Cardenuto (2016) examina os duelos entre o pai (intelectual público à moda antiga) e a filha (documentarista contemporânea da subjetividade) mantendo sempre em vista as questões históricas em jogo. Em especial, chama atenção a sensibilidade do autor para captar as implicações políticas de algo que vem à tona com força na avaliação feita por Carlos Henrique Escobar após o relato da tortura:

Em diversas sequências de $O$ s dias com ele, defronte da câmera manuseada por sua filha, ele deixa escapar uma forte dissonância em relação ao Brasil contemporâneo, em especial ao fato de que nos últimos anos o país tem sido governado por uma esquerda cuja ação política passa por alianças de interesse com partidos de centro e de direita. Contrário às conciliações do poder, indisposto com uma esquerda que lhe soa institucionalizada e que agregou quadros do antigo PCB, Carlos Henrique apresenta no filme traços de ressentimento histórico e de recusa a um projeto cada vez mais distante das transformações desejadas pelo socialismo. Oriundo de uma oposição armada que foi, em grande parte, alijada das esferas de poder e de decisão, o filósofo encontra-se em desacordo com as negociações ideológicas presentes na democracia brasileira, sendo essa desarmonia um fator que 
provavelmente pesou em sua decisão de morar na Europa. (CARDENUTO, 2016, p. 123). ${ }^{104}$

Há uma aposta interpretativa aí. Uma chave de leitura histórica que joga luz sobre o ressentimento do dramaturgo com Ferreira Gullar, que oferece elementos para um exame do amargo balanço retrospectivo enunciado abertamente por Carlos Henrique logo após ter narrado em detalhes a experiência da tortura. Chega-se, enfim, ao terreno mais concreto da historicidade das imagens, o que não significa desconsiderar os percalços visíveis na obra, "uma reflexividade que expõe as inquietações e os processos de construção vivenciados pela cineasta durante a filmagem de seu documentário" (CARDENUTO, 2016, p. 124).

Pois seria de uma ingenuidade gritante tomar o relato desenvolto de Carlos Henrique como um enunciado mais verdadeiro do que as tergiversações filosóficas ou as esquivas ficcionais que precederam essa "entrevista". Ora, pensar nesses termos seria o mesmo que fazer uma reivindicação "regressiva" da visada referencial. Como se fosse possível voltar à época da "inocência" do documentário ou da historiografia. Neste ponto Hayden White (1992a, p. 44-48) tem razão: um relato "desnarrativizado", a crônica literal, supostamente despojada de estilo, nada disso garante uma maior fidedignidade - eis uma constatação básica que, contudo, não valida a hipérbole tropológica. Noël Carroll (1996) cai nessa armadilha "regressiva" em sua tentativa de refutação do "ceticismo pós-moderno" no campo de estudos do documentário. Querendo, legitimamente, manter a potencialidade cognitiva do cinema documental, Carroll acaba se aferrando aos pilares tradicionais do cientificismo: relações de causalidade, objetividade etc. Os contraexemplos apresentados pelo autor ao longo da argumentação são sempre de documentários informativos clássicos. Ao tecer sua crítica em nome de uma "mentalidade epistemológica mais conservadora" (CARROLL, 1996, p. 301, tradução nossa), como chega a admitir, Carroll mira o alvo certo, mas usa a munição errada. Ou melhor, sua artilharia contra o ceticismo dá um passo para trás.

O passo à frente, ainda que titubeante, seria a busca de uma interpretação inventiva. Enxergar apenas a lacuna no filme é pouco. Mas igualmente redutor seria depurar as imagens de suas aporias, privilegiando o teor do relato fluido que Carlos Henrique Escobar oferece nesse momento singular do documentário. Um último movimento deste capítulo propõe uma análise que confronte criativamente as verdades legíveis tanto no testemunho aberto quanto nas evasivas e nos vazios de Os dias com ele. Para isso, vale rever a passagem da cadeira vazia, fazendo um esforço interpretativo que vire do avesso a retórica do irrepresentável. A

\footnotetext{
${ }^{104} \mathrm{O}$ texto de Reinaldo Cardenuto foi publicado em inglês. As citações aqui correspondem à versão original em português, gentilmente cedida pelo autor.
} 
argumentação, assim, avança tateando, vai do impossível às potencialidades da representação, chegando afinal à aposta que retorna ao ponto de partida, mas com outros olhos. Mais uma vez, Carlo Ginzburg e Georges Didi-Huberman indicam os meandros do caminho teóricometodológico. O primeiro, de modo mais geral, ao professar um labor historiográfico em que coexistam "hipóteses arriscadas" e "rigor na pesquisa das provas" (GINZBURG, 2010, p. 250). O segundo, especificamente pelo cruzamento de duas de suas formulações. Começando pelo "duplo regime da imagem", ou seja, a ideia de que as imagens comportam em si, dialeticamente, a lacuna e o vestígio, o que foi destruído e o que sobrevive, a ausência e o resquício, uma obscuridade e uma verdade, o impossível e o apesar de tudo (DIDIHUBERMAN, 2012, p. 51-52, 136 e 209). Em outras palavras:

[...] é preciso contar ainda com este duplo regime das imagens, com este fluxo e refluxo da verdade que nelas se manifesta: quando a sua superfície de desconhecimento é atingida por uma turbulência, uma lâmina de conhecimento, então atravessamos o momento difícil e fecundo de uma prova de verdade. (DIDI-HUBERMAN, 2012, p. 111, grifo do autor).

Em Os dias com ele, no clímax dos embates entre pai e filha, a cadeira fica vazia por um longo tempo, os dois discutem em off, fora do alcance da câmera. Contudo, no final do plano - uma tomada cuja duração fica demarcada pela redução paulatina da luminosidade natural -, quando o desacordo chega ao ápice da saída de Carlos Henrique até mesmo do fora de campo, quando ele encerra a filmagem unilateralmente - "Amanhã", ele diz ao abandonar a cineasta com sua câmera ligada -, enfim, quando o refluxo e o fracasso se impunham, Maria Clara irrompe na imagem, atingindo aquela superfície vazia tal qual uma turbulência. Os impasses que ecoavam desde o espaço invisível da cena se revertem em um gesto afirmativo de autoexposição. Ela se senta na cadeira até então desocupada e lê o mandado de prisão no centro da discórdia da vez. No jogo entre o off e o visível, entre a inércia e a turbulência, entre a retração e o afluxo, entre a ausência e a presença, entre o nada e a história - como diz Carlos Henrique na discussão com a filha -, enfim, nessas tensões que afloram da duração incomum do plano, essa imagem traz a carga do "duplo regime". Nela se intensifica um curto-circuito em cadeia que atravessa todo o documentário: entre as gerações; entre as temporalidades; entre a resistência à opressão passada e a reação frente à direção do filme; entre a insubmissão do militante e a desobediência da cineasta; entre a imagem pública que o intelectual deseja legar à audiência e o retrato privado que a filha insiste em arrancar daquele convívio. A tensão dos dias passados com ele se projeta em uma temporalidade histórica. Os embates da memória intergeracional são aqui de alta voltagem: nem só negatividade (o vazio da cadeira), nem só 
positividade (a leitura do mandado oficial pela filha). A passagem da cadeira condensa uma dialética potente entre o vazio e o documento.

Como interpretar os termos dessa dialética? Como escapar de uma análise que concentre todas as atenções em apenas um desses polos, descartando o outro? Como extrair desse atrito uma indagação referencial? A segunda formulação de Didi-Huberman (2012, p. 148, grifo do autor) dá uma resposta frutífera a essas questões: por meio de uma leitura que convoque "todos os elementos do saber - documentos escritos, testemunhos contemporâneos, outras fontes visuais - suscetíveis de serem reunidos pela imaginação histórica numa espécie de montagem ou de puzzle [...]". Vale esclarecer: "imaginação" aqui não significa invenção. Defendendo uma historiografia que conjugue criativamente provas e possibilidades, Ginzburg (2011c, p. 334) alerta: das muitas soluções disponíveis ao historiador para lidar com as lacunas do passado, "entre as que certamente têm que ser excluídas está a invenção". Aqui a reivindicação da inventividade histórica - diferente da invenção - se dá em função da cognição, da busca de um conhecimento que assume a forma de uma montagem. Colateralmente, a intenção é demonstrar que a interpretação historiográfica, ao contrário da caricatura muitas vezes traçada, não ignora a dimensão imaginativa. Via de regra, são as leituras do irrepresentável que carecem de imaginação e de originalidade, repetindo sempre os mesmos tópicos da doxa contemporânea, descartando precipitadamente "todos os elementos do saber" que escapam à retórica do vazio.

Diversamente, a montagem professada por Didi-Huberman (2012, p. 156) - à luz das quatro fotografias do Sonderkommando e da obra de Jean-Luc Godard - "não se apressa a concluir ou a enclausurar":

[...] porque a "legibilidade" dessas imagens - e, por conseguinte, o seu eventual papel num conhecimento do processo em questão - só pode ser construída quando estas estabelecem ressonâncias ou diferenças com outras fontes, imagens ou testemunhos. O valor de conhecimento nunca seria intrínseco a uma única imagem, tal como a imaginação não consiste em imiscuir-se passivamente numa só imagem. Trata-se, ao contrário, de pôr o múltiplo em movimento, de não isolar nada, de fazer surgir os hiatos e as analogias, as indeterminações e as sobredeterminações em jogo nas imagens. (DIDI-HUBERMAN, 2012, p. 155).

Didi-Huberman (2012, p. 156, 171, 174 e 176, grifo do autor) desenvolve a ideia: a montagem "abre e complexifica a nossa apreensão da história", "associando várias perspectivas ou vários tempos do mesmo fenômeno". A "montagem intensifica a imagem e confere à experiência visual um poder que as nossas certezas ou hábitos visíveis pacificam ou 
velam", sendo "uma forma de dar a conhecer apesar de tudo aquilo que é impossível ver inteiramente, aquilo que permanece inacessível como um todo". "Ela procede, filosoficamente, de modo dialético [...]: ela é a arte de tornar a imagem dialética."

A dialética deve, assim, ser entendida como uma colisão desmultiplicada de palavras e de imagens: as imagens chocam entre si para que surjam palavras, as palavras chocam entre si para que surjam imagens, as imagens e as palavras entram em colisão para que o pensamento advenha visualmente. (DIDI-HUBERMAN, 2012, p. 177).

José Carlos Avellar (2016, p. 123) já colocou a cadeira de Os dias com ele ao lado de outras cadeiras do cinema brasileiro. Aquela de Terra estrangeira (Walter Salles e Daniela Thomas, Brasil, 1995), "que um dia o antiquário Igor mostrou para Paco, pouco antes da viagem para a terra estrangeira: a cadeira que não é uma cadeira, mas um 'vestígio da maior aventura de todos os tempos". Também a "cadeira do pai de Josué, que sabia fazer tudo de madeira”, de Central do Brasil (Walter Salles, Brasil, 1998), e a "cadeira que produz em Theo uma explosão de raiva, 'O que essa cadeira está fazendo aqui?'”, de A busca (Luciano Moura, Brasil, 2012). Avellar inclui ainda em seus paralelos "a cadeira descrita por Kafka na Carta ao pai, a poltrona de onde ele regia o mundo".

Outras cadeiras mais serão evocadas na montagem proposta nas páginas seguintes. Iniciando por One and three chairs, obra de arte conceitual de Joseph Kosuth, de 1965, que já é por si só uma montagem (fig. 191). Percorrendo as salas do Museum of Modern Art (MoMA) de Nova Iorque, o visitante em algum momento se depara com uma cadeira vazia. Não é a cadeira de um vigilante ou monitor que deixou seu posto. Afixadas na parede, ladeando o objeto, estão a fotografia da cadeira em tamanho real e a reprodução da definição de dicionário da palavra "cadeira". São uma e três cadeiras. Uma obra de arte. Alguns princípios semióticos fundamentais estão na origem de sua concepção: uma das cadeiras é a fotografia, o resultado de um registro mecânico, da luz que um dia atingiu a película, ao mesmo tempo ícone e índice daquele objeto; outra é o significante verbal "cadeira", a palavra tal qual codificada no dicionário; entre as duas, a cadeira "em si". A fotografia e a palavra, no campo das representações, a cadeira vazia real, no campo do referente. Ladeada por seus signos, aquela cadeira explicita, por contraste, a dimensão referencial da representação. Está claro que One and three chairs, na chave da arte conceitual, coloca-se no fundo como uma proposição que indaga as fronteiras entre representação e realidade, levando ao questionamento do próprio estatuto da arte (WILDE, 2007). Mas, frente ao despojamento estilístico diretamente ligado à reflexividade teórica radical dessa obra, não custa lembrar o 
básico: apenas em uma das três cadeiras é possível que alguém se sente - e o visitante só não se senta nela porque aquela peça em particular foi, justamente, transformada em obra de arte. As cadeiras de Joseph Kosuth são ao mesmo tempo uma e três. Dentre estas três, apenas uma é real, diferente da fotografia da cadeira e da definição de dicionário da palavra "cadeira". Uma cadeira não muito diferente daquela na qual Maria Clara Escobar pôde se sentar, preenchendo o vazio, para ler o documento oficial com o mandado de prisão do pai (fig. 192). O vazio não anula o referente.

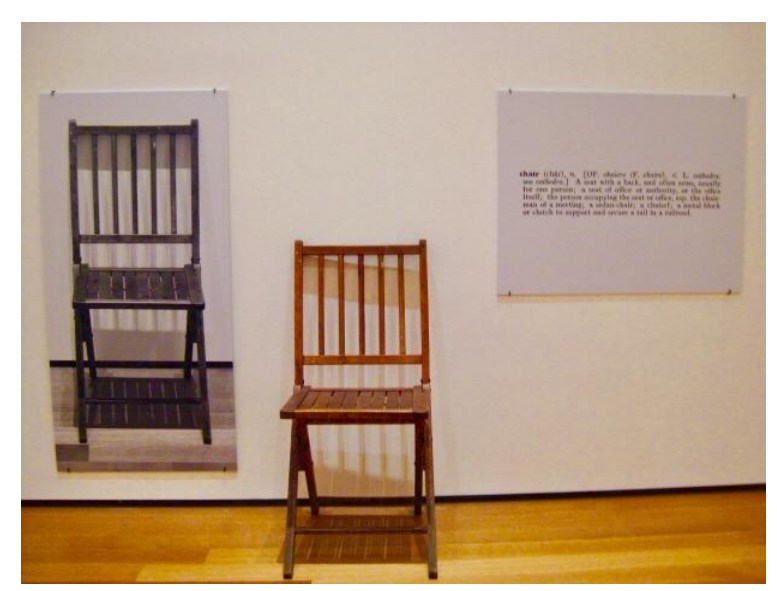

Figura 191 - One and three chairs (Joseph Kosuth, 1965). Fonte: Acervo pessoal.

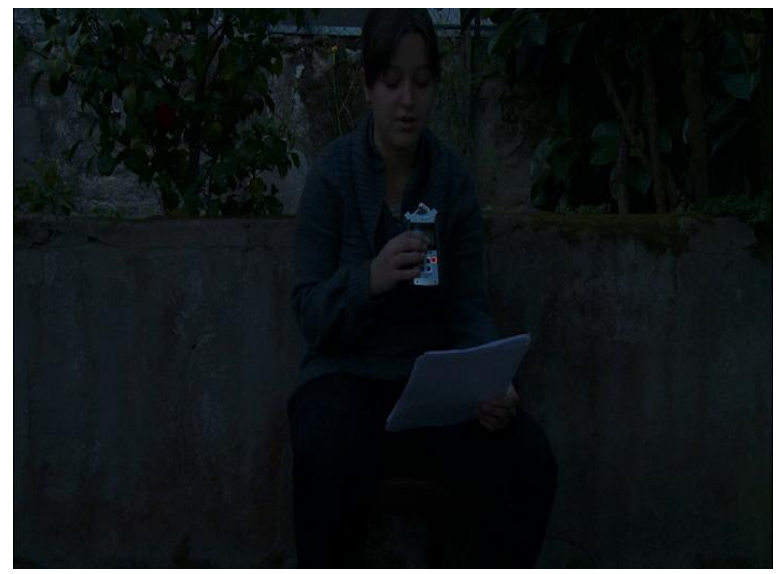

Figura 192 - A filha, à luz crepuscular, ocupa a cadeira deixada vazia pelo pai e lê o documento. Fonte: Os dias com ele (Maria Clara Escobar, 2013).

Eis a primeira justaposição desta montagem, a pista referencial elementar, ainda no campo da analogia estética. O segundo passo se dirige ao terreno histórico. Ou melhor, dos documentos históricos. Ocupando a cadeira, Maria Clara Escobar tem em mãos uma cópia do mandado de prisão expedido contra o pai pelo Ministério do Exército. "Tudo isso é deles, é uma mentira, é a burocracia deles", Carlos Henrique havia dito, querendo, com pleno direito, não dar voz a seus algozes. As análises que descartam de saída o teor do mandado como que acatam esse interdito, ficando só com o polo vazio da dialética. Mas vale aqui seguir a filha em sua desobediência e ler com ela o documento:

Tenho a honra de comunicar à Vossa Excelência que, nesta data, cumprindo diligências e investigações impostas pelo Inquérito Policial Militar do qual sou encarregado, expedi mandado de prisão contra Carlos Henrique de Escobar Fagundes, por prática de atividades subversivas ligadas à organização denominada Resistência Armada Nacional (RAN), nos termos da legislação vigente. Informo, outrossim, à Vossa Excelência que os citados indiciados se encontram presos em dependências do I Exército. Aproveito a oportunidade para renovar à Vossa Excelência os protestos de alta estima e respeito. Ministério do Exército, I Exército, Rio de Janeiro, 27 de abril de 1973. 
É “a burocracia deles”, sem dúvida. Um texto frio, protocolar, lido por Maria Clara em tom monocórdio. Mas é só aí que o espectador acaba informado sobre a organização de esquerda à qual Carlos Henrique estava ligado: a Resistência Armada Nacional (RAN), grupo clandestino que começou a se formar no segundo semestre de 1969 e cuja linha política fundia marxismo e nacionalismo revolucionário. Com foco de atuação entre setores da classe média e dissidentes nacionalistas no interior das Forças Armadas, de início sua base era composta sobretudo por quadros oriundos da tentativa de guerrilha na serra do Caparaó, incluindo militantes remanescentes do Movimento Nacionalista Revolucionário (MNR). Em dezembro de 1970, a publicação do jornal intitulado Independência ou morte foi um dos primeiros passos da nova agrupação que surgia, a qual só posteriormente, em 7 de setembro de 1972, adotaria a denominação RAN. No início desse mesmo ano, a RAN funda outra revista, a Prisma, acrônimo para "Pensamento Revolucionário Intelectual Socialista Marxista". Estruturada no Rio de Janeiro e em Minas Gerais, a RAN não teve muito tempo de levar seus projetos adiante. No início de 1973, tão logo desencadeara as primeiras, e simples, ações armadas, foi desbaratada pela repressão nos dois estados onde existia. Ao longo de abril daquele ano, quase uma centena de pessoas acusadas de integrá-la foi detida. Carlos Henrique Escobar estava entre elas. Todos esses dados sobre a RAN constam no Tomo III do projeto Brasil: nunca mais, dedicado a traçar o "Perfil dos Atingidos" pela violência ditatorial (ARQUIDIOCESE DE SÃO PAULO, 1985, p. 101-102). ${ }^{105}$ Como se sabe, esse projeto encabeçado pela Arquidiocese de São Paulo foi um marco inicial importantíssimo para o esclarecimento das atrocidades cometidas pelo regime brasileiro. Diferentemente do congênere Nunca más argentino (COMISIÓN NACIONAL SOBRE LA DESAPARICIÓN DE PERSONAS, 2011), fundado principalmente na coleta dos testemunhos orais dos sobreviventes (cf. CRENZEL, 2014), o Nunca mais brasileiro teve como fonte, precisamente, a papelada oficial gerada pela burocracia da Justiça Militar (ARQUIDIOCESE DE SÃO PAULO, 1998, p. 22-24).

Debruçando-se sobre essa enorme massa documental, perscrutando as 3.719 páginas do arquivo BNM 701, referente à ação penal contra a RAN do Rio de Janeiro que se estendeu entre 1973 e 1979, é possível ter uma ideia acerca da natureza da militância de Carlos Henrique de Escobar Fagundes. Àquela altura, pelo que se extrai dos documentos, ele era professor na Escola de Comunicação da Universidade Federal do Rio de Janeiro e havia prestado serviços de tradução para importantes casas editoriais, como a Edições Tempo

\footnotetext{
${ }^{105}$ Sobre a RAN, cf. também: RIDENTI, 2010, p. 31; MACIEL, 2009, p. 124-127.
} 
Brasileiro e a Zahar Editores (BNM 701, 2013, p. 1859, 2392 e 2394). Essas pistas conduzem à informação de que Carlos Henrique era um colaborador assíduo da revista Tempo brasileiro, ligada à primeira editora. E também de que, pela Zahar, ele traduziu, por exemplo, uma compilação de ensaios intitulada Marxismo e estruturalismo, bem como o livro A formação do pensamento econômico de Karl Marx, de Ernest Mandel, ambos publicados em 1968. Quanto à militância mais direta, pelo exame do arquivo BNM 701 fica-se sabendo que Carlos Henrique Escobar integrava um dos três Grupos de Ação (GA) da revista Prisma, ligada à RAN. Os documentos da ação penal vão deixando rastros esparsos acerca dessa publicação clandestina. Sobre seu teor, há indicações a respeito de pelo menos duas das edições da Prisma. Uma delas teria sido dedicada, ao que consta por sugestão de Carlos Henrique, ao tema "O poder", discutido em duas partes: a primeira baseada na obra de Lênin referida como O que é o Estado; a segunda a partir de um artigo de João Quartim de Moraes, "A natureza de classe do Estado brasileiro", publicado na revista Les Temps Modernes em 1971 (BNM 701, 2013, p. 3227). Outro número da Prisma teria tido como tema a figura de Tiradentes (BNM 701, 2013, p. 169-170). Os integrantes dos GAs da revista contribuíam mensalmente para o sustento financeiro da publicação, a qual ainda era vendida por cinco cruzeiros para os militantes. A princípio, a intenção era que a revista tivesse periodicidade mensal, mas as dificuldades na elaboração e na distribuição fizeram com que seus números surgissem a cada dois meses (BNM 701, 2013, p. 170). Todos esses são traços do engajamento de Carlos Henrique Escobar como intelectual. Ou melhor, segundo as palavras de sua defesa registradas na ação penal: na "formação de um grupo de intelectuais que estivessem interessados em discutir sobre a realidade brasileira". Essas "tarefas não seriam realizadas abertamente, mas não seria também exigido dos participantes uma atuação na clandestinidade" (BNM 701, 2013, p. 2459). Dessa ida ao arquivo BNM 701, acaba surgindo uma imagem, sem dúvida lacunar, inevitavelmente distorcida pela sanha acusatória da repressão, mas, ainda assim, uma imagem do militante Carlos Henrique Escobar, de sua condição de intelectual que atuava em oposição à ditadura. ${ }^{106} \mathrm{~A}$ desobediência da filha ao ocupar a cadeira e ler em cena o documento oficial veementemente refutado pelo pai abre para esta análise o caminho dos arquivos. Emerge daí um esboço de retrato do homem público que o filósofo e dramaturgo insiste em tentar legar por meio do documentário da filha. O desejo de Carlos Henrique acaba cumprido a contragosto.

\footnotetext{
${ }^{106}$ Sobre o papel dos intelectuais na oposição à ditadura brasileira, cf. NAPOLITANO, 2014, p. 205-228; RIDENTI, 2010, p. 146-161.
} 
É "a mentira deles", ele havia retrucado. Em grande medida, sim. Mas foi pela leitura a contrapelo daquela mentira judicial que os investigadores do projeto Brasil: nunca mais conseguiram rastrear as violações documentadas pela própria máquina repressiva. Aquelas fontes são "vidros deformantes" (GINZBURG, 2014, p. 49, tradução nossa), certamente. Porém, isso não faz com que não haja nenhuma prova ali. Na introdução do livro que sintetiza o relatório do projeto Brasil: nunca mais, esse caráter do testemunho involuntário extraído das entranhas burocráticas da ditadura é um aspecto a ser celebrado: "o que se produzisse como constatação de irregularidades, de atos ilegais, de medidas injustas, de denúncias sobre torturas e mortes, teria a dimensão da prova indiscutível. Definitiva." (ARQUIDIOCESE DE SÃO PAULO, 1998, p. 24). Ora, quando a fonte consultada pelo historiador provém de processos judiciais, quando aquilo que o acusado fala lhe é extraído pela tortura, o "vidro" se torna ainda mais deformante. Afinal, a tortura é uma "insidiosa técnica de interrogatório", a qual "tende a arrancar do acusado aquilo que o inquisidor crê firmemente ser a verdade" (GINZBURG, 2007a, p. 30). Já o próprio projeto Brasil: nunca mais havia descrito esse vício da confissão obtida sob tortura. No início da fase policial, o acusado, tão logo sequestrado e submetido nos DOI-CODIs aos "interrogatórios preliminares" - leia-se: tortura -, "indefeso e incomunicável, era obrigado a confessar aquilo que seus interrogadores queriam, depois de longas sessões de tortura." (ARQUIDIOCESE DE SÃO PAULO, 1998, p. 175). O mesmo relatório ressalva ainda: "As confissões obtidas nos órgãos de segurança não eram, evidentemente, livres, nem espontâneas. Muitas vezes, não eram sequer verossímeis, posto que as declarações tinham que concordar com as informações anteriores que as autoridades tinham sobre o detido." (ARQUIDIOCESE DE SÃO PAULO, 1998, p. 182). Datas forjadas de prisões, falseamento de prazos legais e condições do interrogatório eram a regra, testemunhas aleatórias assinavam os documentos. Mentiras em série eram registradas nos papéis no momento de "legalizar" o Inquérito Policial Militar (ARQUIDIOCESE DE SÃO PAULO, 1998, p. 173-176). No caso de Carlos Henrique Escobar, as incongruências sobre a data de sua prisão afloram já no documento lido por Maria Clara: o mandado é de 27 de abril de 1973, mas "os citados indiciados se encontram presos em dependências do I Exército". Nas alegações finais em favor de Carlos Henrique e Maria da Glória Ribeiro da Silva, o advogado que os defendia desqualifica a prova que embasa a acusação de ambos, "meramente inquisitorial de natureza oral” (BNM 701, 2013, p. 2462). Essas fontes oficiais, como bem se sabe, têm inúmeras armadilhas.

Mas elas também contêm os desmentidos feitos pelos próprios acusados. Este era um aspecto curioso da burocracia repressiva brasileira: superada a fase policial do inquérito, o réu 
tinha a oportunidade de refutar perante a Justiça Militar aquilo que se alegava que ele houvesse confessado durante os "interrogatórios preliminares”. "É que, em Juízo, na presença de seu defensor, o réu político tinha condições de negar - ou retratar - as confissões extrajudiciais e relatar o modo como elas haviam sido obtidas." (ARQUIDIOCESE DE SÃO PAULO, 1998, p. 182). No depoimento prestado à $2^{\text {a }}$ Auditoria do Exército, Carlos Henrique faz exatamente isso:

[...] que o depoente foi preso no dia 15 de abril do corrente ano [1973] e levado para a PE; lá desnudaram sua esposa em sua frente e deram-lhe um soco na cara; aplicaram choques elétricos no depoente; colocaram $\mathrm{o}$ depoente na 'geladeira', onze dias sem comer e sem beber, onde ficava uma sirene ligada permanentemente, razão pela qual o depoente agora será submetido a uma operação no ouvido como consequência dos ruídos respectivos; [...] se não assinasse o depoimento teria a prisão preventiva, e após assiná-lo, dias depois, foi libertado. (BNM 701, 2013, p. 1108-1109).

Eis "a burocracia deles", mas esse trecho em especial registra a verdade de Carlos Henrique. Ainda no calor dos eventos, ele dava o testemunho que anos depois relutaria tanto em conceder à filha cineasta. Foi a partir das incontáveis passagens análogas a essa registradas na papelada oficial que o projeto Brasil: nunca mais logrou detalhar os "modos e instrumentos de tortura" empregados pelo regime brasileiro. Carlos Henrique passou pela "geladeira", e o livro Brasil: nunca mais traz uma compilação de descrições semelhantes desse método. Na mesma página, o relatório inclui descrições de outro instrumento de tortura: a "cadeira do dragão".

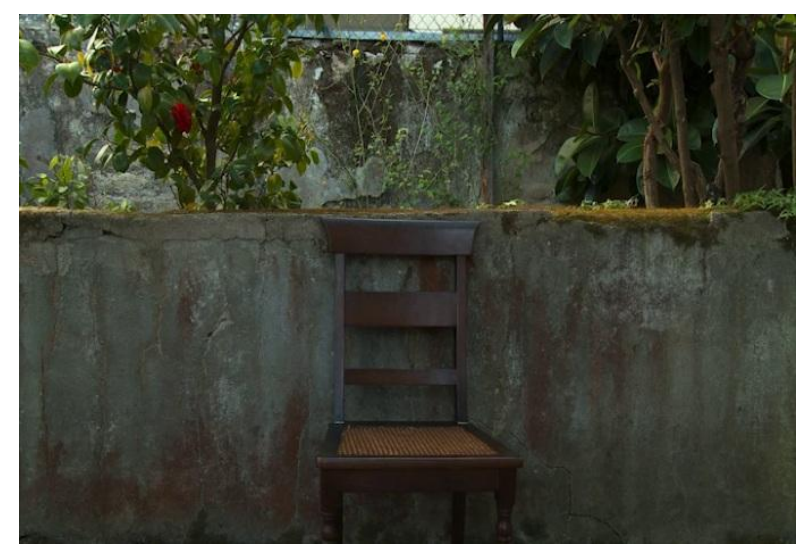

[...] o interrogado foi obrigado a se sentar em uma cadeira, tipo barbeiro, à qual foi amarrado com correias revestidas de espumas, além de outras placas de espuma que cobriam seu corpo; que amarraram seus dedos com fios elétricos, dedos dos pés e das mãos, iniciando-se, também, então uma série de choques elétricos; que, ao mesmo tempo, outro torturador com um bastão elétrico dava choques entre as pernas e pênis do interrogado. (ARQUIDIOCESE DE SÃO PAULO, 1998, p. 37).

Figura 193 - A cadeira vazia e a "cadeira do dragão". Fonte: Os dias com ele (Maria Clara Escobar, 2013).

Imaginar a dor concreta por trás da cadeira deixada vazia por Carlos Henrique Escobar (fig. 193). A segunda montagem propõe esse efeito de sentido, justapondo o vazio da imagem e o documento histórico. Carlos Henrique passou pela "geladeira", isso ficou registrado nos 
papéis oficiais e foi depois relatado no testemunho dado à filha. Outros passaram pela “cadeira do dragão", ${ }^{107}$ pelo "pau-de-arara", pela "pimentinha", pelo "telefone”, pelo choque elétrico, pelo afogamento, pela palmatória etc. (ARQUIDIOCESE DE SÃO PAULO, 1998, p. 34-42; COMISSÃO NACIONAL DA VERDADE, 2014, p. 366-375). Para quem não passou por nada disso, qualquer esforço de imaginação em torno desse rol de sevícias será sempre insuficiente perante a violência física real infligida. Ainda assim, essa dor não pode ficar relegada à obscuridade dos porões, ao abismo do irrepresentável. Imaginá-la é um imperativo. As palavras documentadas atestam o horror, trazendo à luz a experiência traumática. Quando tais palavras são confrontadas com o fotograma da cadeira vazia de Os dias com ele, elas revestem aquela imagem de uma carga referencial ineludível. O registro burocrático torna-se, assim, mais do que uma prova das atrocidades cometidas pelo Estado durante aqueles anos. Ele abre uma nova gama de significados pelo choque dialético com essa tomada na qual tantas análises só viram vazio.

Isso conduz à explicitação do referente atual, do "agora" concreto sobre o qual esta interpretação está fundada. Carlos Henrique, no balanço retrospectivo que faz após relatar para a câmera da filha as atrocidades sofridas, conclui: "Venceram os torturadores." Nesse ponto, ele manifesta explicitamente seu ressentimento com o lugar à margem reservado a ele e seus companheiros de militância no Brasil contemporâneo. Emergem daí os nexos entre presente e passado, entre a conjuntura democrática e aquela história autoritária. Ao elencar amargamente os vencedores de então, Carlos Henrique denuncia a "conciliação" democrática forjada ao longo dos anos no Brasil, esse país onde ele deixou de ver o seu lugar. Tal condição à margem seria uma chave para entender seu exílio tardio em Portugal. A ausência, nesses termos, deixa de ser apenas vazio, lacuna, falta. É a dolorosa ausência de um pai que se distanciou da filha, não se pode diminuir esse peso privado. Mas também é uma ausência carregada de densidade histórica. Antes de sair de cena e deixar a cadeira vazia, Carlos Henrique Escobar havia saído de cena de um Brasil cuja democracia se funda na anistia de assassinos e torturadores. Ao se ausentar, recusando-se a ler o documento da ditadura, ao não tolerar a possibilidade de dar voz a seus algozes, ele está como que acusando, por contraste, a tolerância da sociedade brasileira com a violência repressiva. Quando revisto à luz do ressentido diagnóstico traçado por Carlos Henrique, o abandono da cadeira ecoa o abandono do país motivado pela radical discordância com os rumos tomados pelas esquerdas. Ele, que

\footnotetext{
${ }^{107}$ Essa mesma descrição aqui citada da versão carioca da "cadeira do dragão", compilada no livro Brasil: nunca mais, seria depois reproduzida no tópico dedicado a esse método de tortura incluído no relatório final da Comissão Nacional da Verdade (2014, p. 367-368).
} 
fora um filiado de primeira hora do Partido dos Trabalhadores (PT), ${ }^{108}$ agora criticava abertamente os protagonistas do governo nacional petista. O preço pago pela cadeira presidencial foi muito alto: a transigência com os entulhos autoritários.

É em torno dessa outra cadeira, a presidencial, que esta análise faz uma última e arriscada aposta interpretativa. Ir além do vazio da cadeira de Os dias com ele, propondo uma montagem que inclua a dimensão referencial e os documentos daquela história, é também uma tentativa de compreender a relação do Brasil contemporâneo com o passado autoritário. O processo de realização de Os dias com ele se iniciou em 2011, com a primeira de duas viagens que Maria Clara Escobar faria a Portugal para entrevistar o pai (ESCOBAR, 2015, p. 17). Em janeiro de 2013, o documentário teve sua pré-estreia absoluta na Mostra de Cinema de Tiradentes, conquistando os prêmios da crítica e do júri jovem de melhor filme da Mostra Aurora. Em abril de 2014, o título foi lançado comercialmente nas salas de cinema. Todo olhar para o passado tem os pés no presente: 2011 foi o ano inaugural do primeiro mandato de Dilma Rousseff; em 2013 viriam as Jornadas de Junho; em 2014, Dilma Rousseff era reeleita; em 2016, a ordem democrática seria rompida pelo afastamento da presidenta. É difícil rever Os dias com ele hoje e não escutar nos rancores de Carlos Henrique Escobar um diagnóstico cortante sobre a fragilidade da democracia brasileira. Logo viria a turbulência política e o colapso da "conciliação" democrática conservadora da Nova República, desde o início pautada exatamente pelo presidencialismo de coalizão (NAPOLITANO, 2016). O balanço amargo de Carlos Henrique ganha novas ressonâncias diante dos fatos políticos vividos pelo país pouco depois que o filme surgia. Os dias com ele lidava com os impasses da representação da memória em um momento no qual se desencadeava uma crise aguda da representatividade política. Aquela transigência pragmática das esquerdas em nome da cadeira presidencial acabou resultando em sua própria ruína. Se o intelectual marxista externava a memória ressentida pelo projeto revolucionário vencido, o arranjo governista presente que ele criticava, então triunfante, logo viria a ser derrubado pelo mesmo fisiologismo sobre o qual se sustentava. Dos destroços daquela aliança orgânica se nutriria um polivalente conservadorismo. A política de acomodação mostrou seus limites, o país se polarizou, as vozes autoritárias retornam à cena. Surge uma conjuntura política na qual a benevolência velada com os algozes vem se transformando cada vez mais em exaltação aberta do autoritarismo.

\footnotetext{
${ }^{108}$ Carlos Henrique de Escobar Fagundes filiou-se ao PT do Rio de Janeiro em 10 de maio de 1981. O registro de sua filiação está disponível no banco de dados do Tribunal Regional Eleitoral do Rio de Janeiro: <http://www.tre-rj.jus.br/site/partidos_politicos/filiacao/filiacao.jsp〉. Acesso em: 3 nov. 2017.
} 
O negacionismo é uma ameaça real que paira sobre a discussão teórica desenvolvida neste capítulo (DIDI-HUBERMAN, 2012, p. 133-134). A problematização das leituras do irrepresentável feita nestas páginas diz respeito a um posicionamento epistemológico. Há aí uma defesa das potencialidades cognitivas da representação, uma aposta nas interpretações criativas em torno do referente histórico. Mas essa crítica também atende a um imperativo ético contra toda e qualquer possibilidade de negacionismo. Jacques Rancière (1997, p. 47, tradução nossa), tendo como alvo a lógica do irrepresentável, alerta: "Nosso presente é presa não do ceticismo, como se diz às vezes em tom de vantagem, mas da negação." Carlo Ginzburg (2014, p. 42, tradução nossa) já escreveu: "O limite do relativismo é ao mesmo tempo cognoscitivo, político e moral." Paul Ricœur (2007, p. 271), reconstituindo a polêmica entre Ginzburg (2011e) e Hayden White (1992a), concluíra: “o arrazoado [do italiano] em favor da realidade do passado histórico [...] assume assim o duplo aspecto de uma atestação incontestável e de um protesto moral [...]." Vale esclarecer: não é que o prisma epistemológico do irrepresentável seja, por si só, negacionista. Em geral, esse viés analítico está tentando lidar, de total boa-fé e com uma franca empatia, com a dor e o trauma dos outros. A questão é que o descarte do referente (e de tudo o que possa atestá-lo) que costuma acompanhar essas abordagens tende a ser mobilizado abusivamente por aqueles que, com máfé ou descarado cinismo, querem relativizar ou mesmo negar um passado de atrocidades. Esse tipo de "negacionismo vergonhoso" (RANCIÈRE, 1997, p. 65, tradução nossa) vem ganhando voz no Brasil. Sua forma é o revisionismo conservador que tenta redimir o período ditatorial, em um diapasão que vai das versões atenuantes eruditas à gritaria intervencionista de tribunos e "patriotas" raivosos (cf. NAPOLITANO, 2015, p. 32-35, 2017, p. 335-343). Frente a tal ofensiva, nada pode ser mais perigoso do que um discurso vazio.

\section{Dialética entre aporias e apostas: o vazio, o vestígio, a performance, o testemunho}

É da dialética entre as aporias da representação e as apostas referenciais que surge um conhecimento possível sobre o passado e o presente da rememoração. Toda vez que o gesto analítico se aferra a apenas um desses polos, a abordagem reduz os termos da questão, livrando-se facilmente dos problemas. Por um lado, as leituras absolutamente concentradas no vazio ignoram o desafio colocado pela concretude histórica, contentando-se com a tautologia do fracasso, com o império da ficção e a intransitividade da busca. Por outro, qualquer tentativa de depurar as imagens de seus impasses em nome de uma realidade transparente cairia em uma postura epistemológica regressiva, como se fosse possível voltar à "era da 
inocência" positivista. Muito mais frutífero é se debruçar sobre as imagens levando em conta sua "plasticidade dialética", ou seja, a potência que têm de "produzir um efeito com a sua negação" (DIDI-HUBERMAN, 2012, p. 107, grifo do autor). Sem dúvida, as imagens de Os dias com ele dão a ver os vazios e as performances. Mas há também nelas o documento, o testemunho. A tensão constante entre esses opostos é o que gera a riqueza da obra fílmica e da memória intergeracional que aí se manifesta. A intepretação pela montagem convoca as referências externas sinalizadas pelas imagens, desdobrando os sentidos da rememoração em uma busca que avança tateando, que não fica paralisada frente ao absoluto do irrepresentável, que se esforça para atestar um passado traumático. Mas não é o caso de se iludir: "Para quem quer saber e, nomeadamente, para quem quer saber como, o saber não oferece nem milagre, nem descanso. É um saber sem fim: a interminável aproximação do acontecimento e não a sua apreensão numa certeza revelada.” (DIDI-HUBERMAN, 2012, p. 112, grifo do autor). A palavra "aposta" mantém as incertezas no horizonte, lembrando sempre que a aporia está no cerne de qualquer representação. Toda aposta contém um risco, a questão referencial nunca se resolve de uma vez por todas. E é exatamente por isso que entrar na arena real da memória do autoritarismo é um imperativo. 


\section{CONSIDERAÇÕES FINAIS}

\section{MEMÓRIA INTERGERACIONAL, HISTORICIDADE DAS IMAGENS}

A atenção às dinâmicas e densidades históricas das imagens desestabiliza a grade analítica que cerca o documentarismo intergeracional sobre as ditaduras do Cone Sul. Surge daí um fenômeno multifacetado. O leitor já terá deduzido que esta tese não oferecerá uma fórmula sumária para definir a memória intergeracional. Isso, contudo, está longe de significar uma esquiva do debate. Pelo contrário, o panorama aqui apresentado foi sendo construído, justamente, à medida que os principais topoi desse campo de estudos eram colocados em questão. A problematização das noções de "guinada subjetiva", de "pós-memória", de “indeterminação formal" e de "irrepresentável” era o motor das quatro proposições centrais delineadas no curso das análises. A primeira delas sustenta que esse é um fenômeno transnacional em vários sentidos e temporalidades, desde as vivências narradas, passando pelas configurações visuais, pelos modos de produção cinematográfica e pelas circulações em festivais. A segunda enfatiza as complexas interações no âmbito de um circuito de laços entre as gerações da memória, pleno de heranças e alusões imprevistas, aproximações e distanciamentos, transmissões e apropriações. A terceira proposição situa a tensão entre forma e indeterminação no cerne dessa tendência estética, esmiuçando a mobilização de um vasto repertório de artifícios do cinema documentário. Por último, vem a afirmação de que essa produção merece ser interpretada à luz de uma aposta na representação do passado como meio de enfrentar os atualíssimos desafios da rememoração. No final do trajeto, chegase a um ponto que está além dos enquadramentos conceituais. A prática analítica destrincha uma cinematografia que traz à tona a vivacidade de um passado revisto pela lente da intimidade, mas na qual também se cristalizam determinados chavões da contemporaneidade. A paciente descrição dos fatores em jogo apresenta a formação de um prisma afetivo de rememoração, o qual se afasta das matrizes da vitimização e do heroísmo ao mesmo tempo que, em duas décadas de representações, vai sedimentando seus próprios paradigmas. Eis, em poucas linhas, os contornos gerais da memória intergeracional das ditaduras que resultam do olhar historiográfico lançado para a filmografia documental da região.

Cristalizações e revisão do passado; sedimentações e perspectivas inusuais de rememoração. Em duas palavras: forma e indeterminação. Os polos dialéticos que conduziram a análise no Capítulo III atravessam todos os capítulos, conectando e tensionando as questões 
centrais discutidas ao longo da tese. Neste momento conclusivo, vale a pena sumarizar os vasos comunicantes que entrelaçam os contornos gerais do fenômeno, alinhavando os nexos já assinalados no decorrer do texto. A chancela dada pelos festivais a uma poética "globalizada" do documentário subjetivo contemporâneo (Capítulo I) retroalimenta a formatação da estilística do documentário coeso de busca (Capítulo III). Os vetores imponderáveis do circuito de laços intergeracionais (Capítulo II) dão margem para a premissa do irrepresentável nas interpretações dessas obras (Capítulo IV). Tais correlações não se dão em paralelo, elas implicam uma contradição de fundo, a qual confere uma tensa unidade às indagações: aquela entre o eixo da forma - que agrega os influxos históricos (prêmios nos festivais) e as reiterações estéticas (fórmulas cinematográficas) que vão dando contornos estilísticos a essa cinematografia - e o eixo da indeterminação - as transferências conceituais e circulações culturais imprevisíveis no espaço intergeracional, associadas à agenda da irrepresentabilidade do passado doloroso. No conjunto, os capítulos da tese compõem um quadro feito de ressonâncias e contrastes, uma trama intrincada na qual os elementos se friccionam, vinculando-se e contrapondo-se na encruzilhada entre forma e indeterminação.

Fissurado o arcabouço teórico, explicitadas as antinomias estruturantes, abre-se enfim uma paisagem na qual a historicidade complica os processos de memória e inquieta a compreensão. Se, por um lado, o documentarismo intergeracional não é feito só de novidades a serem celebradas, por outro, as fórmulas que vão se consolidando tampouco seriam razão para desacreditar em bloco essa cinematografia. Ora, sendo esse um fenômeno histórico, ele não poderia deixar de ser contraditório, composto tanto por filmes potentes, "extraordinários", quanto por outros mais convencionais, que se enquadram em certos lugares-comuns contemporâneos. Não rotular o objeto de estudo, perceber como as obras escapam aos apriorismos analíticos, debruçar-se sobre as imagens antes de tudo, tais foram os fundamentos metodológicos entranhados nos cruzamentos entre história e cinema ao longo deste percurso. E, a partir das pistas inscritas na matéria audiovisual, ir aos materiais externos: referências intertextuais, documentos de produção, bancos de dados cinematográficos, catálogos de festivais, publicações de época, polêmicas públicas, fontes da repressão, em suma, os elementos que, sinalizados desde a imanência das obras, iluminam as imagens reciprocamente desde o extrafílmico.

Isso inclui, é claro, a bibliografia específica. Porque a escrita acadêmica não examina desde fora esse fenômeno. Ela é um agente histórico relevante no bojo dessas dinâmicas. Livros, capítulos, artigos, dissertações, teses, esta tese, tudo isso compõe uma linha de força bem atuante no emaranhado de vetores da memória intergeracional. Ressaltar tendências 
estéticas, destacar certos títulos, ignorar outros, trazer e ressignificar ideias de fora, reiterar determinadas agendas, descurar das repetições formais, eis alguns dos gestos analíticos que sem dúvida incidem nessa órbita. Cada uma das citações e ressalvas presentes nestas páginas foi feita em nome de uma compreensão mais global da atmosfera que gravita em torno do cinema documentário ligado aos descendentes no Cone Sul. Uma crença sincera na discussão é o que move as problematizações.

Se a subjetividade e a reflexividade dos enunciados está em pauta nas análises dos filmes, nada mais coerente do que voltar o discurso acadêmico contra seus próprios postulados nesse campo. Desconfiar dos lugares-comuns teóricos sobre a memória e o documentário contemporâneo é, no fundo, sustentar a postura reflexiva que costuma ser valorizada nas obras. No entanto, "desconfiar" não significa descartar apressadamente. Não há qualquer pretensão aqui de se fazer tábula rasa desse terreno de estudos - ao menos dessa ingenuidade esta pesquisa não padece. Muito pelo contrário, o debate proposto, não custa insistir, é franco, ele leva a sério as formulações criticadas, dialogando demoradamente com elas, examinando minuciosamente seus pressupostos e suas contradições, revendo as noçõeschave de frente e pelo avesso.

Mas isso tampouco condena as indagações a uma deriva cética infinita. Repensar incessantemente as imagens e as premissas é um caminho para o conhecimento possível do passado rememorado e do presente da rememoração (DIDI-HUBERMAN, 2012, p. 86). Quando se desestabiliza reflexivamente o arcabouço conceitual que vem pautando as leituras desse documentarismo, começa-se a enxergar melhor aquilo que, desde dentro das representações, aponta para algo que extrapola os filmes e as balizas analíticas: o horizonte referencial, com suas vicissitudes e atestações, com suas imagens e seus embates bem reais na densa arena da memória. 


\section{REFERÊNCIAS}

ACHUGAR, Mariana. Discursive processes of intergenerational transmission of recent history: (re)making our past. Basingstoke: Palgrave Macmillan, 2016.

AGÊNCIA NACIONAL DO CINEMA. Consulta de projetos audiovisuais. 2007. Disponível em: 〈https://goo.gl/jmbt8p>. Acesso em: 4 dez. 2017.

Consulta de projetos audiovisuais. 2012. Disponível em: 〈https://goo.gl/jtcPyA $\rangle$. Acesso em: 10 dez. 2017.

Filmes brasileiros e estrangeiros lançados - 2011. Observatório Brasileiro do Cinema e do Audiovisual (OCA), 2016. Disponível em: 〈https://goo.gl/CB71qy>. Acesso em: 4 dez. 2017.

AGUILAR, Gonzalo. Con el cuerpo en el laberinto: sobre $M$ de Nicolás Prividera. In: SARTORA, Josefina; RIVAL, Silvina. Imágenes de lo real: la representación de lo político en el documental argentino. Buenos Aires: Libraria, 2007a. p. 171-187.

Maravillosa melancolía. Cazadores de utopías: una lectura desde el presente. In: MOORE, María José; WOLKOWICZ, Paula (Org.). Cines al margen: nuevos modos de representación en el cine argentino contemporáneo. Buenos Aires: Libraria, 2007b. p. 17-32.

Otros mundos: un ensayo sobre el nuevo cine argentino. 2. ed. Buenos Aires: Santiago Arcos editor, 2010.

ALCOBA, Laura. La casa de los conejos. Buenos Aires: Edhasa, 2014.

ALONSO, Mauricio. Los rubios: otra forma, otra mirada. In: SARTORA, Josefina; RIVAL, Silvina. Imágenes de lo real: la representación de lo político en el documental argentino. Buenos Aires: Libraria, 2007. p. 157-169.

ÁLVAREZ, Efrén Cuevas. Del cine doméstico al autobiográfico: caminos de ida y vuelta. In: GUTIÉRREZ, Gregorio Martín (Ed.). Cineastas frente al espejo. Madrid: T\&B Editores, 2008. p. 101-120.

. De vuelta a casa: variaciones del documental realizado con cine doméstico. In: (Ed.). La casa abierta: el cine doméstico y sus reciclajes contemporáneos. Madrid:

Ocho y Medio, 2010a. p. 121-166.

Diálogo entre el documental y la vanguardia en clave autobiográfica. In: TORREIRO, Casimiro; CERDÁN, Josetxo (Ed.). Documental y vanguardia. Madrid: Cátedra, 2005. p. 219-250.

Introducción: redescubrir el cine doméstico. In: (Ed.). La casa abierta: el cine doméstico y sus reciclajes contemporáneos. Madrid: Ocho y Medio, 2010b. p. 21-35.

AMADO, Ana. Cine argentino y política (1980-2007): la imagen justa. 2008. 250 f. Tese (Doutorado em Estudos Latino-Americanos) - Faculdade de Letras, Universidade de Leiden, 
Leiden, 2008. Disponível em: 〈https://openaccess.leidenuniv.nl/handle/1887/12952〉. Acesso em: 17 nov. 2015.

AMADO, Ana. Escenas de post-memoria. Pensamiento de los confines, Buenos Aires, n. 16, p. 113-123, jun. 2005a.

Herencias: generaciones y duelo en las políticas de la memoria. Revista Iberoamericana, [Pittsburgh], v. 69, n. 202, p. 137-153, enero-marzo. 2003. Disponível em: <https://doi.org/10.5195/reviberoamer.2003.5690>. Acesso em: 4 dez. 2017.

Órdenes de la memoria y desórdenes de la ficción. In: AMADO, Ana; DOMÍNGUEZ, Nora (Org.). Lazos de familia: herencias, cuerpos, ficciones. Buenos Aires: Paidós, 2004. p. 43-80.

. La imagen justa: cine argentino y política (1980-2007). Buenos Aires: Colihue, 2009.

- Las nuevas generaciones y el documental como herramienta de la historia. In: ANDÚJAR, Andrea et al. (Org.). Historia, género y política en los '70. Buenos Aires: Feminaria Editora, 2005b. p. 221-240.

ANDERMANN, Jens. Expanded fields: postdictatorship and the landscape. Journal of Latin American Cultural Studies, v. 21, n. 2, p. 165-187, June 2012. Disponível em: <http://dx.doi.org/10.1080/13569325.2012.694810>. Acesso em: 7 jun. 2017.

. Nuevo cine argentino. Buenos Aires: Paidós, 2015.

ANDREW, Dudley. Time zones and jetlag: the flows and phases of world cinema. In: ĎUROVIČOVÁ, Nataša; NEWMAN, Kathleen (Org.). World cinemas, transnational perspectives. New York: Routledge, 2010. p. 59-89.

AON, Luciana. Aproximaciones a las representaciones de los directores-hijos. Revista Faro, Valparaíso, ano 7, n. 13, p. 178-187, sept. 2011. Disponível em: 〈https://goo.gl/VvkVhY $\rangle$. Acesso em: 18 dez. 2017.

APREA, Gustavo. Documental, testimonios y memorias: miradas sobre el pasado militante. Buenos Aires: Manantial, 2015.

ARÁNGUIZ, Tamara Vidaurrázaga. Los niños(as) de la revolución en El edificio de los chilenos. Sociedad \& Equidad, n. 4, p. 153-164, jul. 2012. Disponível em: <http://www.sye.uchile.cl/index.php/RSE/article/view/20965>. Acesso em: 31 maio 2017.

ARANTES, Maria Auxiliadora de Almeida Cunha. Dor e desamparo: filhos e pais, 40 anos depois. Psicologia Clínica, Rio de Janeiro, v. 20, n. 2, p. 75-87, 2008. Disponível em: <http://dx.doi.org/10.1590/S0103-56652008000200006>. Acesso em: 4 abr. 2017.

ARAÚJO, Ñsaindy Barrett de. Duas pátrias, duas mães. In: COMISSÃO DA VERDADE DO ESTADO DE SÃO PAULO "RUBENS PAIVA". Infância roubada: crianças atingidas pela ditadura militar no Brasil. São Paulo: Alesp, 2014. p. 101-103. Disponível em: <https://goo.gl/KHuJMz >. Acesso em: 3 abr. 2017. 
ARENES, Carolina; PIKIELNY, Astrid. Que tu viejo rompa el silencio. Anfibia, 10 jul. 2017. Disponível em: 〈https://goo.gl/AivR7g〉. Acesso em: 4 dez. 2017.

ARFUCH, Leonor. Espacio biográfico y memoria en la cultura contemporánea: intervenciones sobre el "documental subjetivo". In: BETTENDORFF, Paulina; RIAL, Agustina Pérez (Org.). Tránsitos de la mirada: mujeres que hacen cine. Buenos Aires: Libraria, 2014. p. 131-144.

ARQUIDIOCESE DE SÃO PAULO. Brasil: nunca mais. 29. ed. Petrópolis: Editora Vozes, 1998.

Brasil: nunca mais. Perfil dos atingidos. Tomo III. São Paulo, 1985. Disponível em: $\langle$ http://www.dhnet.org.br/w3/bnm/tomo_iii_perfil_dos_atingidos.pdf $>$. Acesso em: 1 nov. 2017.

ARTHUR, Paul. Jargons of authenticity: three American moments. In: RENOV, Michael (Ed.). Theorizing documentary. New York: Routledge, 1993. p. 108-134.

ARTHUSO, Raul. Demasiadamente humano. Revista Cinética, jan. 2013. Disponível em: <https://goo.gl/rN1T18>. Acesso em: 4 dez. 2017.

ASSMANN, Aleida; CONRAD; Sebastian. Introduction. In: (Ed.). Memory in a Global Age: discourses, practices and trajectories. London: Palgrave Macmillan, 2010. p. $1-16$.

ASSMANN, Aleida. Memory, individual and collective. In: GOODIN, Robert E.; TILLY, Charles (Ed.). The Oxford handbook of contextual political analysis. Oxford: Oxford University Press, 2006. p. 210-224.

The Holocaust: a global memory? Extensions and limits of a new memory community. In: ASSMANN, Aleida; CONRAD; Sebastian (Ed.). Memory in a Global Age: discourses, practices and trajectories. London: Palgrave Macmillan, 2010. p. 97-117.

AUMONT, Jacques; MARIE, Michel. Dicionário teórico e crítico de cinema. 4. ed. Campinas: Papirus, 2009.

AVELLAR, José Carlos. Pai país, mãe pátria. São Paulo: IMS, 2016.

BARRENHA, Natalia Christofoletti. Herdeiros do exílio: memória e subjetividade em três documentários chilenos contemporâneos. Doc On-line, n. 15, p. 195-228, dez. 2013a. Disponível em: 〈http://www.doc.ubi.pt/15/dossier_natalia_barrenha.pdf>. Acesso em: 4 maio 2017.

Silêncios históricos e pessoais: memória e subjetividade no documentário latinoamericano contemporâneo. In: PAIVA, Carla Conceição da Silva; ARAÚJO, Juliano José de; BARRETO, Rodrigo Ribeiro (Org.). Cultura audiovisual: transformações estéticas, autorais e representacionais em multimeios. Campinas: Unicamp/Instituto de Artes, 2013b. p. 327-350. Disponível em: 〈https://goo.gl/8gkXKa> . Acesso em: 4 dez. 2017. 
BARRENHA, Natalia Christofoletti; PIEDRAS, Pablo (Org.). Silêncios históricos e pessoais: memória e subjetividade no documentário latino-americano contemporâneo. Campinas: Editora Medita, 2014. (Catálogo da mostra). Disponível em: 〈https://goo.gl/wxbYPu $\rangle$. Acesso em: 4 jul. 2015.

BARRIL, Claudia. Las imágenes que no me olvidan: cine documental autobiográfico y (pos)memorias de la dictadura militar chilena. Santiago: Editorial Cuarto Propio, 2013.

BARROSO, Gonzalo. La representación de la dictadura de Pinochet en el cine documental chileno entre 1973 y 2013: de la imagen testimonial al relato memorístico. Filmhistoria Online, v. 25, n. 1, p. 19-34, 2015. Disponível em: <http://revistes.ub.edu/index.php/filmhistoria/article/view/12139>. Acesso em: 4 jun. 2018.

BARROW, Sarah; FALICOV, Tamara L. Latin American cinemas today: reframing the national. Transnational cinemas, v. 4, n. 2, p. 143-145, 2013. Disponível em: <https://doi.org/10.1386/trac.4.2.143_2>. Acesso em: 12 abr. 2017.

BARTHES, Roland. A câmara clara: nota sobre a fotografia. Rio de Janeiro: Nova Fronteira, 1984.

BARTOLOMEU, Anna Karina; VEIGA, Roberta. Rastro e aura em Diário de uma busca. In: VEIGA, Roberta; MAIA, Carla; Victor Guimarães (Org.). Limiar e partilha: uma experiência com filmes brasileiros. Belo Horizonte: PPGCOM/UFMG, 2015. p. 126-152. Disponível em: <https://goo.gl/FSKeRM>. Acesso em: 4 dez. 2017.

BECEYRO, Raúl et al. Cine documental: la objetividad en cuestión. Punto de vista, Buenos Aires, ano 28, n. 81, p. 14-23, abr. 2005a. Disponível em: <http://www.ahira.com.ar/revistas/pdv/81/pdv81.pdf >. Acesso em: 14 dez. 2017.

et al. Cine documental: la primera persona. Punto de vista, Buenos Aires, ano 28, n. 82, p. 27-36, agosto 2005b. Disponível em: <http://www.ahira.com.ar/revistas/pdv/81/pdv82.pdf $>$. Acesso em: 14 dez. 2017.

BELLO, María José. Documentales sobre la memoria chilena: aproximaciones desde lo íntimo. Cinémas d'Amérique latine, n. 19, p. 77-79, 2011. Disponível em: <http://cinelatino.revues.org/1065>. Acesso em: 31 maio 2017.

BELLOUR, Raymond. Autoportraits. Communications, v. 48, n. 1, p. 327-287, 1988. Disponível em: 〈https://goo.gl/h6y9fP>. Acesso em: 4 dez. 2017.

BENJAMIN, Walter. Experiência e pobreza. In: Magia e técnica, arte e política: ensaios sobre literatura e história da cultura. 7. ed. São Paulo: Brasiliense, 1994. (Obras escolhidas, v. 1). p. 114-119.

BENNER, William R. El documental sin fin: filmar al desaparecido. Archivos de la Filmoteca, Valencia, n. 73, p. 123-138, oct. 2017. Disponível em: 〈https://goo.gl/b4qPUa $>$. Acesso em: 4 dez. 2017.

BERGALA, Alain. Si “yo" me fuera contado. In: GUTIÉRREZ, Gregorio Martín (Ed.). Cineastas frente al espejo. Madrid: T\&B Editores, 2008. p. 27-33. 
BERGER, Verena. La búsqueda del pasado desde la ausencia: Argentina y la reconstrucción de la memoria de los desaparecidos en el cine de los hijos. Quaderns de Cine, Alicante, n. 3, p. 23-36, 2008. Disponível em: 〈https://goo.gl/UwGSGT>. Acesso em: 4 dez. 2017.

Travelling Cinema: la road movie latinoamericana en el contexto global. In: LEFERE, Robin; LIE, Nadia (Org.). Nuevas perspectivas sobre la transnacionalidad del cine hispánico. Leiden; Boston: Brill Rodopi, 2016. p. 159-178.

BERNADES, Horacio. El hombre que veía demasiado. Página/12, Buenos Aires, 25 mayo 2003. Disponível em: 〈https://goo.gl/WhNb0〉. Acesso em: 4 dez. 2017.

La carta abierta de una hija a su padre montonero. Página/12, Buenos Aires, 29 jul. 2004, Espectáculos. Disponível em: 〈https://goo.gl/ATb4V9) . Acesso em: 4 dez. 2017.

BERNARDET, Jean-Claude. A entrevista. In: . Cineastas e imagens do povo. São Paulo: Companhia das Letras, 2003. p. 281-296.

Documentários de busca: 33 e Passaporte húngaro. In: MOURÃO, Maria Dora; LABAKI, Amir (Org.). O cinema do real. São Paulo: Cosac Naify, 2005. p. 142-156.

BERNINI, Emilio. Un estado (contemporáneo) del documental: sobre algunos films argentinos recientes. Kilómetro 111, Buenos Aires, n. 5, p. 41-57, nov. 2004.

BETTENDORFF, Paulina; RIAL, Agustina Pérez (Org.). Tránsitos de la mirada: mujeres que hacen cine. Buenos Aires: Libraria, 2014.

BEZERRA, Julio. As novas faces do cinema. Revista de cinema, 26 set. 2012. Disponível em: <https://goo.gl/sTM7AC>. Acesso em: 4 dez. 2017.

BLEJMAR, Jordana; FORTUNY, Natalia. Introduction. Journal of romance studies, v. 13, n. 3, p. 1-5, Winter 2013. Especial issue: "Revisiting postmemory: the intergenerational transmission of trauma in post-dictatorship Latin American culture." Disponível em: <https://doi.org/10.3828/jrs.13.3.1>. Acesso em: 16 jan. 2017.

BLEJMAR, Jordana. Playful memories: the autofictional turn in post-dictatorship Argentina. Cham: Palgrave Macmillan, 2016.

Toying with history: playful memory in Albertina Carri's Los rubios. Journal of romance studies, v. 13, n. 3, p. 44-61, Winter 2013. Disponível em: <https://doi.org/10.3828/jrs.13.3.44>. Acesso em: 8 nov. 2017.

BLOCH, Marc. Apologia da história: ou, o ofício de historiador. Rio de Janeiro: Jorge Zahar Editor, 2001.

BNM 701. Projeto "Brasil: nunca mais digit@l”. 2013. Disponível em: <http://bnmdigital.mpf.mp.br/sumarios/700/701.html>. Acesso em: 2 nov. 2017. 
BONALDI, Pablo Daniel. Hijos de desaparecidos: entre la construcción política y la construcción de la memoria. In: JELIN, Elizabeth; SEMPOL, Diego (Org.). El pasado en el futuro: los movimientos juveniles. Buenos Aires: Siglo Veintiuno Editores, 2006. p. 143-184.

BORDWELL, David; THOMPSON, Kristin. Film art: an introduction. 5. ed. New York: McGraw-Hill, 1997.

BOSSY, Michelle; VERGARA, Constanza. Documentales autobiográficos chilenos. Santiago: Fondo de Fomento Audiovisual del Consejo Nacional de la Cultura y las Artes, 2010. Disponível em: 〈https://goo.gl/bYT3qK>. Acesso em: 4 dez. 2017.

BRASIL, André. Formas do antecampo: performatividade no documentário brasileiro contemporâneo. Revista Famecos, Porto Alegre, v. 20, n. 3, p. 578-602, set.-dez. 2013. Disponível em: 〈http://dx.doi.org/10.15448/1980-3729.2013.3.14512>. Acesso em: 4 dez. 2017.

BRASIL. Portarias $\mathrm{n}^{\circ} 1.937$ e $\mathrm{n}^{\circ} 1.938$, de 25 de novembro de 2014. Diário Oficial da União, Poder Executivo, Brasília, DF, 26 nov. 2014, Seção 1, p. 75. Disponível em: <https://goo.gl/MgviTE>. Acesso em: 10 dez. 2017.

. Conselho Nacional de Cinema, Setor de Registro de Direitos Autorais. Diário Oficial da União, Poder Executivo, Brasília, DF, 3 set. 1986, Seção 1, p. 80. Disponível em: <https://goo.gl/7UvPtP>. Acesso em: $10 \mathrm{dez} .2017$.

BRECKENRIDGE, Janis. Performing memory and identity: Albertina Carri's Los rubios. Letras femeninas, v. 34, n. 2, p. 11-27, Invierno 2008. Disponível em: <http://www.jstor.org/stable/23021923 > . Acesso em: 26 ago. 2017.

BRESCIANI, Stella; NAXARA, Márcia (Org.). Memória e (res)sentimento: indagações sobre uma questão sensível. Campinas: Editora da Unicamp, 2001.

BRITO, Ana Paula. Escrachos aos torturadores da ditadura: ressignificando os usos da memória. São Paulo: Expressão Popular, 2017.

BRITO, Angela Xavier de; VASQUEZ, Ana. « On déguste l'amer caviar de l'exil à plusieurs sauces »: un schéma théorique pour comprendre les exils latino-américains. In: SANTOS, Idelette Muzart-Fonseca dos; ROLLAND, Denis (Org.). L'exil brésilien en France: histoire et imaginaire. Paris: L'Harmattan, 2008. p. 207-224.

BROOKS, Peter. The melodramatic imagination: Balzac, Henry James, melodrama, and the mode of excess. New Haven: Yale University Press, 1995.

BRUSS, Elizabeth W. Eye for I: making and unmaking autobiography in film. In: OLNEY, James (Ed.). Autobiography: essays theoretical and critical. Princeton: Princeton University Press, 1980. p. 296-320.

BRUZZI, Stella. New documentary: a critical introduction. 2. ed. London: Routledge, 2006.

BUENOS AIRES FESTIVAL INTERNACIONAL DE CINE INDEPENDIENTE, 13., 2011, Buenos Aires. Catálogo... Buenos Aires: Bafici, 2011. 
CAMPO, Mônica Brincalepe. O vazio da história e os lugares de memória em Los rubios, de Albertina Carri. In: ESTUDOS DE CINEMA E AUDIOVISUAL SOCINE, 16., 2012, São Paulo. Anais... São Paulo: Socine, 2013. p. 362-370. Disponível em: <https://goo.gl/RhuF1n>. Acesso em: 4 dez. 2017.

CARDENUTO, Reinaldo. Negotiating memories in Brazilian documentary: the dialogue between history and subjectivity. In: PINAZZA, Natália (Ed.). New approaches to Lusophone culture. Amherst: Cambria Press, 2016. p. 111-140.

CARRI, Albertina. Los rubios: cartografía de una película. Buenos Aires: Buenos Aires Festival Internacional de Cine Independiente (Bafici), 2007.

CARRI, Roberto. Isidro Velázquez: formas prerrevolucionarias de la violencia. 1. reimp. Buenos Aires: Colihue, 2011.

. Poder y dependencia. Antropología 3er Mundo, Buenos Aires, n. 6, ano 2, p. 97-112, [1970]. Disponível em: 〈https://goo.gl/6MwpME〉. Acesso em: 4 dez. 2017.

CARROLL, Noël. Nonfiction film and the postmodernist skepticism. In: BORDWELL, David; CARROLL, Noël (Ed.). Post-theory: reconstructing film studies. Madison: The University of Wisconsin Press, 1996. p. 283-306.

CARVALHO, Gabriela de Souza; GUTFREIND, Cristiane. A heroicização do militante: o caso Marighella. In: CONGRESSO DE CIÊNCIAS DA COMUNICAÇÃO NA REGIÃO SUL, 15., 2014, Palhoça. Anais... São Paulo: Intercom, 2014. Não paginado. Disponível em: <https://goo.gl/FmqkkF>. Acesso em: 4 dez. 2017.

CASTRO, Flavia. O exílio invisível das crianças. The Huffington Post, 30 mar. 2014. Disponível em: 〈https://goo.gl/Yvp86K>. Acesso em: 4 dez. 2017.

CASTRO, João Paulo Macedo e. Ritos da memória: trajetórias e experiências sobre a ditadura militar. Mana, Rio de Janeiro, v. 20, n. 1, p. 7-38, abr. 2014. Disponível em: <http://dx.doi.org/10.1590/S0104-93132014000100001〉. Acesso em: 10 mar. 2017.

CATALÁ, Josep M. Film-ensayo y vanguardia. In: TORREIRO, Casimiro; CERDÁN, Josetxo (Ed.). Documental y vanguardia. Madrid: Cátedra, 2005. p. 109-158.

CATELA, Ludmila da Silva. Situação-limite e memória: a reconstrução do mundo dos familiares de desaparecidos da Argentina. São Paulo: Hucitec; Anpocs, 2001.

CENTRE NATIONAL DE LA CINÉMATOGRAPHIE. Résultats des commissions: Fonds d'aide à l'innovation audiovisuelle (FAI) - aide à l'écriture et au développement documentaire de création. [Paris], 2005. Disponível em: 〈https://goo.gl/cS9dyd >. Acesso em: 8 abr. 2017.

CHANAN, Michael. El discurso espacial de la road movie en América Latina. In: LEFERE, Robin; LIE, Nadia (Org.). Nuevas perspectivas sobre la transnacionalidad del cine hispánico. Leiden; Boston: Brill Rodopi, 2016. p. 179-185. 
CHARTIER, Roger. A história cultural: entre práticas e representações. 2. ed. Lisboa: Difel, 2002.

CIANCIO, Belén. ¿Cómo (no) hacer cosas con imágenes?: sobre el concepto de posmemoria. Constelaciones, n. 7, p. 503-515, dic. 2015. Disponível em: <http://constelacionesrtc.net/article/view/1128/pdf >. Acesso em: 3 jun. 2018.

COELHO, Sandra Straccialano. Deslocamentos e reinvenção do passado no documentário autobiográfico argentino: uma análise de Los rubios (2003), Fotografías (2007) e Familia tipo (2009). In: AVANCA CINEMA INTERNATIONAL CONFERENCE, 2016, Avanca. Anais... Avanca: Cineclube de Avanca, 2016. p. 1-8. Disponível em: <https://goo.gl/si54wX >. Acesso em: 4 dez. 2017.

COMISIÓN NACIONAL SOBRE LA DESAPARICIÓN DE PERSONAS. Nunca más: informe de la Conadep. 8. ed. Buenos Aires: Eudeba, 2011.

COMISSÃO DA VERDADE DO ESTADO DE SÃO PAULO "RUBENS PAIVA". Infância roubada: crianças atingidas pela ditadura militar no Brasil. São Paulo: Alesp, 2014. p. 101103. Disponível em: 〈https://goo.gl/KHuJMz〉. Acesso em: 4 dez. 2017.

COMISSÃO NACIONAL DA VERDADE. Relatório. Brasília: CNV, 2014. v. 1. Disponível em: 〈https://goo.gl/xy97xM>. Acesso em: 4 dez. 2017.

CONSEIL REGIONAL D'ÎLE DE FRANCE. Rapport pour la commission permanente du conseil regional. [Paris], oct. 2010. Disponível em: <https://goo.gl/NvVdy2>. Acesso em: 4 dez. 2017.

COQUET, Itauana Fonseca. Nômades, exilados e sobreviventes: o íntimo e o público e as imagens da ditadura militar no cinema documental contemporâneo brasileiro. 2014. $114 \mathrm{f}$. Dissertação (Mestrado em Comunicação Social) - Departamento de Comunicação Social, Pontifícia Universidade Católica do Rio de Janeiro, Rio de Janeiro, 2014. Disponível em: <https://www.maxwell.vrac.puc-rio.br/27031/27031.PDF>. Acesso em: 31 maio 2017.

CRENZEL, Emilio. La historia política del Nunca más: la memoria de las desapariciones en la Argentina. 1. reimp. Buenos Aires: Siglo Veintiuno Editores, 2014.

CURIA, Dolores. Historias desobedientes. Página/12, Buenos Aires, 5 jun. 2017. Disponível em: 〈https://goo.gl/q1Ty6p >. Acesso em: 4 dez. 2017.

DE BAECQUE, Antoine. Le cas Kapò: "De l'abjection", ou comment Jacques Rivette forge une morale de la représentation des camps de la mort. Revue d'histoire de la Shoah, n. 195, p. 211-239, juil.-déc. 2011.

DE HAUWERE, Katrien. El uso de fotografía en el cine de los hijos de desaparecidos. Nuevo Mundo Mundos Nuevos, jul. 2012. Disponível em: 〈http://nuevomundo.revues.org/63154>. Acesso em: 7 set. 2017.

DENNISON, Stephanie (Org.). Contemporary Hispanic cinema: interrogating the transnational in Spanish and Latin American film. Woodbridge: Tamesis, 2013a. 
DENNISON, Stephanie. Debunking neo-imperialism or reaffirming neo-colonialism? The representation of Latin America in recent co-productions. Transnational cinemas, v. 4, n. 2, p. 185-195, 2013b. Disponível em: 〈https://doi.org/10.1386/trac.4.2.185_1〉. Acesso em: 12 abr. 2017.

DE VALCK, Marijke. Film festivals: from European geopolitics to global cinephilia. Amsterdam: Amsterdam University Press, 2007.

DIDI-HUBERMAN, Georges. Imagens apesar de tudo. Lisboa: KKYM, 2012.

DIELEKE, Edgardo; BRAVO, Álvaro Fernández. Documentales argentinos y brasileños: un mapa en fragmentos. Grumo. Rio de Janeiro: 7 Letras, n. 6, v. 1, p. 12-19, nov. 2007. Disponível em: 〈https://goo.gl/oNSRh8>. Acesso em: 4 jan. 2014.

DIGIOVANNI, Lisa Renee. Visual archives of loss and longing in Chile: Mi vida con Carlos by Germán Berger-Hertz. Journal of Romance Studies, v. 13, n. 3, p. 62-74, Winter 2013. Disponível em: 〈https://goo.gl/oSgFXg>. Acesso em: 4 dez. 2017.

DOSSE, François. A história em migalhas: dos Annales à Nova História. Bauru: Edusc, 2003.

DUARTE-PLON, Leneide. Filme de Flavia Castro emociona franceses. Folha de S. Paulo, São Paulo, 16 jul. 2011. Ilustrada. Disponível em: 〈https://goo.gl/K578Us $\rangle$. Acesso em: 4 dez. 2017.

DUHALDE, Eduardo Luis. Posfacio: A propósito de Roberto Carri y de su obra. In: CARRI, Roberto. Isidro Velázquez: formas prerrevolucionarias de la violencia. 1. reimp. Buenos Aires: Colihue, 2011. p. 125-141.

ĎUROVIČOVÁ, Nataša. Preface. In: ĎUROVIČOVÁ, Nataša; NEWMAN, Kathleen (Org.). World cinemas, transnational perspectives. New York: Routledge, 2010a. p. ix-Xv.

Vector, flow, zone: towards a history of cinematic translatio. In: ĎUROVIČOVÁ, Nataša; NEWMAN, Kathleen (Org.). World cinemas, transnational perspectives. New York: Routledge, 2010b. p. 90-120.

ECO, Umberto. Lector in fabula: a cooperação interpretativa nos textos narrativos. 2. ed. São Paulo: Perspectiva, 2004.

Opera aperta: forma e indeterminazione nelle poetiche contemporanee. Milano: Bompiani, 2016.

Os limites da interpretação. 2. ed. São Paulo: Perspectiva, 2015.

ESCOBAR, Maria Clara. Anotações sobre um processo. In: MAIA, Carla; ESCOBAR, Maria Clara. Duas notas sobre Os dias com ele. Rio de Janeiro: Instituto Moreira Salles, 2015. p. 17-22. (Livreto encartado no DVD).

ESPAGNE, Michel. La notion de transfert culturel. Revue Sciences/Lettres, n. 1, 2013. Disponível em: 〈http://rsl.revues.org/219>. Acesso em: 6 fev. 2015. 
ESPAGNE, Michel. Sur les limites du comparatisme en histoire culturelle. Genèses, n. 17, p. 112-121, 1994. Disponível em: 〈https://goo.gl/YgNXw5>. Acesso em: 4 dez. 2017.

ESTEVE, Laia Quílez. Autobiografía y ficción en el documental contemporáneo argentino. Los rubios de Albertina Carri: un caso paradigmático. In: RANGIL, Viviana (Org.). El cine argentino de hoy: entre el arte y la política. Buenos Aires: Biblos, 2007. p. 71-85.

La representación de la dictadura militar en el cine documental argentino de segunda generación. 2009. 538 f. Tese (Doutorado em Estudos de Comunicação) Departamento de Estudios de Comunicación, Universitat Rovira i Vigili, Tarragona, 2009. Disponível em: 〈http://www.tdx.cat/handle/10803/8596>. Acesso em: 4 dez. 2017.

Sutiles pretéritos: (post)memoria(s) y (auto)biografía(s) en el cine documental contemporáneo. In: GUTIÉRREZ, Gregorio Martín (Ed.). Cineastas frente al espejo. Madrid: T\&B Editores, 2008. p. 83-99.

FABRIS, Mariarosaria. Lembranças de um tempo de guerra. In: SEMINÁRIO NACIONAL CINEMA EM PERSPECTIVA, 3., 2014, Curitiba. Anais... Curitiba: Unespar/FAP, 2014. Disponível em: <https://goo.gl/ihEKhm>. Acesso em: 4 dez. 2017.

FAIGÓN, Miguel. La institucionalización de la "sociología nacional" y sus estrategias. In: JORNADAS DE SOCIOLOGÍA DE LA UNIVERSIDAD NACIONAL DE LA PLATA, 7., 2012, La Plata. Anais... La Plata: UNLP, 2012. Disponível em: 〈https://goo.gl/ptzChJ〉. Acesso em: 4 dez. 2017.

FALICOV, Tamara. "Cine en construcción" / "Films in progress": how Spanish and Latin American filmmakers negotiate the construction of a globalized arthouse aesthetic. Transnational cinemas, v. 4, n. 2, p. 253-271, 2013. Disponível em: <https://doi.org/10.1386/trac.4.2.253_1>. Acesso em: 12 abr. 2017.

Migrating from South to North: the role of film festivals in funding and shaping Global South film and video. In: ELMER, Greg et al. (Org.). Locating migrating media. Lanham: Lexington Books, 2010. p. 3-21.

FEITOSA, Sara Alves. Um personagem, três diretores, três filmes: uma análise da trajetória de Carlos Marighella nos documentários de Tendler, Pronzato e Ferraz. Doc On-line, n. 15, p. 273-289, dez. 2013. Disponível em: 〈www.doc.ubi.pt/15/dossier_sara_feitosa.pdf〉. Acesso em: 12 maio 2014.

FELDMAN, Ilana. Do pai ao país: o documentário autobiográfico em face do fracasso das esquerdas no Brasil. In: HOLANDA, Karla; TEDESCO, Marina Cavalcanti (Org.). Feminino e plural: mulheres no cinema brasileiro. Campinas: Papirus, 2017. p. 213-225.

. Do privado ao político: em torno de Os dias com ele. In: ESTUDOS DE CINEMA E AUDIOVISUAL SOCINE, 17., 2013, Florianópolis. Anais... São Paulo: Socine, 2014. p. 336-343. Disponível em: 〈https://goo.gl/DPDVUz〉. Acesso em: 4 jul. 2015.

Imagens apesar de tudo: problemas e polêmicas em torno da representação, de Shoah a $O$ filho de Saul. ARS, São Paulo, v. 14, n. 28, p. 134-153, jul.-dez. 2016a. Disponível em: <http://dx.doi.org/10.11606/issn.2178-0447.ars.2016.124999>. Acesso em: 10 abr. 2017. 
FELDMAN, Ilana. Jogos de cena: ensaios sobre o documentário brasileiro contemporâneo. 2012a. 162 f. Tese (Doutorado em Ciências da Comunicação) - Escola de Comunicação e Artes, Universidade de São Paulo, São Paulo. Disponível em: 〈https://goo.gl/hv4ZkE $\rangle$. Acesso em: 4 dez. 2017.

O êxito do fracasso: notas sobre o documentário brasileiro contemporâneo. In: BRASIL, André (Org.). Teia 2002-2012. Belo Horizonte: Teia, 2012b. p. 289-305. Disponível em: 〈https://goo.gl/mDrWWF>. Acesso em: 4 dez. 2017.

Os dias com ele é filme corajoso sobre lacunas na relação com pai. Folha de $S$. Paulo, São Paulo, 20 mar. 2016b. Ilustríssima. Disponível em: 〈https://goo.gl/dWwDpj〉. Acesso em: 4 dez. 2017.

FERNANDES, Juliana Ventura de Souza. Repare bem (2012) e as estratégias de construção da memória em diálogo com o Estado brasileiro: o caso da Comissão de Anistia. In: DELLAMORE, Carolina; AMATO, Gabriel; BATISTA, Natália (Org.). A ditadura na tela: o cinema documentário e as memórias do regime militar brasileiro. Belo Horizonte: Faculdade de Filosofia e Ciências Humanas, 2018. p. 25-41.

FERNANDES, Maria Cristina. Filhos do exílio. Época, n. 56, p. 46-53, 14 jun. 1999.

FERRO, Marc. Cinema e história. São Paulo: Paz e Terra, 2010.

FLÉCHET, Anaïs. Por uma história transnacional dos festivais de música popular: música, contracultura e transferências culturais nas décadas de 1960 e 1970. Patrimônio e memória, v. 7, n. 1, p. 257-271, jun. 2011. Disponível em: 〈https://goo.gl/WPHaCa〉. Acesso em: 4 dez. 2017.

et al. (Org.). Une histoire des festivals: $\mathrm{XX}^{\mathrm{e}}-\mathrm{XXI}^{\mathrm{e}}$ siècle. Paris: Publications de la Sorbonne, 2013.

FONTES, Izabel. A ditadura militar brasileira documentada: Os dias com ele. Guavira Letras, Três Lagoas, n. 20, p. 154-163, jan.-jun. 2015. Disponível em: 〈https://goo.gl/mgF7UQ>. Acesso em: 4 dez. 2017.

FOSTER, Lila Silva. Cinema amador brasileiro: história, discursos e práticas (1926-1959). 2016. 266 f. Tese (Doutorado em Meios e Processos Audiovisuais) - Escola de Comunicações e Artes, Universidade de São Paulo, São Paulo, 2016. Disponível em: <https://goo.gl/U5osvm>. Acesso em: 4 dez. 2017.

FRANÇA, Andréa; MACHADO, Patricia. A imagem-excesso, a imagem-fóssil, a imagemdissenso: três propostas cinematográficas para a experiência da ditadura no Brasil. In: GONÇALVES, Osmar (Org.). Narrativas sensoriais: ensaios sobre cinema e arte contemporânea. Rio de Janeiro: Editora Circuito, 2014a. p. 209-233.

; I Imagem-performada e imagem-atestação: o documentário brasileiro e a reemergência dos espectros da ditadura. Galáxia, São Paulo, n. 28, p. 70-82, dez. 2014b. Disponível em: <https://revistas.pucsp.br/index.php/galaxia/article/view/16497/16723 >. Acesso em: 14 out. 2017. 
FREUD, Sigmund. Luto e Melancolia. In: . Obras completas (1914-1916): Introdução ao narcisismo, ensaios de metapsicologia e outros textos. São Paulo: Companhia das Letras, 2010a. v. 12, p. 109-125.

Recordar, repetir e elaborar. In: Obras completas (1911-1913): Observações psicanalíticas sobre um caso de paranoia relatado em uma autobiografia ("O caso Schreber”), artigos sobre técnica e outros textos. São Paulo: Companhia das Letras, 2010b. v. 10, não paginado.

FRIED, Gabriela. On remembering and silencing the past: the adult children of the disappeared in the Southern Cone of Latin America. A comparative study of Argentina and Uruguay. PAPER SUBMITTED TO THE UCLA COMPARATIVE ANALYSIS WORKSHOP, p. 1-24, feb. 1999. Disponível em: 〈https://goo.gl/zvFfdp〉. Acesso em: 4 dez. 2017.

FUICA, Beatriz Tadeo. Memory or postmemory? Documentaries directed by Uruguay's second generation. Memory Studies, v. 8, n. 3, p. 298-312, 2014. Disponível em: <http://mss.sagepub.com/content/8/3/298 >. Acesso em: 20 jul. 2016.

FUKS, Julián. A resistência. São Paulo: Companhia das Letras, 2015.

GAILLARD, Anne Marie. Exils et retours: itinéraires chiliens. Paris: L’Harmattan, 1997.

GÁLVEZ, Valeria Valenzuela. Sujeito, narração e montagem: novos modos de representação no documentário latino-americano contemporâneo. 2008. 131 f. Dissertação (Mestrado em Análise da Imagem e do Som) - Instituto de Arte e Comunicação Social, Universidade Federal Fluminense, Niterói, 2008. Disponível em: 〈https://goo.gl/WG3UWA $>$. Acesso em: 4 dez. 2017.

GARIBOTTO, Verónica; GÓMEZ, Antonio. Más allá del "formato memoria": la repostulación del imaginario postdictatorial en Los rubios de Albertina Carri. A contracorriente, v. 3, n. 2, p. 107-126, Invierno 2006. Disponível em: <https://goo.gl/HWauSz>. Acesso em: 4 dez. 2017.

GERVAISEAU, Henri Arraes. O abrigo do tempo: abordagens cinematográficas da passagem do tempo. São Paulo: Alameda, 2012.

GIANNETTI, Louis; LEACH, Jim. Understanding movies. 2. ed. Toronto: Prentice Hall, 2001.

GINZBURG, Carlo. Detalhes, primeiros planos, microanálises: à margem de um livro de Siegfried Kracauer. In: O fio e os rastros: verdadeiro, falso, fictício. São Paulo: Companhia das Letras, 2011a. p. 231-248.

Feitiçaria e piedade popular: notas sobre um processo modenense de 1519. In: Mitos, emblemas, sinais: morfologia e história. 2. ed. São Paulo: Companhia das Letras, 2007a. p. 15-39. 
GINZBURG, Carlo. Investigando Piero: o Batismo, o ciclo de Arezzo, a Flagelação de Urbino. São Paulo: Cosac Naify, 2010.

Micro-história: duas ou três coisas que sei a respeito. In: O fio e os rastros: verdadeiro, falso, fictício. São Paulo: Companhia das Letras, 2011b. p. 249-279.

. Nenhuma ilha é uma ilha: quatro visões da literatura inglesa. São Paulo: Companhia das Letras, 2004.

O queijo e os vermes. São Paulo: Companhia das Letras, 2006a.

Prefácio. In: Mitos, emblemas, sinais: morfologia e história. 2. ed. São Paulo: Companhia das Letras, 2007b. p. 7-14.

Prefácio. In: LIMA, Henrique Espada. A micro-história italiana: escalas, indícios e singularidades. Rio de Janeiro: Civilização Brasileira, 2006b. p. 9-12.

Provas e possibilidades (Posfácio a Natalie Zemon Davis, O retorno de Martin Guerre). In: 2011c. p. 311-335. . O fio e os rastros: verdadeiro, falso, fictício. São Paulo: Cia. das Letras, Rapporti di forza: storia, retorica, prova. Milano: Feltrinelli, 2014.

. Rappresentazione: la parola, l'idea, la cosa. In: Occhiacci di legno: nove riflessioni sulla distanza. Milano: Feltrinelli, 2011d. p. 82-99.

Sinais: raízes de um paradigma indiciário. In: . Mitos, emblemas, sinais: morfologia e história. 2. ed. São Paulo: Cia. das Letras, 2007c. p. 143-179.

Unus testis: o extermínio dos judeus e o princípio de realidade. In: . O fio e os rastros: verdadeiro, falso, fictício. São Paulo: Companhia das Letras, 2011e. p. 210-230.

GLEGHORN, Charlotte. Genealogias e identidades autobiográficas: os casos de Um passaporte húngaro e Los rubios. Contracampo, Niterói, n. 19, 2008. Disponível em: <https://goo.gl/EwjjdE>. Acesso em: 4 jan. 2014.

GOETSCHEL, Pascale; HIDIROGLOU, Patricia. Introduction: Le festival, object de l'histoire. In: FLÉCHET, Anaïs et al. (Org.). Une histoire des festivals (XX $X^{e}-X X I^{e}$ siècles). Paris: Publications de la Sorbonne, 2013. p. 7-15.

GORENDER, Jacob. Combate nas trevas: a esquerda brasileira - das ilusões perdidas à luta armada. São Paulo: Editora Ática, 1987.

GOURSAT, Juliette. Contesting consensual memory: the work of remembering in Chilean autobiographical documentaries. In: DEPREZ, Camille; PERNIN, Judith. Post-1990 documentary: reconfiguring independence. Edinburgh: Edinburgh University Press, 2015. p. 112-124. 
GRAY, David Winks. Placing memory: postdictatorial documentaries in the Southern Cone. 2015. 198 f. Tese (Doutorado em Film and Media Studies) - University of California, Santa Barbara, 2015. Disponível em: 〈https://goo.gl/UUVM4M>. Acesso em: 4 dez. 2017.

GREEN, James; QUINALHA, Renan (Org.). Ditadura e homossexualidades: repressão, resistência e a busca da verdade. São Carlos: EdUFSCar, 2014.

GUERRA, Susana. A ditadura superexposta: experiências do olhar sobre o passado autoritário no Brasil e em Portugal. Revista Porto, v. 3, n. 4, p. 122-135, 2016. Disponível em: <https://periodicos.ufrn.br/porto/article/view/10931>. Acesso em: 31 maio 2017.

GUIMARÃES, Patrícia Cunegundes. Álbuns de família e documentários: lugares de memória das ditaduras civis-militares do Cone Sul. 2017. 47 f. Relatório de Exame de Qualificação (Mestrado em Comunicação) - Faculdade de Comunicação, Universidade de Brasília, Brasília, 2017. Disponível em: 〈https://goo.gl/x2spQU〉. Acesso em: 4 dez. 2017.

GUTFREIND, Cristiane Freitas; BARONE, João Guilherme. Notas sobre o documentário político e o cinema brasileiro nos anos 2000. In: GUTFREIND, Cristiane Freitas (Org.). Narrar o biográfico: a comunicação e a diversidade da escrita. Porto Alegre: Sulina, 2015. p. 267-289.

GUTFREIND, Cristiane Freitas; STIGGER, Helena. A resistência armada: Lamarca e Marighella no cinema nacional. Logos 38. v. 20, n. 1, $1^{\circ}$ semestre de 2013. p. 48-60. Disponível em: <https://goo.gl/Qtu9Sz>. Acesso em: 4 dez 2017.

GUTIÉRREZ, Carlos A.; WAGENBERG, Monika. Meeting points: a survey of film festivals in Latin America. Transnational cinemas, v. 4, n. 2, p. 295-305, 2013. Disponível em: <https://goo.gl/WNjHVH>. Acesso em: 4 dez. 2017.

GUTIÉRREZ, Gregorio Martín (Ed.). Cineastas frente al espejo. Madrid: T\&B Editores, 2008.

GUTTER, Nicolás Aponte A. Cerca de la revolución. 2009. Disponível em: <https://goo.gl/fsM5Pp>. Acesso em: 4 dez. 2017.

HADOUCHI, Olivier. Mémoire des luttes contre les dictatures du Cône Sud (Argentine, Chili et Uruguay) dans le cinéma documentaire conteporain. L'Ordinaire des Amériques, n. 213, p. 55-76, 2010. Disponível em: 〈http://orda.revues.org/2412〉. Acesso em: 1 jun. 2017.

HAINGE, Greg. Philippe Grandrieux: sonic cinema. London: Bloomsbury Academic, 2017.

HIGBEE, Will; LIM, Song Hwee. Concepts of transnational cinema: towards a critical transnationalism in film studies. Transnational cinemas, v. 1, n. 1, p. 7-21, 2010. Disponível em: <https://goo.gl/G6V2m5>. Acesso em: 4 dez. 2017.

HIRSCH, Marianne. Family frames: photography, narrative and postmemory. Cambridge: Harvard University Press, 1997. 
HIRSCH, Marianne. Family pictures: Maus, mourning, and post-memory. Discourse: Journal for theoretical studies in media and culture, v. 15, n. 2, p. 3-29, Winter 1992-1993. Disponível em: 〈http://digitalcommons.wayne.edu/discourse/vol15/iss2/1〉. Acesso em: 12 nov. 2015.

The generation of postmemory. Poetics Today, Durham: Duke University Press, 29:1, 2008. p. 103-128.

The generation of postmemory: writing and visual culture after the Holocaust. New York: Columbia University Press, 2012.

HJORT, Mette. On the plurality of cinematic transnationalism. In: ĎUROVIČOVÁ, Nataša; NEWMAN, Kathleen (Org.). World cinemas, transnational perspectives. New York: Routledge, 2010. p. 12-33.

HOLANDA, Karla. Documentário brasileiro contemporâneo e a micro-história. Fênix, v. 3, n. 1, ano 3, p. 1-12, 2006. Disponível em: 〈https://goo.gl/7wvP4y >. Acesso em: 17 mar. 2013.

- Documentaristas brasileiras e as vozes feminina e masculina. Significação, São Paulo, v. 42, n. 44, p. 339-358, dez. 2015. Disponível em: <https://www.revistas.usp.br/significacao/article/view/103434>. Acesso em: 28 out. 2017.

HOUAISS, Antônio. Grande dicionário Houaiss. [Rio de Janeiro]: Uol, [2001]. Disponível em: 〈https://houaiss.uol.com.br>. Acesso em: 27 ago. 2017.

HUYSSEN, Andreas. Apresentação. In: __. Culturas do passado-presente: modernismos, artes visuais, políticas da memória. Rio de Janeiro: Contraponto, 2014. p. 1117.

IBAZETA, María Celina. O Diretor/Personagem nos documentários subjetivos sobre a ditadura argentina. Logos 32 Comunicação e Audiovisual, Rio de Janeiro, ano 17, n. 1, p. 7080, 1. sem. 2010. Disponível em: 〈https://goo.gl/Kmst94〉. Acesso em: 4 dez. 2017.

JELIN, Elizabeth. The past in the present: memories of State violence in contemporary Latin America. In: ASSMANN, Aleida; CONRAD; Sebastian (Ed.). Memory in a Global Age: discourses, practices and trajectories. London: Palgrave Macmillan, 2010a. p. 61-78.

- ¿Víctimas, familiares o ciudadanos/as?: las luchas por la legitimidad de la palabra. In: CRENZEL, Emilio (Org.). Los desaparecidos en Argentina: memorias, representaciones e ideas (1983-2008). Buenos Aires: Biblos, 2010b. p. 227-249.

JOHANSSON, María Teresa; VERGARA; Constanza. Filman los hijos: nuevo testimonio en los documentales En algún lugar del cielo de Alejandra Carmona y Mi vida con Carlos de Germán Berger-Hertz. Meridional: revista chilena de estudios Latinoamericanos, n. 2, p. 89105, abr. 2014. Disponível em: 〈https://goo.gl/ewjTeb>. Acesso em: 4 dez. 2017.

KAISER, Susana. Escraches: demonstrations, communication and political memory in postdictatorial Argentina. Media, Culture \& Society, v. 24, n. 4, p. 499-516, July 2002. Disponível em: 〈http://mcs.sagepub.com/content/24/4/499.abstract>. Acesso em: 21 jul. 2016. 
KOHAN, Martín. La apariencia celebrada. Punto de vista, Buenos Aires, ano 27, n. 78, p. 2430, abr. 2004a. Disponível em: 〈http://www.ahira.com.ar/revistas/pdv/71/pdv78.pdf $>$. Acesso em: 4 dez. 2017.

. Una crítica en general y una película en particular. Punto de Vista, Buenos Aires, ano 27, n. 80, p. 47-48, dic. 2004b. Disponível em: <http://www.ahira.com.ar/revistas/pdv/71/pdv80.pdf >. Acesso em: 4 dez. 2017.

KONIGSBERG, Ira. Diccionario técnico Akal de cine. Madrid: Ediciones Akal, 2004.

KRIGER, Clara. La experiencia del documental subjetivo en Argentina. In: MOORE, María José; WOLKOWICZ, Paula (Org.). Cines al margen: nuevos modos de representación en el cine argentino contemporáneo. Buenos Aires: Libraria, 2007, p. 33-49.

LABBÉ, Paola Lagos. Desviaciones de ruta: puntos de inflexión en los registros de enunciación de los diarios de viajes documentales. In: CONGRESO INTERNACIONAL DE LA ASOCIACIÓN ARGENTINA DE ESTUDIOS DE CINE Y AUDIOVISUAL, 3., 2012, Córdoba. Anais... Córdoba: AsAECA, 2012a. Disponível em: <http://asaeca.org/actas-decongresos-asaeca/>. Acesso em: 18 dez. 2017.

. Primera persona singular: estrategias de (auto)representación para modular el "yo" en el cine de no ficción. Comunicación y Medios, n. 26, p. 12-22, 2012b. Disponível em: <https://goo.gl/ga4662 >. Acesso em: 4 dez. 2017.

LACERDA, Tessa Moura. Reconstruindo Gildo. In: COMISSÃO DA VERDADE DO ESTADO DE SÃO PAULO "RUBENS PAIVA". Infância roubada: crianças atingidas pela ditadura militar no Brasil. São Paulo: Alesp, 2014. p. 285-287. Disponível em: <https://goo.gl/KHuJMz>. Acesso em: 3 abr. 2017.

LADERMAN, David. Driving visions: exploring the road movie. Austin: University of Texas Press, 2002.

LAZZARA, Michael J. Filming Loss: (Post-)Memory, subjectivity, and the performance of failure in recent Argentine documentary films. Latin American perspectives, issue 168, v. 36, n. 5, p. 147-157, Sept. 2009. Disponível em: 〈https://goo.gl/gCgeai >. Acesso em: 18 dez. 2016.

LEFERE, Robin; LIE, Nadia. Introducción al volumen. In:________ (Org.). Nuevas perspectivas sobre la transnacionalidad del cine hispánico. Leiden; Boston: Brill Rodopi, 2016. p. 3-16.

LEJEUNE, Philippe. Cine y autobiografía, problemas de vocabulario. In: GUTIÉRREZ, Gregorio Martín (Ed.). Cineastas frente al espejo. Madrid: T\&B Editores, 2008. p. 13-26.

. Le pacte autobiographique. Paris: Éditions du Seuil, 1996.

LERER, Diego. La fábula de la reconstrucción. Clarín, Buenos Aires, 23 oct. 2003, Espectáculos. Disponível em: 〈https://goo.gl/pa46FE〉. Acesso em: 4 dez. 2017.

. Un beso antes de morir. Clarín, Buenos Aires, 29 jul. 2004, Espectáculos, p. 13. 
LEVEY, Cara. Escrache: resistance in the streets of Buenos Aires. In: CASAS, Arturo; BOLLING, Bern (Org.). Resistance and emancipation: cultural and poetic practices. Bern: Peter Lang, 2011. p. 301-318.

. Of HIJOS and Niños: revisiting postmemory in post-dictatorship Uruguay. History \& memory, v. 26, n. 2, p. 5-39, outono/inverno 2014. Disponível em: <http://muse.jhu.edu/article/553782>. Acesso em: 29 mar. 2017.

LEVI, Giovanni. Sobre a micro-história. In: BURKE, Peter (Org.). A escrita da história: novas perspectivas. São Paulo: Editora Unesp, 1992. p. 133-161.

LEVI, Primo. Se questo è un uomo. Torino: Einaudi, 2014.

LIANDRAT-GUIGUES, Suzanne; GAGNEBIN, Murielle (Dir.). L'essai et le cinéma. Seyssel: Éditions Champ Vallon, 2004.

LIE, Nadia. Lo transnacional en el cine hispánico: deslindes de un concepto. In: LEFERE, Robin; LIE, Nadia (Org.). Nuevas perspectivas sobre la transnacionalidad del cine hispánico. Leiden; Boston: Brill Rodopi, 2016. p. 17-35.

LIE, Nadia; MAHLKE, Kirsten. Focus: transnational memory in the Hispanic World. Preface. European review. v. 2, n. 4, p. 543-545, Oct. 2014. Disponível em: <https://doi.org/10.1017/S1062798714000325>. Acesso em: 27 jan. 2017.

LIE, Nadia; PIEDRAS, Pablo. Identidad y movilidad en el cine documental latinoamericano contemporáneo: Familia tipo (2009) e Hija (2011). Confluencia: revista Hispánica de cultura y literatura, v. 30, n. 1, p. 72-86, Fall 2014. Disponível em: <https://doi.org/10.1353/cnf.2014.0009>. Acesso em: 20 abr. 2017.

LINDEPERG, Sylvie. "Nuit et brouillard": un film dans l'histoire. Paris: Odile Jacob, 2007.

LLANOS, Bernardita. El documental de la generación postdictadura y su mirada al pasado: $E l$ edificio de los chilenos y Mi vida con Carlos. In: VILLARROEL, Mónica (Coord.). Travesías por el cine chileno y latinoamericano. Santiago: LOM Ediciones; Centro Cultural La Moneda, 2014. p. 217-226.

LUPTON, Catherine. Memories of the future. London: Reaktion Books, 2005.

LUSNICH, Ana Laura. Del comparatismo al transnacionalismo: bases de un estudio del cine argentino y mexicano del período clásico-industrial. Toma Uno, Córdoba, n. 3, p. 99-110, 2014. Disponível em: 〈https://goo.gl/2yxzFt〉. Acesso em: 4 dez. 2017.

LVOVICH, Daniel; BISQUERT, Jaquelina. La cambiante memoria de la dictadura: discursos públicos, movimientos sociales y legitimidad democrática. Los Polvorines: Universidad Nacional de General Sarmiento; Buenos Aires: Biblioteca Nacional, 2008.

MACHADO, Irene. Olhares excedentes: dilemas da hipótese cinebiográfica sobre militantes políticos. In: GUTFREIND, Cristiane Freitas (Org.). Narrar o biográfico: a comunicação e a diversidade da escrita. Porto Alegre: Sulina, 2015. p. 213-266. 
MACHADO, Patricia. A intimidade na tela do cinema: reconfigurações do espetáculo e da vida privada na contemporaneidade. Revista Contemporânea, Rio de Janeiro, v. 13, 2009. p. 95-105. Disponível em: <https://goo.gl/MaooHQ>. Acesso em: 4 dez. 2017.

MACIEL, Wilma Antunes. Militares de esquerda: formação, participação política e engajamento na luta armada (1961-1974). 212 f. Tese (Doutorado em História Social) Faculdade de Filosofia, Letras e Ciências Humanas, Universidade de São Paulo, São Paulo, 2009. Disponível em: 〈https://goo.gl/jP9Smh〉. Acesso em: 4 dez. 2017.

MACÓN, Cecilia. Los rubios o del trauma como presencia. Punto de vista, Buenos Aires, ano XXVII, n. 80, p. 44-47, dic. 2004. Disponível em: <http://www.ahira.com.ar/revistas/pdv/71/pdv80.pdf >. Acesso em: 4 dez. 2017.

MAIA, Carla. Hipóteses para Os dias com ele. In: MAIA, Carla; ESCOBAR, Maria Clara. Duas notas sobre Os dias com ele. Rio de Janeiro: Instituto Moreira Salles, 2015a. p. 5-15. (Livreto encartado no DVD).

História e, também, nada: o testemunho em Os dias com ele, de Maria Clara Escobar. Cinémas d'Amérique latine, Toulouse, n. 22, p. 140-151, 2014. Disponível em: <http://cinelatino.revues.org/882>. Acesso em: 4 jul. 2015.

. Pequenas histórias face à grande história. Rebeca, ano 4, ed. 7, p. 395-415, jan.-jun. 2015b. Disponível em: 〈http://dx.doi.org/10.22475/rebeca.v4n1.155>. Acesso em: 4 dez. 2017.

MARQUES, Ana Rosa. A construção dos personagens na performance e montagem de $O s$ dias com ele. In: ESTUDOS DE CINEMA E AUDIOVISUAL SOCINE, 18., 2014, Fortaleza. Anais... São Paulo: Socine, 2015. p. 422-428. Disponível em: 〈https://goo.gl/PkoqAf〉. Acesso em: 4 dez. 2017.

MARTIN, Marcel. El lenguaje del cine. Barcelona: Gedisa Editorial, 2002.

MASMUN, Carla. Raymundo Gleyzer y el Grupo Cine de la Base: compromiso, activismo y resistencia. In: LUSNICH, Ana Laura; PIEDRAS, Pablo (Org.). Una historia del cine político y social en Argentina: formas, estilos y registros (1969-2009). Buenos Aires: Nueva Librería, 2011. p. 163-183.

MAUAD, Ana Maria. Imagens que faltam, imagens que sobram: práticas visuais e cotidiano em regimes de exceção (1960-1980). Estudos Ibero-Americanos, Porto Alegre, v. 43, n. 2, p. 397-413, maio-ago. 2017. Disponível em: 〈https://goo.gl/vyZZvT>. Acesso em: 16 dez. 2017.

MAZZUCCHELLI, Francesco; DER LAARSE; Rob van; REIJNEN, Carlos. Introduction: traces of terror, signs of trauma. Versus, n. 119, p. 3-19, July-Dec. 2014. Disponível em: <https://goo.gl/D8nrwg>. Acesso em: 18 dez. 2017.

MIDDENTS, Jeffrey. The first rule of Latin American cinema is you do not talk about Latin American cinema. Transnational cinemas, v. 4, n. 2, p. 147-164, 2013. Disponível em: <http://dx.doi.org/10.1386/trac.4.2.147_1>. Acesso em: 15 jun. 2016. 
MIGLIORIN, Cezar. Carta 4: Os dias com ele, para Maria Clara Escobar. In: . Cartas sem resposta. Belo Horizonte: Autêntica Editora, 2015. p. 57-64.

Impressões do crítico Cezar Migliorin sobre o filme Os dias com ele. $16^{a}$ Mostra de Cinema de Tiradentes, 27 jan. 2013. Disponível em: 〈https://goo.gl/nvmfKv〉. Acesso em: 4 jul. 2015.

MIRANDA, André. No documentário Diário de uma busca, Flavia Castro aposta na memória para tratar da vida do militante Celso Afonso Castro. $O$ Globo, Rio de Janeiro, 23 ago. 2011, Cultura. Disponível em: 〈https://goo.gl/tB5DPN>. Acesso em: 4 dez. 2017.

MOGUILLANSKY, Marina. Cines del Sur: la integración cinematográfica entre los países del Mercosur. Buenos Aires: Imago Mundi, 2016.

MOINE, Raphaëlle. Le genre cinématographique: une catégorie de l'interprétation. Belphégor, v. 3, n. 1, 2003. Disponível em: 〈https://goo.gl/1HFm7y $\rangle$. Acesso em: 4 dez. 2017.

MOLFETTA, Andrea. La representación que recupera el pasado: Modos del relato y de la enunciación en la memoria de la militancia y de la dictadura. In: LUSNICH. Ana Laura; PIEDRAS, Pablo. Una historia del cine político y social en Argentina (1969-2009). Buenos Aires: Nueva Librería, 2011a. p. 529-539.

Performando el documental en la Argentina: dinámicas de la intersubjetividad en el proceso de conciencia histórica de los films de Caldini, Di Tella y Carri. In: LUSNICH. Ana Laura; PIEDRAS, Pablo. Una historia del cine político y social en Argentina (1969-2009). Buenos Aires: Nueva Librería, 2011b. p. 559-573.

MORAES, Emanuella Leite Rodrigues de; OLIVEIRA, Marinyze Prates de. Fios emaranhados: (des)enlaces biográficos no documentário Elena. Significação, São Paulo, v. 42, n. 43, p. 40-56, 2015. Disponível em: <http://dx.doi.org/10.11606/issn.23167114.sig.2015.96074>. Acesso em: 31 maio 2017.

MORAL, Juan Díaz del Moral. Historia de las agitaciones campesinas andaluzas. Madrid: Alianza, 1967.

MORENO, María. Esa rubia debilidad. Página/12, Buenos Aires, 19 out. 2003. Radar.

MORETTI, Amílcar. El dolor tramitado como juego. El día, La Plata, 16 nov. 2003, Espectáculos, p. 17.

MORETTIN, Eduardo. Humberto Mauro, cinema, história. São Paulo: Alameda, 2013.

O cinema como fonte histórica na obra de Marc Ferro. In: CAPELATO, Maria Helena et al. (Org.). História e cinema. São Paulo: Alameda, 2007. p. 40-64.

MOSER, Walter. Présentation. Le road movie: un genre issu d'une constellation moderne de locomotion et de médiamotion. Cinémas: revue d'études cinématographiques, v. 18, n. 2-3, p. 7-30, 2008. Disponível em: 〈http://id.erudit.org/iderudit/018415ar>. Acesso em: 20 abr. 2017. 
MOUJÁn, Pedro Fernández. Un tratado sobre la ficción de la memoria. Río Negro, General Roca, 17 abr. 2003, p. 61.

NAFICY, Hamid. An accented cinema: exilic and diasporic filmmaking. Princeton: Princeton University Press, 2001.

NAPOLITANO, Marcos. 1964: história do regime militar brasileiro. São Paulo: Contexto, 2014.

A crise brasileira, em perspectiva histórica. In: MATTOS, Hebe; BESSONE, Tânia; MAMIGONIAN, Beatriz G. (Org.). Historiadores pela democracia: o golpe de 2016, a força do passado. São Paulo: Alameda, 2016. Não paginado.

. A História depois do papel In: PINSKY, Carla Bassanezi (Org.). Fontes históricas. 2. ed. São Paulo: Contexto, 2006. p. 235-289.

. Coração civil: a vida cultural brasileira sob o regime militar (1964-1985). São Paulo: Intermeios, 2017.

Recordar é vencer: as dinâmicas e vicissitudes da construção da memória sobre o regime militar brasileiro. Antíteses, v. 8, n. 15 esp., p. 9-44, nov. 2015. Disponível em: <http://www.uel.br/revistas/uel/index.php/antiteses/article/view/23617>. Acesso em: 15 maio 2017.

NEHRING, Marta. "Por que você é tão tristinha?" In: COMISSÃO DA VERDADE DO ESTADO DE SÃO PAULO "RUBENS PAIVA". Infância roubada: crianças atingidas pela ditadura militar no Brasil. São Paulo: Alesp, 2014. p. 43-47. Disponível em: <https://goo.gl/KHuJMz >. Acesso em: 3 abr. 2017.

NEWMAN, Kathleen. Notes on transnational film theory: decentered subjectivity, decentered capitalism. In: ĎUROVIČOVÁ, Nataša; NEWMAN, Kathleen (Org.). World cinemas, transnational perspectives. New York: Routledge, 2010. p. 3-11.

NICHOLS, Bill. Blurred boundaries: questions of meaning in contemporary culture. Bloomington: Indiana University Press, 1994.

. Introduction to documentary. 2. ed. Bloomington: Indiana University Press, 2010.

Representing Reality: issues and concepts in documentary. Bloomington: Indiana University Press, 1991.

NORA, Pierre. Entre mémoire et histoire: la problématique des lieux. In: (Org.). Les lieux de mémoire. v. 1, Paris: Gallimard, 1984. p. XVII-XLII.

NORIEGA, Gustavo. Estudio crítico sobre Los Rubios: entrevista a Albertina Carri. Buenos Aires: Picnic Editorial, 2009. 
NOUZEILLES, Gabriela. Postmemory cinema and the future of the past in Albertina Carri's Los rubios. Journal of Latin American cultural studies, v. 14, n. 3, p. 263-278, Dec. 2005. Disponível em: 〈http://dx.doi.org/10.1080/13569320500382500>. Acesso em: 8 nov. 2017.

NÚÑEZ, Nohora Viviana Cardona. Realizaciones posmemorísticas desde la perspectiva de género y el transatlantismo en los umbrales del siglo XXI. 2014. $371 \mathrm{f}$. Tese (Doutorado) Facultad de Estudios Superiores, Universidad de Ottawa, Ottawa, 2014. Disponível em: <http://hdl.handle.net/10393/31709>. Acesso em: 25 jan. 2017.

ODIN, Roger. Cinéma et production de sens. Paris: Armand Colin Éditeur, 1990.

El cine doméstico en la institución familiar. In: ÁLVAREZ, Efrén Cuevas (Ed.). La casa abierta: el cine doméstico y sus reciclajes contemporáneos. Madrid: Ocho y Medio, 2010. p. 39-60.

OLAGAN, Nyv. Los rubios: una comedia. Nota 13, 18 ago. 2012. Disponível em: <https://goo.gl/AyoYN9>. Acesso em: 4 dez. 2017.

OLIVA, Fernando. Produção do Videobrasil vai ao exterior. Folha de S. Paulo, São Paulo, 18 jan. 1997. Ilustrada. Disponível em: 〈https://goo.gl/urxFsH>. Acesso em: 4 dez. 2017.

OLIVEIRA, Euller Gontijo de. Arqueologia da ausência: um processo privado de elaboração da perda em audiovisuais de familiares de desaparecidos na ditadura argentina (1976-1983). 2013. 131 f. Dissertação (Mestrado em História) - Faculdade de História, Universidade Federal de Goiás, Goiânia, 2013. Disponível em: <https://pos.historia.ufg.br/up/113/o/D201310.pdf>. Acesso em: 21 nov. 2017.

ORGERON, Devin. Road movies: from Muybridge and Méliès to Lynch and Kiarostami. New York: Palgrave Macmillan, 2008.

ORTEGA, María Luisa. Documental, vanguardia y sociedad: los límites de la experimentación. In: TORREIRO, Casimiro; CERDÁN, Josetxo (Ed.). Documental y vanguardia. Madrid: Cátedra, 2005. p. 185-217.

Las modulaciones del "yo" en el documental contemporáneo. In: GUTIÉRREZ, Gregorio Martín (Ed.). Cineastas frente al espejo. Madrid: T\&B Editores, 2008. p. 65-81.

Nuevos tropos en el documental latinoamericano: subjetividad, memoria y representación. In: WEINRICHTER, Antonio (Org.) .Doc: el documentalismo en el siglo XXI. [S.1]: Festival Internacional de Cine Donostia-San Sebastián, 2010. p. 77-99. Disponível em: 〈https://goo.gl/M3wg8X >. Acesso em: 4 dez. 2017.

OSBORNE, Elizabeth. Sounds of absence: Aurality and silence in Chile's Mi vida con Carlos/My Life with Carlos (2010) and El eco de las canciones/The Echo of the Songs (2010). Studies in Spanish \& Latin American Cinemas, v. 14, n. 1, p. 41-57, Mar. 2017. Disponível em: 〈https://doi.org/10.1386/slac.14.1.41_1〉. Acesso em: 2 ago. 2017.

OUBIÑA, David (Org.). Jean-Luc Godard: el pensamiento del cine. Cuatro miradas sobre Histoire(s) du cinéma. 1. reimp. Buenos Aires: Paidós, 2005. 
PAGE, Joanna. Memory and mediation in Los rubios: a contemporary perspective on the Argentine dictatorship. New cinemas, v. 3, n. 1, p. 29-40, 2005. Disponível em: <https://doi.org/10.1386/ncin.3.1.29/1>. Acesso em: 7 nov. 2017.

PAIVA, Tatiana Moreira Campos. Herdeiros do exílio: memórias de filhos de exilados brasileiros da ditadura militar. 155 f. Dissertação (Mestrado em História Social da Cultura) Departamento de História, Pontifícia Universidade Católica do Rio de Janeiro, Rio de Janeiro, 2011. Disponível em: 〈https://doi.org/10.17771/PUCRio.acad.9056>. Acesso em: 5 abr. 2017.

. Memórias de filhos de militantes e as heranças políticas de uma geração. $162 \mathrm{f}$. Tese (Doutorado em História Social da Cultura) - Departamento de História, Pontifícia Universidade Católica do Rio de Janeiro, Rio de Janeiro, 2006. Disponível em: <https://doi.org/10.17771/PUCRio.acad.19276>. Acesso em: 5 abr. 2017.

PAPADIMITRIOU; Lydia; RUOFF, Jeffrey. Film festivals: origins and trajectories. New review of film and television studies, v. 14, n. 1, p. 1-4, 2016. Disponível em: <http://dx.doi.org/10.1080/17400309.2015.1106686 >. Acesso em: 30 abr. 2017.

PARADA, María Marcela. Cine autobiográfico femenino: éste no es mi padre. In: ESTUDOS DE CINEMA E AUDIOVISUAL SOCINE, 18., 2014, Fortaleza. Anais... São Paulo: Socine, 2015. p. 630-635. Disponível em: 〈https://goo.gl/PkoqAf〉. Acesso em: 4 dez. 2017.

PEDRO, Joana Maria. Lectures brésiliennes du féminisme français et mecanismes d'identification au Brésil. In: SANTOS, Idelette Muzart-Fonseca dos; ROLLAND, Denis (Org.). L'exil brésilien en France: histoire et imaginaire. Paris: L'Harmattan, 2008. p. 261279

PEREIRA, Miguel. Carri e Murat: memória, política e representação. Significação, São Paulo, n. 32, p. 189-203, 2009. Disponível em: <http://www.revistas.usp.br/significacao/article/view/68098>. Acesso em: 12 nov. 2015.

PEREZ, Mariana Eva. Their lives after: theatre as testimony and the so-called "second generation" in post-dictatorship Argentina. Journal of Romance Studies, v. 13, n. 3, p. 6-16, Winter 2013. Disponível em: 〈http://dx.doi.org/10.3167/jrs.2013.130302〉. Acesso em: 8 nov. 2017.

PERRIAM, Chris; SANTAOLALLA, Isabel; EVANS, Peter W. The transnational in Iberian and Latin American cinemas: editors' introduction. Hispanic Research Journal, v. 8, n. 1, p. 3-9, Feb. 2007. Disponível em: 〈https://doi.org/10.1179/174582007X164294>. Acesso em: 4 dez. 2017.

PIEDRAS, Pablo. El cine documental en primera persona. Buenos Aires: Paidós, 2014.

. La cuestión de la primera persona en el documental latinoamericano contemporáneo: la representación de lo autobiográfico y sus dispositivos. Cine Documental, Buenos Aires, n. 1, não paginado, 2010. Disponível em: 〈https://goo.gl/orFvhW〉. Acesso em: $18 \mathrm{dez} .2017$.

PINAZZA, Natália. Journeys in Argentine and Brazilian cinema: road films in a Global Era. New York: Palgrave Macmillan, 2014. 
PINTO, Catalina Donoso. Sobre algunas estrategias fílmicas para una propuesta de primera persona documental. Comunicación y Medios, n. 26, p. 23-30, 2012. Disponível em: <https://goo.gl/YtEo71>. Acesso em: 4 dez. 2017.

POLLAK, Michel. Memória, esquecimento, silêncio. Estudos Históricos, Rio de Janeiro, v. 2, n. 3, p. 3-15, 1989. Disponível em: 〈https://goo.gl/Iavmdb>. Acesso em: 4 dez. 2017.

PRADO, Maria Ligia Coelho. Repensando a história comparada da América Latina. Revista de História, São Paulo, n. 153, p. 11-33, dez. 2005. Disponível em: <http://dx.doi.org/10.11606/issn.2316-9141.v0i153p11-33>. Acesso em: 2 dez. 2017.

PRELORENTZOU, Renato. Futuro do pretérito: tempo e narrativa na história, no romance, na tese. 2015. 235 f. Tese (Doutorado em Teoria Literária e Literatura Comparada) Faculdade de Filosofia, Letras e Ciências Humanas, Universidade de São Paulo, São Paulo, 2015. Disponível em: 〈https://goo.gl/x28F36>. Acesso em: 18 dez. 2017.

QUIETO, Lucila. Arqueología de la ausencia. 1999-2001. Ensaio fotográfico. Disponível em: <https://goo.gl/hmsqij >. Acesso em: 4 dez. 2017.

RABADÁN, Minerva Campos. Construcción y legitimación de los cines (trans)nacionales en el circuito internacional de festivales: el caso de América Latina. 2016. 358 f. Tese (Doutorado em Meios de Comunicação) - Departamento de Periodismo y Comunicación Audiovisual, Universidad Carlos III de Madrid, Getafe, 2016. Disponível em: <http://hdl.handle.net/10016/23801>. Acesso em: 3 jun. 2018.

RADSTONE, Susannah. What place is this: transcultural memory and the locations of memory studies. Parallax, v. 17, n. 4, p. 109-123, 2011. Disponível em: <http://dx.doi.org/10.1080/13534645.2011.605585>. Acesso em: 1 jul. 2016.

RAMÍREZ, Elizabeth. Estrategias para (no) olvidar: notas sobre dos documentales chilenos de la post-dictadura. Aisthesis, n. 47, p. 45-63, 2010. Disponível em: <http://dx.doi.org/10.4067/S0718-71812010000100004>. Acesso em: 31 maio 2017.

RAMOS, Fernão Pessoa. Mas afinal... o que é mesmo documentário? São Paulo: Editora Senac, 2008.

RANCIÈRE, Jacques. A partilha do sensível: estética e política. 2. ed. São Paulo: EXO experimental org; Editora 34, 2009.

L'inoubliable. In: COMOLLI, Jean-Louis; RANCIÈRE, Jacques. Arrêt sur histoire. Paris: Centre Georges Pompidou, 1997. p. 47-70.

O destino das imagens. Rio de Janeiro: Contraponto, 2012.

REIS FILHO, Daniel Aarão. A revolução faltou ao encontro: os comunistas no Brasil. São Paulo: Editora Brasiliense, 1990. 
RENOV, Michael. Domestic ethnography and the construction of the "other" self. In: The subject of documentary. Minneapolis: University of Minnesota Press, 2004a. p. 216-229.

. The subject in history: the new autobiography in film and video. In: The subject of documentary. Minneapolis: University of Minnesota Press, 2004b. p. 104-119.

. The subject of documentary. Minneapolis: University of Minnesota Press, 2004c.

REYNOSO, Alejandro. Nietas/os. 2016. Ensaio fotográfico, color. Disponível em: <https://goo.gl/jQkdgx >. Acesso em: 4 dez. 2017.

RICEUR, Paul. A memória, a história, o esquecimento. Campinas: Editora da Unicamp, 2007.

RIDENTI, Marcelo. O fantasma da revolução brasileira. 2. ed. São Paulo: Editora Unesp, 2010 .

RIERA, Elena López. Albertina Carri: el cine y la furia. Valencia: Ediciones de la Filmoteca, 2009.

RIVETTE, Jacques. De l'abjection. Cahiers du Cinéma, n. 120, p. 54-55, juin 1961.

RODRÍGUEZ, Cecilia; ESPINOZA, Adriana. A memória enquistada: uma aproximação ao trauma transgeracional. Caderno de Ciências Humanas - Especiaria, v. 9, n. 15, p. 159-180, jan.-jun. 2006. Disponível em: 〈https://goo.gl/E9x6sw>. Acesso em: 4 dez. 2017.

ROITMAN, Julieta. Miragens de si: ensaios autobiográficos no cinema. 2007. $141 \mathrm{f}$. Dissertação (Mestrado em História) - Centro de Ciências Sociais, Pontifícia Universidade Católica do Rio de Janeiro, Rio de Janeiro, 2007. Disponível em: 〈https://goo.gl/hkKSK5 $>$. Acesso em: 4 dez. 2017.

ROLLEMBERG, Denise. Carlos Marighella e Carlos Lamarca: memórias de dois revolucionários. In: FERREIRA, Jorge; REIS FILHO, Daniel Aarão (Org.). As esquerdas no Brasil: revolução e democracia. 1964... Rio de Janeiro: Civilização Brasileira, 2007. v. 3. Disponível em: 〈https://goo.gl/KgsPhY>. Acesso em: 4 dez. 2017.

. Esquecimento das memórias. In: MARTINS FILHO, João Roberto (Org.). O golpe de 1964 e o regime militar: novas perspectivas. São Carlos: EdUFSCar, 2006. p. 81-91.

. Exílio: entre raízes e radares. Rio de Janeiro: Record, 1999.

ROS, Ana. The Post-dictatorship generation in Argentina, Chile, and Uruguay: collective memory and cultural production. New York: Palgrave MacMillan, 2012.

ROSENSTONE, Robert. A história nos filmes, os filmes na história. São Paulo: Paz e Terra, 2010 .

ROTHBERG, Michael. Multidirectional memory: remembering the Holocaust in the Age of Decolonization. Stanford: Stanford University Press, 2009. 
ROVAI, Mauro Luiz. Memória e esquecimento no filme Diário de uma busca. In: AGUILERA, Yanet (Org.). Imagem e exílio: cinema e arte na América Latina. São Paulo: Discurso Editorial, 2015. p. 211-225.

RÚA, Santiago Cueto. HIJOS de víctimas del terrorismo de Estado: justicia, identidad y memoria en el movimiento de derechos humanos en Argentina, 1995-2008. Historia crítica, Bogotá, n. 40, p. 122-145, enero-abr. 2010. Disponível em: <http://dx.doi.org/10.7440/histcrit40.2010.08>. Acesso em: 3 ago. 2016.

RUBY, Jay. The ethics of imagemaking; or "They're going to put me in the movies. They're going to make a big star out of me...". In: ROSENTHAL, Alan (Ed.). New challenges for documentary. Berkeley: University of California Press, 1988a. p. 308-318.

The image mirrored: reflexivity and the documentary film. In: ROSENTHAL, Alan (Ed.). New challenges for documentary. Berkeley: University of California Press, 1988b. p. 64-77.

RUFFINELLI, Jorge. De los otros al nosotros: familia fracturada, visión política y documental personal. In: SARTORA, Josefina; RIVAL, Silvina. Imágenes de lo real: la representación de lo político en el documental argentino. Buenos Aires: Libraria, 2007. p. 141-155.

. Documental político en América Latina: un largo y corto camino a casa (década de 1990 y comienzos del siglo XXI). In: TORREIRO, Casimiro; CERDÁN, Josetxo (Ed.). Documental y vanguardia. Madrid: Cátedra, 2005. p. 285-347.

. Uruguay 2008: the year of the political documentary. Latin American Perspectives, Issue 188, v. 40, n. 1, p. 60-72, Jan. 2013. Disponível em: <http://www.jstor.org/stable/41702333 > . Acesso em: 21 maio 2017.

RUSSO, Pablo. Entrevista a Flavia Castro, directora de Diario de una búsqueda. Tierra en trance, [2011]. Disponível em: 〈https://goo.gl/bhDn8p〉. Acesso em: 4 dez. 2017.

SALIBA, Elias Thomé. As imagens canônicas e a História. In: CAPELATO, Maria Helena et al. (Org.). História e cinema. São Paulo: Alameda, 2007. p. 85-96.

SARLO, Beatriz. Tempo passado: cultura da memória e guinada subjetiva. São Paulo: Companhia das Letras; Belo Horizonte: Editora UFMG, 2007.

SCHANTON, Pablo. Una propuesta sin golpes bajos. Clarín, Buenos Aires, 18 out. 2003. Revista Ñ, n. 32.

SCHELOTTO, Magdalena. La dictadura cívico-militar uruguaya (1973-1985): la construcción de la noción de víctima y la figura del exiliado en el Uruguay post-dictatorial. Nuevo Mundo Mundos Nuevos, marzo 2015. Disponível em: <http://nuevomundo.revues.org/67888>. Acesso em: 27 mar. 2017.

SCHWAB, Gabriele. Haunting legacies: violent histories and transgenerational trauma. New York: Columbia University Press, 2010. 
SEIGEL, Micol. Beyond compare: comparative method after the transnational turn. Radical History Review, issue 91, p. 62-90, Winter 2005. Disponível em: <https://doi.org/10.1215/01636545-2005-91-62>. Acesso em: 4 dez. 2017.

SELIPRANDY, Fernando. A luta armada no cinema: ficção, documentário, memória. São Paulo: Intermeios, 2015a.

. Imagens de Marighella: o cineasta militante, a diretora-sobrinha, o mesmo herói.

IdeAs: Idées d'Amérique, n. 7, Printemps/Été 2016. Disponível em: <http://ideas.revues.org/1578>. Acesso em: 9 nov. 2016.

. Los rubios e os limites da noção de pós-memória. Significação, São Paulo, v. 42, n. 44, p. 120-141, 2015b. Disponível em: <http://dx.doi.org/10.11606/issn.23167114.sig.2015.103652>. Acesso em: 27 set. 2017.

. O monumental e o íntimo: dimensões da memória da resistência no documentário brasileiro recente. Estudos Históricos, Rio de Janeiro, v. 26, n. 51, p. 55-72, jan.-jun. 2013. Disponível em: 〈http://bibliotecadigital.fgv.br/ojs/index.php/reh/article/view/7195>. Acesso em: 4 dez. 2017.

SERPENTE, Alejandra. Diasporic Chilean and Argentinian narratives in the UK: the traces of second generation postmemory. 2013. $343 \mathrm{f}$. Tese (Doutorado no Institute of the Americas) - School of Arts and Social Science, University College London, London, 2013. Disponível em: 〈https://goo.gl/EswJkc >. Acesso em: 4 dez. 2017.

The traces of "post-memory" in second-generation Chilean and Argentinean identities. In: LESSA, Francesca; DRULIOLLE, Vincent (org). The memory of State terrorism in the Southern Cone: Argentina, Chile, and Uruguay. New York: Palgrave Macmillan, 2011. p. 133-156.

SEYDEL, Ute. Espacios de rememoración transgeneracionales y transnacionales: los hijos de detenidos-desaparecidos en el cine documental mexicano e argentino. Alter/nativas, n. 5, p. 132, 2015. Disponível em: 〈https://goo.gl/pueYiU〉. Acesso em 4 dez. 2017.

SILVA. Denise Mota da. Vizinhos distantes: circulação cinematográfica no Cone Sul. São Paulo: Annablume; Fapesp, 2007.

SILVA, Helenice Rodrigues da. O exílio dos intelectuais brasileiros e chilenos, na França, durantes as ditaduras militares: uma história cruzada. Nuevo Mundo Mundos Nuevos, jun. 2007. Disponível em: 〈http://nuevomundo.revues.org/5791>. Acesso em: 8 abr. 2017.

SILVA, Mariana Duccini Junqueira da. Sujeitos em busca de si: a dimensão da primeira pessoa como construção documental. In: CONGRESSO INTERNACIONAL IBERCOM, 14., 2015, São Paulo. Anais... São Paulo: Ibercom, 2015. p. 5429-5439. Disponível em: <https://goo.gl/UlPGjX〉. Acesso em: 4 dez. 2017.

SILVA, Suéllen Rodrigues Ramos da; MOUSINHO, Luiz Antonio. Um olhar sobre Elena: a encenação que se desdobra. Doc On-line, n. 19, p. 5-21, mar. 2016. Disponível em: 〈http://www.doc.ubi.pt/19/dossier_1.pdf>. Acesso em: 31 maio 2017. 
SIRINELLI, Jean-François. A geração. In: AMADO, Janaína; FERREIRA, Marieta de Moraes (Org.). Usos e abusos da história oral. 2. ed. Rio de Janeiro: Editora FGV, 1998. p. 131-137.

SORLIN, Pierre. Sociología del cine: la apertura para la historia de mañana. Ciudad de México: Fondo de Cultura Económica, 1985.

SOUZA, Maria Luiza Rodrigues. Um estudo das narrativas cinematográficas sobre as ditaduras militares no Brasil (1964-1985) e na Argentina (1976-1983). 2007. 234 f. Tese (Doutorado em Ciências Sociais) - Centro de Pesquisa e Pós-Graduação sobre as Américas, Universidade de Brasília, Brasília, 2007. Disponível em: 〈https://goo.gl/DgC5cX〉. Acesso em: 4 dez. 2017.

SPIEGELMAN, Art. Maus: a história de um sobrevivente. São Paulo: Companhia das Letras, 2009.

STAM, Robert. Film theory: an introduction. Malden: Blackwell Publishing, 2007.

Reflexivity in film and literature: from Dom Quixote to Jean-Luc Godard. New York: Columbia University Press, 1992.

SULEIMAN, Susan Rubin. The 1.5 generation: thinking about child survivors and the Holocaust. American Imago, v. 59, n. 3, p. 277-295, 2002. Disponível em: <https://muse.jhu.edu/article/182>. Acesso em: 3 jun. 2018.

TANGE, Alison. Literary and visual representations of traumatic memory of the Pinochet dictatorship in Chile. 2013. 78 f. Dissertação (Mestrado em Espanhol) - Modern Languages and Literatures, Loyola University Chicago, Chicago, 2013. Disponível em: <http://ecommons.luc.edu/luc theses/1826>. Acesso em: 6 jun. 2017.

TAVARES, Denise. Nem perdão, nem esquecimento: o aparato repressivo no Equador e no Paraguai a partir de Con mi corazón en Yambo e Cuchillo de palo. In: ABREU, Nuno Cesar; SUPPIA, Alfredo; FREIRE, Marcius (Org.). Golpe de vista: cinema e ditadura militar na América do Sul. São Paulo: Alameda, 2018. p. 417-434.

TAVARES, Flávio. Memórias do esquecimento. São Paulo: Editora Globo, 1999.

TAYLOR, Diana. "You are here": the DNA of performance. The Drama Review, v. 46, n. 1 (T173), p. 149-169, Spring 2002. Disponível em: 〈https://goo.gl/uLc8Ch>. Acesso em: 4 dez. 2017.

TELES, Edson; SAFATLE, Vladimir (Org.). O que resta da ditadura: a exceção brasileira. São Paulo: Boitempo, 2010.

TELES, Janaína de Almeida. "Dói gostar dos outros". In: COMISSÃO DA VERDADE DO ESTADO DE SÃO PAULO "RUBENS PAIVA". Infância roubada: crianças atingidas pela ditadura militar no Brasil. São Paulo: Alesp, 2014. p. 261-266. Disponível em: <https://goo.gl/KHuJMz $>$. Acesso em: 4 dez. 2017. 
TELES, Janaína de Almeida. Os herdeiros da memória: a luta de familiares de mortos e desaparecidos políticos no Brasil. 2005. 294 f. Dissertação (Mestrado em História Social) Faculdade de Filosofia, Letras e Ciências Humanas, Universidade de São Paulo, São Paulo, 2005.

TERÁN, Oscar. Pensar la memoria. In: CONGRESO INTERNACIONAL DE FILOSOFÍA DE LA HISTORIA, 1., 2000, Buenos Aires. Anais... Buenos Aires: OEI, 2000. Não paginado. Disponível em: 〈https://goo.gl/89FwrP>. Acesso em: 4 dez. 2017.

TERRON, Joca Reiners; LAUB, Michel (Ed.). Elena: o livro do filme de Petra Costa. Porto Alegre: Arquipélago Editorial, 2014.

TOMAZZONI, Marco. Tragédia familiar inspira o documentário Diário de uma busca. Último segundo, 28 ago. 2011. Disponível em: 〈https://goo.gl/kVqgVn〉. Acesso em: 4 dez. 2017.

VALE, Glaura Cardoso. Mise-en-film da fotografia em três documentários brasileiros. Galáxia, n. 32, p. 93-105, ago. 2016. Disponível em: <http://dx.doi.org/10.1590/198225542016223097>. Acesso em: 7 set. 2017.

VALLE, Maria Ribeiro do. 1968: o diálogo é a violência - movimento estudantil e ditadura militar no Brasil. 2. ed. Campinas: Editora da Unicamp, 2008.

VANOYE, Francis. Le narcissique et l'autobiographique. In: ESQUENAZI, Jean-Pierre; GARDIES, André (Dir.). Le Je à l'écran. Paris: L'Harmattan, 2006. p. 105-120.

VEIGA, Roberta. Autobiografia "não autorizada": por uma experiência limiar no documentário na primeira pessoa. Doc On-line, n. 19, p. 42-59, mar. 2016a. Disponível em: 〈http://www.doc.ubi.pt/19/dossier_3.pdf > . Acesso em: 31 maio 2017.

Por uma política da rememoração: a potência histórica do cinema de experiência pessoal. Contracampo, Niterói, v. 35, n. 3, p. 187-210, dez. 2016b - mar. 2017. Disponível em: 〈http://www.contracampo.uff.br/index.php/revista/article/view/865 >. Acesso em: 15 out. 2017.

VENTURA, Zuenir. 1968: o ano que não terminou. 3. ed. São Paulo: Editora Planeta do Brasil, 2008.

VERZERO, Lorena. Estrategias para crear el mundo: la década del setenta en el cine documental de los dos mil. In: FELD, Claudia; MOR, Jessica Stites (Org). El pasado que miramos: memoria e imagen ante la historia reciente. Buenos Aires: Paidós, 2009. p. 181-217.

VEYNE, Paul. Como se escreve a história e Foucault revoluciona a história. 4. ed. Brasília: Editora da Universidade de Brasília, 1998.

VEZZETTI, Hugo. Activismos de la memoria: el "escrache". Punto de vista, n. 62, p. 1-7, 1998. Disponível em: 〈http://www.ahira.com.ar/revistas/pdv/61/pdv62.pdf >. Acesso em: 4 dez. 2017. 
VIOLI, Patrizia. Paesaggi della memoria: il trauma, lo spazio, la storia. Milano: Bompiani, 2014.

WAGNER, Valeria. Unhostly historical discourses in Ariel Dorfman's Heading South, looking North: a bilingual journey and Albertina Carri's The blonds. Discourse, v. 27, n. 2, p. 155-178, 2005. Disponível em: 〈https://muse.jhu.edu/article/213715>. Acesso em: 6 nov. 2017.

WEINSTEIN, Barbara. Pensando a história fora da nação: a historiografia da América Latina e o viés transnacional. Revista eletrônica da Anphlac, n. 14, p. 9-36, jan.-jun. 2013. Disponível em: 〈https://goo.gl/368Mgh>. Acesso em: 4 dez. 2017.

WERNER, Michael; ZIMMERMANN, Bénédicte. Penser l'histoire croisée: entre empirie et réflexivité. Annales: Histoire, Sciences Sociales, n. 1, ano 58, p. 7-36, janv.-févr. 2003. Disponível em: <https://goo.gl/Jcv4vh>. Acesso em: 4 dez. 2017.

WHITE, Hayden. Enredo e verdade na escrita da história. In: MALERBA, Jurandir (Org.). A história escrita: teoria e história da historiografia. São Paulo: Contexto, 2006. p. 191-210.

Historical emplotment and the problem of truth. In: FRIEDLÄNDER, Saul (Ed.). Probing the limits of representation: Nazism and the "Final Solution". Cambridge: Harvard University Press, 1992a. p. 37-53.

. Meta-história: a imaginação histórica do século XIX. São Paulo: Edusp, $1992 b$.

The content of the form: narrative discourse and historical representation. Baltimore: The Johns Hopkins University Press, 1987.

Trópicos do discurso: ensaios sobre a crítica da cultura. São Paulo: Edusp, 1994.

WILDE, Carolyn. Matter and meaning in the work of art: Joseph Kosuth's One and three chairs. In: GOLDIE, Peter; SCHELLEKENS, Elisabeth (Ed.). Philosophy and conceptual art. New York: Oxford University Press, 2007. p. 119-137.

WILLIAMS, Raymond. Base e superestrutura na teoria cultural marxista. Revista USP, São Paulo, n. 65, p. 210-224, mar.-maio 2005. Disponível em: <http://dx.doi.org/10.11606/issn.2316-9036.v0i66p209-224>. Acesso em: 18 jan. 2017.

WILSON, Kristi. The split-person narrative: resisting closure, resistant genre in Albertina Carri's Los rubios. Latin American perspectives, issue 188, v. 40, n. 1, p. 88-100, Jan. 2013. Disponível em: 〈http://www.jstor.org/stable/41702335〉. Acesso em: 8 nov. 2017.

WONG, Cindy Hing-Yuk. Film festivals: culture, people, and power on the global screen. New Brunswick: Rutgers University Press, 2011.

YOUNG, James. At memory's edge: after-images of the Holocaust in contemporary art and architecture. New Haven: Yale University Press, 2000. 
YOZELL, Erica Miller. Re-mapping the Argentine post-dictatorship narratives in Albertina Carri's Los rubios. Latin American Literary Review, v. 39, n. 77, p. 45-63, Jan.-Jun. 2011. Disponível em: 〈http://www.jstor.org/stable/41478075>. Acesso em: 15 nov. 2017.

ZAMBRA, Alejandro. Formas de voltar para casa. São Paulo: Cosac Naify, 2014. 


\section{FICHAS TÉCNICAS DOS FILMES DO CORPUS PRINCIPAL}

DIÁRIO de uma busca. Direção: Flavia Castro. Produção: Flavio Ramos Tambellini, Estelle Fialon e Flavia Castro. Roteiro: Flavia Castro. Som: Valéria Ferro. Fotografia: Paulo Castiglioni. Montagem: Flavia Castro e Jordana Berg. Brasil e França: Tambellini Filmes e Les Films du Poisson, 2010. 1 DVD (108 min), cor e P\&B.

LOS RUBIOS. Direção: Albertina Carri. Produção: Albertina Carri e Barry Ellsworth. Intérpretes: Analía Couceyro, Albertina Carri, Santiago Giralt, Jesica Suárez, Marcello Zanelli. Roteiro: Albertina Carri e Alan Pauls. Assistentes de direção: Marcelo Zanelli e Santiago Giralt. Música: Gonzalo Córdoba, Charly García e Ryuichi Sakamoto. Som: Jesica Suárez. Fotografia: Catalina Fernández. Montagem: Alejandra Almirón, Catalina Fernández e Carmen Torres. Argentina, 2003. 1 DVD (89 min), cor e P\&B.

MI vida con Carlos. Direção: Germán Berger-Hertz. Produção: Germán Berger-Hertz. Roteiro: Germán Berger-Hertz, Joaquim Jordá e Roberto Brodsky. Música: Miguel Miranda e José Miguel Tobar. Som: Boris Herrera, Andrés Carrasco, Amanda Villavieja e Freddy González. Fotografia: Miguel Ioan Littin. Montagem: Andrea Chignoli e Danielle Fillios. Chile e Espanha: Todo por las niñas e Cinedirecto Producciones, 2009. (83 min), cor, 35mm.

OS DIAS com ele. Direção: Maria Clara Escobar. Produção executiva: Paula Pripas. Com: Carlos Henrique de Escobar, Ana Sacchetti Escobar, Emílio Sacchetti e Maria Clara Escobar. Edição: Julia Murat e Juliana Rojas. Edição de som e mixagem: Ricardo Cutz. São Paulo: Filmes de Abril, 2013. (107 min.), cor, digital. 


\section{LISTA DOS FILMES DO CORPUS EXPANDIDO}

(por país, seguindo cronologia de produção)

\section{Argentina:}

Los Argenmex 20 años después: la historia ésta (Jorge Denti, México, 1996, 56 min);

Pasaportes (Inés Ulanovsky, Argentina, 1997, 17 min);

Hasta la memoria, siempre (Rodrigo Vázquez, Argentina, 1997, 26 min);

H.I.J.O.S. de la historia (Roberto Leonardo, Argentina, 1998, 12 min);

Papá Iván (María Inés Roqué, México / Argentina, 2000, 55 min);

En memoria de los pájaros (Gabriela Golder, França / Argentina, 2000, 17 min);

(h) Historias cotidianas (Andrés Habegger, Argentina, 2000, 80 min);

Panzas (Laura Bondarevsky, Argentina, 2000, 45 min);

H.I.J.O.S. (Francisco Zinzer, Argentina, 2000, $10 \mathrm{~min}$ );

Generación golpe (Fabián Agosta e Lisandro Costa, Argentina, 2001, 47 min);

Che vo cachai (Laura Bondarevsky, Argentina, 2002, 76 min);

H.I.J.O.S.: El alma en dos (Carmen Guarini e Marcelo Céspedes, Argentina, 2002, 80 min);

Organizaciones horizontales (Fausta Quattrini, Argentina, 2002, 70 min);

El tiempo y la sangre (Alejandra Almirón, Argentina, 2004, 65 min);

Encontrando a Víctor (Natalia Bruschtein, México / Argentina, 2004, 30 min);

Nietos (identidad y memoria) (Benjamín Ávila, Argentina, 2004, 75 min);

Hermanos de sangre (Fabián Vittola, Argentina, 2005, 50 min);

Diario argentino (Lupe Pérez García, Argentina / Espanha, 2006, 79 min);

Nacimos en su lucha, viven en la nuestra: 10 años de H.I.J.O.S. La Plata (Camilo Cagni, Pablo Balut, Pablo Roesler e Juan Aíub, Argentina, 2006, 48 min);

Mansión Seré (Jorge Bianchini, Argentina, 2006, 80 min);

Semillas de utopía (Rodolfo Colombara e Emanuela Peyretti, Itália, 2006, 95 min); 
Argenmex: exiliados hijos (Violeta Burkart Noë e Analía Miller, Argentina, 2007, 56 min);

¿Quién soy yo? Los niños encontrados de Argentina (Estela Bravo, Argentina / EUA / Reino Unido, 2007, $75 \mathrm{~min}$ );

$M$ (Nicolás Prividera, Argentina, 2007, 150 min);

Victoria (Adrián Jaime, Argentina, 2008, 85 min);

Tiempo suspendido (Natalia Bruschtein, México / Argentina, 2015, 68 min);

La parte por el todo (Roberto Persano, Santiago Nacif Cabrera e Andrés Martínez Cantó, Argentina, 2015, $72 \mathrm{~min}$ );

70 y Pico (Mariano Corbacho, Argentina, 2016, 103 min);

La guardería (Virginia Croatto, Argentina, 2016, 100 min);

Retour: volver (Martin Bourgault, Canadá / Argentina, 2016, 61 min);

El padre (Mariana Arruti, Argentina, 2016, $71 \mathrm{~min}$ );

El (im)posible olvido (Andrés Habegger, Argentina / Brasil / México, 2016, 86 min);

Cuatreros (Albertina Carri, Argentina, 2016, 85 min).

\section{Chile:}

En algún lugar del cielo (Alejandra Carmona, Chile, 2003, 60 min);

Reinalda del Carmen, mi mamá y yo (Lorena Giachino Torréns, Chile, 2006, 85 min);

El telón de azúcar (Camila Guzmán Urzúa, França / Cuba / Espanha, 2006, 80 min);

Héroes frágiles (Emilio Pacull, Chile / França, 2007, 85 min);

La promesa de mi madre (Marianne Hougen-Moraga, Dinamarca / Chile / Reino Unido, 2007, $36 \mathrm{~min})$;

La quemadura (René Ballesteros, Chile / França, 2009, 65 min);

El memorial (Andrés Brignardello Valdivia, Chile, 2009, 63 min);

El edificio de los chilenos (Macarena Aguiló e Susana Foxley, Chile / Cuba / França / Bélgica, 2010, 99 min);

El eco de las canciones (Antonia Rossi, Chile, 2010, 71 min);

Abuelos (Carla Valencia Dávila, Equador / Chile, 2010, 93 min); 
Allende mi abuelo Allende (Marcia Tambutti, Chile / México, 2015, 90 min);

Venían a buscarme (Álvaro de la Barra, Chile, 2016, 82 min);

Guerrero (Sebastián Moreno, Chile, 2017, 65 min);

El color del camaleón (Andrés Lübbert, Chile / Bélgica, 2017, 87 min);

Mute (Claudia Aguilera, Chile, 2017, 62 min);

El pacto de Adriana (Lissette Orozco, Chile, 2017, 96 min).

\section{Brasil:}

15 filhos (Maria Oliveira e Marta Nehring, Brasil, 1996, 19 min);

Marighella (Isa Grinspum Ferraz, Brasil, 2011, 100 min);

Repare bem (Maria de Medeiros, Brasil / Portugal / Espanha, 2012, 95 min);

Em busca de Iara (Flavio Frederico, Brasil, 2013, 92 min);

Orestes (Rodrigo Siqueira, Brasil, 2015, 93 min);

Elena (Petra Costa, Brasil, 2012, 82 min).

\section{Uruguai:}

Los huérfanos del Cóndor (Emilio Pacull, França / Uruguai, 2003, 56 min);

HIJOS Uruguay (Lucas Silva e Víctor Burgos Barreiro, Uruguai, 2006, 16 min);

Secretos de lucha (Maiana Bidegain, Uruguai / França, 2007, 85 min);

D.F. (destino final) (Mateo Gutiérrez, Uruguai, 2008, $110 \mathrm{~min}$ );

A contrarreloj (Pablo Sobrino, Uruguai, 2011, $5 \mathrm{~min}$ );

Tus padres volverán (Pablo Martínez Pessi, Uruguai, 2015, 80 min);

Todos somos hijos (Esteban Barja e Carlos Conti, Uruguai, 2015, 70 min).

\section{Paraguai:}

Cuchillo de palo (Renate Costa, Paraguai / Espanha, 2010, 93 min). 
APÊNDICE A - PRÊMIOS E CIRCULAÇõeS dos títulos do CORPUS NOS FESTIVAIS de CINEMA POR PAÍS (1996-2017)

\begin{tabular}{|c|c|c|c|}
\hline País & Festival & Prêmios ${ }^{1}$ & Circulações (sem prêmios) \\
\hline \multicolumn{4}{|c|}{ América Latina } \\
\hline \multirow{3}{*}{ Argentina } & $\begin{array}{l}\text { Buenos Aires Festival Internacional de Cine Independiente } \\
\text { (Bafici) }\end{array}$ & $\begin{array}{l}\text { Los rubios: prêmios do público de melhor filme; } \\
\text { melhor filme argentino; menções especiais do júri } \\
\text { oficial e do júri Signis (2003). } \\
\text { El telón de azúcar: prêmio da Federação } \\
\text { Internacional de Críticos de Cinema (Fipresci) } \\
\text { (2007). } \\
\text { Cuchillo de palo: prêmio na competição de direitos } \\
\text { humanos (2010). } \\
\text { El pacto de Adriana: menção especial na } \\
\text { competição de direitos humanos (2017). }\end{array}$ & $\begin{array}{l}\text { H.I.J.O.S.: El alma en dos (2002); Che vo } \\
\text { cachai (2003); Organizaciones } \\
\text { horizontales (2003). El tiempo y la sangre } \\
\text { (2004); M (2007); Victoria (2008); Los } \\
\text { rubios (2009); La quemadura (2010); El } \\
\text { eco de las canciones (2010); Abuelos } \\
\text { (2011); Diário de uma busca (2011); M } \\
\text { (2013); Elena (2013). }\end{array}$ \\
\hline & Festival Internacional de Cine de Mar del Plata & $\begin{array}{l}\text { M: prêmios de melhor filme e Fipresci (2007). } \\
\text { Tiempo suspendido: menção especial no quadro do } \\
\text { prêmio Tato Miller do Sindicado de la Industrias } \\
\text { Cinematográfica Argentina (Sica-Apma) (2015). } \\
\text { Allende mi abuelo Allende: segundo prêmio da } \\
\text { Reunión Especializada de Autoridades } \\
\text { Cinematográficas y Audiovisuales del Mercosur } \\
\text { (Recam) (2015). }\end{array}$ & $\begin{array}{l}\text { Hasta la memoria, siempre (1997); (h) } \\
\text { Historias cotidianas (2001); Reinalda del } \\
\text { Carmen, mi mamá y yo (2007); Tiempo } \\
\text { suspendido (2015); La guardería (2015); } \\
\text { Cuatreros (2016). }\end{array}$ \\
\hline & Festival Internacional de Cine Político (FICiP) & $\begin{array}{l}\text { Repare bem: melhor filme de longa-metragem } \\
\text { (2014). } \\
\text { La guardería: primeiro prêmio na competição }\end{array}$ & $\begin{array}{l}\text { Tiempo suspendido (2016); } 70 \text { y Pico } \\
\text { (2016); El padre (2016). }\end{array}$ \\
\hline
\end{tabular}

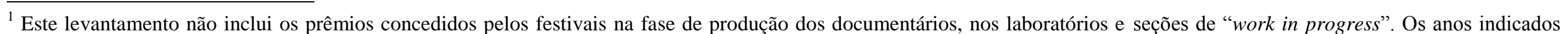
dizem respeito à edição do festival em que os títulos foram premiados ou exibidos. 


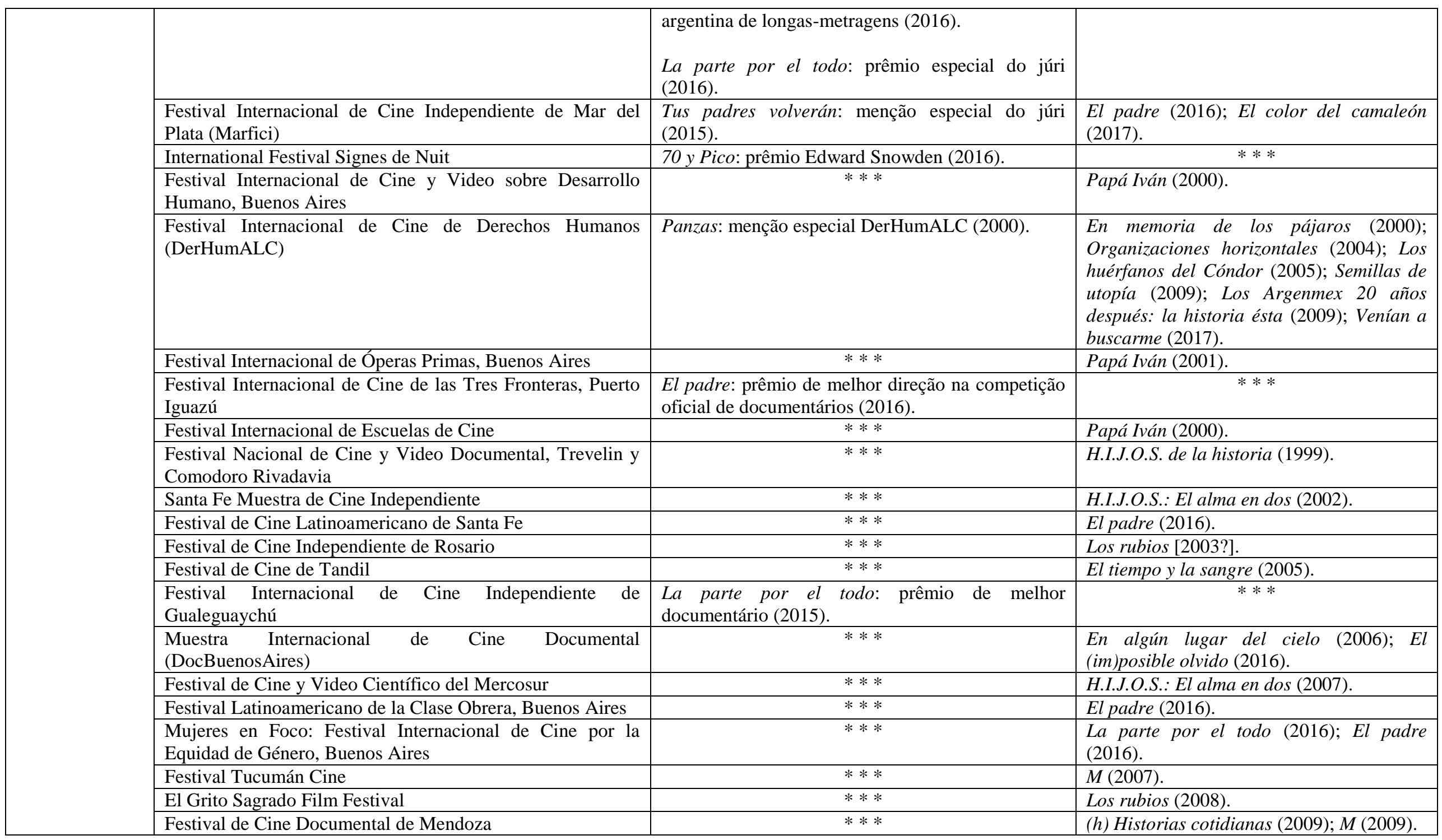




\begin{tabular}{|c|c|c|c|}
\hline & Festival de Cine Latinoamericano de La Plata & $* * *$ & La parte por el todo (2015). \\
\hline & $\begin{array}{l}\text { Festival Internacional de Cine Documental de Argentina } \\
\text { (FIDBA) }\end{array}$ & $* * *$ & $\begin{array}{l}\text { El padre (2016); El color del camaleón } \\
\text { (2017). }\end{array}$ \\
\hline & Festival de Cine Latinoamericano de Rosario & $* * *$ & $\begin{array}{l}\text { Tiempo suspendido (2016); Allende mi } \\
\text { abuelo Allende (2016). }\end{array}$ \\
\hline & REC, Festival de Cine de Universidades Públicas, La Plata & $* * *$ & 70 y Pico (2016). \\
\hline & Festival Latinoamericano de Video de Rosario & Generación golpe: menção especial (2001). & Pasaportes (2000); Victoria (2008). \\
\hline & Festival de Cine del Conurbano en Banfield & $* * *$ & Victoria (2010). \\
\hline & Santiago del Estero Film Festival (SEFF) & $* * *$ & 70 y Pico (2017). \\
\hline & Festival Internacional Tres Continentes del Documental & $* * *$ & Generación golpe (2002). \\
\hline & Festival de Cine Nacional & $\begin{array}{l}\text { Nietos (identidade y memoria): prêmio do público } \\
\text { (2004). }\end{array}$ & $* * *$ \\
\hline & Certamen de Cine y Video de Santa Fe & Generación golpe: primeiro prêmio (2001). & $* * *$ \\
\hline & Muestra de Cine Latinoamericano en Bolivia & $* * *$ & D.F. (destino final) (2014). \\
\hline Bolívia & $\begin{array}{l}\text { Festival Internacional de Cine de los Derechos Humanos } \\
\text { "Bolivia, el séptimo ojo es tuyo" (FESTIMO) }\end{array}$ & $* * *$ & $\begin{array}{l}\text { Victoria (2009); El color del camaleón } \\
(2017) .\end{array}$ \\
\hline & Rio Cine & 15 filhos: Sol de Ouro (1996). & $* * *$ \\
\hline & Festival do Ceará & $\begin{array}{l}15 \text { filhos: prêmio de melhor documentário, [1996 } \\
\text { ou 1997]. }\end{array}$ & $* * *$ \\
\hline & Festival de Curitiba & $\begin{array}{l}15 \text { filhos: prêmio de melhor documentário, [1996 } \\
\text { ou 1997]. }\end{array}$ & $* * *$ \\
\hline Brasil & Festival de Cinema de Gramado & $\begin{array}{l}\text { Mi vida con Carlos: prêmios de melhor longa- } \\
\text { metragem estrangeiro, de melhor fotografia e } \\
\text { prêmio do público de melhor filme (2010). } \\
\text { Diário de uma busca: prêmios da crítica e do júri } \\
\text { de estudantes de cinema (2010). } \\
\text { Repare bem: prêmio de melhor longa-metragem } \\
\text { estrangeiro (2013). }\end{array}$ & $* * *$ \\
\hline & Festival do Rio & $\begin{array}{l}\text { Diário de uma busca: prêmios de melhor longa- } \\
\text { metragem documental e Fipresci (2010). }\end{array}$ & $\begin{array}{l}\text { Marighella (2011); Em busca de Iara } \\
\text { (2013). }\end{array}$ \\
\hline & $\begin{array}{l}\text { Festival do Filme Documentário e Etnográfico de Belo } \\
\text { Horizonte (forumdoc.bh) }\end{array}$ & $\begin{array}{l}\text { Diário de uma busca: prêmio de melhor longa- } \\
\text { metragem na competição nacional (2011). }\end{array}$ & $\begin{array}{l}\text { Marighella (2012); Os dias com ele } \\
\text { (2013); Orestes (2015); Cuatreros (2017). }\end{array}$ \\
\hline & Festival de Brasília do Cinema Brasileiro & $\begin{array}{l}\text { Elena: prêmios de direção, montagem, direção de } \\
\text { arte (categoria documentário) e melhor }\end{array}$ & $* * *$ \\
\hline
\end{tabular}




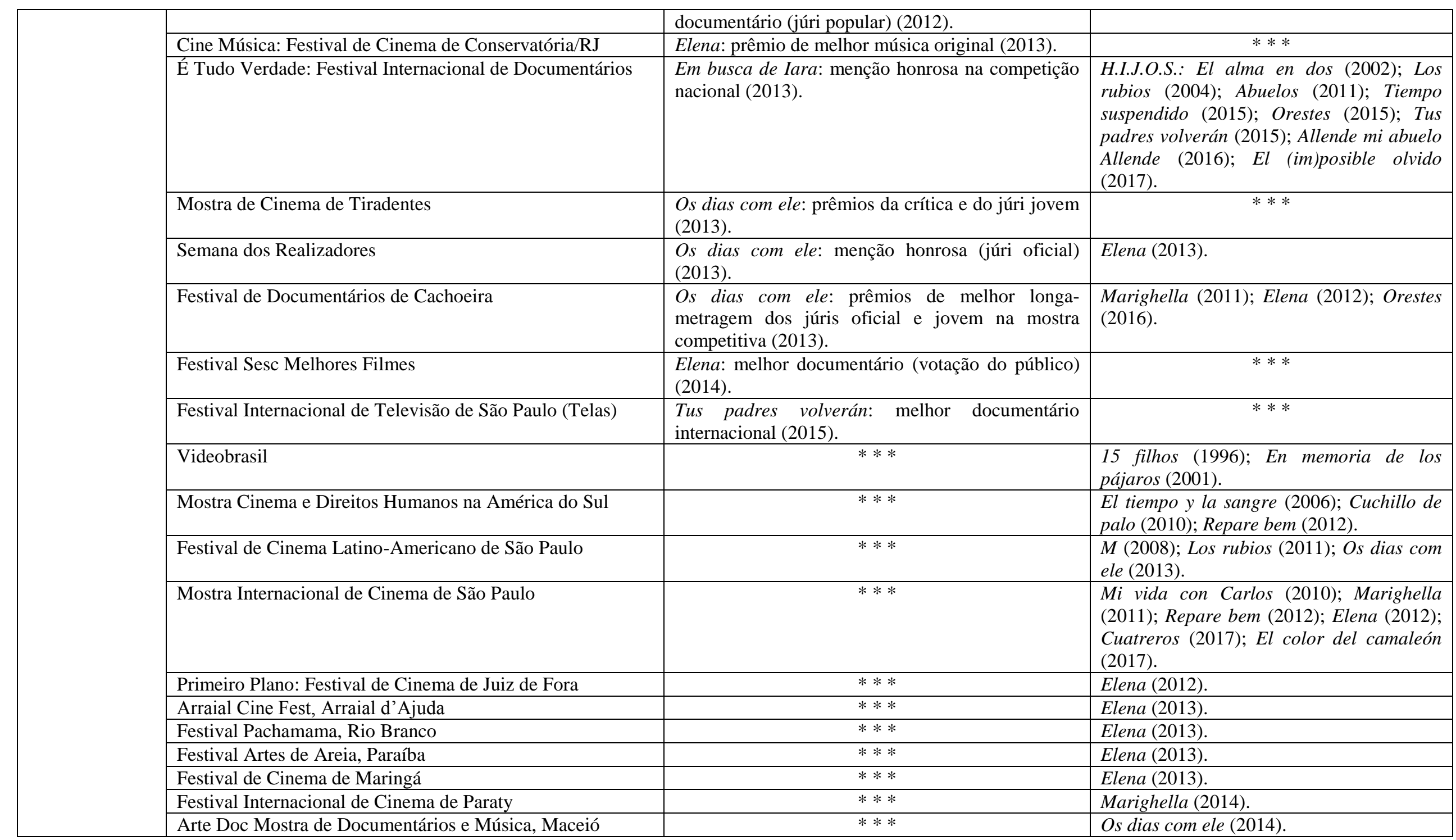




\begin{tabular}{|c|c|c|c|}
\hline & Festival Ibero-americano de Cinema e Vídeo (Cinesul) & $\begin{array}{l}\text { ¿Quién soy yo? Los niños encontrados de } \\
\text { Argentina: prêmio do público de melhor longa- } \\
\text { metragem documental (2008). }\end{array}$ & $* * *$ \\
\hline & Festival de Inverno Ouro Preto e Mariana & $* * *$ & Elena (2013). \\
\hline \multirow{6}{*}{ Chile } & Festival Internacional de Documentales de Santiago (Fidocs) & $\begin{array}{l}\text { En algún lugar del cielo: Grande Prêmio (2003). } \\
\text { El edificio de los chilenos: Grande Prêmio da } \\
\text { competição nacional (2010). }\end{array}$ & $\begin{array}{l}\text { Los huérfanos del Cóndor (2004); } \\
\text { Reinalda del Carmen, mi mamá y yo } \\
\text { (2006); M (2007); La promesa de mi madre } \\
\text { (2007); Mi vida con Carlos (2010); El eco } \\
\text { de las canciones (2010); Diário de uma } \\
\text { busca (2011); Abuelos (2015); Guerrero } \\
\text { (2017); El color del camaleón (2017); } \\
\text { Mute (2017). }\end{array}$ \\
\hline & Festival Internacional de Cine de Santiago (Sanfic) & $\begin{array}{l}\text { El telón de azúcar: prêmios de melhor diretor e } \\
\text { Signis na competição internacional (2007). } \\
\text { M: menção especial da academia, Universidad de } \\
\text { Artes, Ciencias y Comunicación (Uniacc) (2007). } \\
\text { La quemadura: prêmio de melhor diretor na } \\
\text { competição de cinema chileno (2010). } \\
\text { Allende mi abuelo Allende: prêmio do público } \\
\text { (2015). } \\
\text { El color del camaleón: prêmios de melhor direção } \\
\text { na competição de cinema chileno; prêmio do } \\
\text { público de melhor filme (2017). }\end{array}$ & $\begin{array}{l}\text { Reinalda del Carmen, mi mamá y yo } \\
\text { (2007); Tiempo suspendido (2015). }\end{array}$ \\
\hline & Festival de Cine//B & La quemadura: prêmio especial do júri (2010). & Abuelos (2010). \\
\hline & ChileReality Festival de Cine Documental de Chillán & $\begin{array}{l}\text { Héroes frágiles: prêmio de melhor documentário } \\
(2008) \text {. } \\
\text { El edificio de los chilenos: prêmio de melhor } \\
\text { documentário (2010). }\end{array}$ & **** \\
\hline & Festival de Documentales de La Pintana (Pintacanes) & $\begin{array}{l}\text { El edificio de los chilenos: prêmio de melhor } \\
\text { documentário (2010). }\end{array}$ & $* * *$ \\
\hline & Festival Internacional de Cine del Norte de Chile (Ficnor) & Mi vida con Carlos: prêmio de melhor filme & $* * *$ \\
\hline
\end{tabular}




\begin{tabular}{|c|c|c|c|}
\hline & & $(2011)$. & \\
\hline & $\begin{array}{l}\text { Festival de Cine Social y de Derechos Humanos de } \\
\text { Valparaíso }\end{array}$ & $\begin{array}{l}\text { El memorial: prêmio Memória e Ditadura (2009). } \\
\text { El edificio de los chilenos: prêmio Memória e } \\
\text { Ditadura (2011). }\end{array}$ & $* * *$ \\
\hline & Festival de Cine Documental de Chiloé & $\begin{array}{l}\text { El eco de las canciones: prêmio especial do júri } \\
\text { (2011). }\end{array}$ & $\begin{array}{l}\begin{array}{l}\text { Reinalda del Carmen, mi mamá y yo } \\
\text { (2007). }\end{array} \\
\end{array}$ \\
\hline & Bienal de Video de Santiago & $* * *$ & 15 filhos (1997). \\
\hline & Festival Internacional de Cine de Viña del Mar (FICViña) & $* * *$ & $\begin{array}{l}\text { Los rubios (2005); En algún lugar del cielo } \\
(2005) ; \text { El memorial }(2010) ; \text { Los rubios } \\
(2011) ; \text { Los rubios } \quad(2012) ; \text { Guerrero } \\
\text { (2017). }\end{array}$ \\
\hline & Festival Internacional de Cine de Valparaíso & $* * *$ & Em algún lugar del cielo (2004). \\
\hline & Festival Internacional de Cine de Valdivia (FICVALDIVIA) & $* * *$ & $\begin{array}{l}\text { Reinalda del Carmen, mi mamá y yo } \\
\text { (2007); Mi vida con Carlos (2010); La } \\
\text { quemadura (2010); El eco de las canciones } \\
\text { (2010); Venían a buscarme (2016). }\end{array}$ \\
\hline & Festival Iberoamericano de Cine de Atacama & $* * *$ & $\begin{array}{l}\text { Reinalda del Carmen, mi mamá y yo } \\
(2007) .\end{array}$ \\
\hline & Festival de Cine de Derechos Humanos Cine Forum & $* * *$ & (h) Historias cotidianas (2009). \\
\hline & Festival de Cine de La Serena (Fecils) & $* * *$ & Mute (2017). \\
\hline & Festival de Cine Documental de Puerto Varas (Surdocs) & $* * *$ & Tiempo suspendido (2015). \\
\hline \multirow{7}{*}{ Colômbia } & Festival Franco-Latinoamericano, Bogotá & 15 filhos: menção honrosa (1996). & $* * *$ \\
\hline & Festival Internacional de Cine de Cartagena de Indias & $\begin{array}{l}\text { El edificio de los chilenos: prêmio especial na } \\
\text { competição de documentários (2011). }\end{array}$ & $* * *$ \\
\hline & Muestra Internacional Documental de Bogotá (MIDBO) & $* * *$ & $\begin{array}{l}\text { Papá Iván (2001); D.F. (destino final) } \\
\text { (2009). }\end{array}$ \\
\hline & Muestra Cine Documental, Santiago de Calli & $* * *$ & El tiempo y la sangre (2006). \\
\hline & Festival de Cine de Bogotá & $* * *$ & Secretos de lucha (2007). \\
\hline & Bogotá International Film Festival (BIFF) & $* * *$ & Cuatreros (2017). \\
\hline & Festival Equinoxio & $* * *$ & Tiempo suspendido (2016). \\
\hline Costa Rica & Costa Rica International Film Festival & $* * *$ & Tiempo suspendido (2015). \\
\hline Cuba & $\begin{array}{l}\text { Festival Internacional del Nuevo Cine Latinoamericano, } \\
\text { Havana }\end{array}$ & $\begin{array}{l}\text { Papá Iván: Primeiro Prêmio Coral na categoria } \\
\text { documentário (2000). } \\
\text { H.I.J.O.S.: El alma en dos: menção especial na }\end{array}$ & $\begin{array}{l}\text { (h) Historias cotidianas (2000); Los rubios } \\
\text { (2003); Che vo cachai (2004); En algún } \\
\text { lugar del cielo (2004); Repare bem (2013); } \\
\text { Orestes (2015); El (im)posible olvido }\end{array}$ \\
\hline
\end{tabular}




\begin{tabular}{|c|c|c|c|}
\hline & & $\begin{array}{l}\text { categoria documentário (2002). } \\
\text { Nietos (identidade y memoria): Terceiro Prêmio } \\
\text { Coral na categoria documentário (ex aequo) (2004). } \\
\text { El telón de azúcar: Primeiro Prêmio Coral na } \\
\text { categoria documentário (2007). } \\
\text { ¿Quién soy yo? Los niños encontrados de } \\
\text { Argentina: Prêmio Coral de documentário de um } \\
\text { realizador não latino-americano sobre a América } \\
\text { Latina, prêmio Documentário Memória, prêmio do } \\
\text { Cibervoto ao documentário e prêmio do Canal } \\
\text { Telesur (2007). } \\
\text { El edificio de los chilenos: Segundo Prêmio Coral } \\
\text { na categoria documentário (2010). } \\
\text { Cuchillo de palo: menção especial na categoria } \\
\text { documentário (2010). } \\
\text { Abuelos: prêmio Documentário Memória (2011). } \\
\text { Diário de uma busca: prêmio especial do júri na } \\
\text { categoria documentário (2011). } \\
\text { Elena: Primeiro Prêmio Coral na categoria } \\
\text { documentário (2013). } \\
\text { Os dias com ele: menção no prêmio Documentário } \\
\text { Memória (2013). } \\
\text { Tiempo suspendido: prêmio da Federación de } \\
\text { Escuelas de la Imagen y el Sonido de América } \\
\text { Latina (Feisal) (2015). }\end{array}$ & $\begin{array}{l}\text { (2016); La parte por el todo (2016); } \\
\text { Cuatreros (2017). }\end{array}$ \\
\hline
\end{tabular}




\begin{tabular}{|c|c|c|c|}
\hline & & $\begin{array}{l}\text { El color del camaleón: prêmio Documentário } \\
\text { Memória (2017). }\end{array}$ & \\
\hline & $\begin{array}{l}\text { Festival Internacional de Documentales "Santiago Álvarez } \\
\text { In Memoriam" }\end{array}$ & $\begin{array}{l}\text { La parte por el todo: Grande Prêmio Santiago } \\
\text { Álvarez (2017). }\end{array}$ & El tiempo y la sangre (2005). \\
\hline \multirow[t]{3}{*}{ Equador } & $\begin{array}{l}\text { Encuentros del Otro Cine: Festival Internacional de Cine } \\
\text { Documental (EDOC), Quito }\end{array}$ & Abuelos: prêmio do público (2010). & $\begin{array}{l}\text { Os dias com ele (2013); Tus padres } \\
\text { volverán (2016); La guardería (2016); El } \\
\text { padre (2016). }\end{array}$ \\
\hline & Festival de Cine Cero Latitud, Quito & $* * *$ & Los rubios [2003 ou 2004]. \\
\hline & Festival Internacional de Cine de Guayaquil & $* * *$ & La parte por el todo (2016). \\
\hline Guatemala & Festival Internacional Memoria, Verdad, Justicia & $* * *$ & Tus padres volverán (2015). \\
\hline \multirow{5}{*}{ México } & $\begin{array}{l}\text { Encuentro Hispanoamericano de Cine y Video Documental } \\
\text { Independiente (Contra el Silencio, Todas las Voces) }\end{array}$ & $\begin{array}{l}\text { Papá Iván: menção honrosa (2000). } \\
\text { Che vo cachai: menção honrosa (2004). }\end{array}$ & $\begin{array}{l}\text { Generación golpe (2002); La parte por el } \\
\text { todo (2016). }\end{array}$ \\
\hline & Muestra Internacional de Cortometraje Monterrey & Papá Iván: menção especial (2001). & $* * *$ \\
\hline & Festival Expresión en Corto, Guanajuato & Papá Iván: melhor documentário (2001). & $* * *$ \\
\hline & Festival Internacional de Cine en Guadalajara (FICG) & $\begin{array}{l}\text { Cuchillo de palo: menção especial do júri na } \\
\text { categoria documentário ibero-americano (2010). } \\
\text { Elena: menção especial do júri na categoria } \\
\text { documentário ibero-americano (2013). } \\
\text { Tiempo suspendido: prêmio especial do júri na } \\
\text { categoria documentário ibero-americano, prêmio } \\
\text { Fipresci e menção especial no prêmio Mezcal } \\
(2015) \text {. } \\
\text { El pacto de Adriana: prêmio especial do júri na } \\
\text { categoria documentário ibero-americano (2017). }\end{array}$ & $\begin{array}{l}\text { El telón de azúcar (2007); Los rubios } \\
\text { (2008); Allende mi abuelo Allende (2015); } \\
\text { El color del camaleón (2017). }\end{array}$ \\
\hline & $\begin{array}{l}\text { Festival de la Memoria: Documental Iberoamericano } \\
\text { (Cuernavaca) }\end{array}$ & $\begin{array}{l}\text { El edificio de los chilenos: prêmio Luciana Cabarga } \\
\text { ao melhor documentário realizado por uma mulher, } \\
\text { menção honrosa no prêmio Signis (2011). } \\
\text { Tiempo suspendido: prêmio do público (2015). } \\
\text { La guardería: menção honrosa na seção memória } \\
\text { (2016). }\end{array}$ & La parte por el todo (2016). \\
\hline
\end{tabular}




\begin{tabular}{|c|c|c|c|}
\hline & Festival Internacional de Cine Guanajuato (GIFF) & $\begin{array}{l}\text { Tiempo suspendido: menção especial na categoria } \\
\text { documentário mexicano (2015). }\end{array}$ & $* * *$ \\
\hline & 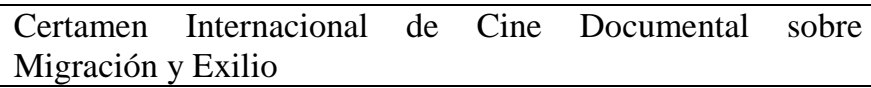 & Tiempo suspendido: menção honrosa (2015). & $* * *$ \\
\hline & $\begin{array}{l}\text { Festival Cinetekton: Festival Internacional de Cine y } \\
\text { Arquitectura de la Ciudad de Puebla }\end{array}$ & $\begin{array}{l}70 \text { y Pico: menção do júri na categoria } \\
\text { documentário de longa-metragem (2016). }\end{array}$ & $* * *$ \\
\hline & $\begin{array}{l}\text { Festival Internacional de Cine en la Ciudad de México } \\
\text { (FICCMÉXICO) }\end{array}$ & $* * *$ & Papá Iván (2000). \\
\hline & Muestra Internacional de Mujeres en el Cine y Televisión & $* * *$ & Encontrando a Víctor (2006). \\
\hline & $\begin{array}{l}\text { Festival Internacional de Cine Documental de la Ciudad de } \\
\text { México (DOCSDF) }\end{array}$ & $* * *$ & D.F. (destino final) (2012); Elena (2013). \\
\hline & Festival Internacional de Cine de Morelia & $* * *$ & $\begin{array}{l}\text { Repare bem (2013); Allende mi abuelo } \\
\text { Allende (2015). }\end{array}$ \\
\hline & Semana de Cine Mexicano en San Luis Potosí & $* * *$ & Tiempo suspendido (2015). \\
\hline & Festival de Cine Universitario de Puebla (Unifilmfest) & $* * *$ & Tiempo suspendido (2015). \\
\hline & $\begin{array}{l}\text { Muestra Internacional de Cine con Perspectiva de Género } \\
\text { (MIC Género) }\end{array}$ & $* * *$ & Tiempo suspendido (2015). \\
\hline & Documenta QRO, Querétaro & $* * *$ & Tiempo suspendido (2015). \\
\hline & Oaxaca Film Fest & $* * *$ & Tiempo suspendido (2015). \\
\hline & Tulancingo Cinefestival, Hidalgo & $* * *$ & Tiempo suspendido (2015). \\
\hline & Festival Pantalla de Cristal & $* * *$ & Tiempo suspendido (2015). \\
\hline & Festival de Cine Documental Mexicano Zanate, Colima & $* * *$ & Tiempo suspendido (2015). \\
\hline & Festival Internacional de Cine del Desierto & $* * *$ & Tiempo suspendido (2016). \\
\hline & Cineseptiembre & $* * *$ & Tiempo suspendido (2016). \\
\hline & Festival Internacional de Cine de Mérida y Yucatán & $* * *$ & Tus padres volverán (2016). \\
\hline & Festival Pre-INPUT & $* * *$ & Papá Iván (2001). \\
\hline Panama & Festival Internacional de Cine de Panamá & $* * *$ & Elena (2013). \\
\hline Peru & $\begin{array}{l}\text { Festival de Cine de Lima: Encuentro Latinoamericano de } \\
\text { Cine }\end{array}$ & $\begin{array}{l}\text { El telón de azúcar: segundo prêmio do júri na } \\
\text { categoria documentário (2007). }\end{array}$ & $\begin{array}{l}\text { Victoria (2008); Mi vida con Carlos } \\
\text { (2010); Cuchillo de palo (2010); Elena } \\
\text { (2013); Allende mi abuelo Allende (2015); } \\
\text { Tus padres volverán (2015); El color del } \\
\text { camaleón (2017). }\end{array}$ \\
\hline & Festival Iberoamericano de Cine Digital de Lima & Abuelos: melhor filme (2012). & $* * *$ \\
\hline & Festival Internacional de Video/Arte/Electrónica, Lima & $* * *$ & Em memoria de los pájaros (2001). \\
\hline & Transcinema: Festival Internacional de No-Ficción & $* * *$ & Cuatreros (2017). \\
\hline
\end{tabular}




\begin{tabular}{|c|c|c|c|}
\hline \multirow{2}{*}{$\begin{array}{l}\text { República } \\
\text { Dominicana }\end{array}$} & $\begin{array}{l}\text { Festival Internacional de Cine Documental de República } \\
\text { Dominicana y el Caribe (RDOC) }\end{array}$ & $\begin{array}{l}\text { Tus padres volverán: prêmio de melhor } \\
\text { documentário latino-americano (2016). }\end{array}$ & $* * *$ \\
\hline & Dominican Global Film Festival & $* * *$ & Tiempo suspendido (2015). \\
\hline \multirow{12}{*}{ Uruguai } & Festival Cinematográfico Internacional del Uruguay & $\begin{array}{l}\text { Papá Iván: menção na categoria documentário de } \\
\text { média-metragem (2001). } \\
\text { La guardería: prêmio de melhor filme na } \\
\text { competição de cinema de direitos humanos (2016). } \\
\text { El pacto de Adriana: prêmio de melhor filme na } \\
\text { competição de cinema de direitos humanos (2017). } \\
\text { Cuatreros: menção especial na competição de } \\
\text { longas-metragens ibero-americanos (2017). }\end{array}$ & $\begin{array}{l}\text { Che vo cachai (2003); El tiempo y la } \\
\text { sangre (2005); Secretos de lucha (2008); } \\
\text { Elena (2013); Os dias com ele (2014); Tus } \\
\text { padres volverán (2015); Tiempo } \\
\text { suspendido (2016); La parte por el todo } \\
\text { (2016). }\end{array}$ \\
\hline & Festival Internacional de Cine de Punta del Este & $\begin{array}{l}\text { Diário de uma busca: prêmio da crítica de melhor } \\
\text { filme (2011). }\end{array}$ & $\begin{array}{l}\text { D.F. (destino final) (2009); Mi vida con } \\
\text { Carlos (2011). }\end{array}$ \\
\hline & Festival Internacional Cine del Mar (Punta del Este) & $\begin{array}{l}\text { Allende mi abuelo Allende: prêmio de melhor } \\
\text { documentário (2016). }\end{array}$ & $* * *$ \\
\hline & $\begin{array}{l}\text { Festival Internacional de Cine Latino de Punta del Este } \\
\text { (Latinuy) }\end{array}$ & $* * *$ & 70 y Pico (2016). \\
\hline & $\begin{array}{l}\text { Festival Internacional de Cine Documental del Uruguay } \\
\text { (Atlantidoc) }\end{array}$ & $* * *$ & $\begin{array}{l}\text { Secretos de lucha (2007); Todos somos } \\
\text { hijos (2015); Tus padres volverán (2015). }\end{array}$ \\
\hline & Festival de Cine Nacional “Luz, cámara... Guichón” & $* * *$ & D.F. (destino final) (2008). \\
\hline & $\begin{array}{l}\text { DocMontevideo: Encuentro Documental de las Televisoras } \\
\text { Latinoamericanas }\end{array}$ & $* * *$ & $\begin{array}{l}\text { M (2010); Elena (2013); Allende mi abuelo } \\
\text { Allende (2015). }\end{array}$ \\
\hline & Detour: Festival de Cine Nuevo de Uruguay & $* * *$ & $\begin{array}{l}\text { Tus padres volverán (2015); Todos } \\
\text { somoshijos (2016). }\end{array}$ \\
\hline & Semana Nacional del Cine & $* * *$ & Todos somos hijos (2015). \\
\hline & $\begin{array}{l}\text { Tenemos Que Ver: Festival Internacional de Cine y } \\
\text { Derechos Humanos de Uruguay }\end{array}$ & $* * *$ & Todos somos hijos (2016). \\
\hline & $\begin{array}{l}\text { Muestra de Documentales y Derechos Humanos en el } \\
\text { Museo de la Memoria de Montevideo }\end{array}$ & $* * *$ & 70 y Pico (2016). \\
\hline & Festival Piriápolis de Película & $* * *$ & Victoria (2008). \\
\hline \multirow[t]{2}{*}{ Venezuela } & Festival de Cine Documental CARACAS DOC & $\begin{array}{l}\text { Reinalda del Carmen, mi mamá y yo: principal } \\
\text { prêmio na competição internacional (2007). }\end{array}$ & $* * *$ \\
\hline & Festival Internacional de Cine de Caracas & $* * *$ & La parte por el todo (2016). \\
\hline
\end{tabular}




\begin{tabular}{|c|c|c|c|}
\hline \multicolumn{4}{|c|}{ América do Norte } \\
\hline \multirow{12}{*}{ Canadá } & $\begin{array}{l}\text { Hot Docs Canadian International Documentary Festival } \\
\text { (Toronto) }\end{array}$ & $\begin{array}{l}\text { Mi vida con Carlos: top dez referência do público } \\
\text { (2010). }\end{array}$ & Elena (2013). \\
\hline & $\begin{array}{l}\text { Rencontres internationales du documentaire de Montreal } \\
\text { (RIDM) }\end{array}$ & $\begin{array}{l}\text { Cuchillo de palo: prêmios Caméra au poing e } \\
\text { Première Caméra (2010). }\end{array}$ & El eco de las canciones (2010). \\
\hline & Toronto International Film Festival & $* * *$ & $\begin{array}{l}\text { Los rubios (2003); El telón de azúcar } \\
\text { (2006). }\end{array}$ \\
\hline & Toronto Latin Media Festival (aluCine) & $* * *$ & Encontrando a Victor (2005). \\
\hline & Festival del Cortometraje, Toronto & $* * *$ & Encontrando a Víctor (2006). \\
\hline & Vancouver International Film Festival (VIFF) & $* * *$ & Cuchillo de palo (2010). \\
\hline & Latin American Film Festival, Ottawa & $* * *$ & Cuchillo de palo (2012). \\
\hline & Montreal Festival du Nouveau Cinéma & $* * *$ & Os dias com ele (2013). \\
\hline & Brazilian Film Festival of Montreal & $* * *$ & Elena (2014). \\
\hline & Vancouver Latino Film Festival & $* * *$ & Tiempo suspendido (2016). \\
\hline & Festival International du Film sur l'Art (Fifa), Montreal & $* * *$ & Retour: volver (2009). \\
\hline & Toronto Hispano-American Film Festival (THAFF) & $\begin{array}{l}\text { ¿Quién soy yo? Los niños encontrados de } \\
\text { Argentina: prêmio de melhor documentário (2008). }\end{array}$ & $* * *$ \\
\hline \multirow{11}{*}{ EUA } & San Diego Latino Film Festival & $\begin{array}{l}\text { Mi vida con Carlos: prêmio de melhor } \\
\text { documentário (2010). }\end{array}$ & $\begin{array}{l}\text { Cuchillo de palo (2011); Allende mi abuelo } \\
\text { Allende (2016). }\end{array}$ \\
\hline & $\begin{array}{lllll}\begin{array}{l}\text { Cine Las Américas } \\
\text { (Austin/Texas) }\end{array} & \text { International } & \text { Film } & \text { Festival } \\
\end{array}$ & El edificio de los chilenos: menção honrosa (2011). & $* * *$ \\
\hline & New York International Latino Film Festival & $\begin{array}{l}\text { El edificio de los chilenos: prêmio de melhor } \\
\text { documentário (2011). }\end{array}$ & $* * *$ \\
\hline & LASA Film Festival & $\begin{array}{l}\text { El edificio de los chilenos: prêmio Spirit of Film } \\
\text { (2012). }\end{array}$ & $\begin{array}{l}\text { Repare bem (2014); Tus padres volverán } \\
\text { (2016). }\end{array}$ \\
\hline & Los Angeles Brazilian Film Festival & Elena: prêmio de melhor documentário (2013). & $* * *$ \\
\hline & Arlington International Film Festival (AIFF) & Elena: prêmio de melhor filme (2014). & $* * *$ \\
\hline & Chicago International Film Festival & $\begin{array}{l}\text { Tiempo suspendido: Placa de Ouro na competição } \\
\text { de documentários (2015). }\end{array}$ & $* * *$ \\
\hline & Latin Beat, Film Society of Lincoln Center, Nova Iorque & $* * *$ & $\begin{array}{l}\text { Los rubios (2003); Mi vida con Carlos } \\
\text { (2010); Cuchillo de palo (2010). }\end{array}$ \\
\hline & Princeton Film Festival & $* * *$ & Los rubios (2003). \\
\hline & Miami International Film Festival & $* * *$ & $\begin{array}{l}\text { Los rubios (2004); Allende mi abuelo } \\
\text { Allende (2016). }\end{array}$ \\
\hline & Tribeca Film Festival & $* * *$ & El telón de azúcar (2007). \\
\hline
\end{tabular}




\begin{tabular}{|c|c|c|c|}
\hline & San Francisco International Film Festival & $* * *$ & $\begin{array}{l}\text { El telón de azúcar (2007); Allende mi } \\
\text { abuelo Allende (2016). }\end{array}$ \\
\hline & Woodstock Film Festival & $* * *$ & Mi vida con Carlos (2010). \\
\hline & Denver International Film Festival & $* * *$ & Mi vida con Carlos (2010). \\
\hline & Palm Springs International Film Festival & $* * *$ & $\begin{array}{l}\text { Mi vida con Carlos (2011); Allende mi } \\
\text { abuelo Allende (2016). }\end{array}$ \\
\hline & Los Angeles Film Festival & $* * *$ & Cuchillo de palo (2011); 70 y Pico (2016). \\
\hline & $\begin{array}{l}\text { AFI (American Film Institute) Latin American Film } \\
\text { Festival, Washington, D.C. }\end{array}$ & $* * *$ & Cuchillo de palo (2011); Cuatreros (2017). \\
\hline & New Hampshire Film Festival & $* * *$ & Elena (2013). \\
\hline & Brazilian Film Festival of New York & $* * *$ & Elena (2013). \\
\hline & South by Southwest (SXSW), Austin & $* * *$ & Elena (2013). \\
\hline & Chicago Latino Film Festival & $* * *$ & Repare bem (2015). \\
\hline & Latin American Film \& Art Festival, Los Angeles & $* * *$ & Tiempo suspendido (2015). \\
\hline & Seattle International Film Festival & $* * *$ & Allende mi abuelo Allende (2016). \\
\hline & Cine Latino Minneapolis Saint Paul Film Festival & $* * *$ & Allende mi abuelo Allende (2016). \\
\hline & Annapolis International Film Festival & $* * *$ & Allende mi abuelo Allende (2016). \\
\hline & Havana Film Festival New York & $* * *$ & $\begin{array}{l}\text { H.I.J.O.S.: El alma en dos (2002); Nietos } \\
\text { (identidade y memoria) (2005); ¿Quién soy } \\
\text { yo? Los niños encontrados de Argentina } \\
(2008) ; \text { Allende mi abuelo Allende (2016). }\end{array}$ \\
\hline & International Latino Film Festival San Francisco Bay Area & $* * *$ & $\begin{array}{l}\text { ¿Quién soy yo? Los niños encontrados de } \\
\text { Argentina (2008). }\end{array}$ \\
\hline & Seattle Latino Film Festival & $* * *$ & Tus padres volverán (2016). \\
\hline & & Europa & \\
\hline & Festival “Cine joven”, Berlim & Che vo cachai: prêmio do público [2004?]. & $* * *$ \\
\hline & $\begin{array}{lllll}\text { International Leipzig } & \text { Festival for Documentary and } \\
\text { Animated Film (DOK Leipzig) } & & & \\
\end{array}$ & $\begin{array}{l}\text { El edificio de los chilenos: menção honrosa do júri } \\
\text { internacional na competição jovens talentos (2010). }\end{array}$ & El eco de las canciones (2010). \\
\hline & European Media Art Festival, Osnabrück & $* * *$ & $\begin{array}{l}15 \text { filhos (1997); En memoria de los } \\
\text { pájaros (2000). }\end{array}$ \\
\hline Alemanha & Digitale: Feira de arte eletrônica em Colônia & $* * *$ & 15 filhos (1997). \\
\hline & Kurzfilmtage: International short film festival Oberhausen & $* * *$ & 15 filhos [1997 ou 1998]. \\
\hline & Filmfest Hamburg & $* * *$ & $\begin{array}{l}\text { En memoria de los pájaros (2000); Allende } \\
\text { mi abuelo Allende (2015). }\end{array}$ \\
\hline & CineLatino, Tübingen, Stuttgart, Heidelberg e Frankfurt & $* * *$ & Los rubios (2004); Nietos (identidade y \\
\hline
\end{tabular}




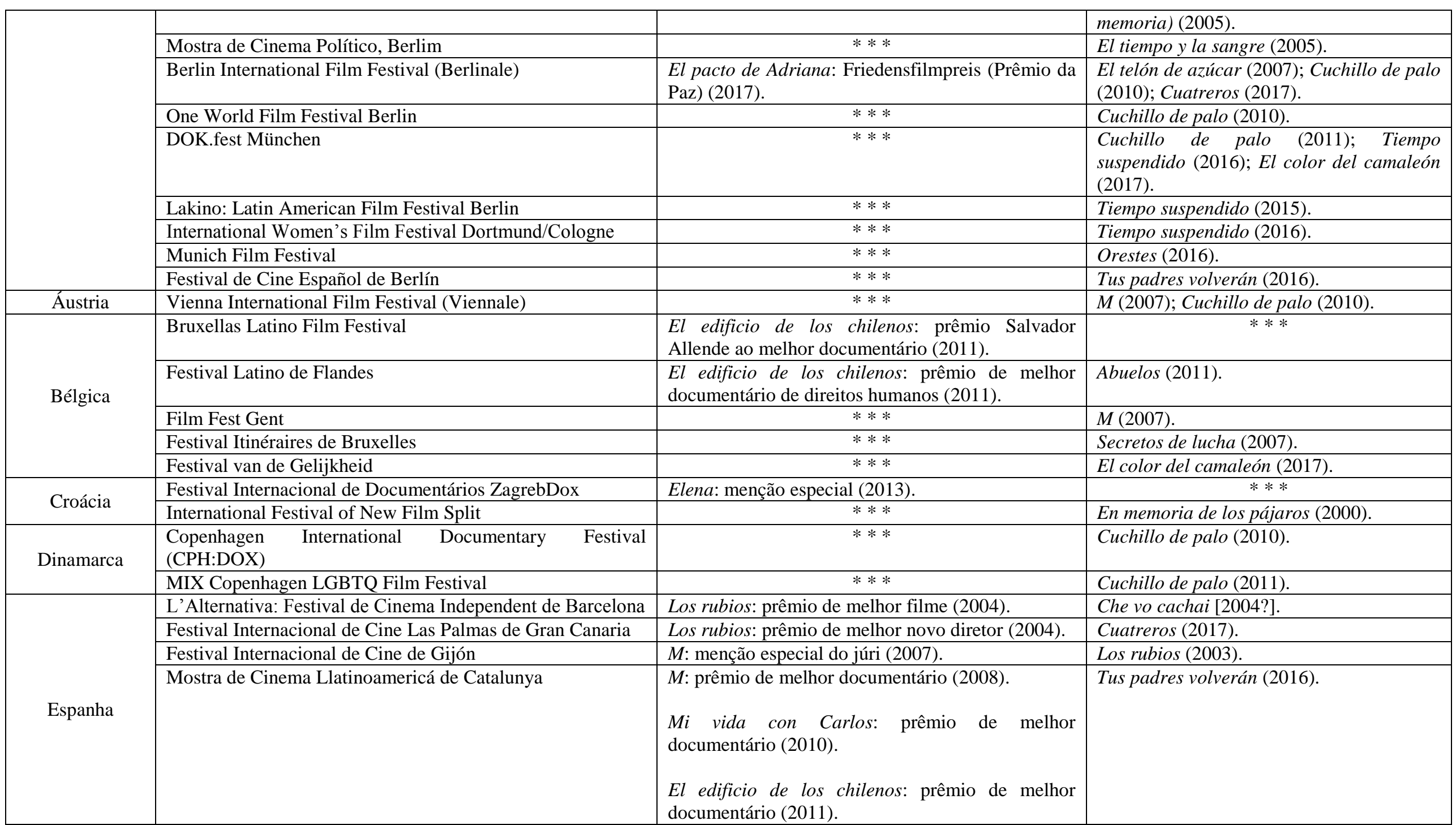




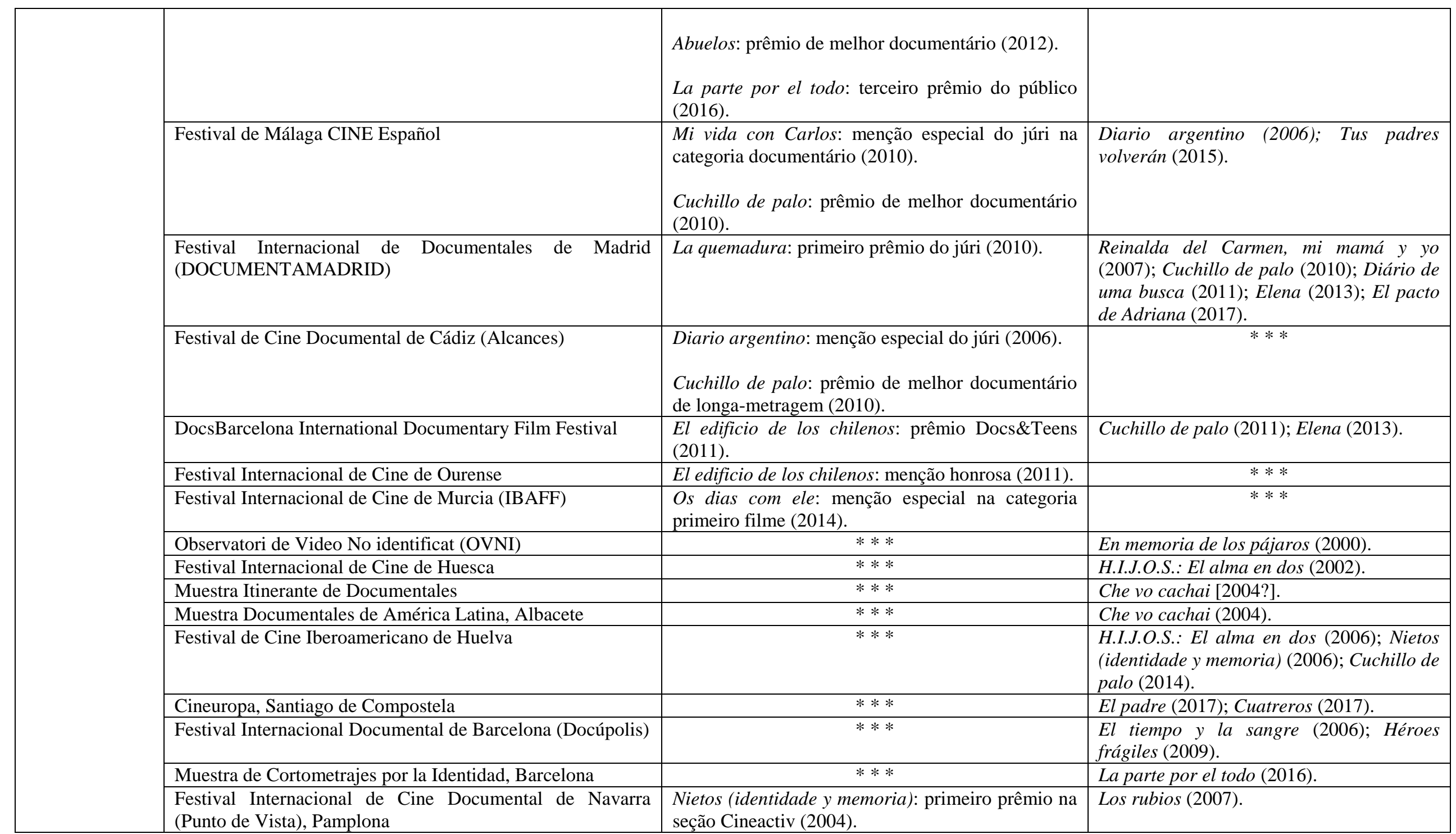




\begin{tabular}{|c|c|c|c|}
\hline & Festival Internacional de Cine de San Sebastián & $* * *$ & $\begin{array}{l}\text { Nietos (identidade y memoria) (2004); Los } \\
\text { rubios (2010); Allende mi abuelo Allende } \\
\text { (2015). }\end{array}$ \\
\hline & $\begin{array}{l}\text { Festival Internacional de Cine Documental de Guía de Isora } \\
\text { (MiradasDoc) }\end{array}$ & $* * *$ & Cuchillo de palo (2010). \\
\hline & $\begin{array}{l}\text { Festival Internacional de Cine gay-lesbo-trans de Bilbao } \\
\text { (Zinegoak) }\end{array}$ & $* * *$ & Cuchillo de palo (2011). \\
\hline & $\begin{array}{l}\text { Muestra de Cine Realizado por Mujeres de Zaragoza y } \\
\text { Huesca }\end{array}$ & $* * *$ & Cuchillo de palo (2011). \\
\hline & Semana Internacional de Cine de Valladolid & $* * *$ & Tiempo suspendido (2015). \\
\hline & Muestra de Cine Día de Brasil, Barcelona & $* * *$ & Orestes (2016). \\
\hline & Festival Cinematográfico Internacional El Ojo Cojo, Madri & $* * *$ & Victoria (2008). \\
\hline & Jornades de Drets Humans i Cinema de Tarragona & $* * *$ & $\begin{array}{l}\text { Héroes frágiles (2011); Los huérfanos del } \\
\text { Cóndor (2011). }\end{array}$ \\
\hline Estônia & World Film Festival & $* * *$ & Tiempo suspendido (2016). \\
\hline \multirow[b]{2}{*}{ Finlândia } & Espoo Ciné International Film Festival & $* * *$ & Cuchillo de palo (2010). \\
\hline & $\begin{array}{l}\text { Cinemaissí: Festival de Cine Latinoamericano y Caribeño de } \\
\text { Finlandia }\end{array}$ & $* * *$ & La parte por el todo (2016). \\
\hline \multirow{6}{*}{ França } & Festival Vidéoformes, Clermont Ferrand & En memoria de los pájaros: grande prêmio (2000). & $* * *$ \\
\hline & Festival Estavar Llivia & $\begin{array}{l}\text { En memoria de los pájaros: prêmio Eurorégion } \\
(2000) .\end{array}$ & $* * *$ \\
\hline & Cinélatino: Rencontres de Toulouse & $\begin{array}{l}\text { El telón de azúcar: prêmio Signis na categoria } \\
\text { documentário (2007). } \\
\text { El pacto de Adriana: prêmio Signis na categoria } \\
\text { documentário (2017). }\end{array}$ & $\begin{array}{l}\text { En memoria de los pájaros (2000); Panzas } \\
\text { (2002); Che vo cachai (2004); Los rubios } \\
\text { (2004); Secretos de lucha (2008); Abuelos } \\
\text { (2011); Tiempo suspendido (2016); Tus } \\
\text { padres volverán (2016). }\end{array}$ \\
\hline & $\begin{array}{l}\text { Festival International de Films Documentaires Cinéma du } \\
\text { Réel, Paris }\end{array}$ & $\begin{array}{l}\text { El telón de azúcar: prêmio Louis Marcorelles } \\
\text { (2007). } \\
\text { La quemadura: prêmio Joris Ivens para o melhor } \\
\text { primeiro filme (2010). }\end{array}$ & (h) Historias cotidianas (2001). \\
\hline & Festival International du Film Insulaire, Île de Groix & $\begin{array}{l}\text { El telón de azúcar: prêmios L'Île d'Or e do público } \\
\text { (2007). }\end{array}$ & $* * *$ \\
\hline & Festival de Biarritz: cinémas et cultures d'Amérique latine & $\begin{array}{l}\text { Secretos de lucha: prêmio Documental Unión } \\
\text { Latina-Festival de Biarritz (2007). }\end{array}$ & $\begin{array}{l}\text { Che vo cachai (2003?); Elena (2013); } \\
\text { Tiempo suspendido (2015); La parte por el } \\
\text { todo (2016); El color del camaleón (2017). }\end{array}$ \\
\hline
\end{tabular}




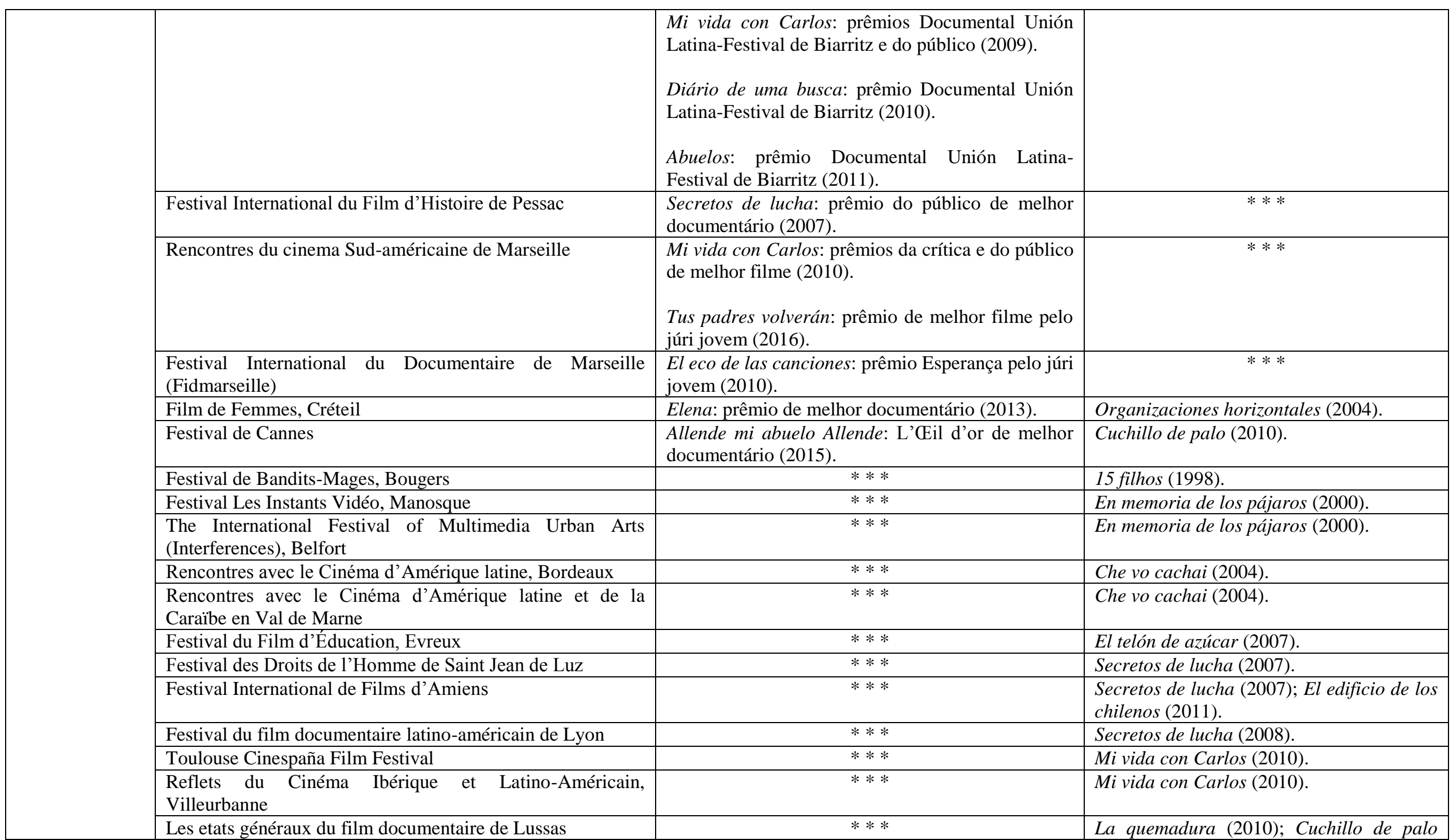




\begin{tabular}{|c|c|c|c|}
\hline & & & $(2010)$. \\
\hline & $\begin{array}{l}\text { Festival des } 3 \text { continents: Cinémas d'Afrique, d'Amérique } \\
\text { latine et d'Asie, Nantes }\end{array}$ & $* * *$ & Cuchillo de palo (2010); Cuatreros (2017). \\
\hline & Festival international du film de Belfort (EntreVues) & $* * *$ & Cuchillo de palo (2010). \\
\hline & $\begin{array}{l}\text { Festival d'un bord au l'autre: Festival de films LGBT, } \\
\text { Orléans }\end{array}$ & $* * *$ & Cuchillo de palo (2010). \\
\hline & Festival du Cinéma Brésilien de Paris & $* * *$ & Diário de uma busca (2011). \\
\hline & Arc-En-Ciel Festival de Films LGBT, Toulouse & $* * *$ & Cuchillo de palo (2011). \\
\hline & Festival du Film Gay et Lesbienne de Nice & $* * *$ & Cuchillo de palo (2011). \\
\hline & Festival international des programmes audiovisuels (FIPA) & $* * *$ & $\begin{array}{l}\text { H.I.J.O.S.: El alma en dos [2002?]; Em } \\
\text { busca de Iara (2014). }\end{array}$ \\
\hline & Brésil en Mouvements & $* * *$ & Os dias com ele (2014). \\
\hline & France Amérique latine & $* * *$ & Tiempo suspendido (2016). \\
\hline & Festival de Cinéma Espagnol de Marseille (CineHorizontes) & $* * *$ & Héroes frágiles (2007). \\
\hline Grécia & Thessaloniki Documentary Festival & $* * *$ & $\begin{array}{l}\text { H.I.J.O.S.: El alma en dos (2003); El } \\
\text { edificio de los chilenos (2011); Elena } \\
\text { (2013). }\end{array}$ \\
\hline & Athens International Film Festival & $* * *$ & Los rubios (2008). \\
\hline Hungria & Budapest International Documentary Film Festival & $\begin{array}{lllll}\begin{array}{l}\text { Tiempo suspendido: } \\
\text { documentário (2015). }\end{array} & \text { prêmio } & \text { de } & \text { melhor } \\
\end{array}$ & $* * *$ \\
\hline & Pandemonium, Londres & $* * *$ & 15 filhos (1998). \\
\hline & London Film Festival & $* * *$ & Los rubios (2003). \\
\hline & London Latin American Film Festival & $* * *$ & M(2007); La quemadura (2010). \\
\hline Inglaterra & Open City Docs Fest Londres & $* * *$ & Elena (2013). \\
\hline & The London International Documentary Festival (LIDF) & $* * *$ & Em busca de Iara (2015). \\
\hline & London Human Rights Film Festival & $* * *$ & Allende mi abuelo Allende (2015). \\
\hline & Guth Gafa International Documentary Film Festival & $* * *$ & Cuchillo de palo (2011). \\
\hline Irıanda & Galway Film Fleadh & $* * *$ & Elena (2013). \\
\hline Islândia & Reykjavik International Film Festival & $* * *$ & Elena (2013). \\
\hline & Festival Internazionale di Cinema delle Donne di Torino & $\begin{array}{l}\text { Papá Iván: segundo prêmio do júri na competição } \\
\text { internacional de documentários (2002). }\end{array}$ & Organizaciones horizontales (2004). \\
\hline Itália & $\begin{array}{l}\text { Festival del Cinema Africano, d'Asia e America Latina, } \\
\text { Milão }\end{array}$ & $\begin{array}{l}\text { El telón de azúcar: menção especial na categoria } \\
\text { documentário (2007). }\end{array}$ & Abuelos (2011). \\
\hline & Ischia Film Festival & $\begin{array}{llll}\text { Mi vida con Carlos: prêmio de melhor } \\
\text { documentário (2010). }\end{array}$ & $* * *$ \\
\hline
\end{tabular}




\begin{tabular}{|c|c|c|c|}
\hline & Festival dei Popoli, Florença & Cuchillo de palo: prêmio de melhor filme (2010). & $\begin{array}{l}\text { H.I.J.O.S.: El alma en dos (2002); Diario } \\
\text { argentino (2006). }\end{array}$ \\
\hline & Netmage, Bolonha & $* * *$ & En memoria de los pájaros (2000). \\
\hline & $\begin{array}{l}\text { International Biennial of Electronic Arts, Quality Television } \\
\text { and Multimedia Publishing, Roma }\end{array}$ & $* * *$ & En memoria de los pájaros (2002). \\
\hline & Festival del Cinema Latino-Americano di Trieste & $\begin{array}{l}\text { Nietos (identidade y memoria): prêmio Video } \\
\text { America (2004). } \\
\text { La parte por el todo: melhor filme da seção } \\
\text { contemporânea (2016). }\end{array}$ & $\begin{array}{l}\text { Che vo cachai (2003); H.I.J.O.S. (2003); El } \\
\text { tiempo y la sangre (2005); (h) Historias } \\
\text { cotidianas (2006); H.I.J.O.S.: El alma en } \\
\text { dos (2006); Victoria (2009); La quemadura } \\
\text { (2010); Tus padres volverán (2016); El } \\
\text { color del camaleón (2017). }\end{array}$ \\
\hline & TekFestival. Roma & $* * *$ & $\begin{array}{l}\text { Reinalda del Carmen, mi mamá y yo } \\
\text { (2007). }\end{array}$ \\
\hline & Biografilm Festival, Bolonha & $* * *$ & Elena (2013). \\
\hline & Lucania Film Festival & $* * *$ & Elena (2013). \\
\hline & Sicilia Queer Film Festival & $* * *$ & Cuchillo de palo (2014). \\
\hline & Sguardi Altrove Film Festival, Milão & $* * *$ & Nietos (identidade y memoria) (2015). \\
\hline & Levante Film Fest, Bari (Itália) & $* * *$ & Semillas de utopia (2006). \\
\hline \multirow[b]{2}{*}{ Noruega } & Bergen International Film Festival & $* * *$ & Cuchillo de palo (2010). \\
\hline & $\begin{array}{llll}\text { Nordic Anthropological Film } & \text { Association } & \text { (NAFA) } \\
\text { Anthropological Film Festival } & & \\
\end{array}$ & $* * *$ & Tiempo suspendido (2016). \\
\hline \multirow{4}{*}{ Países Baixos } & World Wide Video Festival, Amsterdã & $* * *$ & $\begin{array}{l}15 \text { filhos (1997); En memoria de los } \\
\text { pájaros (2000). }\end{array}$ \\
\hline & International Film Festival Rotterdam (IFFR) & $* * *$ & $\begin{array}{l}15 \text { filhos (1998); Los rubios (2004); Mi } \\
\text { vida con Carlos (2010). }\end{array}$ \\
\hline & 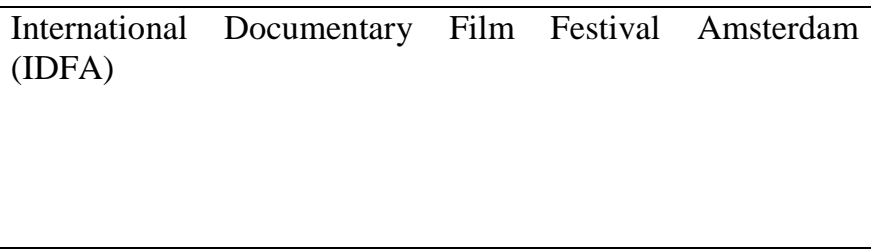 & $* * *$ & $\begin{array}{l}\text { H.I.J.O.S.: El alma en dos (2002); Hasta la } \\
\text { memoria, siempre (2005); Victoria (2008); } \\
\text { Abuelos (2010); Cuchillo de palo (2010); } \\
\text { Elena (2012); Tiempo suspendido (2015); } \\
\text { Allende mi abuelo Allende (2015); } \\
\text { Guerrero (2016). }\end{array}$ \\
\hline & Amnesty International Film Festival, Amsterdã & $* * *$ & (h) Historias cotidianas (2001). \\
\hline \multirow{3}{*}{ Polônia } & Planete+ Doc Film Festival, Varsóvia & Elena: prêmio Canon de cinematografia (2013). & $* * *$ \\
\hline & Warsaw International Film Festival & $* * *$ & $M(2007)$. \\
\hline & Two Riversides Film and Art Festival & $* * *$ & Cuchillo de palo (2010); Elena (2013). \\
\hline
\end{tabular}




\begin{tabular}{|c|c|c|c|}
\hline \multirow[t]{4}{*}{ Portugal } & Doclisboa & $\begin{array}{l}\text { Cuchillo de palo: prêmio SIC Notícias para melhor } \\
\text { documentário de investigação (2010). } \\
\text { Diário de uma busca: prêmios RTP2 para melhor } \\
\text { documentário de investigação e CPLP para o } \\
\text { melhor longa ou média-metragem dos países de } \\
\text { língua portuguesa (2011). } \\
\begin{array}{l}\text { Os dias com ele: prêmio de melhor primeiro ou } \\
\text { segundo longa-metragem da competição } \\
\text { portuguesa (2013). }\end{array}\end{array}$ & $* * *$ \\
\hline & Videolisboa: Festival Internacional de Vídeo & $* * *$ & En memoria de los pájaros (2001). \\
\hline & Festival de Cinema Itinerante da Língua Portuguesa, Lisboa & $* * *$ & Repare bem (2014). \\
\hline & Porto/Post/Doc: Film \& Media Festival & $* * *$ & Cuatreros (2017). \\
\hline Rep. Checa & One World Human Rights Documentary Film Festival & Cuchillo de palo: prêmio de melhor filme (2010). & $* * *$ \\
\hline Sérvia & European Feature Documentary Film Festival, Belgrado & $* * *$ & Mi vida con Carlos (2010). \\
\hline \multirow[t]{3}{*}{ Suécia } & Göteborg Film Festival & $* * *$ & $\begin{array}{l}\text { Los rubios (2003); Mi vida con Carlos } \\
\text { (2010); Cuchillo de palo (2011); Allende } \\
\text { mi abuelo Allende (2016). }\end{array}$ \\
\hline & Tempo Documentary Festival & $* * *$ & Elena (2013). \\
\hline & Internationella Exilfilmfestivalen & $* * *$ & Guerrero (2017). \\
\hline \multirow{7}{*}{ Suíça } & Festival Filmar en América Latina, Genebra & $\begin{array}{l}\text { Che vo cachai: prêmios da crítica e do público } \\
\text { (2003). } \\
\text { Tus padres volverán: prêmio do público (2015). }\end{array}$ & $\begin{array}{l}\text { Secretos de lucha (2007); Héroes frágiles } \\
\text { (2008); Tiempo suspendido (2015); Tus } \\
\text { padres volverán (2015); La parte por el } \\
\text { todo (2016). }\end{array}$ \\
\hline & Festival Nord-Sud, Genebra & $* * *$ & En memoria de los pájaros (2000). \\
\hline & $\begin{array}{l}\text { VIPER Basel International Festival for Film Video and New } \\
\text { Media }\end{array}$ & $* * *$ & En memoria de los pájaros (2000). \\
\hline & Festival Internazionale del Film Locarno & $* * *$ & $\begin{array}{l}\text { Los rubios (2003); Cuchillo de palo } \\
\text { (2013). }\end{array}$ \\
\hline & $\begin{array}{l}\text { Black Movie: Geneva International Independent Film } \\
\text { Festival, Genebra }\end{array}$ & $* * *$ & $\begin{array}{l}\text { Diario argentino (2009); Cuchillo de palo } \\
\text { (2011). }\end{array}$ \\
\hline & Festival Visages à Vevey & $* * *$ & Diário de uma busca (2013). \\
\hline & Visions du Réel: Festival International de Cinéma à Nyon & Diario argentino: prêmio do público jovem (2006). & $* * *$ \\
\hline \multirow{2}{*}{ Turquia } & Istanbul International Film Festival & $* * *$ & El telón de azúcar (2007). \\
\hline & !f Istanbul International Independent Film Festival & $* * *$ & Cuchillo de palo (2011). \\
\hline
\end{tabular}




\begin{tabular}{|c|c|c|c|}
\hline & Festival on Wheels, Ancara & $* * *$ & Tiempo suspendido (2015). \\
\hline & TRT Documentary Awards, Ancara & $* * *$ & Tiempo suspendido (2016). \\
\hline Ucrânia & $\begin{array}{l}\text { Docudays UA International Human Rights Documentary } \\
\text { Film Festival }\end{array}$ & $* * *$ & Diário de uma busca (2012). \\
\hline \multicolumn{4}{|c|}{ (1) } \\
\hline \multirow{3}{*}{ China } & BRAPEQ Brazil Film Festival 2013, Pequim & $* * *$ & Elena (2013). \\
\hline & Women Make Waves Film Festival, Taiwan & $* * *$ & Elena (2013). \\
\hline & Shangai International Film Festival & $* * *$ & Elena (2013). \\
\hline Coreia do Sul & Busan International Film Festival & $* * *$ & Allende mi abuelo Allende (2015). \\
\hline \multirow[t]{2}{*}{ Israel } & Jerusalem International Film Festival & $* * *$ & $\begin{array}{l}\text { El telón de azúcar (2007); Héroes frágiles } \\
\text { (2007); La quemadura (2011). }\end{array}$ \\
\hline & Tel Aviv International Documentary Film Festival & $* * *$ & Elena (2013). \\
\hline \multirow{3}{*}{ Japão } & Tokyo Video Festival & $\begin{array}{l}\text { En memoria de los pájaros: prêmio Tokyo Video } \\
\text { Festival (2002). }\end{array}$ & $* * *$ \\
\hline & Yamagata International Documentary Film Festival & $M$ : segundo prêmio (2007). & $* * *$ \\
\hline & Latin Beat Film Festival & $* * *$ & Allende mi abuelo Allende (2015). \\
\hline \multicolumn{4}{|c|}{ Oceania } \\
\hline \multirow{4}{*}{ Austrália } & Sydney Latin American Film Festival (SLAFF) & $\begin{array}{l}\text { Secretos de lucha: prêmio do público de melhor } \\
\text { documentário (2008). }\end{array}$ & Tus padres volverán (2016). \\
\hline & Sydney Film Festival & $* * *$ & El telón de azúcar (2007). \\
\hline & Melbourne Latin American Film Festival & $* * *$ & Secretos de lucha (2008). \\
\hline & Melbourne International Film Festival & $* * *$ & Elena (2013). \\
\hline Nova Caledônia & Festival International du Cinéma des Peuples & $\begin{array}{l}\text { El telón de azúcar: prêmio principal (Ânûû-rû } \\
\text { âboro) (2007). }\end{array}$ & $* * *$ \\
\hline \multicolumn{4}{|c|}{ África } \\
\hline Burkina Faso & Festival Pan-Africano de Cinema e Vídeo, Ouagadougou & $* * *$ & 15 filhos (1998). \\
\hline Egito & Cairo International Women Film Festival & $* * *$ & Tiempo suspendido (2016). \\
\hline Marrocos & Festival International de Documentaire de Agadir (Fidadoc) & $* * *$ & Elena (2013). \\
\hline
\end{tabular}

